\title{
Archival Investigations for Potential Colonial-Era Shipwrecks in Ultra-Deepwater within the Gulf of Mexico
}

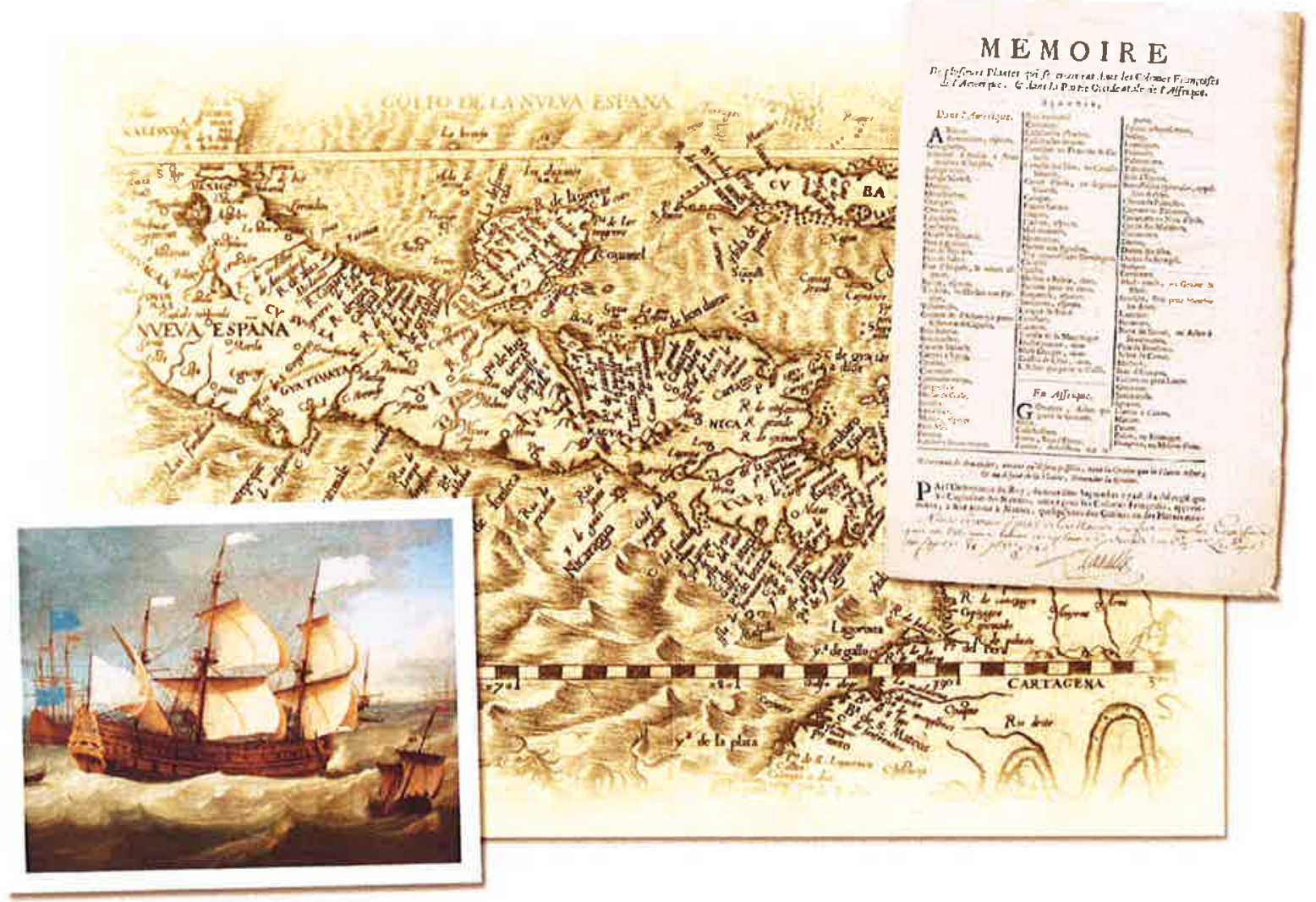

U.S. Department of the Interior

Bureau of Ocean Energy Management, Regulation and Enforcement

Gulf of Mexico OCS Region 


\section{Archival Investigations for Potential Colonial-Era Shipwrecks in Ultra-Deepwater within the Gulf of Mexico}

Authors

Michael C. Krivor

John de Bry

Nicholas J. Linville

Debra J. Wells

Prepared under BOEMRE Contract

M08PC20030

by

Southeastern Archaeological Research, Inc.

428 East Government St.

Pensacola, FL 32502

Published by

U.S. Department of the Interior

Bureau of Ocean Energy Management, 


\section{DISCLAIMER}

This report was prepared under contract between the Bureau of Ocean Energy Management, Regulation and Enforcement (BOEMRE) and Southeastern Archaeological Research, Inc. (SEARCH). This report has been technically reviewed by BOEMRE, and it has been approved for publication. Approval does not signify that the contents necessarily reflect the views and policies of BOEMRE, nor does mention of trade names or commercial products constitute endorsement or recommendation for use. It is, however, exempt from review and compliance with BOEMRE editorial standards.

\section{REPORT AVAILABILITY}

This report is available only in compact disc format from the Bureau of Ocean Energy Management, Regulation and Enforcement, Gulf of Mexico OCS Region, at a charge of \$15.00, by referencing OCS Study BOEMRE 2011-004. The report may be downloaded from the BOEMRE website through the Environmental Studies Program Information System (ESPIS). You will be able to obtain this report also from the National Technical Information Service in the near future. Here are the addresses. You may also inspect copies at selected Federal Depository Libraries.

\author{
U.S. Department of the Interior \\ Bureau of Ocean Energy Management, \\ Regulation and Enforcement \\ Gulf of Mexico OCS Region \\ Public Information Office (MS 5034) \\ 1201 Elmwood Park Boulevard \\ New Orleans, Louisiana 70123-2394 \\ Telephone requests may be placed at \\ (504) 736-2519, 1-800-200-GULF, or \\ Rush Orders: 1-800-553-6847 \\ Fax: (504) 736-2620
}

\author{
U.S. Department of Commerce \\ National Technical Information Service \\ 5285 Port Royal Road \\ Springfield, Virginia 22161 \\ Phone: (703) 605-6040 \\ Fax: (703) 605-6900 \\ E-mail: bookstore@ntis.gov
}

\section{CITATION}

Suggested citation:

Krivor, M.C., J. de Bry, N.J. Linville, and D.J. Wells. 2011. Archival investigations for Colonial-era shipwrecks in ultra-deepwater within the Gulf of Mexico. U.S. Dept. of the Interior, Bureau of Ocean Energy Management, Regulation and Enforcement, Gulf of Mexico OCS Region, New Orleans, LA. OCS Study BOEMRE 2011-004. 166 pp. 


\section{ABOUT THE COVER}

The map: Anonymous map of the Gulf of Mexico, Caribbean, Central America, and part of South America, 1530 (Ge. D. 7957, Bibliothèque Nationale, Paris).

The painting: The Fleet of Vice-Admiral Jean d'Estrées (detail), second half of seventeenth century, French (Musée de la Marine, Paris).

The document: List of plants from the Americas and Africa to be brought back for the royal gardens of Louis XV, 1740 (Center for Historical Archaeology Collection). 


\section{ABSTRACT}

The Bureau of Ocean Energy Management, Regulation and Enforcement (BOEMRE), an agency of the U.S. Department of the Interior, is charged with the responsibility of considering the effects of its actions on significant submerged cultural resources on the Outer Continental Shelf (OCS) of the United States, from State Waters to the limit of the Exclusive Economic Zone (EEZ). In an effort to protect submerged cultural resources from potential effects of oil and gas activity within the Gulf of Mexico (GOM), BOEMRE seeks to amass and assess primary archival material relative to early vessel losses (ca. sixteenth to eighteenth century) in UltraDeepwater (UDW) (>5,000 feet) within the GOM.

To achieve project goals, BOEMRE requested that various repositories (international and national) be identified and visited in an effort to gather primary archival resources. Relevant documents were to be transcribed and translated to English by a professional paleographer then saved in PDF format. Historical data and imagery acquired under this contract was to be analyzed to identify each vessel casualty and establish its type, date of construction, nationality, ownership (past and present), use history, mission, and cargo (if any) at time of loss, as well as factors contributing to its loss. One of the goals of the analysis is to determine each vessel's likely location and potential present condition. Ultimately, a greater understanding of the likelihood and presence of historic shipwrecks within the UDW of the GOM will enable BOEMRE to anticipate and protect these sites. More specifically, archival information relative to colonial-era shipwrecks will augment BOEMRE's ability to utilize adaptive management strategies in its regulation of OCS oil and gas activities within the GOM, in an effort to minimize impacts to potentially significant submerged cultural resources.

Archival repositories considered most relevant to the current investigation were identified by Southeastern Archaeological Research, Inc. (SEARCH). From October 2008 through September 2009 SEARCH successfully completed archival research at a variety of repositories thought to contain primary documents and materials relative to early-colonial-period (sixteenth- to eighteenth-century) vessel losses within UDW of the GOM. The repositories visited during this investigation included the Archivo General de Indias (AGI) in Seville, Spain; the Archives Nationales in Paris, France; the Centre des Archives d'Outre-Mer (CAOM) (Colonial Archives) in Aix-en-Provence, France; the St. Augustine Foundation Center for Historic Research in St. Augustine, Florida; and the P.K. Yonge Library of Florida History at the University of Florida in Gainesville, Florida.

The current investigation successfully identified previously unknown, early-colonial-period (sixteenth- to eighteenth-century) vessel losses potentially located within UDW of the GOM. A total of nine Spanish vessel losses (within the GOM) were identified at the AGI, in Seville, Spain. In France, a total of seven vessels (six French and one English) were found at the CAOM (in Aix-en-Provence, France) that may have been lost within the GOM. Results of research at the archives within the United States failed to identify any potential candidates (although a number of shallow water wrecks were identified).

Results indicate that previously unidentified early-colonial-period vessel losses certainly exist within UDW of the GOM. However, determining where these vessel losses may have occurred 
within the GOM is complex considering that many occurred away from land and with a total loss of life. Therefore, attempting to decipher where a wreck may have occurred along a sailing route can be difficult. One must consider estimated sailing times between ports, vessel type and speed, weather patterns, currents, and a variety of other variables that ultimately affect where and when a specific vessel may have been lost. Coupled with limitations of primary documents (including vague locational information relative to a given vessel loss), estimating the location of a given shipwreck within UDW is nearly impossible. It has been found that primary documents do not necessarily strengthen the location of these lost shipwrecks. In fact, the majority of documents found during the current investigation contained no reference to where a vessel may have wrecked, other than it simply did not arrive at its intended destination.

While this investigation has been successful in identifying additional vessel losses within the GOM that were previously unknown, it may not be economically feasible to conduct similar research efforts in the future. Simply stated, this is an idealistic task considering the sheer amount of primary documentation available to researchers in numerous repositories in various countries. While this investigation confirmed that primary documents relative to such vessel losses can be found in appropriate international and national repositories, time may be better spent relying on remote-sensing surveys to identify undocumented wreck sites within the GOM, followed by archival research specific to that site. Analysis of hull remains and cargo can certainly narrow the scope of research relative to a specific site, allowing researchers to focus more on a specific time period and nationality. Future archival research should be directed to specific repositories based on data collected from remote-sensing surveys and/or archaeological investigations within UDW of the GOM. Data presented within this report may help to identify the nationality and temporal period of shipwrecks within the GOM. 


\section{ACKNOWLEDGMENTS}

Numerous individuals must be acknowledged for the variety of assistance they have provided for this investigation. SEARCH would like to acknowledge Dr. Chris Horrell, BOEMRE archaeologist and Contracting Officer's Representative (COR), who was very patient during all aspects of this research. His support of our constantly changing efforts to provide BOEMRE with the most pertinent data was beneficial.

SEARCH thanks Ms. Isabel Simó Rodríguez, Director of the Archivo General de Indias (AGI), who kindly offered her assistance as well as the support of the entire AGI staff during work at the AGI. In addition, Ms. Victoria Stapells-Johnson, an accomplished archival researcher, provided valuable advice and guidance at the AGI. Mr. Luis Miguel Glave, a talented archival researcher specializing in the most difficult script used by legal clerks, notaries, and lawyers in the sixteenth and seventeenth centuries, kindly interrupted his own work to assist in deciphering some of cryptic words and abbreviations encountered while at the AGI.

Ms. Martine Cornède, Director of the Centre des Archives d'Outre-Mer (French Colonial Archives), graciously opened her Center to SEARCH and facilitated the research at this repository. Mrs. Isabelle Dion, Curator-in-Chief of the Centre des Archives d'Outre-Mer, allowed access to documents that were otherwise out of circulation and unavailable to readers. Her husband, Mr. Jacques Dion, in charge of Documentary Studies, provided sources that made the trip to Aix-en-Provence a success.

Mr. Érik Le Maresquier, Director of Publication of the Archives Nationales in Paris, made available reference publications and archive inventories that made research efforts much easier. Mr. Philippe Henrat, Curator-in-Chief at the Archives Nationale and Curator of the Naval Section (Fonds Marine), provided valuable advice and directions in locating data pertaining to ships sailing the Gulf of Mexico. Mr. Etienne Taillemite, Honorary Inspector General of the Archives of France, helped us to understand various titles and functions of colonial officials from the colony of La Louisiane.

Mr. Jean Boudriot, the legendary French nautical expert and most prolific author, assisted greatly on the archaic terminology that applies to seventeenth- and eighteenth-century French sailing vessels, their tackles and appurtenances, and methods of sailing. In addition, Dr. Eugene Lyon, historian and archival researcher, provided valuable advice on the St. Augustine Foundation's collection in St. Augustine, Florida.

Ms. Joy MacMillan, Director, the St. Augustine Foundation, Inc., facilitated work at that repository, assisting in locating specific microfilm reels, making photocopies of references, and making work at the Foundation a pleasant experience. Mr. Robert "Chef" McGuire proved that being a professional gourmet chef is only one of his many talents, by finding an important citation SEARCH had difficulty locating.

SEARCH would like to acknowledge the assistance of Mr. Bruce S. Chappell, archivist at the P.K. Yonge Library. His knowledge of the collections made our job much easier. 
We must also recognize the assistance of Ms. Pilar Luna, the State Underwater Archaeologist of Mexico, as well as Ms. Flor Trejo and Mr. Robert E. Junco (paleographers at the Archivo General de la Nación in Mexico City, Mexico). All three lent valuable insight into the holdings at the Archivo General de la Nación and were instrumental in assisting with the direction of this research.

SEARCH would like to thank Dr. Denise Lakey for coming onboard with this project and offering her talents as a paleographer. In addition, SEARCH must thank Dr. Don Keith, with Ships of Discovery, for information and sources relative to the 1554 fleet as well as Mr. Dave Moore for providing knowledge regarding shipwrecks in the GOM. Mr. Greg Cook of the University of West Florida (UWF) is thanked for information relative to the Emanuel Point wrecks in Pensacola Bay, Florida.

Last but not least, SEARCH must acknowledge the extraordinary talent and work of Dr. John A. de Bry, paleographer, for putting in more time and effort on this project than we ever expected. This report would have little substance without Dr. de Bry's knowledge of archives and expertise in transcribing and translating historic documents. 


\section{TABLE OF CONTENTS}

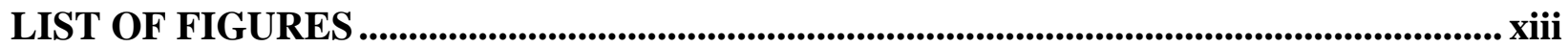

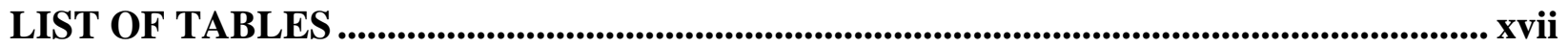

1.0 INTRODUCTION................................................................................................................1

$2.0 \quad$ HISTORICAL CONTEXT ...................................................................................5

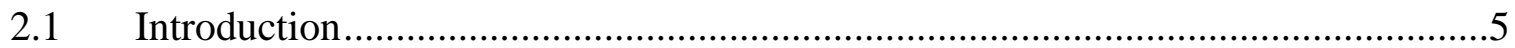

2.2 From Contact to Colonies: The Gulf of Mexico in the Sixteenth Century

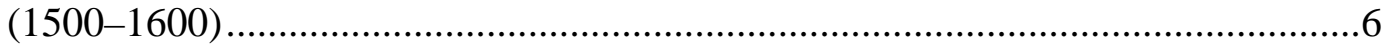

2.3 New Explorations: The Gulf of Mexico in the Seventeenth Century

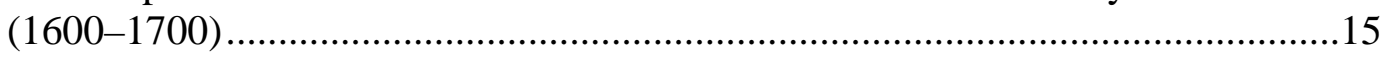

2.4 The French Colonies: The Gulf of Mexico in the Early to Mid-Eighteenth Century (1700-1756) ........................................................................................17

2.5 The Diversification of Trade: The Gulf of Mexico in the Late Eighteenth Century to Mexican Independence (1756-1821)...................................................20

$2.6 \quad$ Ports and Cargo within the GOM …………….................................................25

2.6.1 Veracruz, Mexico (Established 1519).........................................................26

2.6.2 Havana, Cuba (Established 1515)..........................................................2

2.6.3 New Orleans, Louisiana (Established 1717).............................................28

2.6.4 Pensacola, Florida (Established 1698) ....................................................28

2.6.5 Biloxi, Mississippi (Established 1699) ………….....................................29

2.6.6 Dauphin Island (Established 1699) .............................................................29

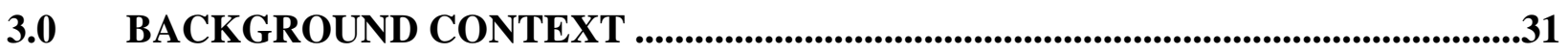

3.1 Previous Shipwreck Inventories within the GOM ...................................................31

3.2 Historic Vessel Types within the GOM (Sixteenth to Eighteenth Centuries) ........35

3.2.1 Aviso ……......................................................................................35

3.2.2 Barque (or Bark) ...............................................................................35

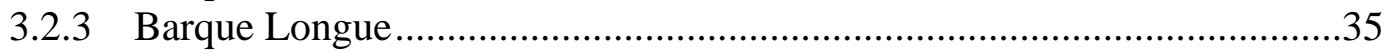

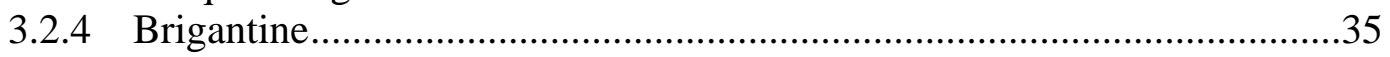

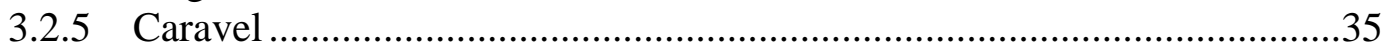

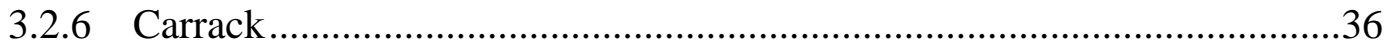

3.2.7 Chebec (or Xebec) …………………………...................................36

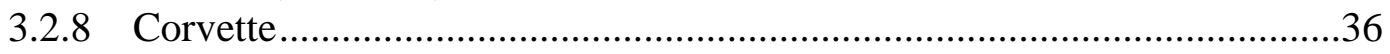

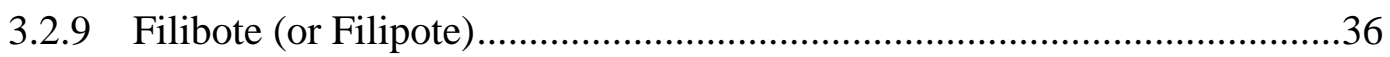

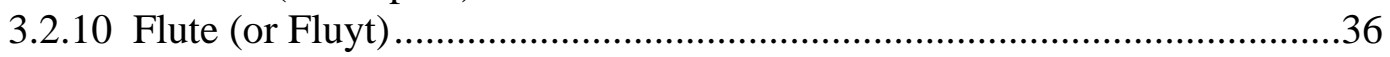

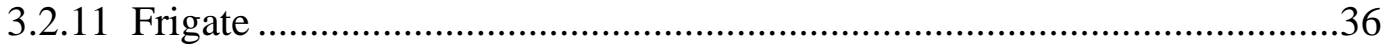

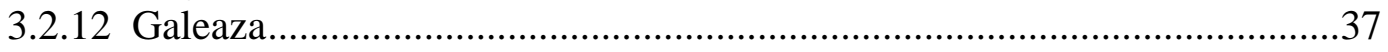

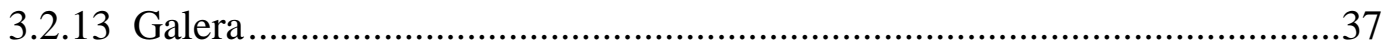




\section{TABLE OF CONTENTS (continued)}

Page

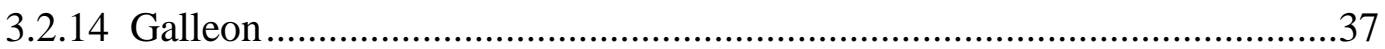

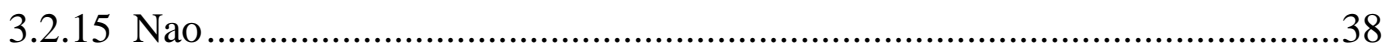

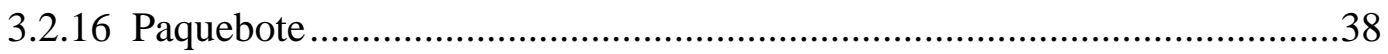

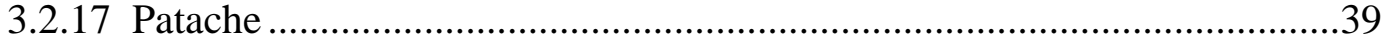

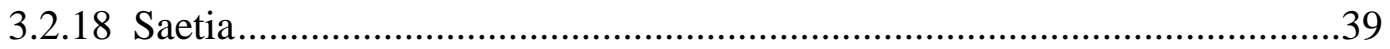

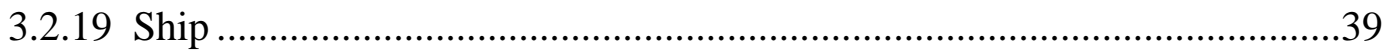

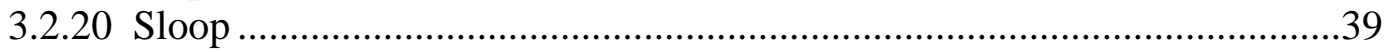

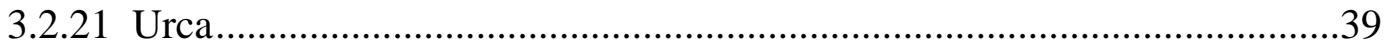

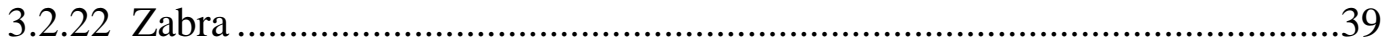

3.3 Known Sixteenth- to Eighteenth-Century Shipwreck Sites and Survey

Expectations within the GOM .........................................................................40

3.3.1 1554 Plate Fleet, Padre Island, Texas (1554) .......................................43

3.3.2 Emanuel Point I (EPI) and Emanuel Point II (EPII) Shipwrecks, Pensacola Bay, Florida (1559) .........................................................47

3.3.3 Tortugas Deepwater Shipwreck (1622) ................................................52

3.3.4 Nuestra Señora de Atocha, Florida Keys (1622) ......................................55

3.3.5 San Felipe, Florida Keys (1733) ...........................................................57

3.3.6 El Nuevo Constante, Louisiana (1766) ...................................................60

3.3.7 El Cazador, Grand Isle, Louisiana (1784) ..........................................64

3.3.8 The Mica Wreck, GOM (1775-1830) ................................................66

3.3.9 The Mardi Gras Wreck, GOM (1810-1820) ...........................................70

3.4 Historic Vessel and Sediment Accumulation within UDW of the GOM ..............74

4.0 ACQUISITION OF ARCHIVAL RESOURCES ....................................................77

5.0 RESULTS ....................................................................................................................83

5.1 Archivo General de Indias (AGI) (Archives of the Indies), Seville, Spain ...........83

5.1.1 Lost Ship Number 1: Duro (1898), Volume VII......................................88

5.1.2 Lost Ship Number 2: Duro (1898), Volume VII......................................88

5.1.3 Lost Ship Number 3: Duro (1898), Volume IX ......................................91

5.1.4 Lost Ship Number 4: Tira 4, Tira 5, Tira 8, and Tira 9 ...........................91

5.1.5 Lost Ship Number 5: Tira 4, Tira 5, Tira 8, and Tira 9 ..........................93

5.1.6 Lost Ship Number 6: Tira 4, Tira 5, Tira 8, and Tira 9 ...........................93

5.1.7 Lost Ship Number 7: Tira 4, Tira 5, Tira 8, and Tira 9 ...........................94

5.1.8 Lost Ship Number 8: Tira 19 ...............................................................94

5.1.9 Lost Ship Number 9: Tira 21 ...............................................................96

5.2 The Archives Nationales (Paris, France) and the Centre des Archives d'Outre-Mer (CAOM) (Aix-en-Provence, France).............................................98

5.2.1 Lost Ship Number 10: CAOM C9 A142 (No Folio Number) and CAOM C13 B1 (Folio 423). 102

5.2.2 Lost Ship Number 11: CAOM C13 A8 (Folio 399) .................................104

5.2.3 Lost Ship Number 12: CAOM C13 A16 (Folio 178) ..............................106 


\section{TABLE OF CONTENTS (continued)}

5.2.4 Lost Ship Number 13: CAOM C13 A16 (Folio 178) .............................107

5.2.5 Lost Ship Number 14: CAOM C13 A26 (Folio 127) ..............................107

5.2.6 Lost Ship Number 15: CAOM C13 A26 (Folio 127) ...............................109

5.2.7 Lost Ship Number 16: CAOM C13 A30 (Folio 131) and CAOM C13 A32 (Folio 215) ...............................................................111

5.3 Additional Documents from Spanish and French Archives ...............................111

5.4 St. Augustine Foundation’s Center for Historic Research, St. Augustine, Florida

5.5 P.K. Yonge Library of Florida History at the University of Florida,

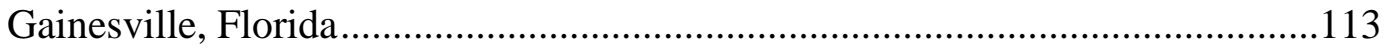

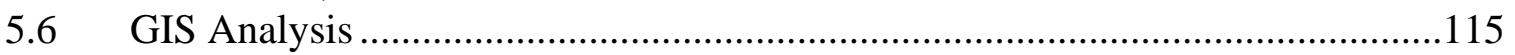

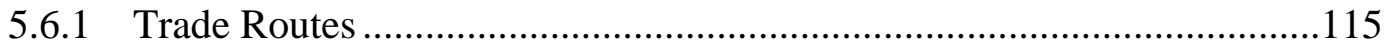

5.6.2 Hurricanes and Vessel Losses............................................................123

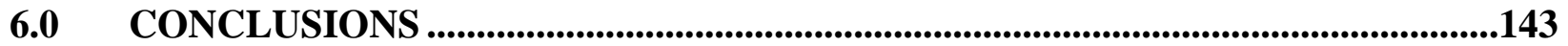

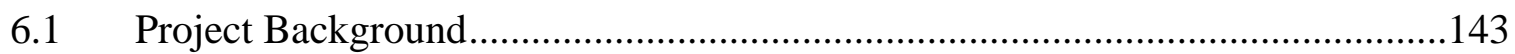

6.2 Archivo General de Indias (AGI), Seville, Spain .........................................145

6.3 Archives Nationales, Paris, France .................................................................146

6.4 Centre des Archives d'Outre-Mer (CAOM), Aix-en-Provence, France...............146

6.5 St. Augustine Foundation’s Center for Historic Research, St. Augustine,

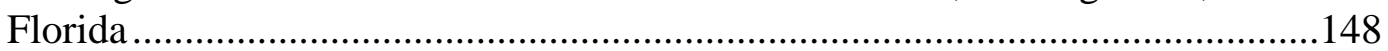

6.6 P.K. Yonge Library of Florida History, University of Florida, Gainesville,

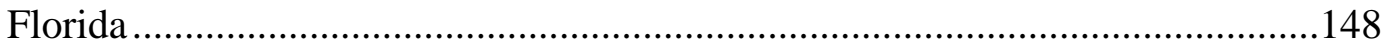

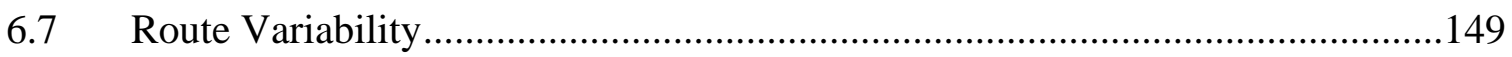

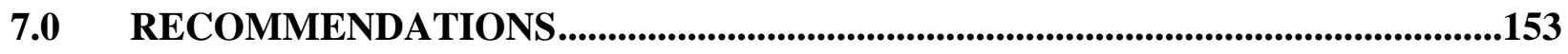

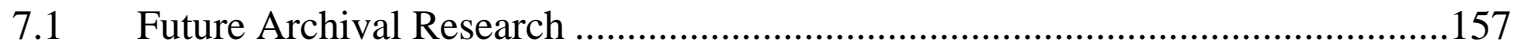

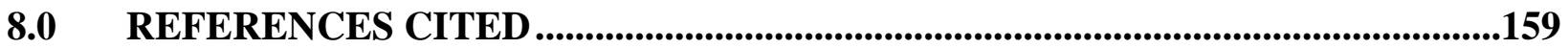

APPENDIX A Documents Providing Information on Spanish, French, and English Ships Presumed Lost in the Deep Waters of the Gulf of Mexico in the Colonial Period

APPENDIX B Documents Providing Information on Spanish and French Cargoes of Ships Sailing in the Gulf of Mexico in the Colonial Period ...................229

APPENDIX C Documents Providing Information on Losses or Ship Accidents Outside of the Deep Waters of the Gulf of Mexico ...............................255

APPENDIX D Documents Providing Information on the Process of the Salvaging of Vessels .....................................................................................269

APPENDIX E Documents Providing Information on the Various Sailing Routes and Connections in the Gulf of Mexico. 


\section{LIST OF FIGURES}

Page

Figure 1-1. BOEMRE UDW study area including bathymetry ..............................................2

Figure 1-2. Various deepwater canyons of interest within the BOEMRE UDW study area......3

Figure 2-1. 1703 French chart (inset) of the Gulf of Mexico .................................................5

Figure 2-2. 1520 map of the Gulf of Mexico created by Hernán Cortés...................................8

Figure 2-3. 1777 depiction of an Indian harvesting cochineal ............................................10

Figure 2-4. Mid-nineteenth-century depiction of a buccaneer by Alfred R. Waud..................13

Figure 2-5. Late-seventeenth-century depiction of La Salle's arrival to the Mississippi

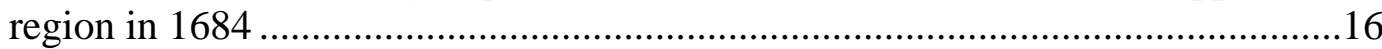

Figure 2-6. 1736 map titled Florida: The North Part of the Gulf of Mexico with Adjacent

Territories Belonging to Great Britain and France ..............................................19

Figure 2-7. $\quad$ A View of Pensacola, in West Florida by George E. Gauld, dating to the

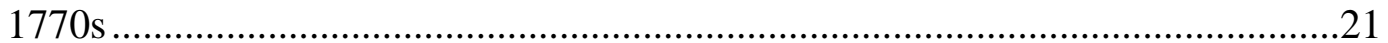

Figure 3-1. Plotted location of sixteenth- to eighteenth-century shipwrecks within the GOM from the BOEMRE shipwreck database..................................................4 41

Figure 3-2. Site plan of 41 KN 10 (one of the three 1554 wrecks) ......................................45

Figure 3-3. Site plan of Emanuel Point I (EPI) shipwreck ..................................................48

Figure 3-4. Site plan of Emanuel Point II (EPII) shipwreck ...............................................50

Figure 3-5. Site plan of the Tortugas Deepwater Shipwreck...............................................53

Figure 3-6. S Site plan of Nuestra Señora de Atocha ...........................................................56

Figure 3-7. Site plan of San Felipe .................................................................................59

Figure 3-8. Magnetic contour map of El Nuevo Constante ..................................................62

Figure 3-9. Side-scan sonar image of El Nuevo Constante ...................................................63

Figure 3-10. Side-scan sonar image of the Mica Wreck .......................................................66

Figure 3-11. Sketch drawing of the Mica Wreck ..........................................................68

Figure 3-12. Site plan of the Mardi Gras Wreck ................................................................72

Figure 4-1. The Archivo General de Indias (AGI) located in Seville, Spain .........................78

Figure 4-2. The reading room located within the Archivo General de Indias .........................78

Figure 4-3. Reading room located at the CAOM in Aix-en-Provence, France ........................80

Figure 5-1. Registers dispatched to the province of New Spain, 1600..................................92

Figure 5-2. $\quad$ Document describing the loss of San Juan Bautista in parts unknown ................95

Figure 5-3. 1612 document describing the sailing instructions of the aviso ship

San Nicolás to New Spain...............................................................................97

Figure 5-4. The second letter regarding the loss of Marie Thérèse, written on February 10, 1773, at Port-Au-Prince by the governor of Saint-Domingue, Marquis Louis Laurent de Vallière

Figure 5-5. Letter describing the sinking of la Bellone off Dauphin Island (at the mouth of Mobile Bay) in 1725. 105

Figure 5-6. Letter dated March 8, 1741, describing the loss of the king's vessel that was moored at La Balise and taken out by a storm into the Gulf of Mexico, whence it was never heard of again

Figure 5-7. 1733 manuscript map of the Mississippi Delta region (detail) showing La Balise, Dauphin Island, and part of Mobile Bay 109 


\section{LIST OF FIGURES (continued)}

Page

Figure 5-8. A March 8, 1741, letter reporting to the king regarding the loss of a French naval vessel at La Balise as well as the lack of knowledge concerning another ship of the French navy, a flute, or cargo ship, called la Somme.

Figure 5-9. Letter dated October 24, 1748, confirming the loss of the king's flute le Chameau ....

Figure 5-10.

Figure 5-11.

Figure 5-12.

Spanish vessel routes in the GOM, 1504-1550

Spanish vessel routes in the GOM, 1536-1650

Routes of Nuestra Senora de la Concepción, 1621-1622

A comparison of vessel routes within the GOM, 1610-1626.

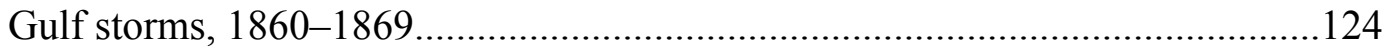

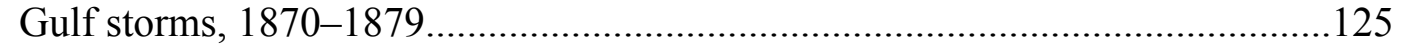

Figure 5-27.

Gulf storms, 1880-1889.

Gulf storms, 1890-1899.

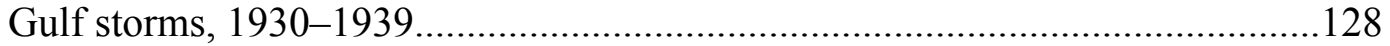

Figure 5-32.

Gulf storms, 1940-1949.

Gulf storms, 1970-1979.

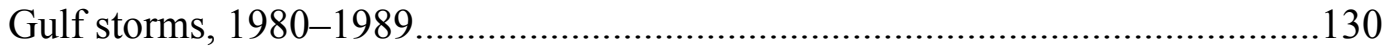

Figure 5-37.

Gulf storms, 1990-1999.

Map showing possible wreck zone of the Spanish vessel Galgo (1783).....

Figure 5-40. Map showing possible wreck zone of the Spanish vessel Descubridor (1817).

Figure 5-41. Map showing possible wreck zone of the Spanish vessel San Antonio de Padua (1600)

Figure 5-42. Map showing possible wreck zone of the Spanish vessel Santa Catalina de Sena (1600) 


\section{LIST OF FIGURES (continued)}

Page

Figure 5-43. Map showing possible wreck zone of two unknown Spanish vessels that were lost independently of one another (1600).

Figure 5-44. Map showing possible wreck zone of the Spanish vessel San Juan Bautista (1712) ........................................................................................................136

Figure 5-45. Map showing possible wreck zone of the Spanish vessel San Nicolás (1612) 136

Figure 5-46. Map showing possible wreck zone of the French vessel Marie Thérèse (1772).

Figure 5-47. Map showing possible wreck zone of the French vessel la Bellone (1725)

Figure 5-48. Map showing possible wreck zone of a French Royal Navy vessel (1732) ........138

Figure 5-49. Map showing possible wreck zone of an unknown English vessel (1732).........138

Figure 5-50. Map showing possible wreck zone of a French Royal Navy vessel (1740).......139

Figure 5-51. Map showing possible wreck zone of the French vessel la Somme (1740)

Figure 5-52. Map showing possible wreck zone of the French vessel le Chameau (1746)

Figure 6-1. Sixteenth- and seventeenth-century shipping routes in the GOM .151 


\section{LIST OF TABLES}

Page

Table 2-1. Estimated Number of Hurricanes in the Caribbean and Adjacent Regions by Month.

Table 2-2. $\quad$ Spanish Fleets, 1680-1739 .........................................................................17

Table 2-3. Estimated Total Number of Voyages from West Florida to the British Empire,

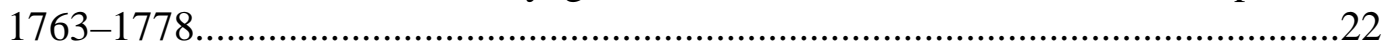

Table 2-4. Ports Established within the GOM during the Sixteenth to Eighteenth

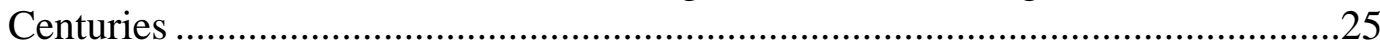

Table 3-1. Shipwreck Frequencies in the GOM, 1625-1800..........................................34

Table 3-2. $\quad$ Chronological Trends in Gulf Shipwreck Distributions by 50-Year Period...........40

Table 3-3. Shipwrecks Dating from the Sixteenth to Eighteenth Centuries Listed on the BOEMRE Shipwreck Database .............................................................................41

Table 3-4. Additional Vessel Losses within the GOM ......................................................42

Table 3-5. Historic Vessels (ca. Sixteenth to Eighteenth Centuries) Located in and Around the GOM, Documented to Varying Degrees by Archaeologists and Treasure

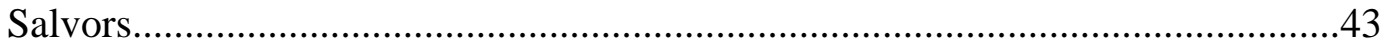

Table 3-6. Scantling Comparison between EPI and EPII ...................................................51

Table 3-7. Estimated Sediment Accumulation from 1500 to 1800 within UDW of the

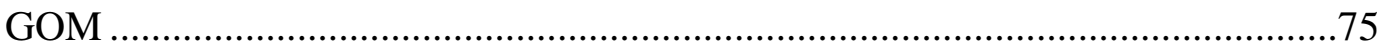

Table 5-1. Various Registers Reviewed at the AGI Relative to Inbound and Outbound

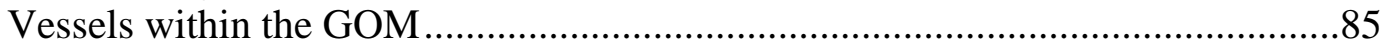

Table 5-2. $\quad$ Register of Ships Sailing to the Americas Alone (Without Fleet)...........................85

Table 5-3. Register of Returning Ships Sailing in Convoy .......................................................85

Table 5-4. $\quad$ Register of Returning Ships Sailing Alone (Without Fleet) ....................................86

Table 5-5. Total Legajos Consulted within the AGI Relative to Vessel Losses within the

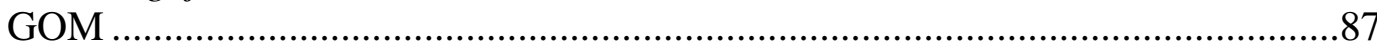

Table 5-6. Potential Vessel Losses within UDW of the GOM Identified at AGI,

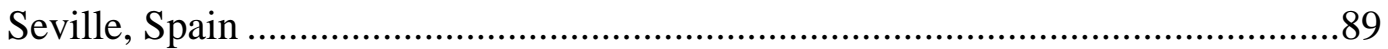

Table 5-7. $\quad$ Record Groups Consulted at the Archives Nationales, Paris, France......................98

Table 5-8. $\quad$ Record Groups Consulted at the CAOM, Aix-en-Provence, France ........................99

Table 5-9. Potential Vessel Losses within UDW of the GOM Identified at the CAOM, Aix-en-Provence, France ....................................................................................100

Table 5-10. Record Groups Consulted at the St. Augustine Foundation Center for Historic Research, St. Augustine, Florida.........................................................................113

Table 5-11. Legajos Reviewed at the P.K. Yonge Library of Florida History, University of Florida, Gainesville, Florida ..............................................................................114

Table 5-12. Vessel Losses within the GOM Identified at the P.K. Yonge Library of Florida History, University of Florida, Gainesville, Florida .............................................114

Table 5-13. Vessels with Potential for Location within the Study Area..................................141

Table 6-1. Vessel Losses Potentially within UDW of the GOM Identified at the AGI........145

Table 6-2. Vessel Losses Potentially within UDW of the GOM Identified at the

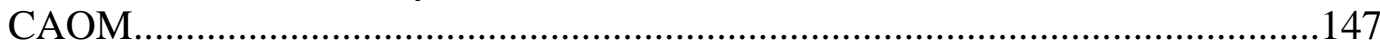

Table 6-3. Vessel Losses within the GOM Identified at the P.K. Yonge Library of Florida History 


\subsection{INTRODUCTION}

The Bureau of Ocean Energy Management, Regulation and Enforcement (BOEMRE), an agency of the U.S. Department of the Interior, is charged with the responsibility of considering the effects of its actions on significant submerged cultural resources on the Outer Continental Shelf (OCS) of the United States, from State Waters to the limit of the Exclusive Economic Zone (EEZ). This protection of the nation's cultural heritage is derived from several pieces of legislation including the National Historic Preservation Act (NHPA) of 1966 (as amended), the National Environmental Policy Act (NEPA) of 1969, the Outer Continental Shelf Lands Act (OCSLA) of 1978, and Executive Order 11593.

In an effort to protect submerged cultural resources from potential effects of oil and gas activity within the Gulf of Mexico (GOM), BOEMRE seeks to amass and assess primary archival material relative to early vessel losses (ca. sixteenth to eighteenth century) in Ultra-Deepwater (UDW) ( $>5,000$ feet) within the GOM. More specifically, BOEMRE is interested in vessel losses associated with the Spanish fleets leaving annually from Veracruz in Mexico bound for Havana, Cuba, and eventually for Spain. Losses of ships on this route are poorly understood and are the focus of this research. It is recognized that historic sailing routes likely passed over 16 oil and gas protraction areas in U.S. federal waters within the northern GOM (Figure 1-1). BOEMRE is particularly focused on the potential for early-period shipwrecks in the Sigsbee Escarpment, Keathley Canyon, DeSoto Canyon, Mississippi Canyon, Green Canyon, and Walker Ridge areas (Figure 1-2).

The fact that wooden sailing ships foundered and sunk in UDW in the GOM during the sixteenth through the eighteenth centuries is well established, but little effort has been made toward compiling a comprehensive inventory of potential deepwater shipwrecks. Most ships that sank in the open sea disappeared without a trace, usually with no survivors; thus, whatever archival record is found must be carefully analyzed to arrive at a hypothetical location for any particular loss. Spain is not the only country to have lost ships in the region; France and England have also suffered historic vessel losses within the GOM.

Southeastern Archaeological Research, Inc. (SEARCH) of Pensacola, Florida, was subsequently contracted to conduct research for the project entitled Archival Investigations for Potential Colonial-Era Shipwrecks in Ultra-Deepwater within the Gulf of Mexico. The focus of this investigation was to locate primary documents and imagery associated with historic vessels (ca. sixteenth to eighteenth centuries) that may have sunk within UDW of the GOM. Specifically, the study intended to identify potential vessel losses far from land associated with other causes such as fire, structural hull failure, foundering during a storm, or armed attack. Vessels laden with goods from Veracruz, Mexico, bound for Spain (via Havana) made the passage along a route that sailed north-northwest to about $26^{\circ}$ North Latitude before turning east toward Florida (LugoFernández et al. 2007). In addition to examining vessel losses and routes established by the Spanish, the current investigation also sought to acquire archival documents highlighting vessel losses incurred by other nationalities (including the French) as well as examining additional trade routes throughout the GOM. 


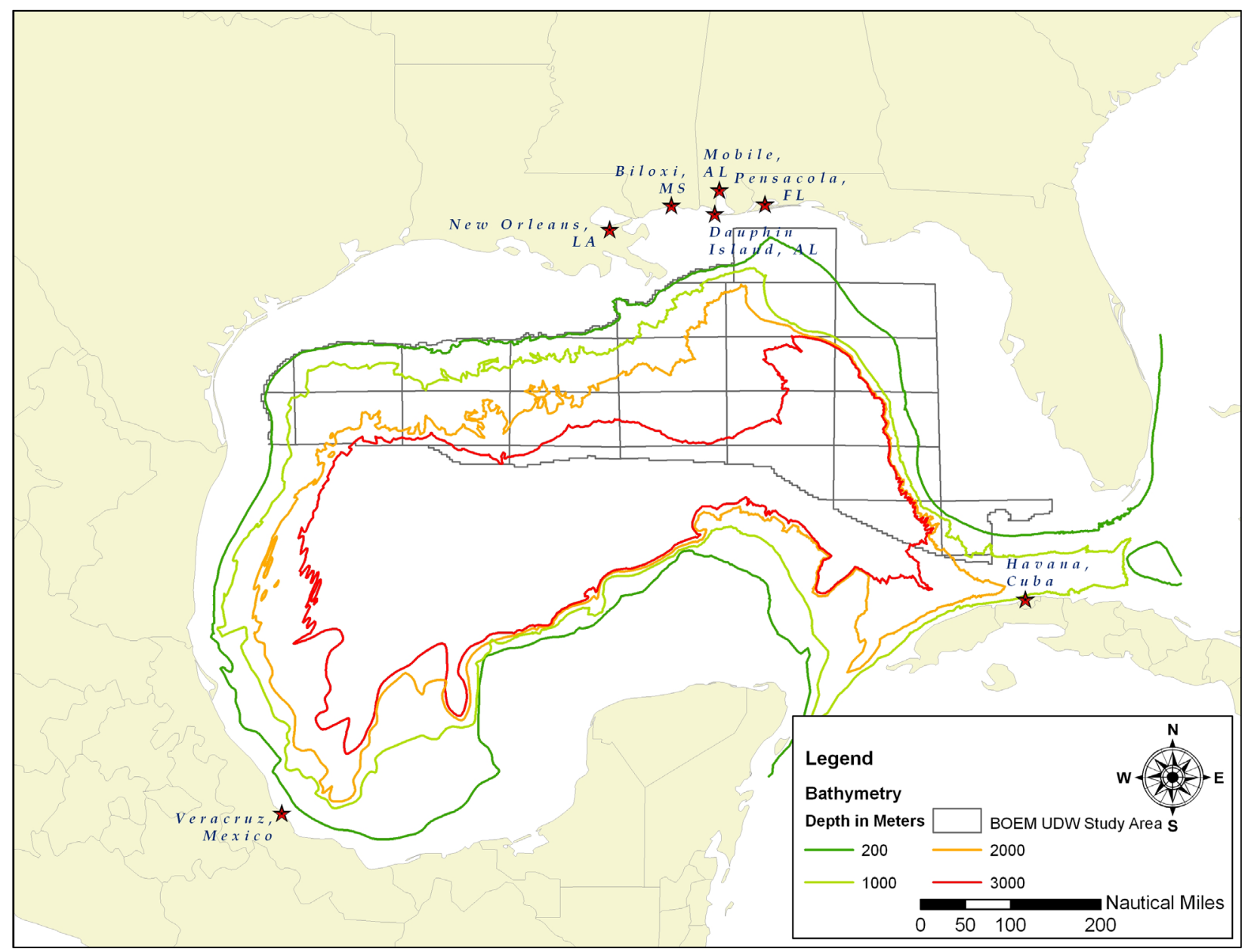

Figure 1-1. BOEMRE UDW study area including bathymetry.

Services provided by SEARCH under this contract were in compliance with BOEMRE's responsibilities under the National Historic Preservation Act of 1966 (P.L.-89-665), as amended; Executive Order 11593; the Archaeological and Historic Preservation Act of 1974 (P.L. 93-291); 36 CFR 60-66, 79, and 800, as appropriate; the Secretary of the Interior's Standards and Guidelines for Archaeology and Historic Preservation (Federal Register 1983:48:190:4471644742); applicable Texas, Louisiana, Mississippi, and Alabama State historic preservation regulations and guidelines that are in effect on the date of this contract; the BOEMRE Handbook for Archaeological Resource Protection (USDOI, MMS 1996); and other laws, rules, regulations, and guidelines as applicable and appropriate.

To achieve project goals, BOEMRE requested that various repositories be identified and visited in an effort to gather primary archival resources. Relevant documents were to be transcribed and translated to English by a professional paleographer then saved in PDF format. Historical data and imagery acquired under this contract was to be analyzed to identify each vessel casualty and establish its type, date of construction, nationality, ownership (past and present), use history, mission, and cargo (if any) at time of loss, as well as factors contributing to its loss. One of the goals of the analysis is to determine each vessel's likely location and potential present condition. Ultimately, a greater understanding of the likelihood and presence of historic shipwrecks within the UDW of the GOM will enable BOEMRE to anticipate and protect these sites. More 


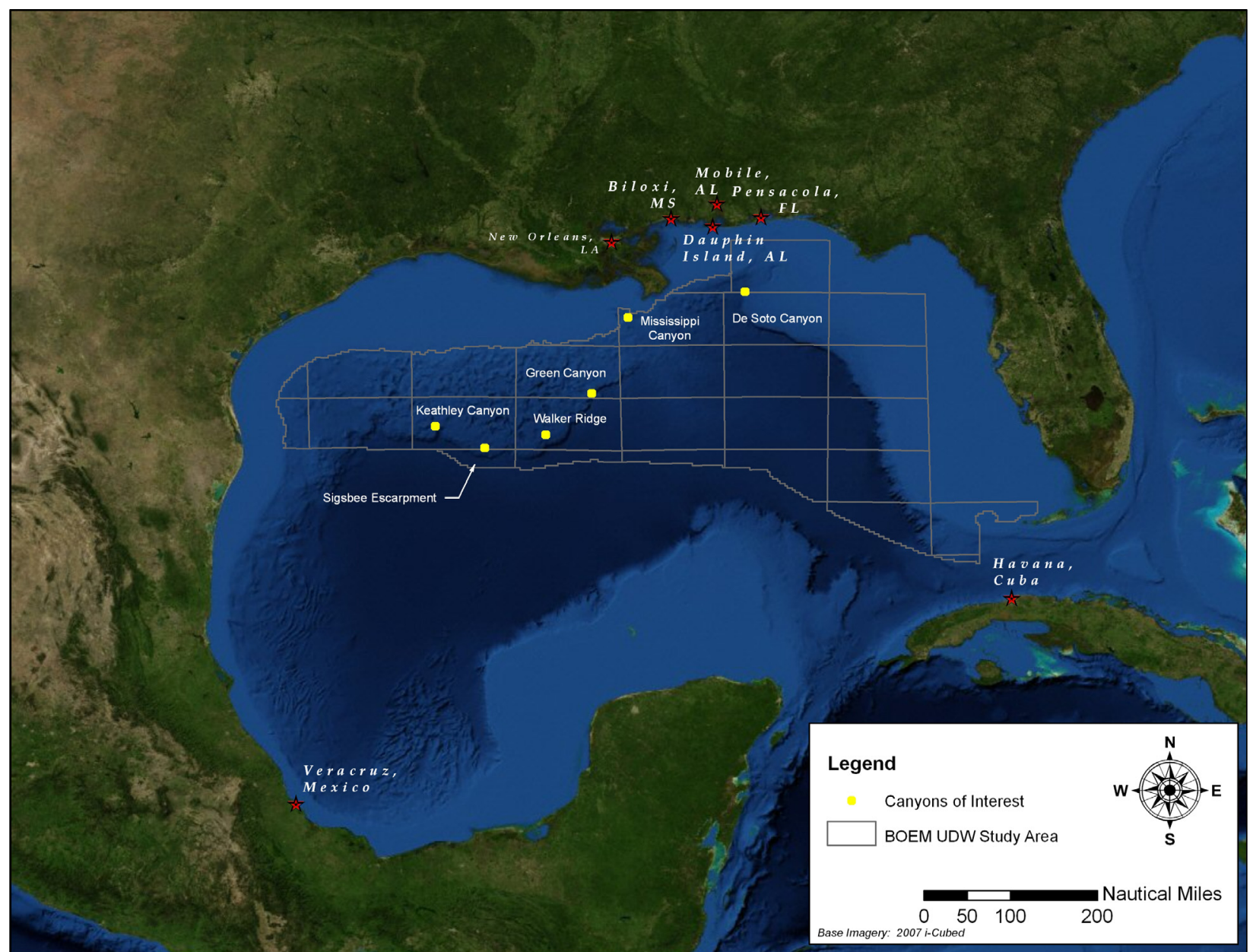

Figure 1-2. Various deepwater canyons of interest within the BOEMRE UDW study area.

specifically, archival information relative to colonial-era shipwrecks will augment BOEMRE's ability to utilize adaptive management strategies in its regulation of OCS oil and gas activities within the GOM, in an effort to minimize impacts to potentially significant submerged cultural resources. 


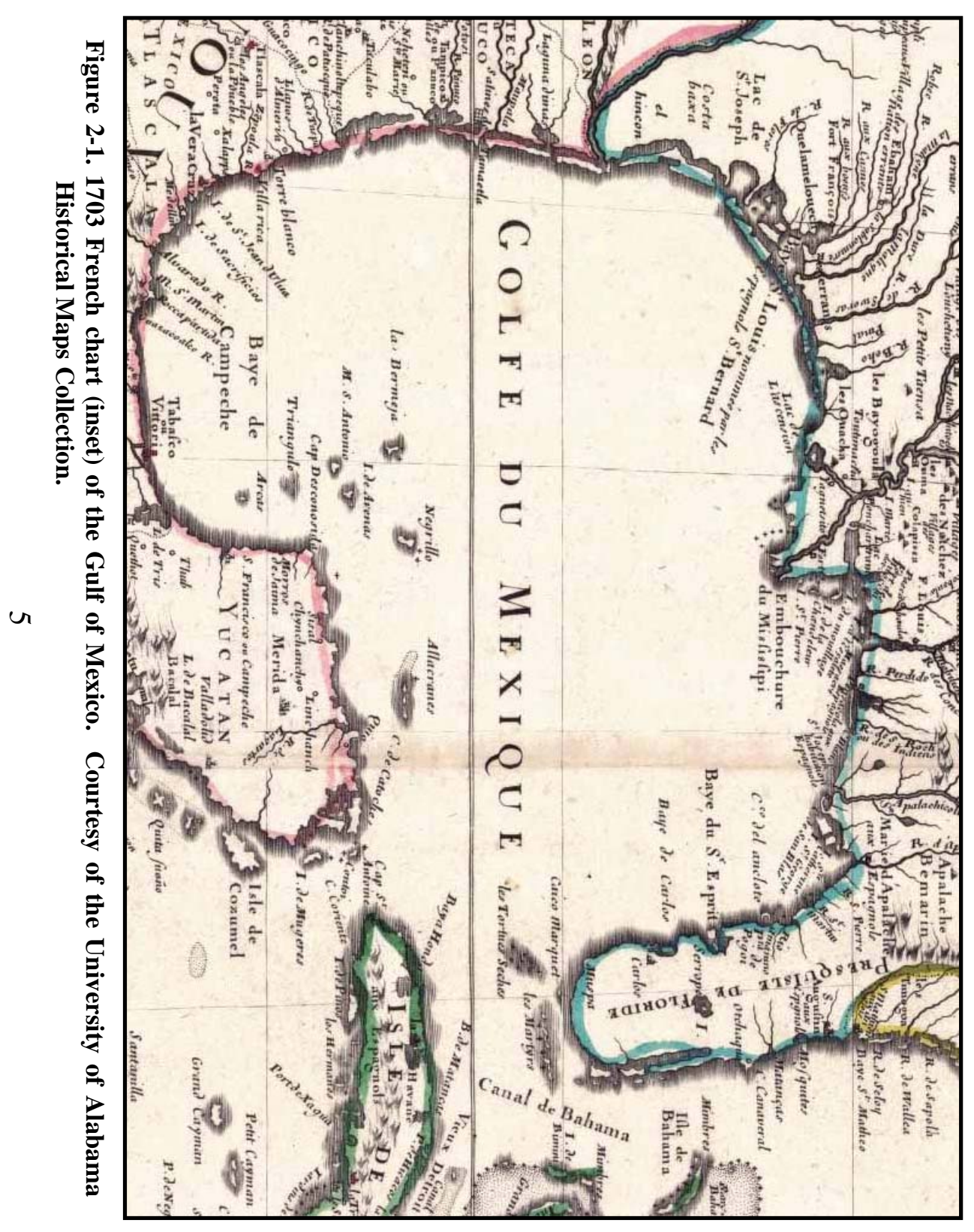

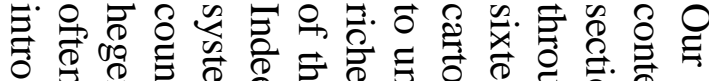

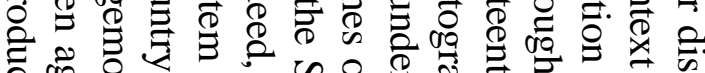

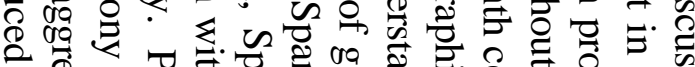

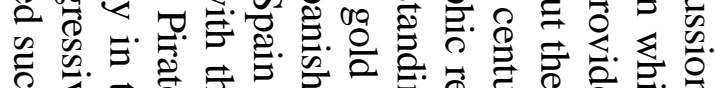

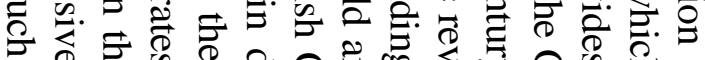

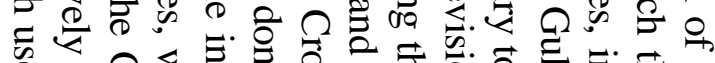

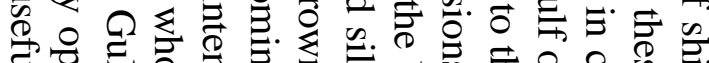

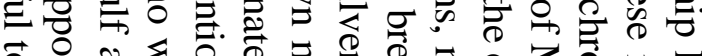

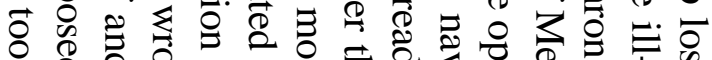

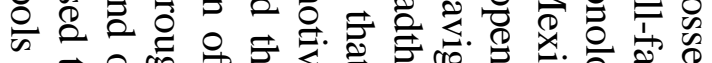

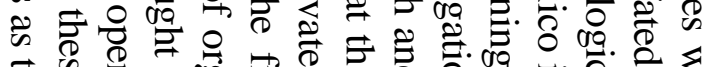

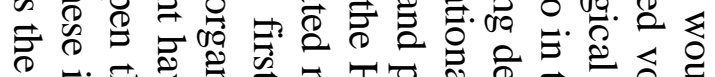

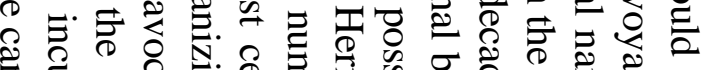

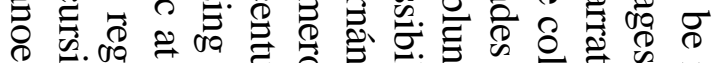

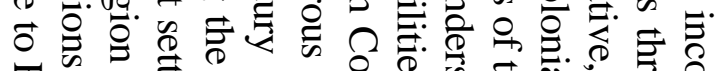

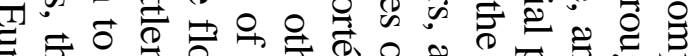

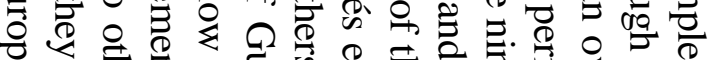

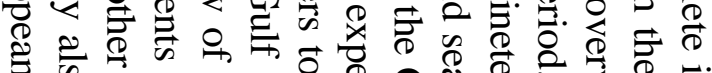

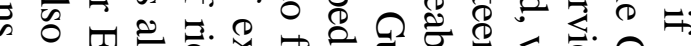

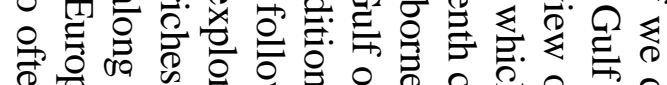

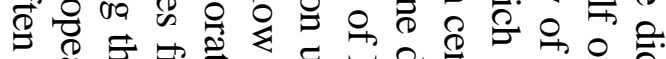

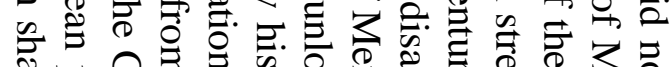
눙 0

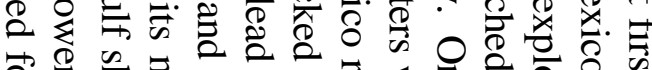

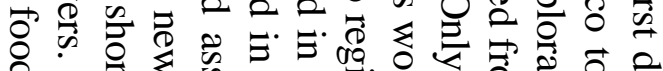

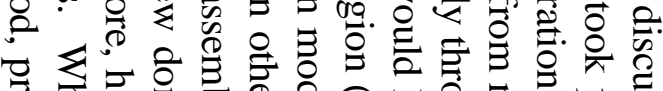

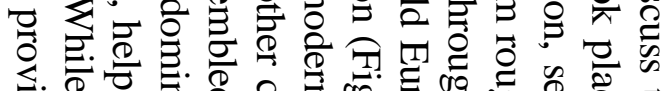

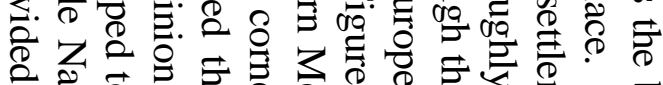

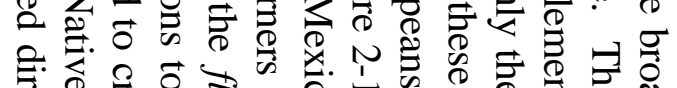

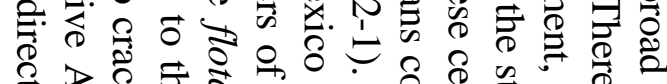

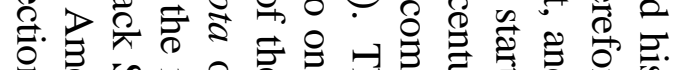

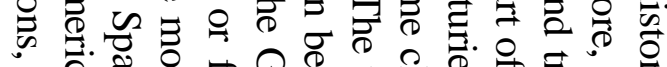

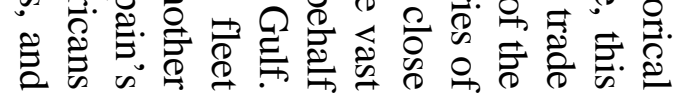


For Europeans, the Gulf became a passageway for the exploitation of what is now Mexico and the southern and western parts of the United States. In the late seventeenth and early eighteenth centuries, as wars and unrest in Europe shifted Spain's attention away from the Gulf, the French and, to a lesser extent, the English made their own inroads in the region. Finding no vast quantities of silver or gold, they explored and developed other possibilities of wealth accrual that the Gulf region had to offer-agriculture, furs, naval stores, and timber among them. Like Spain, France and England strove, via detailed trade laws, to ensure the benefits for the mother country.

The latter half of the eighteenth century, however, saw the gradual unbinding of trade restrictions in Europe's American colonies, including those of the Gulf, as the march toward independence began. From the Spanish naos of the early sixteenth century to the multinational and assorted vessels of the early nineteenth century, ships were the thread that wove this history together.

\subsection{From Contact to Colonies: The Gulf of Mexico in the Sixteenth Century (1500-1600)}

The Europeans who reached the Gulf of Mexico at the start of the sixteenth century were without today's basic knowledge of the geographic extent of the Gulf. This body of water, an arm of the Atlantic, measures 1,600 kilometers (approximately 995 miles) from east to west, 900 kilometers (approximately 560 miles) from north to south, and has a surface area of 1.5 million square kilometers (580,000 square miles). The shoreline from present-day Cape Sable, Florida, to the tip of the Yucatán Peninsula is approximately 5,700 kilometers (3,540 miles). Another stretch of shoreline, the northwestern part of Cuba, is approximately 380 kilometers (approximately 240 miles). Along this shoreline are countless reefs, banks, and islands of various sizes. The total shoreline increases to 27,000 kilometers (16,780 miles) if the width of its many bays, estuaries, and rivers is included. Naturally, water flows into the Gulf through the Yucatán Strait between Florida and the Yucatán Peninsula and exits through the Florida Strait between Cuba and Florida, eventually forming the Gulf Stream along the western coast of Florida (Nipper et al. 2010). Over the course of several centuries from their initial contact with the Gulf, at the expense of or with the assistance of Indians and Africans, Europeans opened this vast region to the Old World.

Europeans first reached the Gulf of Mexico nearly a decade and a half after Christopher Columbus's first voyage to the New World. During his fourth voyage (1502-1504), Columbus skirted the western coast of Central America but did not reach the Gulf, yet he noted strong currents that pulled his ships toward the Yucatán Channel. Sebastiàn de Ocampo, a former servant of Queen Isabella of Spain who had come to Hispaniola on Columbus's second voyage as an exile, has been recognized by Gulf historian Robert S. Weddle (1985) as the first European to discover the Gulf of Mexico. Ocampo, though restricted to Hispaniola by the terms of his exile, circumnavigated Cuba on behalf of colonial officials at the start of the sixteenth century (Bourne 1904:105; Shipp 1881:4). During the journey, which took place from 1508 to 1509, Ocampo and his crew witnessed the open Gulf as they rounded the western part of Cuba. However, the Spanish did not continue exploration of the Gulf for several years. 
In 1513, Juan Ponce de León, whose three ships haphazardly reached the western shore of Florida, was the next to enter the Gulf. Later voyages of Hernández de Córdoba (1517) and Juan de Grijalva (1518) to the Yucatán peninsula and Mexico, though sometimes disoriented and always in conflict with local Indians, resulted in a growing number of maps and stories about the Gulf. Some of these early sources were highly speculative and others sheer fantasy, but they were enticing enough to inspire further exploration. The Spanish Empire, heavily focused on acquiring precious metals, had nearly exhausted the supply of gold and silver in the Caribbean and depleted the Indian labor force. The Spanish viewed the Gulf region as the next frontier, a land of treasures untold (Weddle 1985).

The Hernán Cortés' expedition, consisting of a 100-ton nao, three 80-ton caravels, and seven smaller vessels, set out from Cuba in 1518 to explore the Gulf region. He and his army would spend the next decade brutally conquering the metal-rich Aztec Empire which, in 1521, Cortés renamed El Nuevo España del Mar Océano, New Spain of the Ocean Sea. During the 1520s, Cortés also halted the expeditions of other Spanish conquistadors at the Pànuco River region in northwestern Mexico and in Honduras. He stifled the other explorers as means to protect his empire since he planned on establishing a colony on the river, which was rumored to be navigable and had deposits of gold and silver. As a means to control trade, in 1519, the Cortés expedition established the port of Veracruz (San Juan de Ulua), which would later serve as a major port, fortress, prison, and royal palace. Another result of the Cortés expedition was the creation of a new map of the Gulf of Mexico in 1524 (Figure 2-2). The map was based on Pineda's Chart after his cruise around the Gulf coast looking for a passage to the west and the Pacific Ocean. Unlike earlier charts, Cortés's chart provides a fairly accurate location of La Florida, Cuba, and Yucatán; however, the Yucatán is still shown as an island, as it had been from the earliest maps. Even with this level of exploration, there still remained many questions and much confusion about the geographical extent and potential of the region (Weddle 1985).

Until the early 1540s, the Gulf of Mexico had no name to the Spanish other than el Mar Océano ("the Ocean Sea"), the name given to the Atlantic Ocean, as the earth's oceans were considered to be one. After Vasco Núñez de Balboa's sighting of the Pacific Ocean in 1513, cartographers renamed the Atlantic the North Sea and the newly discovered ocean the South Sea. Indeed, new discoveries led to further specification, and the Gulf became variously known as el Seno Mexicano (the Mexican gulf or Mexican pocket), the Golfo de México, and Golfo de Nueva España (Weddle 1985).

With the Spanish conquest of Mexico and Central America well underway by the late 1520s, Spain devoted new energy to exploring and conquering other parts of the Gulf shore that might yield riches similar to those of the Aztecs. In 1527, Francisco de Montejo targeted the Yucatán, beginning a 20-year campaign to assert Spanish dominance in the region (Mathes 2005:6). That same year, Pánfilo de Narváez, a veteran of earlier expeditions across Jamaica and Cuba as well as one against Cortés in Mexico, was permitted to lead the conquest of Florida. The Narváez expedition illustrates the lack of understanding of the Gulf region at the time as well as the blinding nature of greed. Reaching modern-day Tampa Bay in April 1528, Narváez and most of his army disembarked and proceeded northward, planning to reunite with the ships at a bay that was thought to be up the peninsula. Pushing through a nearly incessant assault by the native Timucua and Apalache, and matching it with his own brand of brutality along the way, 


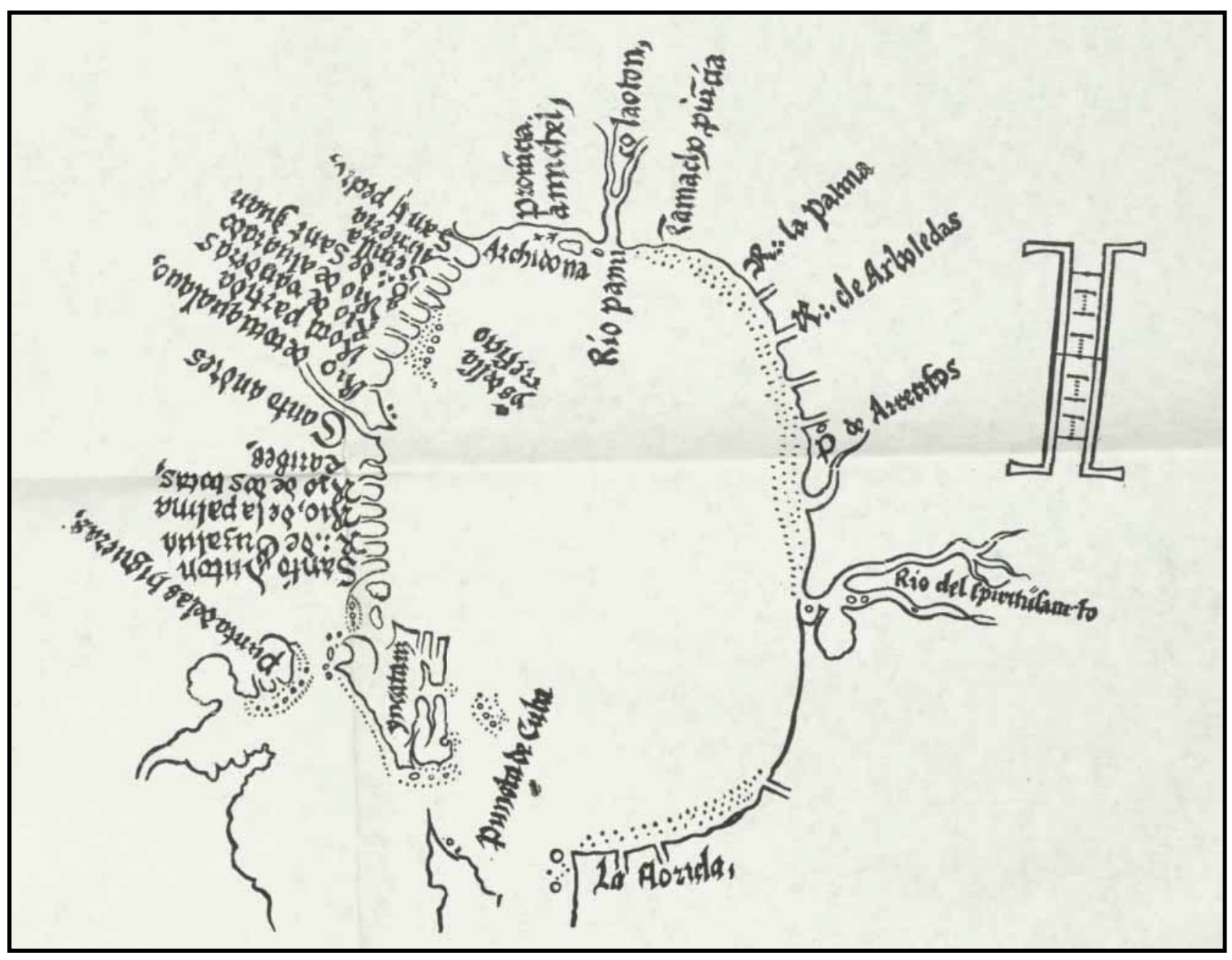

Figure 2-2. 1520 map of the Gulf of Mexico created by Hernán Cortés. Courtesy of the University of Miami Libraries.

Narváez's expedition gradually disintegrated. With the fleet disoriented or returned to Cuba, the stranded party, now in Ochlocknee Bay, made five crude boats of local wood and horsehair rope. Several of these boats made it as far as the Matagorda Island area of Texas, where Narváez became "very feeble, sick, and full of leprosy," according to one of his counterparts (Weddle 1985:197). Narváez and a two-man crew departed into the Gulf and disappeared. The other stragglers, among them Cabeza de Vaca, who famously recounted the odyssey, watched their numbers dwindle to just a few; years later, in 1536, they were finally rescued by a Spanish slaving ship in the Sonora region of Mexico (Weddle 1985).

The disastrous failure of the Narváez expedition did not deter Spain's quest to master the Gulf of Mexico region. A veteran of the Francisco Pizarro conquest of Peru, Hernando de Soto and 500 cohorts landed in Florida in 1538 near Tampa Bay. For the next half-decade, he and his men left a trail of havoc across the modern southeastern United States and down the Mississippi River (which they called the Rio del Espiritu Santo), the muddy bottom of which became de Soto's final resting place in 1542. The 322 survivors, finished with the conquest, fashioned seven boats made of local material and whatever else could be spared. A 53-day voyage through inclement weather, decreasing water supplies, and clouds of Indian arrows and mosquitoes surprisingly brought them to the Spanish settlement on the Panúco River (Weddle 1985). Again, it appeared 
that the natives and the natural climate of Florida would make it impossible for Spanish colonization.

While the Spanish conquistadors met with varied success along the Gulf of Mexico, Spanish colonial officials had to face new threats from their European neighbors. In the early years of Spanish colonization, when the New World's seas were largely unknown to other European powers, the Spanish merchant fleets required little security. Usually a single warship accompanied each fleet and served as adequate protection (Phillips 1986). However, as knowledge of the riches of the Americas increased among other European nations by the 1520s, the risk to the safety of the Spanish fleet became greater. In 1513, Spanish sailors discovered that the Gulf Stream would take ships back to Spain from the port of Havana, and, by 1523, the Spanish Crown had made the defense of the sea lane a major priority. The Spanish Navy organized a naval squadron called the Armada de la Guardia de la Carrera de las Indias to police the European side of the trip, since the only real threat was from French raiders. However, after the outbreak of the fourth Habsburg-Valois war in 1542, Spanish officials, fearing the expansion of the raiders, ordered all ships sailing to and from the New World to sail in groups of at least 10 ships and to be armed (McAlister 1984:201-202). This convoy system would provide the basis of future Spanish naval practices in the New World.

With the expansion of pirates and privateers in the Caribbean in the 1560s, Paul Hoffman (1980:126) argues that the merchants in Spanish ports such as Seville forced the Spanish government to issue a series of laws passed between 1564 and 1586 that revised the fleet system, reestablished the convoy system, and set the stage for trade until the latter eighteenth century. The new military strategy called for the Spanish Navy to assign four heavily armed warships, also known as the Armada de la Guardia de la Carrera de las Indias, to the merchant convoys or flotas. One squadron (two ships) would sail with the Tierra Firme (northern South America) fleet, while the other squadron would sail with the New Spain (Mexico) fleet. The two largest warships that escorted the fleet were referred to as the capitana, and the two lesser warships were referred to as the almiranta. For the reminder of Spain's active role in colonization, the bulk of its trade with the New World, generally known as the Carerra de las Indias, sailed on these great fleets (Lugo-Fernández et al. 2007; Phillips 1986).

As part of the convoy system, the Spanish also created a prevailing ideal timetable for voyages. Wind and weather conditions as well as international relations shaped the timetable of the fleets. Voyages were planned in order to avoid stormy seas as much as possible and to avoid the fever season of New World ports. Historians have offered numerous explanations of this timetable, but Carla Rahn Phillips' explanation seems to be the most accurate. From 1555 on, Phillips suggests, the Spanish sent two annual convoys to the New World: one to New Spain and one to Tierra Firme. Between 1561 and 1564, the Crown, along with the Council of the Indies and the Casa de Contrataciòn, developed an official schedule. The New Spain fleet was to depart Spain in April and the Tierra Firme fleet in August. In practice, the New Spain fleet left about July 1, reached Havana for nourishment by August, and finally arrived in Mexico the following month. This timetable avoided most of the pestilential summer of New Spain while risking late summer storms in the Gulf. Once in New Spain, the fleet conducted business through winter and spring. In May or early June, they departed for Spain via another stop of several weeks in Havana, 
where they were to reunite with the Tierra Firme fleet, whose schedule was slightly different. The New Spain fleet reached Spain by October 1 (Phillips 1986).

Spain tried to plan for the security of the fleet and stick to a specific schedule, but it was often challenging. Several problems affected the Spanish economic pursuits in the New World. Money shortages slowed outfitting in Spain, disruptions in Europe hampered the ability of Spanish merchants to fill cargoes, and sailing difficulties often emerged in the long route from the Old World to the New World. Wars also created interruptions (Phillips 1986). The 1554 shipwrecks on Padre Island provides an illustration that the flota did not always transpire as planned - some ships left early, some left later, and some did not make it at all, and ships were scuttled once they made it to the New World (Arnold and Wickman 2010).

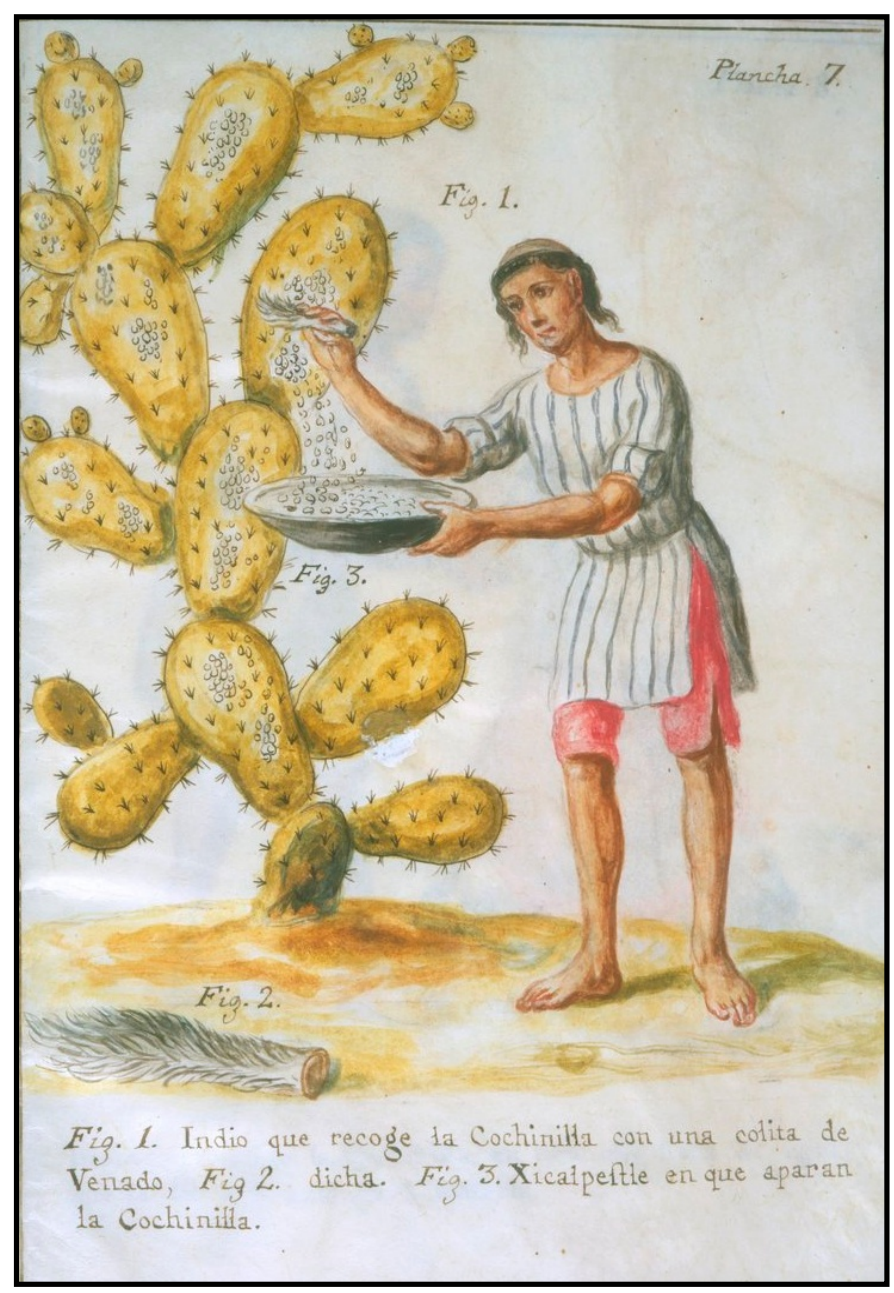

Figure 2-3. 1777 depiction of an Indian harvesting cochineal. This vibrant dye, prized in Europe, was derived from insects that attached themselves to cacti in certain regions of New Spain (Mexico). Printed in Memoria sobre la naturaleza, cultivo, y beneficio de la grana by José Antonio de Alzate y Ramírez.
The loss of three Spanish vessels and the lives of nearly all passengers underscored to Spain the need for better navigational knowledge and security in the Gulf of Mexico. In April 1554, four Spanish ships set sail from Veracruz on their return voyage to Spain via Havana with a cargo of cochineal, bales of cowhides, produce, an estimated 2 million pesos, and over 300 passengers (Figure 2-3). Twenty days out, a Gulf storm cast three of the four vessels on Padre Island along the southern coast of present-day Texas. The fourth vessel later reached Havana in decrepit condition. More than half the passengers of the three stranded ships drowned. A small contingent is believed to have traveled back to Mexico to report the accident while the other survivors began what they thought would be a short trek southward toward Mexico. The physical difficulties of the journey as well as harassment by Indians reduced their number to but one survivor, an arrow-riddled priest who reached Tampico. Veracruz sent out a salvage operation, but a more complete recovery of the material losses was not made until the mid-twentieth century (Arnold and Wickman 2010; Weddle 1985).

Dr. Pedro Santander was one of few voices that spoke of the hazards of mounting expeditions to the unconquered 
areas of the Gulf coast that were solely focused on harnessing precious metals or saving souls. As the royal overseer of Veracruz, Santander recommended that securing the entire Gulf of Mexico should be of equal importance to saving souls and gathering wealth. He advocated the creation of a Gulf patrol that would serve to protect ships, salvage losses, rescue castaways, and establish and supply coastal garrisons from Veracruz to the western coast of Florida. Santander also noted that future expeditions should investigate what past ones had typically ignored: the possibility that other types of wealth, aside from precious metals, existed in the Gulf region. While Santander was not elected to lead an expedition of his own, his ideas are thought to have influenced later efforts, such as Pedro Menéndez de Avilés' bold, yet ultimately failed, attempt to establish Spanish outposts on the western coast of the Florida peninsula (Weddle 1985).

The Spanish economic colonization of Mexico and the Gulf of Mexico was not entirely in the hands of Spaniards. A small number of English merchants operated out of Veracruz as guests of the Spanish during a brief period of comradeship in the mid-sixteenth century. Englishman John Hawkins, a slave trader and semi-pirate, was the first to make a detailed account of what he saw in Veracruz and the Gulf. His incursion into the Gulf of Mexico was a portent of things to come. Attempting to trade in the Caribbean, Hawkins' assortment of ships was blown off course into the Gulf of Mexico. As the Spanish-English relationship declined, English ventures into the Gulf became more antagonistic, and Hawkins returned to the Gulf in 1568, this time traveling all the way to San Juan de Ulúa. There, the arriving Spanish fleet intercepted Hawkins and his force. In retreat, Hawkins left 114 men in the Panúco River region, where most of them later died (Walling 1907).

Hawkins' activities against Spanish shipping in the Gulf became commonplace. English pirates scorched Campeche and then Tabasco in the 1590s. Piracy - whether the work of buccaneers, privateers, corsairs, or filibusterers - grew to plague proportions in the Gulf of Mexico in the ensuing decades (Weddle 1985). After the defeat of the Spanish Armada in 1588 and the shift in political power in Europe, Spain was never more at risk of losing control of the riches it had so carefully guarded.

Also, the Spanish faced other European nations and the privateers they brandished. For example, Piet Heyn, a Dutch privateer captain, overtook the flota in 1628 at Matanzas, Cuba. With the flota consisting of two galleons and 11 merchant ships from New Spain and two galleons from Honduras, the incident was a catastrophe for Spanish shipping and colonial administration. The ships carried cargos of silver, gold, pearls, indigo, sugar, and "Campeche wood" as well as silk and dyestuff. From 1628 to 1635, the Dutch were relentless in their attacks on Spanish shipping in the Caribbean (Lane 1998:70; Phillips 1986; Weddle 1985).

Early in the colonial period, when the riches and opportunities of the New World were just becoming known, the Spanish Crown typically allowed only native Spaniards to sail on its ships as a way of promoting secrecy. Of course, a glaring exception was the man credited with opening the New World for Spain, Christopher Columbus, who was Genoese by birth. As time passed and native sailors became difficult to recruit, foreigners were permitted aboard. Ferdinand Magellan's expedition of 1519, to cite one example, was a veritable melting pot. Portugal, Italy, France, Germany, and Sicily were several of the many states represented among 
the crew (Taylor 1922). This use of multinational crews resulted in other nation-states' gaining experienced seamen.

Devised in the fourteenth century, the Consulado de Mare was the law that governed the conditions of service for sailors in the Spanish empire in the colonial period (Taylor 1922). By its terms, a potential sailor had to be 20 to 50 years of age and have approximately three years of experience as an apprentice. After 1582, King Philip II ordered that sailors had to provide a certificate to demonstrate that they had recently confessed their sins. There were several terms under which sailors could be contracted to ship owners. They could be paid for the duration of the voyage, paid a lump sum, paid by the month, or paid by the mile (even if that meant "to the end of the world" [actual law quoted in Taylor 1922:634). The law also allowed sailors to labor in return for a share of the freight or for the right of the sailor to load goods on his own account (Taylor 1922).

In addition to economic opportunities, the sea also offered some other material benefits. Rations, in some cases, were better than what was offered on land in Europe. In 1534, the basic daily ration typically consisted of 1.5 pounds of bread, two pints of water, two pints of wine, and a pint of water for bathing. In addition to this, a portion of salt pork, fish, or sometimes beef was added and/or beans, peas, oil, vinegar, and rice. Indeed, a steady supply of food was motivation enough for many a sailor, but the mishaps of sea travel had a way of compromising the onboard supply of rations. Even the most bountiful supply of rations could suffer from intrusion by seawater, invasions by cockroaches and rats, and unexpectedly extended voyages (Taylor 1922).

Starvation concerns aside, there were other discomforts for sailors that could and often did lead to death. Disease is perhaps the most obvious and often stemmed from the unsanitary conditions aboard and in port. Yellow fever, cholera, scurvy, and other maladies could severely reduce a crew in this era of primitive medical knowledge. Sailors also learned that New World civilizations were also sometimes very hostile to the Europeans. Nearly everywhere the early expeditions to the New World landed, the Spanish and the Indians violently clashed. Because of the new environment, a simple wound could lead to infection and death. Capture by the Indians could also lead to torture or sacrifice. For these and other reasons, Spanish captains and officers kept tight restrictions on sailors going ashore (Taylor 1922; Weddle 1985).

Discipline onboard was strict. For quarreling with the ship owner, a sailor could be penalized half his wages or the goods he carried in the ship. The gravity of the offense dictated the punishment. For raising a weapon against the ship owner, the sailor was bound and locked in the ship's prison. Those onboard who failed to assist in restraining such an offender were also punished. On occasions when a sailor believed a ship owner was wrongfully attacking him, the sailor was not permitted to defend himself unless he could attract a group of witnesses. But until he had sufficient witnesses, the sailor's only recourse, as defined by the Consulare de Mare, was to elude his assailant by running from one end of the ship to the other. Mutiny was punished by the death penalty (Taylor 1922).

Given the inevitable hardship and peril of a life as a sailor, what compelled men to go to sea? Pablo E. Pérez Mallaína (1998) delineates a number of reasons in his study of the men of the sixteenth-century Indies fleet. The poverty of one's homeland was probably the most compelling 
force. On a ship, there was at least an understanding that one would be regularly fed. Some were drawn to a life of adventure. Stories of unknown empires, golden hills, and abundant native women sounded better to some than the isolation of rural life. The sea also offered opportunities of advancement that might not have been available on land, and so some sought out this life in hopes of gaining wealth or prestige. Others, whose fathers or uncles served as pilots, captains, or officers, were carrying on a family tradition. Not all sailors chose the life on their own volition. Many a sailor's career began as the result of being kidnapped onto a ship (Pérez Mallaína 1998).

Adding to the often arduous and miserable life of a colonial sailor was the terrifying possibility of shipwreck. As illustrated above, shipwrecks in the New World offered many additional dangers to the sailors. A variety of forces could cause a shipwreck. For example, sailing at night was risky because the sheer lack of visibility increased the chance of slamming into a reef. Also, fire was not an infrequent cause of shipwrecks. A carelessly placed candle or an unattended cooking fire could engulf the ship in short time. In 1561, 23 ships moored in Seville burned. Reports indicated that the source of the blaze was a sailor who had set a cat on fire. Of course, corsair, privateer, or pirate attacks certainly also jeopardized the well-being of a ship and its crew. When faced with these outside threats, the sailor quickly turned into a soldier. Because the

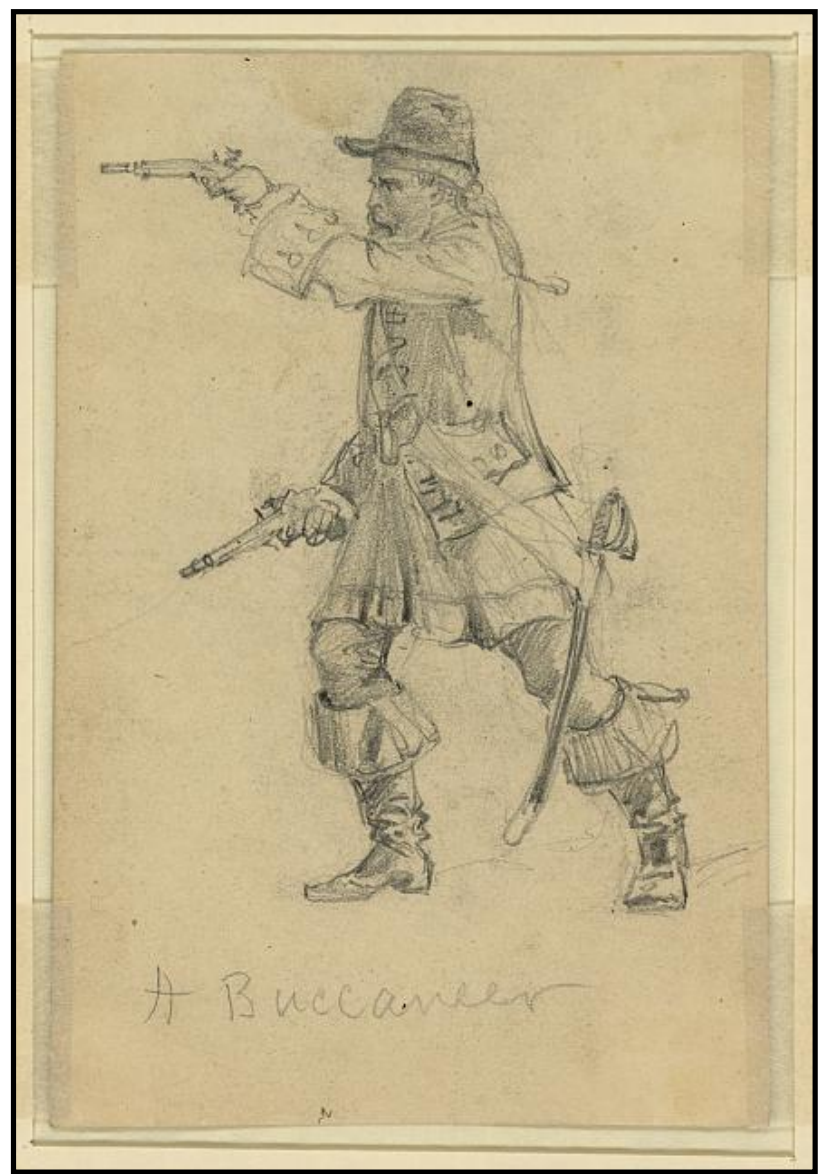

Figure 2-4. Mid-nineteenth-century depiction of a buccaneer by Alfred R. Waud. Courtesy of the Library of Congress. punishment for pirates was death, both sides usually fought savage battles (Pérez Mallaína 1998) (Figure 2-4).

The most obvious cause for the loss of a ship, perhaps, was the force of nature. Heavy waves could overturn a ship or literally pound it to pieces. An overloaded ship, as were many vessels of the colonial period, was especially at risk of meeting this fate. Midsixteenth-century pilot Juan Escalante de Mendoza noted that a ship loaded to the mast tops was like a "flask filled with water, which a small blow could break into pieces" (quoted in Pérez Mallaína 1998:177). Terrifying as it must have been to be aboard a distressed ship on the open sea, shipwrecks most frequently occurred in the vicinity of the coast, where reefs and other uncharted obstacles were constant hazards. So common was this threat that, even in the event of a severe storm, a ship's captain preferred to fight it in the open sea rather than risk being dashed against the rocks (Pérez Mallaína 1998).

Very prevalent in the Gulf of Mexico, especially during the shipping season, hurricanes (and in other seasons, northers) 
were a horrifying experience (Table 2-1). When a storm was on the rise, the first order was to feed the crew in order to provide them with energy for the certainly long battle ahead. The captain, master, and pilot stoked the crew with vows to fight alongside them. The initial tactic was to secure the sails and rigging. To do this amid the howling winds and surging waves of the mad sea was to risk one's life. Because of the wind and rain, communication and vision were severely compromised. Such a terrifying situation worsened when the hull was breached. Tarred canvas could be used to bandage these holes, but hand-operated bilge pumps were the primary means of removing the water. All available manpower was assigned to the task. Around the inside of the hull, a line of chalk represented the maximum height to which the water could rise without the ship's sinking. The men furiously worked for days and sometimes longer to remove the water.

Table 2-1

Estimated Number of Hurricanes in the Caribbean and Adjacent Regions by Month

\begin{tabular}{|l|l|l|l|l|}
\hline \multicolumn{1}{|c|}{ Month } & $\mathbf{1 6}^{\text {th }}$ Century & $\mathbf{1 7}^{\text {th }}$ Century & $\mathbf{1 8}^{\text {th }}$ Century & \multicolumn{1}{c|}{ Total } \\
\hline June & 2 & 1 & 2 & 5 \\
\hline July & 4 & 1 & 17 & 22 \\
\hline August & 7 & 11 & 39 & 57 \\
\hline September & 9 & 14 & 32 & 55 \\
\hline October & 6 & 10 & 23 & 39 \\
\hline November & 1 & 0 & 7 & 8 \\
\hline December & 0 & 0 & 1 & 1 \\
\hline Month unknown or not well defined & 15 & 22 & 29 & 66 \\
\hline Total & $\mathbf{4 4}$ & $\mathbf{5 9}$ & $\mathbf{1 5 0}$ & $\mathbf{2 5 3}$ \\
\hline
\end{tabular}

Source: Millás 1968

Besides natural forces, problems with the ships themselves could wreak havoc with a crew. For example, in the 1520s, the voyage of Álvaro de Saavedra Cerón to the Moluccas ran into such trouble when a leak was discovered shortly after departure from Mexico. The crew of the flagship spent two and a half months fighting the leak. Andrés Urdantea, a survivor of the Loaísa Expedition, another voyage of this period, recounted the experience of operating the pumps:

And with the high seas we experienced, the ship opened up in many places. As it was so stormy, we took on so much water that even with two pumps worked with hard labor we were not able to accomplish much, and each day we thought we were going to drown.... If we went two hours without working [the pumps], we spent another two hours working them, and we were also hard pressed by the sea and by the scant and spoiled rations and little water, and many died from overwork (quoted in Pérez Mallaína 1998:72).

When the force of water became too strong, it was time to start throwing cargo overboard. The ballast was first to go, followed by the least valuable merchandise, the sea chests of sailors and passengers, and the cannons. If this did not work, the superstructures of the ship were cut down and the masts felled, and in extreme cases the hull was girdled with anchor cables to keep it from breaking apart. The most severe cases of disrepair, however, rarely called for the chucking of 
precious metals. When all efforts failed, the ship was abandoned (Pérez Mallaína 1998). Of course, the primary goal was to save the ship and the cargo.

By the late sixteenth century, the Spanish galleons shipped precious metals to Spain for private individuals as well as the Crown. When used in this context, these ships were called armada $y$ flota or galeones de plata (Phillips 1986). The Spanish Crown granted permission for the operation of so-called navios de aviso, or dispatch ships, and also navios de azogue, or mercury ships. Smaller and faster than the galleons of the fleet proper, these small boats served important roles other than transporting precious metals. The navios de aviso informed colonists of the dates of departure of the fleet from Spain and returned to the mainland with news from the colonies. The navios de azogue mainly served the silver industry of New Spain by transporting mercury that was sent to the mines for use in the processing of silver ore. Because of mercury's importance in silver production, in 1559, Spain made mercury a state monopoly and granted it additional protection. Neither of these smaller fleets was permitted to carry additional goods and passengers until the late sixteenth century. By the middle of the seventeenth century, navios de azogue received the right to carry goods and military ammunition (Pearson and Hoffman 1995; Márquez 2006).

\subsection{New Explorations: The Gulf of Mexico in the Seventeenth Century (1600-1700)}

Despite Spanish explorers' and navigators' numerous attempts to understand it, the Gulf shore from the Florida peninsula westward to the Río Grande remained tierra incognita as late as the seventeenth century. Three-quarters of a century would pass without any significant settlement or notable advances in geographical understanding on the behalf of Spain. There were several causes for this delay. First, European wars distracted Spain's efforts in the Gulf region, as did an upswing in piracy. Often operating irrespective of peace agreements in Europe, pirates flew under Dutch, French, or English flags, and nearly as often they functioned independent of any nation. By the close of the seventeenth century, pirates had attacked most of the Spanish settlements of the Gulf of Mexico at least once, resulting in slower merchant trade and impeding the growth of the settlements (Weddle 1985).

As the case of Puerto de Caballos, Honduras, demonstrates, piracy could have a long-lasting impact on local economies. The port had emerged as a center for cochineal export by the time Dutch corsairs attacked in 1625 . So devastating was the Dutch attack that the growing port was shut down for many years. Nearly two decades passed until it reopened, and not until the completion of a fort at the mouth of the harbor did it truly develop as a port (Lee 1951). Pirates harassed local and international shipping in the region and, in some cases, exhausted local economic resources. English pirates denuded valuable logwood and dyewood stands in some parts of the coastal Gulf (Weddle 1985).

Some parts of the Gulf region were beds of pirate activity during the period. French and English pirates first struck the fledgling Spanish port settlement at Apalache (now St. Marks, Florida) in the 1670s. To prevent against future attacks, the Spanish built a fort, Fort San Marcos de Apalache, but a return attack in 1682 again destroyed the settlement. On this occasion, the pirates also captured a merchant ship from Havana that was in port. In the meantime, Anclote 
Key (off the coast of present-day Pinellas County, Florida) had become a haven for pirates, whose numbers were estimated at 400 . They terrorized ships en route from Havana to Mexico. These attacks paled in comparison to the so-called Rape of Veracruz in 1683, when a thousand pirates had their way until the Spanish fleet drove them off. The pirates next targeted Campeche. Spanish officials countered the pirate threat by establishing the Armada de las Islas de Barlovento y Seno Mexicano in 1635 as a concerted effort to rid the Gulf of pirates, but manpower shortages, geographic overextension, and lack of financial support limited its impact (De Quesada 2006:50; Weddle 1985).

As the marauders were tramping all over the sea and shore that the Spanish had considered theirs for a century, the Spanish in the Gulf could do little to quell the problem because of trouble at home and the geographical expanse of piracy, much less devote attention and sponsorship of new explorations of this mysterious region. France, therefore, assumed the role, particularly in the

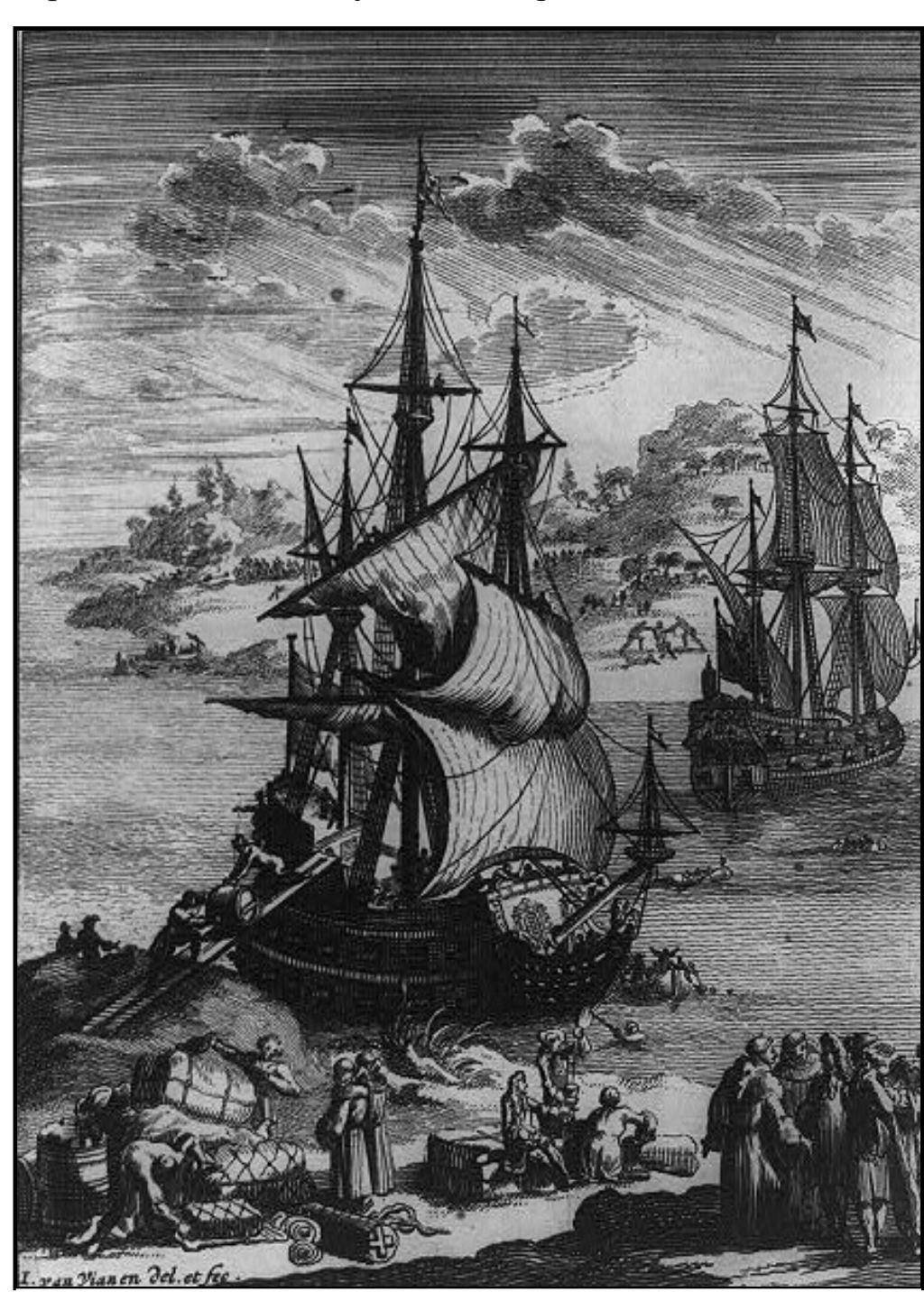

Figure 2-5. Late-seventeenth-century depiction of La Salle's arrival to the Mississippi region in 1684. Courtesy of the Library of Congress. northern Gulf. France spurred a new age of exploration and knowledge in the Gulf (Weddle 1985).

The first major French explorer of the Gulf region was Robert Cavelier, Sieur de La Salle, who sailed from France for the mouth of the Mississippi River in 1684 with four ships and 280 men and women in order to establish a French settlement that would serve to harass the Spanish and check English expansion in the region (Figure 2-5). Two years earlier, an expedition he led from Canada had reached the mouth of the river. This time, La Salle and his contingent were hampered by internal dissension, geographical confusion, illness and overwork, Indian troubles, and pirate attacks. Believing the Nueces River at Matagorda Bay to be the Mississippi he had earlier discovered, La Salle made this the hub of several years of explorations into the surrounding countryside of present-day Texas (Weddle 1991). 
In 1687, La Salle was assassinated by his own men and the remainder of his colony was decimated by diseases and Indian attacks, but the expedition was not a complete failure for France. Only the Narváez and de Soto expeditions of a century earlier had ventured into presentday Texas and Louisiana to such an extent. Some of the veterans of the La Salle contingent who managed to survive became trusted advisors in later French voyages to the region (Weddle 1991, 2001).

La Salle's activities also inspired a new period of Spanish exploration in the northern Gulf of Mexico as Spain attempted to arrest the progress of its French rival. The Rivas-Iriarte expedition sailed from Veracruz and would circumnavigate the Gulf of Mexico in two specially built piraguas in 1686-1687. Rowing northward, they reached Tampico and then Matagorda Bay, where they encountered La Salle's damaged ships and assumed that any colony the French might have formed there was a failure. The expedition scouted Atchafalaya Bay, the Mississippi passes, Mobile Bay, Pensacola Bay, and St. Marks before reaching Havana and then back to their starting point at Veracruz. Due to their shallow-draft ships, members of the Rivas-Iriarte expedition may have been the first Europeans to view the shoal-studded western Louisiana coast (Weddle 1991, 2001).

Like their earlier efforts, later Spanish explorations in the Gulf were of mixed success. Bad weather obstructed the efforts of Terán de los Ríos, operating out of east Texas in the 1690s, to expand settlements. Andrés de Pez y Malzárraga proved to be less knowledgeable regarding geography than his predecessors, but he was a strong advocate of settlement on Pensacola Bay. Andrés de Arriola led this settlement while insisting that the Mississippi River was more favorable, although in truth, the Spanish were rather uncertain of its location (Weddle 1991).

\subsection{The French Colonies: The Gulf of Mexico in the Early to Mid-Eighteenth Century (1700-1756)}

By the start of the eighteenth century, the Spanish fleet system was in a state of crisis for several reasons. As Bulmer-Thomas et al. (2006) discovered in their analysis of the late-seventeenthand early-eighteenth-century fleet system (Table 2-2), the departure of the fleet was increasingly irregular. This trend was a consequence of increased costs and fiscal pressure in Spain, which was often at war and under a blockade in this period. Additionally, the departure and arrival of the fleet was subject to rigid regulations that unintentionally created delays. The emerging contraband trade of Spanish America and its neighbors, meanwhile, was chipping away at the need for such a fleet between Spain and the colonies (Márquez 2006). The fleet to Tierra Firme (northern

Table 2-2 South America) was altogether abolished in 1739 and never revived. The fleet to New Spain (Mexico) remained in use, although it was increasingly unsuccessful. In 1754, a royal decree ordered that one fleet would leave for New Spain every two years. This schedule was not maintained in practice (Pearson and Hoffman 1995).

Spanish Fleets, 1680-1739

\begin{tabular}{|l|l|l|}
\hline \multicolumn{1}{|c|}{ Period } & Fleets & Galleons \\
\hline $1680-1700$ & 9 & 4 \\
\hline $1700-1713$ & 4 & 2 \\
\hline $1713-1720$ & 3 & 1 \\
\hline $1720-1739$ & 7 & 4 \\
\hline
\end{tabular}

Source: Bulmer-Thomas et al. 2006 
With the Spanish floundering, the French, led by Pierre Le Moyne d'Iberville, were firmly rooted in the Mississippi region in this period. Iberville previously had led French efforts to secure the Hudson Bay region and Newfoundland from the English. Noting his ability and leadership, Louis XIV assigned Iberville to the northern Gulf of Mexico to find the mouth of the Mississippi River and strongly assert France's presence in the region. Iberville sailed for the Gulf in 1699, planning to reconnoiter Pensacola Bay, but Andrés de Arriola had already explored that area. Iberville then journeyed to Mobile Bay and, next, Ship Island in the Mississippi Sound. His explorations in the vicinity, supported by the advice of local Indians, led him to the Mississippi River and, ultimately, a positive confirmation of its mouth. As a way to exercise military control of the region, Iberville also established a fort on Biloxi Bay (McWilliams 1991).

Returning to France, Iberville left his younger brother, Jean-Baptiste Le Moyne, Sieur de Bienville, to continue exploring the region. Bienville firmly established the French presence in the northern Gulf of Mexico. Much like the fort at Biloxi, Bienville founded a fort on the Mobile River and a port on nearby Dauphin Island. The site of the fort was moved to the present site of Mobile in 1711 after the growing colony around the fort was flooded. Seven years later, Bienville located a site on the Mississippi River (later New Orleans) that he deemed ideal for a capital, but several years passed until the town was established in 1718 by the French Mississippi Company. The fort on Biloxi Bay was moved in 1719 to present-day Biloxi, which served as the capital until 1723, when the agricultural and navigational advantages of New Orleans warranted the transfer of the capital to that location (McWilliams 1991).

Running concurrently with all of the exploration of the Gulf coast, Louis Juchereau de St. Denis led important explorations west of Biloxi Bay and up the Mississippi River in the 1710s. He also pushed westward, reaching Spanish outposts on the Rio Grande. Operating on the basis of a short-lived French-Spanish alliance consequent to the War of the Spanish Succession in Europe, St. Denis assisted the Spanish in establishing six new missions and a presidio in east Texas. Though ultimately rebuked by the Spanish in Mexico, St. Denis was influential in having set up a contraband trade between the two powers in the region and also increasing geographical knowledge (Chipman and Lemée 2010).

France's progress in the northern Gulf of Mexico was partly a consequence of the War of the Spanish Succession (1702-1713), in which France was allied with Spain. Indeed, France capitalized on this arrangement to secure trade privileges in Spanish America. Sensing weakness in the Spanish economic base, the French Guinea Company gained control of the Asiento de Negros, which permitted them to monopolize the sale of slaves to Spanish America and also export a significant amount of merchandise. Soon, French ships were seen in the Gulf and other parts of the Spanish Empire in increasing frequency. Port records indicate that more than 50 French ships conducted business in Veracruz between 1701 and 1707. At the conclusion of the war in 1713, the Asiento de Negros was awarded to Great Britain for 30 years as well as the right to send annually one loaded ship to Cartagena, Portobello, or Veracruz. As the operation of the Spanish fleet system was decaying in the eighteenth century, Spain slowly allowed permission for other countries to trade in its colonies (Acton et al. 1902:272-273; Márquez 2006).

Because of the renewed interest in the Gulf region, the French and the Spanish revised mapping and navigation (Figure 2-6). There was improving and advancing settlement in new places, but 


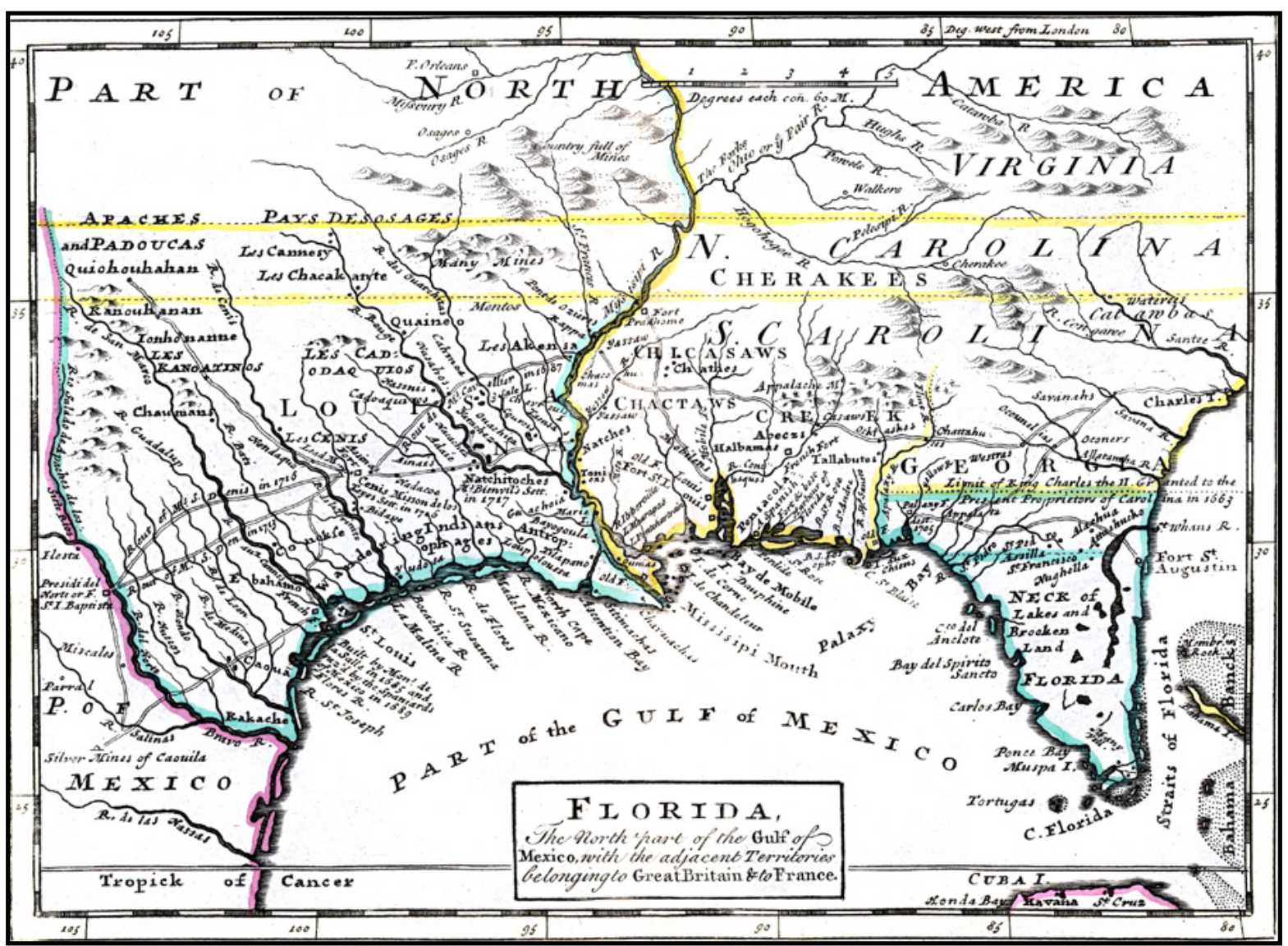

Figure 2-6. 1736 map titled Florida: The North Part of the Gulf of Mexico with Adjacent Territories Belonging to Great Britain and France. Courtesy of the University of Florida Libraries.

there were older places that, despite their natural benefits, remained largely ignored. Tampa Bay (Espiritu Santo to the Spanish), for example, was visited by the early explorers Leòn (1513), Narváez (1528), and de Soto (1539), among others. However, until the early nineteenth century, only an occasional timber schooner or fishing vessel from Havana ventured to the bay (Weddle 1995).

In 1719, a French royal authorization allowed the Company of the West to transport prostitutes, vagabonds, thieves, and other criminals from the largest cities in France to the fledgling Louisiana colony as a means to clean up France and provide citizens for the struggling colony. Some 900 criminals made the voyage to Louisiana until the permission was repealed in 1721. Only half of this number survived in the colony; the others fell to disease shortly after reaching Louisiana. Additionally, two French vessels with 210 such passengers were lost en routele duc de Noailles and le Maréchal d'Estrées (Hardy 1966).

France's nascent Louisiana colony was reliant on flour shipments from France. When these failed to supply the needs of colonists, the colonial government often requested and received shipments from Veracruz. By the 1730 s, the Illinois country regularly provided flour down the Mississippi River, but shipments from France still occurred. During the disruptions of the French and Indian War, New Orleans again turned to Veracruz for flour (Ekberg 1996). The French Crown allowed direct commerce between Louisiana and other French possessions in 
1737. Also during the 1730s and 1740s, France traded directly with New Orleans but not intensively because Louisiana was unable to insure returns of sufficient value (Clark 1969).

In addition to food, the French required naval stores. For the entire eighteenth century, lumber (particularly cypress) was a major export of Louisiana. Early on, settlers to the region sold planks to the Spanish in Pensacola. Captains of ships from ports on Martinique, Guadeloupe, Saint-Domingue, and Cuba, however, were more frequent buyers, and in return they imported brandy, indigo seed, and flour. Furs and foodstuffs also were notable exports from Louisiana to the French-controlled islands of the Caribbean. By mid-century, dozens of ships annually arrived from the French Caribbean to New Orleans with imports of wine, flour, and rum in exchange for building materials, rice, peas, and beans (Moore 1983).

\subsection{The Diversification of Trade: The Gulf of Mexico in the Late Eighteenth Century to Mexican Independence (1756-1821)}

The Seven Years' War (1756-1763) disrupted the healthy trade between Louisiana and the French Caribbean. So valuable was this trade that in 1766, just three years after Spain gained control of Louisiana as a result of the Treaty of Paris of 1763, the Spanish Crown allowed the colony to continue trading with other nations even as restrictions were introduced in their other New World possessions. Nevertheless, by 1768, Spain issued a royal decree that restricted the Spanish Louisiana trade to Seville, Barcelona, and other ports in Spain, but only in Spanish ships. For several years to come, the formerly vibrant trade with the French Caribbean was closed to Spanish Louisiana. A break in restrictions came in 1770 with a royal decree that allowed Spanish Louisiana to trade directly with Havana and other Spanish ports. Merchants in New Orleans, many of them English, were not content with these terms, and an illicit trade was active. They traded with Veracruz, Martinique, and Campeche. They also imported flour from New York, Baltimore, and Philadelphia (Woodward 2003). Furs, indigo, cotton, corn, rice, and lumber are known to have been common exports from Spanish Louisiana to Havana in this period. The American Revolution promoted further trade between Spanish Louisiana, which supplied tobacco and cotton, and the United States, which supplied flour. In 1776, new reforms reopened Spanish Louisiana trade with France, lowered duties, and permitted the importation of black slaves from the French West Indies (Moore 1983; Woodward 2003).

Spain's fleet system, now a nearly 200-year-old concept, continued to be plagued by inefficiencies. Though the Crown had ordained that the fleet sail to Veracruz once every two years, in actuality a fleet had only sailed in $1739,1757,1760$, and 1765 . Disaster struck the 1765 fleet, which was preparing for its return to Spain at Veracruz in July 1766. Delayed until August, the fleet finally sailed with passengers, soldiers, and crew aboard. The merchant ships El Triunfante, Nuestra Señora del Rosario (also called La Perla), and El Jasón carried cargoes of hides, dyes (cochineal, annatto, and dyewood), Chinese pottery, purgative woods, medicinal products, vanilla pods, chocolate, tortoise shell, and other items. Another ship, the frigate $E l$ Corazón de Jesús y Santa Bárbara, joined the fleet for protection until it could reach its exclusive destination of Caracas at the time of departure. El Dragón, serving as capitana, and El Jasón, one of the merchant ships serving as almiranta, carried precious metals. Off Veracruz the fleet was dispersed and badly damaged in a violent hurricane. The ships ended up in Havana, Campeche, and Veracruz except for the merchant ships El Nuevo Constante and El Corazón de 
Jesús y Santa Bárbara, which were driven ashore along Louisiana. Documents relative to the homebound cargo of the El Nuevo Constante indicate it was carrying "dyestuffs, medicinals, chocolate, copper, leather, turtle shell, and ceramics" (Pearson and Hoffman 1995:224).

The increasingly liberal trade laws of Louisiana provided much-needed capital in the colony that was then used to support the expansion of the plantation system. Of course, this required abundant slave labor, and between the years 1772 and 1808 (shortly after the United States acquired Louisiana), hundreds of slave cargoes arrived in Louisiana. Jean-Pierre Leglaunec (2005) counted 350 slave ships arriving during this period. Their ports of departure were across the Caribbean (Jamaica, Cuba Santo Domingo, Grenada, and elsewhere), Europe (Bordeaux and London), North America (New York, Savannah, Charleston, Baltimore, and Philadelphia), the Spanish colonies (Pensacola and Campeche), and Africa (Senegal) (Leglaunec 2005).

While New Orleans was arguably the most important port along the Gulf, other port towns grew during this period. With its deep port and favorable geographic position, Pensacola (Figure 2-7) was the primary port of the territory that the British acquired in 1763 (and lost in 1783) called West Florida. The port was convenient to the Caribbean and the Spanish colonies. Jamaica could be reached in six days, Campeche could be reached in eight, and Veracruz could be reached in 10, but ships from ports well beyond the region frequented the port. From the first

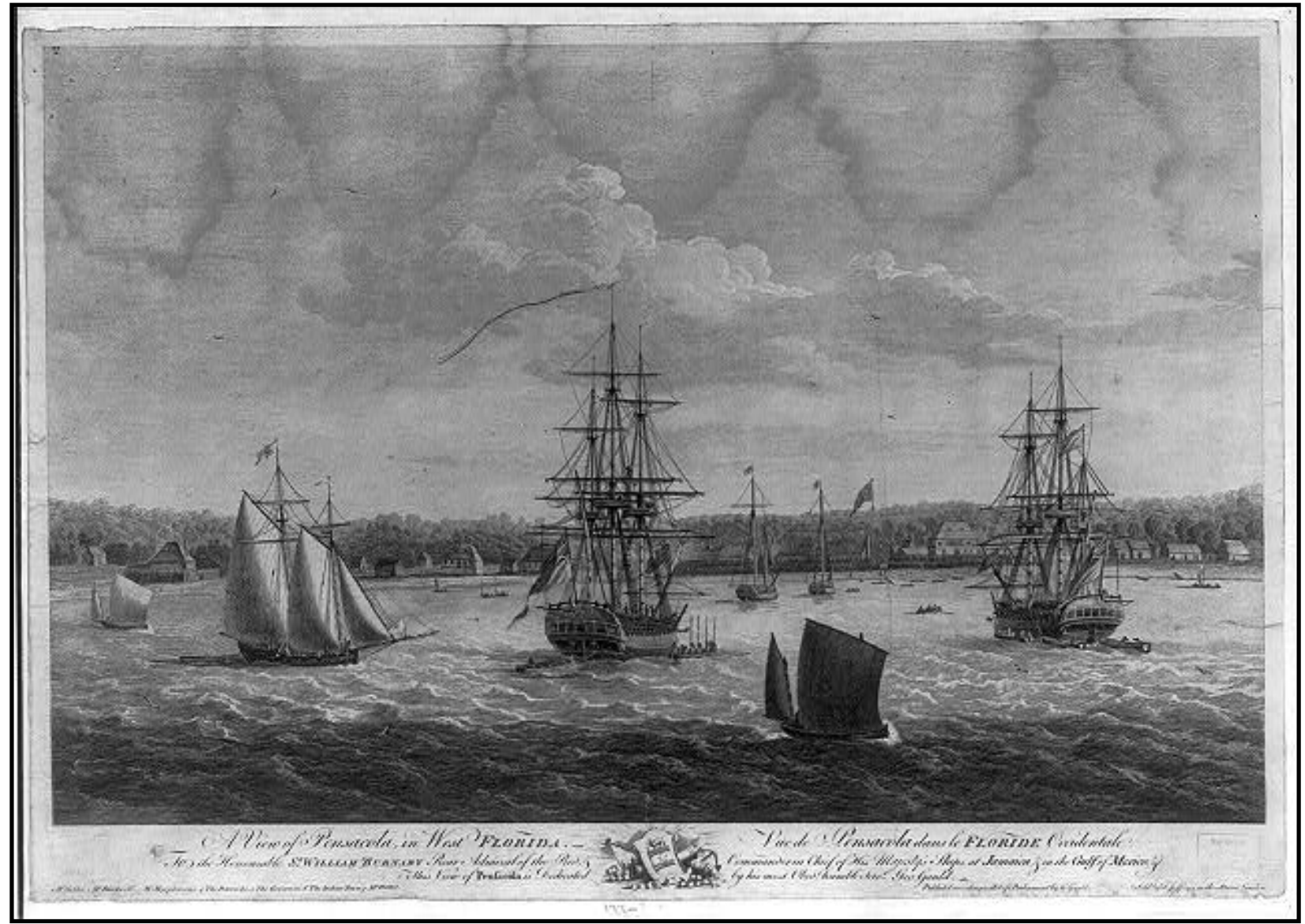

Figure 2-7. A View of Pensacola, in West Florida by George E. Gauld, dating to the 1770s. Courtesy of the Library of Congress. 
months of British occupation, the mother country's international packet system served the port. These ships, typically smaller than 200 tons, sailed from Great Britain to various stops in the Caribbean before arriving with the mail to Pensacola. Alongside this route, another packet shuttled between Boston, New York, Pensacola, Charleston, and the lesser port of West Florida, Mobile. Pensacola Packet was a 53-ton, two-masted schooner. Small vessels of this type were the most common in British West Florida. On occasion, a large warship of the Royal Navy entered Mobile or Pensacola (Fabel 1988).

Merchant ship traffic in the ports of British West Florida came from the above-mentioned locales as well as St. Augustine, Savannah, New Orleans, and Madeira. Generally speaking, maritime traffic into the province, as Fabel (1988:142) estimated, was "heavy" in the mid1760 s, with 93 vessels in 1764, 108 in 1765, 62 in 1766, and 63 in 1767. For 1768 through 1773, traffic dropped to an average of 30 vessels per year. The number again jumped in 1776 to 68 , but after the outbreak of the American Revolution, it slowed as a result of the insecurity of shipping lanes for British ships in the Gulf. Using various period sources, Fabel estimated the total number of voyages from West Florida to various places in the British Empire between 1763 and 1778 (Table 2-3). The British in West Florida were exporting lumber, naval stores, skins, and indigo and importing a variety of items including bricks, kettles, textiles, wine, shingles, coffee, salt, and playing cards (McAlister 1959).

As they did the Spanish, natural forces affected the English in the Gulf. Fabel (1988) has researched the consequences of hurricanes on British West Florida. For example, a hurricane struck Pensacola on October 22, 1766. Violent winds blew from 10 o'clock at night to 6 o'clock the next morning before the wind favorably shifted. Four vessels in the harbor survived while seven were lost, the latter including the brig Rebecca of Charleston and the brig Bay of Honduras of Jamaica (Fabel 1988).

The same hurricane wrought destruction on ships in the Gulf. Arriving to Pensacola on November 2, HMS Ferret had been totally dismasted. Additionally, five Spanish galleons en route from Veracruz to Spain were driven ashore southwest of Pensacola at St. Barnard's Bay. A later hurricane, this one occurring on October 9, 1778, destroyed 14 of 17 vessels in the port of Pensacola. To be sure, all of the above were extreme cases of hurricane destruction, but as Fabel notes, rarely a year passed in the colonial period without reports of ships lost in the Gulf of Mexico region (Fabel 1988).

In late October 1780, a hurricane destroyed a Spanish expedition that Bernardo de Gàlvez was outfitting for a military strike against Pensacola (McAlister 1959). According to N. Orwin Rush (1966), this fleet, commanded by Don Josef Solano, left Havana on October 16, 1780. 
Consisting of seven warships, five frigates, 49 transports carrying 164 officers and 3,829 men, and a few other unidentified vessels, the force was caught in a hurricane only two days out of Havana. The storm scattered the vessels, and many were forced to jettison some or all of their contents. As many as 20 ships returned to Havana, having made it as far north as the present latitude of Sarasota, Florida. At least 23 ended up around Campeche, some grounded and others afloat. Another ship ended up in New Orleans. The modern-day sources describing this disaster (Haarman 1960; Rush 1966), as well as two sources from the period (see Wilkie 1983), are in disagreement as to the actual number of ships and the extent of damages or losses to the fleet, but it appears that at least one ship was unaccounted for in the event. Whatever the case, the first of three attempts to invade Pensacola thusly failed (Rush 1966).

Spanish warships, under the command of Bernardo de Gálvez, finally captured Mobile and Pensacola for the Spanish in 1780 and 1781, respectively. At the conclusion of the American Revolution, the British relinquished this territory to Spain as part of the Treaty of Paris of 1783. The Spanish retained Pensacola as the capital of West Florida during their tenure (1783-1821). In the first decade of the nineteenth century, a fairly healthy trade developed, although the traffic in the port could not compare to that of Veracruz or Havana. After the American acquisition of Louisiana in 1803, Governor Vincente Folch, with little or no permission from his superiors, ended duties on items imported from New Orleans, thereby fostering trade between the two ports. Flour was a common export from New Orleans to Pensacola in this period. Pensacola's main export appears to have been pine lumber. Because of Spain's inability to keep Pensacola supplied, trade in the port became increasingly Americanized (McAlister 1959).

While the American continent was fairly stable after the Revolutionary War, European entanglements often affected Spanish possessions in the Gulf, even as trade between Spain and its colonies began to recover in 1782. Spain's war with Great Britain (1779-1783) and a subsequent war with France (1793-1795) interrupted transatlantic shipping, yet over the next decade and a half, exports from Spain to its colonies increased fourfold and imports from the colonies to Spain increased tenfold (Fisher 1998). In the meantime, Spanish decrees issued between 1788 and 1792 opened the slave trade in its colonies to foreigners. British shippers were especially prominent in this aspect of the trade. The number of slaves exported from the British West Indies to the Spanish colonies rose from 2,283 in 1792 to 4,153 in 1795. Some of these cargoes passed through the Gulf of Mexico (Pearce 2001). Bermuda and the British North American colonies of Cape Breton, New Brunswick, Newfoundland, and Nova Scotia participated in trade with the Spanish colonies in the late 1780s and early 1790s, although minimally. The Spanish colonies rarely imported from British North America and, when they did so, fish, bread, and flour were the items. In return, the Spanish colonies sent the British North American colonies coffee, white and brown sugar, molasses, and hides (Pearce 2001).

Known imports from the Spanish colonies, including those of the Gulf of Mexico, to the British West Indies of the first half of the 1790s included specie, dyes and dyewoods, other woods, drugs, livestock and hides, foodstuffs, plantation produce, and miscellaneous items. Specie and livestock and hides were the most common (Pearce 2001). Of all the British West Indies, Jamaica received the bulk of imports from the Spanish colonies in the early 1790s. As Pearce (2001) discovered, Jamaica was trading exclusively with the Spanish colonies by 1795. 
Despite the rumblings of revolution, Spain and its colonies kept up a fairly healthy trade between 1797 and 1820. Relying on shipping registers and related administrative correspondence in the Archives of the Indies, historian John Fisher has broken down the numbers for this period for the major ports of Spanish America. The records clearly indicate that the Gulf of Mexico remained very active in shipping. New Spain, as compared to the Pacific, the Rio de la Plata, the Caribbean, Venezuela, and New Granada, received 55 percent of Spain's exports by 1797. In fact, Spain had become dependent on New Spain as an export market. On the other hand, Veracruz was sending only 5 percent of its exports to Spain and other parts of the empire; the other 95 percent went to the United States and European ports (other than Spain). The impact of the Peninsular War (1808-1814) in Spain reduced imports to Veracruz from the mother country by half. Countries that were neutral in the conflict, as well as other Spanish American ports, filled the gap. By this time, most of the colonies of Spanish American were enjoying de facto or de jure free trade with foreigners, even in Veracruz and Havana, where loyalty to the Crown was most concentrated (Fisher 1998).

Veracruz had been the principal western terminus of the trade between Spain and New Spain for three centuries. In 1781, merchants in the port lobbied the Crown to establish a consulado or merchant guild in order to advance their trade. The port of Veracruz, they argued, "is the sole key to the vast, fertile, and opulent kingdom of New Spain." The merchant guild was seen as a way to further the economic growth of the port and the region. The leaders argued that:

It is the goal and anchorage of all the fleets, mercury ships, and other vessels of registry which sail from Spain and from the other overseas possessions in America. It is the neck through which necessarily must pass the wares and products which they bring for importing to the various places on the mainland. In sum, it is one of the ports of greatest traffic in your Majesty's realms and, consequently, the most important center of business transactions (Veracruz merchant guild, 1781, quoted in Smith 1943:5).

The decay of the fleet system continued as the eighteenth century progressed. Licensed ships were becoming preferred for their flexibility. The fleet to New Spain clung to life, nevertheless, and survived slightly longer than the fleet to South America. Between 1757 and 1776, there were six voyages. The last flota to New Spain sailed from the mother country in 1779 (LugoFernández et al. 2007; Márquez 2006; Stein and Stein 2003).

Alongside the trade with Spain and other foreign nations, Veracruz participated in a profitable coastwise trade with other coastal towns in New Spain. These towns traded with Veracruz and also, until 1821, were required to pay duties at Veracruz before proceeding to trade elsewhere. At the turn of the nineteenth century, ships from across the Americas called on Veracruz. They hailed from Tampico, Campeche, Tabasco, Maracaibo, Havana, La Guaira, Carmen, and Caracas. Veracruz was a popular port for U.S. traders by the 1790s. Vessels from New Orleans, Baltimore, New York, and Philadelphia also came to Veracruz (Smith 1943). They sometimes purchased entire cargoes from Spain that had been delivered to Veracruz (Fisher 1998). Cuba was comparatively more attractive to Americans. At the turn of the century, U.S. ships had become so prevalent in Havana that some had begun to consider the United States the "metropolis" of Cuba (Fisher 1998:465). 
Spain's weakness in the realm of world geopolitics, the spread of republican ideas, and the expansionism of the young United States in the late eighteenth and early nineteenth centuries sealed the fate of its empire around the Gulf of Mexico. France followed a similar fate. Spain's Louisiana province was ceded to France in a secret treaty in 1800 (but never formally occupied by that nation). Three years later, the United States acquired this vast territory as well as parts of Spanish West Florida via the Louisiana Purchase. Revolution was sweeping the former Spanish colonies in the 1810s, and in 1821 Mexico won independence. The same year saw the remnants of Spanish West Florida (along with East Florida) ceded to the United States. Already in a state of metamorphosis in the late eighteenth century, shipping in the Gulf of Mexico in the nineteenth century entered a new era free of the restraints of overseas powers.

\subsection{Ports and Cargo within the GOM}

The initial research plan focused on early colonial-period shipwrecks in UDW that most likely would have been associated with the Spanish fleets leaving annually from Veracruz, Mexico, bound for Havana, Cuba, and ultimately Spain. However, discussions with BOEMRE identified additional trade routes within the GOM that should be taken into account relative to vessel losses within UDW. Vessels plying these additional trade routes may also have been lost within UDW of the GOMR and therefore may be encountered during future remote-sensing surveys. This section intends to identify those ports that were established within the GOM during the sixteenth to eighteenth centuries and the various cargoes that were being transported into and out of these ports by sailing vessels during this period. Table 2-4 provides a list of the various ports established within the GOM during the sixteenth to eighteenth centuries.

Table 2-4

Ports Established within the GOM during the Sixteenth to Eighteenth Centuries

\begin{tabular}{|l|l|}
\hline \multicolumn{1}{|c|}{ Port } & Year Established \\
\hline Veracruz, Mexico & 1519 \\
\hline Havana, Cuba & 1515 \\
\hline Pensacola, Florida & 1698 \\
\hline Biloxi, Mississippi & 1699 \\
\hline Dauphin Island, Alabama & 1699 \\
\hline Mobile, Alabama & 1701 \\
\hline New Orleans, Louisiana & 1717 \\
\hline
\end{tabular}

By the start of the nineteenth century, a number of new ports had opened up across the GOM, primarily associated with the growth of the cotton industry, and later the lumber, grain, and sugar trades, all of which helped the expansion of trade routes across the GOM. This includes Lake Charles, Louisiana (1803); Galveston, Texas (1821); Key West, Florida (1822); Tampa, Florida (1831); Velasco, Texas (1831); Indianola, Texas (1844-1886); Corpus Christi, Texas (1848); Brownsville, Texas (1849); Brashear City, Louisiana (1860); Cedar Key, Florida (1860s-1880s); Pascagoula, Alabama (1870s); Grand Chenier, Louisiana (1870-1920s); Gulfport, Florida 
(1887); and Port Arthur, Texas (1897) (Atauz et al. 2006:9). Since the establishment of these ports postdates the current investigation, they will not be discussed in any detail.

\subsubsection{Veracruz, Mexico (Established 1519)}

Founded in 1519 by Hernán Cortés as Villa Rica de la Vera Cruz (because he had landed in that country on Friday of the Cross), the first settlement consisted only of a camp made up of wooden structures surrounded by a wooden palisade and trenches, while the port was rudimentary and inadequate (Chaunu 1959:702). After a few years this complex was abandoned in favor of a new site, about 60 kilometers to the south, situated at the mouth of the Antigua River (Velasco 1894:212). However, this new site was hardly better than the first, so much so that throughout the better part of the sixteenth century up to the year 1600 two ports were in use: the port of Veracruz at the mouth of the Antigua River and the port on the island of San Juan de Ulúa 25 kilometers to the south. The latter was primarily used as a military port (Chaunu 1959:702703). Although the advantages presented by the island were obvious to the carrera officials, San Juan de Ulúa was used as a secondary port as the residents of la Vera Cruz were not willing to bear the expense of another move (Chaunu 1959:703). Yet the town itself was unhealthy, hot, and surrounded by dunes and swamps, a place where diseases such as malaria and yellow fever took their toll on the population.

The port was too exposed to the elements, and the treacherous bar at the mouth of the river claimed many ships. By 1570, there were only about 200 mediocre dwellings constructed of wood and limestone (Velasco 1894:212-214); the town lacked everything, even water, which had to be brought in large ceramic jars from a nearby pond. There were some 600 African slaves, more numerous than Spaniards, because few Indians populated the region. Faced with all the hardships of this second location, a logical solution was finally adopted in 1600. There was already a much more satisfactory site across the island of San Juan de Ulúa, closer to the Medellín River, with a good water source and the embryo of a good port. Some houses had already been built there by the third quarter of the sixteenth century, and the place was known as Las Ventas de Buytron (Calderón 1953:17). Thus was born La Nueva Vera Cruz (the new Veracruz), the third and final site of what was to become in just a few short years one of the most important Spanish ports in the Americas.

This new and permanent transition took place barely two years after Puerto Belo had replaced Nombre de Dios in 1598. Veracruz now provided Mexico with a port capable of handling the rapid expansion of its economy and contributed to the new city's prosperity. Reaching its plateau by 1620 (Chaunu 1959:704), Veracruz handled almost twice as much of the combined maritime traffic of Santo Domingo, San Juan de Puerto Rico, and la Habana.

While Veracruz was starting to truly prosper, basic necessities were still lacking in the region and had to be imported from Spain to fulfill the needs of the colonists. Manufactured goods such as tools, household items, clothing, and weapons, along with wine, spirits, oil, and other luxuries were brought by fleets and merchant ships. As specified by Olds (1976):

Gold, silver, and other treasures must have made up the major part of cargo, although there probably were some household goods and other personal 
belongings being carried back to Spain by passengers and crew. In these early days [sixteenth century] of colonization the New World had little but treasure to export, but the ships arriving from Spain were heavily laden with necessities for the colonists - manufactured goods such as tools, household items, clothing, and weapons, along with wine, oil, and other luxuries (Olds 1976:100).

While gold and silver were an important part of the cargo sailing back to Spain, many other products were shipped from Veracruz. In the Atlantic maritime traffic between Spain and New Spain there are, in fact, only two ports to consider: Seville and Veracruz. Although Veracruz was only a loading and unloading point (a transit area), Mexico was a vast and rich land, and Spain fully exploited all its resources (Chaunu 1959:707). The north of Mexico was the mine region par excellence. Taking into consideration all products exported from the Spanish-American colonies toward Europe, silver alone represented 50 percent of the value (Chaunu 1959:774). It has been estimated that "average annual shipments of silver from New Spain ran from one to 35 million pesos, or from five to over 170 millions of today's dollars" (Davis 1977:10).

The south, in the Tehuantepec area, was the most humid region and is still regarded today as the most productive area in terms of agriculture; it was heavily populated at the time of the Conquest. In addition to precious metals, products shipped from the port of Veracruz included indigo, cochineal dye, tobacco, coffee, cacao, sugar, ginger, cotton, wool, hides, leather (cueros curtidos, treated hides), Brazil wood (from Campeche), tinta wood, copal, sarsaparilla, liquidambar, Cañafístola cassia fistula and Jalap Ipomoea purga (both medicinal plants), and from the Manila galleon trade between the Philippines and Acapulco, gold, precious stones, Chinese blue-on-white export porcelain, silk, beeswax, and spices (Chaunu 1959:768-773).

\subsubsection{Havana, Cuba (Established 1515)}

Encompassing 110,860 square kilometers (roughly the size of the state of Virginia), Cuba is by far the largest of the Antillean islands and occupies a unique strategic position in the region. Although Havana was originally founded in 1515 by the conquistador Diego Velázquez de Cuéllar, the first location was on the south coast near the present town of Surgidero de Batabanó. However, that initial establishment encountered problems similar to the ones experienced in Veracruz. Eventually, after several failed attempts to establish a viable port, Pánfilo de Narváez founded San Cristóbal de la Habana. It was to become the turntable of Spanish colonial maritime traffic, commerce, and immigration. Gold initially found on the island was quickly depleted. To replace this ephemeral economy, the Spanish colonists developed a resource that had been part of the island well before the Contact period: sugar. The island's production of sugar is modest in comparison to other islands, representing only 2 percent of Hispaniola's production and between 7 and 8 percent of Puerto Rico's (Chaunu 1959:560). The second export out of Cuba was leather, which in fact was more important than sugar in volume. There was also a very small production of cochineal and indigo. Cuba possessed copper mines; the production was sporadic, yet at times considerable. Finally, by the middle of the seventeenth century, shipbuilding took on such importance that it was equal to that of northern Spain (Chaunu 1959:563). Most of what was shipped from Havana was represented by products from other parts of the Spanish colonies. 


\subsubsection{New Orleans, Louisiana (Established 1717)}

Ships sailing from France to the Gulf Coast region, then a vast region encompassing what is now Louisiana, Mississippi, Alabama, and part of Florida (referred to as "la Louisiane"), carried a variety of goods for the colony. This included weapons, clothing, tools, lard, flour, salt, wine and spirits, pacotille (inexpensive items, such as brass finger rings, glass jewelry, and other items of little value to be traded to the Indians), and slaves usually bought in West Africa.

Ships sailing to France from New Orleans, Mobile, Dauphin Island, Biloxi, and Pensacola carried beaver skins, deerskins, indigo, cotton, hemp, linseed, and wood. There was also a very active trade with Martinique and Saint-Domingue (present-day Haiti). Ships from those ports came to Louisiana to buy timber and sell poultry and vegetables, mostly to Pensacola. They also brought flour and spirits, but at such excessive prices that the inhabitants could scarcely afford those products. Conversely, beaver furs were sold so cheaply to the merchants aboard those ships that the fur traders (coureurs de bois) often threatened to stop furnishing them to the people of Pensacola (Lacoursière 1982:64-66)

By the nineteenth century, trade into and out of New Orleans had increased dramatically. This included a large increase in cotton:

In general, ships that sailed to European destinations carried cotton as their main cargo. On their way back to New Orleans from Europe, these ships brought mainly luxury goods such as silks and other luxury textiles, garments, candy and chocolate, spices and herbs, gourmet foods and wines, and jewelry are among these popular items. The northbound ships that sailed mostly to New York and Philadelphia either carried cotton or they re-distributed what seems to be a portion of the non-perishable luxury goods of European origin. Typical merchandise of this type were silk and other luxury fabrics and textiles, musical instruments, jewelry, and dresses. Typical return cargoes of such ships generally included iron (from New York), candles, and textiles and furs (Atauz et al. 2006:46).

While the exportation of these goods did not really expand until the early nineteenth century, it is useful to understand the variety of goods being brought into and out of this important Gulf port.

\subsubsection{Pensacola, Florida (Established 1698)}

During the late seventeenth century, the need for timber, primarily for ships' masts and spars, at Veracruz prompted King Charles II to order the viceroyalty in Mexico to utilize timber resources in Pensacola. Timber was needed for the vessels of the Armada de Barlovento and the annual Spanish flotas (Hunter 2000:8). In 1695, the Conde de Galve ordered Andrés de Arriola to conduct a survey of the northern coast of the Gulf of Mexico. The primary goal of this reconnaissance was to prevent rival European nations from occupying Pensacola Bay. In addition, Arriola was to "repair the shortage of... masts and spars with which it was possible to prepare the Windward Fleet" by cutting down a number of large trees and transporting them to the Mexican port of Veracruz (Hunter 2000:8-9). 
Over the next few years a limited number of shipments of timber left Pensacola bound for Veracruz, including the "Santa Rosa [which] departed from Pensacola Bay [in 1702] with the shipment of masts, bound for Mexico" (Hunter 2000:14). While the lumber trade between Pensacola and Veracruz lasted for approximately 20 years, "only four shipments of timber for masts and spars were successfully delivered from the presidio to Veracruz and the depleted storehouses of the Windward Fleet" (Hunter 2000:17).

\subsubsection{Biloxi, Mississippi (Established 1699)}

Established in 1699, Biloxi, Mississippi, was primarily an outpost, and it appears that the area experienced many problems including crop failures, lack of maritime traffic and trade, and incursion by English ships attempting to engage in illicit trade with the French colonists. Most ships sailing into Biloxi Bay came from other Louisiana ports such as New Orleans, Mobile, and Dauphin Island.

\subsubsection{Dauphin Island (Established 1699)}

Dauphin Island was quite important and had its own administration. Much merchandise and many products shipped from Mobile were transited through Dauphin Island and loaded aboard European-bound ships. 


\subsection{BACKGROUND CONTEXT}

To provide a background context for the current investigation a review of the following is provided:

- Previous shipwreck inventories within the GOM,

- Historic vessel types within the GOM,

- Known sixteenth- to eighteenth-century shipwreck sites and survey expectations within the GOM, and

- Historic vessels and sediment accumulation in UDW of the GOM.

\subsection{Previous Shipwreck Inventories within the GOM}

A number of previous cultural resources studies addressing the potential for historic properties (primarily shipwrecks) have been conducted in the past relative to the GOM (Coastal Environments, Inc. [CEI] 1977; Garrison et al. 1989; Pearson et al. 2003). These studies sought to gather data relative to shipwrecks within the GOM to assist in establishing the proper guidelines to identify and protect such resources.

In 1977, a pilot study to assess the incidence of shipwrecks within the GOM from the Rio Grande River, Texas, to the Florida Keys was prepared for the U.S. Department of the Interior (CEI 1977:iv). The study employed a variety of sources including unpublished and published accounts of vessel losses, known shipwrecks, charts, and maps to estimate the total number and distribution of shipwrecks (and artifacts) within the GOM. It was determined that a compilation of shipwrecks "based primarily upon secondary sources would be sufficient... to identify the theoretical boundaries of relatively high and relatively low occurrence of historical-period shipwreck sites within the Gulf of Mexico" (CEI 1977:4-5). From the data collected:

A listing of 1,904 reported losses and/or known wrecks was compiled, with a basic data sheet for each wreck. It is estimated that the total number of significant wrecks in the study area is between 2,500 and 3,000 (CEI 1977:iv).

The report offered a synopsis of the exploration, early sailing routes, settlement patterns, technological changes, commerce, and commercial development of the Northern GOM presented in four periods (1500-1699, 1700-1819, 1820-1865, and 1866-1945). In addition, a spatial and temporal distribution of shipwrecks and artifacts was analyzed within the report.

The conclusions reached by the study in 1977 determined that approximately 70 percent of shipwrecks within the GOM date from the beginning of the nineteenth century and that the remaining 30 percent "which sank during the $16^{\text {th }}, 17^{\text {th }}$, and $18^{\text {th }}$ centuries, are generally of primary archaeological and historical importance" (CEI 1977:96). Lastly, the study determined that 80 to 90 percent of shipwrecks within the GOM are located within 10 kilometers of the present shoreline and that concentrations of shipwrecks could be expected in areas of historically high marine traffic. These areas of high marine traffic were identified as "the approaches and entrances to seaports and the mouths of navigable rivers and straits, and with natural marine 
hazards, such as shoals and reefs" (CEI 1977:96). With regard to vessel losses within UDW, the report concludes that shipwrecks may occur where shipping lanes have crossed for centuries, and while the incidence of wrecks may be higher along these routes, "it is not believed these areas warrant special treatment" (CEI 1977:96).

In an effort to update the various standards employed by BOEMRE for the identification and assessment of potentially significant submerged resources within the GOM, a second study was funded to assist in building an interpretative framework for the evaluation of unidentified remote-sensing targets (Garrison et al. 1989). The specific objectives of the study (comprised of two tasks) were:

- To reevaluate and make recommendations to change, if necessary, the location of Cultural Resource Management Zone 1 in the GOM [Gulf of Mexico].

- To determine the relationship between line spacing of magnetometer readings and side-scan sonar [targets] and the detection of objects at or below the seafloor.

- To investigate whether remote sensing data gathered during a cultural resource survey in the GOM can be analyzed to discriminate between cultural resource[s] and recent debris (Garrison et al. 1989).

Garrison et al. (1989) utilized data (primarily historical, archaeological, geological, and geophysical research) that postdated the original 1977 study to build on the existing body of knowledge relative to submerged cultural resources within the GOM. Research on archaeological sites that were examined post-1977 was incorporated into the study, including investigations of the Padre Island shipwreck excavations (Arnold and Weddle 1978) and El Nuevo Constante (Pearson and Hoffman 1995). In addition, secondary sources were examined such as Chaunu and Chaunu (1955-1957) to gain insight into the "causes and distributions of shipwrecks on the northern Gulf Continental Shelf” (Garrison et al. 1989:II-8).

A variety of conclusions presented within the 1989 study are pertinent to the current investigation. These conclusions include:

- The number and frequency of shipwrecks within the GOM increased over time [This contradicts the findings from the 1977 study, which determined that the peak of shipwrecks occurred from 1880 to 1910].

- Garrison et al. (1989) predicted that 9.1 percent of vessels involved in the Spanish Carrera fleet were lost as a result of storms. Chaunu and Chaunu's (1955-1957) study estimated that 16 percent of vessels were lost as a result of storm events.

- An examination of 14 historic hurricane events from 1722 to 1981 claimed a total of 146 ship losses, for an average of 10 vessels per storm.

- Vessel traffic risked the hazards of sailing closer to shore (versus the safety of deeper water) for faster voyages by taking advantage of coastal currents.

- The probability of shipwrecks within the GOM increased with the development of commerce (following the colonization of Florida, Louisiana, and Texas). 
- Many sixteenth- to seventeenth-century vessel losses can be attributed to a lack of navigational aids; such losses increase throughout the eighteenth century (and with the development of new ports) (Garrison et al. 1989:II-115118).

In addition to these conclusions, Garrison et al. (1989) addressed the pattern and distribution of shipwrecks throughout the GOM, which is also pertinent to this investigation. This included an assessment of ships lost in the open sea versus those lost near shore. Assessment of research conducted by a number of additional authors (Bascom 1971; CEI 1977; Marx 1971; Muckelroy 1978) proposed the following:

Marx estimated that approximately 98 percent of all shipping losses in the western hemisphere prior to 1825 occurred in less than $10 \mathrm{~m}$ of water. CEI's authors follow this proposition. Muckelroy suggested that the 10-m boundary probably underestimated the potential for deep-water archaeology. Bascom concluded from a study of $19^{\text {th }}$-century losses at Lloyds of London that about 20 percent of all sinkings occur away from the coast.... An inspection of our [Garrison et al. 1989] shipwreck distribution plots shows that 75 percent of shipwrecks occur in nearshore waters and the remainder in the open sea (Garrison et al. 1989:II-118).

Building on these findings, Garrison et al. (1989) suggest that routes varied from the sixteenth to eighteenth centuries depending on trade winds and currents. Since vessels during this period were more reliant on these environmental factors, their routes could vary as much as 2 degrees in position (120 miles). Garrison et al. (1989) determined that locational precision of these was not possible due to this rather broad variability. This assumption was also applied to hurricane paths, which they argued were variable and uncertain (Garrison et al. 1989: II-118).

Information gathered from the CEI (1977) study and the Garrison et al. (1989) study allowed BOEMRE to determine where remote-sensing surveys for historic shipwrecks would be required within the GOM. By 2000, 2,835 archaeological reports had been submitted to BOEMRE, which had been conducted within 3-mile-square lease blocks and along pipeline right-of-ways within the GOM (Pearson et al. 2003:1-3).

In June 2000, BOEMRE awarded a contract to Panamerican Consultants, Inc., of Memphis, Tennessee, to reevaluate and refine the previous studies of historic shipwrecks within the GOM (Pearson et al. 2003). To accomplish the established objectives of the project, the study was divided into four tasks:

- Archival Data Collection

- Correlation of Seafloor Hang Sites, Lease Block Survey Data, and Shipwreck Archival Data

- Comparison of Marine Magnetometer Technologies and Survey Line Spacing

- Data Synthesis, Development of a Shipwreck Predictive Model, Analysis of Magnetometer Technology, and Final Report of Findings (Pearson et al. 2003:1-4) 
The ultimate goal of the study was to provide BOEMRE with additional information to develop strategies and guidelines for addressing historic shipwrecks relative to permitted and funded activities within the GOM. The study also sought to establish spatial distributions of shipwrecks within the GOM and to define high-probability areas to assist in directing future remote-sensing surveys.

Certain findings of the report are relevant to the current investigation. One of the conclusions identified that "there is no strong correlation with the season of the year and frequency of losses, suggesting that neither hurricanes nor winter storms are overriding factors in the losses of vessels throughout the course of a year" (Pearson et al. 2003:7-3). This conforms to the findings from both Garrison et al. (1989) and Chaunu and Chaunu (1955-1957), who reported, respectively, that only 9.1 percent and 16 percent of vessel losses were directly related to the weather.

In addition, the 2003 study found that:

The overall distribution of wrecks in the study area [GOM] reflect broad settlement and economic trends and their influence on maritime traffic and routes. Very few losses occurred in the study area prior to 1750 , and significant increases in numbers do not appear until after $1850 \ldots$. Few early vessels are seen lost in the western Gulf and the early losses after 1700 are generally indicative of settlement and trading activities along the central and eastern Gulf relating to the expansion of French settlement and control along the northern Gulf coast.... The patterns of wreck distributions over time... clearly show that, at a broad level, the locations of loss correlate with the development of historic shipping routes (Pearson et al. 2003:7-4).

A review of shipwreck frequencies within the GOM (compiled from the 2001 shipwreck database) confirm a scarceness of shipwrecks from 1625 to 1725 , with numbers increasing in later years (especially by the early nineteenth century). This information was gathered from 1,419 vessels (67.4 percent) of those presented in the 2001 shipwreck database. While the table presented in Pearson et al. (2003) continues to 2001, only those frequencies from the sixteenth to eighteenth centuries are presented here (Table 3-1).

Table 3-1

\section{Shipwreck Frequencies in the GOM, 1625-1800 (Table Modified from Pearson et al. 2003:4-12)}

\begin{tabular}{|l|l|}
\hline \multicolumn{1}{|c|}{ Year } & \multicolumn{1}{c|}{$\begin{array}{c}\text { Number of } \\
\text { Shipwrecks }\end{array}$} \\
\hline $1625-1650$ & 0 \\
\hline $1651-1675$ & 0 \\
\hline $1676-1700$ & 0 \\
\hline $1701-1725$ & 0 \\
\hline $1726-1750$ & 5 \\
\hline $1751-1775$ & 7 \\
\hline $1776-1800$ & 4 \\
\hline Total & 16 \\
\hline
\end{tabular}

With regard to vessel losses within UDW, Pearson et al. (2003) determined that the potential for wreck sites in deeper water (beyond the 60-meter contour) was overall relatively low, with a higher density of wrecks in the eastern half of the Gulf versus the western half of the Gulf. The higher density of wrecks within the eastern half of the gulf was attributed to higher vessel traffic patterns east of the Mississippi River up until the last quarter of the nineteenth century. While the expansion of trade routes and ports in the western half of the Gulf increased after this time, Pearson et al. (2003) suggest that even in modern times, higher numbers of vessels continue traversing the eastern half of the Gulf (Pearson et al. 2003:4-46). 


\subsection{Historic Vessel Types within the GOM (Sixteenth to Eighteenth Centuries)}

Throughout the sixteenth to eighteenth centuries, a variety of vessel types were prevalent across the GOM. Ranging from small dispatch vessels (the aviso) to the much larger galleons, these various vessel types were identified during the current archival research and therefore may be found within the GOM (for a more comprehensive listing of vessel types dating to the twentyfirst century, see Pearson et al. 2003:4-22). A review of vessel types common during the sixteenth to eighteenth centuries may assist in identifying future shipwreck sites within UDW of the GOM.

\subsubsection{Aviso}

An aviso (or dispatch ship) was a small, fast ship typically used to carry dispatches or official papers across the Atlantic as quickly as possible. This type of vessel was sent out as necessary and rarely carried merchandise or precious metals (Pearson and Hoffman 1995:11).

\subsubsection{Barque (or Bark)}

A barque was a three-masted vessel employing a foremast, mainmast, and mizzenmast. The two foremasts are square-rigged, as in a ship. The after (or mizzen) mast has no yards, being fitted with a topmast only, and carries a gaff sail (called the "spanker") and a gaff topsail (Paasch 1908:10).

\subsubsection{Barque Longue}

The barque longue was a small corvette-type ship whose architecture disappeared during the first quarter of the eighteenth century. French explorer Robert Cavelier de La Salle's La Belle was a barque longue (Boudriot 2000).

\subsubsection{Brigantine}

A brigantine is a two-masted vessel employing a foremast and mainmast. The foremast is squarerigged. The mainmast (taller than the foremast) utilizes a boom sail, also called a mainsail, and is fitted with a topmast, carrying a gaff topsail (Paasch 1908:11).

\subsubsection{Caravel}

Caravels were first mentioned in the mid-thirteenth century as Portuguese 20-ton open boats with a single mast and lateen sail. By 1440 they were fully decked, frame-built, with carvel-style planking, no forecastle, and a long, low after-castle extending to the mainmast. Of shallow draft, they were fast and maneuverable and could tack between 60 and 65 degrees into wind. They had a length-to-beam ratio of up to 5:1. Averaging 50 to 60 tons, they were employed as fast, light warships, exploration vessels, and light freighters (Nelson 2001:19). 


\subsubsection{Carrack}

A carrack (carraca or nao in Spanish; nau in Portuguese; nef in French) was a large sailing vessel popular from the fifteenth and sixteenth centuries (see nao below), well suited for troop transport and large cargoes as well as for exploration. The carrack was extensively used by both the Spanish and Portuguese on voyages of exploration and discovery along the coast of South America. It was the first frame-built type, built in the early fifteenth century. It was a revolutionary change in building technique and had huge scope for development. It was more advanced in every respect than its predecessor, the cog. By the latter part of the century, some examples were 1,500 tons with four masts and multi-sails (Nelson 2001:217).

\subsubsection{Chebec (or Xebec)}

This type was a long and narrow three-mast lateen-rigged ship with oars. Originally designed and built in the Mediterranean, the xebec was favored by corsairs and pirates. After the eighteenth century, the chebec, also known as a chebacco boat, was a common North American inshore fishing boat until about 1820 (Delgado 1997:479).

\subsubsection{Corvette}

A corvette was a small, lightly armed, maneuverable warship, faster and smaller than a frigate. Most corvettes and sloops of the seventeenth and early eighteenth centuries were 12 to 15 meters (39.6 to 49.6 feet) in length, and of 40 to 70 tons burden. According to Auguste Jal (1848:528), the term corvette is derived from a vessel type from lower Brittany known as Korveten. The first incidence of the term corvette was recorded in 1664 in a French Navy inventory of ships (Boudriot 1990:6).

\subsubsection{Filibote (or Filipote)}

A filibote is a medium-sized coastal freighter that is roomy and cheap to build. These vessels were also easy to navigate (Davis 1975).

\subsubsection{Flute (or Fluyt)}

A flute was a cargo sailing vessel of heavy build with a flat bottom; it usually had a large porthole in the stem to enable the loading of large pieces of timber (Proulx 1984). Originating from Holland, the flute got its name from Vlieland area. Usually between 120 and 500 tons burden, it carried between eight and 20 guns. The vessel was three-masted with square multisails (Nelson 2001:218).

\subsubsection{Frigate}

In the eighteenth century, the term frigate referred to ships that were usually as long as a ship-ofthe-line and were square-rigged on all three masts (full-rigged), but were faster and with lighter 
armament, and were typically used for patrolling and escort. In the definition adopted by the British Admiralty, they were rated ships of at least 28 guns, carrying their principal armament on a single continuous deck (the upper deck), while ships-of-the-line possessed two or more continuous decks bearing batteries of guns. While the earlier frigates carried no more than 28 guns, the size of the frigate and the number of guns increased during the course of the eighteenth century, from 28 to 32 guns and all the way to 40 guns by the 1790s (Lavery 1987:122).

\subsubsection{Galeaza}

A galeaza (galleass in English) was a large galley with lateen sails and 25 or more rows of oars with seven to nine men per oar. A deck above the rowers supported up to 50 guns; cannons were also mounted on the stern castle. Two large oars on the stern were used to maneuver. Galleasses were successfully used in the 1571 Battle of Lepanto (Lesure 1990:125-137; Moya 1981:396).

\subsubsection{Galera}

A galera (galley in English) was a vessel mainly dependent on oar power for propulsion. Guns were mounted on the foredeck, facing forward. Utilizing one to three masts, this type of vessel was lateen-rigged (Nelson 2001:218).

\subsubsection{Galleon}

Spanish galleons, often associated with treasure, pirates, and conquistadores, epitomize Spanish maritime power throughout the sixteenth and seventeenth centuries. While romantically portrayed throughout history, galleons can be more accurately described as the workhorses of the Spanish empire, used extensively within European waters as well as those of the GOM (Konstam 2004:3).

Very little written evidence exists relative to the construction and design of sixteenth-century galleons. Shipwrights of the period rarely wrote down design and construction practices, preferring to pass on their knowledge to other shipwrights or next of kin directly. However, through a review of available historical records, ship models, pictorial evidence, and archaeological data, we can surmise the following:

Typically it was a high-sided vessel with a very tall stern castle structure (usually split into two or more levels), a lower forecastle, a flat stern, a protruding beak at the bow (like a spur on a galley), and usually a single unbroken gundeck. The hull had a pronounced tumble-home (hull sides sloping inward from bottom to top), and this tapering continued into the stern castle. A galleon's lines were graceful, and particularly fine at the stern, in contrast to its somewhat bluff bow. We know that galleons of this period were sleeker than naos; having a length-to-beam ratio of $4: 1$, as opposed to the average nao ratio of $3: 1$. We have already determined that the average galleon of c. 1550 had a burden of some toneladas. Its hull shape made it a stable platform for artillery, while the high stern castle proved a bonus in close-range fighting, as it served as a bastion for the embarked soldiers. 
Beneath the gundeck there was a decently proportioned hold, while the high superstructure provided room for the carrying of passengers or extra troops (Konstam 2004:7).

The evolution of the galleon is somewhat ambiguous:

Very few of the ships going to the Indies were identified by type in the first half of the sixteenth century, but of those identified, 35.4 percent were galleons. In an average Indies fleet of 1551-1600, some 44 percent of the ships of known types were identified as galleons or naos (Phillips 1986:42).

Early galleons in Spain could thus be considered smaller than merchant ships, as they evidently continued to be in France (Phillips 1986:42). By the late sixteenth century, galleons attained their characteristic profile:

a high aft-castle; low, set-back forecastle; beak protruding below the bowsprit; high, flat stern; and full rigging, complete with topsails on the fore and main masts. It was faster, more maneuverable, and better able to sail into the wind than earlier galleons (Phillips 1986:44).

During the early part of the seventeenth century, galleons were being constructed with heavier internal hull bracing, were carrying more armament, and were sailing with larger crews. While not designated specifically as warships, galleons were slowly fulfilling this role. Galleons carried a variety of cargoes, depending on their route, though they were only supposed to carry "legal" cargoes. Legal cargoes included "mercury, royal documents, papal bulls, and extra supplies on the outward voyage, and treasure and official documents on the homeward voyage" (Phillips 1986:45).

\subsubsection{Nao}

Naos, in the late sixteenth-century fleets, were usually more numerous, generally smaller and more lightly manned than the galleons, but that was not always the case. Both naos and galleons changed in size during the course of the sixteenth century. A list of naos from the north coast in royal service in 1505 (before the galleons developed) included 10 warships with an average size of 271.7 toneladas and a manning ratio of 22 sailors per 100 toneladas (one man for each 4.5 toneladas) (Phillips 1986:42).

\subsubsection{Paquebote}

Paquebote (packet in English) is the term given to a vessel trading regularly between two ports; for instance, a London vessel constantly plying between that port and Havana would be known as a "Havana-packet." Spanish paquebotes were usually used to carry mail (Paasch 1908:86). 


\subsubsection{Patache}

A patache was a small and swift two-masted sailing vessel used by squadrons as aviso to carry dispatches and for exploration (Pino 2001:311).

\subsubsection{Saetia}

This type of vessel was a small lateen-rigged sixteenth-century sailing vessel with just one mizzenmast. It is thought that the design of the vessel originated in the Mediterranean. The Saetia disappeared during the first quarter of the seventeenth century (Moya 1981:408).

\subsubsection{Ship}

This refers to a three-masted ship including a foremast, mainmast, and mizzenmast. Each of the three masts is fitted with a topmast, topgallant-mast and royal-mast. All are square-rigged (Paasch 1977:5).

\subsubsection{Sloop}

In the mercantile marine, this term is not clearly defined; the term is generally applied to a vessel of considerable size having one mast and rigged as a cutter but of less finished design and neatness both in the form of the hull as well as the rig; they are employed in the transport of cargoes, for fishing purposes, etc. In England, the distinction between a cutter and a sloop appears to be that a cutter is fitted with a long running bowsprit, and carries a forestaysail and one or more jibs, while a sloop is fitted with a short standing bowsprit on which one headsail only, comprising forestaysail and jib in one, is carried (Paasch 1908:13).

\subsubsection{Urca}

An urca was a type of sixteenth-century ship, smaller than a galleon and with a broader beam and rounded hull, lightly armed and used to carry merchandise, heavy cargo, and military stores from place to place. The Spanish chiefly employed this type of vessel, first in the Mediterranean, then in the Americas. The French and the Dutch utilized a similar vessel called a flute. During the seventeenth century, it was principally used to transport mercury from Spain to the Americas (Moya 1981:411).

\subsubsection{Zabra}

A zabra was a ship of up to 600 toneladas with two masts and square sails that could be outfitted with oars. Zabras were part of Phillip II's Invincible Armada, although oars were not used (Moya 1981:413). 


\subsection{Known Sixteenth- to Eighteenth-Century Shipwreck Sites and Survey Expectations within the GOM}

A number of sixteenth- to eighteenth-century shipwrecks within the GOM have been identified through previous archival research, remote-sensing surveys (conducted relative to oil and gas activities), archaeological surveys and investigations, and treasure hunting, as well as a variety of other activities (such as fishing and beachcombing). Review of the historical context, as well as previous investigations, indicates these vessel losses tend to follow chronological trends that can assist in determining the distribution and patterning of shipwrecks within the GOM. As presented in Garrison et al. (1989), these trends (outlined in 50-year periods) indicate that vessel traffic within the GOM gradually increased from the sixteenth to eighteenth centuries and that the nationality of vessels expanded from the Spanish to the French and later the British (Table 3-2). It may be surmised that the earliest vessel losses within the GOM are associated with the Spanish, with an increasing number of other nationalities contributing to vessel losses as time progressed through the eighteenth century.

Table 3-2

Chronological Trends in Gulf Shipwreck Distributions by 50 -Year Period*

\begin{tabular}{|c|l|}
\hline \multicolumn{1}{|c|}{ Years } & \multicolumn{1}{c|}{ Trend } \\
\hline $1500-1549$ & Losses reflect period of Spanish exploration of northern Gulf of Mexico \\
\hline $1550-1599$ & $\begin{array}{l}\text { Distribution begins to show pattern of losses determined by flota routes. Losses off } \\
\text { Texas are flota vessels wrecked by storm while on this route. Losses off Florida are } \\
\text { likewise. The Straits begin to take their toll. }\end{array}$ \\
\hline $1600-1649$ & $\begin{array}{l}\text { The principal losses are still Spanish flota vessels. The 1622 hurricane losses on the } \\
\text { Keys are a significant portion of the shipwreck pattern for this period. }\end{array}$ \\
\hline $1650-1699$ & $\begin{array}{l}\text { The pattern reflects the first French losses in the Gulf at Matagorda Bay in 1685. The } \\
\text { remainders are Spanish losses. }\end{array}$ \\
\hline $1700-1749$ & $\begin{array}{l}\text { The distribution shows the first major change in northern Gulf's shipwreck pattern. This } \\
\text { is due to the French colonization of Louisiana and the increase in a similar interest by } \\
\text { the Spanish in Pensacola to balance the French. }\end{array}$ \\
\hline $1750-1799$ & $\begin{array}{l}\text { The pattern of shipwrecks in the northeastern Gulf is the result of two basic processes: } \\
\text { colonization and commerce. The French and Spanish have reached the height of their } \\
\text { maritime activity in the Northern Gulf of Mexico. The flotas end in the last quarter of this } \\
\text { century. }\end{array}$ \\
\hline
\end{tabular}

${ }^{*}$ As presented in Garrison et al. 1989:II-100.

A review of the GOM shipwreck database (updated April 10, 2009) maintained by BOEMRE identified a total of 19 vessels dating from the sixteenth to eighteenth centuries (Table 3-3). While the location of a number of the vessels on this list are actually known (e.g., El Nuevo Constante), the location of many of these vessels is not known with any reliability. Whereas the BOEMRE shipwreck database does provide a location for each of the wrecks presented in Table 3-3, the accuracy of such coordinates is questionable as many of the wrecks have never been positively identified (Figure 3-1). This list includes those vessels thought to be located in federal waters and does not includes those wrecks located near shore, in state waters. 
Table 3-3

\section{Shipwrecks Dating from the Sixteenth to Eighteenth Centuries Listed on the BOEMRE Shipwreck Database}

\begin{tabular}{|l|l|l|l|}
\hline \multicolumn{1}{|c|}{ Vessel Name } & Alternate Name & Year of Loss & \multicolumn{1}{c|}{ Nearest Land } \\
\hline San Jorge & n/a & 1625 & Unknown \\
\hline El Cazador & n/a & 1784 & Grande Isle, Louisiana \\
\hline El Nuevo Constante & Duke of York & 1766 & Southwest Louisiana \\
\hline La Prince de Conty & n/a & 1731 & Unknown \\
\hline Galgo & n/a & 1783 & Unknown \\
\hline Vigilante & n/a & 1732 & Unknown \\
\hline Nuestra Senora del Amparo & El Principe de Orange & 1772 & Entrance to Mississippi River \\
\hline La Louisiane & n/a & 1738 & Belise Bar \\
\hline Betsey & n/a & 1750 & Unknown \\
\hline La Caraquena & Guipuzcana & 1776 & Galveston Island \\
\hline America la Reseda & n/a & 1779 & Louisiana \\
\hline Le Constance & n/a & 1766 & Chandeleur Islands \\
\hline Rhode Island & n/a & 1752 & Unknown \\
\hline Alexander & n/a & 1752 & Unknown \\
\hline Dolphin & n/a & 1748 & Cape Florida \\
\hline Dolphin & n/a & 1752 & Unknown \\
\hline Statea & n/a & 1752 & Unknown \\
\hline Lancaster & n/a & 1752 & Unknown \\
\hline May & n/a & 1752 & Unknown \\
\hline
\end{tabular}

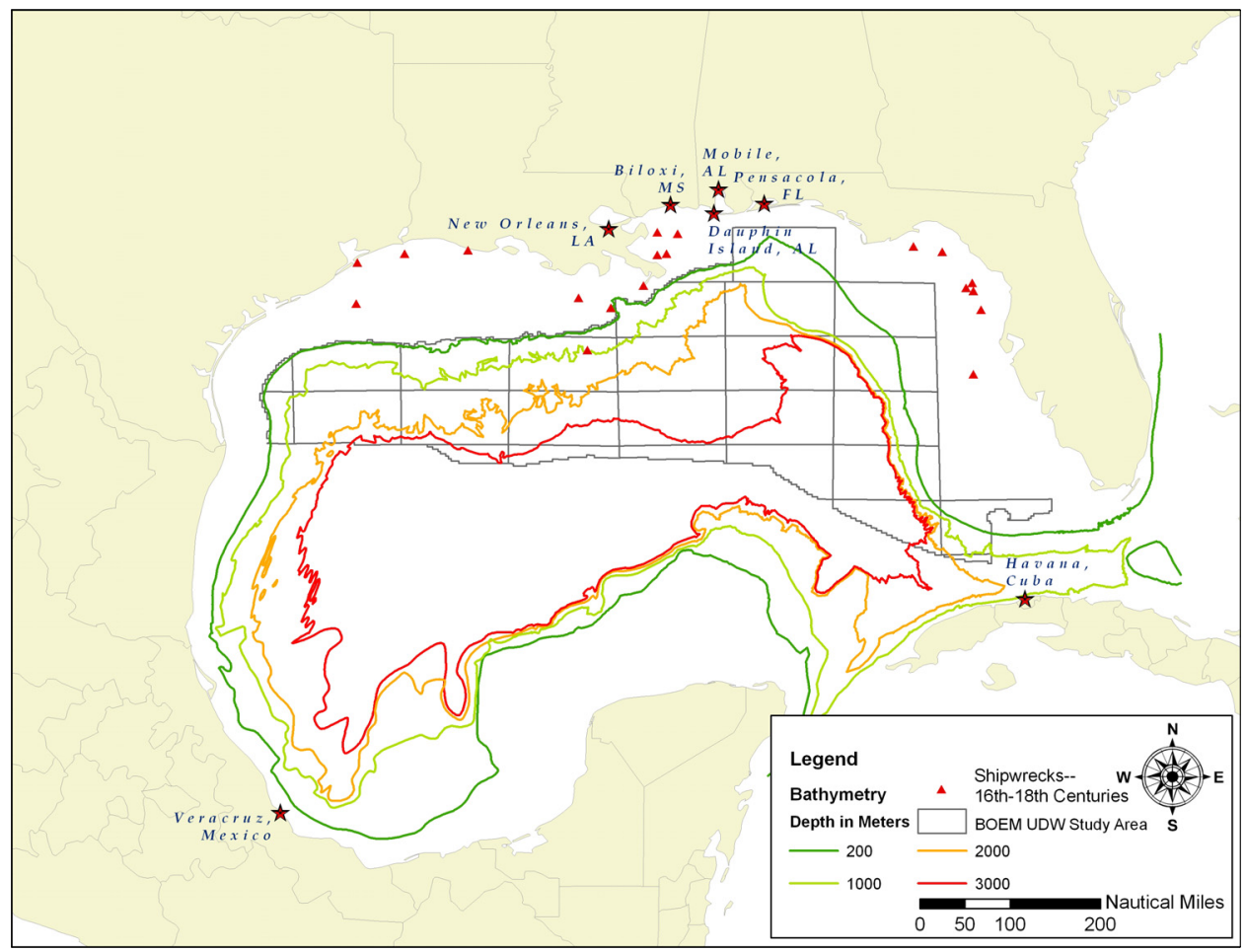

Figure 3-1. Plotted location of sixteenth- to eighteenth-century shipwrecks within the GOM from the BOEMRE shipwreck database. 
In addition to BOEMRE's shipwreck database, recent archival research more specific to Spanish vessels en route from Veracruz to Havana (Lugo-Fernandez et al. 2007) has identified a number of additional potential vessel losses dating from the sixteenth to eighteenth centuries within the GOM (Table 3-4). Data for this table was compiled primarily from secondary sources including Chaunu and Chaunu (1955-1957) and García-Baquero González (1976), as well as a variety of other sources.

Table 3-4

Additional Vessel Losses within the GOM*

\begin{tabular}{|l|l|l|l|}
\hline Year Lost & \multicolumn{1}{|c|}{ Name of Ship } & \multicolumn{1}{c|}{ Name of Master } & \multicolumn{1}{c|}{ Type of Ship } \\
\hline 1562 & Unknown & Pedro Menendez & Nao \\
\hline 1567 & N.S. de los Remedios & Lazaro de Rosas & Nao \\
\hline 1573 & La Madalena & Cristobal Sanchez & Nao \\
\hline 1586 & Unknown & n/a & Barco con situado \\
\hline 1592 & Nao de Diego Felipe Andino & n/a & Nao \\
\hline 1592 & Nao grande de Granillo & n/a & Nao \\
\hline 1592 & Nao de Miguel de Alzate & n/a & Nao \\
\hline 1595 & El San Crucifixo de Burgos & Pedro de Madariaga & Galleon \\
\hline 1600 & Unknown & Diego Rodriguez & Nao \\
\hline 1606 & Unknown & Pedro de Izaguirre & Frigate \\
\hline 1615 & Candelaria & Juan Estevan & Nao \\
\hline 1719 & S. Juan Bautista & n/a & Frigate \\
\hline 1725 & S. Bartolomé "El Cambi" & n/a & Unknown \\
\hline 1730 & Constante & n/a & Ship \\
\hline
\end{tabular}

${ }^{*}$ As presented in Lugo-Fernandez et al. 2007:39.

In addition to vessel losses identified through archival research efforts, a number of vessels dating from the sixteenth to eighteenth centuries have been documented (to varying degrees) within the GOM and adjacent areas. Known archaeological sites (dating from the sixteenth to eighteenth centuries) within the GOM and other similar environments (such as the Dry Tortugas and the Florida Keys) can offer insight into the potential preservation and subsequent identification of undiscovered wreck sites. A review of hull remains, cargo, and artifacts recovered from these wreck sites may assist in identifying newly found wreck sites within the GOM in the future. Even though some of the wreck sites presented below are located in nearshore and even bay environments, a review of their hull construction, cargo, and artifact remains can offer insight into the vessel types and various cargoes being transported across the current study area. The vessels below are presented in chronological order and represent historic vessels examined by both archaeologists and treasure salvors (Table 3-5). Information gathered from both groups can be informative relative to historic vessel losses within UDW of the GOM. 
Table 3-5

Historic Vessels (ca. Sixteenth to Eighteenth Centuries) Located in and Around the GOM, Documented to Varying Degrees by Archaeologists and Treasure Salvors

\begin{tabular}{|l|l|l|}
\hline \multicolumn{1}{|c|}{ Vessel(s) } & \multicolumn{1}{c|}{ Year of Loss } & \multicolumn{1}{c|}{ Location } \\
\hline 1554 Plate Fleet & 1554 & Padre Island, Texas \\
\hline Emanuel Point I and Emanuel Point II & 1559 & Pensacola Bay, Florida \\
\hline Tortugas Deepwater Shipwreck & 1622 & Dry Tortugas \\
\hline Nuestra Señora de Atocha & 1622 & Florida Keys \\
\hline San Felipe & 1733 & Florida Keys \\
\hline El Nuevo Constante & 1766 & Louisiana \\
\hline El Cazador & 1784 & Grand Isle, Louisiana \\
\hline The Mica Wreck & $1775-1830$ & GOM \\
\hline The Mardi Gras Wreck & $1810-1820$ & GOM \\
\hline
\end{tabular}

\subsubsection{Plate Fleet, Padre Island, Texas (1554)}

One of the earliest recorded shipwreck events within the GOM includes three shipwrecks associated with the 1554 Plate Fleet, which wrecked off Padre Island, Texas. In 1554, four ships departed for Spain from Mexico including:

the San Esteban, under master Francisco del Huerto; the Espíritu Santo, under master Damián Martín; the Santa María de Yciar, under master Alonso Ojos, with Miguel de Jáuregui, the owner, sailing as captain and pilot; and the San Andrés, under master Antonio Corzo (Arnold and Weddle 1978:326).

It was later relayed to the Spanish Crown that:

The lord permitted three ships to be wrecked on the $29^{\text {th }}$ of [April] off the coast of Florida near the Río de las Palmas at 26 1 1/2 degrees, where more than 250 persons died and more than a million ducats were lost due to the lack of caution by pilots and sailors. Efforts are being made to recover something of what was lost [Quesada 1554] (Arnold and Weddle 1978:35).

The cause of the vessel losses was attributed to foul weather, and it is unknown whether the vessels may have lost steerage, causing them to be driven to shore, or if the vessels simply ran out of room to sail during the storm. All three vessels were ultimately driven ashore at Padre Island, a barrier island that extends from Corpus Christi to Port Isabel, Texas (Arnold and Weddle 1978:36).

While foul weather was to blame for the wrecked vessels, it was not a hurricane that caught the vessels on their voyage to Havana. Hurricane season within the GOM extends from June through October, and the vessels were wrecked in late April. It is possible that the vessels encountered an equinoctial storm, "the result of unsettled weather conditions attending the vernal and autumnal equinoxes, about March 21 and September 23. Spring's unsettled weather in the Gulf region often extends well into May" (Arnold and Weddle 1978:36). 
The vessels had been at sea for 20 days when they encountered the foul weather that caused their demise. The typical sailing time between Veracruz and Havana was between 12 and 40 days, with the average being 18 to 20 days. It is assumed that the fleet of four vessels must have been well past the halfway point to Havana before the storm struck, and then was forced to sail in adverse conditions for several days before running aground off Padre Island (Arnold and Weddle 1978:36).

Salvage operations to recover merchandise and goods was assembled in Veracruz, set sail on July 15, and arrived at Padre Island on July 22, 1554. Salvage of the three vessels continued until September 12 when a weighing of the treasure was undertaken, resulting in the following totals:

The bullion from the San Esteban was calculated at 524 arrobas, with 9000 pesos in coin counted in addition. Espiritu Santo's salvage amounted to 391 arrobas, and 11,000 pesos, while Santa Maria's weighed 62 quintales, or 248 arrobas, and there were 2000 pesos in coin. By this calculation, the salvage totaled 29,078 pounds of silver bullion and 22,000 pesos-less than half of the total amount carried by the three ships (Arnold and Weddle 1978:144).

The wreck sites were eventually forgotten, left to slowly deteriorate in the waters off Padre Island. It was not until the late 1960s that treasure hunters began searching for lost vessels, after reports of coins washing ashore spiked their interest. Treasure-hunting activities continued until late 1967, when they were halted by court order (Davis 1977:39). After artifacts were returned to the State of Texas, a State Antiquities Code was passed by the legislature that established the Antiquities Committee "to supervise salvage and preservation of prehistoric and historic artifacts from state lands, including items from the tidelands" (Davis 1977:39). It was not until the early 1970s that investigation of the wreck sites was undertaken by the Antiquities Committee and the Texas State Marine Archaeologist. The three sites investigated were "virtually equidistantly spaced about $4 \mathrm{~km}$ (2.5 miles) apart, with the southern of the three at the Mansfield Cut" (Arnold and Weddle 1978:326).

\section{Site Characteristics}

The shipwreck sites associated with the 1554 fleet were located near shore and in a relatively unstable marine environment. Having been pushed to shore by the storm, the vessels were likely exposed for some time and, as a result, were impacted by salvage attempts and environmental factors (such as surge, tide, mobile sediments, storm events, and various marine organisms):

Excavations at one of the 1554 Spanish fleet wrecks (Site 41KN10, believed to be the vessel San Esteban) off Padre Island, Texas, revealed that all the remains of the vessel were buried by 0.6 to $1.3-\mathrm{m}$ of sand, silt, and shell. It was believed that the wreckage had migrated downward through loose sediments to an underlying dense and impenetrable Pleistocene clay surface. Marine growth on artifacts indicated that the wreckage had been exposed in the water column for long periods of time prior to the initial excavations in 1972 (Arnold and Weddle 1978:195-198). This site lies close to shore where current and wave dynamics and sediments are somewhat different from those in offshore areas; however it is 
reasonable to assume that the offshore wrecks in lower Texas can become totally or partially buried. This is certainly true for two nineteenth century wrecks known from the offshore area of the upper Texas coast, the Hatteras and New York, both of which were partially buried when discovered (Pearson et al. 2003:3-32).

Very little of the hull remains of any of the wrecked vessels were ever located, likely the result of the aforementioned factors (Figure 3-2). Therefore, an assessment of the hull remains associated with the 1554 Plate Fleet is difficult. However, it has been determined that the:

ships that went aground were not the large Spanish treasure-frigates or galleons that later were more frequent in the Gulf and Caribbean.... The wrecked ships were small-sized traders, less than 100 feet long, capable of carrying a few tons of cargo. The Ships of the $16^{\text {th }}$ century carried bulky cargo and a lot of sail. This accounts for the most obvious things about them-the large, practical hulls and the abundant rigging (Davis 1977:49).

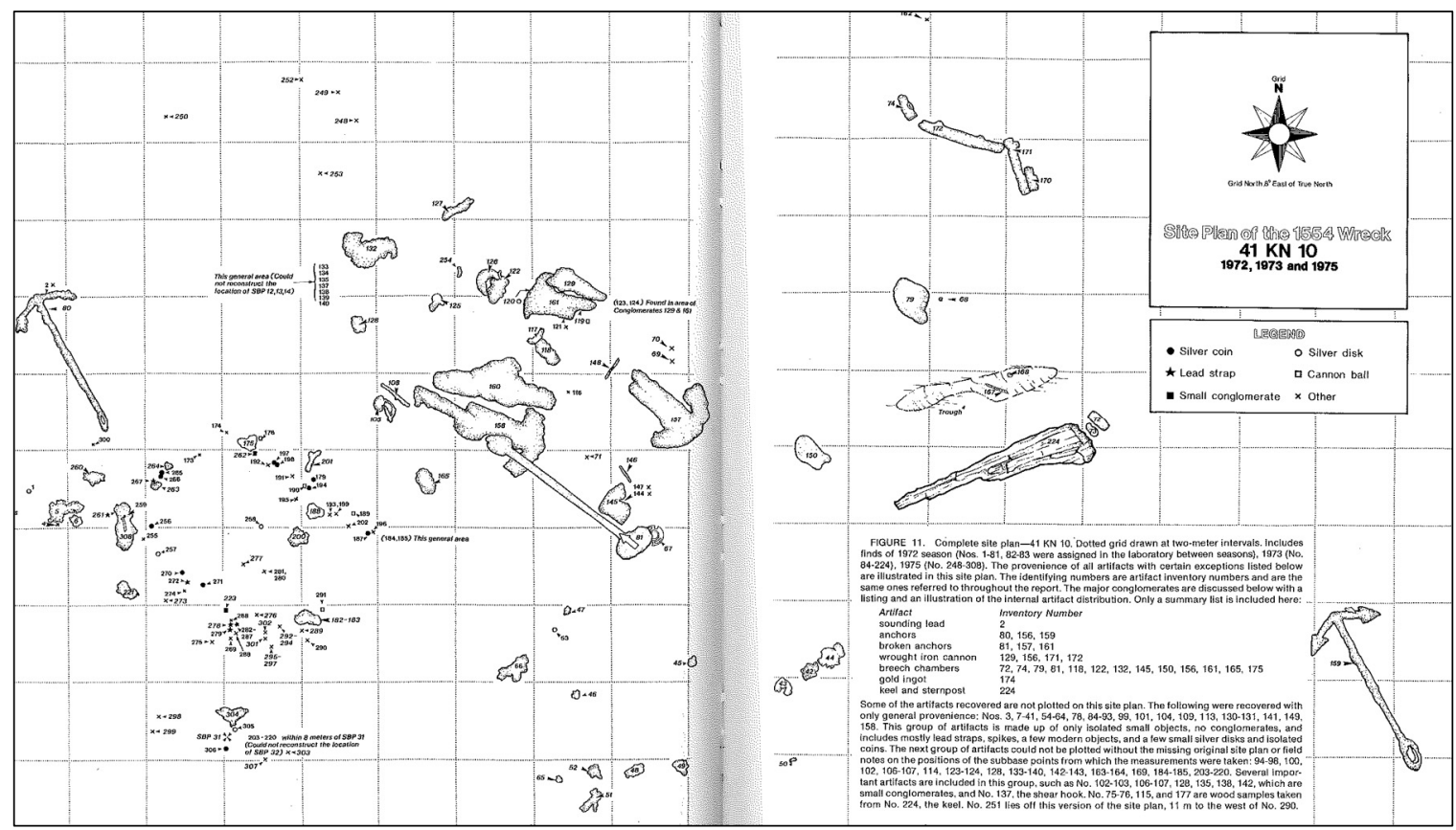

Figure 3-2. Site plan of 41 KN 10 (one of the three 1554 wrecks) (as presented in Arnold and Weddle 1978:210-211).

In addition to a lack of hull remains associated with the wreck sites of the 1554 Plate Fleet, a lack of understanding of ship construction practices during the sixteenth century adds to the difficulty in reconstructing these early exploratory vessel types. Shipwrights of the period kept their knowledge of ship construction in their heads, passing information on to next of kin or to workers within the same company (Olds 1976:153).

Archival research of the cargos associated with the 1554 fleet offer valuable information relative to vessels outbound from Mexico to Havana, and then on to Spain. Research of primary documents relative to the 1554 fleet was undertaken from 1972 to 1977 in various repositories in 
Spain, Mexico, England, and France. Researchers concluded that the "richest source of documentary materials regarding Spanish colonial America is the Archivo General de Indias (AGI) in Seville" (McDonald and Arnold 1979:xvii). Research efforts relative to the 1554 Plate Fleet gathered approximately 35,000 pages of microfilmed documents, several hundred pages of photocopied documents, and early navigational maps of the GOM. Material gathered has been very useful in providing relevant information to maritime traffic within the GOM from the sixteenth to eighteenth centuries as well as identifying, describing, and interpreting early Spanish shipwrecks within the GOM (McDonald and Arnold 1979:xvii).

The homebound register of Santa Maria de Yciar was the only primary document found relative to the 1554 homebound fleet, which identified the vessels' cargo and shipboard items. This document provides a wealth of information relative to the exportation of gold and silver, trade relations, and commodities being produced in New Spain. Registers were a record of each partida (parcel of cargo) loaded onto the ship. Every ship was required to carry a register, with copies provided to other ships in the fleet in the event a vessel and cargo were lost. The register listed the item being transported, a brief description of the item, its sender, and intended recipient. Upon arrival in Seville, all cargo was conveyed to the House of Trade, where royal officials used the register to allocate the partidas to the rightful owners (McDonald and Arnold 1979:81).

The register of Santa Maria de Yciar was conducted in both Veracruz and San Juan de Ulúa from February 27 to April 7, 1554, prior to the fleet's departure:

The total weight of the cargo, not counting armaments, equipment, and provisions, is estimated conservatively at 50,000 pounds. Almost 2,500 pounds of various types of pesos of gold and silver were recorded, with more than 10,000 pounds of silver bullion in planchas (translated here as sheets).... Commodities registered included more than 20,000 pounds of cochineal; 8,400 pounds of liquidambar; 1,250 pounds of white sugar; 3,200 pounds of wool; and more than 1,200 cowhides (McDonald and Arnold 1979:81).

The register also lists the variety of armaments onboard the homebound vessel. These armaments, recorded by the ship's gunner, Lorenzo Hernández, comprised:

10 pieces of heavy artillery, 32 pieces of light artillery (versos), and 100 harquebuses. Munitions included nine barrels of powder and 500 cannon balls. Additional weapons listed were crossbows, spears, and shields (McDonald and Arnold 1979:81).

A brief description of the ships' provisions was also provided within the register, including " 5,000 pounds of biscuit (vizcocho), two barrels of meat, beans, olive oil, vinegar, and 50 barrels of water" (McDonald and Arnold 1979:81). The boatswain, Pedro de Isase, claimed the vessel was equipped with four anchors, five cables, as well as rigging and sails sufficient for the voyage (McDonald and Arnold 1979:81). 


\subsubsection{Emanuel Point I (EPI) and Emanuel Point II (EPII) Shipwrecks, Pensacola Bay, Florida (1559)}

The Emanuel Point I (EPI) and Emanuel Point II (EPII) shipwrecks, located in Pensacola Bay, Florida, represent two of the earliest shipwrecks identified to date in Florida. Both vessels were part of Tristán de Luna's fleet that was caught in a hurricane while anchored in the bay in 1559. Examination of these two vessels (EPI and EPII) can offer insight into the vessel types of the period as well as goods being transported across the GOM for a colonization attempt.

Archival sources indicate there were 11 vessels associated with Luna's fleet. The purpose of the fleet was to establish a colony in Florida and secure the northern frontier of New Spain for the Crown. One thousand colonists and servants, 500 soldiers, and some 240 horses were employed for the colonization effort. While one of the vessels (San Juan de Ulúa) was sent back to Veracruz to obtain more supplies for Pensacola, the remainder of the fleet stayed in Pensacola.

The fleet, at anchor, was unexpectedly caught in a hurricane, which claimed all the vessels except for one caravel and two barks (Smith et al. 1998). The loss of the seven vessels (including unloaded cargo) was a major blow to the colonization of Pensacola, which was subsequently abandoned two years later in 1561. Pensacola remained abandoned until 1698 when a permanent presidio was established (Smith et al. 1998:3).

\section{Emanuel Point I}

The EPI wreck site was discovered in 1992 during a pilot survey of Pensacola Bay. Conducted by the Florida Bureau of Archaeological Research (BAR), the survey intended to locate and identify a variety of shipwrecks within the bay that spanned a broad range of the historic period. The survey was successful in locating more than 45 sunken vessels, many of which had simply been abandoned (Smith et al. 1998:1). Excavations of EPI continued from 1992 through 1998.

\section{Site Characteristics}

Initial examination of the EPI indicated that the wreck site was mostly buried under sediment with only a portion of the ballast mound protruding above the seafloor. Exposed portions of the ballast mound served as a substratum for oysters as well as other marine organisms. A variety of sediment layers (which have ultimately preserved the remnants of EPI) consist of loose, coarse sand and fine silt at the surface layer, followed by a layer of dense shell remains (bound by compacted silt) and then a complex layer of "loose silt and shell which represents the original deposition of marine sediments that entered the hull as it wrecked and disintegrated" (Smith et al. 1995:19). Sediments covering the wreck location are not unexpected considering the location of the wreck site within Pensacola Bay and the close proximity of the Escambia River, as well as seasonal tides and storms.

Analysis of the hull remains associated with EPI suggests the vessel was a large Spanish ship that had sailed from Mexico to Florida (Figure 3-3). Subsequent investigations of EPI revealed that the vessel was larger than originally anticipated: 


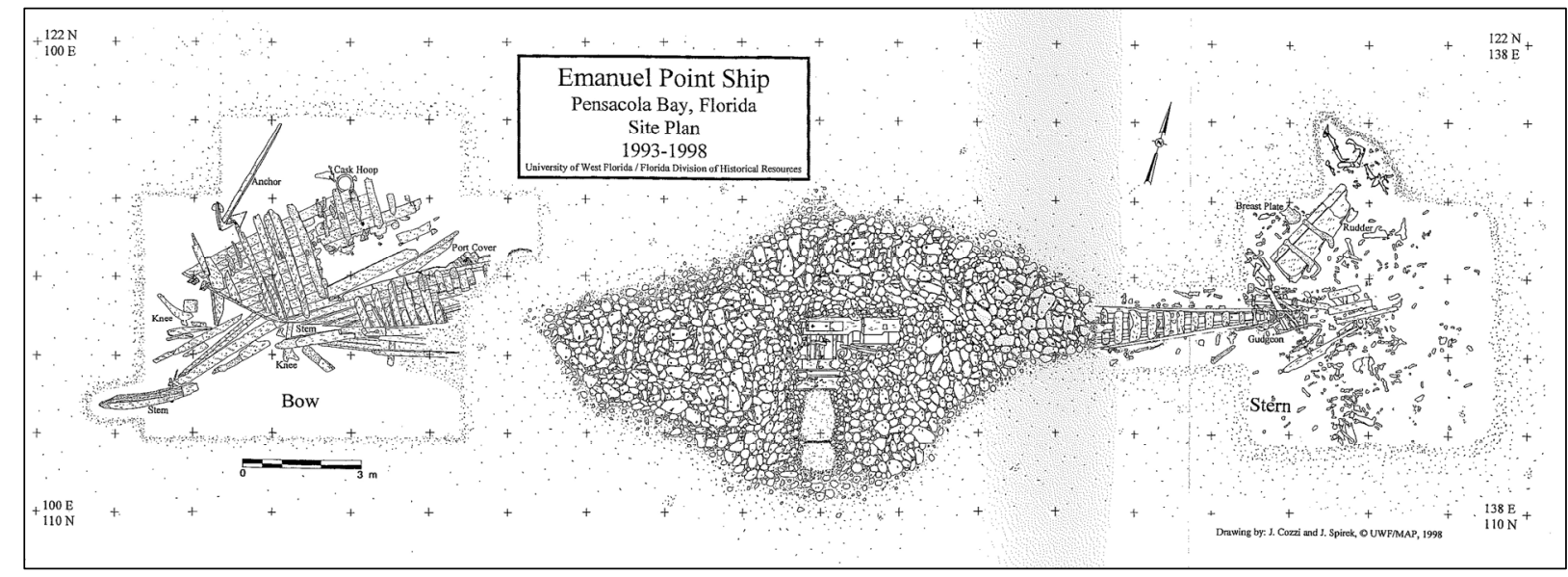

Figure 3-3. Site plan of Emanuel Point I (EPI) shipwreck (as presented in Smith et al. 1998:30).

With a keel length of more than $23 \mathrm{~m}$. her hull length is estimated to have been more than $34 \mathrm{~m}$. (over 100 feet). She must have been one of the capital ships of each convoy she sailed with, and probably carried her fair share of passengers and merchandise to the colonies, returning to Spain with substantially profitable cargoes. Her role in the fleet of Tristán de Luna more likely was that of a large freighter, transporting a bulk of people and their equipment, like a moving van, to a new destination. In proportion to the overall size of the wrecked ship's hull... there is a relatively small amount of ballast on her central timbers, indicating that she had been heavily loaded on her last voyage and required only light ballasting prior to lading (Smith et al. 1998:165).

Other findings from the excavation of the EPI hull indicate the vessel was a veteran of ocean transport. Numerous repairs to the hull were identified during the excavations, including a replaced tail frame in the stern, as well as the substitution of American oak for European oak in various frames (indicating the vessel had been repaired in the New World). The presence of numerous lead patches also implies the vessel was well traveled (Smith et al. 1998:165).

Excavations indicate that the hull of EPI met a violent end within the protected waters of Pensacola Bay. This was the result of striking a shallow shoal after the vessel broke anchor during the hurricane. The hull broke apart longitudinally, with the port side separating from the ship as she filled with water. Additional findings from the excavations of the hull remains highlight the wreck event itself:

Her back broken, frames sheared apart, the sunken vessel came to rest, heeling slightly to the wounded port side. Below decks, everything was thrown forward by the impact; pots and pans were toppled, tablewares cascaded towards the bow, and barrels and jars of provisions released their contents as they broke open. At some point, the galleon's rudder became unshipped from its hinges and landed flat on the sand bar next to the stern. In addition, the upper side of the starboard bow collapsed, falling outward and away from the stern to which it was attached, perhaps under the weight of the ship's anchor (Smith et al. 1998:166). 
Although the decks and upper works of the vessel were either salvaged after the wreck event or displaced over time from deterioration, the lower hull remained relatively intact, preserved by sediments within Pensacola Bay.

\section{Artifacts}

Investigation of EPI identified a well-preserved assemblage of artifacts highlighting early Spanish exploration and colonization of the southeastern United States. Recovered items included:

European and Native American ceramics, Old World and New World botanical and faunal remains, wooden tools, stone and lead ammunition, copper galley wares, as well as the remains of insects and rodents that inhabited the bilge during the sailing career of the vessel (Smith et al. 1998:2).

A review of the cargo was helpful in confirming the vessel as that of one of Tristán de Luna's fleet vessels. The recovery of ceramic storage containers and glazed tablewares corroborate that the vessel dated to the mid-sixteenth century. These types of ceramics can be expected on Spanish colonial sites, "whether maritime or terrestrial" (Smith et al. 1998:167).

Military items recovered from the EPI were relatively sparse, likely the result of salvage operations after the wreck event. Emphasis on the recovery of these items would have been paramount considering the perilous situation the colonists faced. Items recovered during the excavation of EPI included artillery shot (stone, iron, lead, and composite types), copper crossbow bolt heads, a breast plate, and obsidian blades, to name a few (Smith et al. 1998:168).

The presence of mercury identified within the bilge helped to assign a terminus post quem for the EPI shipwreck. Mercury was utilized during the silver amalgamation process but was not imported to the New World until 1556.

Standard shipboard items recovered during the excavation included copper cooking utensils, a skillet, a saucepan, a bronze pestle, a mortar, and a heavily riveted cauldron. Additional ceramics found include ceramic tablewares, lead-glazed plate and bowl fragments, and a majolica plate (Smith et al. 1998:ii).

While only 40 percent of the EPI has been excavated to date, thousands of artifacts and field specimens and a substantial portion of the lower hull have been recorded. The findings from the EPI excavations can offer tremendous insight into sixteenth-century ship construction and cargoes of the period.

\section{Emanuel Point II}

Ensuing remote-sensing surveys and diver investigations conducted by the University of West Florida (UWF) Archaeology Institute (located in Pensacola, Florida) identified the suspected remains of a second vessel, also believed to be associated with Tristán de Luna's fleet (lost in 1559). Remote-sensing surveys, conducted by UWF, have been ongoing since 2004 within 
Pensacola Bay and have located 129 magnetic and side-scan sonar targets. During the 2006 field season, 35 targets were investigated by divers, 18 of which were positively identified (Cook et al. 2009:3). Examination of "Target 17" identified a mostly buried ballast pile, approximately 14 meters in length. Additional dives confirmed the presence of a shipwreck, presumed to be associated with the ill-fated de Luna fleet. The shipwreck was dubbed Emanuel Point II (EPII) due to its suspected association with the de Luna fleet; test units on the shipwreck site were excavated in 2007 and 2008.

\section{Site Characteristics}

Discussions with UWF indicate that the remains of EPII were mostly buried when it was investigated in 2006 and that only the top surfaces of a couple of ballast stones were visible. The presence of an oyster shell layer on top of the buried ballast mound suggests the wreck was exposed at some point (Greg Cook, personal communication, April 2010). Test excavations on site confirmed the presence of ballast stones, hull timbers, and artifacts (Figure 3-4). The preliminary assessment of the site:

revealed the presence of an almost completely submerged ballast pile at least $14 \mathrm{~m}$ in length; fragments of lead strips that had been tacked over the vessel's planking seams, identical to those found on the Emanuel Point I Ship; iron fasteners in the form of encrustations; Spanish olive jar sherds; and one sherd of tin-glazed pottery identified as Columbia Plain majolica. Intact hull timbers were noted below the ballast in two areas. Of particular note, divers recorded the

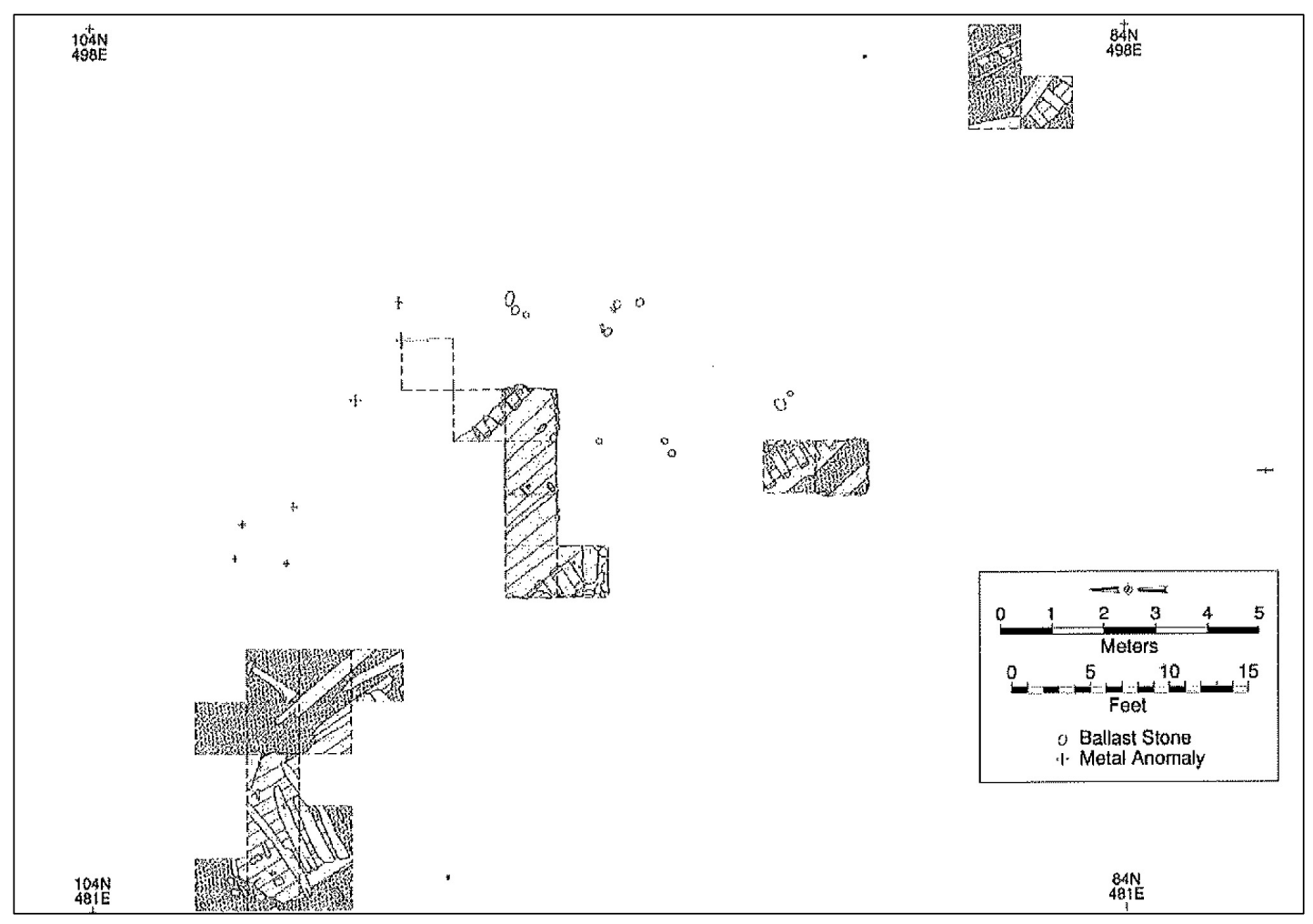

Figure 3-4. Site plan of Emanuel Point II (EPII) shipwreck (as presented in Cook et al. 2009:52). 
presence of filler pieces fitted between frames and on the upper limits of ceiling planking, which has been noted on several other Iberian sixteenth century wreck sites (Cook et al. 2009:51).

While excavations of EPII are ongoing, a comparison of hull remains indicate that EPII is significantly smaller than EPI. Table 3-6 provides a review of scantling measurements.

Table 3-6

Scantling Comparison between EPI and EPII*

\begin{tabular}{|c|c|}
\hline Emanuel Point I & Emanuel Point II \\
\hline Preserved hull length:34.6 meters & Preserved hull length: 18.6 meters \\
\hline $\begin{array}{l}29 \mathrm{~cm} \text { molded } \\
31 \mathrm{~cm} \text { sided }\end{array}$ & $\begin{array}{l}27 \mathrm{~cm} \text { molded } \\
30 \mathrm{~cm} \text { sided }\end{array}$ \\
\hline $\begin{array}{l}34 \mathrm{~cm} \text { molded } \\
22 \mathrm{~cm} \text { sided }\end{array}$ & $\begin{array}{l}15 \mathrm{~cm} \text { molded } \\
20 \mathrm{~cm} \text { sided }\end{array}$ \\
\hline $\begin{array}{l}16 \mathrm{~cm} \text { molded } \\
19-22 \mathrm{~cm} \text { sided } \\
41-45 \mathrm{~cm} \text { on center spacing }\end{array}$ & $\begin{array}{l}16-18 \mathrm{~cm} \text { molded } \\
18-22 \mathrm{~cm} \text { sided } \\
40-45 \mathrm{~cm} \text { on center spacing }\end{array}$ \\
\hline $5.5 \mathrm{~cm} \times 25 \mathrm{~cm}$ & $5.5 \mathrm{~cm} \times 23 \mathrm{~cm}$ \\
\hline Ceiling planking: & Ceiling planking: \\
\hline Lead sheathing present & Lead sheathing present \\
\hline
\end{tabular}

${ }^{*}$ As presented in Cook et al. 2009:56.

\section{Artifacts}

Ongoing excavations of the EPII site have recovered a variety of artifacts to date including lithics (i.e., ballast stones), various metal objects (in the form of concretions, lead patches, and sheathing), glass, flora (i.e., wood, seeds, organic material), fauna (i.e, animal remains), and brick. It is evident from test excavations that the most prolific types of artifacts recovered to date include ceramics. Since 2006, a total of 496 ceramic sherds have been recovered from EPII:

From this total $64 \%$ represented olive jar, $2.2 \%$ were Isabela polychrome, $0.6 \%$ were El Morro ware, 3.4\% Columbia Plain, 5\% Melado ware, 1.6\% Green Bacín, $0.4 \%$ green lead glazed coarse earthenware, $5.4 \%$ lead glazed coarse earthenware and the remaining ceramic sherds were indeterminate coarse earthenware. This last type of coarse earthenware represented a large portion of the ceramics at 17.4\% (Cook et al. 2009:64).

It is not surprising that ceramics represent the largest body of artifacts recovered to date. Used primarily to transport food stores, historical accounts relative to the de Luna fleet indicate that "most of the food was left on board the ships until a secure warehouse could be constructed on land" (Cook et al. 2009:66). It is apparent that the hurricane that doomed the de Luna fleet struck before a warehouse could be constructed.

Similar to those of EPI, the remains of EPII were mostly buried in sediment. This is not surprising considering the near-shore location of the wreck site within Pensacola Bay and the 
close proximity of the Escambia River (a source of mobile sediments), as well as seasonal tides and occasional storm events.

\subsubsection{Tortugas Deepwater Shipwreck (1622)}

During the 1950s, shrimp fishermen working off the Dry Tortugas snagged their deepwater nets on an obstruction and consequently recovered two large ceramic amphorae. These ceramics were later identified as colonial-era Spanish olive jars. While it was believed the amphorae came from an early-colonial-period Spanish shipwreck, the depth of the wreck (402 meters [1,326 feet]) made exploration of the site unfeasible at the time.

It was not until 1989 that the site was revisited by Seahawk Deep Ocean Technology (Seahawk) of Tampa, Florida. Armed with a Remote Operated Vehicle (ROV), the group was successful in recovering the vessel's bronze bell. A request for admiralty and maritime jurisdiction was filed in the U.S. District Court in Miami, Florida, and subsequently awarded to Seahawk on November 29, 1990 (Flow 1999:1).

\section{Site Characteristics}

The initial visual survey of the Tortugas Deepwater Shipwreck was accomplished with a Phantom DHD2 ROV. Deployed from the R/V Seahawk, the ROV visually surveyed the wreck site and "revealed an area approximately 10 meters wide and 15 meters long with evidence of wooden timbers, piles of ballast stone and dozens of the seventeenth century style ceramic amphora" (Flow 1999:20). Located in over 396 meters (1,300 feet) of water, it is apparent that much of the hull remains were exposed on the seafloor, the result of low sedimentation rates within the area. During onsite investigations of the site bottom, currents averaged 1.5 to 4 knots.

Very little is known about the hull remains of the Tortugas Deepwater Shipwreck. In fact, the only description of the hull relates to the orientation of the wreck site:

The longitudinal axis of the site appears to be aligned roughly along a northwest/southeast line, with the bow area lying at approximately 155 degrees or to the southeast.... The first indication of the bow/stern orientation was revealed after plotting the preliminary site plan with positional data gleaned from a circumsurvey ROV dive. The majority of the ballast pile is positioned toward the southeast two-thirds of the visible site (Flow 1999:14).

However, a site plan of the wreck site was completed, likely compiled from video surveys of the wreck site. Examination of the site plan identifies a number of exposed hull timbers and planks at the northwest end of the wreck site in addition to a sizable ballast mound (Figure 3-5).

\section{Artifacts}

Recovery of artifacts from the site was undertaken in 1990 and continued through 1991. Conservation and analysis of artifacts was completed in 1998. Overall, a total of 16,903 artifacts were recovered from the wreck site. 


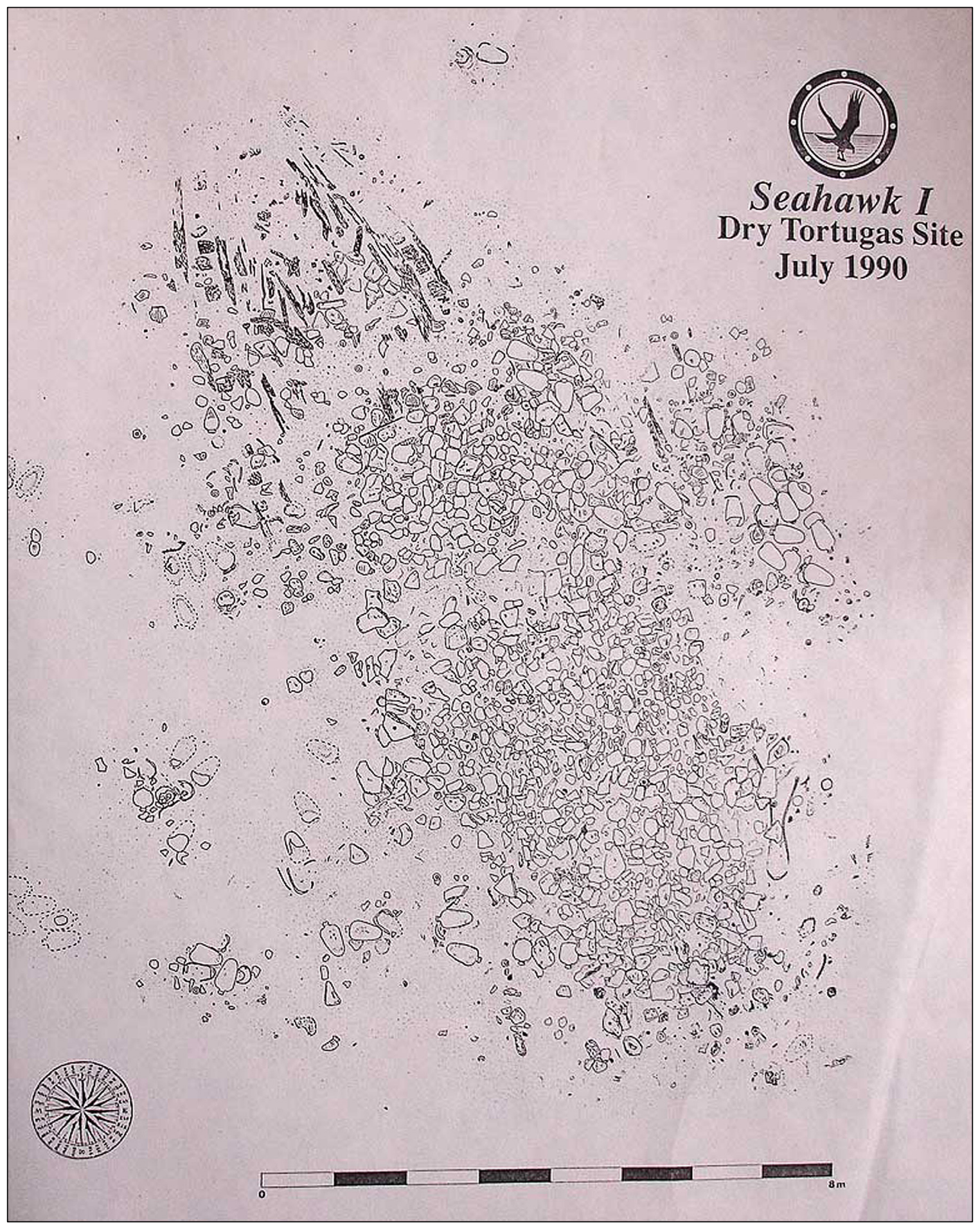

Figure 3-5. Site plan of the Tortugas Deepwater Shipwreck (as presented in Flow 1999:15). 
Broad categories of recovered artifacts included ceramics, glass, metals, organics, and stone. Ceramic types recovered included aboriginal ware (likely of New World manufacture), olive jars (76 intact, 10 intact but cracked, and 123 separate rims and several thousand sherds), and glazed and unglazed earthenwares. Miscellaneous ceramic items recovered from the wreck site included ceramic beads, a brick fragment, various small sherds, and a small number of fragments of unknown use (Flow 1999:46-47).

Glassware was present on site but not plentiful. "A total of 127 sherds of glass were recovered, including square bottle bases in two sizes: five bases of approximately $100 \mathrm{~mm}$ square, and three bases approximately 60mm square" (Flow 1999:48). Color of the glass sherds varied from clear, clear with a white stripe, dark brown, green, light green, smoky gray, and yellow. In addition, several pieces of decorative glass were recovered.

A variety of beads were also recovered during salvage operations. This included a "total of 282 beads and bead fragments of glass, stone, wood, and ceramic" (Flow 1999:52). A number of pearls, some with drilled holes (suggesting use as a necklace), were also recovered from the Tortugas Deepwater Shipwreck.

Metal objects recovered from the site included a variety of brass, bronze, copper, gold, silver, iron, and lead artifacts. More specifically, this included a brass religious medallion, three bronze astrolabes, a bronze bell, two bronze mortar and pestles, a copper cauldron, a copper ladle, numerous gold objects (including coins, bars, bits, chain, jewelry stems, and rings), 1,148 silver coins, 14 iron cannonballs, and 200 lead shot (Flow 1999:58-88).

Organic artifacts recovered included bone fragments (animal and human), human teeth, ivory, leather shoe pieces, pearls, seeds (almond, peach/plum, woody palm nut, coconuts, olives, hazelnut, and a grape seed), and a tortoise shell. Tortoise shell artifacts included a triangular/ wedge-shaped tool (of unknown use) as well as a hair comb with case (Flow 1999:89-98).

Lithic artifacts included ballast and a variety of stone objects. A total of 1,664 ballast stones were excavated from the site. The ballast stones varied in size but were typically "gray sandstone, very angular, pitted, and friable" (Flow 1999:99). Other stone artifacts recovered included a handgrinding stone and base, two whetstones, an inkwell, and a small piece of polished jade (Flow 1999:99-101).

Assessment of artifacts recovered from the Tortugas Deepwater Shipwreck suggests the vessel dates to the early seventeenth century and is possibly associated with the 1622 fleet. Coins found on site date to no later than 1622, which provides a terminus post quem for the site. In addition, comparison of artifacts (including gold finger bars and olive jar markings) with those recovered from Nuestra Señora de Atocha (lost in 1622) suggests a similar date. Although the vessel has not been positively identified, it has also been suggested that it may date to 1623 or later (based on reported vessel loss accounts in the Florida Straits in 1623 and 1625, respectively). Assessment of the number of olive jars found on site (compared to the number of olive jars recovered from Nuestra Señora de Atocha, Nuestra Señora de Guadalupe, and Conde de Tolosá) suggests the vessel was a moderate-sized vessel (Flow 1999:11-12). 


\subsubsection{Nuestra Señora de Atocha, Florida Keys (1622)}

In 1622, one of the worst disasters hit the homeward-bound fleet after departing Havana, Cuba, on September 4. A flota of 28 vessels was caught in a hurricane within the Straits of Florida. Accounts vary as to how many vessels and how much treasure was lost as a result of the hurricane. One account states that eight ships, merchandise valued at 4 million pesos, and 1,000 lives were lost. A second account states that 550 people and a cargo valued at a million and a half ducats were lost. Apparently the flagships Santa Margarita and Nuestra Señora de Atocha sank within sight of one another west of Florida's Marquesas Keys (Arnold and Weddle 1978:326).

A review of historic records indicate that Nuestra Señora de Atocha was carrying "901 silver ingots, 250,000 silver coins, 161 pieces of gold bullion, 582 copper planks, some 350 chests of indigo, and 25 tons of tobacco in her registered cargo" (Lyon and Mathewson 1975:3).

During the 1960s, treasure salvers began to seek out wreck sites associated with the 1622 fleet. Using Spanish archival records, these salvors eventually focused their field investigations around the Marquesas. In June 1970, Mel Fisher first found an anchor believed to belong to a galleon. Nearby, Fisher soon found "a few coins, a gold chain, and two gold bars" (Lyon and Mathewson 1975:7). It was not until 1973 that major discoveries were made, including the recovery of 6,000 silver coins, gold bars and coins, other various gold artifacts, muskets and swords, an astrolabe, rings and chains, and munitions. Comparison of the salvaged goods indicated that the wreck was that of Nuestra Señora de Atocha (Lyon and Mathewson 1975:7).

While Nuestra Señora de Atocha is perhaps one of the more widely known treasure galleons, very little is publicized about the actual wreck site and the total number and type of artifacts recovered. Since the site was salvaged, only those items of monetary value are presented in available literature. Therefore, only a cursory review of available sources is provided here with regard to the site characteristics and artifacts associated with Nuestra Señora de Atocha.

\section{Site Characteristics}

Analysis of various components of the wreck suggest that the site found by Fisher and his team was the remains of Nuestra Señora de Atocha, a galleon associated with the 1622 fleet (and not one of the smaller vessels sailing with the fleet). This includes the analysis of the artifact assemblage and the large size of the anchor, as well as the sizable ballast stones found in association with the site. It was estimated that ballast stones found on site ranged from 50 to 85 pounds (Lyon and Mathewson 1975:11). It was not until the 1980s (16 years after the search began) that a portion of the actual hull was found (Figure 3-6). Located in relatively shallow water, the wreck was concealed by sediments. After the wreck site was uncovered, descriptions of the site indicated:

The main axis of the site lined up northwest to southeast, just like the artifact scatter we had been following all those years. The main part of the ballast pile measured 75 feet long, 30 feet wide, and four feet deep at the center.... The stern of the ship lay pointed northwestwards, with the bow pointing to the southeast 


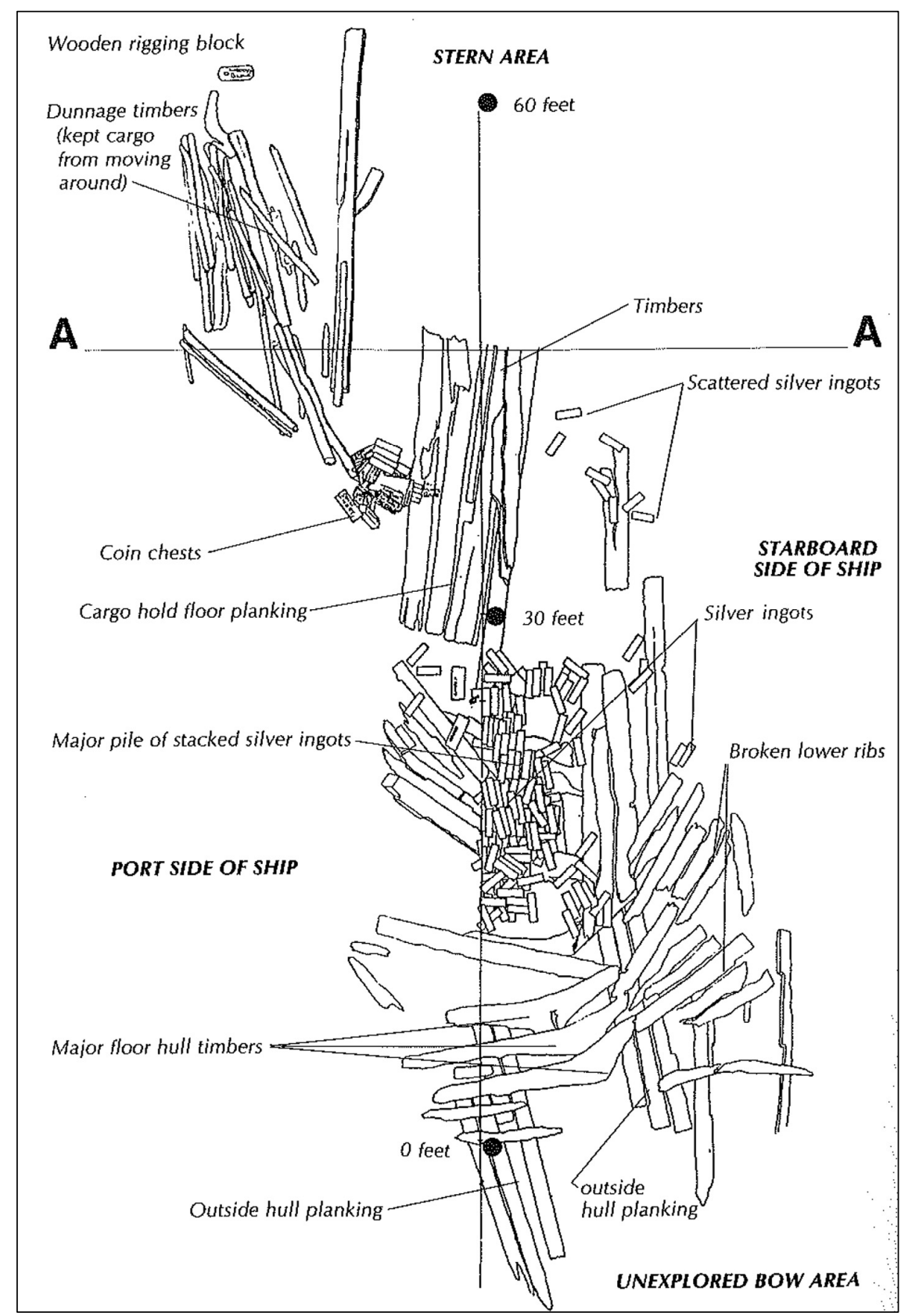

Figure 3-6. Site plan of Nuestra Señora de Atocha (as presented in Mathewson 1986:106). Note the site plan appears to be mislabeled between either the port/starboard side or the bow/stern of the vessel. 
towards the Outer Reef.... In the pile of timbers, we found no evidence of the keel, or keelson - the backbone of the ship. We were also missing the entire stern section, including the towering sterncastle and the bow. We had found what remained of the sterncastle in the Quicksands, and the absence of the bow confirmed the reports in the Spanish documents that the bow was battered on the Outer Reef as the Atocha tried to anchor (Mathewson 1986:114).

\section{Artifacts}

It is clear from the artifacts recovered from the Nuestra Señora de Atocha that the vessel represented one of the large galleons associated with the 1622 fleet. Large amounts of gold and silver in various forms (bars, chains, and coins) were ultimately recovered from the site. Gold bars ranged in size from 6 to 77 troy ounces (Mathewson 1986:128). Other items recovered that constituted portions of the cargo include jewelry, jewelry boxes, religious artifacts, rings, pendants, coral, silver pitchers, and various silver accessories (such as whistles and tooth and ear picks) (Mathewson 1986:126-142). In 1985, a meeting held by Mel Fisher's daughter (Taffi Quesada) to review the progress of the salvage identified what had been recovered to date, including:

1,041 silver ingots, more than 115 gold bars of various shapes and sizes weighing more than 250 lbs.; over 60 gold coins, most of them two-escudo pieces minted in Spain; 200 copper ingots; more than 30 wooden coin chests containing over 100,000 silver coins; over 750 pieces of silverware; more than 350 uncut emeralds; thousands of pottery sherds, and a whole range of objects of everyday use (Mathewson 1986:115).

More typical, everyday items recovered from Nuestra Señora de Atocha include armor, munitions, and various metal objects (locks, boat hooks, leg irons, and shackles). Data relative to additional artifacts recovered from the site were unavailable.

\subsubsection{San Felipe, Florida Keys (1733)}

In July 1733, the Nuevo España flota sailed from Havana, Cuba, for Spain with approximately 12.4 million pesos in silver and gold, as well as general cargo. Two days into the voyage, the fleet was struck by a hurricane that drove 23 ships ashore along the Florida Keys. Although a relief squadron was dispatched from Havana and a number of the vessels refloated, 15 of the wrecked vessels could not be repaired and were later burned to the waterline (after salvage). Records indicate that all of the registered gold and silver (as well as unregistered treasure) was successfully recovered by the Spanish (Beeker and James 1996:1).

The shipwrecks were rediscovered during the 1950s and 1960s when modern salvage efforts disturbed the sites to varying degrees. In the late 1980s, during surveys conducted by the Florida Bureau of Archaeological Research (BAR), Division of Historical Resources, with participation from Indiana University and Florida State University, 11 of the salvaged wreck sites were examined by archaeologists. Results of the investigations determined that the vessel El Lerri was 
one of the most archaeologically significant and intact of all the wreck sites investigated (Beeker and James 1996:1).

In the early 1990s, Indiana University conducted a field school at the site under a 1A-32 archaeological research permit issued by the State of Florida. The field school sought to conduct a "nondestructive data recovery program designed to address specific research questions relating to the vessel's identity, history, construction materials, as well as site dynamics" (Beeker and James 1996:1). Results of the field school determined that the wreck site most likely represented the vessel San Felipe, an English-built, 485 toneleda merchantman that carried nonprecious cargo (Beeker and James 1996:4).

Historical research relative to San Felipe indicates that the vessel:

set sail on the return voyage [to Spain] with that same fleet-now consisting of 5 galleons, 13 merchant ships (plus a few smaller ships that do not normally get counted in the fleet) - from Havana in July 1733. San Felipe's cargo was mainly organic: sugar purgative, snuff, cochineal, indigo, vanilla beans, chocolate, and (probably) wooden trays or washing tubs. Her cargo register lists some worked silver, but if there was any cargo of bullion or specie, it did not appear in the manifest document. However, given that San Felipe was a merchant ship, not one of the galleons, it would not be expected to carry large quantities of treasure (Beeker and James 1996:13).

While the vessel is located in a shallow-water environment, very different from UDW within the GOM, the vessel's association with the flota system of the eighteenth century, site characteristics, and artifacts can shed light on vessel types and cargoes prevalent during that time (and that may be found within the GOM).

\section{Site Characteristics}

The ballast mound and intact lower hull remains of San Felipe constitute the most prominent features of the site (Figure 3-7). Documented remains included an articulated keel, floors, futtocks, ceiling, and hull planks. Wood hull timbers exhibited signs of damage from both marine-boring organisms (teredo worms) and environmental conditions, such as exposure to sand particles.

The field school was able to map in detail six floor timbers and six first-futtock timbers that were covered by five ceiling planks:

Varying between 11.5 and 14 inches moulded, and between 16.5 and 18 inches sided, the floor and futtocks are relatively massive in size. The frame timbers are partially covered by four inch thick ceiling planks fastened with treenails.... The floors and futtocks were not horizontally edge fastened to each other. This construction method differs from the French (Beeker and James 1996:23-27). 


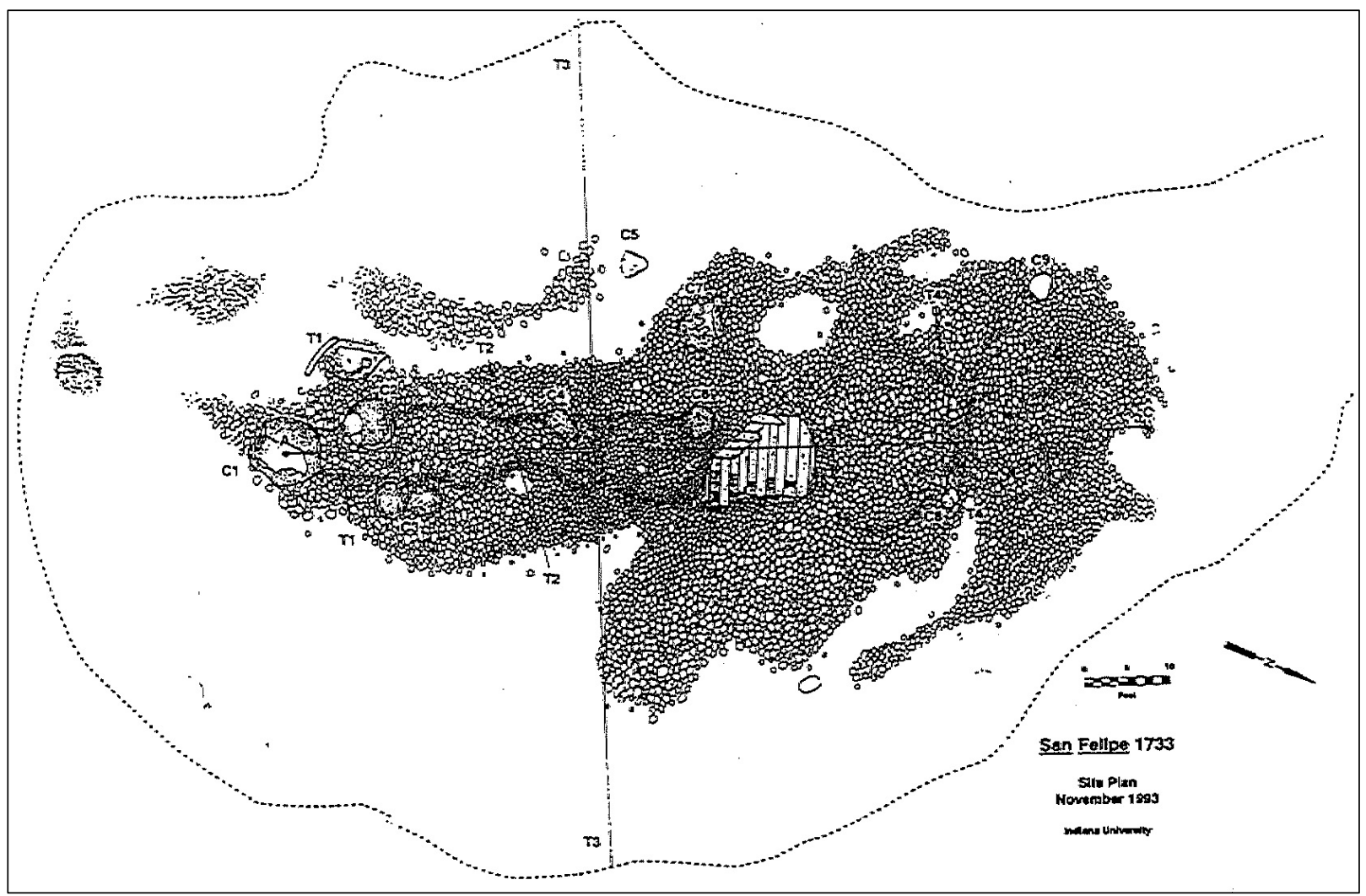

Figure 3-7. Site plan of San Felipe (as presented in Beeker and James 1996:24).

A unique feature of the lower hull indicated that the floor frames were capped by faired cross chocks or fillet pieces, "the frames themselves also fairing or scarphing into and atop the next floor frame above" (Beeker and James 1996:28). It is interesting to note that no keelson was identified during the investigation. However, it is believed that the vessel must have had a keelson, and its absence is likely attributed to previous salvage activities (Beeker and James 1996:23-33).

\section{Artifacts}

No artifacts were recovered from San Felipe by Indiana University during the field school investigation in the 1990s. However, it was reported that approximately 3,000 artifacts were removed from the site by treasure salvors. None of the artifacts are on display, no recovery records are available, and therefore, no analysis of these artifacts is possible. Salvage records do report that, in 1988, a buckle, ring, and hinge were recovered from the site by Henry Taylor (under contract to Carl Fizmer, who held the admiralty claim to the site) (Beeker and James 1996:34). Treasure salvors also reportedly recovered a large admiralty anchor from the site that included portions of rigging elements (consisting of three chain plates).

Looting activities on site (after the Indiana University field school was complete) uncovered an additional chain plate. Attached to the chain plate were several fragments of thin-walled earthenware identified as Guadalajara polychrome. Produced in Mexico, this type of ceramic dates to post-1650 (in Florida contexts) and reaches its peak of popularity by the first half of the 
eighteenth century. "The Flota wrecks of 1715, 1733 in Florida, and the 1766 Flota (El Nuevo Constante [see below]) all carried Guadalajara ware" (Beeker and James 1996:38).

Wood analysis of various hull components identified three basic types: pine, oak, and elm. "The keel, ceiling, hull planks, and treenails sampled are white oak (Quercus sp., white group). Firring strakes are hard pine (Pinus sp. Section diploxylon, sylvestris group). The wood sampled from the deadeye is American Elm (Ulmus sp.), indigenous to the northeastern United States" (Beeker and James 1996:42).

Prevalent across the wreck site were ballast stones that were either loose or slightly calcreted. Most stones were cobble- or boulder-sized, ranging from 7 to 53 centimeters (2.75 to 20.86 inches) in diameter. While some ballast stones were noticeably displaced, either by severe tidal/wave action or by salvors, a portion of the ballast pile appears to remain undisturbed and rests in the original stacking pattern incurred during the loading of the vessel (Beeker and James 1996:44). Analysis of nine ballast stones from the site indicates that the rock types can be found worldwide and, therefore, could have been collected and loaded from anywhere.

Conclusions from the archaeological examination of San Felipe surmise the vessel represents the most intact of the 1733 flota sites. The vessel was an English-built, 485-tonelada merchantman transporting mainly nonprecious cargo (Beeker and James 1996:55). The site was deemed historically and archaeologically significant and, as a result, was placed on the National Register of Historic Places (NRHP) in August 1994.

\subsubsection{El Nuevo Constante, Louisiana (1766)}

In 1979, a shrimper named Curtis Blume who was fishing off the coast of Louisiana snagged his net on an underwater obstruction. When he recovered his net he found three large copper discs, each approximately 50.8 centimeters (20 inches) in diameter and weighing 70 to 80 pounds. He recorded the location of the snag and returned to port, thinking the discs were scrap metal thrown overboard from oil exploration activities common in the area. A friend of Blume's saw the discs in the back of his pickup truck and identified them as ingots similar to those recovered from Spanish shipwrecks off Florida. Blume and a number of associates formed a salvage group identified as Free Enterprise Salvage, Inc., and soon began retrieving gold and silver ingots off the wreck site. Further salvage of the site produced large numbers of artifacts including ballast stones, ship timbers, iron bolts, spikes and nails, leather items, glass, pottery, tortoiseshell, and cannonballs, as well as more gold and silver ingots (Pearson and Hoffman 1995:3-5).

Members of Free Enterprise Salvage, Inc., soon became concerned that the wreck site may be of historical significance and that there may be legal issues since the wreck was located within the state waters of Louisiana. After receiving advice from legal counsel, the group contacted the Louisiana Department of Culture, Recreation, and Tourism in July 1980 and alerted the State of the discovery. A contract was subsequently forged between the State of Louisiana and the salvage company stipulating the group could continue to work on the wreck site under direction of professional archaeologists. The contract also stipulated that the State of Louisiana would retain ownership of all artifacts recovered from the shipwreck. In turn, the salvors would be 
compensated for their discovery and work on the site by receiving 75 percent of the value of the precious metals recovered from the site (Pearson and Hoffman 1995:5-6).

Soon after the site was reported, archival research was undertaken to determine the identification of the wreck site. Review of historic maps indicated a consistent use of the word "Constante" of topographic features in the general area of the shipwreck. In addition, the review of a 1785 account provided by a Spanish pilot identified "Bayou del Constante" as an area where a shipwreck had occurred. Archival research efforts eventually focused on the fleet of 1766 and the vessel El Nuevo Constante. In addition to archival research efforts, information gathered from the archaeological record was compared to historic documents, and it was determined that the vessel was, in fact, El Nuevo Constante.

Review of historic documents was very illuminating with regard to both the inbound and outbound cargo being transported on El Nuevo Constante. The vessel carried an unusual cargo from Cadiz, Spain, to Veracruz, Mexico, consisting of large quantities of mercury $(1,334$ boxes each weighing 150 pounds), iron goods, and aguardiente (spirits), instead of the more familiar items such as cloth, foods, and manufactured items. Documents relative to the vessel's homebound cargo indicate it was carrying "dyestuffs, medicinals, chocolate, copper, leather, turtle shell, and ceramics" (Pearson and Hoffman 1995:224). While the cargo that El Nuevo Constante carried was by no means spectacular, it illustrates a common form of commerce during the mid-eighteenth century. The cargo also highlights certain raw goods that were important to the Spanish and European economies during that period (Pearson and Hoffman 1995:224).

\section{Site Characteristics}

Beginning in 1980, archaeologists began working with the salvors on the site of El Nuevo Constante. This included an examination of materials already recovered from the wreck site. It was decided to conduct a remote-sensing survey of the wreck site including the collection of core samples to "facilitate interpretation of [the] wreck and post-wreck conditions" (Pearson and Hoffman 1995:101). Results of the coring determined that the lithology consisted:

primarily of homogenous, highly organic, light to dark gray clays and silty clay deposits. The surface of the Pleistocene Prairie formation, generally marked by an orange oxidized clay layer, is believed to be at a shallow depth near the site, but none of the cores contacted this surface. All of the sediments within the cores represent recent marine deposition, and the shipwreck had evidently settled into and been covered by these deposits. These clays contributed to the excellent preservation of organic materials at the site by producing a low-oxygen atmosphere that minimized decay. Oyster and barnacle growth and shipworm (teredo worm) damage were confined to the very upper portions of the wreck, primarily the extremities of the longer frame pieces that protruded above the thick, liquid mud covering most of the remains (Pearson and Hoffman 1995:102).

The remote sensing of the site, including the use of a magnetometer and side-scan sonar, was conducted in August 1980. Results of the magnetometer survey identified a large concentration 
of ferrous metal with very little scatter around the wreck (Figure 3-8). Results of the magnetometer survey were somewhat suspect due to positioning problems, shallow water, and rough seas. The side-scan sonar results fared better (Figure 3-9), identifying the outline of the hull, the stern and stem posts, one cannon, test pits opened up by the salvors, and scattered material around the site. The side-scan sonar image was used to create an initial base map of the site for future excavations (Pearson and Hoffman 1995:104-106). Excavation of the site commenced on September 7, 1980, and concluded on February 15, 1981.

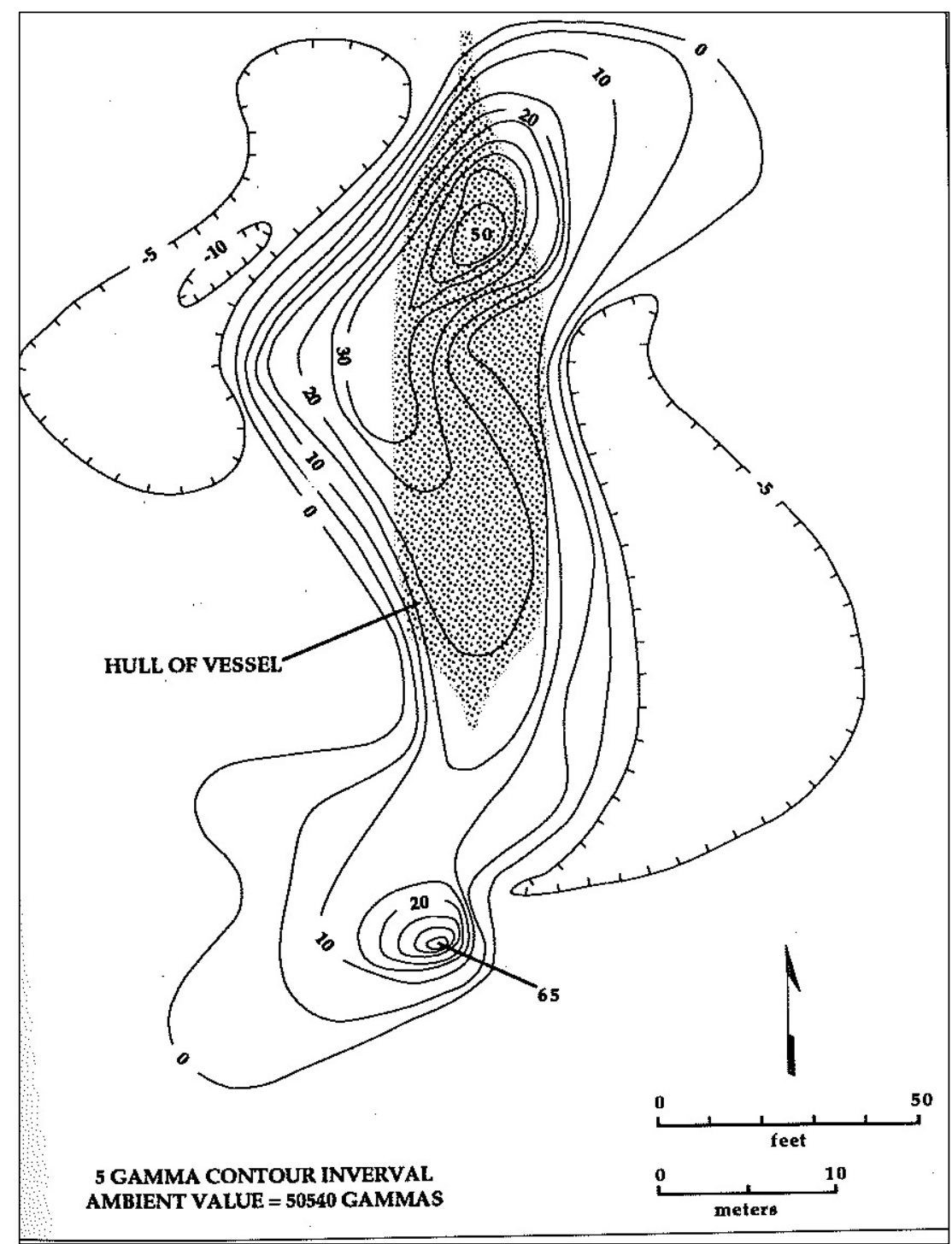

Figure 3-8. Magnetic contour map of El Nuevo Constante (as presented in Pearson and Hoffman 1995:105). 


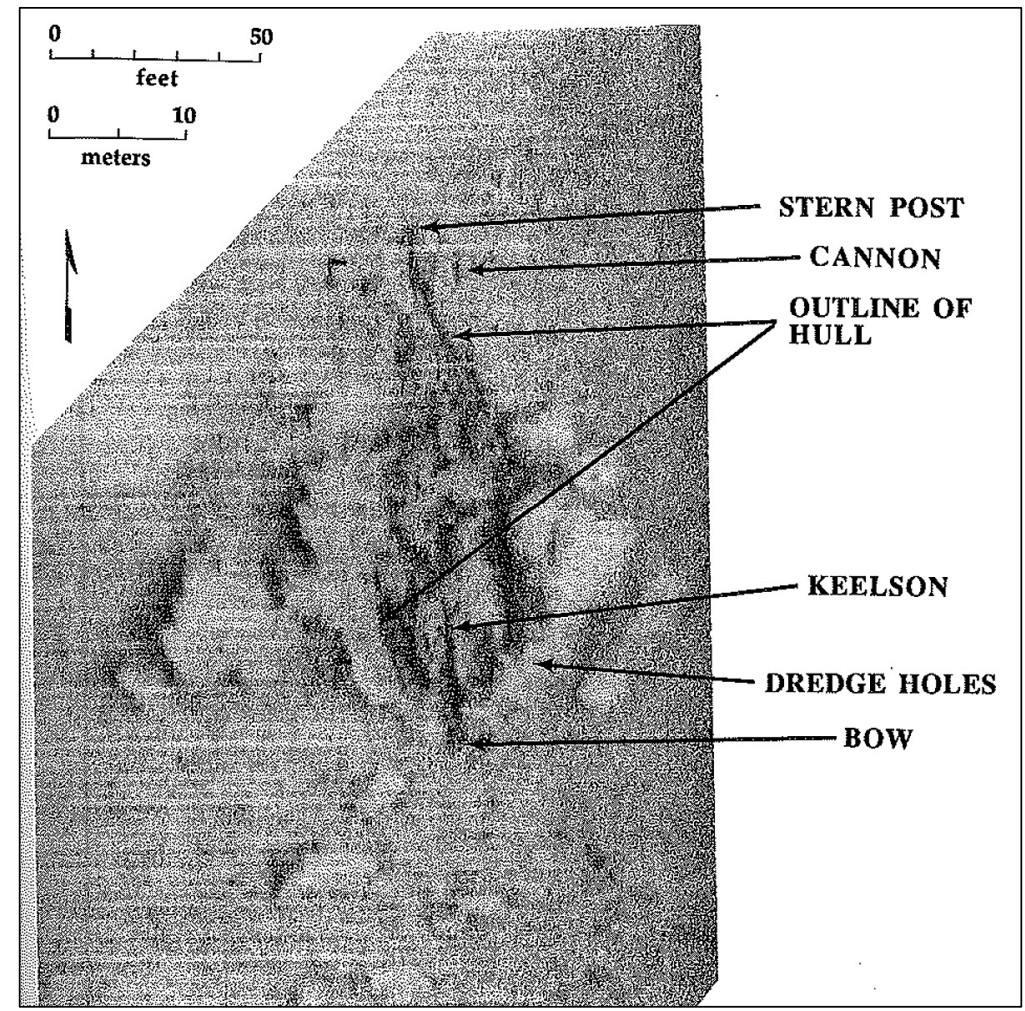

Figure 3-9. Side-scan sonar image of El Nuevo Constante (as presented in Pearson and Hoffman 1995:107).

A thorough analysis of the hull remains associated with El Nuevo Constante was conducted by archaeologists associated with the project. Mapping of the lower hull remains were recorded after the excavation took place. Findings relative to the hull remains are as follows:

The hull section is 127.5 feet in length from stempost to sternpost and approximately 26 feet wide at its widest point. This section represents the lower 3 to 4 feet of the ship's hull. The upper portion of the hull has deteriorated through time and been dispersed. Some section undoubtedly lay close by the intact hull, but no concerted effort was made to find unattached portions of the ship (Pearson and Hoffman 1995:116).

It is not surprising that only the lower hull was intact considering that the vessel wrecked in a near-shore environment that can, at times, be very dynamic. A review of historic maps indicates that when the vessel grounded it was only 478.53 meters (1,570 feet) from shore (Pearson and Hoffman 1995:102). Exposure of the vessel in shallow water would have made the vessel easier to salvage. This includes the removal of cargo, as well as the removal of ship timbers and fasteners. The practice of salvaging wrecked vessels was very common by the eighteenth century, and it is likely that these efforts contributed to the disintegration of the hull in attempts to recover cargo. In addition, it is likely that wood timbers were removed from the vessel for use on shore immediately after the wreck event, also aiding in the deterioration of the hull. 
Since the hull remains were located within a mile of shore it is not surprising that the wreck was covered in sediment. However, it is more surprising that some of the wreck was exposed when it was found in 1979. While it is likely that the hull remains were buried under silt and clay (as well as the ballast mound), it is clear that Curtis Blume (the fisherman who found the wreck) did in fact snag the wreck with his shrimp net. This would infer that some portion of the wreck, most likely the ballast pile, was exposed above the seafloor when it was snagged. Other local fisherman, familiar with the area, "avoided the area because it was known to contain a snag that damaged nets" (Pearson and Hoffman 1995:4).

\section{Artifacts}

The variety of artifacts recovered from El Nuevo Constante included "hundreds of artifacts, including metal and wooden ship fittings and structural members, a variety of armament and defense-related items, objects expressive of the lives of the crew and passengers, and remnants of the vessels cargo" (Pearson and Hoffman 1995:115). The amount recovered is surprising considering that historic documents indicate one-third of the cargo was salvaged soon after the wreck event. It is possible that many of the items recovered during the initial salvage of the vessel were deemed worthless and were discarded before reaching Havana. As mentioned below, a majority of the cargo consisted primarily of raw goods, such as dyestuffs, that may have been ruined during and soon after the wreck event.

Items recovered from the shipwreck in 1980 and 1981 consisted of ballast stones, ship's hardware, anchors, fasteners, fittings, two wrought iron gudgeon straps, rigging elements, bilge pump machinery, lead sheathing, bricks, firewood, coal, armament, hand tools, faunal material, olive jars, various ceramics, glassware, and personal possessions. In addition, the cargo being transported on El Nuevo Constante consisted of export ceramics (such as Guadalajara polychrome), dyestuffs (including cochineal, anatto, indigo, and logwood), tortoiseshell, cacao beans, and leather. Precious metals recovered from the shipwreck included 96 copper ingots (weighing 7,334.75 pounds), 30 pieces of silver bullion (weighing over 80 pounds), and 10 pieces of gold bullion (weighing a total of 50.4 pounds) (Pearson and Hoffman 1995:207-221).

\subsubsection{El Cazador, Grand Isle, Louisiana (1784)}

The wreck of El Cazador was found in federal waters off Grand Isle, Louisiana, in 1993. A Spanish naval vessel, it was lost in 1784, while carrying a cargo of 450,000 pesos of silver reales to New Orleans, Louisiana. Located in 91.44 meters (300 feet) of water, the wreck site was extensively salvaged before the passage of the Reagan National Defense Authorization Act of 2005 (Public Law 108-375), which may have afforded the vessel immunity from commercial salvage (Ford et al. 2008:19).

The wreck site was discovered on August 2, 1993, by butterfish trawler Captain Jerry Murphy. While trawling in 91.44 meters (300 feet) of water, Murphy's trawler net snagged a hang on the ocean floor. After he recovered his net, Murphy and his crew found numerous silver coins, all of which bore the mark of the Mexican mint and were dated to 1783. Murphy quickly contacted his business partner, Jim Rearhard, and told him of his find. They subsequently contacted a 
specialist in maritime law in Key West, Florida, and within three days a legal claim to the shipwreck was filed.

Robert Sténuit of Belgium, a researcher familiar with maritime history and underwater archaeology, was then contacted to identify the shipwreck. Sténuit conducted archival research in the General Archives of the Indies (AGI) in Seville, Spain, and concluded that the vessel was El Cazador (information relative to this wreck site is referenced to www.elcazador.com).

New Orleans, considered the heart of Spain's new holding in the United States, was experiencing a failing economy due to devalued paper currency and an influx of counterfeit bills. To keep the situation from reaching a critical status, King Charles III ordered all paper currency to be redeemed with silver coins. As a result, El Cazador (a "Brig of War") was dispatched by King Charles III to Veracruz, Mexico, on October 20, 1783, under the direction of Captain Gabriel de Campos y Pineda. Once refitted and loaded with the cargo of newly minted Spanish silver reales at Veracruz, the vessel set sail for the port of New Orleans on January 11, 1784 (www.elcazador.com).

El Cazador never reached New Orleans and was officially listed as missing at sea in June 1784. The loss of the vessel was a blow to the Spanish as well as Louisiana's economy. While Spain quickly dispatched more silver to the territory, it was too late. By 1800, King Charles IV of Spain agreed to cede Louisiana back to France.

\section{Site Characteristics}

Very little is known about the site characteristics associated with El Cazador other than it was found in 91.44 meters (300 feet) of water off Grand Isle, Louisiana. No information relative to the hull of the vessel or how much remained intact when the vessel was found could be located. In addition, it remains unknown how much of the vessel was exposed when it was found. However, reports regarding the condition of the wreck indicate that portions of the wreck were exposed above the seafloor and that wood was present. While very little data is available concerning the wreck overall, it is clear that the "condition of El Cazador seems to argue for reasonably good preservation of wrecks, even wooden ones, in moderately deep waters of the study area" (Pearson et al. 2003:4-37).

\section{Artifacts}

It is unclear exactly what was recovered from the wreck site as no record of the salvage can be located. Historic accounts indicate the vessel was carrying 450,000 pesos of silver reales, but little else is known about what was found on site and what was recovered from the site. It is unknown how many silver reales were recovered. A museum was developed in Grand Bay, Alabama, to display artifacts recovered from the site, but it has since closed. What types of artifacts the museum contained from El Cazador is unknown. Apparently a number of the coins recovered from the site were purchased by the Franklin Mint and have been sold to the general public since April 2007. 


\subsubsection{The Mica Wreck, GOM (1775-1830)}

Discovered by Exxon-Mobil Corporation on February 16, 2001, the Mica Wreck is located in the Mississippi Canyon, within the GOM. Located in 807.7 meters (2,650 feet) of water, the vessel was found during a routine post-installation inspection of an oil and gas pipeline. The inspection found that the pipeline had inadvertently been placed across the middle of a historic shipwreck (Figure 3-10). BOEMRE was notified of the discovery, and additional scientific visits were scheduled to determine the data and significance of the shipwreck (Atauz et al. 2006:1).

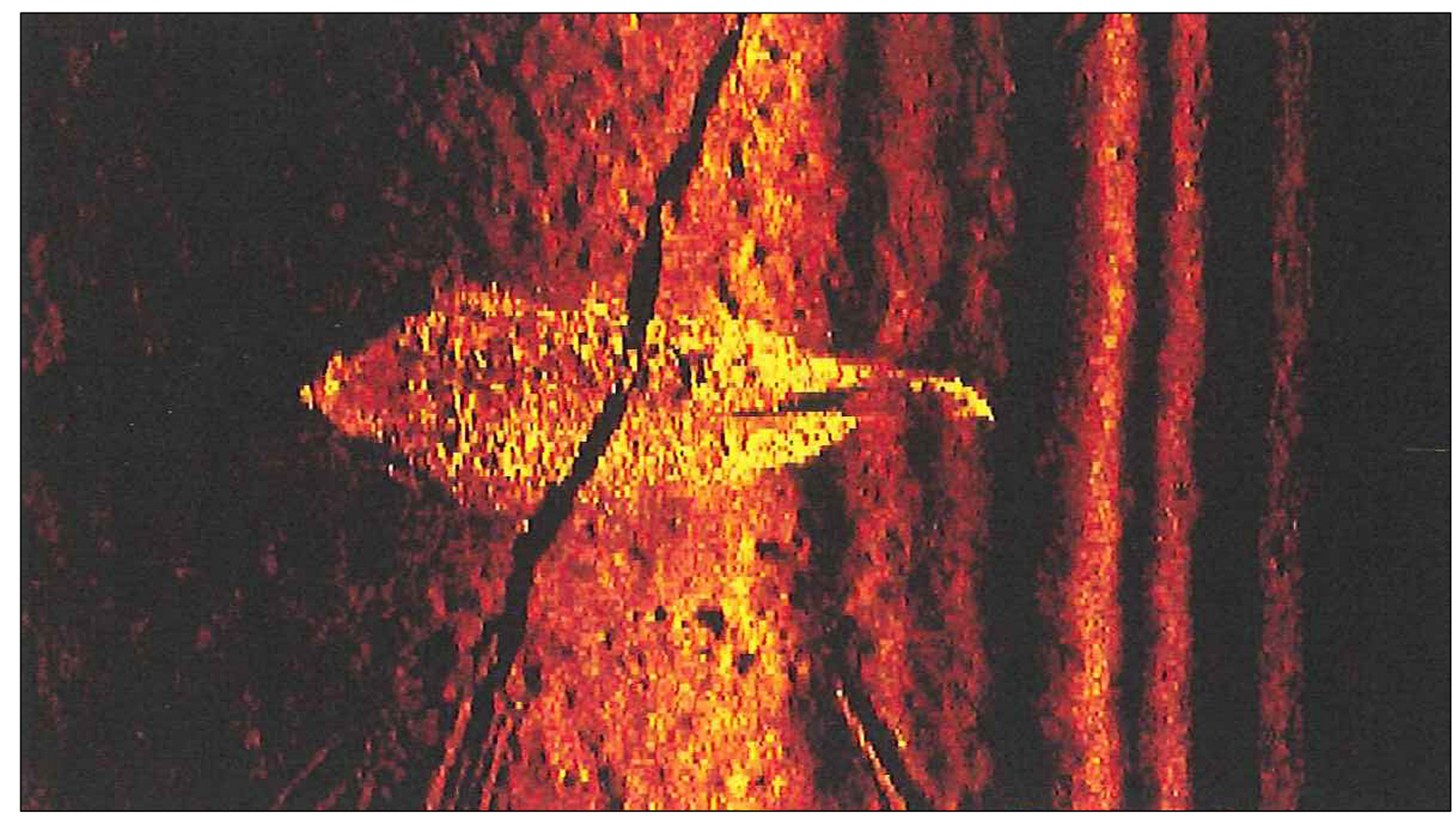

Figure 3-10. Side-scan sonar image of the Mica Wreck. Note the outer hull line in yellow and the pipeline transecting the wreck (as presented in Atauz et al. 2006:18).

Investigations of the site using specialized equipment allowed archaeologists the opportunity to conduct examinations of the site utilizing deep-sea survey equipment. The first investigation at the shipwreck site was undertaken in February 2001. A research design was soon developed that determined that additional investigations would require the use of a ROV or submersible to:

- Excavate a representative portion of the interior of the wreck;

- Recover diagnostic artifacts;

- Excavate up to 15 test units outside the wreck to determine if artifacts exist outside the wreck; and

- Obtain high-quality video and digital images for full documentation of the site (Atauz et al. 2006:16). 


\section{Site Characteristics}

Investigation of the Mica Wreck indicates that the vessel sits on a bed of fine silt, typical for the Mississippi Canyon area, located off the mouth of the Mississippi River. Measurements of the wreck site indicate the vessel remains are 20.4 meters (67 feet) in length. The vessel appears to be in an exceptional state of preservation, with the exception of the modern pipeline, which transects the vessel across the midship section (Figure 3-11).

Pearson et al. (2003) described the condition of the wreck and the low rate of sedimentation within the deepwater setting of the wreck:

These remains consist of an approximately 60-foot-long segment of wooden hull resting upright on the bottom. It appears as if all or most of the length of the hull is extant, and an estimated 9 to 13 feet of its height. Metal sheathing was observed on the exterior of the hull and interior features such as frames and the keelson could be seen. The exposure of these elements suggests that there is very little sediment filling the interior of the hull.... Like the U-166, this wooden wreck is only minimally covered by sediment, supporting the presumptions about the low rates of sedimentation on much of the deep Gulf. However, the fact that the wood on this fairly early wreck appears to be well preserved, while it is entirely gone on the recent submarine wreck, suggests that the preservation of organics in deepwater settings in the GOM are variable and the result of complex phenomena that are not yet fully understood (Pearson et al. 2003:4-37).

The bow of the vessel was easily identifiable by the presence of cant frames which protrude "through an estimated 2 meters (6.6 feet) of sediment that fills the foremost part of the hull" (Atauz et al. 2006:25). Copper sheathing was observed on the outside part of the stem in the general area of the bow. Examination of the remainder of the vessel indicates that the lower hull remains, consisting of a keelson, frames, planking, and rigging elements, are mostly intact. Review of the vessel's rigging elements and lack of armament suggests the vessel was a merchant ship, likely a schooner (Atauz et al. 2006:27-29). By comparing the vessel's hull length to historical records, archaeologists determined that the Mica shipwreck was likely a 110- to 120-ton ship.

\section{Artifacts}

A variety of artifacts were recovered from the Mica Wreck to help study and date the site. This included wood samples, copper sheathing (and fasteners), and a lead hawse pipe. Wood fragments, which had already eroded away from the hull, were collected outside of the hull near the port side of the bow to prevent any damage to the extant hull. While the samples were too small for a dendrochronological analysis, it was possible to determine the tree type and geographical area where the trees grew. Results from two separate laboratories confirmed that the wood samples were either eastern white pine or northern white pine (Pinus strobus). This type of wood, common in eastern North America, was commonly used in shipbuilding from the eighteenth century onward (Atauz et al. 2006:36). 


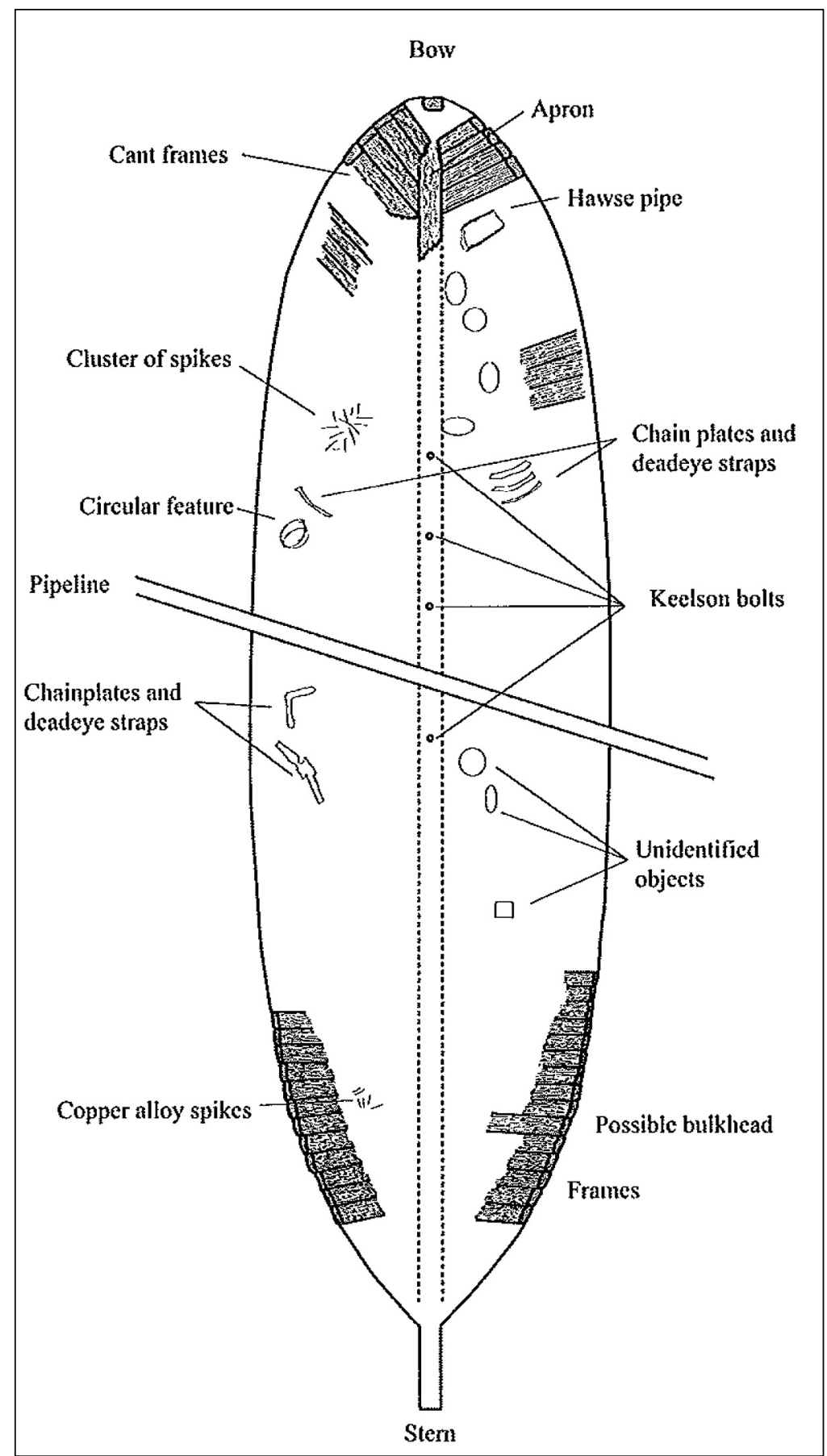

Figure 3-11. Sketch drawing of the Mica Wreck (as presented in Atauz et al. 2006:28).

Copper sheathing and fasteners were also recovered from the bow area of the wreck site. Similar to the wood samples, copper sheathing and fasteners (which had already fallen away from the wreck) were collected from outside the hull to avoid any more damage to the site. The presence of the copper sheathing indicates that the vessel was likely built in the first half of the nineteenth century. Recovered samples of copper sheathing were later analyzed using a refracting electron microscope and an atomic absorption mass spectrometer at Texas A\&M University (Atauz et al. 
2006:37). Fasteners recovered from the site were analyzed in a similar manner. Results of the analysis confirm that the vessel dates to the first half of the nineteenth century.

A lead hawse pipe was also recovered during investigations of the Mica Wreck. The pipe measured 17 centimeters (6.8 inches) in diameter and 41 centimeters (16.2 inches) in length, with a wall thickness of about 2 centimeters ( 0.5 inches). Wear patterns suggest the hawse pipe belonged on the starboard side of the ship. It was also observed that the lower outboard lip was worn, likely the result of the rubbing of an anchor chain or cable while the vessel was at anchor (Atauz et al. 2006:40).

A number of conclusions regarding the Mica Wreck were reached after investigation of the site. These include:

- The ship was built and lost sometime during the first half of the nineteenth century;

- The ship was rigged as a two-masted schooner; and

- The ship was built or repaired in a shipyard on the northeastern coast of North America (Atauz et al. 2006:45).

A review of archival records was not able to determine the identity of the Mica shipwreck. Findings indicate that:

While it is possible that further fieldwork might yield an artifact that might help to identify the shipwreck, it is also likely that the ship's loss may never have been registered. Unless an insurance claim was filed by the owner, it is unlikely that there were any survivors of the shipwreck to report the incident (the off shore location of the site makes it unlikely that anyone survived the wreck) (Atauz et al. 2006:45).

While the vessel remains unidentified, the Mica Wreck offers a glimpse of nineteenth-century coastal trade within the GOM. Archival data suggests the vessel may have been involved in sailing routes to European destinations (such as Liverpool or Le Havre), and to ports on the northeastern coast of North America. In addition, small sailing craft frequented other ports within the GOM as well as the Caribbean (Atauz et al. 2006:46).

Examination of the hull remains suggests that the cargo on board the vessel was perishable and disintegrated long ago (as no remnants of the cargo were observed during archaeological examination of the site). Cargo being transported into and out of the GOM during the early nineteenth century varied depending on the route:

In general, ships that sailed to European destinations carried cotton as their main cargo. On their way back to New Orleans from Europe, these ships brought back mainly luxury goods such as silks and other luxury textiles, garments, candy and chocolate, spices and herbs, gourmet foods and wines, and jewelry are among these popular items. The northbound ships that sailed mostly to New York and Philadelphia either carried cotton or they re-distributed what seems to be a portion 
of the non-perishable luxury goods of European origin. Typical merchandise of this type were silk and other luxury fabrics and textiles, musical instruments, jewelry, and dresser. Typical return cargoes of such ships generally included iron (from New York), candles, and textiles and furs (Atauz et al. 2006:46).

It is also plausible that the Mica shipwreck may have been involved in the coffee, sugar, or flour trade common throughout the South GOM and/or Caribbean regions (Atauz et al. 2006:46). Any of these cargo items would likely have disintegrated long ago.

It was concluded that the Mica Wreck has great archaeological potential. Sampling within the hull may reveal additional information relative to the cargo the vessel was carrying at the time of its demise. In addition, the lower hull is in excellent condition and may offer insight into earlynineteenth-century shipbuilding practices. While the depth of the wreck site makes it costly to study, additional studies of the shipwreck may occur in the future when funds and equipment become available (Atauz et al. 2006:47).

\subsubsection{The Mardi Gras Wreck, GOM (1810-1820)}

The Mardi Gras Shipwreck Site (16GM01) was discovered during a preconstruction survey of the Mardi Gras Pipeline System, conducted by Okeanos Gas Gathering Company (OGGC). Located in 1,219.2 meters (4,000 feet) of water, the shipwreck is approximately 15.2 meters (50 feet) in length and wrecked circa 1815. An archaeological assessment of the wreck site was conducted by the Texas A\&M Oceanography Department and Center for Maritime Archaeology and Conservation, under contract to OGGC. The investigation took place between May 21 and June 7, 2007 (Ford et al. 2008:v).

A data recovery plan was subsequently designed to record the shipwreck and to recover specific artifacts to reduce the site's profile. The recovery plan consisted of the following components:

- Accurate and precise records of the shipwreck site before, during, and after excavation in the form of georectified photomosaics and digital video footage;

- Site plan view map based on photomosaics;

- Recovery and conservation of sufficient artifacts to reduce the surface visibility of the site;

- Analysis of recorded artifacts with the goal of identifying the period, nationality, and occupation of the ship;

- Hull analysis with the goal of identifying the type and period of the vessel;

- Historic research with the goal of providing a historical context for the wreck and possibly identifying the nature, period, nationality, and identity of the ship; and

- Analysis of water, sediment, pollen, and wood samples with the goal of describing the site setting and possible origins of the vessel (Ford et al. 2008:2).

While the vessel postdates the sixteenth to eighteenth centuries, examination of this vessel is useful in that it highlights the condition of a historic, wooden-hulled shipwreck within deepwater 
of the GOM. Examination of the hull, cargo, and or shipboard items can also help identify certain characteristics of early-nineteenth-century vessel types as well as commerce and trade practices within the GOM.

\section{Site Characteristics}

The Mardi Gras Shipwreck (16GM01) is one of the deeper shipwrecks investigated by archaeologists within the GOM. Resting in approximately 1,219.2 meters (4,000 feet) of water, the wreck is located approximately 64 kilometers (40 miles) southeast of the Mississippi Delta's South Pass and is situated in the upper Redfish Valley (Ford et al. 2008:5). The site was:

characterized by a scatter of large and small diagnostic artifacts and features within a discrete $20 \mathrm{~m}(65 \mathrm{ft})$ long by $5 \mathrm{~m}(15 \mathrm{ft})$ wide area of the silty, nearly flat bottom. The hull and artifacts were distributed along a northwest to southeast line, with the probable bow situated to the northwest.... The remains of the ship's hull were visible in specific areas, but the majority of the ship was deteriorated or buried in the sediment.... The artifact assemblage and hull remains suggest that the vessel wrecked circa 1808-1820 and was constructed during the preceding decade (Ford et al. 2008:v).

Overall, the hull was visible in four locations including "a longitudinal timber along the south side of the wreck, frames near the cannon, frames and planking near southeast of the gun box, and frames and planking recovered with the stern concretion" (Ford et al. 2008:161). Analysis of the hull remains suggests that the vessel was an average-sized schooner for the period (after a comparison of the vessel's frames, hull and ceiling planking, and keelson with contemporaneous vessel examples). The overall length of the wreck (14.8 meters [48.5 feet]) matches with the typical length of schooners operating within the GOM during this time (Figure 3-12). Assessment of the recorded scantling suggests that the vessel was likely a 40- to 65-ton vessel (Ford et al. 2008:177).

Two sediment core samples were taken at and near the wreck site to determine sediment type and basic properties. Results indicate that the core sample (Core 1) taken at the wreck site had a very large, coarse fraction (containing shells, shell fragments, wood particles, possible bone fragments, fecal pellets, and various concretions) versus the core sample (Core 2) taken 152.4 meters (500 feet) away. Core 2 consisted primarily of silty clays containing a coarse fraction composed primarily of foraminifera tests and worm tubes (Ford et al. 2008:7).

\section{Artifacts}

Numerous types of artifacts of various nationalities (Great Britain, France, Mexico, Spain, and possibly the United States) were observed and recovered from the Mardi Gras Shipwreck (16GM01). This included glassware, ceramics, metals, organics, composites, arms and munitions, navigational instruments, and concretions.

Glassware found on site consisted of 14 complete (or nearly complete) bottles, one glass pane, one inkpot, and 29 bottle fragments (Ford et al. 2008:78). Bottles found on site consisted 


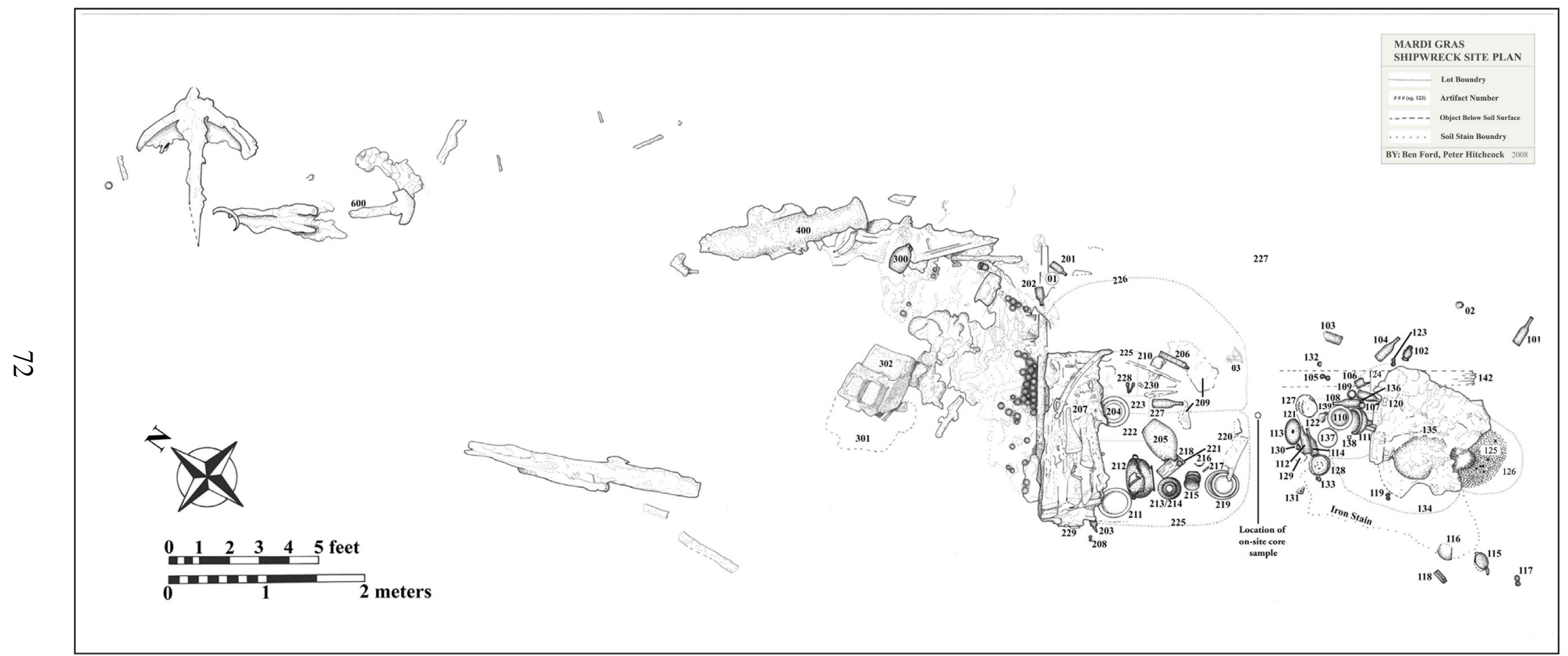

Figure 3-12. Site plan of the Mardi Gras Wreck (as presented in Ford et al. 2008:76). 
primarily of wine and beer bottles, possibly of French and British manufacture. A square-section condiment bottle was also recovered. A single pane of cut glass was recovered as well, identified as a piece of leaded crown glass, which typically predates 1840 (Ford et al. 2008:83). Lastly, a cut leaded-glass inkpot was also recovered.

Ceramics excavated from the site consisted of 14 complete vessels, six broken (but almost complete) vessels, and three sherds. The majority of ceramics consisted of creamware with some stoneware. Vessel types recovered included "three place settings consisting of a plate, tea bowl and saucer, as well as two soup plates, a bowl, tureen and lid, two platters, a pitcher, teapot, caster, two jugs, and a bottle" (Ford et al. 2008:84).

Metal artifacts associated with the wreck site included spoons, buttons, coins, the ship's stove, and an anchor. A total of three pewter spoons of Hanoverian type (two of which were remarkably well preserved) were recovered aft of the weapons box. In the same general area, an unidentified metal cylinder or can was removed from the site. Its purpose has not been determined at this time. One of the larger metal objects recovered during the investigation included the cast iron ship's stove. The stove appears to have been a generic pattern of the time and replaced the use of brick hearths, typically found on earlier-period shipwrecks (pre-1757 approximately). One badly deteriorated anchor was observed on site but not recovered due to its poor state of preservation (Ford et al. 2008:100). Analysis of the anchor design indicates it was forged prior to 1815. Two coins, minted in Mexico, were also successfully recovered from the Mardi Gras Shipwreck. The first was a milled eight-reale piece and the second a two-reale piece. Lastly, nine metal buttons of various types and manufacture were recovered from the wreck.

Organic materials from the wreck site included wood, leather, bone, seed, and rope, which were recovered from various locations around the wreck site. These items were subsequently divided into four categories including personal items, implements, rigging elements, and miscellaneous (Ford et al. 2008:107), More specifically, a leather shoe heel, toothbrush head and handle, bone utensil scales, coffee beans, rope fragments, sheaves, and a yard (possibly a boom or gaff) were recovered (Ford et al. 2008:107-111).

Composite material recovered included a watch face and bezel, a carpenter's plane, and a coffee grinder. All of these objects date to the early nineteenth century, including the coffee mill, which was "in existence as early as 1700 but did not proliferate until circa 1800" (Ford et al. 2008:114).

A number of arms and munitions were documented on the Mardi Gras Shipwreck (16GM01), many of which were not recovered during the investigation. This included:

a 6-pounder "merchant" cannon, a box of mixed arms and edged weapons, multiple iron artillery shot, over 1,000 lead shot, and almost 60 gunflints. These artifacts were distributed throughout the site at two primary locations: approximately amidships on the vessel and towards what is tentatively identified as the stern (Ford et al. 2008:115).

By the early nineteenth century, armed vessels were common throughout the GOM as international warfare was typical in the region. Many European nations still sought to gain 
control of various possessions in the GOM (and Caribbean), and as a result many merchant vessels "needed weapons and munitions in order to deter possible attackers, particularly the privateer fleets exploiting the political discord" (Ford et al. 2008:116). The arms associated with the vessel suggest the Mardi Gras Shipwreck was a nonmilitary, civilian vessel or a privately outfitted gunrunner or privateer.

A variety of navigational instruments including a telescope, compasses, octant fragments, and sandglasses were also recovered from the site. Most appear to have been manufactured in London, which was considered the center for all European production of these types of instruments (Ford et al. 2008:146).

With regard to the cargo associated with the Mardi Gras Shipwreck, it is apparent that the vessel was likely loaded at the time of its demise as no ballast stones were observed on site. While the ballast may be buried beneath sediment within the hull, it is more likely that the vessel was carrying a perishable cargo that has not survived two centuries on the seafloor. Typical perishable exports out of New Orleans during the early nineteenth century may have included cotton, tobacco, and sugar (Ford et al. 2008:188).

\subsection{Historic Vessel and Sediment Accumulation within UDW of the GOM}

As of 2010, 30 shipwrecks have been identified as a result of offshore archaeological surveys within the GOM in water depths greater than 152.4 meters (500 feet). Of these, four are located in water deeper than 1,524.0 meters (5,000 feet). Examination of the sonar records associated with these wrecks in UDW indicates that the hulls of these vessels were either complete or mostly complete and that large segments of these wrecks are exposed above the seafloor. Exposure of these wreck sites indicates that the vessels have never been completely buried by sediments (Pearson et al. 2003:4-36). Currently established remote-sensing survey practices in UDW within the GOM require the use of a side-scan sonar (or a multibeam echosounder) within areas considered to have a high probability for historic shipwrecks. Thus, wrecks may exist that are completely buried that would not be detected by these remote-sensing instruments. However, considering the exposure of known archaeological sites within UDW and paucity of sedimentation rates within UDW of the GOM, it is likely that most undocumented vessels remain exposed to some degree.

Sedimentation rates within the GOM are variable but tend to be higher in near-shore environments as well as near river mouths, where sediments tend to be more mobile. The increased movement of sediment in these areas is much higher, resulting in an increased rate of deposition. However, in deeper waters of the GOM, away from direct sources of sediment, the rates of sedimentation are much lower. It has been estimated that in open-water areas, sedimentation rates average 0.012 meters (0.472 inches) per year (Pearson et al. 2003:4-36). Applying this sedimentation to the historic period in question (sixteenth to eighteenth centuries), we can estimate the amount of sediment potentially deposited on historic shipwrecks in UDW (Table 3-7). 
Table 3-7

Estimated Sediment Accumulation from 1500 to 1800 within UDW of the GOM

\begin{tabular}{|l|l|l|l|}
\hline Year & $\begin{array}{l}\text { Years Before } \\
\text { Present (BP) }\end{array}$ & \multicolumn{1}{|c|}{$\begin{array}{c}\text { Total Sediment } \\
\text { (number of years BP x 0.0472 inches) }\end{array}$} & $\begin{array}{c}\text { Total Sediment } \\
\text { Accumulation (in feet) }\end{array}$ \\
\hline 1500 & 510 & 24.072 inches & 2.006 \\
\hline 1550 & 460 & 21.712 inches & 1.809 \\
\hline 1600 & 410 & 19.352 inches & 1.612 \\
\hline 1650 & 360 & 16.992 inches & 1.416 \\
\hline 1700 & 310 & 14.632 inches & 1.219 \\
\hline 1750 & 260 & 12.272 inches & 1.022 \\
\hline 1800 & 210 & 9.912 inches & 0.826 \\
\hline
\end{tabular}

It should be noted that these accumulation rates are based on only one sedimentation rate average and that the actual accretion rates are likely variable depending on location, currents, and source of sediments. For example, areas off the mouth of the Mississippi River are likely to incur much more sediment accumulation than those areas farther offshore in the GOM. However, it is interesting that two vessels (the World War II submarine U-166 and the nineteenth-century sailing vessel Mica Shipwreck) located in deepwater off the mouth of the Mississippi River exhibited a remarkable degree of preservation and only minimal dispersion, or burial, by sediment. After a review of sediment rates and the degree of preservation found on these two wreck sites, Pearson et al. (2003) argue that "based on findings from deepwater areas around the world, it is likely that a similar potential can be extended to almost all of the deepwater areas in the GOM" (Pearson et al. 2003:4-42).

Another example of sedimentation accumulation on a known historic vessel within deepwater is the eighteenth-century Spanish vessel El Cazador (see above). Located in approximately 91.44 meters (300 feet) of water off Grand Isle, Louisiana, El Cazador wrecked in 1784. Discovered by a fishing boat in 1984, reports regarding the condition of the wreck indicate that portions of the wreck were exposed above the seafloor and that wood was present. While very little data is available concerning the wreck overall, it is clear that the "condition of El Cazador seems to argue for reasonably good preservation of wrecks, even wooden ones, in moderately deep waters of the study area" (Pearson et al. 2003:4-37).

Review of Table 3-6 above indicates that sediment accumulation can be considered relatively negligible within UDW of the GOM. An accumulation of just over 0.60 meters ( 2 feet) since the sixteenth century would likely have little effect on the burial of a historic shipwreck. Unless bottom sediments are unconsolidated (allowing a wreck to become easily buried), it is likely that a wreck dating to the sixteenth century may still remain exposed (to some degree) on the seafloor. Additional factors such as the actual wreck event itself, the presence of biologic agents (such as marine-boring organisms like the teredo worm), and whether the environment is aerobic (versus anaerobic) can all affect the integrity of a wreck site. It has also been observed that:

The wreckage itself contributes to creating an environment conducive to preservation. Structural pieces can serve as sediment straps, speeding up the process of sediment accumulation. Ballast can cover structural elements and 
protect them while in other settings, wreck structure attracts and encourages the growth of marine organisms, such as oysters and barnacles, that can provide protection to wreck elements (Pearson et al. 2003:4-39).

Therefore, while a wreck site may remain exposed for hundreds of years, it may also act as a sediment trap or serve as an "artificial reef." Regardless, it is likely that a wreck site will remain exposed above the seafloor, and be detectable by remote-sensing systems. 


\subsection{ACQUISITION OF ARCHIVAL RESOURCES}

BOEMRE requested that various repositories be identified and visited in an effort to gather primary archival resources relative to vessel losses within UDW of the GOM. All relevant documents were to be transcribed and translated to English by a professional paleographer. All historical data and imagery acquired was to be analyzed to identify vessel casualties, vessel type, date of construction, nationality, ownership (past and present), use history, mission, and cargo (if any) at time of loss, as well as factors contributing to its loss.

SEARCH initially proposed that archival research be conducted in international repositories located in Spain and Mexico. The primary repositories included the Archivo General de Indias (AGI), Seville, Spain; the Archivo General de Simancas (AGS), Valladolid, Spain; the Museo Naval (MNM), Madrid, Spain; and the Archivo General de la Nación (AGN-M), Mexico City, Mexico, as well as repositories within the United States including the St. Augustine Foundation Center for Historic Research in St. Augustine, Florida, and the P.K. Yonge Library of Florida History at the University of Florida in Gainesville, Florida.

The primary repository with greatest potential for identifying early colonial shipwrecks in the UDW in the GOM is the Archivo General de Indias (AGI) located in Seville, Spain (Figures 4-1 and 4-2). This vast repository was created in 1785 when the original repository in Simancas (near Valladolid) was running out of room. As most of the documents pertaining to commerce and administration of the New World colonies had been authored in Seville, it was deemed logical to move all such documents back to their place of origin. To that end, the Renaissance building known as the "Casa Lonja de Mercaderes" was suggested as the new repository by José de Gálvez, Marquis of Sonora, who was at the time Secretary of Correspondence from the Indies. This suggestion was supported and approved by Juan Bautista Muñoz, who had been given the task of writing a history of the New World by the king in 1779.

For unknown reasons, hundreds of legajos (bundles of documents) pertaining to the Indies commerce and maritime traffic were left behind in the Archivo General de Simancas (AGS), making this repository the second-best candidate for identifying Spanish vessel losses in UDW in the GOM. The Museo Naval in Madrid (MNM) was also considered as potentially having archival documents pertaining to ship losses within the GOM.

In an effort to obtain as much information as possible on the identity of the vessels, vessel type and size, cargo, crew complement, owner, captain/master, and any other pertinent information, several sections were suggested for review at the AGI including Contaduría (1,753 legajos), Contratación (5,783 legajos), Indiferente (3,100 legajos), Justicia, Escribanía de Cámara, Consulados, Cuba, Mexico, and Ultramar, among others. It is estimated that each legajo contains anywhere from 1,000 to 2,000 folios on average.

Due to the time allotted for research in the Spanish archives, the amount of information potentially available at AGI, and recommendations from prominent researchers at AGI, a request was made to BOEMRE by SEARCH to revise the archival research plan. This request refined the research efforts to include only archival work at AGI (and not AGS or MNM). This request 


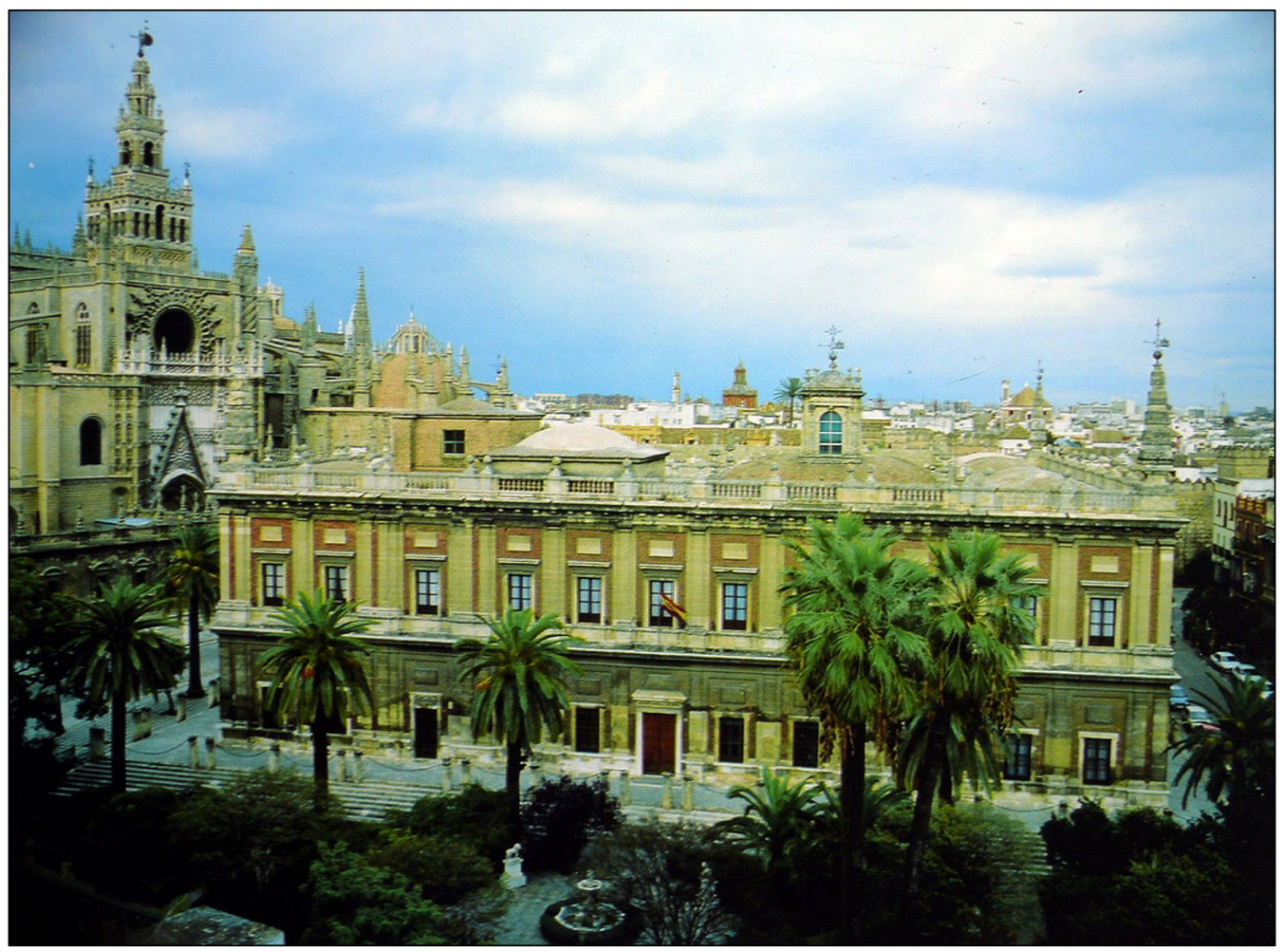

Figure 4-1. The Archivo General de Indias (AGI) located in Seville, Spain.

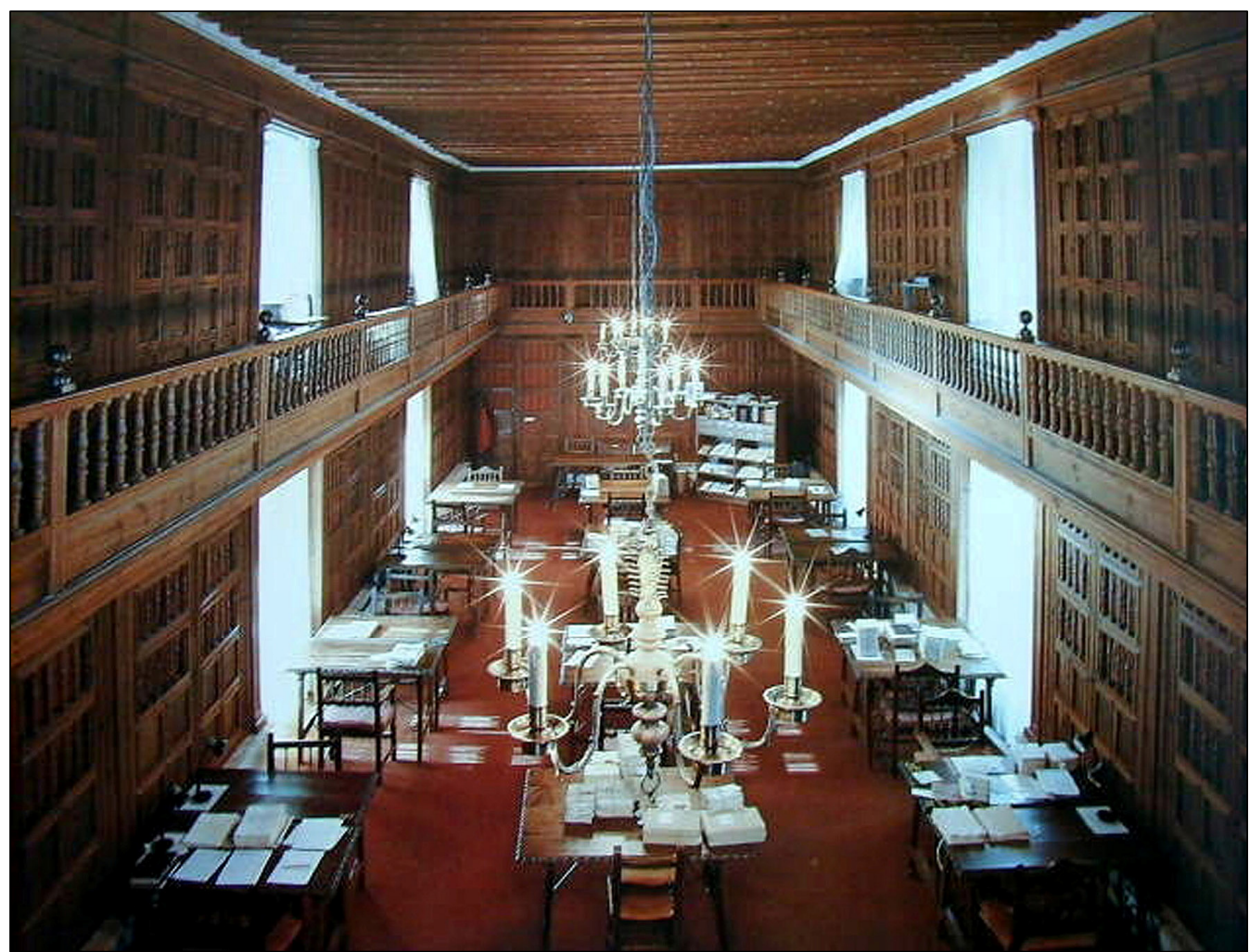

Figure 4-2. The reading room located within the Archivo General de Indias. 
was subsequently approved by BOEMRE, and SEARCH continued to focus all research efforts on records located at AGI.

The Archivo General de la Nación (AGN-M) in Mexico City was also considered a potential repository relative to ships lost at sea in the GOM. Two major sections of interest include the Marina and Consulados (Merchant Guilds) sections. Both sections contain correspondence dealing with maritime traffic, including ship loss reports, cargoes, owner names, captains, and lists of crew members. Archival data relevant to El Nuevo Constante, lost off the coast of Louisiana in 1766, were located at this repository (Pearson and Hoffman 1995). This repository, however, was only considered if relevant documents (located at the Spanish repositories AGI and AGS) suggested that additional or missing documentation may be found in the AGN-M.

Review of the records at the AGI, and subsequent conversations with other researchers familiar with the AGN-M, however, suggested that the repository may produce little to no results with regard to identifying primary archival documents relative to potential historic shipwrecks within the GOM. As a result, SEARCH scheduled a meeting with Ms. Pilar Luna, the State Underwater Archaeologist of Mexico, as well as Ms. Flor Trejo and Mr. Roberto E. Junco, both of whom are paleographers at the AGN-M in Mexico City. This discussion was held at the Society for Historical Archaeology (SHA) meeting held in Toronto, Canada, in January 2009. In attendance at the meeting were Dr. Chris Horrell (BOEMRE Contracting Officer's Representative), Ms. Melanie Damour (BOEMRE archaeologist), Ms. Pilar Luna, Dr. John de Bry (paleographer), Ms. Flor Trejo (paleographer), Mr. Roberto E. Junco (paleographer), and Mr. Michael Krivor (SEARCH Principal Investigator). The purpose of the discussion was to determine the potential for primary archival documents relative to the current investigation at the AGN-M in Mexico City. It was the consensus of Ms. Luna, Ms. Trejo, and Mr. Junco that very little archival material would be found at the AGN-M in Mexico City. Both Ms. Trejo and Mr. Junco have conducted extensive research at the AGN-M and have never found documents pertaining to vessel losses within the GOM. Based on this information, it was determined that time may be better spent at another repository.

To provide BOEMRE with the most applicable data relevant to the current investigation, SEARCH requested a change to the archival research plan to conduct research at two archival repositories in France. The repositories identified by SEARCH included the Archives Nationales (National Archives) in Paris and the Centre des Archives d'Outre-Mer (CAOM) in Aix-enProvence, France. This revision to the archival research plan was subsequently approved by BOEMRE. It was established that following Philip V's ascension to the throne in 1700 and the end of the War of Succession (1701-1714), many ships, French and Spanish, traveled between the ports of New Orleans and Veracruz. From 1720 on, numerous ships sailed between the ports of New Orleans, Mobile, Pensacola, and Havana to various ports on the French part of Hispaniola, in present-day Haiti. These ships would have sailed along routes within UDW of the GOM, and some may have inadvertently wrecked or been lost within the study area.

Research in the French repositories was undertaken first at the Archives Nationales in Paris and then at the CAOM in Aix-en-Provence, France. Considered one of the largest and most important archival collections in the world, the Archives Nationales was created in 1790. The archive houses over 226 linear miles of historic documents dating from A.D. 625 to the present. The 
Archives Nationales in Paris has a very rich and vast repository with an important maritime section focused on French Navy ship traffic, missions, and losses.

The CAOM has tremendous potential for identifying shipwrecks in UDW within the GOM (Figure 4-3). In 1700, the French established Iberville Fort, built just 25 leagues to the east of the mouth of the Mississippi River, but abandoned the fort in 1707 due to the difficulty in keeping this stronghold provisioned. Monsieur de Rémonville, an important ship owner from Saint-Malo, proposed to create another establishment even closer to the great river. In August 1717, the French West India Company replaced the Crozat Company, and one of the first acts of the newly formed organization was to propose the founding of la Nouvelle Orléans on the banks of the Mississippi. As early as April 1718 the construction of the new settlement had begun. In 1722, the decision was taken to move the seat of the French colonial government from Biloxi to New Orleans. As the city took on more and more importance, maritime traffic between New Orleans, Saint-Domingue (present-day Haiti), and various ports in the French Antilles and France increased dramatically. At the same time, Mobile was also enjoying increased prosperity and shipping.

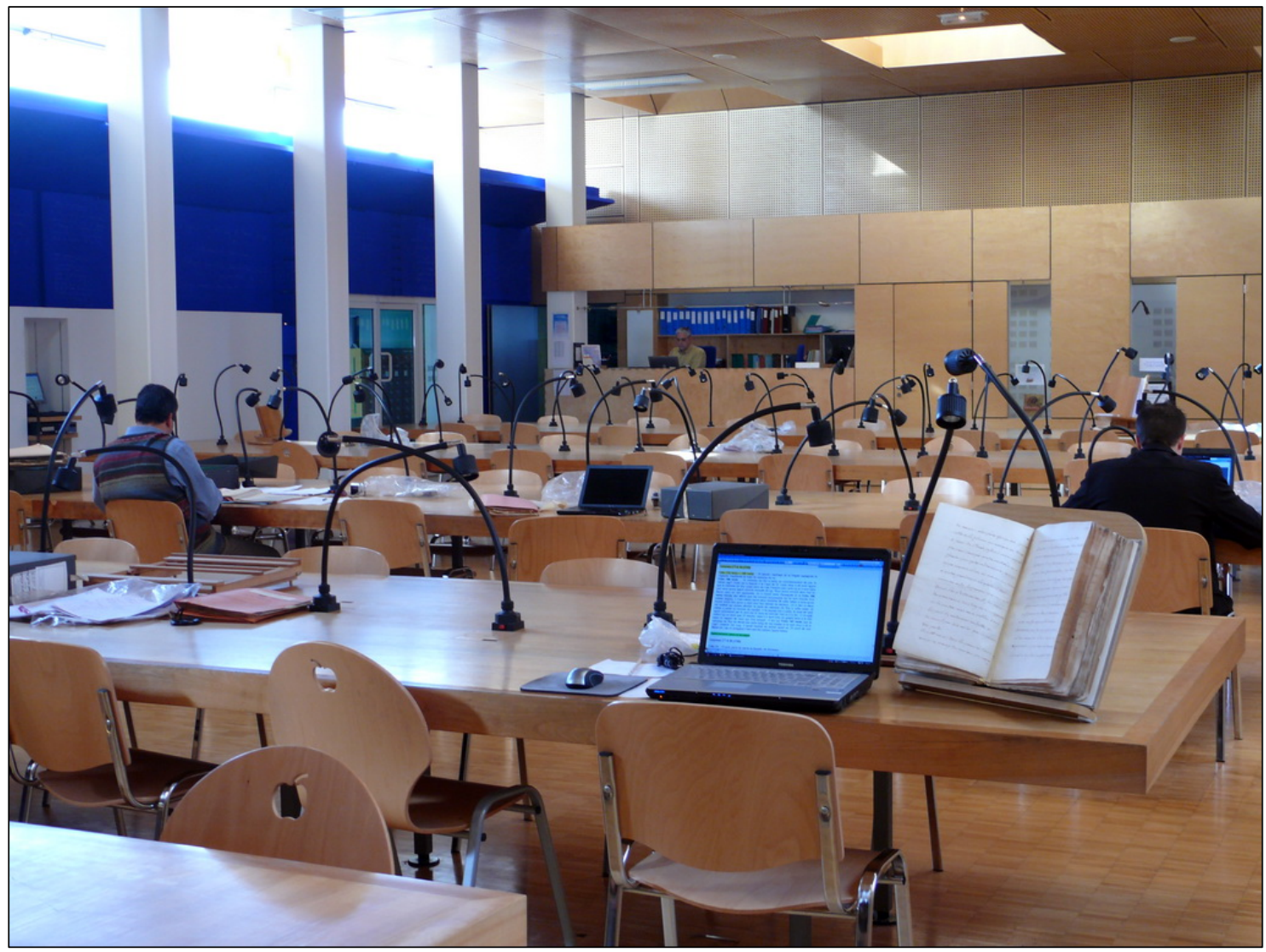

Figure 4-3. Reading room located at the CAOM in Aix-en-Provence, France.

On previous research trips to the CAOM, Dr. de Bry noticed several references to shipwrecks and ships missing between New Orleans, Biloxi, Mobile, Pensacola, and the ports of CapFrançois (present-day Cape Haitian), Léogane, and Havana, among others. From 1700 on, as France and Spain were at peace, ships from Spain often called port in French ports along the 
Gulf Coast and French ships sailed to Havana on their way to France; the sailing routes inevitably crossed the UDW of the Mississippi Canyon, the Atwater Valley, the De Soto Canyon, the Lloyd Ridge, and the Henderson and Florida Plains Planning Areas. It was also established that following Philip V's ascension to the throne in 1700 and the end of the War of Succession (1701-1714), many ships, French and Spanish, traveled between the ports of New Orleans and Veracruz.

SEARCH proposed to also conduct archival research within the United States at the St. Augustine Foundation Center for Historic Research in St. Augustine and the P.K. Yonge Library of Florida History at the University of Florida in Gainesville. Florida was a colony of Spain for some 300 years with little interruption until 1821, when it became a territory of the United States. A wide variety of government documents from this era is available at these repositories. These collections are particularly rich in Spanish colonial source material that may yield information on shipwrecks of the era.

The St. Augustine Foundation Center for Historic Research houses more than 950 reels of primary documents on microfilm from Spanish or Spanish-American archives. In addition to materials from the AGI in Seville and the National Historical Archives in Madrid, this collection holds materials from the Archives of Simancas and the Archives of the Institute of Valencia de Don Juan. The repository also has a duplicate set of the John Batterson Stetson Collection. The Stetson Collection (150,000 photostats) contains documents drawn from the Archivo General de Indias and relates to all phases of Spanish activity in the Southeast Borderlands from 1518 to 1819. Included is the Papeles Procedentes de Cuba, which contains the records of the colonial Spanish posts on the northern rim of the Gulf of Mexico. Documents in the Center's collection cover the tenth to twentieth centuries and are highly navigable due to translations and indexing. Among the most pertinent records to the current project are the private and governmental papers of two eighteenth-century New Spain viceroys.

The P.K. Yonge Library, located at the University of Florida, in Gainesville, Florida, was also recommended by SEARCH as repository for research relative to the current project. Pertinent to the current investigation were the microfilm reproductions of the Papeles Procedentes de Cuba, a section of the AGI containing the records of the colonial Spanish posts on the northern rim of the Gulf of Mexico. Mr. Bruce Chappell, archivist for the Spanish records at the P.K. Yonge Library, provided guidance in using the Papeles Procedentes de Cuba for research on ship losses in the region. He directed SEARCH to Roscoe R. Hill's Descriptive Catalogue (1916), a general index of the voluminous legajos found in the Papeles. SEARCH identified and recorded references to legajos dealing with "navigation" and "shipwrecks." A corollary effort was made to acquire information on vessel traffic in the northern GOM during the colonial period. Numerous documents discussing manifests of ships entering and leaving the region are available in the Papeles Procedentes de Cuba.

The legajos available at the P.K. Yonge Library are, with very few exceptions, limited to the late-eighteenth- and early-nineteenth-century port of Pensacola. Therefore, SEARCH was unable to explore all of the referenced legajos, some of which deal with other colonial Spanish ports including Mobile and New Orleans. These other legajos are, however, available at other repositories, including the Historic New Orleans Collection. SEARCH was able to locate specific 
documents in each legajo using a card catalog index that the P.K. Yonge Library has created. Therefore, it was not necessary to read the entirety of each legajo. Once located within the legajo, pertinent records were photocopied on archival-quality paper. 


\subsection{RESULTS}

From October 2008 through September 2009, SEARCH successfully completed archival research at a variety of repositories thought to contain primary documents and materials relative to early-colonial-period (sixteenth- to eighteenth-century) vessel losses within UDW of the GOM. The repositories visited during this investigation included the Archivo General de Indias (AGI) located in Seville, Spain, the Archives Nationales in Paris, France, the Centre des Archives d'Outre-Mer (CAOM) (Colonial Archives) in Aix-en-Provence, France, the St. Augustine Foundation Center for Historic Research in St. Augustine, Florida, and the P.K. Yonge Library of Florida History at the University of Florida in Gainesville, Florida. The following presents the results of the archival research at each of the aforementioned repositories.

\subsection{Archivo General de Indias (AGI) (Archives of the Indies), Seville, Spain}

Archival research, conducted at the Archivo General de Indias (AGI) located in Seville, Spain, began on October 12, 2008. Over a period of six weeks, dozens of legajos (bundles of individual documents) were reviewed relative to potential vessel losses within UDW of the GOM. Considering that there are approximately 49,666 legajos within the AGI, the research at AGI proved a formidable task. Each legajo contains, on average, 1,000 to 2,000 folios (individual letters or documents). The difficulty in identifying pertinent documents rests in the fact that most ships lost at sea during the sixteenth through eighteenth centuries, far from shore and sailing alone, are usually reported lost with all souls and merchandises, with a highly hypothetical geographical location given, if that much. In most cases the only thing known is that a particular ship sailing from point " $\mathrm{A}$ " to point "B" did not arrive at its intended destination. This represents an enormous obstacle to archival research aimed at identifying such losses.

The AGI is a vast repository that is in many respects poorly organized. Many legajos are only inventoried with a simple description. With such scant information it becomes necessary for the researcher to examine, however briefly, each single folio or set of documents. This is a timeconsuming process that often requires more than a day or two to scrutinize each legajo. Chaunu and Chaunu, who published a monumental work (11 volumes) on Spanish maritime traffic between Spain and the Americas (Chaunu and Chaunu 1955-1957), spent five full years in the AGI with a team of six other paleographers, yet not a single loss in the open GOM was recorded with any degree of certainty.

Specific sections (each containing numerous legajos) within the AGI were consulted first relative to vessel losses in the New World (and the GOM). These sections included the House of Trade (Contratación), which consists of 6,336 legajos; State Accounting Office (Contaduría), which consists of 2,126 legajos; Miscellaneous Documents (Indiferente), which consists of 3,100 legajos; and Merchants' Guilds (Consulados), which consists of 1,903 legajos and 1,255 books. Met with the AGI's millions of folios and an incomplete puzzle (many documents have been lost or are poorly inventoried), researchers pursuing the task of identifying individual vessel losses in UDW within the GOM face a daunting endeavor. 
A valuable tool for reconstructing vessel losses within the GOM can be found in the AGI in the House of Trade (Contratación) section. This tool is the Libro de Registros, broken into nine books contained in five legajos covering the period 1504 through 1783 as follows:

Ct. 2898, Libros de Rexistros de los Años 1580-1579:

1 large book in-folio.

Ct. 2899, Libros de Rexistros de los Años 1580-1626, 2 books:

1 book from 1580 to 1604

1 book from 1604 to 1626

Ct. 2900, Libros de Rexistros de los Años 1627-1700, 2 books:

1 book from 1627 to 1661

1 book from 1661 to 1700

Ct. 2901, Libros de Rexistros de los Años, 1701-1738, 2 books:

1 book from 1701 to 1725

1 book from 1725 to 1738

Ct. 2902, Libros de Rexistros de los Años 1739-1782, 2 books:

1 book from 1739 to 1770

1 book from 1770 to 1783

Ships, whose registers were processed through the Casa de la Contratación, or House of Trade, of Seville are listed along with some basic information such as the name of the ship, the name of the master, and, occasionally, the name of the owner. From 1504 until 1544, only the name of the ship was listed, with some rare exceptions such as "a list of the gold and silver that was transported from New Spain by Francisco López, master of the nao named Santa Catalina that was lost in (or off) Havana, and the register with it" ("una relación del oro y plata que truxo de la Nueva España Francisco López, maestre de la nao nombrada Santa Catalina que se perdió en La Habana y el registro con ella") (Ct. 2898, folio 103 verso), but from 1544 on, more details were provided with each entry.

For each year, the registers are organized by Registros de Ida (Registers of Ships Sailing to the Americas) and Registros de Venida (Registers of Ships Returning) (Table 5-1). However, the registers are scattered within the Contratación and can be difficult to locate. An " $\mathrm{X}$ " in the left margin usually signals a ship that has been lost, and a notation often indicates if the ship was "lost with all souls" ("se perdió en la mar con todo lo que traía"), or if some of the cargo was salvaged, which implies that there were survivors ("parte de las partidas de oro e plata que en ella venian se salvaron"). These registers, however, do not contain manifests, crew rolls, or any other data. The first four books are bound in velum and are approximately the same format ( 23 by 64 centimeters) and of varying thickness; the first book contains about 200 folios while the following three contain approximately 350 folios each; the pages are not always numbered, and when they are, the numbers are not always in the proper sequence (Chaunu and Chaunu 1955-1957:36). 
Table 5-1

Various Registers Reviewed at the AGI Relative to Inbound and Outbound Vessels within the GOM

\begin{tabular}{|l|l|l|}
\hline \multicolumn{1}{|c|}{ Register } & \multicolumn{1}{|c|}{ Years Reviewed } & \multicolumn{1}{c|}{ Contratación (Ct.) Section } \\
\hline Registros de Ida & $1511-1787$ & Ct. 1079-1785; Ct. 1916 to Ct. 2922 \\
\hline Registros de Venida & $1505-1788$ & Ct. 1786-2834; Ct. 2923 \\
\hline Registros de Ida y Venida & $1521-1787$ & Ct. 2835-2839; Ct. 2915; Ct. 5776 \\
\hline Libros Registros de Navios & $1504-1783$ & Ct. 2898-Ct. 2902 \\
\hline
\end{tabular}

The following tables include additional legajos consulted during the current investigation within the Register of Ships Sailing to the Americas alone (Table 5-2), the Register of Ships of Returning Ships Sailing in Convoy (Table 5-3), and the Register of Returning Ships Sailing Alone (without fleet) (Table 5-4). The following tables were based on research conducted by Chaunu and Chaunu (1955-1957). Legajos inspected by Chaunu and Chaunu (1955-1957) were revisited and documents dated beyond 1650 were examined. In addition, legajos and registers covering periods from 1651 and beyond were selected and scrutinized during the current investigation.

Table 5-2

Register of Ships Sailing to the Americas Alone (Without Fleet)

\begin{tabular}{|l|l|l|l|}
\hline \multicolumn{1}{|c|}{ Destination } & \multicolumn{1}{|c|}{ Years } & \multicolumn{1}{c|}{$\begin{array}{c}\text { Number of } \\
\text { Legajos }\end{array}$} & \multicolumn{1}{|c|}{$\begin{array}{c}\text { Legajos Consulted } \\
\text { (Contratación) }\end{array}$} \\
\hline Santo Domingo (Hispaniola) & $1511-1778$ & 2 & Ct. 1451 \\
\hline Florida & $1586-1731$ & 1 & Ct. 1453 \\
\hline Havana & $1590-1784$ & 15 & Ct. 1458-1459 \\
\hline New Spain (Mexico) & $1593-1743$ & 10 & Ct. 1473-1474 \\
\hline Veracruz & $1662-1782$ & 107 & Ct. 2900 \\
\hline Honduras & $1645-1778$ & 22 & Ct. 1590, 2900 \\
\hline Campeche & $1655-1777$ & 3 & Ct. 2902.A \\
\hline Tierra Firme (South America) & $1591-1773$ & 19 & Ct. $1616-1617$ \\
\hline Cartagena & $1593-1779$ & 40 & Ct. 1635 \\
\hline
\end{tabular}

Table 5-3

Register of Returning Ships Sailing in Convoy

\begin{tabular}{|l|l|l|l|}
\hline \multicolumn{1}{|c|}{ Origin } & \multicolumn{1}{|c|}{ Years } & \multicolumn{1}{|c|}{$\begin{array}{c}\text { Number of } \\
\text { Legajos }\end{array}$} & \multicolumn{1}{c|}{$\begin{array}{c}\text { Legajos Consulted } \\
\text { (Contratación) }\end{array}$} \\
\hline Santo Domingo (Hispaniola) & $1590-1653$ & 2 & Ct. 1786-1787 \\
\hline New Spain (Mexico) & $1555-1653$ & 340 & Ct. 1788-1937 \\
\hline Havana & $1610-1789$ & 1 & Ct. 2128 \\
\hline Honduras & $1591-1690$ & 17 & Ct. 2129-2145 \\
\hline Tierra Firme (S. America) & $1551-1769$ & 279 & Ct. 2146-2359 \\
\hline Lima & 1750 & 2 & Ct. 2696 \\
\hline
\end{tabular}


Table 5-4

Register of Returning Ships Sailing Alone (Without Fleet)

\begin{tabular}{|l|l|l|l|}
\hline \multicolumn{1}{|c|}{ Origin } & \multicolumn{1}{|c|}{ Years } & \multicolumn{1}{c|}{$\begin{array}{c}\text { Number of } \\
\text { Legajos }\end{array}$} & $\begin{array}{c}\text { Legajos Consulted } \\
\text { (Contratación) }\end{array}$ \\
\hline Santo Domingo (Hispaniola) & $1505-1777$ & 21 & Ct. 2439-2451 \\
\hline Puerto Plata, Yaguana, Hispaniola & $1551-1598$ & 1 & Ct. 2460 \\
\hline Florida, Cuba, Jamaica, New Orleans & $1570-1779$ & 2 & Ct. 2461 \\
\hline Havana & $1570-1787$ & 21 & Ct. 2469-2470 \\
\hline Veracruz & $1530-1787$ & 105 & Ct. 2490-2492 \\
\hline Honduras & $1552-1778$ & 19 & Ct. 2595-2596 \\
\hline Campeche & $1575-1767$ & 3 & Ct. 2614 \\
\hline Cartagena & $1589-1787$ & 55 & Ct. 2618 \\
\hline Santa Marta & $1533-1750$ & 1 & Ct. 2715 \\
\hline Puerto Belo & $1598-1771$ & 7 & Ct. 2716 \\
\hline Nombre de Díos & $1533-1571$ & 1 & Ct. 2723 \\
\hline Darien, Río de la Hacha & $1522-1747$ & 1 & Ct. 2724 \\
\hline
\end{tabular}

While examining the Libros de Registros is the first step in the process of identifying ships lost at sea, other sections must be scrutinized, principally Contaduría (Accounting) and official and secular correspondence in various sections such as Santo Domingo, Cuba, México, Justicia, and Indiferente, to name a few. If the Libros de Registros seem to be complete, it is not the case of the correspondence of the Contratación and other sections of the AGI. Furthermore, correspondence pertaining to ship losses can be dispersed throughout various sections.

While the list of ships in the Contratación section is incomplete, even fragmentary, the Books of Registers (Libros de Registros), within the Contratación, is mostly complete and provides a reliable base for research. Each year contains of a list of ships sailing from the Iberian Peninsula to the Americas (called the Registros de Ida) and a list of ships sailing back from the New World (called the Registros de Venida).

Although 17,761 voyages to and from the Americas are recorded in the AGI (Chaunu and Chaunu 1955-1957:280), the Books of Registers (Libros de Registros), in most cases, lack the required details to identify geographically precise locations for ship losses. Additionally, these records are not complete, as many ships that were not officially qualified to transport merchandise were omitted from those records. According to Chaunu and Chaunu (1955-1957), over 2,000 voyages failed to be recorded. This is not to say that those vessels did not carry merchandise; in fact, they most certainly did, something the House of Trade (Casa de la Contratación) and the Crown were well aware of. Therefore, Chaunu and Chaunu and their team of researchers had to rely on other sources besides the AGI to complete this work. This included additional research at the Archivo General de Protocolos de Sevilla, a separate repository that contains legal documents, depositions, and trial papers. This particular repository contains depositions by eyewitnesses, passengers, captains, and ship owners pertaining to ship losses. Unfortunately, the documents are poorly inventoried and indexed. In addition, the specialized script used by legal clerks and scribes from the sixteenth to eighteenth century makes research extremely slow and difficult. 
In addition, the Map Department at the AGI, which contains some 6,342 maps and charts, was reviewed. A new system for consulting maps at the AGI is on a computer terminal (as the repository has digitized most, if not all, of the maps in its collection). However, consulting these maps is a very slow and tedious process. Although a number of charts from the Map Department were reviewed, nothing of interest was found.

A total of 64 legajos was consulted and systematically scrutinized for any data that may lead to the identification of potential shipwrecks sunk within the oil and gas protraction areas in U.S. federal waters of the northern GOM (Table 5-5).

Table 5-5

Total Legajos Consulted within the AGI Relative to Vessel Losses within the GOM

\begin{tabular}{|l|l|}
\hline \multicolumn{1}{|c|}{ Legajo } & \multicolumn{1}{|c|}{ Legajos Consulted } \\
\hline Consulados & 402 (Libro), 837 bis \\
\hline Contaduría & 424 \\
\hline Contratación & $\begin{array}{l}317,600,1473,1490,1802,2490,2491,2492,2589,2898,2899,2900, \\
2901,2902-\mathrm{A}, 2908,2928,5144,5185\end{array}$ \\
\hline Correos & $263 \mathrm{~B}$ \\
\hline Cuba & $972-\mathrm{A}, 1197$ \\
\hline Escribanía de Cámara & $20,105,123,124,131,137,172,188-\mathrm{B}$ \\
\hline Indiferente & $12,1153,1198,2557,2558,2600,2729,2736$ \\
\hline México & $1,210,350,351,854,1158,2209-\mathrm{A}, 2966,2967,2968,2969,2970,2971$, \\
\hline Panamá & $2972,2973,2974,2975,2988,3163$ \\
\hline Santo Domingo & 93 \\
\hline Ultramar & $91,126,1812$ \\
\hline
\end{tabular}

In addition to the registers reviewed above (Table 5-5), a number of individual correspondences were reviewed in the following Contratación $(317,600,2908,2928,5144$, and 5185).

Three potential candidates were found in printed material (Duro 1898), and six potential candidates were identified in manuscript documents in the Contratación, México, and Ultramar sections of the AGI. Cesareo Fernández Duro's work The Spanish Navy Since the Union of the Kingdom of Castile and Aragon (Armada española desde la unión de los reinos de Castilla y de Aragón) (1898) provided additional information on ship losses within the GOM. The Duro books (nine volumes) are located in the AGI under the quote $\mathrm{CH} 725$. Shipwrecks of interest were listed in the index section of Volumes II, VII, and IX. The author was a renowned naval historian who conducted extensive studies in original Spanish documents at the AGI to develop this detailed history of the Spanish Royal Navy from the late fifteenth through early nineteenth centuries. Historians of this era generally trust Duro's work despite the fact that he does not provide direct source information. 
As mentioned above, Duro's references are relatively vague. The shipwreck accounts presented below (Lost Ship Numbers 1-3) represent all the data collected from his work relative to those accounts.

An attempt has been made to corroborate losses with known hurricanes in the region in the colonial period as enumerated in the 1968 work of José Carlos Millás. His study spans the years 1492 to 1800 and, while primarily focused on the Caribbean, provides information on hurricanes in neighboring regions, such as the GOM. All newly found vessel losses were cross-referenced with Millás work to determine if in fact the loss was weather related.

Presented below are individual narratives of each reported vessel loss found either within Duro's work (Lost Ship Numbers 1 through 3) or at the AGI (Lost Ship Numbers 4 through 9). A total of nine vessels, potentially lost within UDW of the GOM, were identified (Table 5-6). Full transcriptions of the Spanish documents pertinent to these ship losses are provided in Appendix A. Potential candidates are presented simply as "Lost Ship Number 1" through "Lost Ship Number 9." Translated primary documents (referred to as "Tiras"), identified at the AGI, are provided in sequential order within Appendix A.

There are three different ways of transcribing and translating historical documents. The first method is to do an integral transcription and translation, faithfully transcribing the document letter by letter; the second method is to transcribe and translate the document mixing some modern form to make it more comprehensible for the reader; and the third method consists of doing an integral transcription and an interpretive translation.

For this research project it was decided to employ the third method, faithfully transcribing the original manuscript text, including archaic spelling, all abbreviations and misspellings, adding missing punctuation and accents, then translating the document into modern English while staying as close as possible to the original text. When particular words could not be properly translated with an English equivalent, the word was italicized and explained in a footnote (see Appendix A).

\subsubsection{Lost Ship Number 1: Duro (1898), Volume VII}

Duro's 1898 study lists the loss of the Spanish ship Galgo. The vessel departed from Havana for New Orleans in 1783. (It should be noted that the BOEMRE shipwreck database does list a vessel named Galgo, also lost in 1783). Somewhere along the route in the Gulf of Mexico, Galgo capsized. Further details are not available. Millás (1968) found no evidence of hurricanes in the year 1783 .

\subsubsection{Lost Ship Number 2: Duro (1898), Volume VII}

A Spanish ship called Sandoval sailed from Havana en route to Veracruz in 1787. Duro does not provide the precise date. The vessel was never seen again and likely was lost in the GOM. The possibility is very strong that a hurricane caused this loss. Millás (1968) documented several hurricanes in August 1787 at Dominica. Perhaps one of these hurricanes continued toward Cuba and the GOM, resulting in the loss of Sandoval. Indeed, Millás (1968) notes that the storms 
Table 5-6

Potential Vessel Losses within UDW of the GOM Identified at AGI, Seville, Spain

\begin{tabular}{|c|c|c|c|c|c|c|c|c|c|c|c|c|}
\hline $\begin{array}{l}\text { Lost } \\
\text { Ship } \\
\text { Number }\end{array}$ & $\begin{array}{c}\text { Reference } \\
\text { ID }\end{array}$ & $\begin{array}{c}\text { Nationality } \\
\text { of Vessel }\end{array}$ & $\begin{array}{l}\text { Year } \\
\text { Lost }\end{array}$ & $\begin{array}{l}\text { Name of } \\
\text { Ship }\end{array}$ & $\begin{array}{l}\text { Name of } \\
\text { Captain }\end{array}$ & $\begin{array}{c}\text { Name of } \\
\text { Owner }\end{array}$ & $\begin{array}{c}\text { Port of } \\
\text { Departure }\end{array}$ & $\begin{array}{c}\text { Port of } \\
\text { Destination }\end{array}$ & $\begin{array}{l}\text { Presumed } \\
\text { Area of } \\
\text { Sinking }\end{array}$ & Observations & Source & $\begin{array}{c}\text { Source } \\
\text { Repository }\end{array}$ \\
\hline 1 & Duro VII & Spanish & 1783 & Galgo & José Rus & $\mathrm{n} / \mathrm{a}$ & Havana & New Orleans & $\begin{array}{l}\text { Gulf of } \\
\text { Mexico }\end{array}$ & $\begin{array}{l}\text { Duro writes } \\
\text { that the ship } \\
\text { capsized and } \\
\text { then nothing } \\
\text { else was heard } \\
\text { of it; Duro does } \\
\text { not cite his } \\
\text { source }\end{array}$ & $\begin{array}{l}\text { Armada } \\
\text { Española } \\
\text { desde la unión } \\
\text { de los Reinos } \\
\text { de Castilla y de } \\
\text { Aragón, Duro, } \\
\text { Casareo } \\
\text { Fernández, } \\
\text { Madrid 1898, } 9 \\
\text { volumes } \\
\end{array}$ & $\begin{array}{l}\text { AGI } \\
(\mathrm{CH} 725)\end{array}$ \\
\hline 2 & Duro VII & Spanish & 1787 & Sandoval & $\mathrm{n} / \mathrm{a}$ & $\mathrm{n} / \mathrm{a}$ & Havana & Veracruz & $\begin{array}{l}\text { Gulf of } \\
\text { Mexico }\end{array}$ & $\mathrm{n} / \mathrm{a}$ & $\begin{array}{l}\text { Armada } \\
\text { Española } \\
\text { desde la unión } \\
\text { de los Reinos } \\
\text { de Castilla y de } \\
\text { Aragón, Duro, } \\
\text { Casareo } \\
\text { Fernández, } \\
\text { Madrid 1898, } 9 \\
\text { volumes }\end{array}$ & $\begin{array}{l}\text { AGI } \\
(\mathrm{CH} 725)\end{array}$ \\
\hline 3 & Duro IX & Spanish & 1817 & Descubridor & $\begin{array}{l}\text { Javier } \\
\text { Quiroga }\end{array}$ & $\mathrm{n} / \mathrm{a}$ & Havana & Veracruz & $\begin{array}{l}\text { Gulf of } \\
\text { Mexico }\end{array}$ & $\begin{array}{l}\text { The 14-gun } \\
\text { brigantine } \\
\text { disappeared in } \\
\text { late } \\
\text { September } \\
1817 \text { and was } \\
\text { never heard of } \\
\text { again; aboard } \\
\text { the ship were } 8 \\
\text { officials and } \\
112 \text { sailors and } \\
\text { soldiers }\end{array}$ & $\begin{array}{l}\text { Armada } \\
\text { Española } \\
\text { desde la unión } \\
\text { de los Reinos } \\
\text { de Castilla y de } \\
\text { Aragón, Duro, } \\
\text { Casareo } \\
\text { Fernández, } \\
\text { Madrid 1898, } 9 \\
\text { volumes }\end{array}$ & $\begin{array}{l}\text { AGI } \\
\text { (CH 725) }\end{array}$ \\
\hline 4 & $\begin{array}{l}\text { Tira 4, Tira 5, } \\
\text { Tira 8, Tira } 9\end{array}$ & Spanish & 1600 & $\begin{array}{l}\text { San Antonio } \\
\text { de Padua }\end{array}$ & $\begin{array}{l}\text { Juan } \\
\text { Morales }\end{array}$ & $\mathrm{n} / \mathrm{a}$ & $\begin{array}{l}\text { Havana } \\
\text { (assumed) }\end{array}$ & Veracruz & $\begin{array}{l}\text { Gulf of } \\
\text { Mexico }\end{array}$ & $\mathrm{n} / \mathrm{a}$ & México, 351 & AGI \\
\hline 5 & $\begin{array}{l}\text { Tira 4, Tira 5, } \\
\text { Tira 8, Tira } 9\end{array}$ & Spanish & 1600 & $\begin{array}{l}\text { Santa } \\
\text { Catalina de } \\
\text { Sena }\end{array}$ & $\begin{array}{l}\text { Andrés } \\
\text { Ximenex }\end{array}$ & $\mathrm{n} / \mathrm{a}$ & $\begin{array}{l}\text { Havana } \\
\text { (assumed) }\end{array}$ & Veracruz & $\begin{array}{l}\text { Gulf of } \\
\text { Mexico }\end{array}$ & $\mathrm{n} / \mathrm{a}$ & México, 351 & AGI \\
\hline
\end{tabular}


Table 5-6. Potential Vessel Losses within UDW of the GOM Identified at AGI, Seville, Spain (continued).

\begin{tabular}{|c|c|c|c|c|c|c|c|c|c|c|c|c|}
\hline $\begin{array}{l}\text { Lost } \\
\text { Ship } \\
\text { Number }\end{array}$ & $\begin{array}{l}\text { Reference } \\
\text { ID }\end{array}$ & $\begin{array}{l}\text { Nationality } \\
\text { of Vessel }\end{array}$ & $\begin{array}{l}\text { Year } \\
\text { Lost }\end{array}$ & $\begin{array}{l}\text { Name of } \\
\text { Ship }\end{array}$ & $\begin{array}{l}\text { Name of } \\
\text { Captain }\end{array}$ & $\begin{array}{l}\text { Name of } \\
\text { Owner }\end{array}$ & $\begin{array}{l}\text { Port of } \\
\text { Departure }\end{array}$ & $\begin{array}{c}\text { Port of } \\
\text { Destination }\end{array}$ & $\begin{array}{l}\text { Presumed } \\
\text { Area of } \\
\text { Sinking }\end{array}$ & Observations & Source & $\begin{array}{c}\text { Source } \\
\text { Repository }\end{array}$ \\
\hline 6 & $\begin{array}{l}\text { Tira 4, Tira 5, } \\
\text { Tira 8, Tira } 9\end{array}$ & Spanish & 1600 & $\begin{array}{l}\text { (name } \\
\text { unknown) }\end{array}$ & $\begin{array}{l}\text { Miguel } \\
\text { Diaz }\end{array}$ & $\begin{array}{l}\text { Rafael } \\
\text { Ferrofino }\end{array}$ & $\begin{array}{l}\text { Havana } \\
\text { (assumed) }\end{array}$ & Veracruz & $\begin{array}{l}\text { Gulf of } \\
\text { Mexico }\end{array}$ & $\begin{array}{l}\text { Ship of the } \\
1600 \text { fleet; } \\
\text { presumed to } \\
\text { have sunk } \\
\text { during } \\
\text { hurricane; had } \\
\text { a cargo of } \\
\text { mercury }\end{array}$ & México, 351 & AGI \\
\hline 7 & $\begin{array}{l}\text { Tira 4, Tira 5, } \\
\text { Tira 8, Tira } 9\end{array}$ & Spanish & 1600 & $\begin{array}{l}\text { (name } \\
\text { unknown) }\end{array}$ & & $\begin{array}{l}\text { Francisco } \\
\text { Pabòn }\end{array}$ & $\begin{array}{l}\text { Havana } \\
\text { (assumed) }\end{array}$ & Veracruz & $\begin{array}{l}\text { Gulf of } \\
\text { Mexico }\end{array}$ & $\begin{array}{l}\text { Ship of the } \\
1600 \text { fleet; } \\
\text { presumed to } \\
\text { have sunk } \\
\text { during } \\
\text { hurricane; } \\
\text { patache to the } \\
\text { fleet }\end{array}$ & México, 351 & AGI \\
\hline 8 & Tira 19 & Spanish & 1719 & $\begin{array}{l}\text { San Juan } \\
\text { Bautista }\end{array}$ & $\begin{array}{l}\text { Juan de } \\
\text { Córdoba } \\
\text { Laso de la } \\
\text { Vega }\end{array}$ & & Cadiz & Veracruz & $\begin{array}{l}\text { Gulf of } \\
\text { Mexico }\end{array}$ & $\begin{array}{l}\text { The 60-gun } \\
\text { warship was } \\
\text { reported lost in } \\
\text { the Gulf of } \\
\text { Mexico with all } \\
\text { souls }\end{array}$ & $\begin{array}{l}\text { Ultramar, } 704 \text {, } \\
\text { L bro } 1 \text {, folio } 8 \\
\text { recto - folio } 9 \\
\text { recto }\end{array}$ & AGI \\
\hline 9 & Tira 21 & Spanish & 1612 & San Nicolás & $\begin{array}{l}\text { Andrés } \\
\text { Franco }\end{array}$ & $\begin{array}{l}\text { Martín } \\
\text { Monte } \\
\text { Bernardo }\end{array}$ & Havana (?) & Veracruz & $\begin{array}{l}\text { Gulf of } \\
\text { Mexico }\end{array}$ & $\begin{array}{l}\text { The 50-ton } \\
\text { zabra was } \\
\text { reported lost } \\
\text { before arriving } \\
\text { in Veracruz }\end{array}$ & $\begin{array}{l}\text { Contratación, } \\
1473\end{array}$ & AGI \\
\hline
\end{tabular}


moved rapidly westward from Dominica. The first hurricane struck the island in early August. Though the island itself received little damage, the storm wreaked havoc on the seas. A resident of Dominica reported that an African ship had been cast ashore on the island and several sloops and schooners "were totally lost" (Millás 1968:276). Another hurricane is known to have struck Dominica with much fury on August 23 of the same year. The sugar plantations were left in ruins and numerous ships were upturned. An account of the event states that the hurricane "cast on shore another [African] Guinea ship that was consigned to this island, three brigs, and all the droghers belonging to the island" (Millás 1968:277). One week later, Dominica was struck yet again. This storm also was furious. Many structures were completely destroyed. An African ship and two brigantines were "totally lost" (Millás 1968:277).

Two more hurricanes were reported in 1787, one in Honduras and another in Belize. The track of these storms also could have waylaid Sandoval as it made its way toward Veracruz. The September 2 hurricane that struck northern Honduras, as Millás (1968) writes, could have been the same one that passed over Dominica in late August. No further details on the storm's impact in the region are available. Another storm reached Belize on September 23. This storm is comparatively well documented. A contemporary report from the Bay of Belize describes severe flooding, leveled structures, and more than 100 deaths. "Out of the 15 square-rigged vessels, besides schooners, small craft, and other vessels," the report continues, "eleven of them were totally lost” (Millás 1968).

\subsubsection{Lost Ship Number 3: Duro (1898), Volume IX}

Though little is known about the loss of the Spanish ship Descubridor, the event certainly was tragic. Captained by Javier Quiroga, the 14-gun brigantine departed Havana for Veracruz in 1817 (exact date unknown) with eight officials and 112 sailors and soldiers aboard. In late September of that year, the ship disappeared and was believed to have sunk in the GOM. Millás (1968) found no accounts of hurricanes in this year.

The following represent vessel losses (Lost Ship Numbers 4 through 9) that were identified in individual folios within the AGI. In some cases, multiple letters ("Tiras") were identified relative to one particular loss event (e.g., Lost Ship Number 4 through 7). All translated letters are presented in sequential order within Appendix A.

\subsubsection{Lost Ship Number 4: Tira 4, Tira 5, Tira 8, and Tira 9}

These documents collectively describe the disaster that befell the Spanish fleet on the way to Veracruz in September 1600 (Figure 5-1). Led by General Pedro de Esteban Melgarejo, the fleet consisted of 43 ships of varying sizes. Although it is not stated in the documents, the fleet likely stopped in Havana en route to Veracruz, as was typical. The fleet was nearly to the port of Veracruz when a fierce storm arose on September 17 and greatly dispersed it. Millás (1968) found no evidence of a hurricane for this date, but these documents prove that such a weather event did occur.

When the storm hit, the sailors jettisoned certain portions of the cargo to reduce weight. Sailors furiously tossed overboard hundreds of jars of wine and oil, numerous casks of clothing, as well 


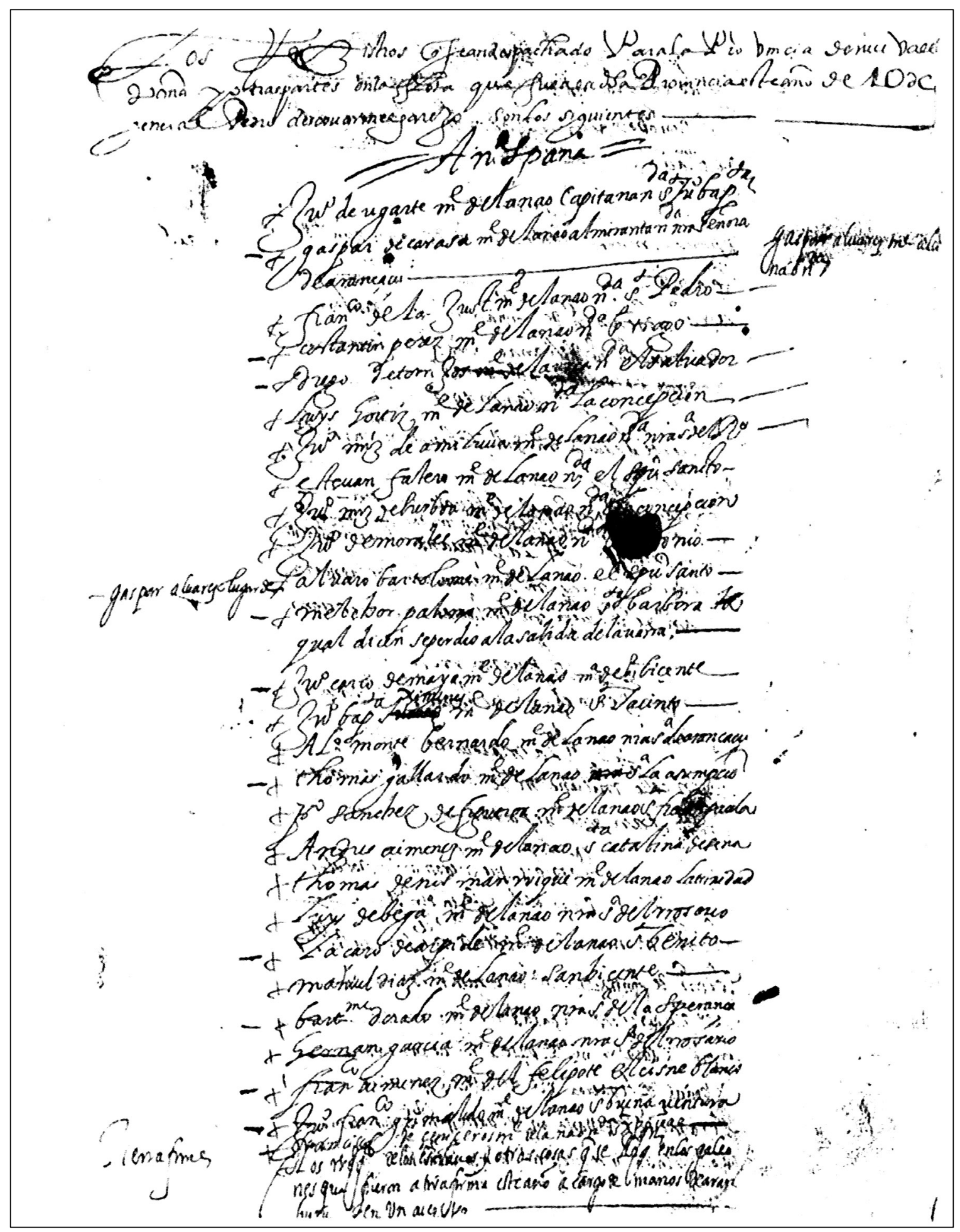

Figure 5-1. Registers dispatched to the province of New Spain, 1600 (Tira 9, Contratació, 2899 f.56r). 
as longboats, wax, artillery, seaman's chests, anchors, chickens, and, in some cases, thousands of pounds of the most valuable cargo of the incoming fleet: mercury. While some passengers and sailors of the fleet survived, many dozens drowned. The news of their deaths, as told in one of the documents, "caused great and general lament and compassion to the world," and the vessels that had once carried them were scattered across the GOM.

It is difficult to come to an exact accounting of the fate of each ship of the 1600 fleet as there is slight disagreement from one document to the next. The documents disagree as to the number of ships that made the port of Veracruz (either 28 or 29) and the number of ships that were smashed against the coast between Veracruz and Campeche (either 12 or 13). However, the documents agree that 43 ships formed the original fleet and, most important to this study, they agree that four of these 43 vessels were lost. Of the four lost vessels, two were known to have sunk (San Antonio and Santa Catalina de Sena), and the fate of the other two (both unnamed ships, one owned by Rafael Ferrofino and the other owned by Francisco Pabòn) was unknown.

San Antonio de Padua was one of four vessels of the 1600 Veracruz fleet that was lost in the GOM as a result of the storm. Like other ships of the fleet, San Antonio de Padua was fully

loaded. Aboard were 70 crates of mercury and 250 casks of clothing as well as passengers and sailors. Juan de Morales served as captain of the 300-ton ship, which stayed close to Santa Catalina de Sena (see Lost Ship Number 5 below) as the storm arose and the fleet dispersed. San Antonio de Padua "sank" the day following the storm in roughly the vicinity of Santa Catalina de Sena, that is, approximately 20 leagues out from the coast of La Villa Rica de la Vera Cruz (the original site of Veracruz that conquistador Hernán Cortés had established in 1519). However, before the vessel disappeared beneath the waves, a frigate arrived to rescue the people who were onboard. Only one individual, a scribe, was reported drowned. The documents state that, of the cargo, "everything was lost."

\subsubsection{Lost Ship Number 5: Tira 4, Tira 5, Tira 8, and Tira 9}

Fully loaded with 110 boxes of mercury and 200 casks of clothing, the 350-ton Santa Catalina de Sena was one of the lost ships of the ill-fated 1600 fleet. For further details on this broad event, refer to Lost Ship Number 4 (discussed above). Along with Captain Andrés Ximénez, there were about 65 passengers and sailors aboard the ship when the storm separated it from the rest of the fleet. The ship then "foundered" about 20 leagues out from the coast of La Villa Rica de la Vera Cruz (the original site of Veracruz that conquistador Hernán Cortés had established in 1519). All of the cargo aboard Santa Catalina de Sena was lost. More than 60 people who were aboard this ship drowned. Only the captain of the ship, Ximénez, "and 2 or 3 sailors" survived, although the documents do not state how these individuals were rescued.

\subsubsection{Lost Ship Number 6: Tira 4, Tira 5, Tira 8, and Tira 9}

An unnamed vessel owned by Rafael Ferrofino was one of four that was lost in the 1600 fleet catastrophe. For further details on this broad event, refer to Lost Ship Number 4 (discussed above). Serving as captain of this ship was Miguel Diaz. The ship held an important cargo of "100 large boxes containing 150 quintales [or 15,000 U.S. pounds]" of mercury. When the ship began to take on water in the storm, these boxes were not jettisoned but rather unloaded onto 
other ships of the fleet, specifically, the capitana and the almiranta. Sometime thereafter, the ship disappeared and its exact whereabouts were unknown. "We are almost certain that the vessel sank to the bottom of the sea," reads one document, "because ever since the ship disappeared there have been no traces of it." The possibility that the ship sank in the deepwater of the GOM seems highly likely.

\subsubsection{Lost Ship Number 7: Tira 4, Tira 5, Tira 8, and Tira 9}

This unnamed vessel, part of the larger 1600 fleet of 43 ships, was owned by Francisco Pabòn. For further details on the trajectory of this fleet, refer to Lost Ship Number 4 (discussed above). Few details are available for this vessel. The documents describe it as a patache to the capitana of the fleet. A patache was a small, swift, two-masted sailing vessel attached to a larger ship. These types of vessels were used to carry news within the fleet or to port, and also were implemented in making explorations. The documents express the belief that Pabòn's patache met the same fate as the ship owned by Ferrofino, that is, the patache was believed to have sunk as no trace of the vessel was found. The documents specifically state that this vessel did not have mercury or clothing aboard. No cargo is mentioned in the documents, which may reflect the fact that this ship was being used as a messenger vessel.

\subsubsection{Lost Ship Number 8: Tira 19}

San Luis, San Joseph, and San Juan Bautista were Spanish warships bound from the port of Cádiz, Spain, for Veracruz. In the past, the ships had served in the Armada of Barlovento (or Windward Fleet), an armed unit of sailing vessels (established in 1575) that served to protect Spanish shipping in the Caribbean and the Gulf of Mexico. The fleet was based out of Cartagena (Colombia), the major islands of the Lesser Antilles, La Guaira (Venezuela), and Veracruz.

Don Francisco Cornejo, captain of San Luis, commanded the three ships that departed Spain for Veracruz on April 21, 1719 (Figure 5-2). As the document states, San Luis and San Juan Bautista, both 60-gun warships, were "lost in a squall in the Gulf of Mexico" in December 1719. San Luis ran aground at an unspecified location, and all aboard were saved. San Juan Bautista, captained by Captain Juan de Còrdoba Laso de la Vega, was not so fortunate and "sunk in parts unknown with all its crew." It is believed that this ship sank in the GOM. The report states that San Joseph survived the storm and was able to return to Cadiz later that year. Millás (1968) found no documentation of hurricanes in this year, although the account of this vessel loss implies that there was a hurricane. 


\section{$\therefore$ and was olvisop partagena}

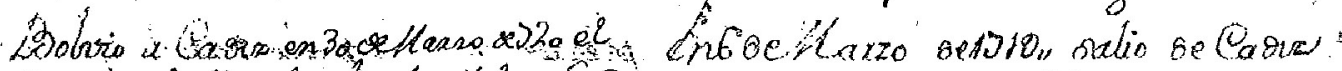

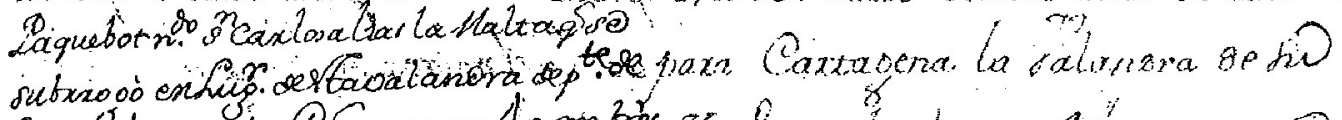

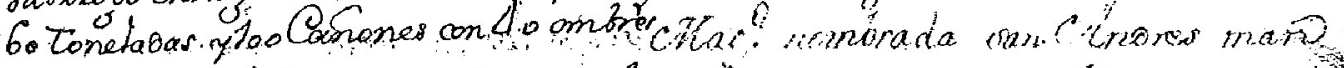

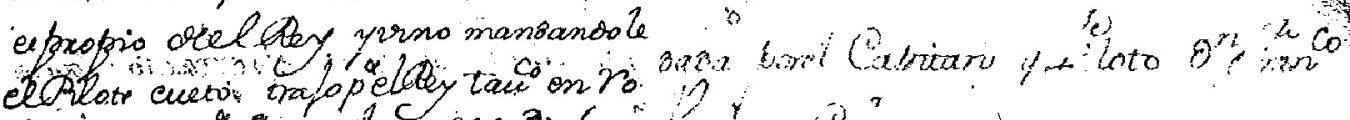

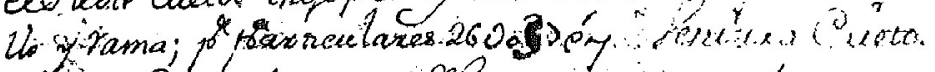

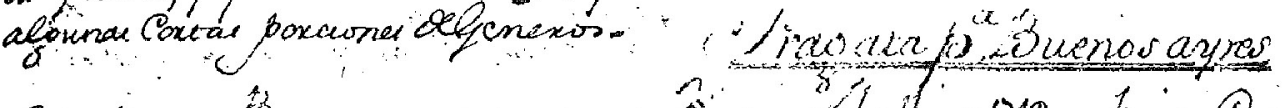

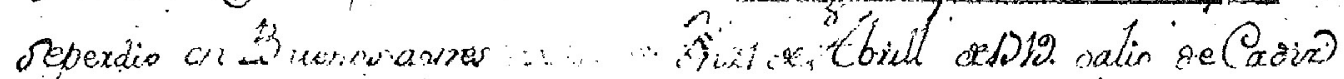

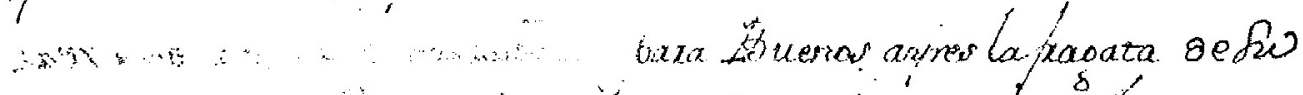

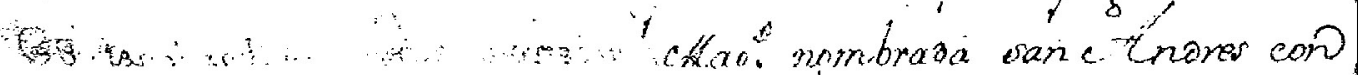

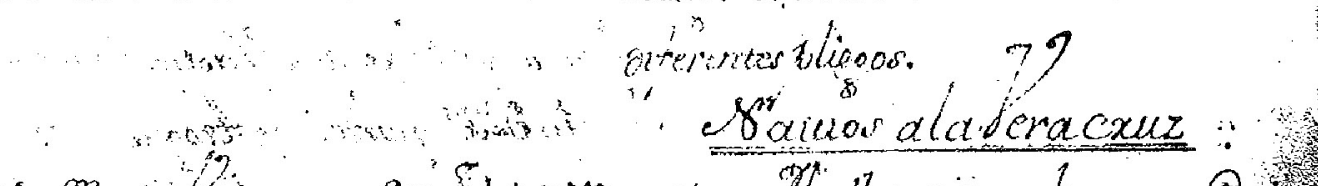

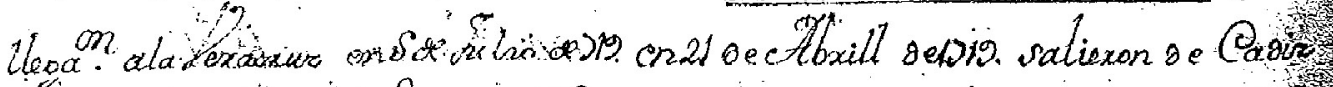

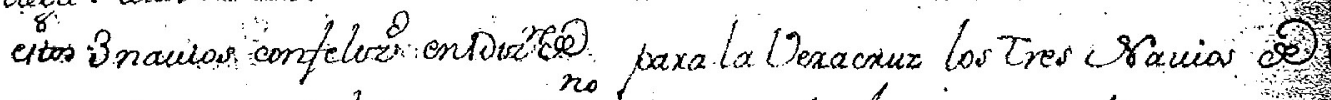

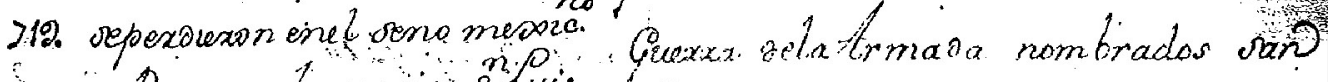

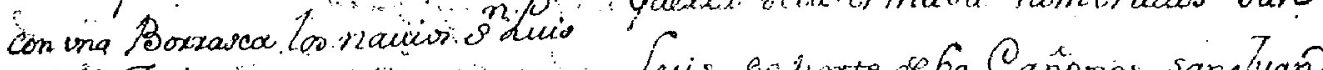

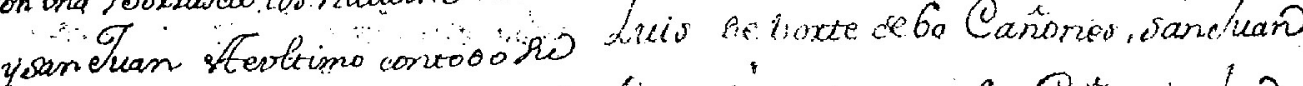

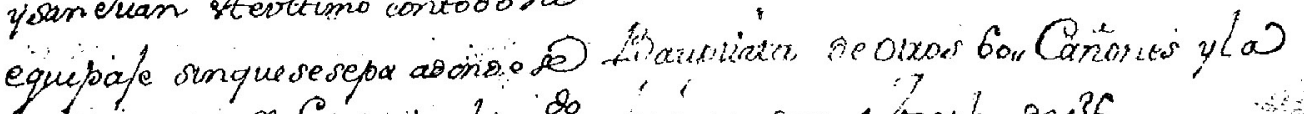

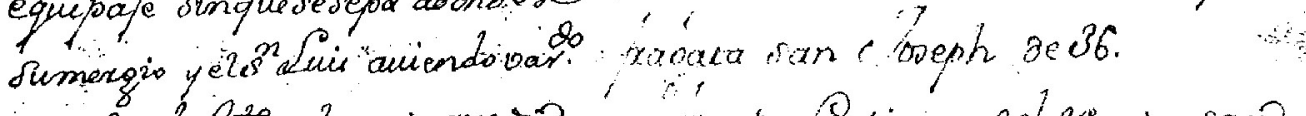

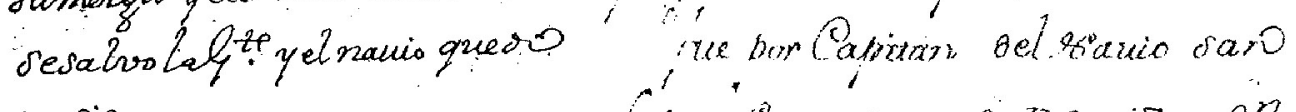
perioioo.

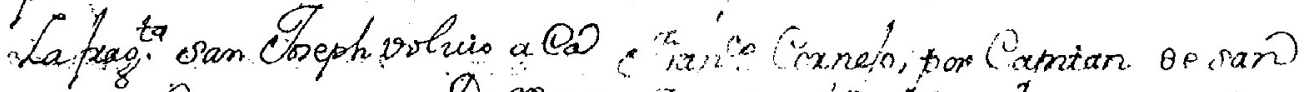

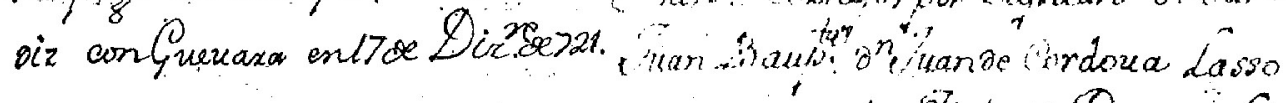

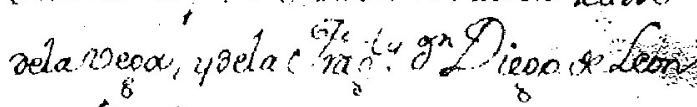

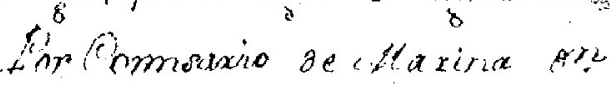

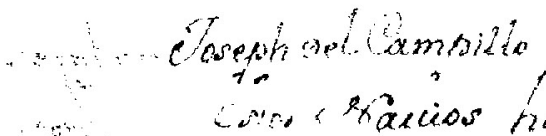
$-3$

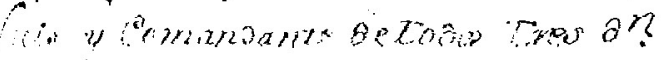

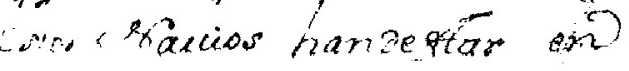

Figure 5-2. Document describing the loss of San Juan Bautista in parts unknown (Tira 19, Ultramar 704, Libro 1 folio 8 recto - folio 9 recto). 


\subsubsection{Lost Ship Number 9: Tira 21}

San Nicolás sailed from Sanlúcar de Barrameda, on the southwestern coast of Spain, for San Juan de Ulua, in the harbor of Veracruz, New Spain (Mexico), in early January 1612 (Figure 5-3). The associated document provides a list of the ship's cargo, a profile of the crew members, a description of the process of a formal departure from Spain, route directions, and other valuable details, but only brief mention of its ultimate disappearance. Preparing for a voyage to Veracruz in December 1611, San Nicolás was a zabra of 600 toneladas (825 cubic meters) in size that was serving as an aviso to Veracruz. Avisos sailed independently of the formal Spanish fleet, carrying dispatches and other important documents to the New World. San Nicolás was carrying several chests of messages for private individuals in addition to royal documents and dispatches destined for New Spain, Guatemala, Campeche, and Manila.

Captain Andrès Franco sailed under the strict orders of the Crown. He was to sail directly for Veracruz with no stops at other ports along the way or face the death penalty. No priests or friars were allowed to sail with the ship. Also, the transportation of gold, silver, slaves, or weapons on the vessel was prohibited. To ensure the safe delivery of the royal documents, Franco was instructed to avoid conflict by fleeing from unidentified vessels and privateers.

A royal inspector of Indies ships visited San Nicolás and reviewed all articles onboard from bow to stern before it departed. The inspector counted pages, cabin boys, and seamen such as Pedro de Paz, described as a "native of the island of Palma," and Francisco Corzo, "born in Arauco in the kingdom of Chile of the Indies." He made certain that adequate provisions were aboard. They consisted of codfish, vinegar, biscuit, wine, "a bit of meat, and water, among other items." Having completed the formalities preceding departure, San Nicolás sailed from Spain on January 5,1612 , never to return. The circumstances of the loss of the vessel are not elucidated in the document, which says no more than that San Nicolás was "Reported to have been lost before arriving in New Spain." Millás (1968) found no evidence of hurricanes in this year. 


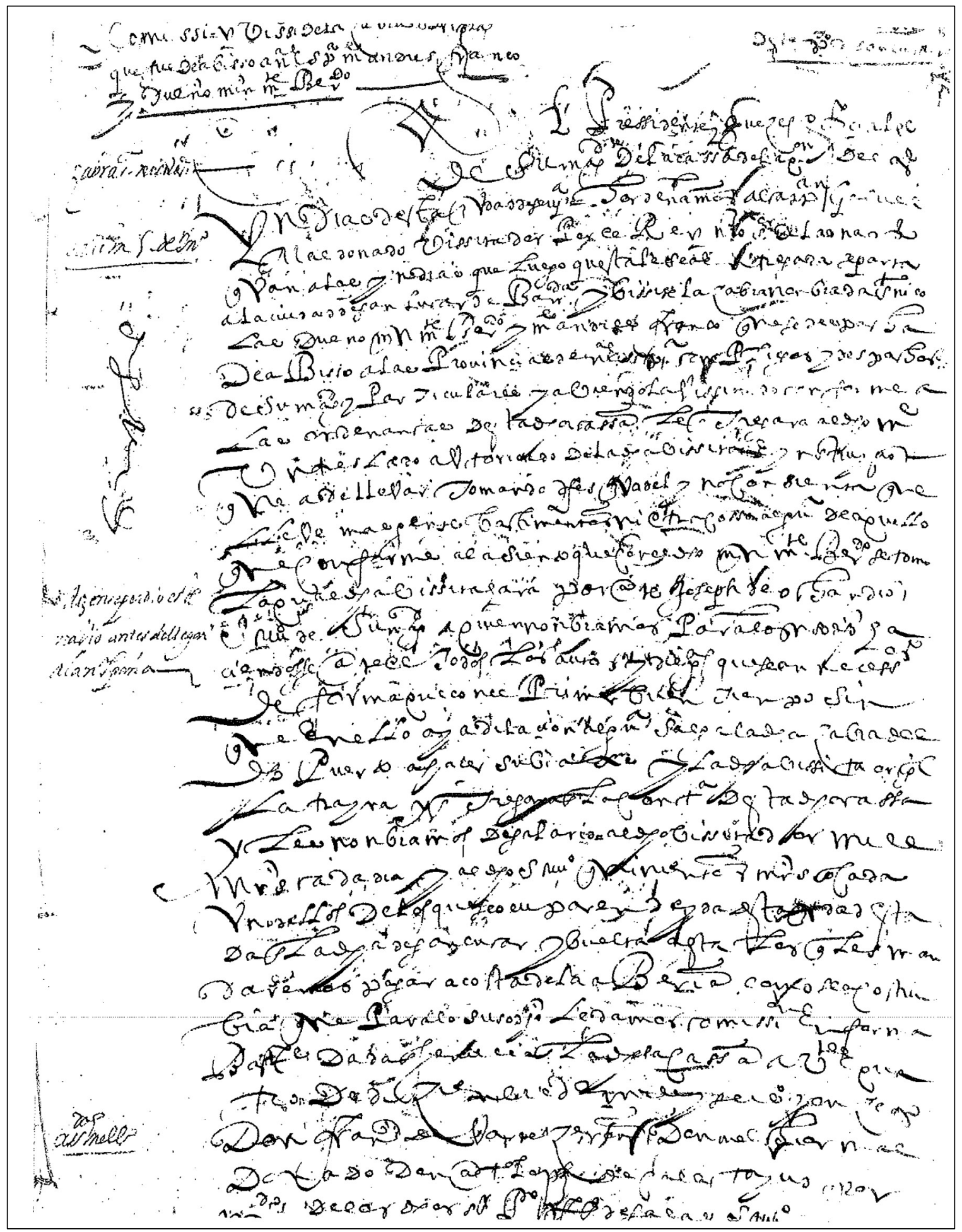

Figure 5-3. 1612 document describing the sailing instructions of the aviso ship San Nicolás to New Spain (Tira 21 Contratación1473, No. 10, Ramo 4). 


\subsection{The Archives Nationales (Paris, France) and the Centre des Archives d'Outre-Mer (CAOM) (Aix-en-Provence, France)}

Archival research in France commenced in March and proceeded through early April 2009. Nearly three weeks were spent in French repositories: three full days at the Archives Nationales in Paris and the balance of time in the Centre des Archives d'Outre-Mer (CAOM) (Colonial Archives) in Aix-en-Provence, France. Time spent at the Archives Nationales was dedicated to consulting inventories of the Colonial Archives (Table 5-7) and planning research in Aix-enProvence. The Archives Nationales (French National Archives) in Paris includes a naval section that was reviewed during the current investigation. Considered one of the largest and most important archival collections in the world, the Archives Nationales was created in 1790. The archive houses over 226 linear miles of historic documents dating from A.D. 625 to the present. This particular repository is well organized, well inventoried, and has the added advantage of allowing photography of any document consulted.

Table 5-7

Record Groups Consulted at the Archives Nationales, Paris, France

\begin{tabular}{|l|l|}
\hline \multicolumn{1}{|c|}{ Record Group } & \multicolumn{1}{c|}{ Description } \\
\hline General Correspondence & Saint-Domingue (present-day Haiti) \\
\hline $\mathrm{C} / 9 \mathrm{a} / 2$ & $\begin{array}{l}\text { Cussy, Governor, to the Minister of the Navy, Colbert (Pierre Paul TARIN } \\
\text { de CUSSY, Governer of Saint-Domingue, died in 1691 - Jean-Baptiste } \\
\text { DU CASSE, Lieutenant Général de Saint-Domingue, died in 1715) }\end{array}$ \\
\hline $\mathrm{C} / 9 \mathrm{a} / 12$ & General Correspondence, 1716 \\
\hline MAR B/3/74 \& AE B/3/323 & Series to consult on Spanish wrecks \\
\hline Marine 4JJ - Logbooks & $\begin{array}{l}\text { Travels to la Louisiane and la Floride; 4 JJ 14, 15, 16, 17, 18, 10 - } \\
\text { Voyages to the "isles" of the Gulf of Mexico or "iles de l'Amérique" in } \\
\text { general." 4 JJ 20, 21, 22, 23, 24, 25, 26 - Voyages to Saint-Domingue } \\
\text { and Martinique, 4 JJ 27, 28, 29, 30, 31, 32, 33 - Voyages to Martinique } \\
\text { only, 4 JJ 34, 35, 36 - Voyages to Saint-Domingue, 4 JJ 37, 38, 39, 40, } \\
\text { 41, 42. }\end{array}$ \\
\hline COL C/9a/4 \& C/9a/5 & $\begin{array}{l}\text { General Correspondence, Saint-Domingue, 1698-1699 and 1700-1701. } \\
\text { JJ/4/20-21 }\end{array}$ \\
$\begin{array}{l}\text { Inventaire des Archives de la Marine, Service Hydrographique Sous-sére } \\
\text { 4 JJ: This is an interesting microfilm file which contains, among other } \\
\text { things, logbooks. This particular data was microfilmed for the Library of } \\
\text { Congress, the University of Southwestern Louisiana, Loyola University of } \\
\text { New Orleans, Memphis State University, and the Mississippi Department } \\
\text { of Archives and History in 1974. This is the second such set of data } \\
\text { microfilmed for the Louisiana Colonial Record Project; the first one } \\
\text { consists of the entire subseries Colonies C13 A, B, C, Received } \\
\text { Correspondence, which was microfilmed in 1970. Loyola University also } \\
\text { prepared a large draft of analyses of ships' logs in Marine 4 JJ 7-26. }\end{array}$ \\
\hline
\end{tabular}

Several promising leads were developed at the Archives Nationales, but time was not sufficient to follow up on various leads. Future research endeavors, if any, should allocate a minimum of one month in the Archives Nationales. This is a very rich and vast repository with an important maritime section focused on French Navy ship traffic, missions, and vessel losses in the Gulf of Mexico. 
The CAOM was identified as having tremendous potential for identifying shipwrecks in UDW within the United States off the coasts of Louisiana and Florida. In 1700, the Iberville Fort was built just 25 leagues to the east of the mouth of the Mississippi River, but was abandoned in 1707 due to the difficulty in keeping this stronghold provisioned. Monsieur de Rémonville, an important ship owner from Saint-Malo, proposed to create another establishment even closer to the great river. In August 1717, the French West India Company replaced the Crozat Company, and one of the first acts of the newly formed organization was to propose the founding of $l a$ Nouvelle Orléans on the banks of the Mississippi. As early as April 1718 the construction of the new settlement had already begun. In 1722, the decision was taken to move the seat of the French colonial government from Biloxi to New Orleans. As the city took on more and more importance, maritime traffic between New Orleans, Saint-Domingue (present-day Haiti), and various ports in the French Antilles and France increased dramatically. At the same time, Mobile was also enjoying increased prosperity and shipping. At the CAOM, the sections with best potential for identifying shipwrecks in UDW within the GOM were reviewed and are presented in Table 5-8.

Table 5-8

Record Groups Consulted at the CAOM, Aix-en-Provence, France

\begin{tabular}{|l|l|}
\hline \multicolumn{1}{|c|}{ Record Group } & \multicolumn{1}{c|}{ Description } \\
\hline Colonies, F3-24, 25, 241, 242 and 243 & Moreau de Saint-Méry Collection \\
\hline $\begin{array}{l}\text { Colonies, Louisiane, C13A-1 through } \\
\text { 37 (1678-1753); C13A-38 through 54 } \\
(1754-1803)\end{array}$ & $\begin{array}{l}\text { In this section there are also some ships' logbooks pertaining to } \\
\text { exploration along the coasts of Louisiana, Mississippi, Alabama } \\
\text { and Florida }\end{array}$ \\
\hline Colonies, C13B-1 & $1699-1803$ \\
\hline Colonies, C13C-1 through 5 & $1675-1782$ \\
\hline
\end{tabular}

Ships sailing from France to la Louisiane, then a vast region encompassing what is now Louisiana, Mississippi, Alabama, and part of Florida, carried a variety of goods for the colony, including weapons, clothing, tools, lard, flour, salt, wine and spirits, and pacotille (cheap items, such as brass finger rings, glass jewelry, and other items of little value to be traded to the Indians) and slaves usually bought in west Africa. Ships sailing to France from New Orleans, Mobile, Biloxi, and Dauphin Island carried beaver skins, deerskins, indigo, and wood. There was also a very active trade with Martinique and Saint-Domingue (present-day Haiti). Ships from those ports came to la Louisiane to buy timber and sell poultry and vegetables, mostly at Pensacola. They also brought flour and spirits but at such excessive prices that the inhabitants could scarcely afford those products. Conversely, beaver furs were sold so cheaply to the merchants aboard those ships that the coureurs de bois (trappers or fur hunters) often threatened to stop furnishing them to the people of Pensacola (Lacoursière 1982:64-66).

Research at the CAOM led to the identification of seven shipwrecks potentially lost within the GOM, four of which were identified by name (Table 5-9). Several shallow-water shipwrecks were also identified during the course of this research. As with the Spanish documents, an attempt has been made to corroborate losses found in French records with known hurricanes in the region in the colonial period as enumerated in the 1968 work of Josè Carlos Millás. His 
Table 5-9

Potential Vessel Losses within UDW of the GOM Identified at the CAOM, Aix-en-Provence, France

\begin{tabular}{|c|c|c|c|c|c|c|c|c|c|c|c|c|}
\hline $\begin{array}{l}\text { Lost Ship } \\
\text { Number }\end{array}$ & $\begin{array}{l}\text { Reference } \\
\text { ID }\end{array}$ & $\begin{array}{l}\text { Nationality } \\
\text { of Vessel }\end{array}$ & $\begin{array}{l}\text { Year } \\
\text { Lost }\end{array}$ & $\begin{array}{l}\text { Name of } \\
\text { Ship }\end{array}$ & $\begin{array}{l}\text { Name of } \\
\text { Captain }\end{array}$ & $\begin{array}{l}\text { Name of } \\
\text { Owner }\end{array}$ & $\begin{array}{c}\text { Port of } \\
\text { Departure }\end{array}$ & $\begin{array}{c}\text { Port of } \\
\text { Destination }\end{array}$ & $\begin{array}{l}\text { Presumed } \\
\text { Area of } \\
\text { Sinking }\end{array}$ & Observations & Source & $\begin{array}{c}\text { Source } \\
\text { Repository }\end{array}$ \\
\hline 10 & $\begin{array}{l}\text { CAOM C9 } \\
\text { A142 (no folio } \\
\text { number) \& } \\
\text { CAOM C13 } \\
\text { B1 (folio 423) }\end{array}$ & French & 1772 & $\begin{array}{l}\text { Marie } \\
\text { Thérèse }\end{array}$ & $\begin{array}{l}\text { Lauwereyus } \\
\text { or Lawrins }\end{array}$ & & New Orleans & $\begin{array}{l}\text { Port-au- } \\
\text { Prince }\end{array}$ & $\begin{array}{l}\text { Gulf of } \\
\text { Mexico }\end{array}$ & $\begin{array}{l}\text { Ship reported lost } \\
\text { between New } \\
\text { Orleans and Port- } \\
\text { au-Prince with all } \\
\text { souls, and a cargo } \\
\text { of } 140,000 \text { pounds } \\
\text { of cannon }\end{array}$ & $\begin{array}{l}\text { CAOM C9 } \\
\text { A142 (no } \\
\text { folio } \\
\text { number) \& } \\
\text { CAOM } \\
\text { C13 B1 } \\
\text { (folio 423) }\end{array}$ & CAOM \\
\hline 11 & $\begin{array}{l}\text { CAOM C13 } \\
\text { A8 (folio 399) }\end{array}$ & French & 1725 & la Bellone & & & Mobile & France & $\begin{array}{l}\text { Dauphin } \\
\text { Island, } \\
\text { Alabama }\end{array}$ & $\begin{array}{l}\text { Ship sank while at } \\
\text { anchor off Dauphin } \\
\text { Island, all cargo } \\
\text { and personal } \\
\text { effects lost }\end{array}$ & $\begin{array}{l}\text { CAOM } \\
\text { C13 A8 } \\
\text { (folio 399) }\end{array}$ & CAOM \\
\hline 12 & $\begin{array}{l}\text { CAOM C13 } \\
\text { A16 (folio } \\
\text { 178) }\end{array}$ & French & 1732 & $\begin{array}{l}\text { Royal Ship } \\
\text { (name } \\
\text { unknown) }\end{array}$ & & $\begin{array}{l}\text { French } \\
\text { Royal } \\
\text { Navy }\end{array}$ & $\begin{array}{l}\text { France \& } \\
\text { Cap François } \\
\text { (Cape } \\
\text { Haitian) }\end{array}$ & New Orleans & $\begin{array}{l}\text { Gulf of } \\
\text { Mexico }\end{array}$ & $\begin{array}{l}\text { Ship sailed from } \\
\text { France in early } \\
\text { June 1732, then } \\
\text { sailed from Cap } \\
\text { François on August } \\
5,1732, \text { bound for } \\
\text { New Orleans and } \\
\text { was never heard of } \\
\text { again }\end{array}$ & $\begin{array}{l}\text { CAOM } \\
\text { C13 A16 } \\
\text { (folio 178) }\end{array}$ & CAOM \\
\hline 13 & $\begin{array}{l}\text { CAOM C13 } \\
\text { A16 (folio } \\
178 \text { ) }\end{array}$ & English & 1732 & $\begin{array}{l}\text { (name } \\
\text { unknown) }\end{array}$ & & & & & $\begin{array}{l}\text { Gulf of } \\
\text { Mexico }\end{array}$ & $\begin{array}{l}\text { Wreckage of ship } \\
\text { was found } \\
\text { between Mobile } \\
\text { and Pensacola } \\
\text { along with the } \\
\text { bodies of two } \\
\text { Englishmen }\end{array}$ & $\begin{array}{l}\text { CAOM } \\
\text { C13 A16 } \\
\text { (folio 178) }\end{array}$ & CAOM \\
\hline 14 & $\begin{array}{l}\text { CAOM C13 } \\
\text { A26 (folio } \\
127 \text { ) }\end{array}$ & French & 1740 & $\begin{array}{l}\text { Royal Ship } \\
\text { (name } \\
\text { unknown) }\end{array}$ & $\begin{array}{l}\text { Captain } \\
\text { Royer }\end{array}$ & $\begin{array}{l}\text { French } \\
\text { Royal } \\
\text { Navy }\end{array}$ & France & Mobile & $\begin{array}{l}\text { Gulf of } \\
\text { Mexico }\end{array}$ & $\begin{array}{l}\text { Ship was moored } \\
\text { at La Balise } \\
\text { (Lookout Island at } \\
\text { the mouth of the } \\
\text { Mississippi) when a } \\
\text { strong gust of wind } \\
\text { took the ship far out } \\
\text { to sea, presumably } \\
\text { in deepwater; } \\
\text { nothing was heard } \\
\text { of her again }\end{array}$ & $\begin{array}{l}\text { CAOM } \\
\text { C13 A26 } \\
\text { (folio 127) }\end{array}$ & CAOM \\
\hline
\end{tabular}


Table 5-9. Potential Vessel Losses within UDW of the GOM Identified at the CAOM, Aix-en-Provence, France (continued).

\begin{tabular}{|c|c|c|c|c|c|c|c|c|c|c|c|c|}
\hline $\begin{array}{l}\text { Lost Ship } \\
\text { Number }\end{array}$ & $\begin{array}{l}\text { Reference } \\
\text { ID }\end{array}$ & $\begin{array}{l}\text { Nationality } \\
\text { of Vessel }\end{array}$ & $\begin{array}{l}\text { Year } \\
\text { Lost }\end{array}$ & $\begin{array}{l}\text { Name of } \\
\text { Ship }\end{array}$ & $\begin{array}{l}\text { Name of } \\
\text { Captain }\end{array}$ & $\begin{array}{l}\text { Name of } \\
\text { Owner }\end{array}$ & $\begin{array}{c}\text { Port of } \\
\text { Departure }\end{array}$ & $\begin{array}{c}\text { Port of } \\
\text { Destination }\end{array}$ & $\begin{array}{l}\text { Presumed } \\
\text { Area of } \\
\text { Sinking }\end{array}$ & Observations & Source & $\begin{array}{c}\text { Source } \\
\text { Repository }\end{array}$ \\
\hline 15 & $\begin{array}{l}\text { CAOM C13 } \\
\text { A26 (folio } \\
127 \text { ) }\end{array}$ & French & 1740 & la Somme & & $\begin{array}{l}\text { French } \\
\text { Royal } \\
\text { Navy }\end{array}$ & $\begin{array}{l}\text { Cap François } \\
\text { (Cape } \\
\text { Haitian) }\end{array}$ & New Orleans & $\begin{array}{l}\text { Gulf of } \\
\text { Mexico }\end{array}$ & $\begin{array}{l}\text { Ship's hull was } \\
\text { repaired in Cap } \\
\text { Francois after she } \\
\text { had grounded on a } \\
\text { reef; sailed for New } \\
\text { Orleans and was } \\
\text { never heard of } \\
\text { again }\end{array}$ & $\begin{array}{l}\text { CAOM } \\
\text { C13 A26 } \\
\text { (folio 127) }\end{array}$ & CAOM \\
\hline 16 & $\begin{array}{l}\text { CAOM C13 } \\
\text { A30 (folio } \\
131 \text { ) \& } \\
\text { CAOM C13 } \\
\text { A32 (folio } \\
\text { 215) \& } \\
\text { CAOM C13 } \\
\text { A30 1746 } \\
\text { (folio 159) }\end{array}$ & French & 1746 & le Chameau & & $\begin{array}{l}\text { French } \\
\text { Royal } \\
\text { Navy }\end{array}$ & France & New Orleans & $\begin{array}{l}\text { Gulf of } \\
\text { Mexico (?) }\end{array}$ & $\begin{array}{l}\text { Ship sailed from } \\
\text { France in June } \\
1746 \text { with } \\
\text { important official } \\
\text { documents and } \\
\text { was never heard of } \\
\text { again }\end{array}$ & $\begin{array}{l}\text { CAOM } \\
\text { C13 A30 } \\
\text { (folio 131) } \\
\text { \& CAOM } \\
\text { C13 A32 } \\
\text { (folio 215) } \\
\text { \& CAOM } \\
\text { C13 A30 } \\
\text { 1746 (folio } \\
\text { 159) }\end{array}$ & CAOM \\
\hline
\end{tabular}


work, as noted above, spans the years 1492 to 1800 and provides information on hurricanes in regions adjacent to the GOM. The analysis below includes a review of any reported hurricanes that may have accompanied a particular loss. These vessel loss accounts begin with Lost Ship Number 10 and proceed through Lost Ship Number 16. Full transcriptions of French documents pertinent to these ship losses are provided in Appendix A.

\subsubsection{Lost Ship Number 10: CAOM C9 A142 (No Folio Number) and CAOM C13 B1 (Folio 423)}

The loss of a French vessel bound from New Orleans in the colony of Louisiana to Port-AuPrince, Saint-Domingue (present-day Haiti) is briefly noted in two letters found in the CAOM. Renè-Jean-Gabriel Fazende, Commissioner of the Colonies in Louisiana, penned the first letter on January 9, 1773. Through "some English ships," he reported, the colony had learned that Marie Thérèse, a vessel heavily laden with 140,000 pounds of cannon that had sailed from New Orleans in August (the specific day is not given) of the preceding year, had "perished with all of its crew and passengers." François Lauwereyus (or Lawrins) was captain of the vessel. Among the passengers aboard, Fazende added, was Jean-Arnoult-Valentin Bobè-Descleaux, chief accountant and comptroller of the French Navy in Louisiana, who carried with him "almost all the accounting documents" of the colony. The identity of the English ships that apparently saw Marie Thérèse is not known. It is also unknown if these English ships saw a ship in despair in open water or along a reef, or if they passed it en route to their own destination. These questions cannot be answered from this first letter, or the next letter, for that matter, but further details regarding Marie Thérèse are available.

The second letter was written on February 10, 1773, at Port-Au-Prince by the Governor of SaintDomingue, Marquis Louis Laurent de Vallière (Figure 5-4). By this date, the colony of Louisiana had already heard about the loss of Marie Thérèse, but the news was just arriving to Saint-Domingue. The governor was familiar with the ship, for it had departed from his city to New Orleans in the early months of 1772 under the command of "Captain Lawrins." The governor's source of information on the loss of the vessel admittedly was "rumor"; therefore, the details he provides may be somewhat inaccurate. He had learned that the loss occurred "several months ago," presumably meaning in the latter months of 1772, but most probably the loss did not occur long after Marie Thérèse's August departure date from New Orleans. Although the governor does not mention the vessel by name, there is no question that he is referring to Marie Thérèse. He mentions passengers and a large quantity of artillery aboard, the latter being exceptionally unique to Marie Thérèse. The vessel, its 130 passengers, and "lots of merchandise" had been "lost with all souls," as rumor told the governor, and he deemed it "very likely" that this was true because Marie Thérèse "was never heard of again." In stating that the vessel was never heard of again, the governor did not mean that there was no knowledge of its fate. After all, rumor of its loss had reached Port-au-Prince. Rather, he meant that there were no survivors from the ship.

Interestingly, the governor, again relying on the rumor he had heard, reported that Marie Thérèse was lost "in the Bahama Channel." This channel runs between the north coast of Cuba and the Great Bahama Bank. The governor's assumption that the ship was lost in this area (an assumption based on rumor) appears to be flawed, for by the 1770 s this channel, for at least a 


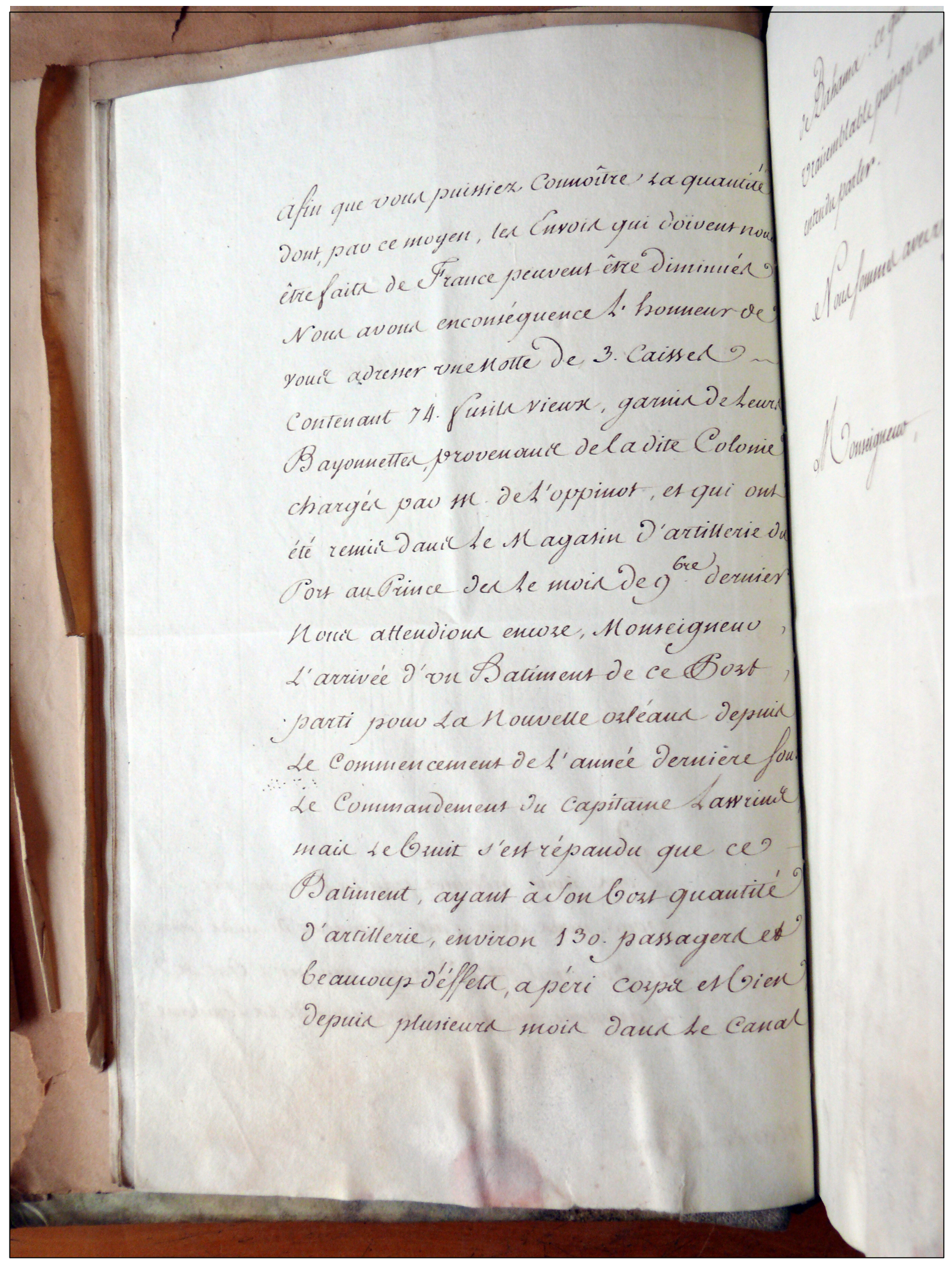

Figure 5-4. The second letter regarding the loss of Marie Thérèse, written on February 10, 1773, at PortAu-Prince by the governor of Saint-Domingue, Marquis Louis Laurent de Vallière (CAOM C9 A142). 
century, had been considered too hazardous to sail, and ships traveling between Port-au-Prince and New Orleans typically sailed south of Cuba and in sight of the coast. Therefore, it is the opinion of the authors of this study that Marie Thérèse was lost elsewhere along the common sailing route, as would also be supported by the English who apparently saw or learned of the ship, and perhaps in deepwater somewhere in the GOM between New Orleans and the western tip of Cuba.

Given the hurricane history of the year 1772 as detailed in Millás (1968), it is incredibly likely that Marie Thérèse was lost in a hurricane (or similarly violent storm). This year was very active in such tropical weather, as Millás confirms eight hurricanes for this year. The first recorded hurricane struck Santo Domingo (present-day Dominican Republic) on August 4-5. An account from the time briefly notes many vessels lost, although there are no specifics as to where they were lost or their identity. The storm then powered westward toward Saint-Domingue before heading northward through the Bahamas. The next hurricane was reported at Santiago de Cuba on August 16; Millás describes it as very weak, if a hurricane at all. A day later, elsewhere in the Caribbean, another small hurricane hit Antigua but quickly dissipated, affecting no other islands. Then, the first of a series of two more hurricanes ripped through the Caribbean and adjacent regions. An August 28 storm passed through the Northern Leeward Islands, St. Thomas, Puerto Rico, Santo Domingo, Saint-Domingue, the south coast of Cuba, the Cayman Islands, and "quite into the Gulf of Honduras" (according to a 1774 account cited in Millás [1968:234]). The second in the series was a storm famous for its severity, for it obliterated plantations and other works on the islands. It arrived on August 30 at the Lesser Antilles and ultimately reached Puerto Rico. Other hurricanes occurring in 1772 apparently did not reach as far as SaintDomingue.

As we know from the French documents discussed above, Marie Thérèse left New Orleans sometime in August 1772. Regardless of whether the vessel departed early or late in the month, the probability that the trajectory of the hurricane that struck Santo Domingo on August 4-5 intersected the ship is high. Likewise, the same is true with respect to the hurricane that reached the Leeward Islands on August 28 and coursed westward into the Gulf of Honduras in the days following.

\subsubsection{Lost Ship Number 11: CAOM C13 A8 (Folio 399)}

This document describes the loss of a colonial-era ship in the GOM while also providing an example of prevailing early-eighteenth-century religious interpretations of ship losses (Figure 5-5). Moreover, this document illustrates that ship losses had ramifications beyond the tragedy of lost lives and valuable cargoes. The sinking of la Bellone, as was surely the case with lost ships from other colonies, compromised the future of the emerging entrepôt of French Louisiana.

On May 15, 1725, Father Raphaël, a Mobile priest of the Capuchin missions of the colony of Louisiana, picked up his pen to write a fellow man of the cloth about the sinking of la Bellone off Dauphin Island (at the mouth of Mobile Bay), an event he explained as principally due to the sins of the people of the colony. The vessel had arrived at the colony in early September 1724, taking on a cargo "richly laden for an up-and-coming [young] colony." Indigo of a quality "better manufactured than in the past" was included, and it was thought that the delivery of such 


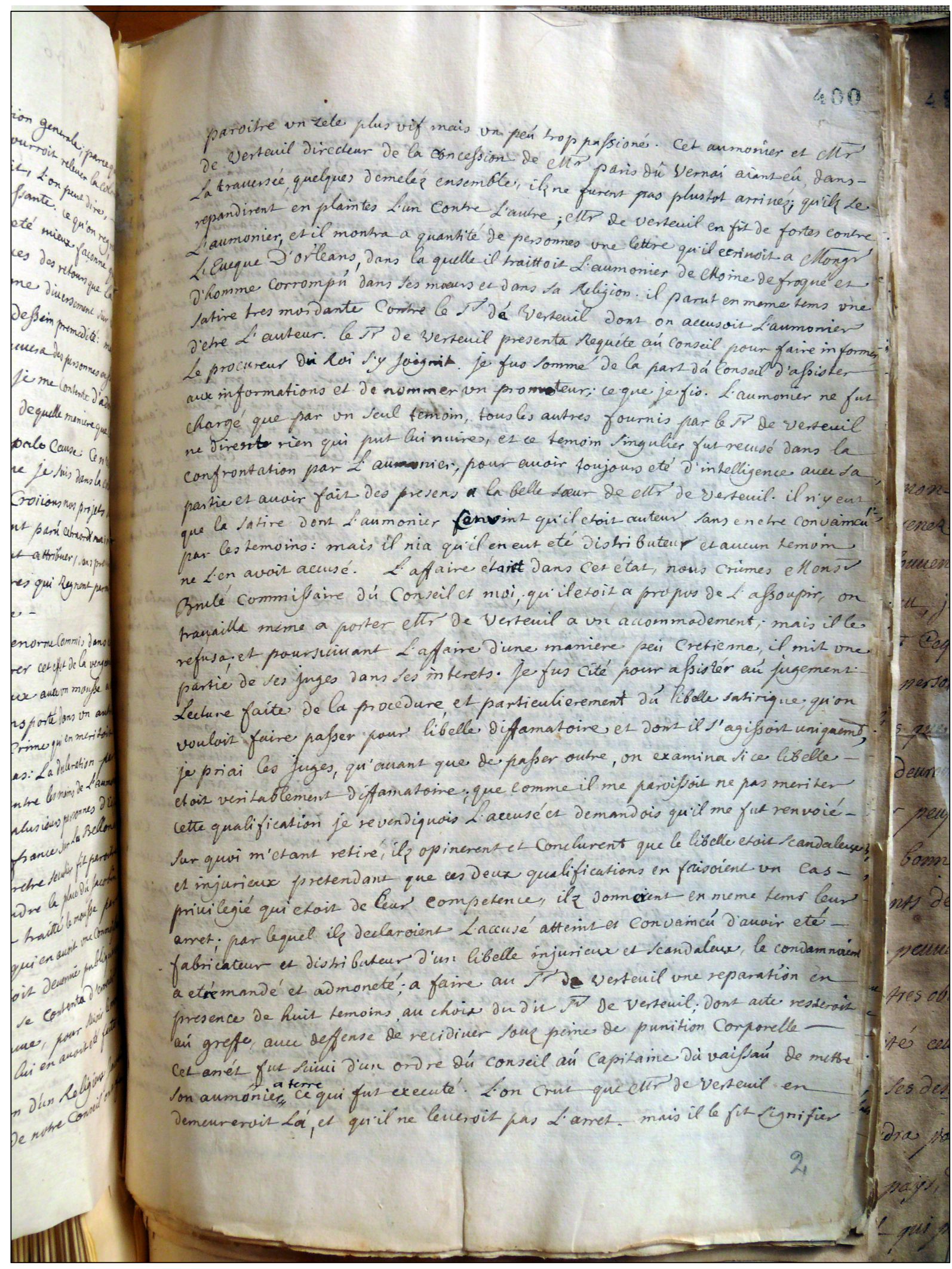

Figure 5-5. Letter describing the sinking of la Bellone off Dauphin Island (at the mouth of Mobile Bay) in 1725 (CAOM C13 A8). 
a product to France "could help the [Louisiana] colony out of the general disgrace it is in the Kingdom" and also instill in the mother country "more solid hopes of returns the colony could expect in the future." La Bellone was scheduled to sail for France at the very start of April 1725. On April 1 or 2 (the author is not certain), the passengers had boarded the vessel and the crew were preparing for a next-day departure. At 6:00 p.m., the ship was pumped as normal and there was no incident. By 3:00 a.m., it had sunk "in front of them in front of Dauphin Island... in so little time that no one realized it" and in calm weather. Two men and two or three children drowned, but a nearby brigantine was able to rescue most of the other passengers.

"The best experts in maritime affairs do not understand anything of such an extraordinary event," Father Raphaël noted. Yet he knew that sometime in the recent past or perhaps in the previous year when la Bellone had reached Mobile, the ship "had suffered through some bad weather" and hit bottom on the bar at the mouth of the Mobile River. Some in Mobile alleged a conspiracy. Though he recognized la Bellone's ailments, Father Raphaël could not help concluding that the sins of the colony, and particularly the abuses rendered upon a deck boy by the ship's captain, were "the principal reason" behind the catastrophe. In any case, the document leaves no doubt that the vessel sank at Dauphin Island as a result of structural issues. Additional archival information relative to la Bellone indicates that the vessel was a 370-ton pinnace (cutter) built in Holland in 1707. The vessel's first voyage was in 1720, and it was listed as lost in Louisiana April 1, 1725 (Service Historique de la Marine 1978:91).

\subsubsection{Lost Ship Number 12: CAOM C13 A16 (Folio 178)}

News of the suspected loss of a vessel of the French navy distressed Governor Étienne de Périer of Louisiana as is evidenced by a January 25, 1733, letter to the King of France from New Orleans. Native American groups in the Mississippi region were in a state of discord, and the French presence was dependent on the arrival of the ship (which, unfortunately, is unnamed in the document). "This loss," the governor concluded, "is causing considerable harm to this colony that is lacking everything."

By way of a French vessel called St. René, the governor had learned that the expected ship departed Cape François (Cape Haitian, Haiti) on August 5, 1732, after a two-month journey across the Atlantic from France. However, since the time of the vessel's departure for New Orleans, a terrible storm had ripped through the Gulf, the governor reported in his letter. A hurricane occurring on August 29, 1732, had caused "great damage." Millás (1968) found no evidence of this hurricane; therefore, Governor Périer's letter is especially noteworthy. "The wind was violent here on land for only 22 hours," he wrote, "but it lasted three to four days at sea according to the report from two [ships] that went through it." Reports of the grounding or loss of several ships in the GOM were reaching New Orleans. Eight leagues east of La Balise (today known as Lookout Island), a Spanish frigate out of Pensacola named la Vigilante (possibly the ship Aguila Volante) came into distress and grounded along the coast. The French, who during this period were briefly allied with the Spanish, managed to save the entire crew of 120 men and sent them to Veracruz.

The fate of the long-awaited French vessel, however, was yet to be told at the time of the governor's letter. Search parties from New Orleans had searched the coast to the east and west 
of the Mississippi River for signs of the ship, but "nothing was observed in that area to indicate the loss of the vessel of the King [i.e., the unnamed French vessel] on this coast." Having heard no news, Governor Périer theorized that the ship may be stranded "at the bottom of the Gulf" (presumably meaning the southern Gulf of Mexico). But if this were the case, he continued, news would have arrived and, as it had not, the governor believed the ship was lost.

\subsubsection{Lost Ship Number 13: CAOM C13 A16 (Folio 178)}

The loss of an unidentified English vessel in August 1732 also is noted in Governor Périer's letter to the French Crown (dated January 25, 1733). While scouring the coast for the lost French navy ship from Cape François, the governor's search party found wreckage "between Pensacola and Mobile." A close inspection determined the wreckage "to be from an English ship," according to the governor's letter. Two bodies were located near the wreckage, and the French searchers determined them to be Englishmen. The bodies apparently had washed ashore by the time the French had arrived at the scene. That only two bodies were discovered presents a strong possibility that the unidentified English ship was lost at sea. Had it crashed against the shore or on a reef, presumably numerous other bodies or even living survivors from the ship would have been found as the French searchers examined the coast along the area. The port of departure and destination of this English vessel is unknown.

\subsubsection{Lost Ship Number 14: CAOM C13 A26 (Folio 127)}

Edmé-Gatien Salmon, a government official in French Louisiana, wrote the king of France a letter on March 8, 1741, from New Orleans to inform him of the increasingly desperate situation of the colony as a result of several maritime incidents, one of them being the loss of a vessel of the French navy (Figure 5-6). "We went through several hurricanes at the end of September [1740]," Salmon wrote. These storms damaged fortifications at La Balise (Lookout Island, Louisiana) at the mouth of the Mississippi River (Figure 5-7), toppled a recently updated jetty at Mobile, and flooded Dauphin Island in the mouth of Mobile Bay and also the Alabama and Mobile rivers to the point that maize growing along their shores was submerged.

Described as a "large ship," the French vessel (unnamed in this document) was commanded by one Captain Royer. The vessel had come to the colony from France and stopped at La Balise on the Mississippi River en route to Mobile. Food supplies and merchandise "earmarked for those in Mobile" were aboard the ship as it awaited departure at La Balise with the September hurricanes descending upon the region. Presumably as a consequence of one of these storms, the ship began to take on water. To prevent the loss of items aboard, the ship was unloaded except for a few cannonballs, and for several days it was moored with three anchors against heavy winds. "The captain [Royer] was alone on board with the 4 Negroes of the King when a gust of wind of extreme force took her out into the Gulf," Salmon reported, "and we never heard of her again."

Millás (1968) found documentation of a hurricane that struck Puerto Rico on September 11, 1740. Perhaps this storm traveled westward into the Gulf to become one of the several that Salmon mentioned in his letter as affecting the Louisiana colony and causing the loss of the French navy vessel. 


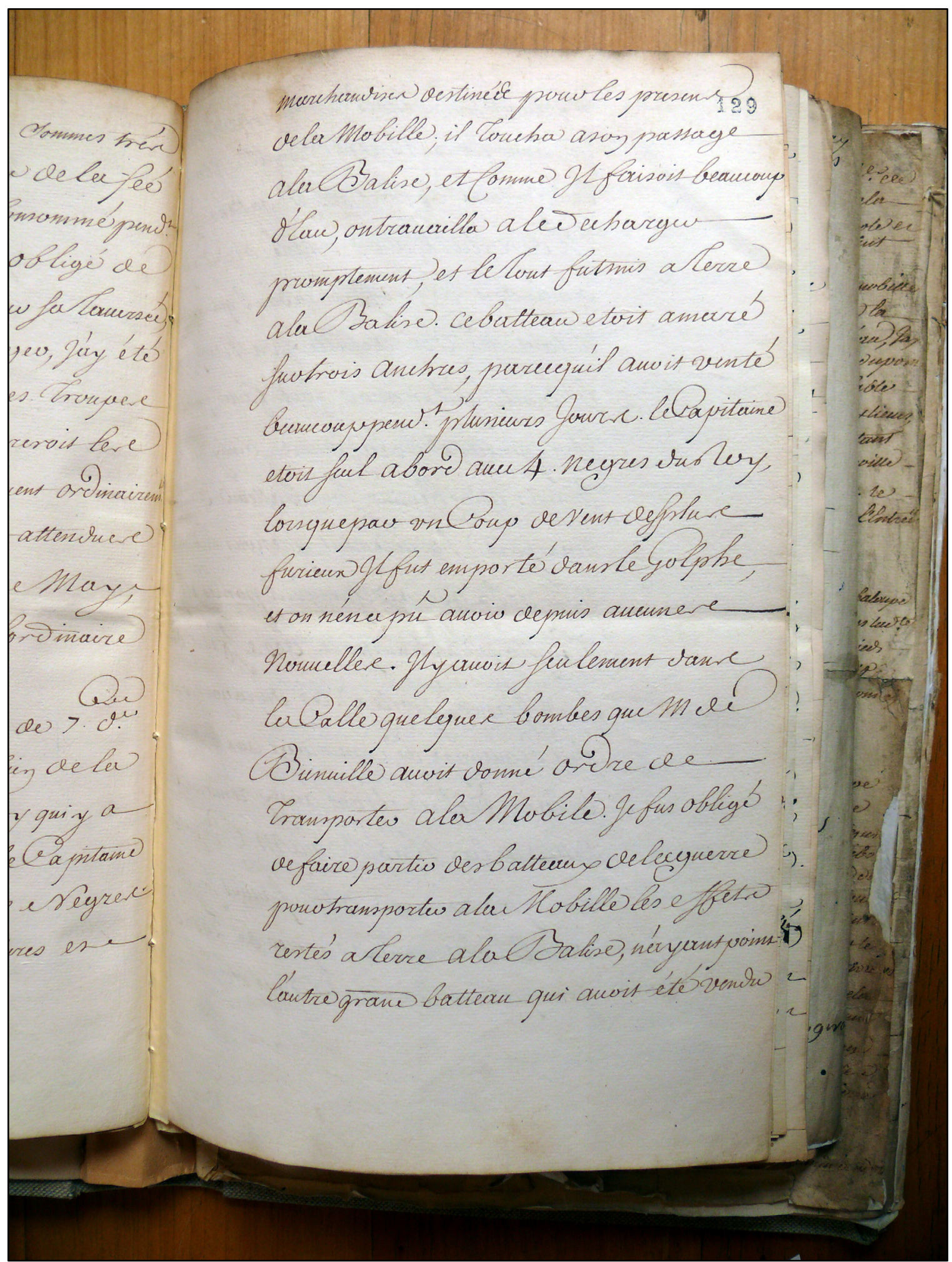

Figure 5-6. Letter dated March 8, 1741, describing the loss of the king's vessel that was moored at La Balise and taken out by a storm into the Gulf of Mexico, whence it was never heard of again (CAOM C13 A26). 


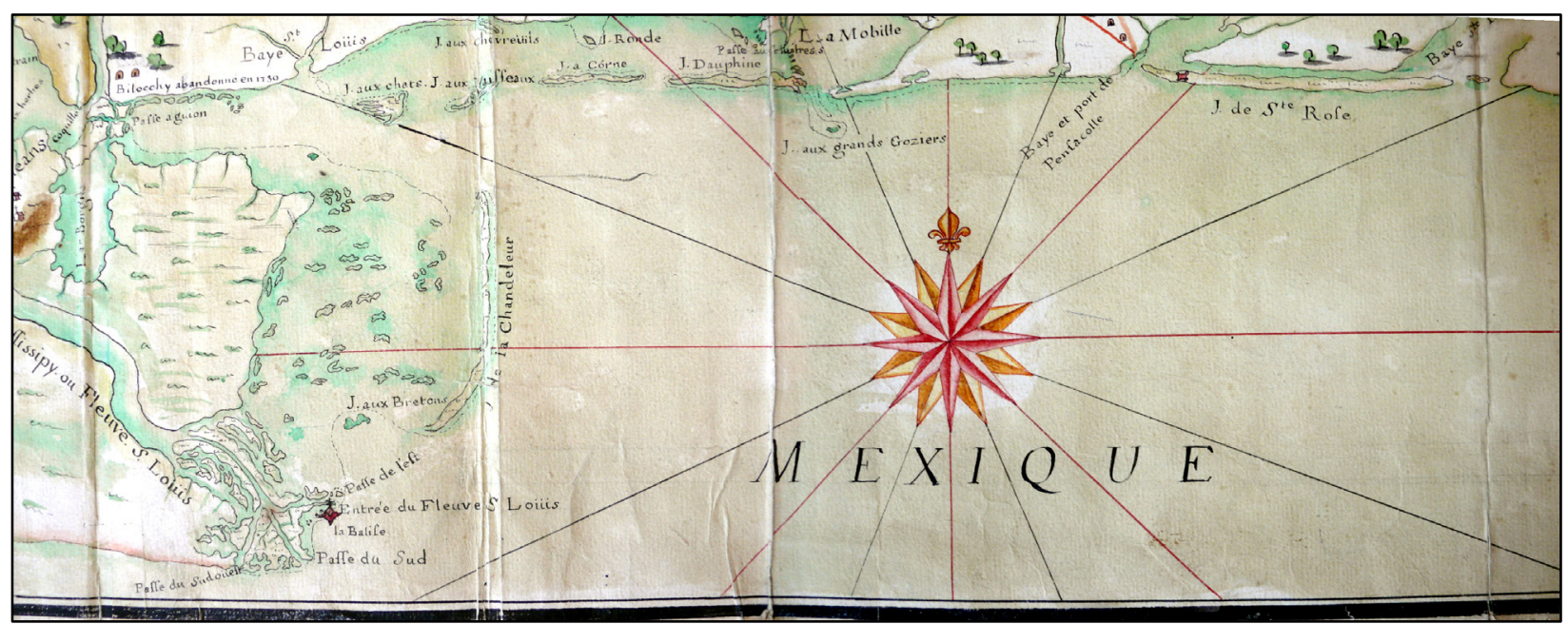

Figure 5-7. 1733 manuscript map of the Mississippi Delta region (detail) showing La Balise, Dauphin Island, and part of Mobile Bay (CAOM Colonies, III/6 PFA/1).

\subsubsection{Lost Ship Number 15: CAOM C13 A26 (Folio 127)}

Salmon's March 8, 1741, letter that reported to the king on the loss of a French naval vessel at La Balise also mentioned the lack of knowledge concerning another ship of the French navy, a flute, or cargo ship, called la Somme (Figure 5-8). A January 12 letter from Cape François (Cape Haitian, Haiti) had informed Salmon that the ship, which was destined for La Balise (Lookout Island, Louisiana), had grounded just outside this departure point and work was underway to repair the ship. The exact date of the accident is not provided. Presumably it occurred sometime just prior to January 12, 1741, or maybe even in December 1740. In any case, as Salmon reported, la Somme was well overdue to La Balise by March 8, 1741, and no word about its circumstances had been received. Salmon's letter seems to imply that something would have been heard of this ship in the meantime, especially because it carried a cargo of desperately needed flour for the colony. Therefore, it is likely that the ship may have been lost somewhere on its route to La Balise and ostensibly in the GOM. There are no reported hurricanes for this year in Millás (1968), but perhaps the fact that the ship had recently suffered damages from grounding impaired it in some way along the route. 


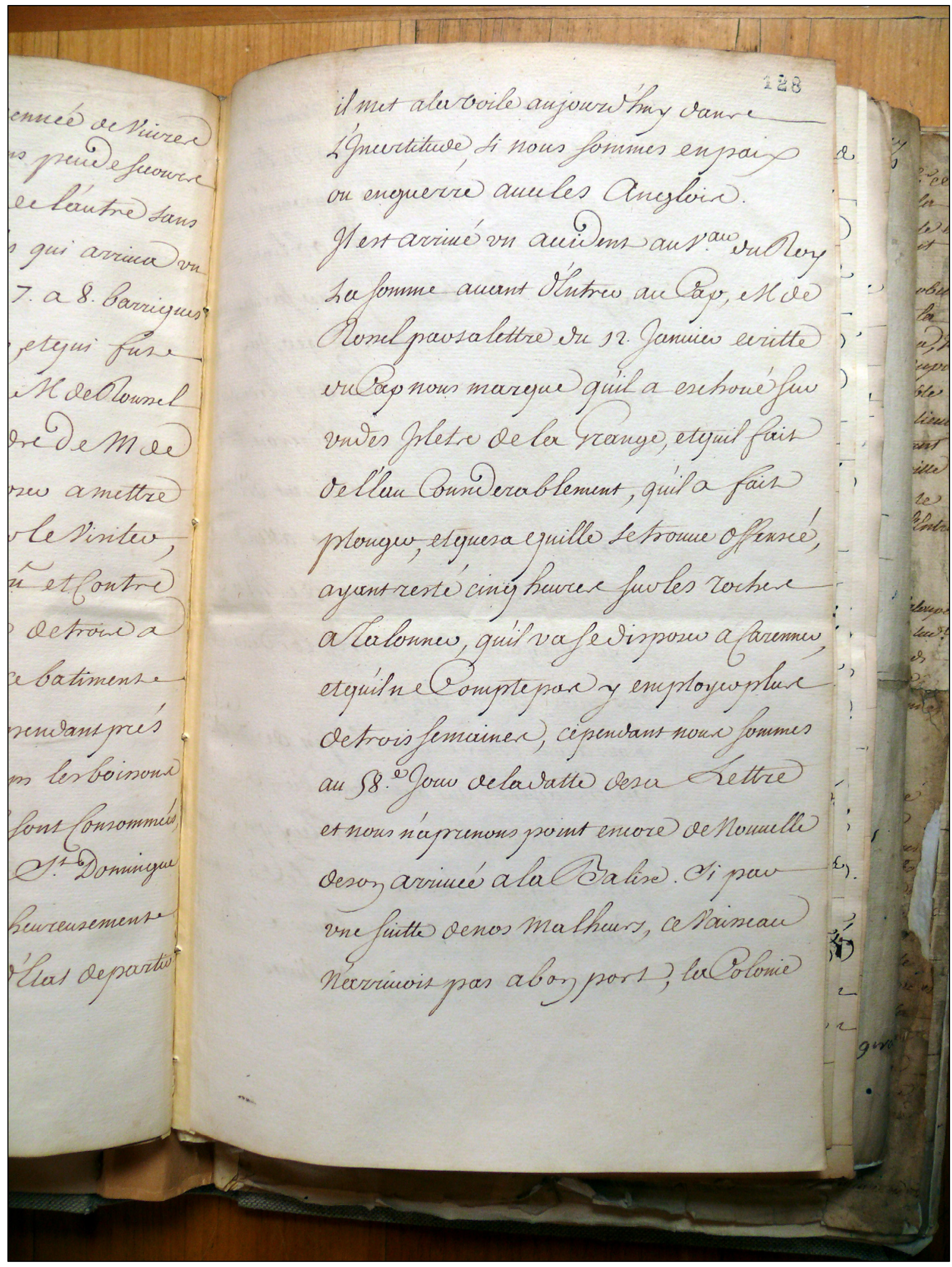

Figure 5-8. A March 8, 1741, letter reporting to the king regarding the loss of a French naval vessel at La Balise as well as the lack of knowledge concerning another ship of the French navy, a flute, or cargo ship, called la Somme. Centre des Archives d'Outre-Mer, Aix-enProvence (CAOM C13 A26). 


\subsubsection{Lost Ship Number 16: CAOM C13 A30 (Folio 131) and CAOM C13 A32 (Folio 215)}

While these two documents do not provide specific evidence of a ship lost in the Gulf of Mexico, the likelihood is sufficient enough that it has been included in this list. Le Chameau was a flute or cargo ship of the French Royal Navy that left France in June 1746, bound for New Orleans, and was never heard of again. In a November 26, 1746, letter, Governor Vaudreuill of Louisiana reported to the Crown that no news of the ship's whereabouts had since been received. A later letter, written from Mobile on October 24, 1748 (Figure 5-9), by Lieutenant Governor Jean Jadard de Beauchamp to the king of France, mentions le Chameau (or possibly le Dromedaire) in passing, as if the ship still had not been accounted for in any reports arriving to Louisiana. Additional research has identified le Chameau as a 400-ton flute, built in Holland in 1716, which sank on June 9, 1725 (Service Historique de la Marine 1978:94). If a hurricane was the cause of the loss of le Chameau, it was not a hurricane that Millás (1968) documented.

\subsection{Additional Documents from Spanish and French Archives}

During the course of archival research, numerous additional documents were uncovered that, while they do not allude to vessel losses within the GOM, were nevertheless of interest to the current investigation. These documents primarily relate to colonial shipping and cargos pertinent to the Gulf of Mexico. These documents have been categorized by general subject matter and are presented in Appendices B through E. While most of the documents from the archives mention cargoes that were being transported across the Gulf, the documents presented in Appendix B are particularly rich in this type of information. Appendix $\mathrm{C}$ presents documents that tell of additional vessel losses along the West Indies route that did not occur in UDW of the GOM. Appendix D consists of two Spanish documents that provide rare information on how the cargo of distressed ships was salvaged and accounted for during the colonial period. Finally, Appendix E consists of documents offering insight into the various shipping routes and trade connections of the GOM.

\subsection{St. Augustine Foundation's Center for Historic Research, St. Augustine, Florida}

Archival research conducted at the St. Augustine Foundation Center for Historic Research in St. Augustine, Florida, was conducted as proposed to BOEMRE on September 14-18, 2009. The majority of resources identified at this repository focused on both shipping routes between St. Augustine and Havana as well Pensacola and Havana.

The Center has over 450 microfilm reels of Spanish manuscript documents, mostly from the AGI; it also has a duplicate set of the Stetson Collection. A majority of the collection is focused mostly on early (sixteenth-century) Spanish Florida, during which time the province was governed from St. Augustine. Most of the consulted correspondence consists of letters and reports exchanged between officials from St. Augustine and Havana (Table 5-10). 


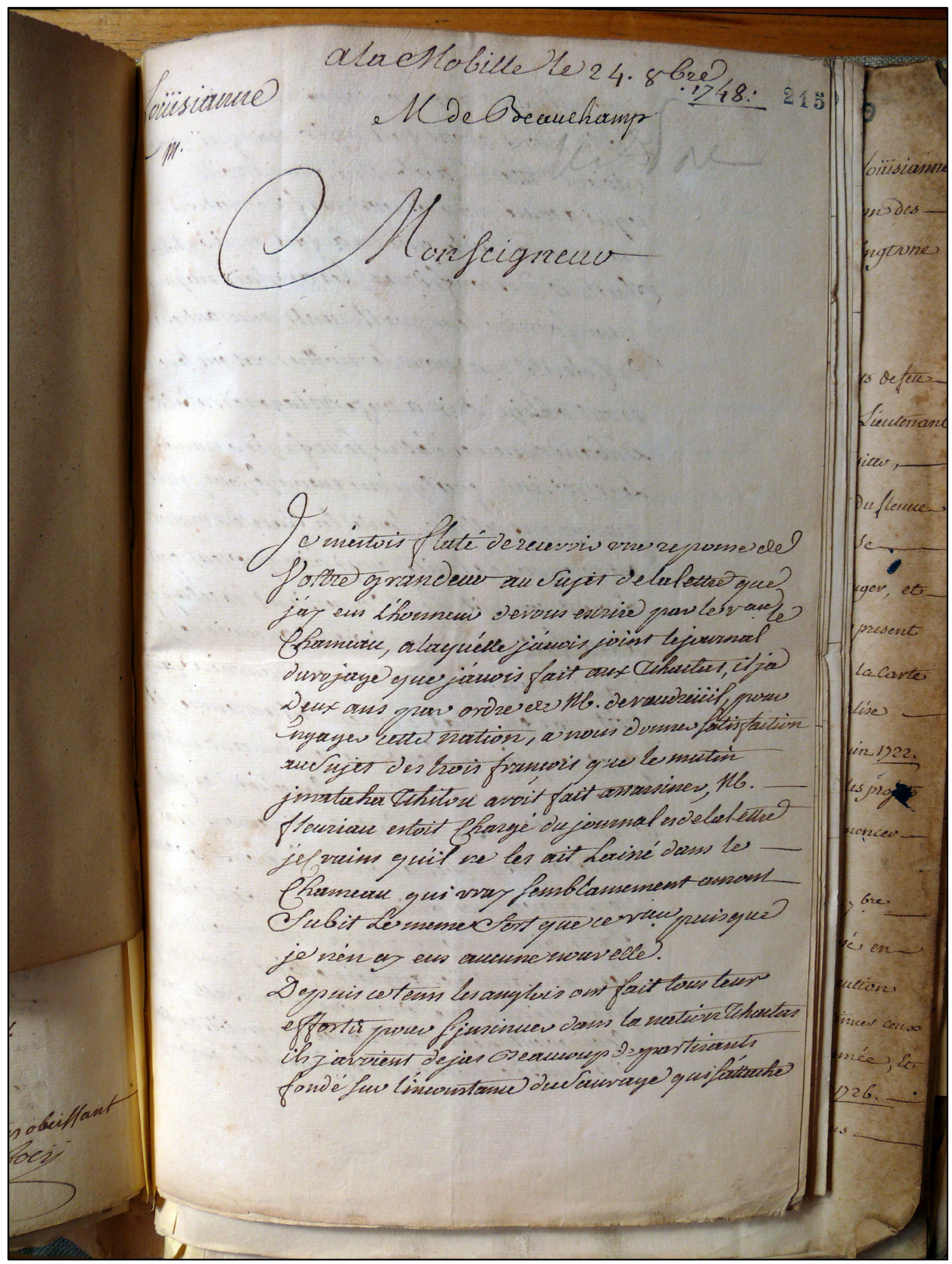

Figure 5-9. Letter dated October 24, 1748, confirming the loss of the king's flute le Chameau (CAOM C13 A32). 
Table 5-10

\section{Record Groups Consulted at the St. Augustine Foundation Center for Historic Research, St. Augustine, Florida}

\begin{tabular}{|l|l|}
\hline \multicolumn{1}{|c|}{ Record Group } & \multicolumn{1}{c|}{ Sections Consulted } \\
\hline México (MX) & $\begin{array}{l}\text { MX 30, No.12G (Microfilm Roll D1-21); MX 31, (Microfilm Roll D3-4b); MX } \\
215 \text { (Microfilm Roll D5-9d); MX 326 (Microfilm Roll D3-18b) }\end{array}$ \\
\hline Santo Domingo (SD) & $\begin{array}{l}\text { SD 1 (Microfilm Roll D2-1a); SD 13 (Microfilm Roll D2-1a); SD 23 (Microfilm } \\
\text { Roll D2-27a) }\end{array}$ \\
\hline Cuba (CUB) & CUB 2263 (Microfilm Roll D3-19b) \\
\hline Contratación (CT) & CT 58 (Microfilm Roll D3-10b; D2-12a; D2-31a) \\
\hline Stetson Collection & $\begin{array}{l}\text { Stetson Collection, No. 1 (Microfilm Roll D7-8f); Stetson Collection, No. 2 } \\
\text { (Microfilm Roll D7-9f); Stetson Collection, No. 2 (1559-1566.03) (Microfilm } \\
\text { Roll D7-10f); Stetson Collection, No. 3 (Microfilm Roll D7-11F); Stetson } \\
\text { Collection, No. 3 (1566-1569.08) (Microfilm Roll D7-12F); Stetson Collection, } \\
\text { No. 4 (1569-1573) (Microfilm Roll D7-13F);Stetson Collection, No. 5 } \\
\text { (Microfilm Roll D7-14F); Stetson Collection, No. 5 (1573.06.27-1584.04.11) } \\
\text { (Microfilm Roll D7-15F) }\end{array}$ \\
\hline
\end{tabular}

In the restricted amount of time allocated for research in this repository, no documents dealing with Florida's west-coast maritime traffic and affairs were located. This is not to say that documents of interest cannot be located there, but a considerable amount of time would be needed to sift through the microfilm collection. It should be noted that conducting research by scrutinizing manuscript documents on microfilm is considerably slower than going through legajos of original documents.

\subsection{P.K. Yonge Library of Florida History at the University of Florida, Gainesville, Florida}

SEARCH conducted research at the P.K. Yonge Library of Florida History at the University of Florida in Gainesville, Florida, during the week of September 14, 2009. The focus of this research was the microfilm reproductions of the Papeles Procedentes de Cuba, a section of the AGI containing the records of the colonial Spanish posts on the northern rim of the Gulf of Mexico. Mr. Bruce Chappell, archivist for the Spanish records at the P.K. Yonge Library, provided guidance in using the Papeles Procedentes de Cuba for research on ship losses in the region. He directed SEARCH to Roscoe R. Hill's Descriptive Catalogue (1916), a general index of the voluminous legajos found in the Papeles. Here, references to legajos dealing with "navigation" and "shipwrecks" were found and recorded. A corollary effort to acquire information on vessel traffic in the northern Gulf of Mexico during the colonial period was made. Numerous documents discussing manifests of ships entering and leaving the region were also available in the Papeles Procedentes de Cuba.

The legajos available at the P.K. Yonge Library are, with very few exceptions, limited to the late-eighteenth- and early-nineteenth-century port of Pensacola. Therefore, SEARCH was unable to explore all of the referenced legajos, some of which dealt with other colonial Spanish ports including Mobile and New Orleans. These other legajos are, however, available at other 
repositories including the Historic New Orleans Collection. The following table identifies the legajos analyzed at the P.K. Yonge Library (Table 5-11).

Table 5-11

Legajos Reviewed at the P.K. Yonge Library of Florida History, University of Florida, Gainesville, Florida

\begin{tabular}{|l|l|l|}
\hline Legajo & \multicolumn{1}{|c|}{ Years Reviewed } & \multicolumn{1}{|c|}{ Description } \\
\hline 261 & $\begin{array}{l}1796-1799,1805-1812,1783,1786-1789,1800, \\
1802,1803\end{array}$ & Correspondencia de Panzacola \\
\hline 274 & $\begin{array}{l}1771,1783,1786-1791,1795-1808,1811-1814, \\
1816,1819-1821\end{array}$ & Papeles varios \\
\hline 278 & $1794-1796$ & Correspondencia de Oficio \\
\hline 2332 & $\begin{array}{l}1781,1783-1788,1804,1806,1808,1809,1811, \\
1813,1817-1819\end{array}$ & Expedientes varios \\
\hline 2334 & $\begin{array}{l}1782,1783,1787,1789,1790,1792,1805-1813, \\
1817-1819\end{array}$ & Expedientes varios \\
\hline
\end{tabular}

SEARCH was able to locate specific documents in each legajo using a card catalog index that the P.K. Yonge Library has created. Therefore, it was not necessary to read the entirety of each legajo. Once located within the legajo, pertinent records were photocopied on archival-quality paper. In all, seven references to ship losses were discovered (Table 5-12).

The subsequent translation of the documents relative to the aforementioned vessel losses indicate that all occurred near shore and therefore may not be relative to the current investigation.

Table 5-12 Vessel Losses within the GOM Identified at the P.K. Yonge Library of Florida History,
University of Florida, Gainesville, Florida

\begin{tabular}{|c|c|c|c|c|c|c|c|c|}
\hline Vessel & Year & Vessel Type & Nationality & Owner & Route & Cargo & $\begin{array}{l}\text { Reason } \\
\text { for Loss }\end{array}$ & Location \\
\hline $\begin{array}{l}\text { Nuestra } \\
\text { Señora del } \\
\text { Carmen }\end{array}$ & 1785 & Brigantine & $\begin{array}{l}\text { Spanish } \\
\text { (Mexican) }\end{array}$ & Unknown & Unknown & $\begin{array}{l}\text { Mexican } \\
\text { Infantry- } \\
\text { men and } \\
\text { civilians }\end{array}$ & $\begin{array}{l}\text { Adverse } \\
\text { weather }\end{array}$ & $\begin{array}{l}\text { Off St. } \\
\text { George } \\
\text { Island }\end{array}$ \\
\hline $\begin{array}{l}\text { la } \\
\text { Esperanza }\end{array}$ & 1785 & Brigantine & Unknown & Unknown & Unknown & Unknown & $\begin{array}{l}\text { Adverse } \\
\text { weather }\end{array}$ & $\begin{array}{l}\text { Off Santa } \\
\text { Rosa Island }\end{array}$ \\
\hline San Andrés & 1785 & Brigantine & Unknown & Unknown & Unknown & Unknown & Unknown & $\begin{array}{l}\text { Off Santa } \\
\text { Rosa Island }\end{array}$ \\
\hline $\begin{array}{l}\text { San } \\
\text { Salvador }\end{array}$ & 1786 & Brigantine & Unknown & $\begin{array}{l}\text { Juan } \\
\text { Salineau }\end{array}$ & Unknown & $\begin{array}{l}\text { "Negros" } \\
\text { (slaves); } \\
\text { other } \\
\text { items }\end{array}$ & $\begin{array}{l}\text { Adverse } \\
\text { weather }\end{array}$ & $\begin{array}{l}\text { Near Cape } \\
\text { San Blas }\end{array}$ \\
\hline $\begin{array}{l}\text { la } \\
\text { Resolución }\end{array}$ & 1795 & Bilander & Unknown & Henry Young & $\begin{array}{l}\text { Bound for } \\
\text { Savannah } \\
\text { from } \\
\text { Jamaica }\end{array}$ & $\begin{array}{l}\text { Coffee, } \\
\text { sugar } \\
\text { (salvaged) }\end{array}$ & Unknown & $\begin{array}{l}\text { On Santa } \\
\text { Rosa Island }\end{array}$ \\
\hline Quántico & 1795 & Schooner & American & Unknown & $\begin{array}{l}\text { Bound for } \\
\text { Pensacola } \\
\text { from New } \\
\text { Providence }\end{array}$ & Flour & Unknown & Unknown \\
\hline $\begin{array}{l}\text { Dos } \\
\text { Hermanas }\end{array}$ & 1808 & Schooner & American & $\begin{array}{l}\text { Bartolomé } \\
\text { Bosque }\end{array}$ & Unknown & Flour & Unknown & Isla Guinal \\
\hline
\end{tabular}




\subsection{GIS Analysis}

In an effort to meet the goal of building a predictive model for colonial shipwrecks within the GOM, SEARCH carried out extensive archival research and examined both historical accounts and scholarly research. Primary and secondary sources were examined to gather information regarding the general evolution of shipping routes within the GOM during the sixteenth through eighteenth centuries. Sources examined included period maps and charts, navigational journals, cargo manifests, shipping documentation, and more recent scholarly research. These sources were compiled in digital form and used to create a series of maps that might inform a predictive model for potential vessel loss within the project area. This data was then plotted using a system of geo-referencing and rubbersheeting to transcribe the route data onto a bathymetric map of the GOM. ESRI ArcGIS 9.3.1 was used to generate data for analysis and to create maps, documents, and final report products. All data is projected into decimal degrees, GCS NAD 1927.

\subsubsection{Trade Routes}

The first step to determining the potential for shipwrecks within the UDW is to understand the evolution of trade routes within the greater context of the region. Examination of routes for the Spanish armada and fleet of New Spain, individual vessels, and Spanish slave vessels, along with the standard track of early French corsairs (Chaunu and Chaunu 1955-1957:Vol. 5) illustrates a progression of routes from the lower Gulf in the early years (1504-1550) to a deeper entrada into the Gulf of Mexico and upper Gulf (Figure 5-10). As discussed earlier, vessel technology changed over this time, and mariners came to understand the tides, tradewinds, and circulation of the currents with greater certainty. Both of these facts affected the standard shipping routes. Figures 5-10 and 5-11 illustrate these changes. These early routes show the traffic corridors between Havana, Cuba, and Veracruz, Mexico. As other ports within the region were established, traffic spread throughout the area. In Figure 5-11, the port of Campeche is an active part of the regional shipping. Incoming vessels from Spain and South America tended to keep to the lower Gulf during this time period as there were no colonies or ports in the upper Gulf to draw their attention. Outgoing vessels, however, tended to route farther north in the mid- to upper Gulf to take advantage of the prevailing winds and currents.

During the sixteenth century, sailing routes were recommended to those vessels departing from San Juan de Ulúa to Havana. Vessels were advised to sail northeastward to approximately latitude $25^{\circ}$, and then turn eastward until the wind was on the quarter. This route was designed to bring a vessel within sight of the Tortugas, approximately 104 kilometers (65 miles) off Key West. It was here that leadlines were to be used to determine if the vessel was west of the islands or south of the islands. Once this was determined, vessels adjusted their course in a southwesterly direction to Havana, Cuba (Arnold and Weddle 1978:98). 


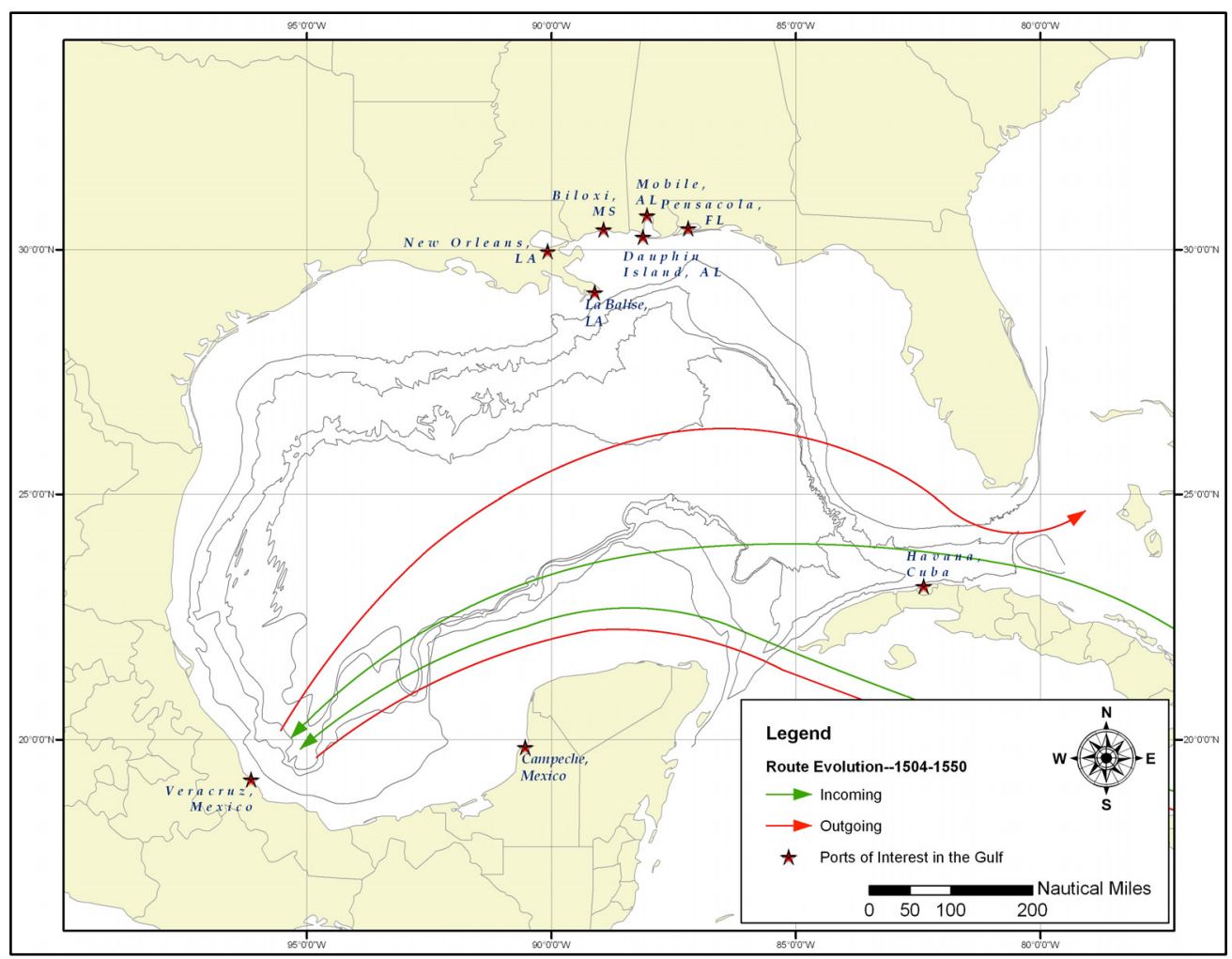

Figure 5-10. Spanish vessel routes in the GOM, 1504-1550.

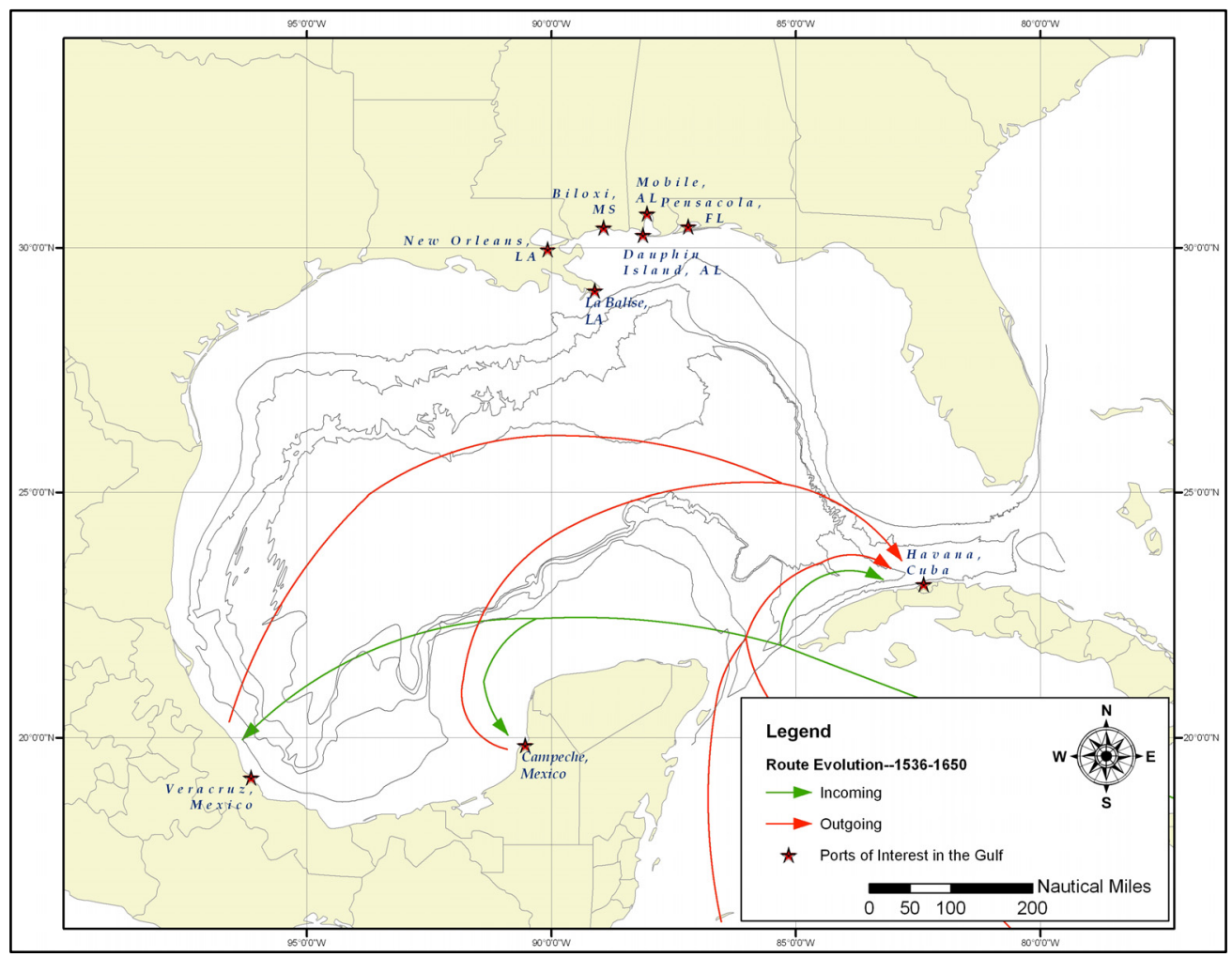

Figure 5-11. Spanish vessel routes in the GOM, 1536-1650 (Chaunu and Chaunu 1957:20-21). Note that outgoing vessels routes extend farther north into the mid-Gulf and project area. 
Sailing routes from San Juan de Ulúa to Havana changed, however, if winds were out of the northeast upon departure from Mexico. It was determined that:

The ship should then beat windward until it reached latitude $27^{\circ} 30^{\prime}$ approximately on a line with Kingsville, Texas, and Palmetto, Florida. Soundings were then to be taken, probably revealing a position about even with the mouth of the Mississippi River-due north of the Alacrán reefs. Thence the course should bend eastward, with soundings again called for off the Florida peninsula, near the Bay of Juan Ponce. And then southwestward until bottom was lost, in search of Cuba (Arnold and Weddle 1978:98).

Another aspect of this evolution in route was the seasonal nature of vessel movements during this period. With greater familiarity with weather patterns and currents, traffic to and from the colonies were timed to take advantage of favorable winds and to avoid the most turbulent weather seasons. Figures 5-12 through 5-15 illustrate the traffic patterns throughout the year. Figure 5-12 shows that incoming traffic was limited to April through September while outgoing traffic shipped from January to March of 1555 . Note that the outgoing route tracks directly through the high-probability zone in the UDW of the upper Gulf.

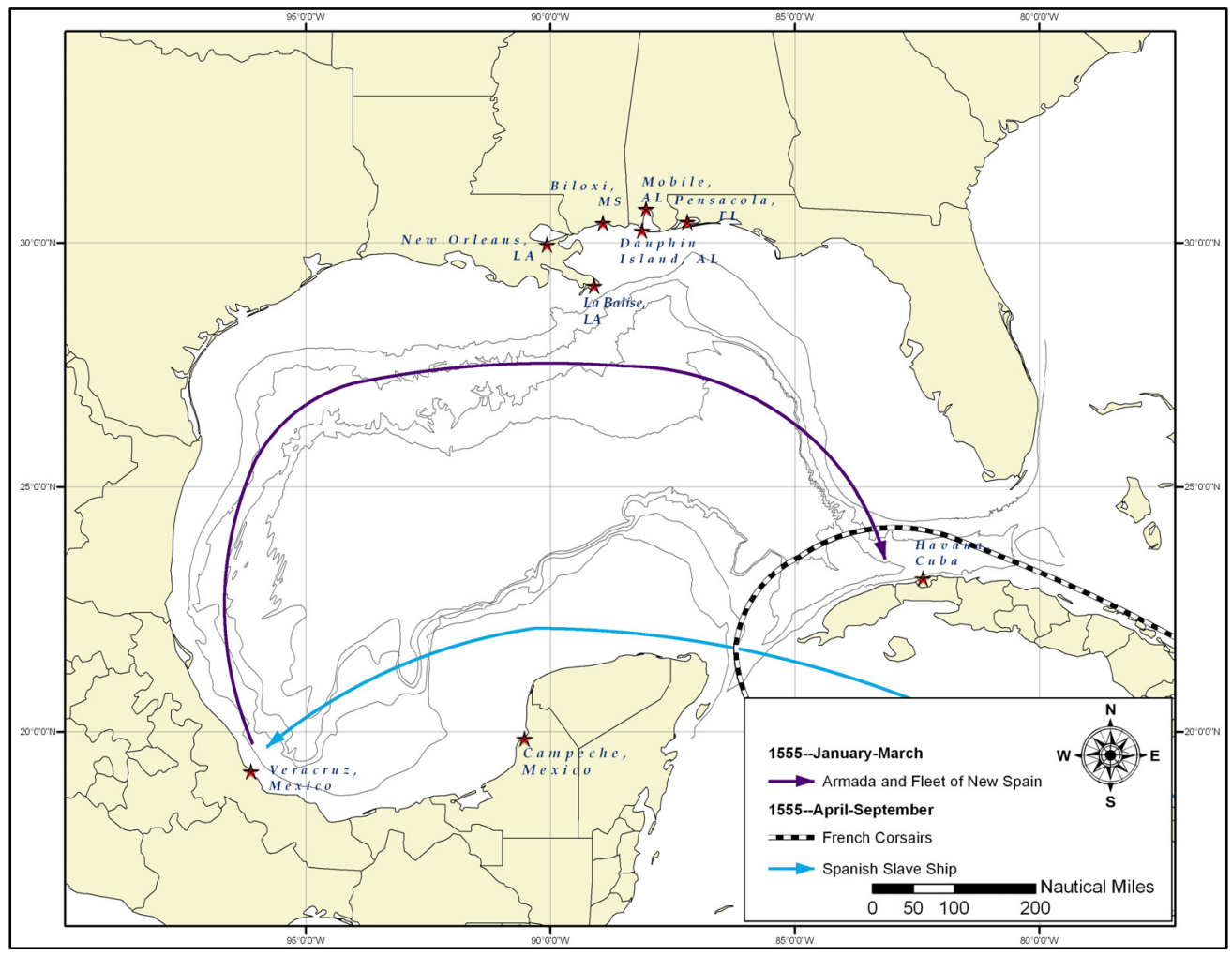

Figure 5-12. 1555 seasonal traffic in the GOM (Chaunu and Chaunu 1957:132-133). 


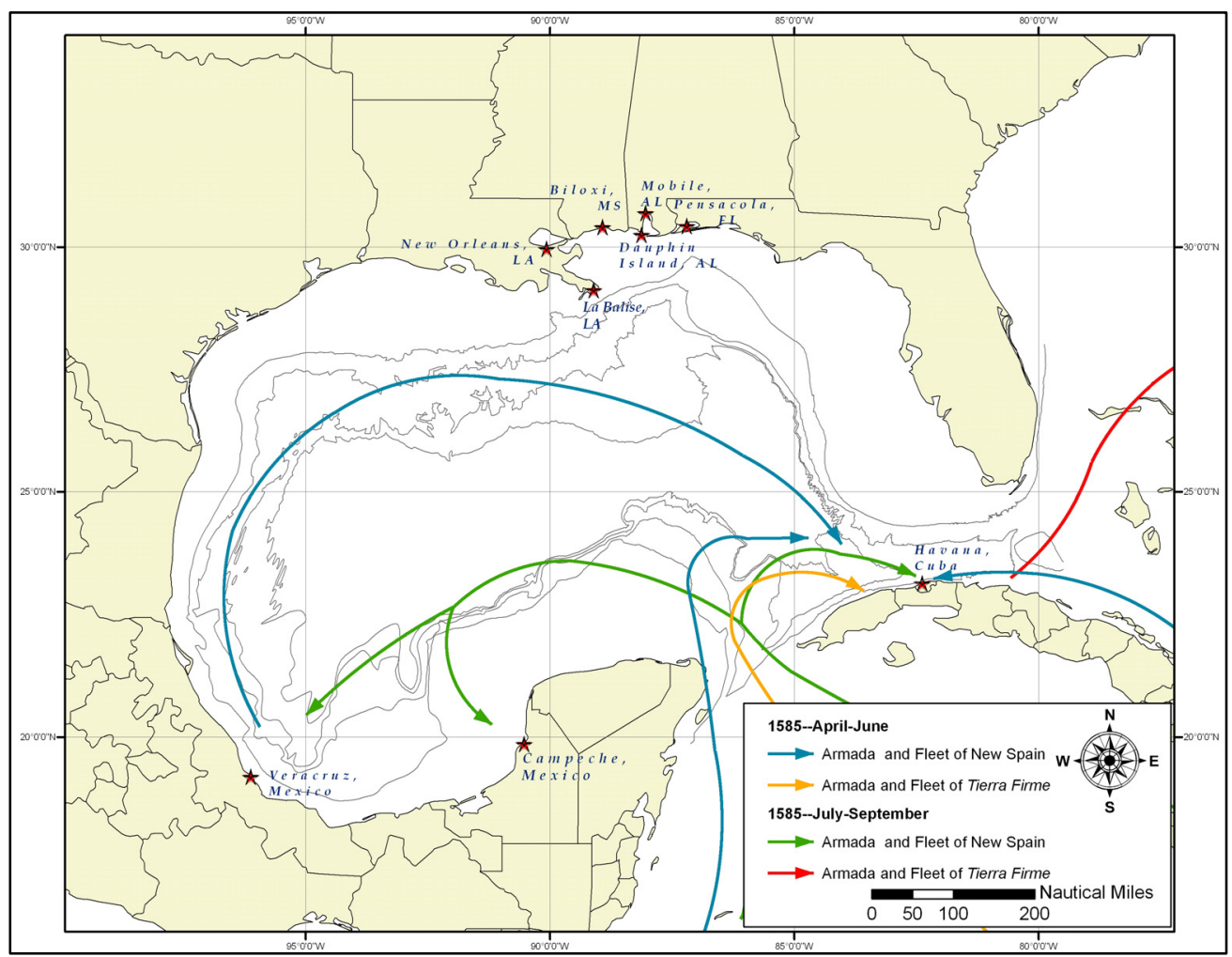

Figure 5-13. 1585 seasonal traffic in the GOM (Chaunu and Chaunu 1957:134-135).

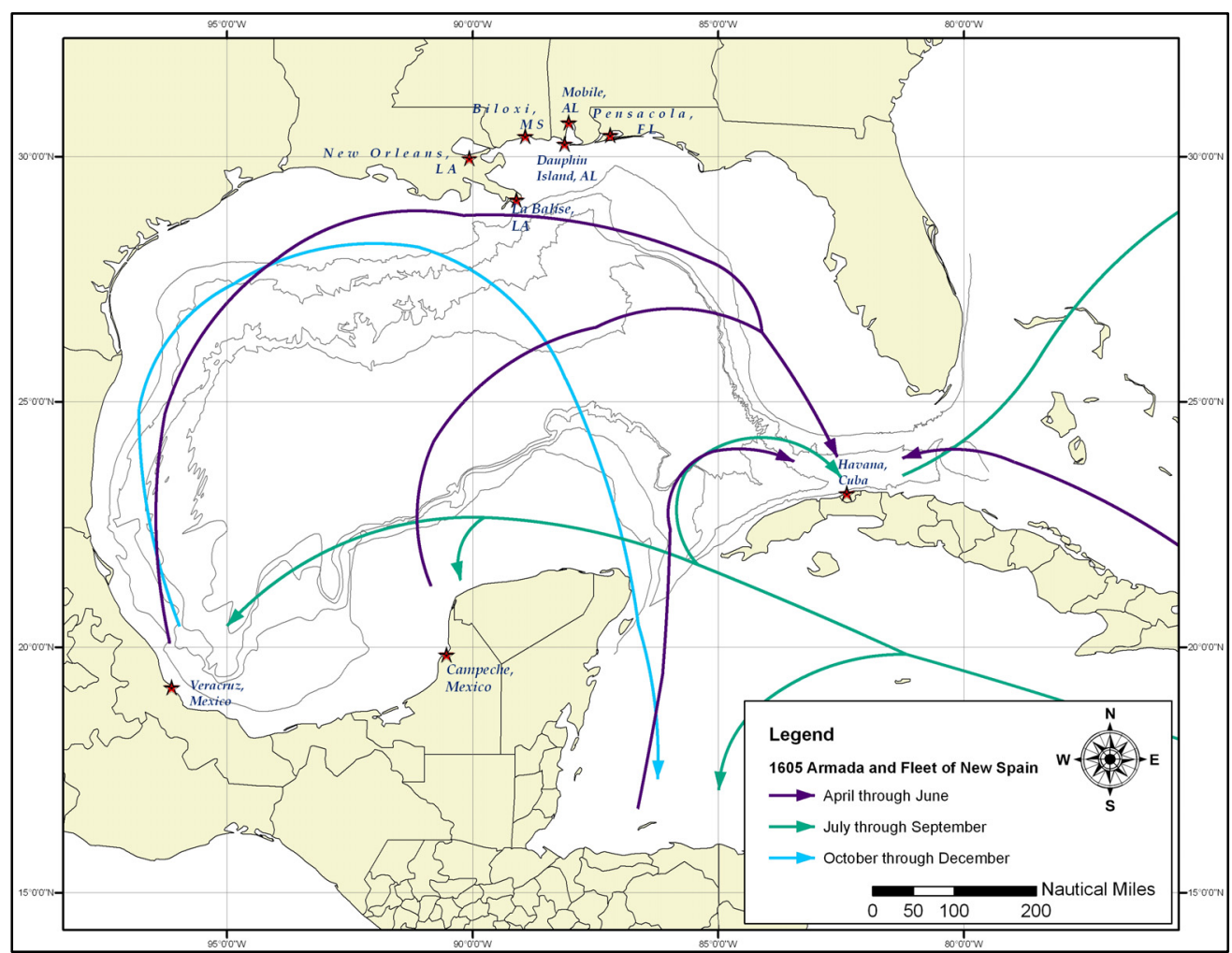

Figure 5-14. 1605 seasonal traffic in the GOM (Chaunu and Chaunu 1957:136-137). 


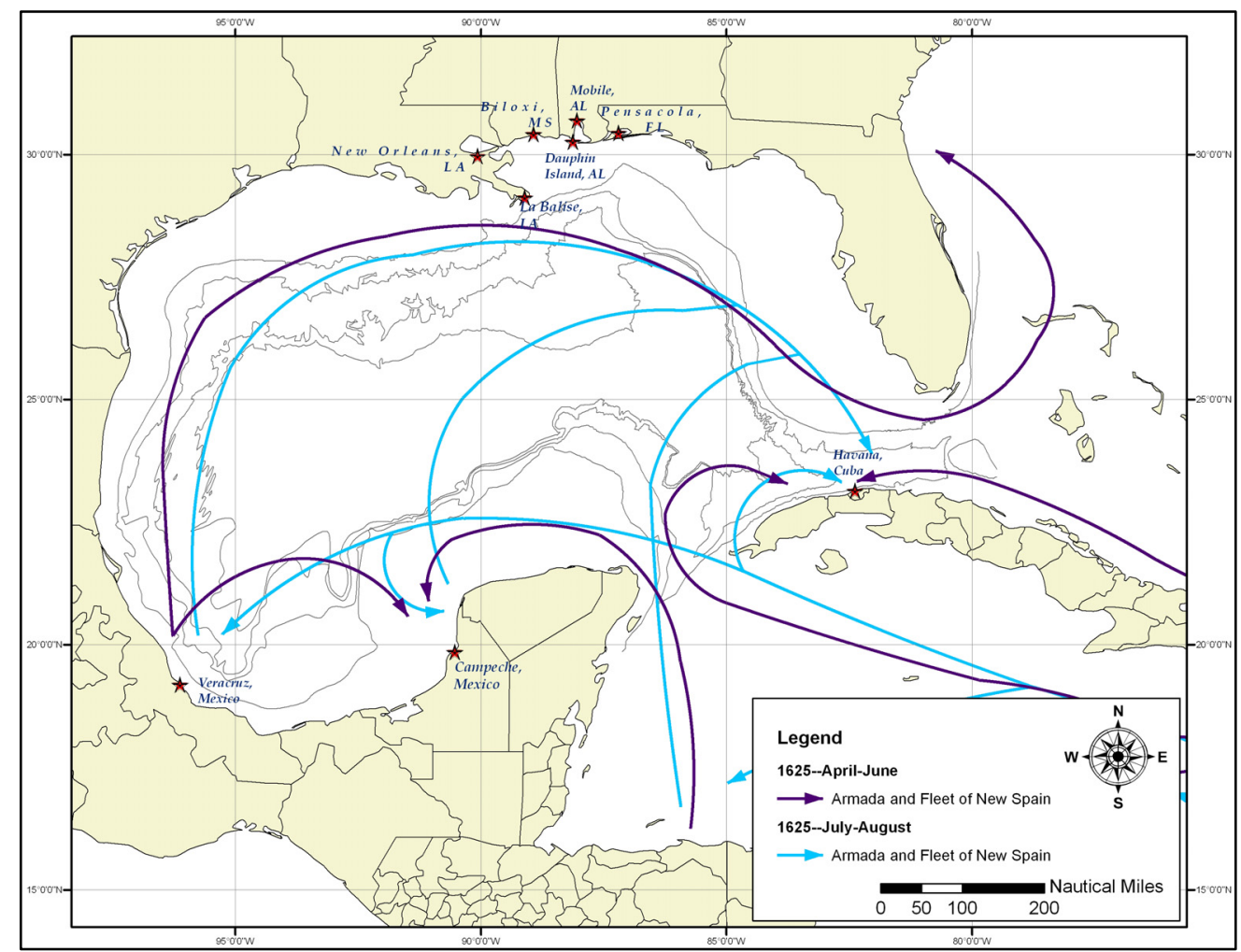

Figure 5-15. 1625 seasonal traffic in the GOM (Chaunu and Chaunu 1957:138-139).

Figure 5-13 shows the increase in the number of ports active in the GOM and the corresponding increase in traffic and routes by the end of the sixteenth century. In Figure 5-14, fleet activity is porting out of both Campeche and Veracruz, but the routes merge just off the Tortugas to head south to Havana. While this merge occurs well south of the area of interest for this study, this figure illustrates that vessels shipping out of Campeche in the early seventeenth century have a lower probability of being lost in the study area, as their route took them well south of that area. This is not true of mid-seventeenth-century traffic, however, as seen in Figure 5-15.

Comparison of the routes of three individual vessels in the first half of the seventeenth century shows how consistently these routes were traveled. Individual captains had preferred routes, and every trip varied due to navigational techniques and the weather, but overall there is great consistency in the general route. Figures 5-16 through 5-19 illustrate this fact. Notice the similarity in the routes to and from Spain and the greater Caribbean (Figure 5-19). 


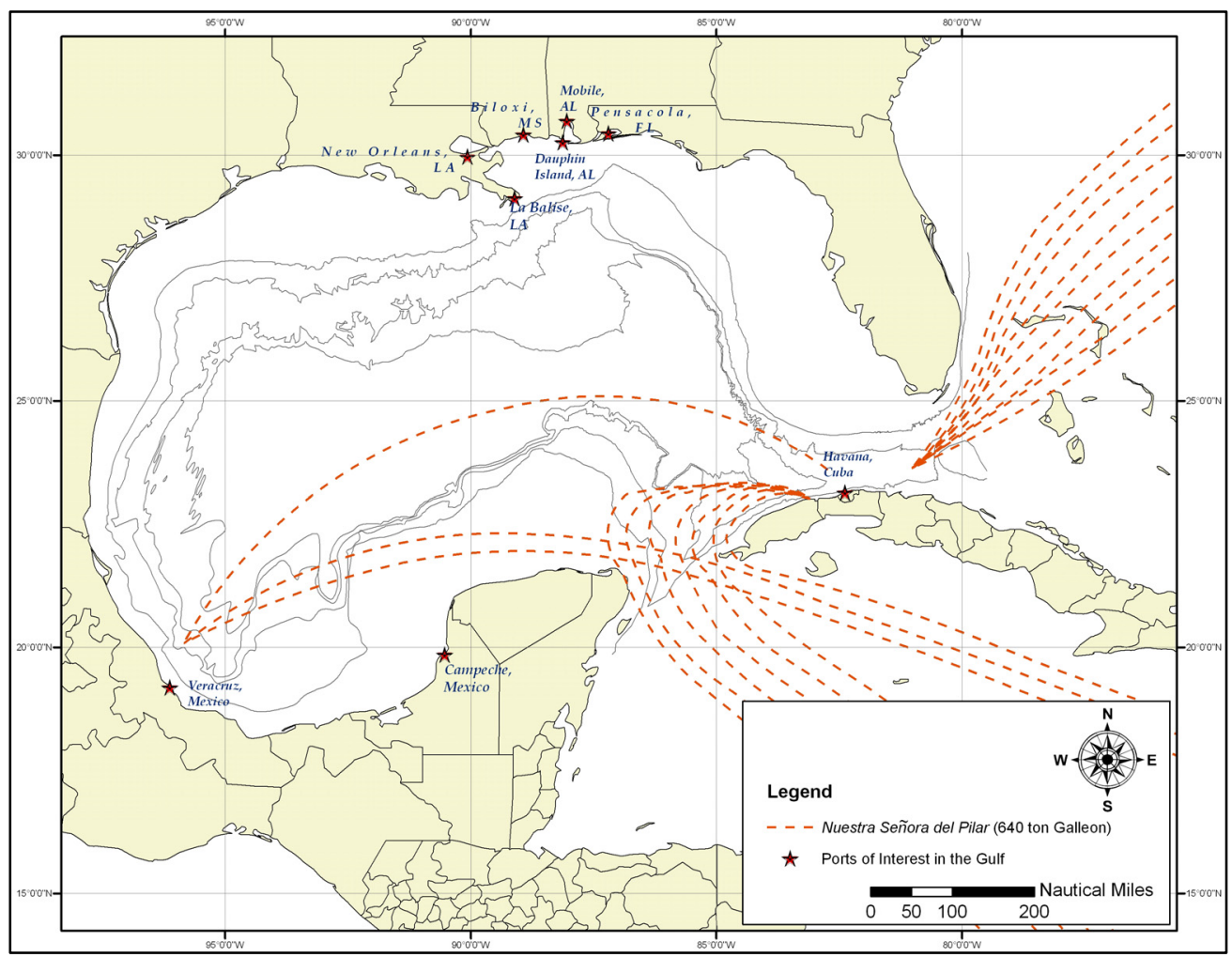

Figure 5-16. Routes of Nuestra Señora del Pilar, 1610-1623 (Chaunu and Chaunu 1957:126).

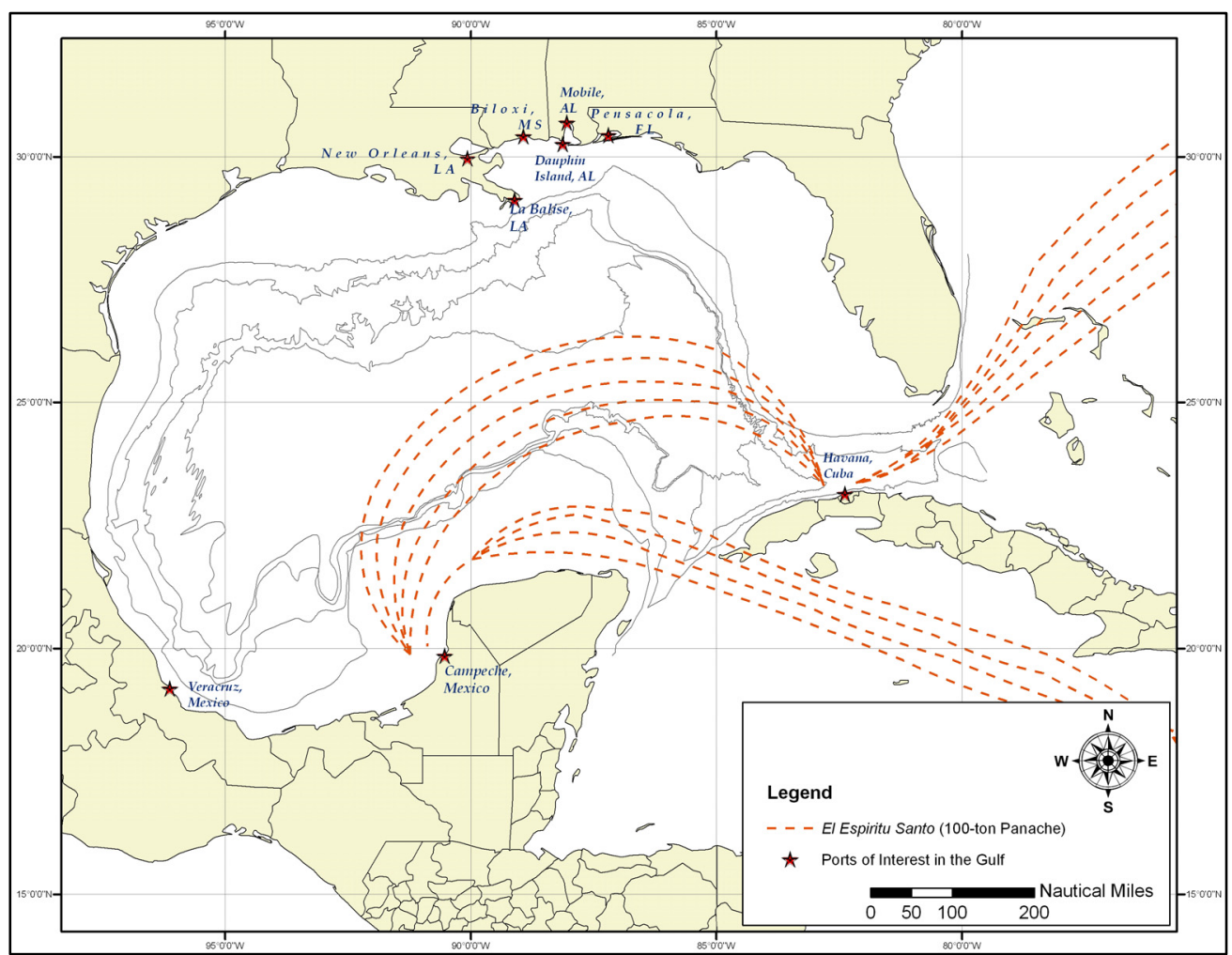

Figure 5-17. Routes of El Espiritu Santo, 1618-1626 (Chaunu and Chaunu 1957:127). 


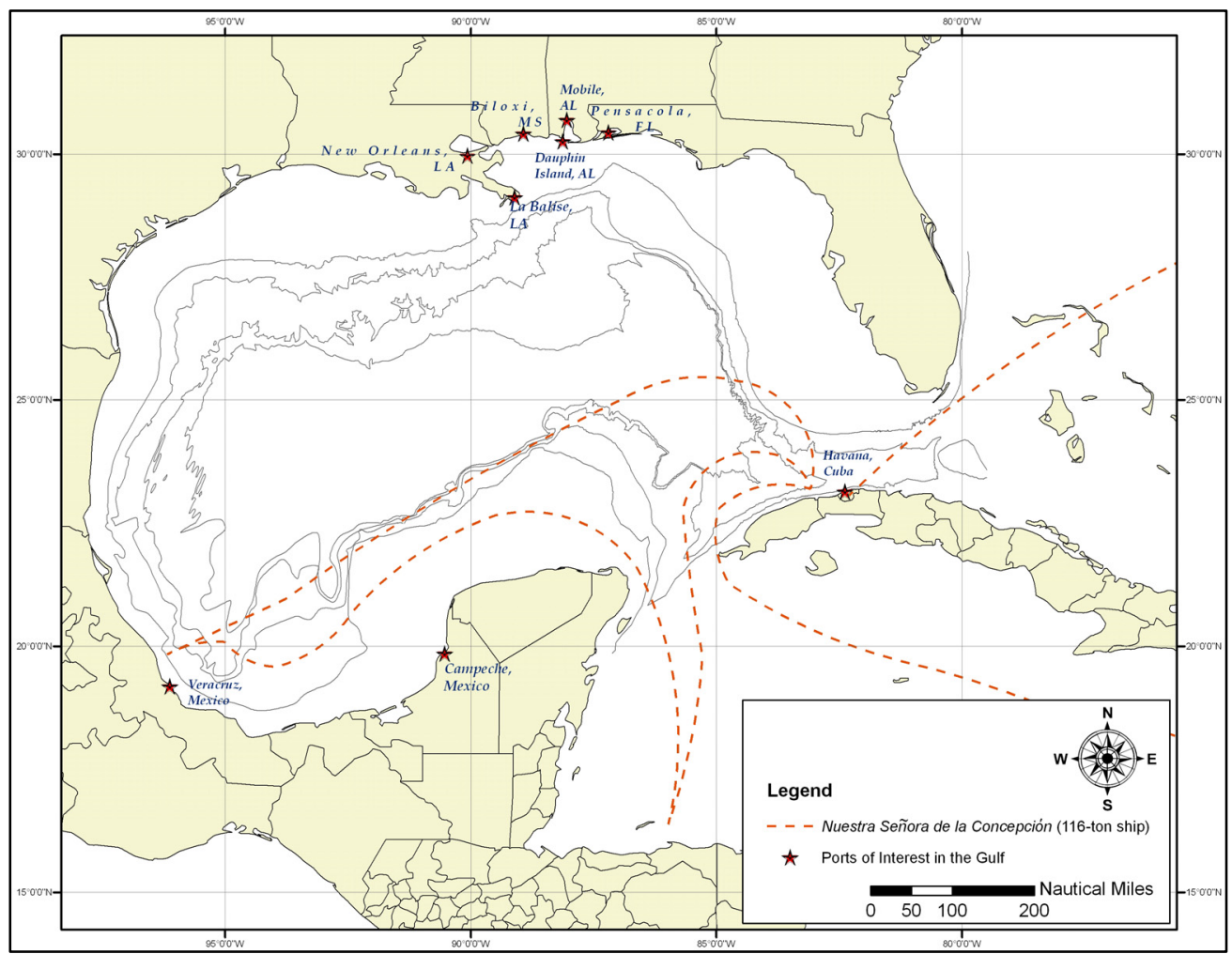

Figure 5-18. Routes of Nuestra Señora de la Concepción, 1621-1622 (Chaunu and Chaunu 1957:127).

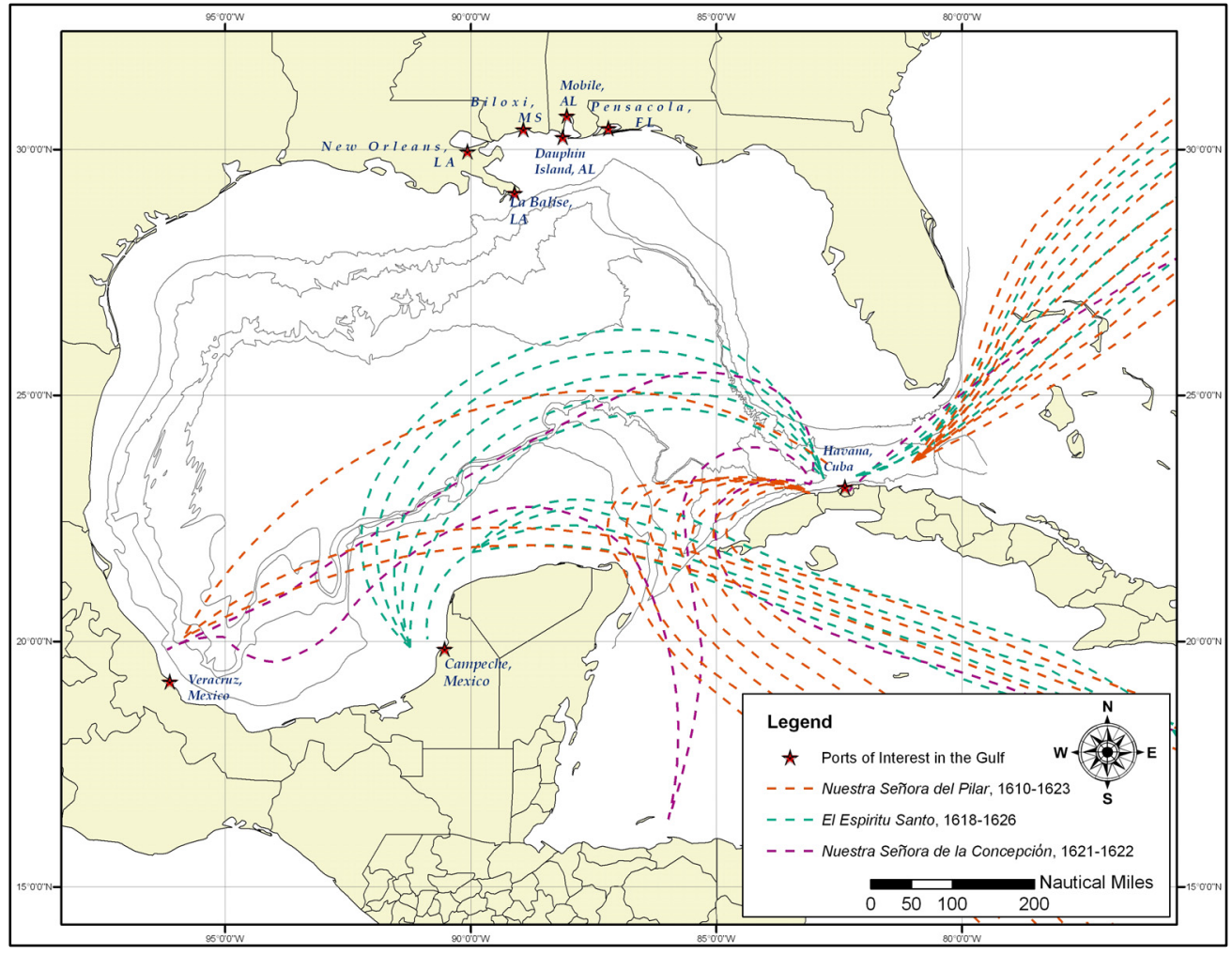

Figure 5-19. A comparison of vessel routes within the GOM, 1610-1626 (Chaunu and Chaunu 1957: 126-127). 
Following the advent of the French into the Gulf coast with the voyages of La Salle and the foundation of La Balise and New Orleans in the late seventeenth century, traffic quickly expanded into the upper Gulf region. An examination of Garrison et al.'s (1989) maps of the colonial shipping routes of the eighteenth and nineteenth centuries clearly illustrates this expansion and the move away from shipping across the UDW of the GOM toward a more coastal model that factored in transshipping from port to port (Figures 5-20 and 5-21). In Figure 5-20, there is still a reliance on the familiar routes that bypass the coast of Texas and take advantage of the upper Gulf currents and winds for travel. By the Early American period, however, with the establishment of coastal ports all along the western Gulf coast, there was a drastic shift in shipping patterns (Figure 5-21). The eastern Gulf traffic patterns remained consistent throughout the sixteenth to eighteenth centuries, with the main variance being the expansion into the upper Gulf. Vessels maintain the offshore Tortugas run throughout the period, as it is the most advantageous route through the Straits of Florida to Havana and out of the GOM.

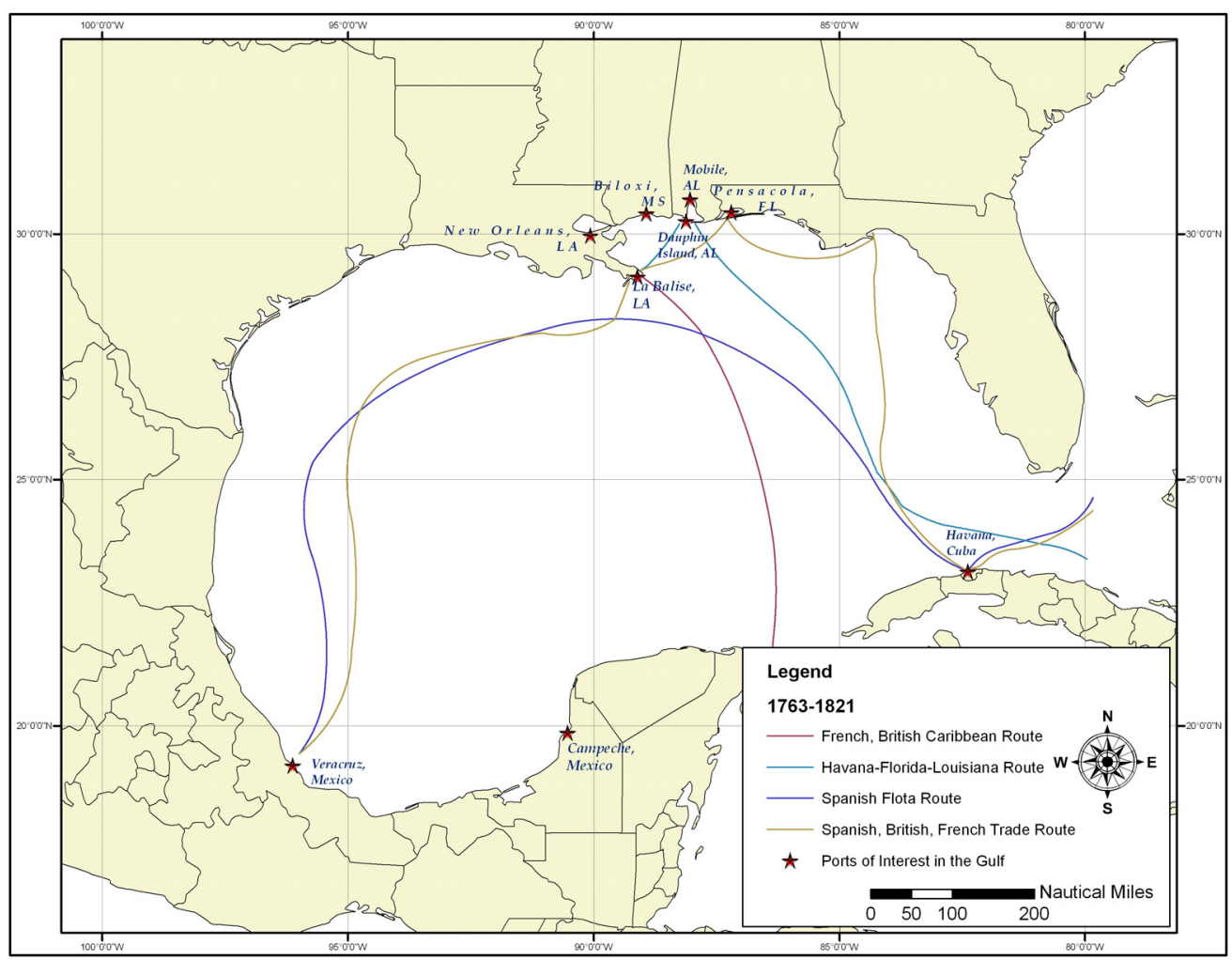

Figure 5-20. A comparison of colonial routes within the GOM, 1763-1821 (Garrison et al. 1989). 


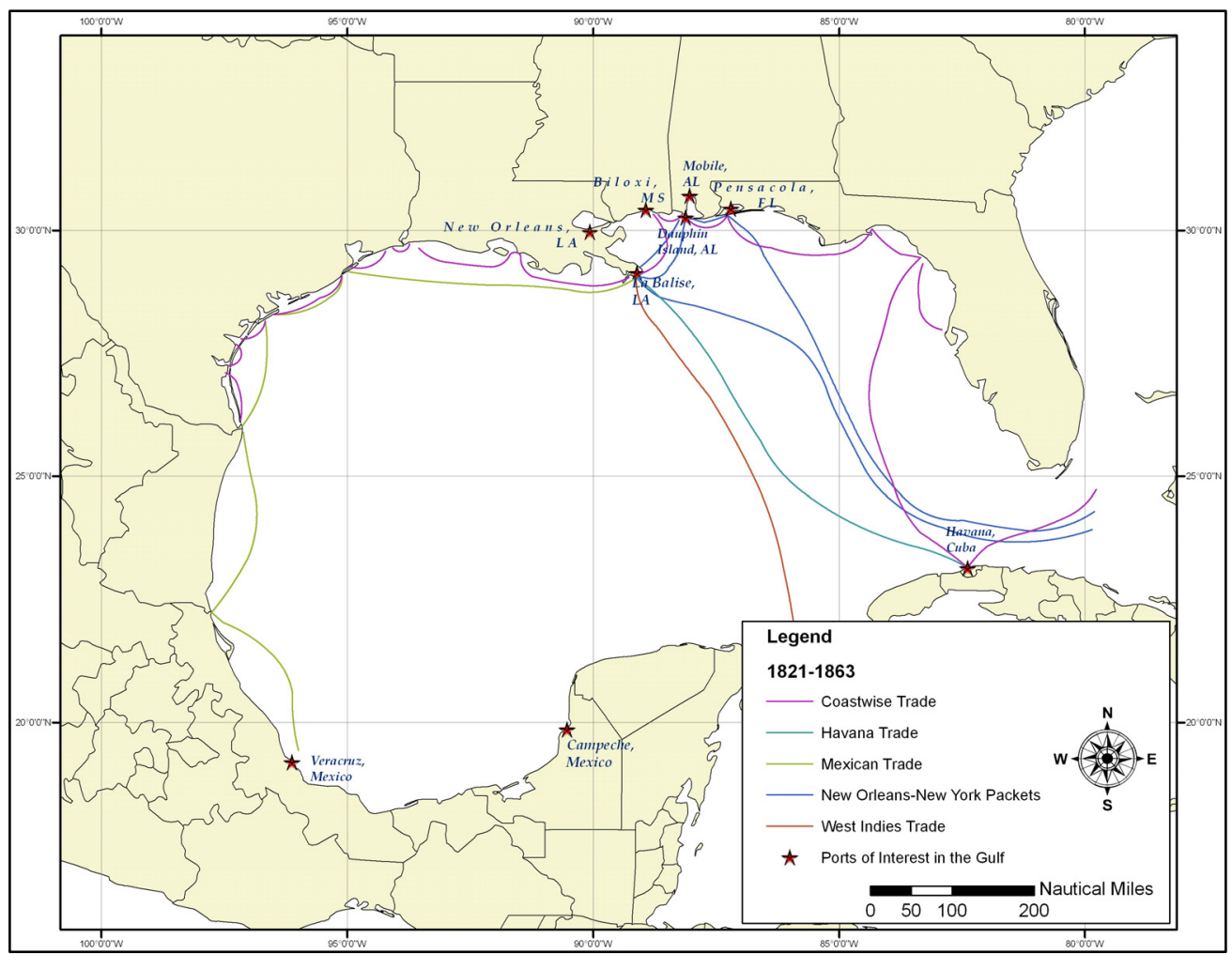

Figure 5-21. A comparison of colonial routes within the GOM, 1821-1863 (Garrison et al. 1989).

\subsubsection{Hurricanes and Vessel Losses}

Many factors affected trade, traffic patterns, and routes in the GOM. As discussed above, there was a seasonal pattern to travel within this region. One reason for this is the predictability of hurricanes and tropical storms in late summer and fall in the region. Hurricane and tropical storm tracking data was examined over 157 years of recordation. These routes were grouped by decade and offer a clear view of the cyclical nature of these weather phenomena. Figures 5-22 through 5-37 illustrate the tracks and varying strengths of each storm. There seems to be a strong tendency for storms in the eastern Gulf to track toward the upper southeastern United States. Storms that come in low in the GOM tend to tack in a westerly direction and move into the interior of Mexico and Texas. These storms were not tracked reliably prior to 1851, but in examining the overall history of storms in this region, it is reasonable to extrapolate that similar patterns existed during the period of study.

Garrison et al. (1989:II-53 - II-69) analyzed the spatial distributions of shipwrecks in relation to the paths of known hurricanes. This analysis did not reveal a strong correlation to vessel loss with the occurrence of storms. This may be a factor of the overall scarcity of storms in the region or the scarcity of data for loss. Delays in shipping sometimes meant that fleets left port late in the season and were heavily impacted by these seasonal storms (the 1715 Plate Fleet is an example of this fact). For vessel loss within the late summer and fall of the year, it is possible to presume that weather may have been a factor when the reason is otherwise unknown. Henry et al. (1975) also performed an evaluation of hurricanes since recording and tracking began and 


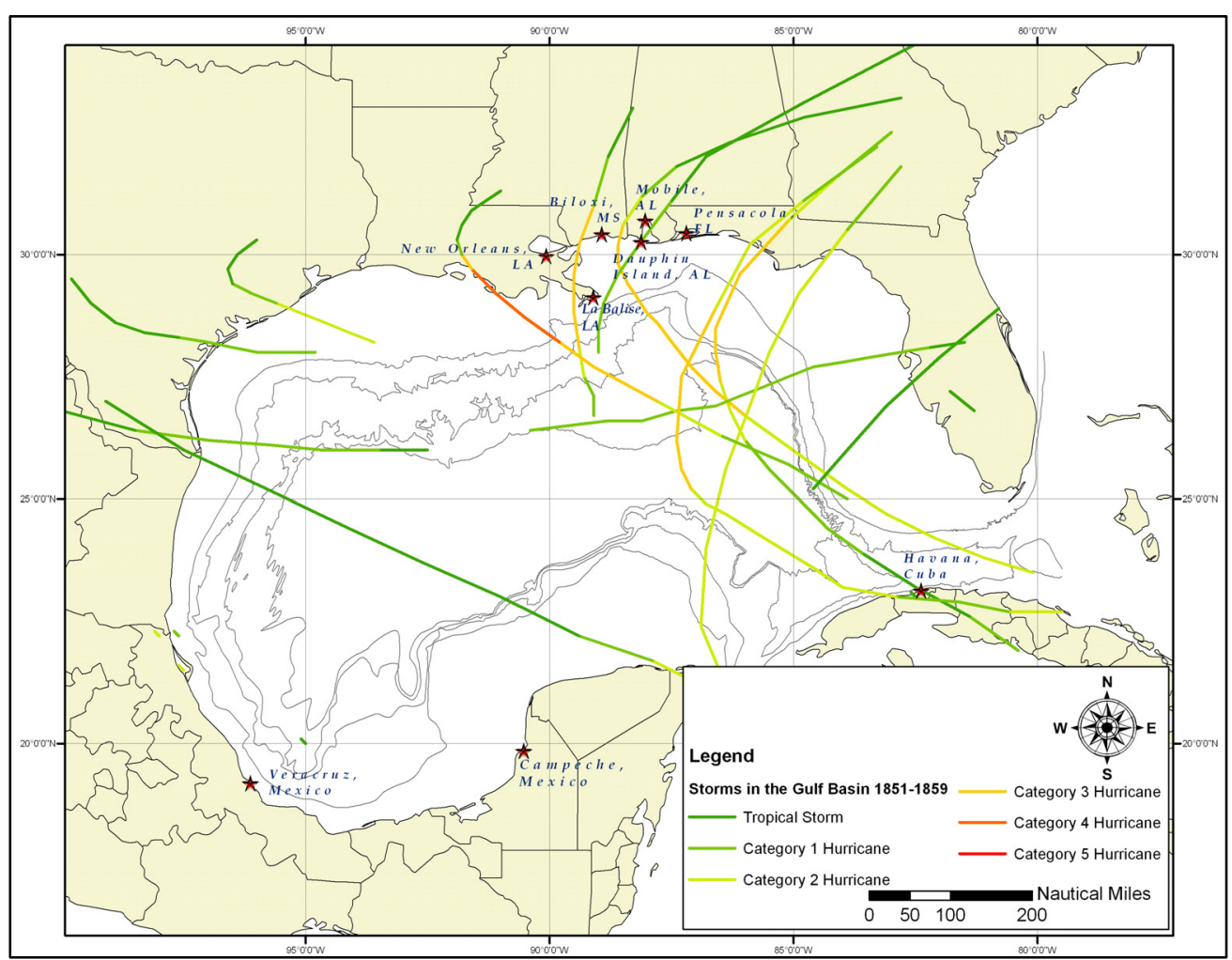

Figure 5-22. Gulf storms, 1851-1859.

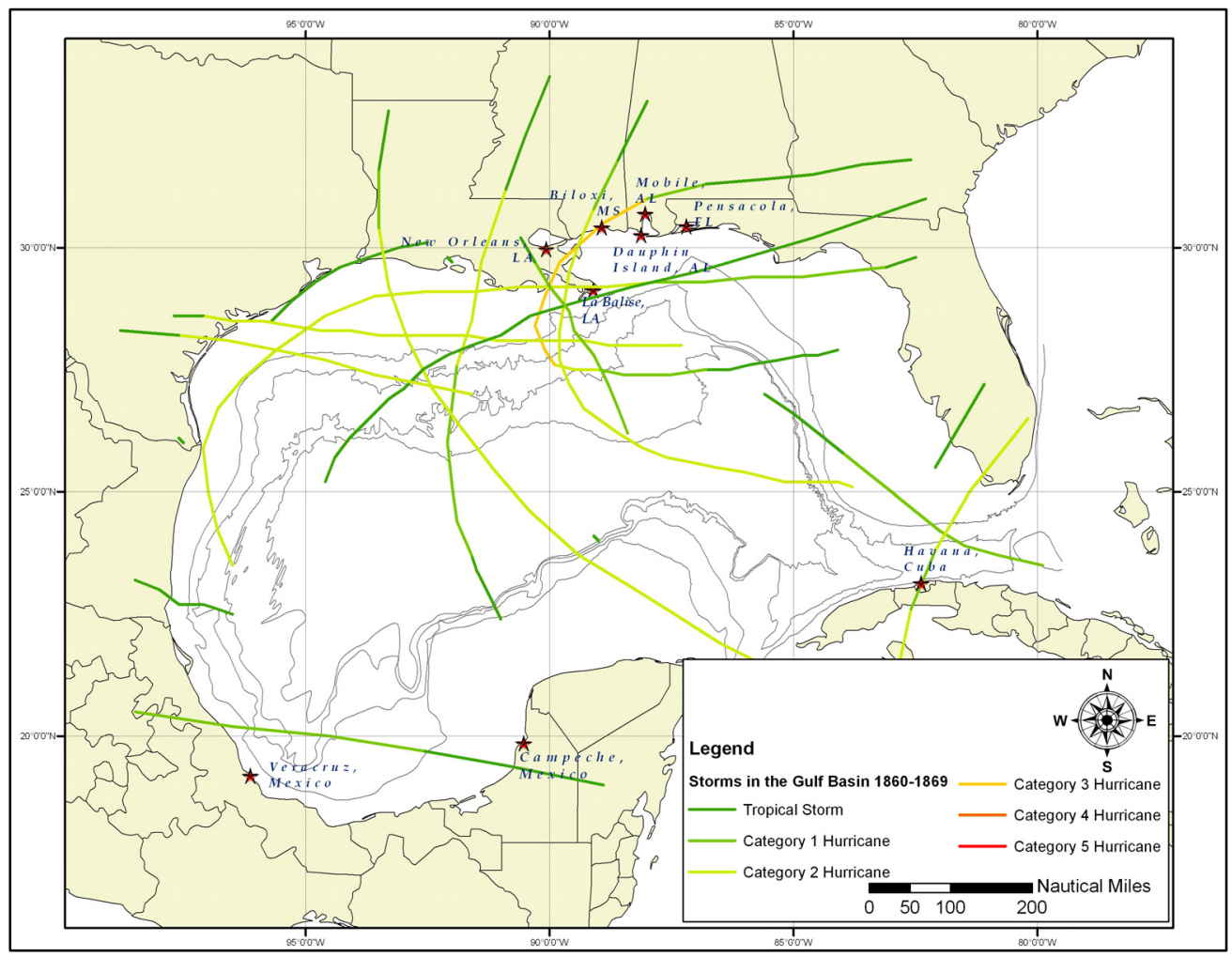

Figure 5-23. Gulf storms, 1860-1869. 


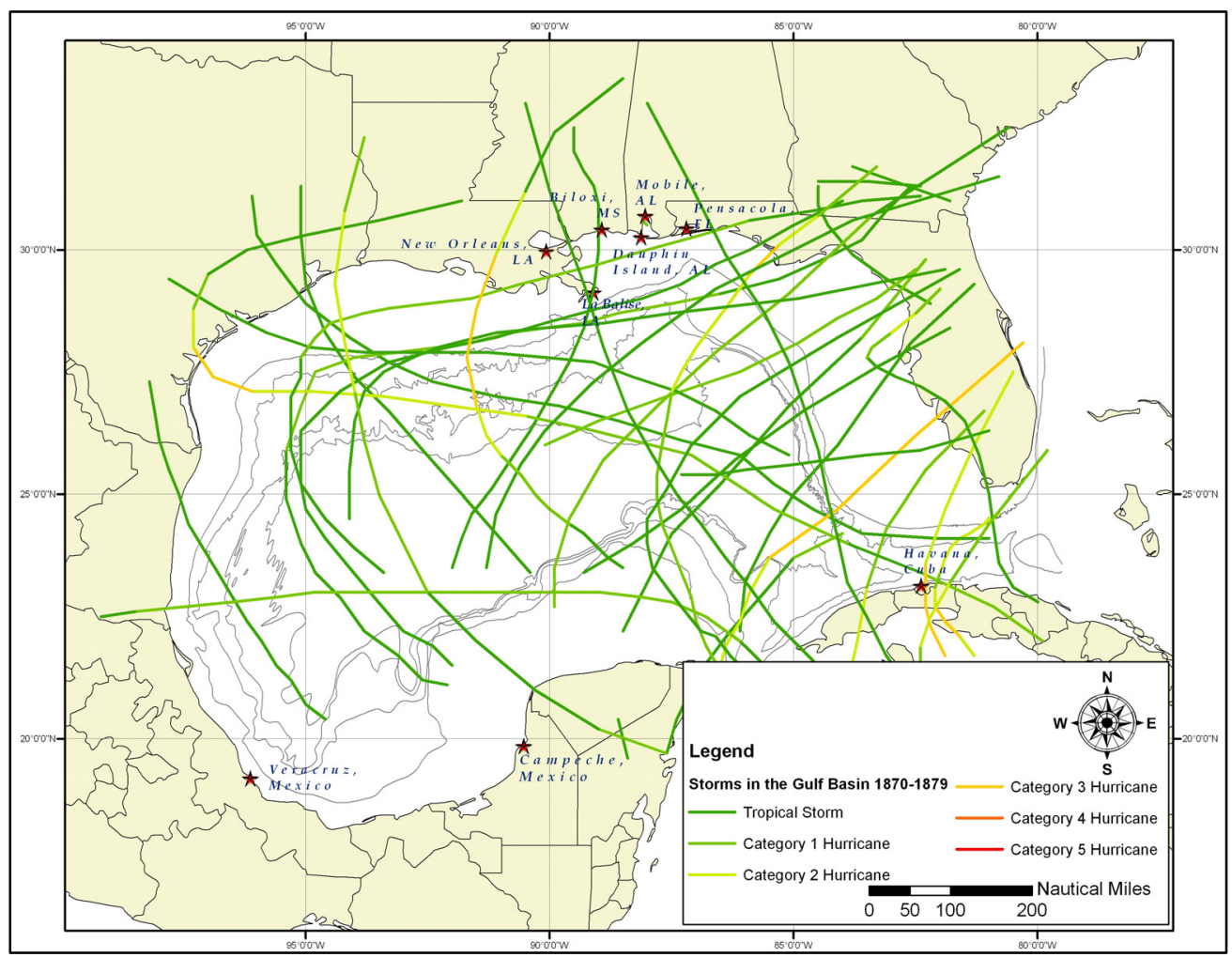

Figure 5-24. Gulf storms, 1870-1879.

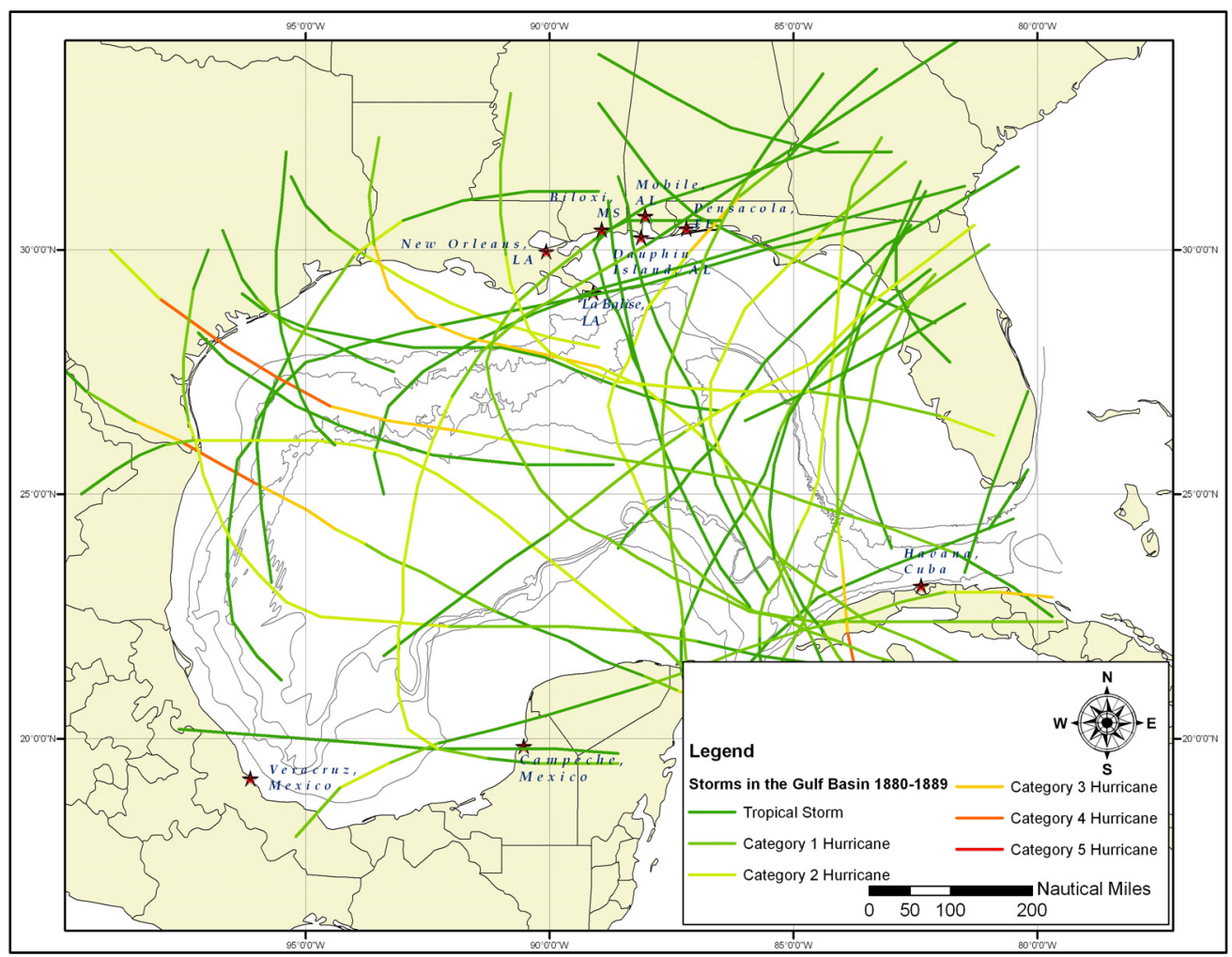

Figure 5-25. Gulf storms, 1880-1889. 


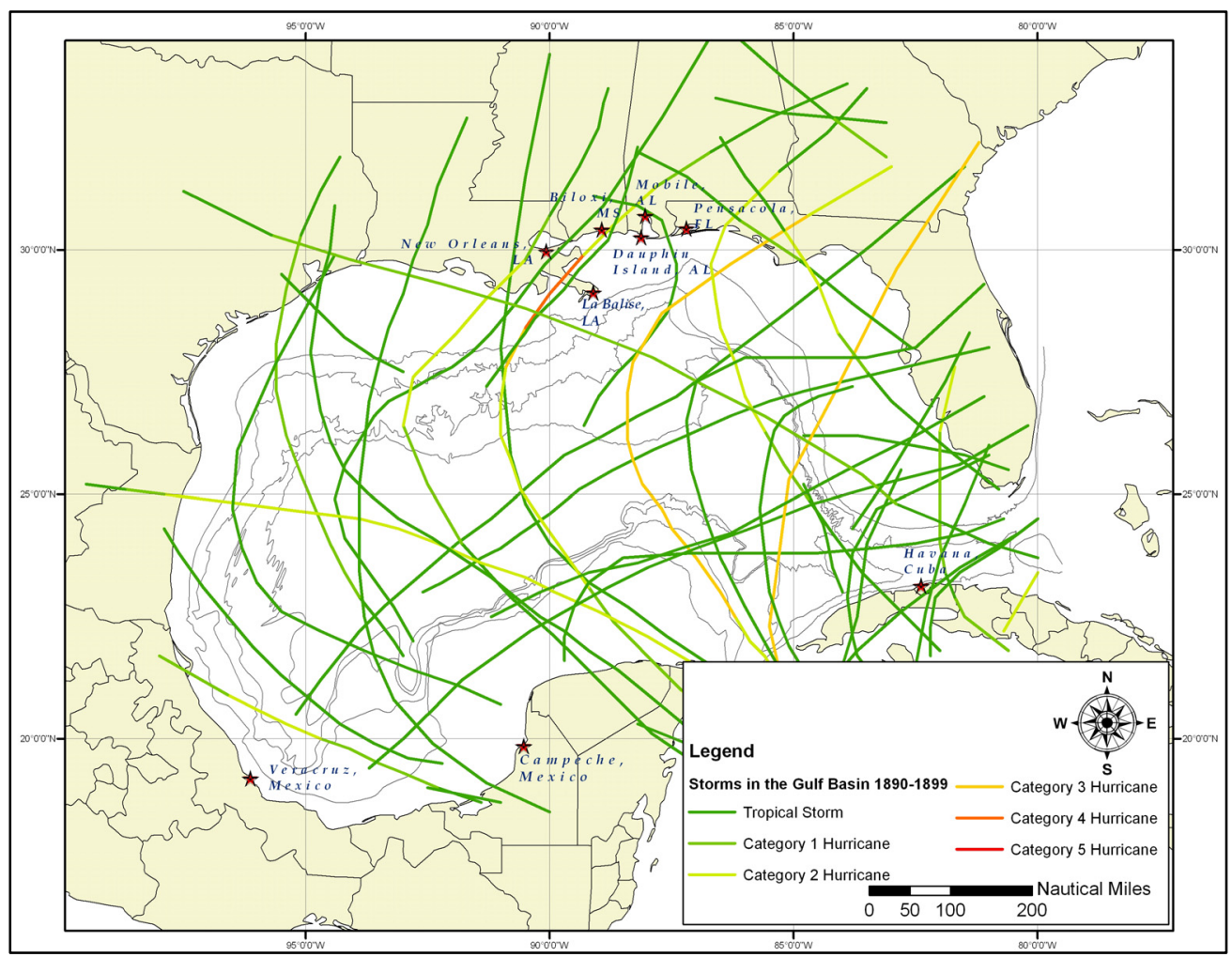

Figure 5-26. Gulf storms, 1890-1899.

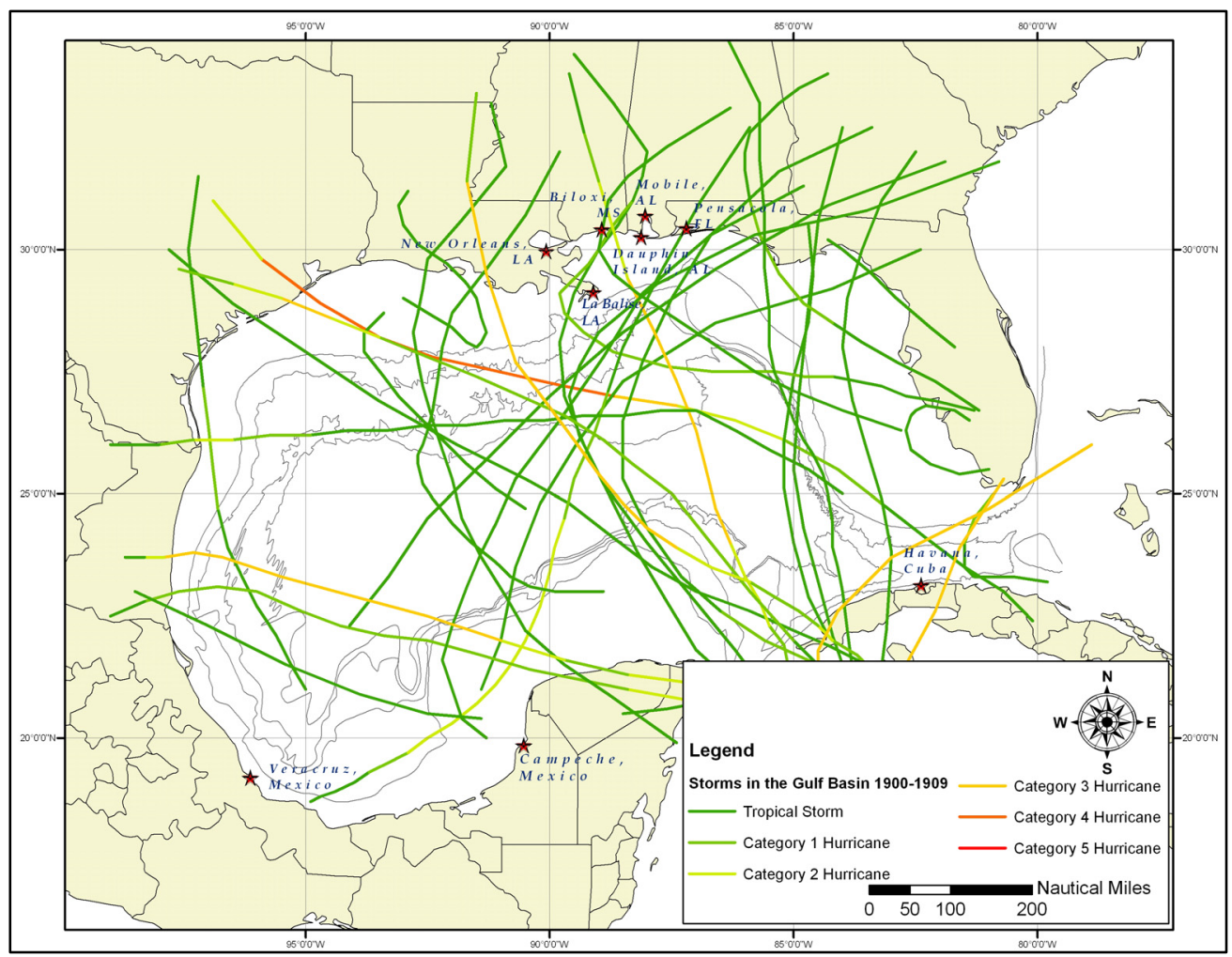

Figure 5-27. Gulf storms, 1900-1909. 


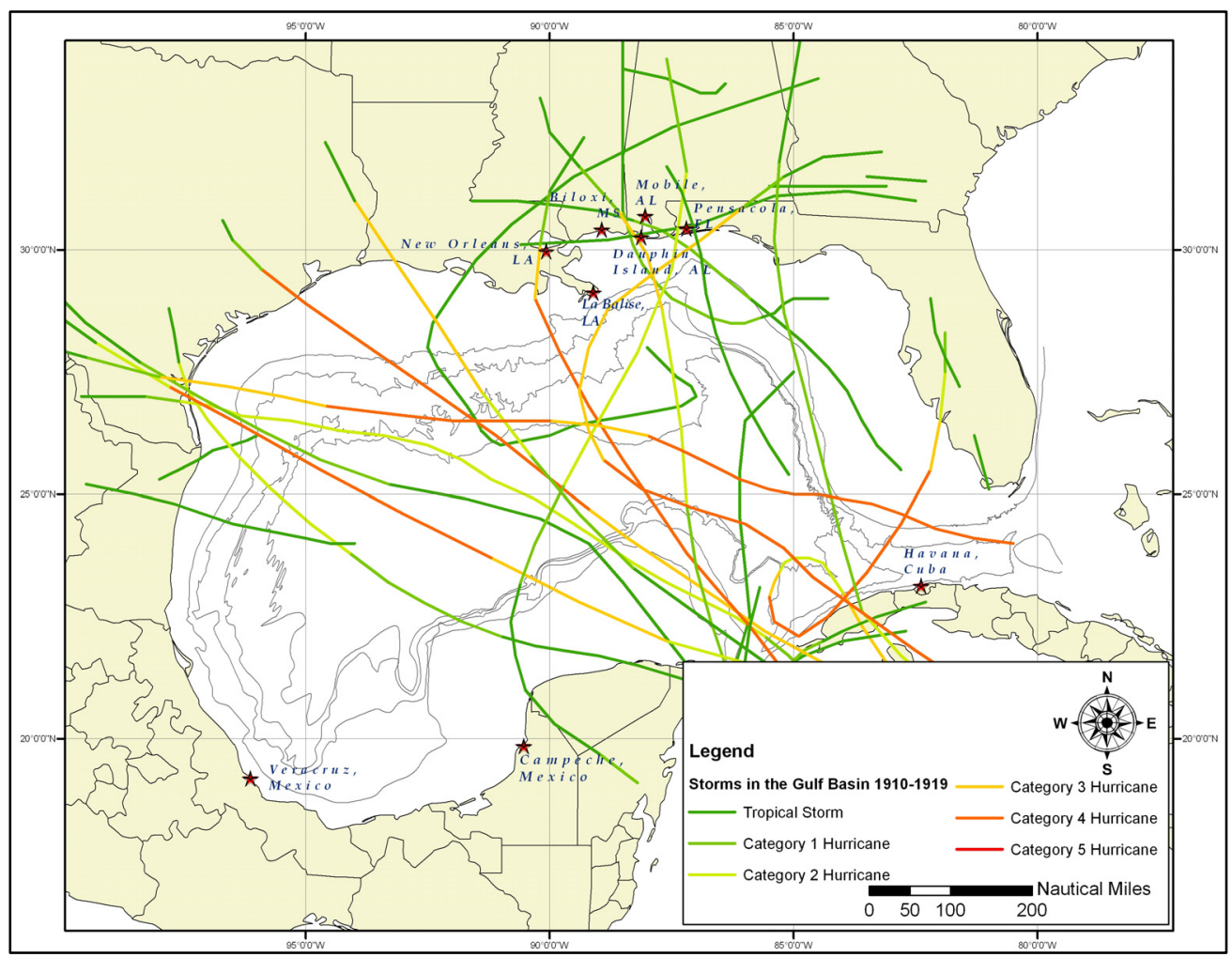

Figure 5-28. Gulf storms, 1910-1919.

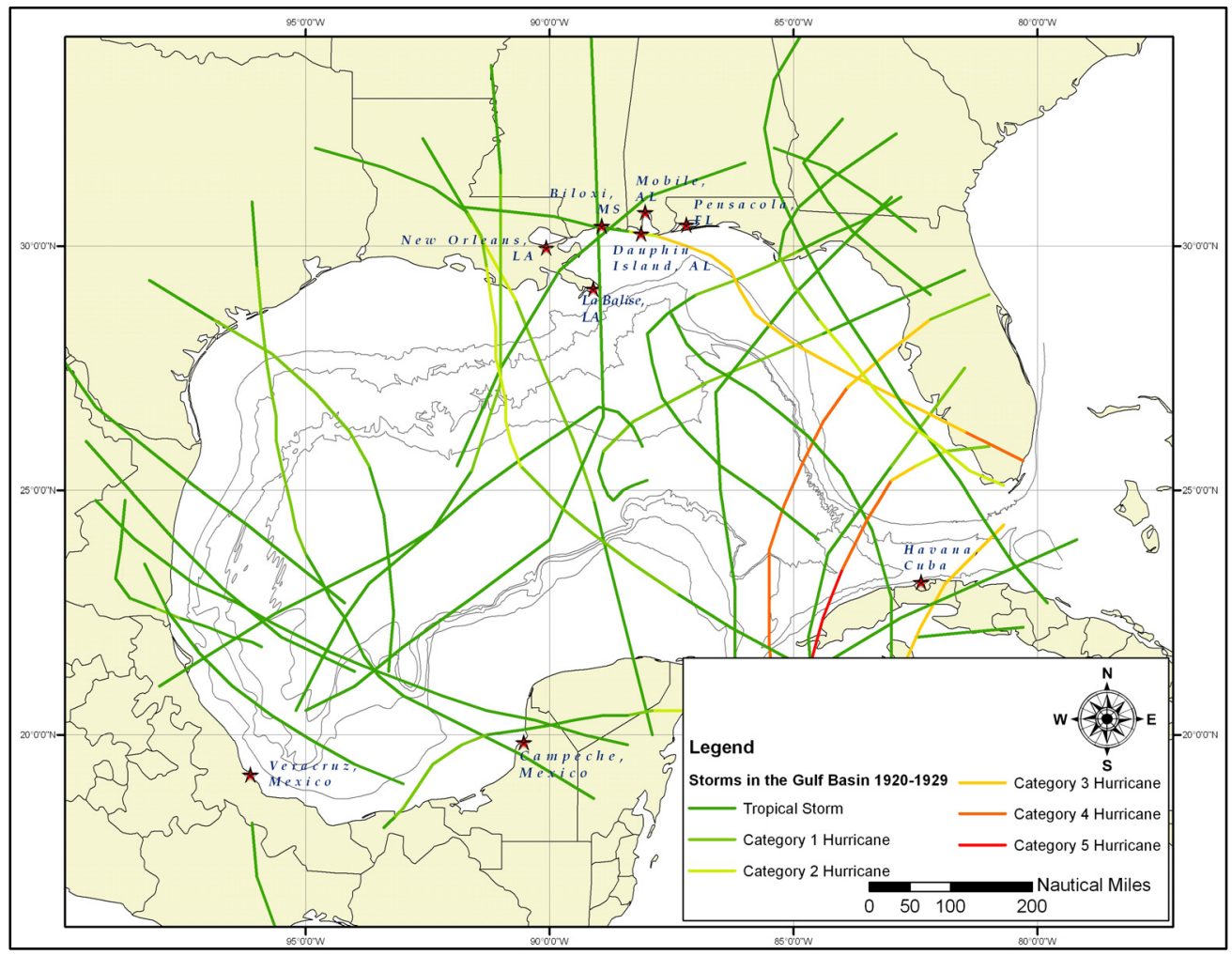

Figure 5-29. Gulf storms, 1920-1929. 


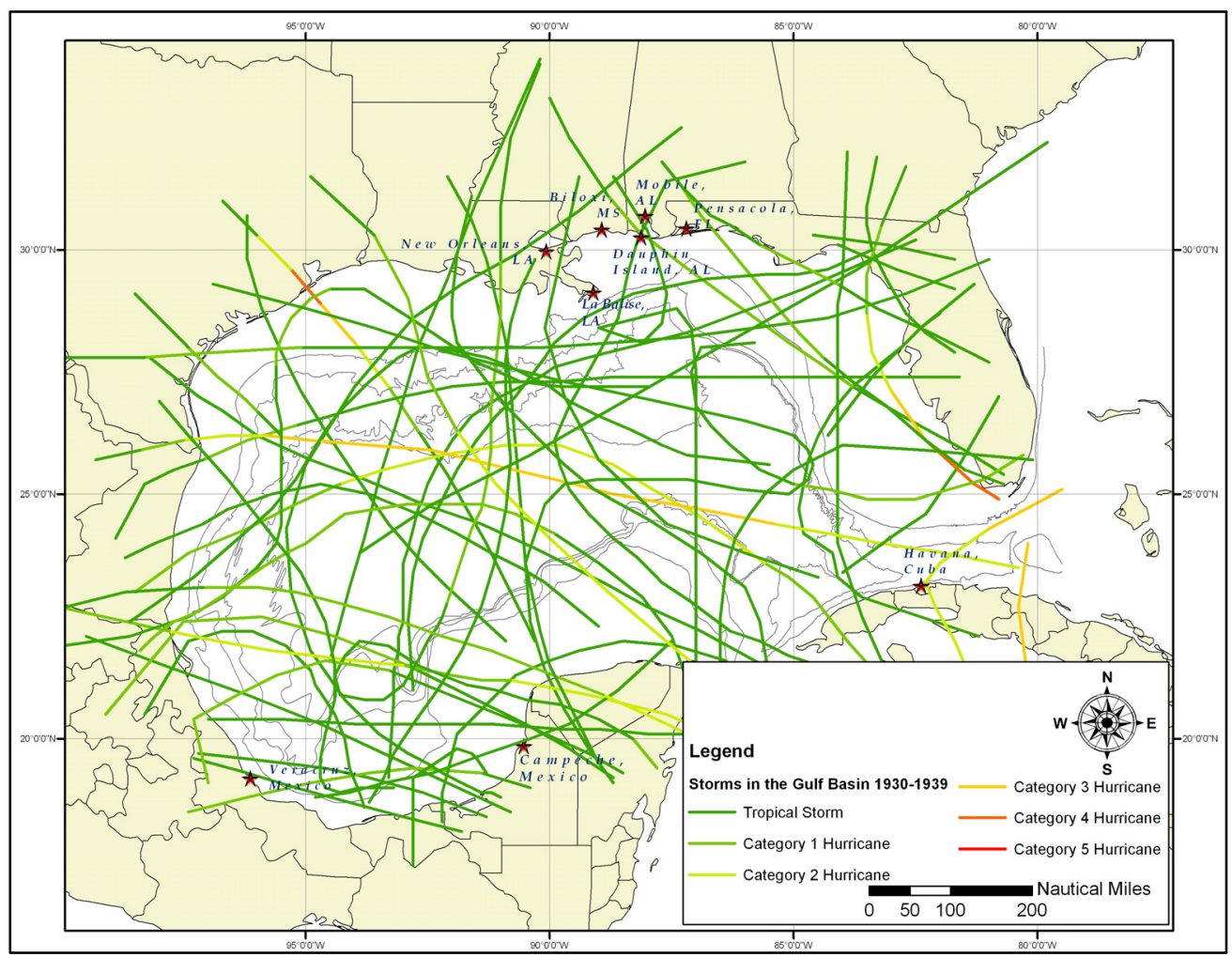

Figure 5-30. Gulf storms, 1930-1939.

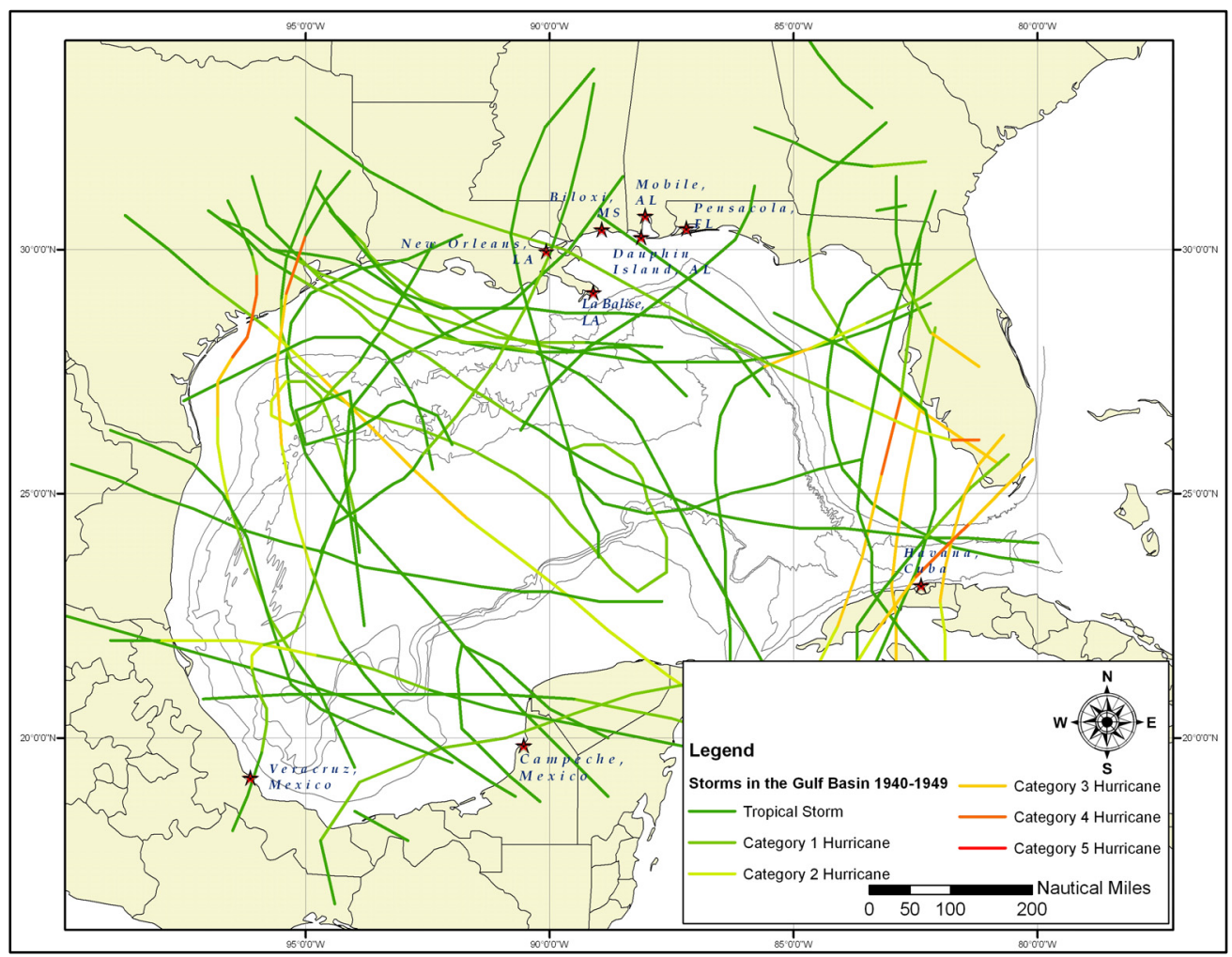

Figure 5-31. Gulf storms, 1940-1949. 


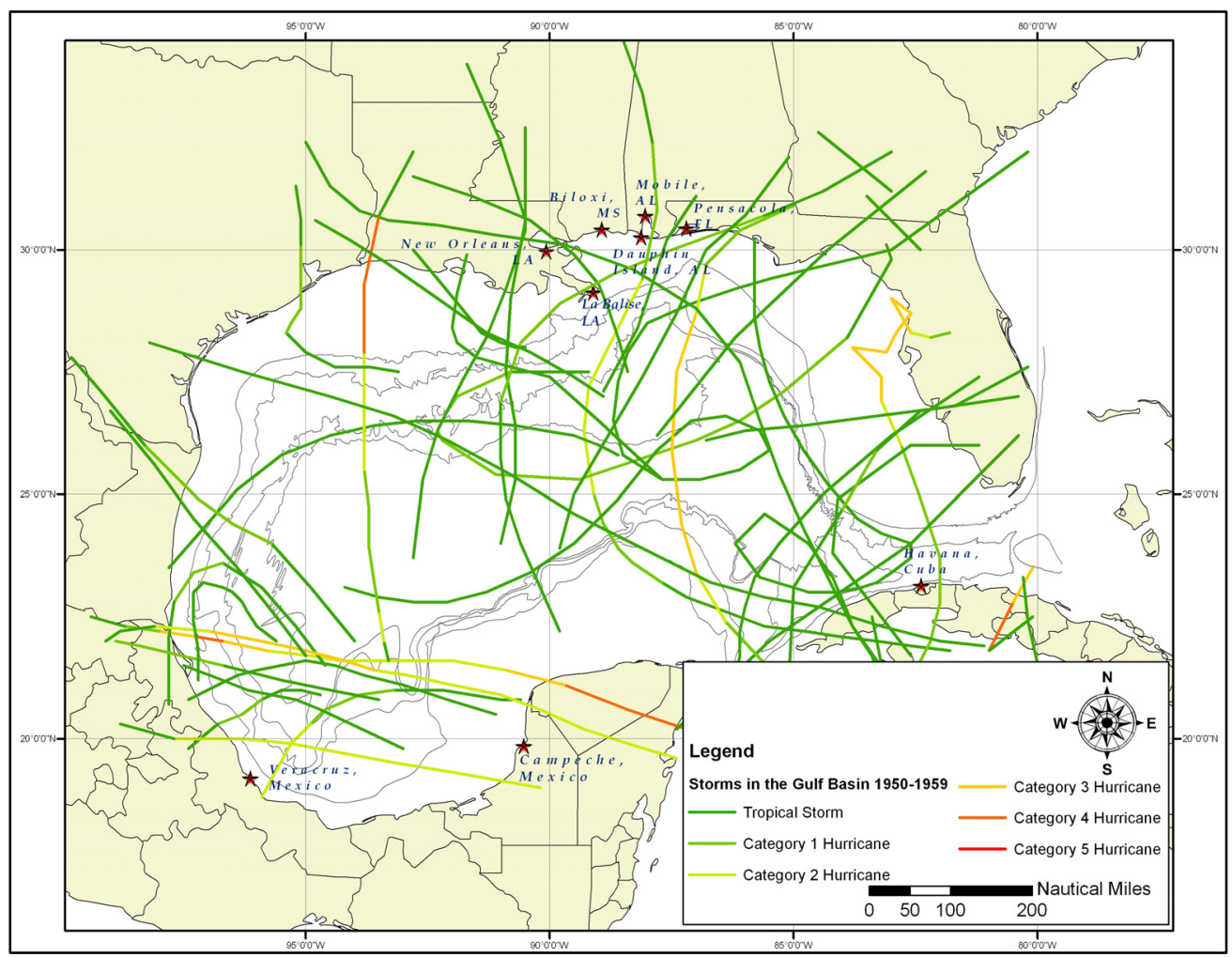

Figure 5-32. Gulf storms, 1950-1959.

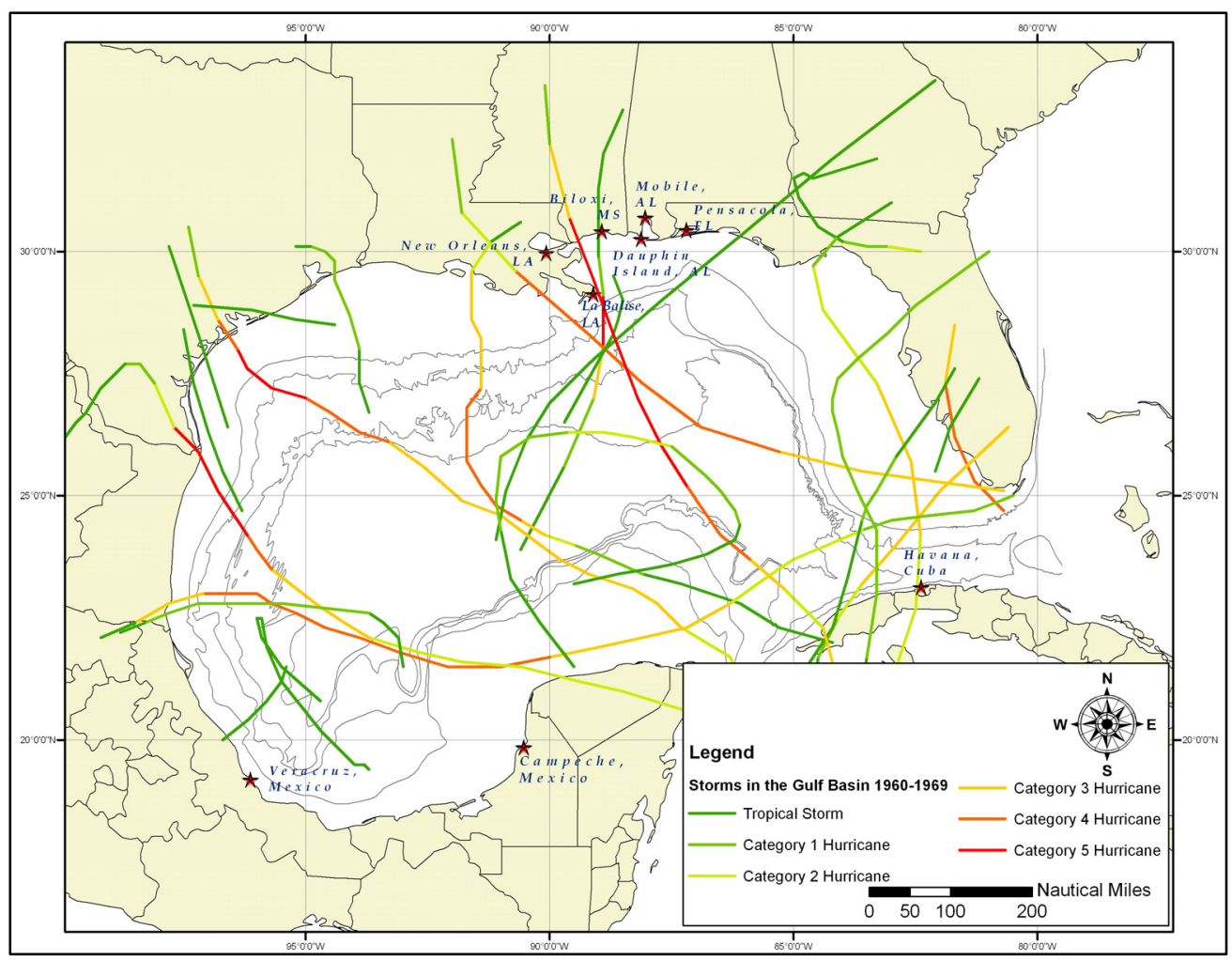

Figure 5-33. Gulf storms, 1960-1969. 


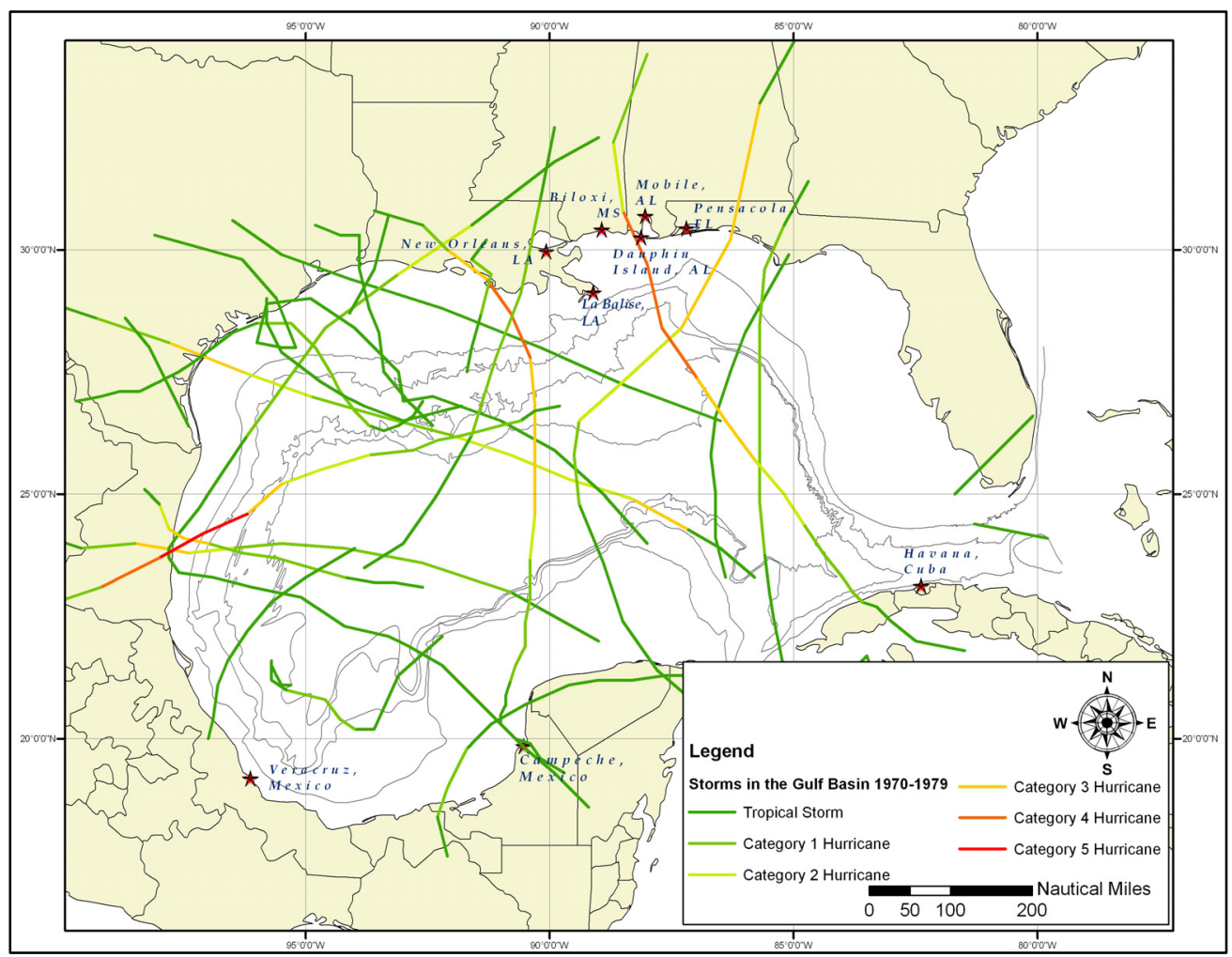

Figure 5-34. Gulf storms, 1970-1979.

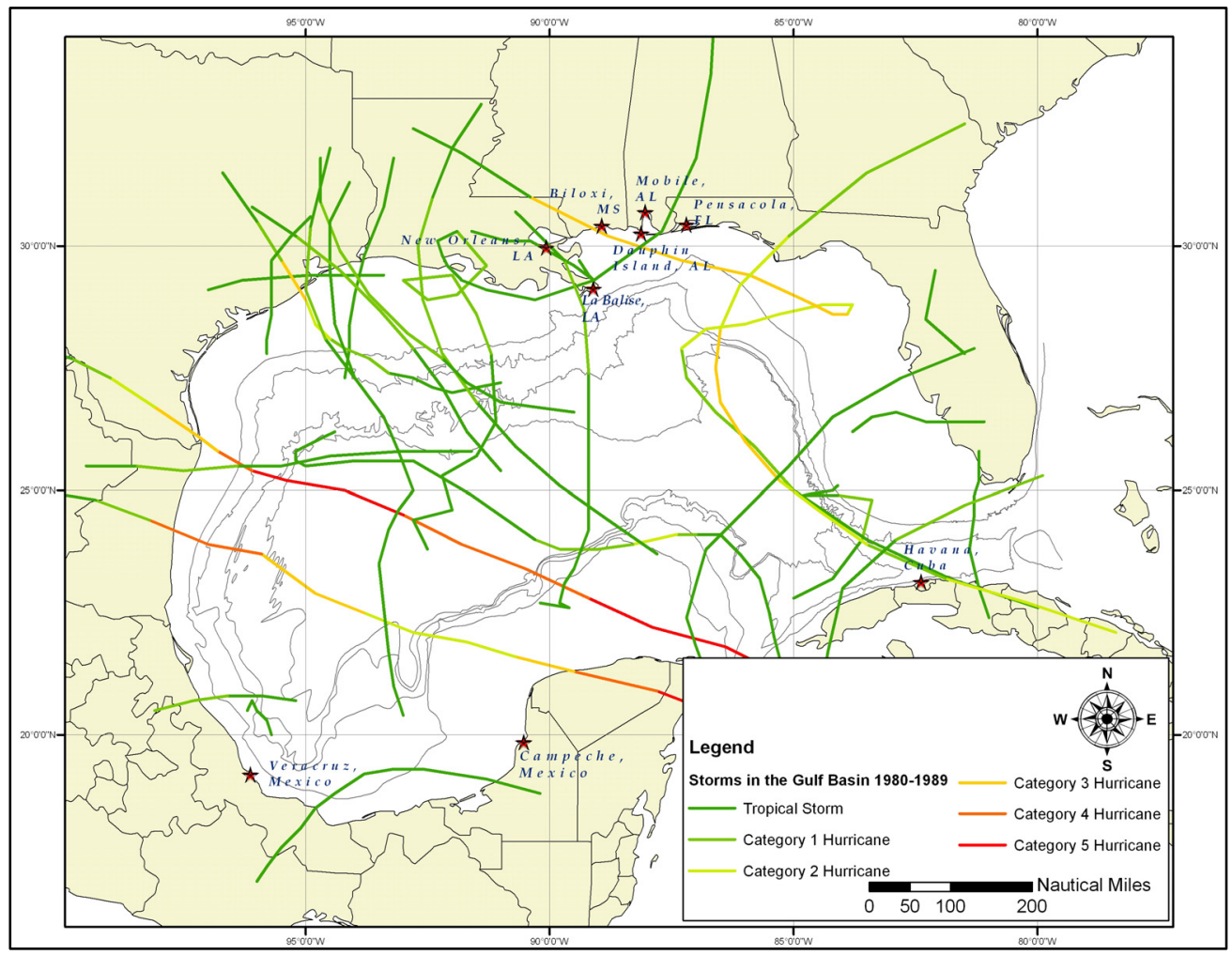

Figure 5-35. Gulf storms, 1980-1989. 


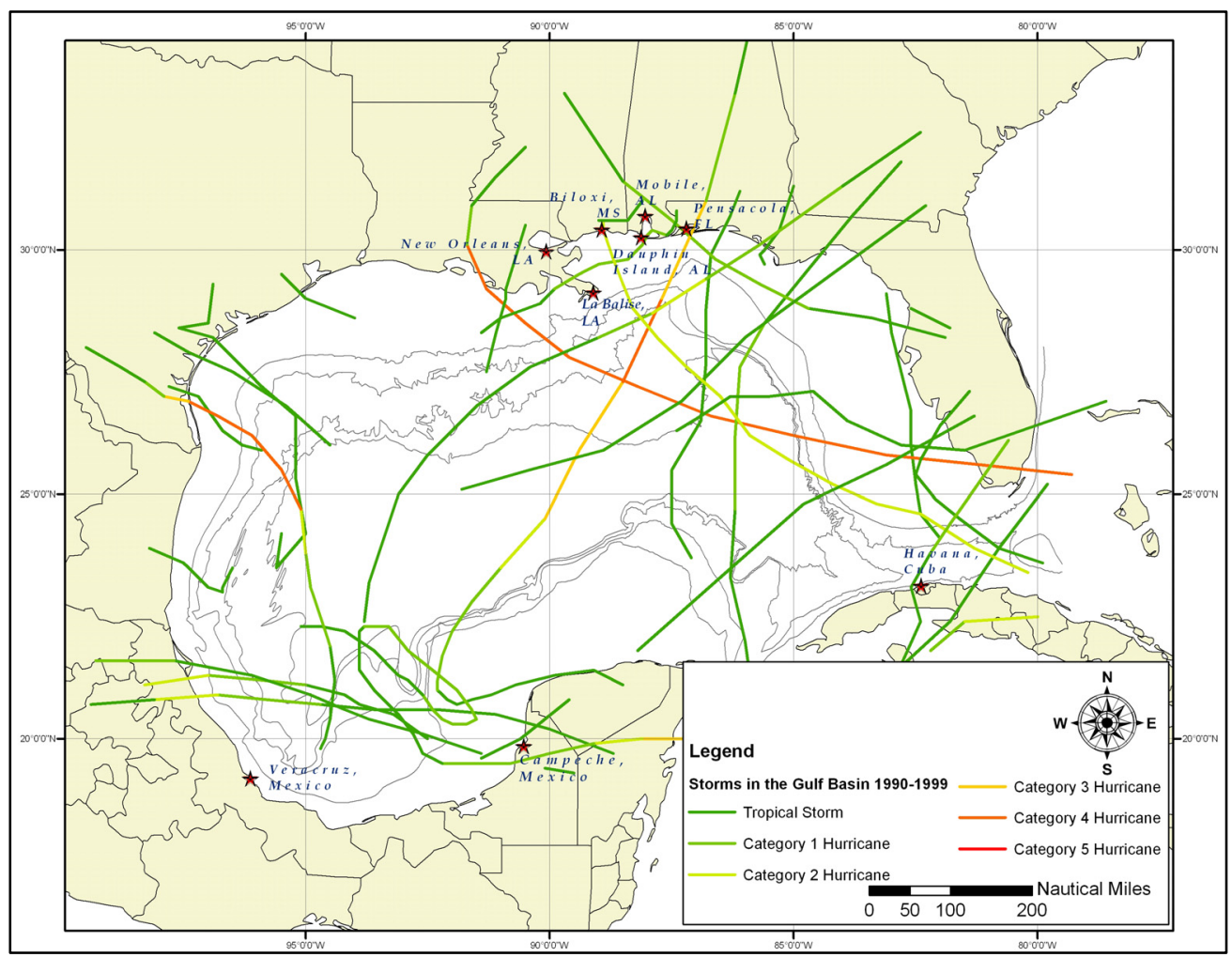

Figure 5-36. Gulf storms, 1990-1999.

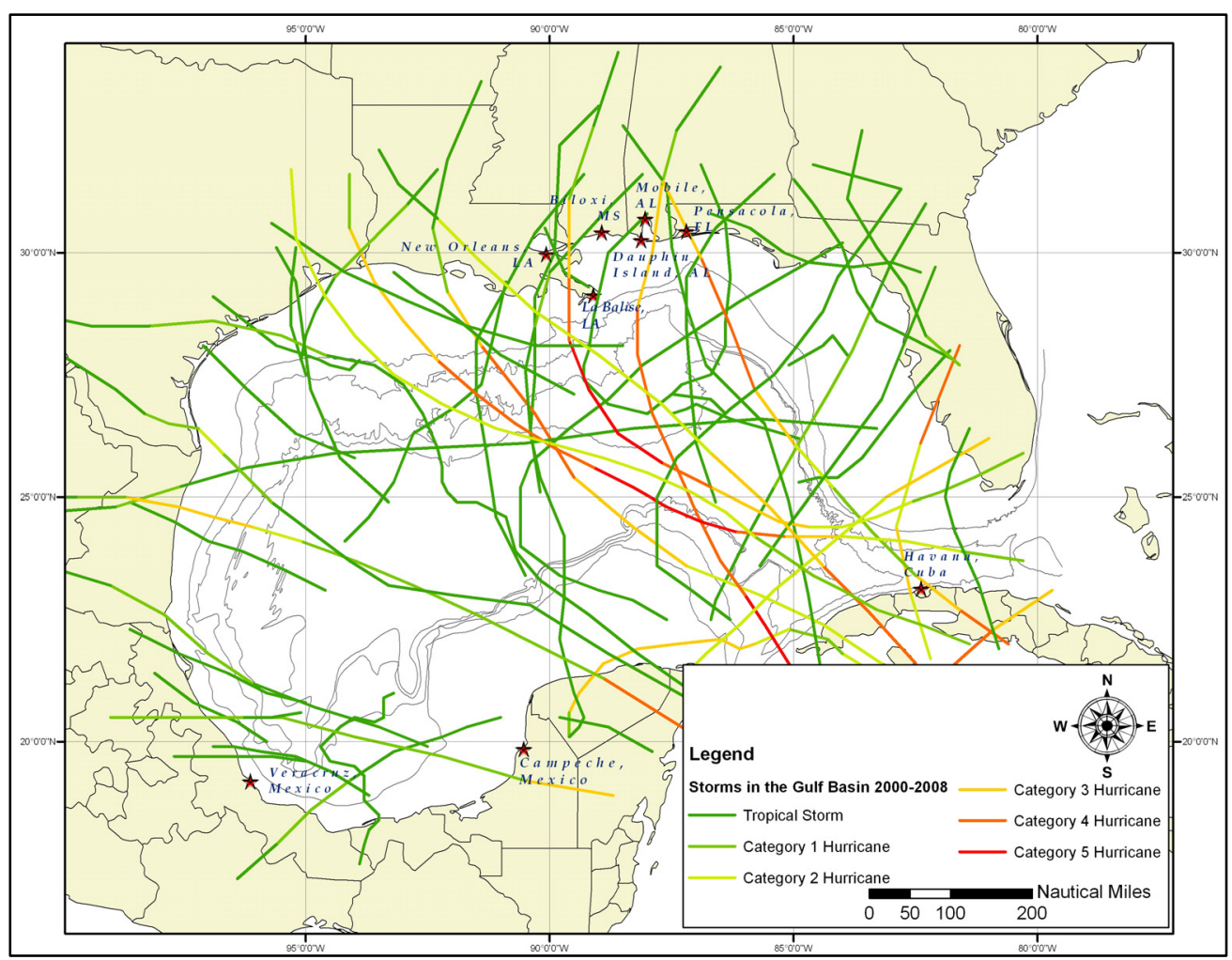

Figure 5-37. Gulf storms, 2000-2008. 
estimate an average of one hurricane per year in the GOM. Expansion of tracking data to include that last four years seems to indicate that this may be a low estimate. More realistically, there may average only one major hurricane per year but there are numerous tropical depressions and storms that could also affect shipping.

Although, according to Pearson and Hoffman (1995), the Spanish adapted their fleet sailing to avoid the hurricane season, departure delays and out-of-season storms took a toll on the Spanish fleet. Pearson et al. (2003) state that "large numbers of ships were lost in the Florida Keys and the Bahama Channels during hurricanes in 1633, 1715, and 1722. In 1766, delays in getting the annual fleet off from Veracruz until September resulted in the loss of two ships run aground on the northern Gulf coast (Pearson and Hoffman 1995)" (Pearson et al. 2003:4-20).

Pearson et al. (2003) also noted, "If a hurricane struck the fleet while it was following this [typical eastern Gulf] route, the general tendency would be for ships to be driven in a roughly northerly or northeasterly direction toward the shore. Most of the early known and reported flota losses consist of vessels that were driven ashore under these circumstances, such as in 1554 and 1622" (Pearson et al. 2003:4-60).

Archival study has revealed 16 ships lost or possibly lost in the GOM. Using the route data gained from this study, corridors for possible vessel location have been created. The probable route, based on the most commonly taken direction for the expected port of call, was buffered by 100 miles on either side to factor in variances in weather and navigation. Maps were created to illustrate these projected probability zones (Figures 5-38 through 5-52). Of the 16 vessels presumed lost in the GOM, six have projected wreck zones that do not fall, at least, partly within the UDW of the upper GOM. Vessels whose remains may lie in this area include three Spanish-, six French-, and one English-owned ship (Table 5-13). The routes for these vessels mostly fall within the eastern portion of the Gulf. Two Spanish vessels, Sandoval and Descubridor, were lost between Veracruz and Havana, while the remaining vessels were lost going to the upper Gulf Coast. 


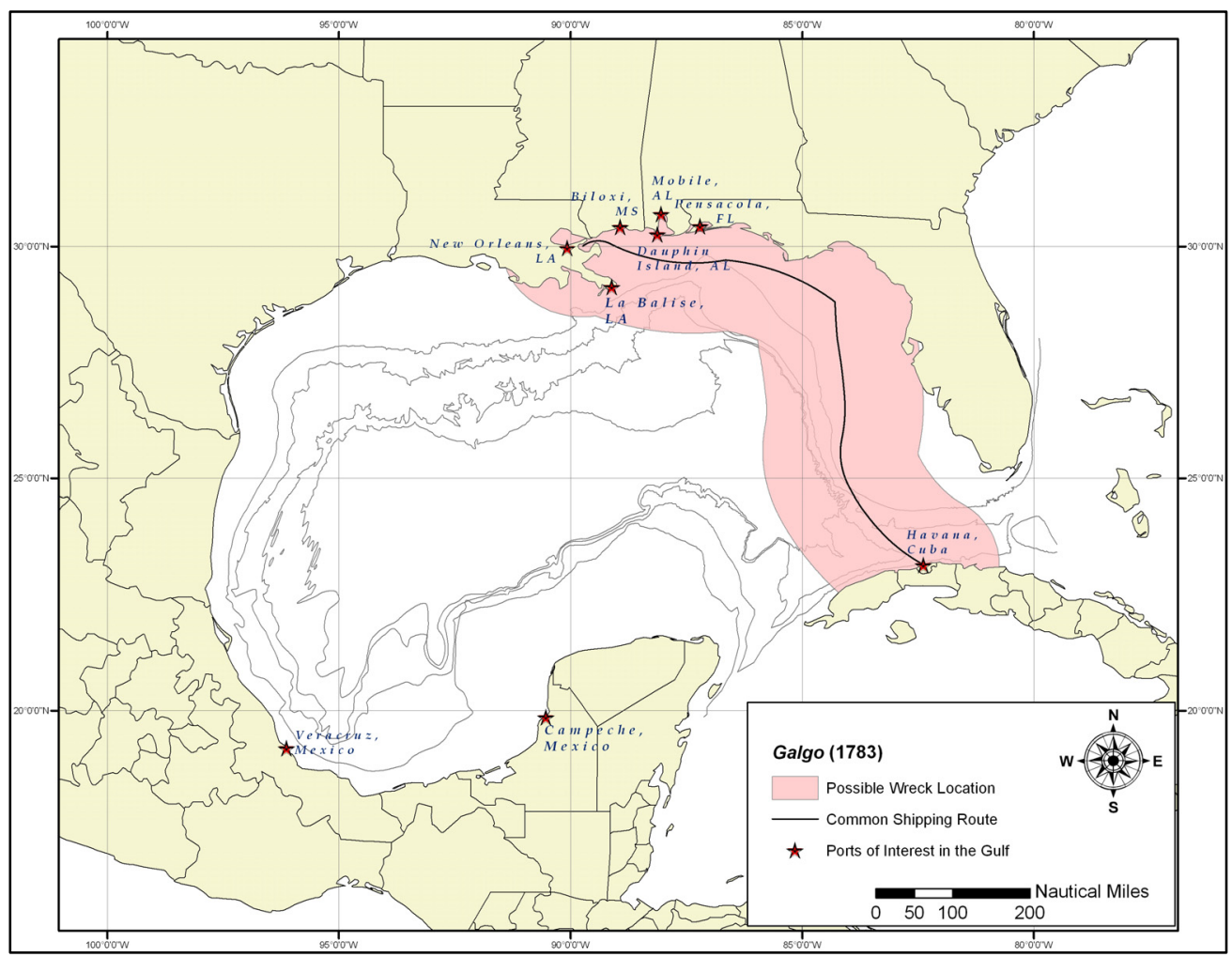

Figure 5-38. Map showing possible wreck zone of the Spanish vessel Galgo (1783).

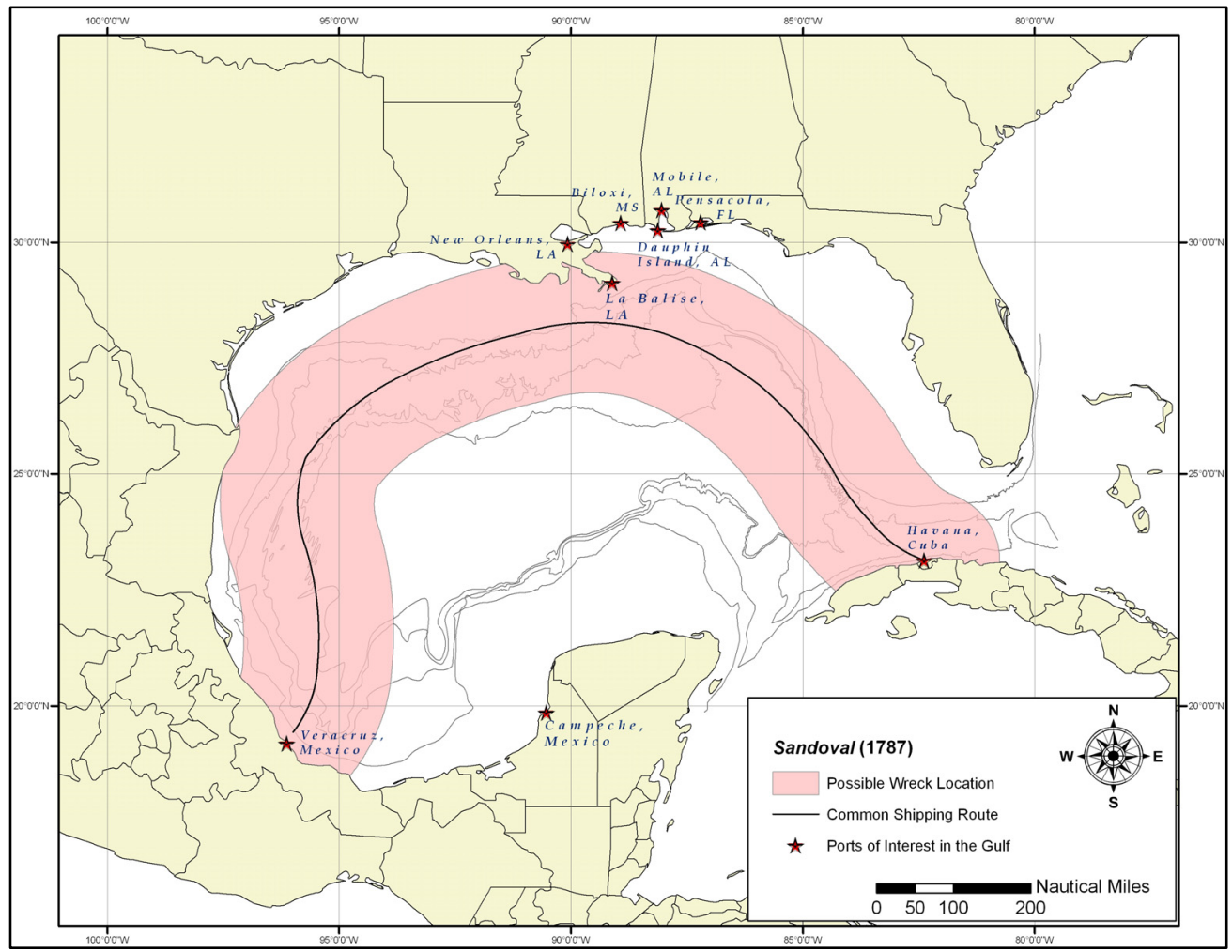

Figure 5-39. Map showing possible wreck zone of the Spanish vessel Sandoval (1787). 


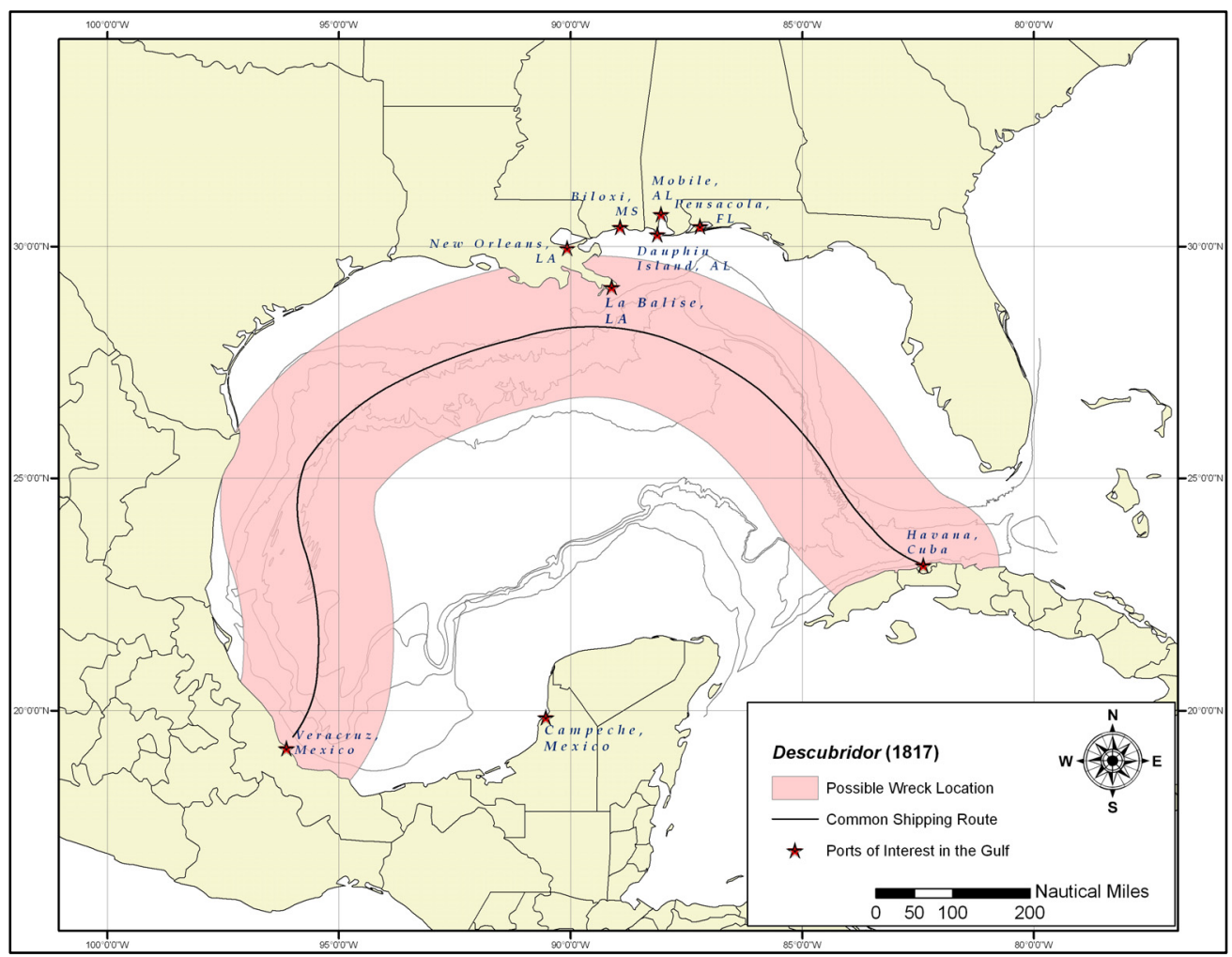

Figure 5-40. Map showing possible wreck zone of the Spanish vessel Descubridor (1817).

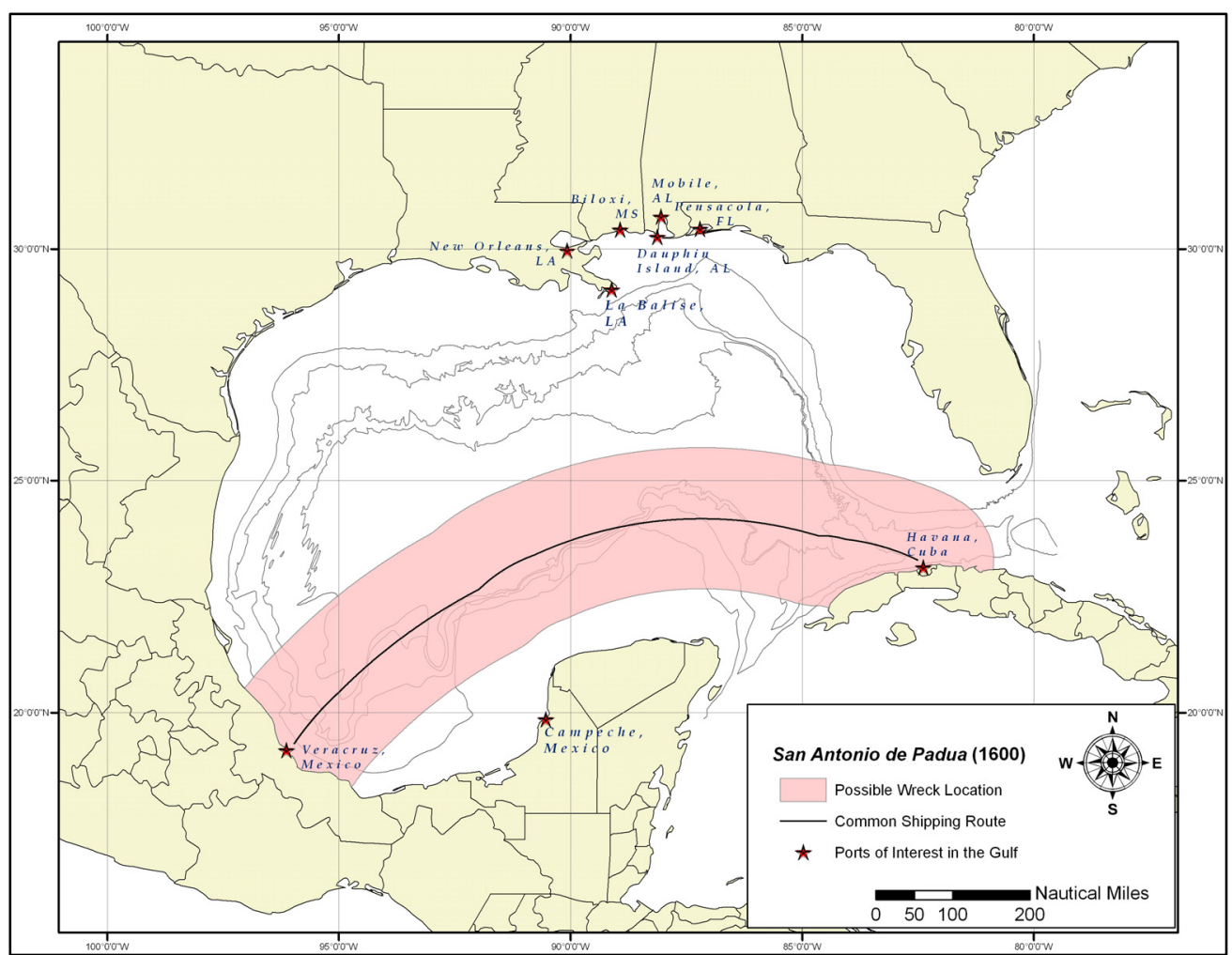

Figure 5-41. Map showing possible wreck zone of the Spanish vessel San Antonio de Padua (1600). 


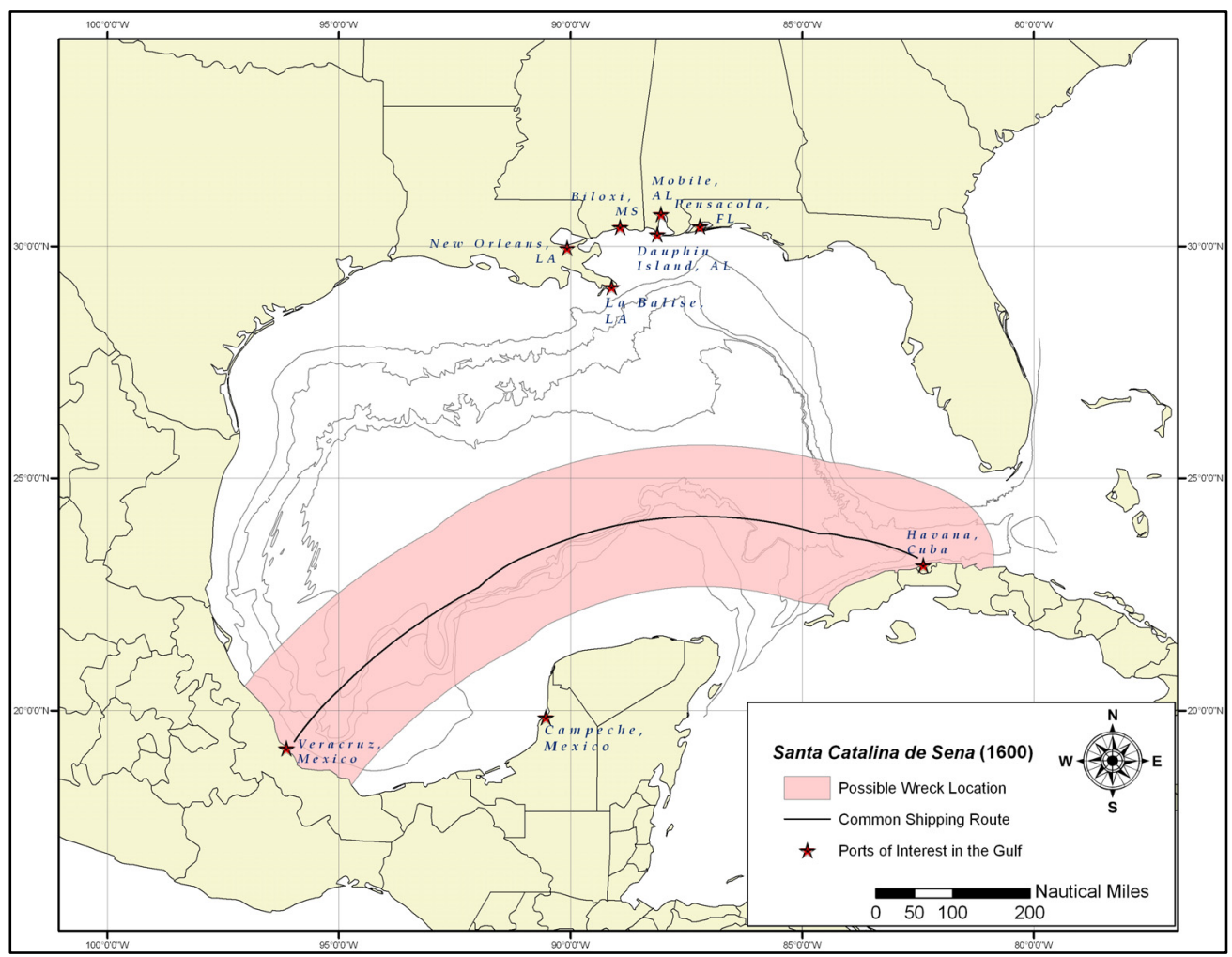

Figure 5-42. Map showing possible wreck zone of the Spanish vessel Santa Catalina de Sena (1600).

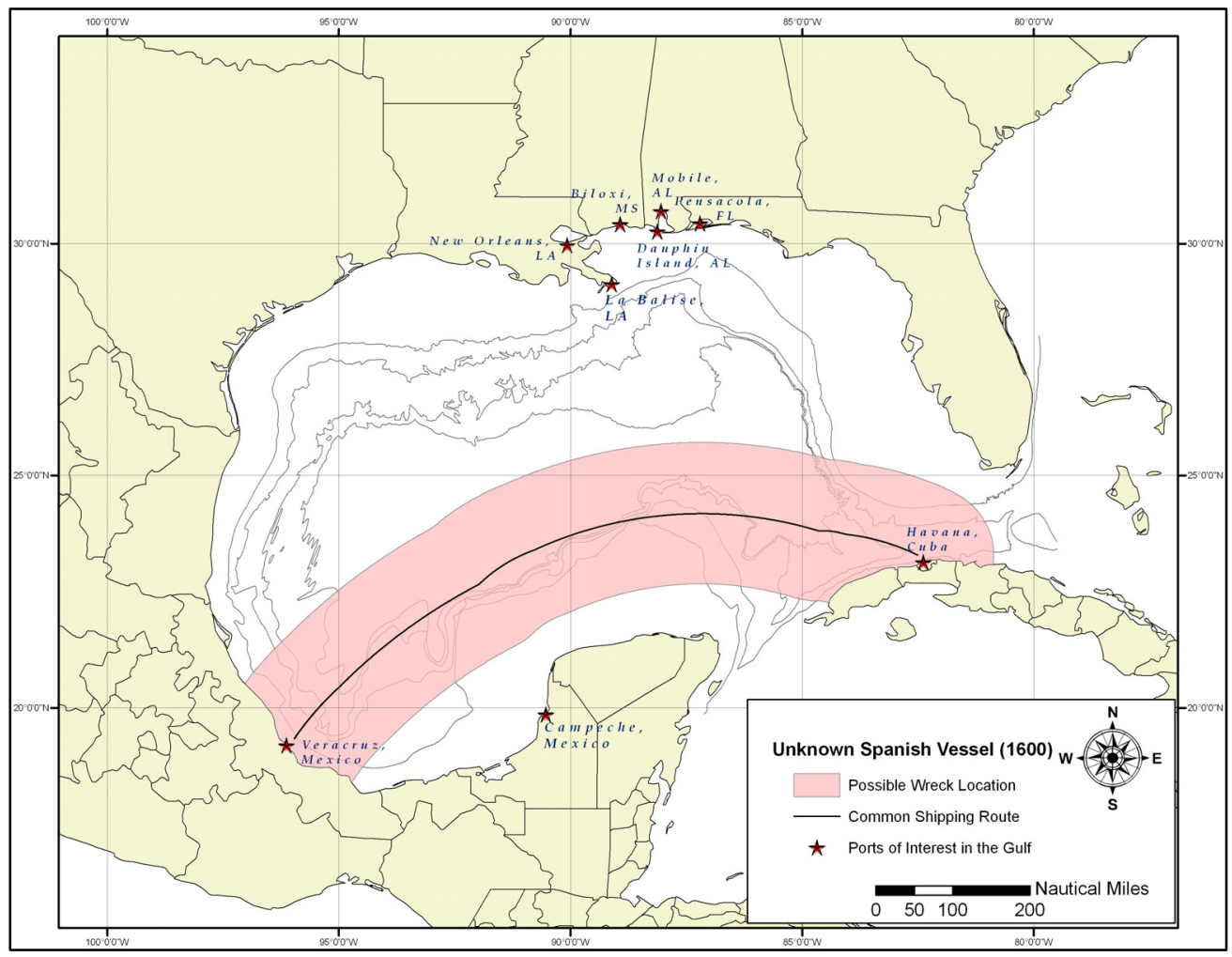

Figure 5-43. Map showing possible wreck zone of two unknown Spanish vessels that were lost independently of one another (1600). 


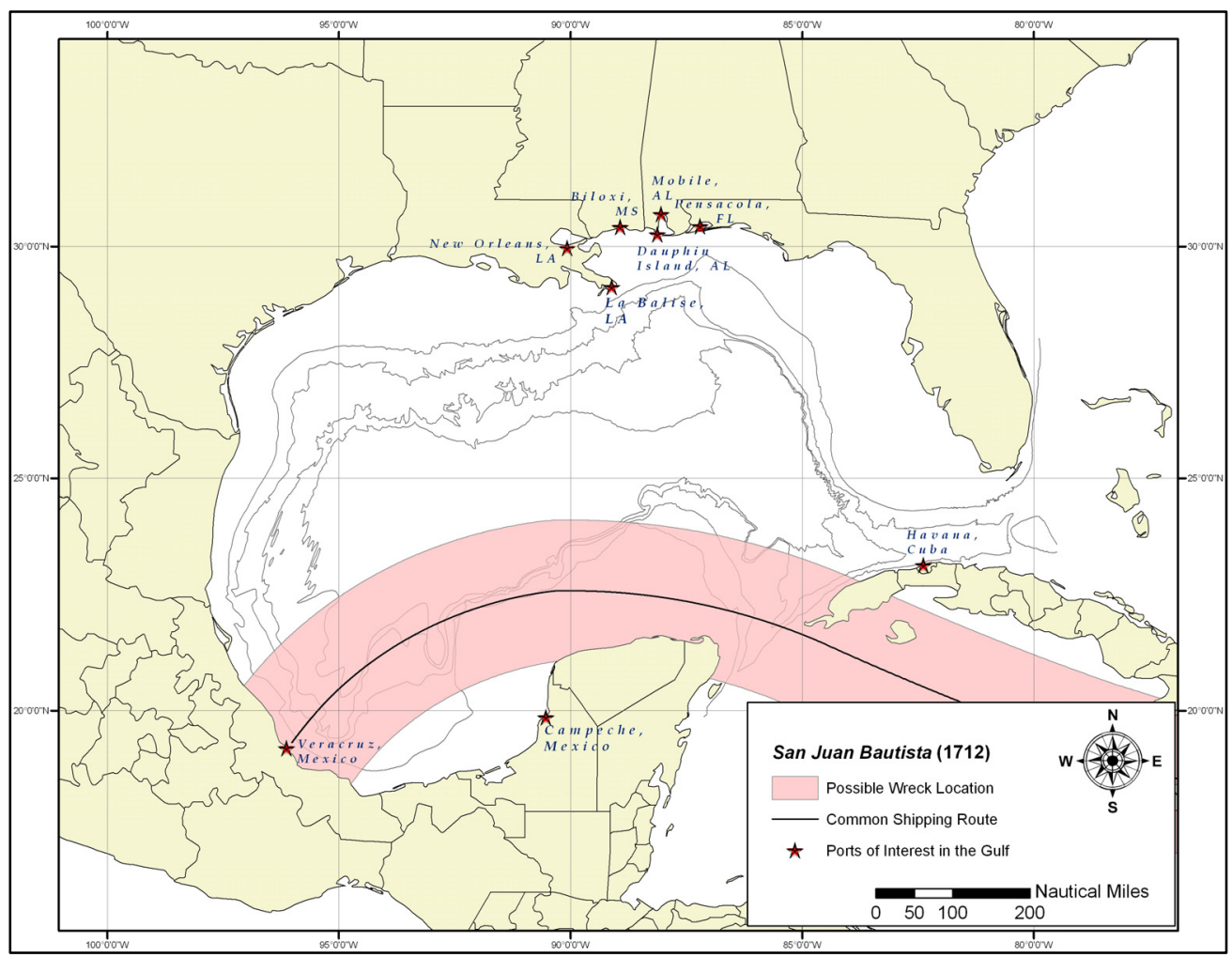

Figure 5-44. Map showing possible wreck zone of the Spanish vessel San Juan Bautista (1712).

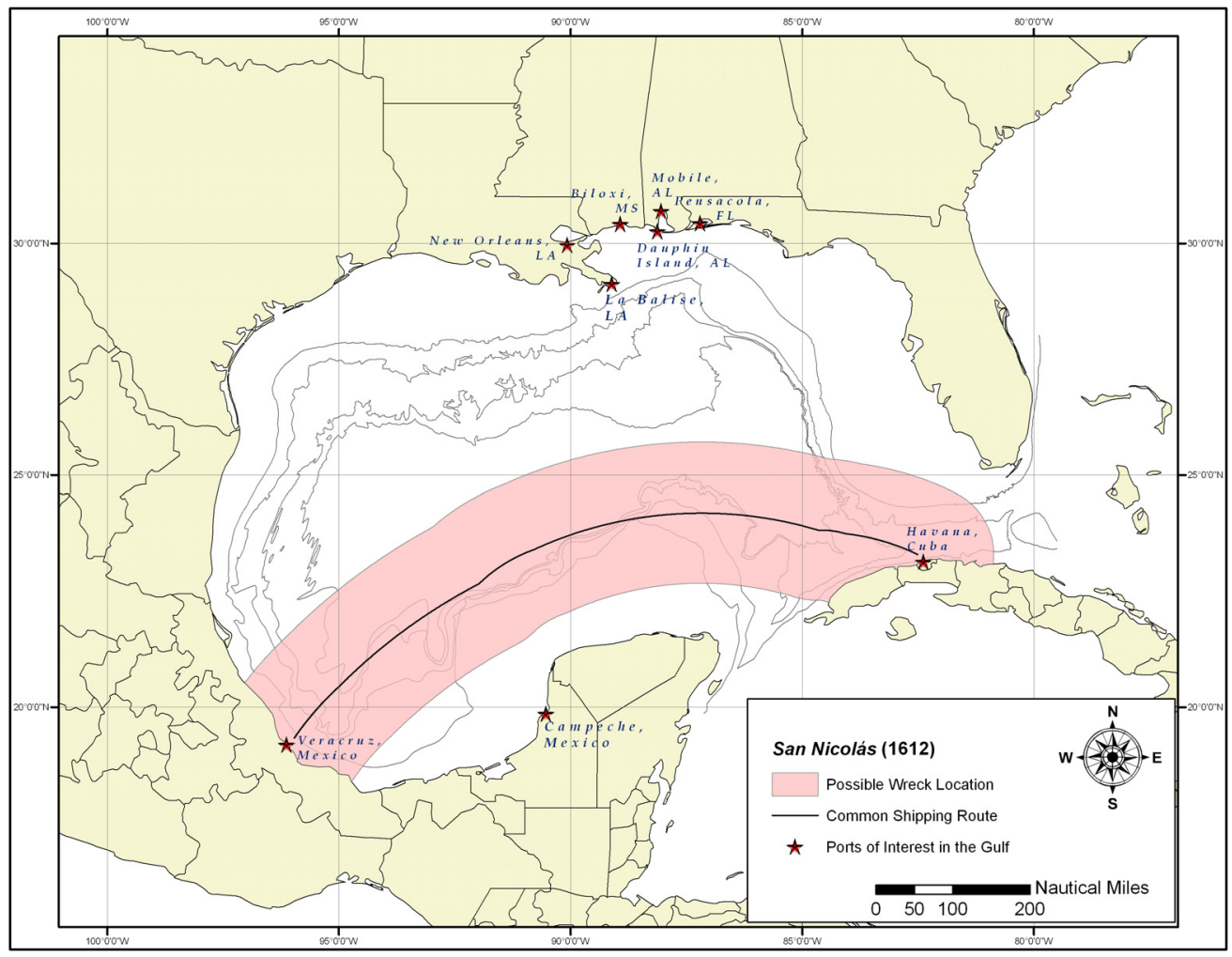

Figure 5-45. Map showing possible wreck zone of the Spanish vessel San Nicolás (1612). 


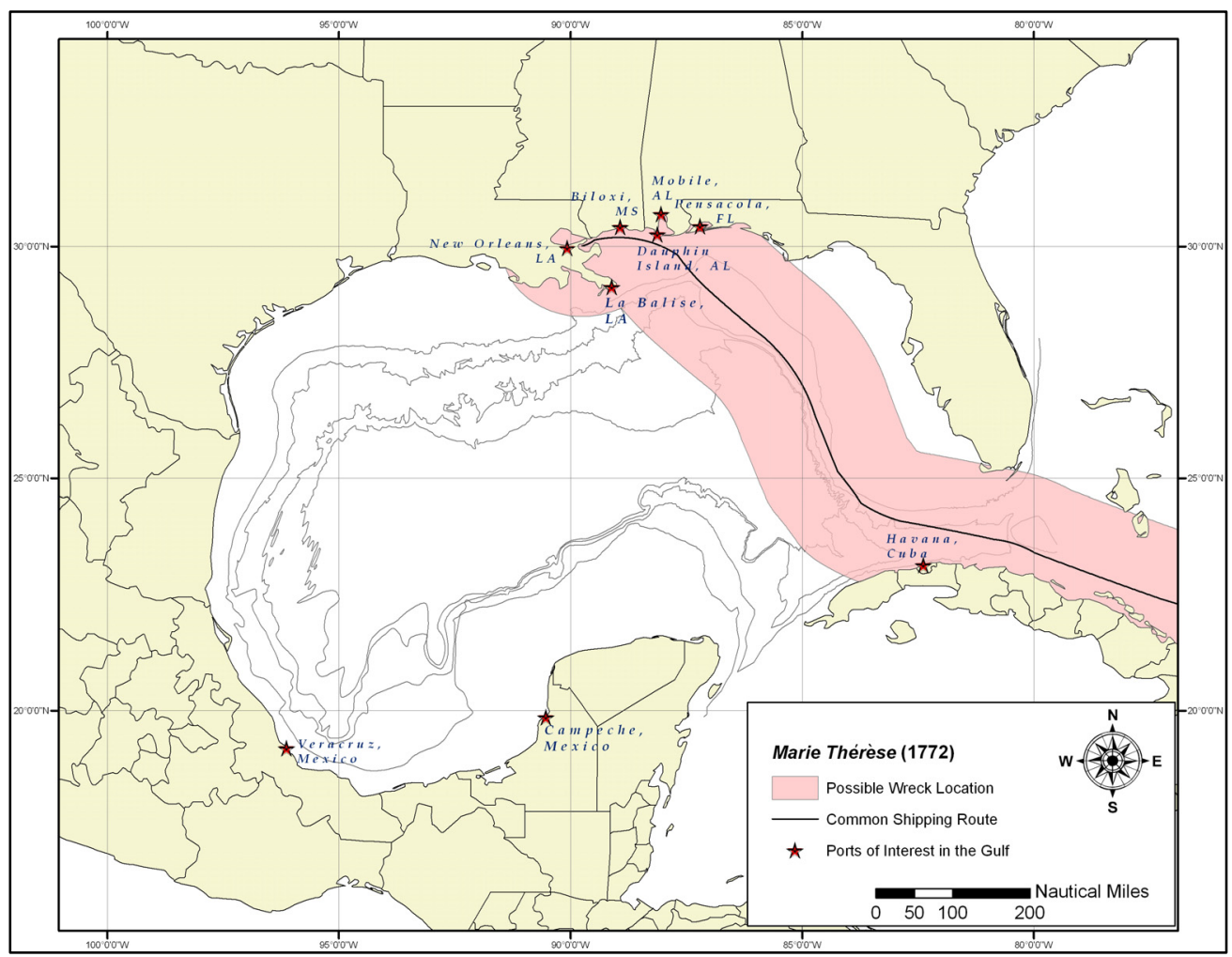

Figure 5-46. Map showing possible wreck zone of the French vessel Marie Thérèse (1772).

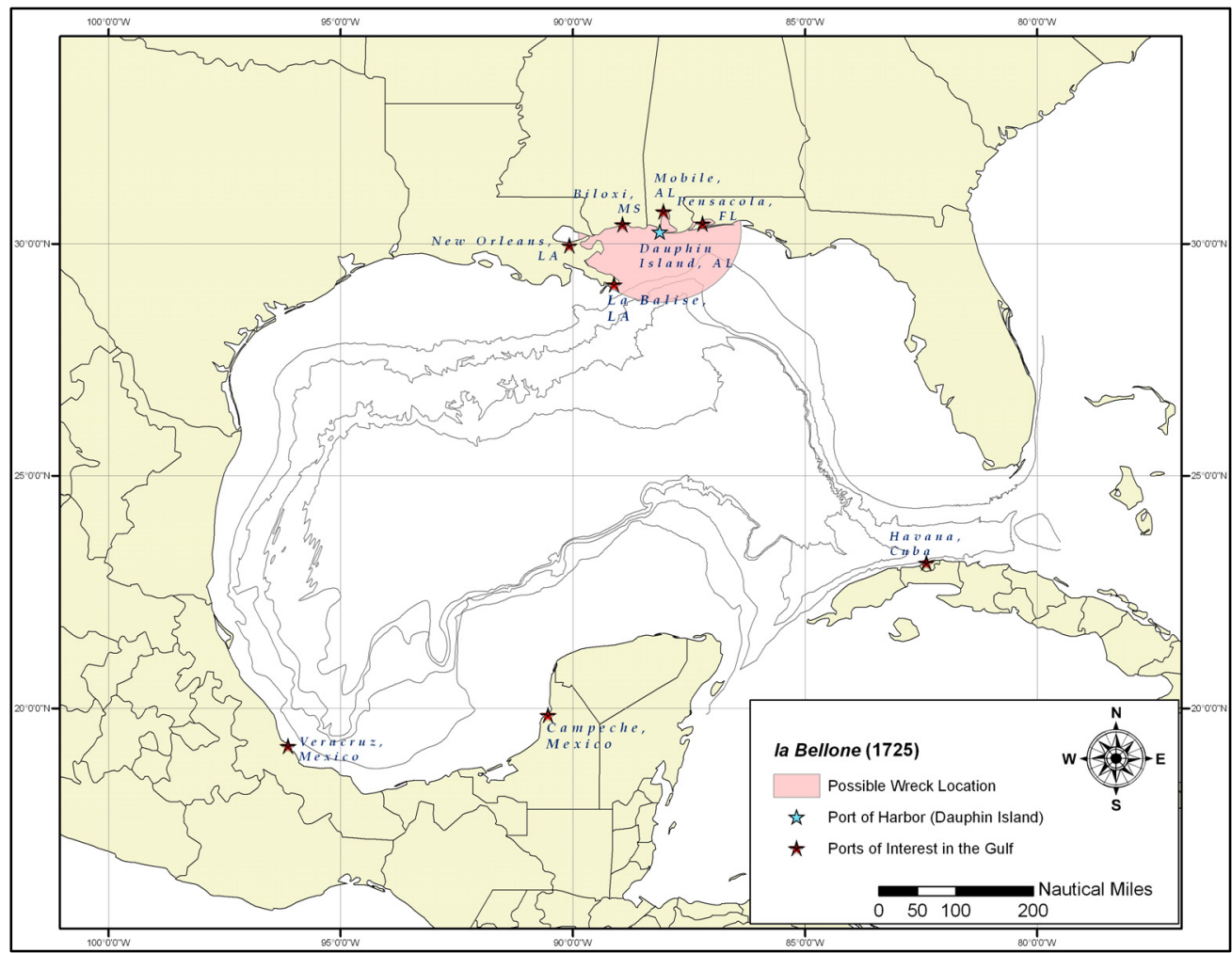

Figure 5-47. Map showing possible wreck zone of the French vessel la Bellone (1725). 


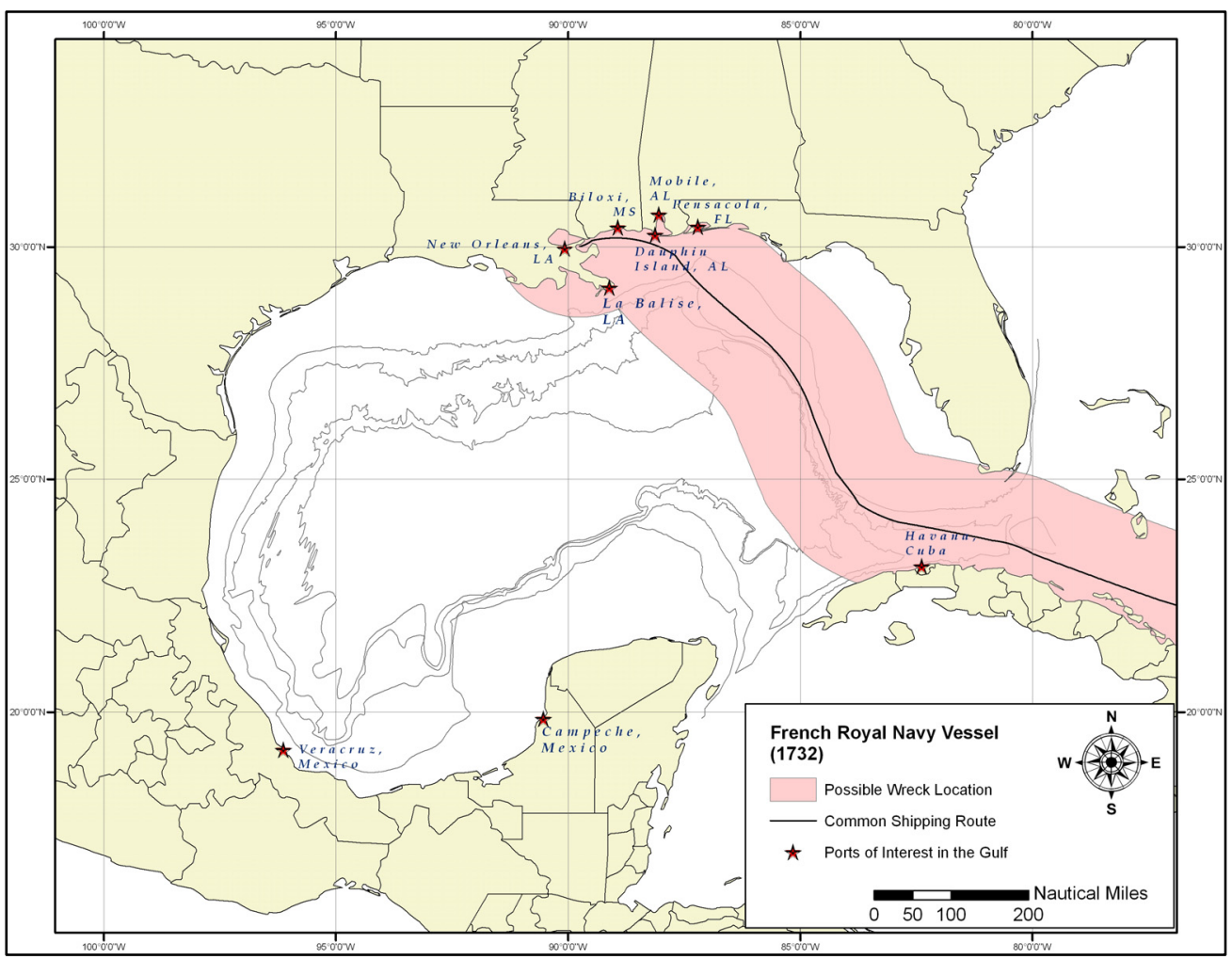

Figure 5-48. Map showing possible wreck zone of a French Royal Navy vessel (1732).

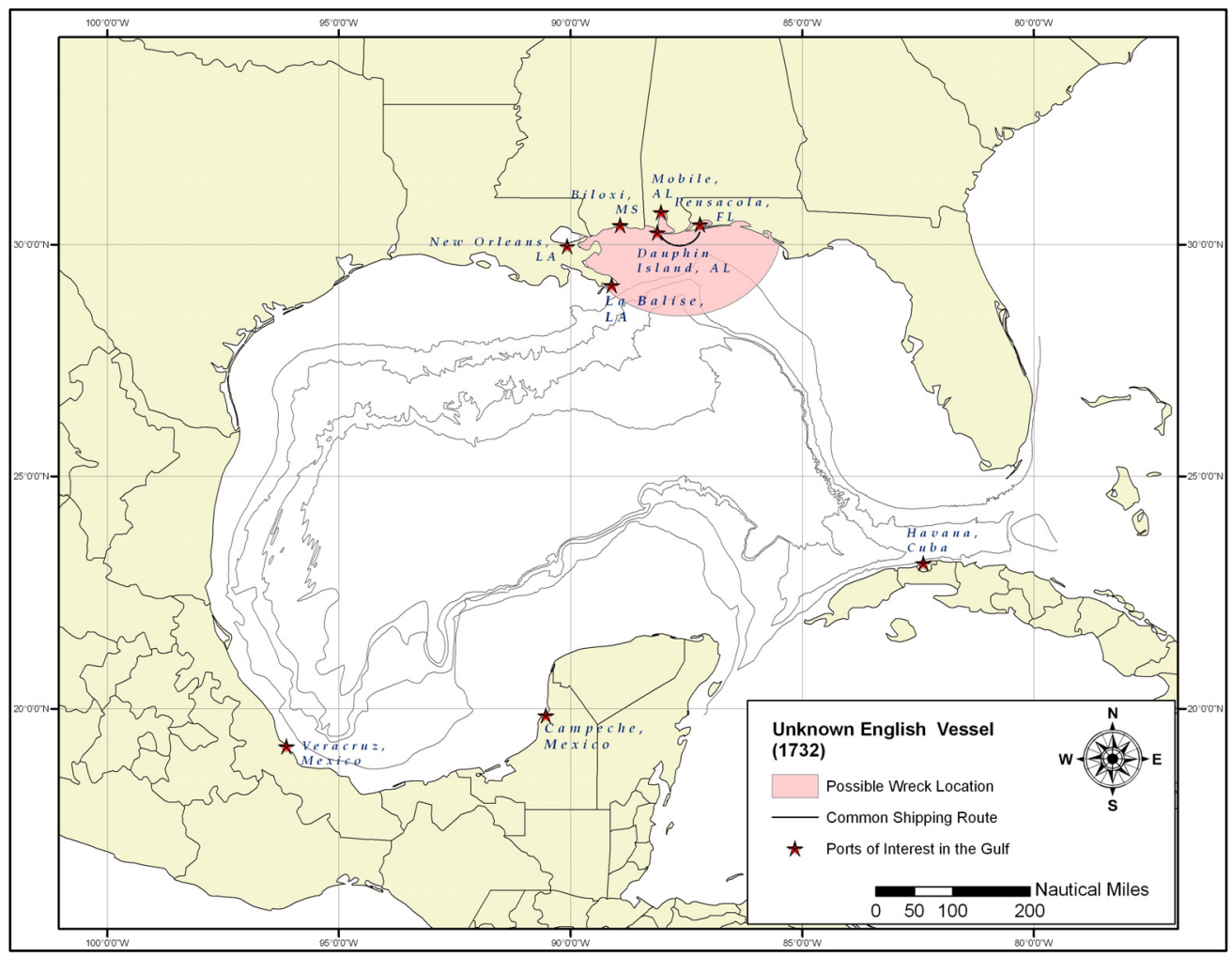

Figure 5-49. Map showing possible wreck zone of an unknown English vessel (1732). 


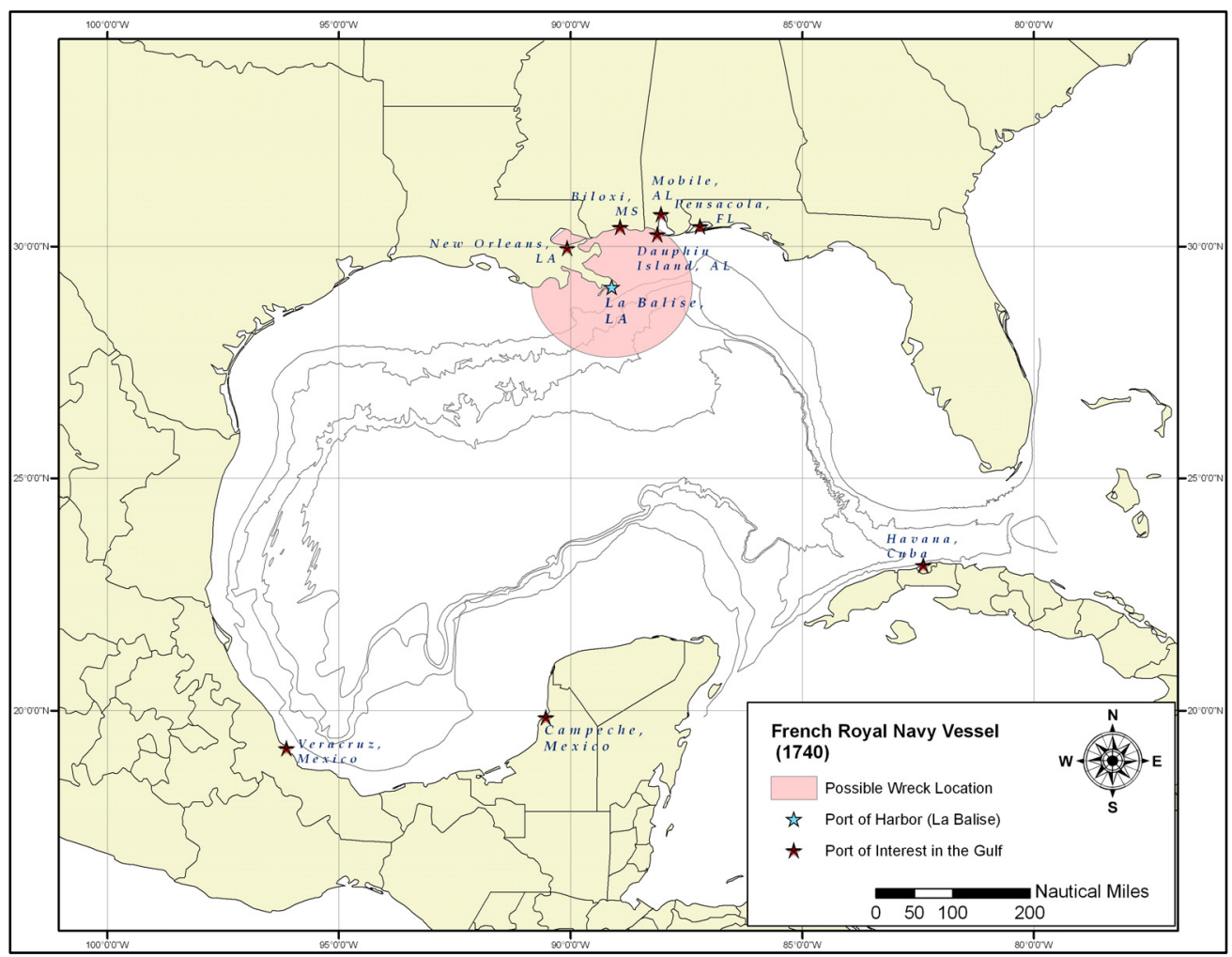

Figure 5-50. Map showing possible wreck zone of a French Royal Navy vessel (1740).

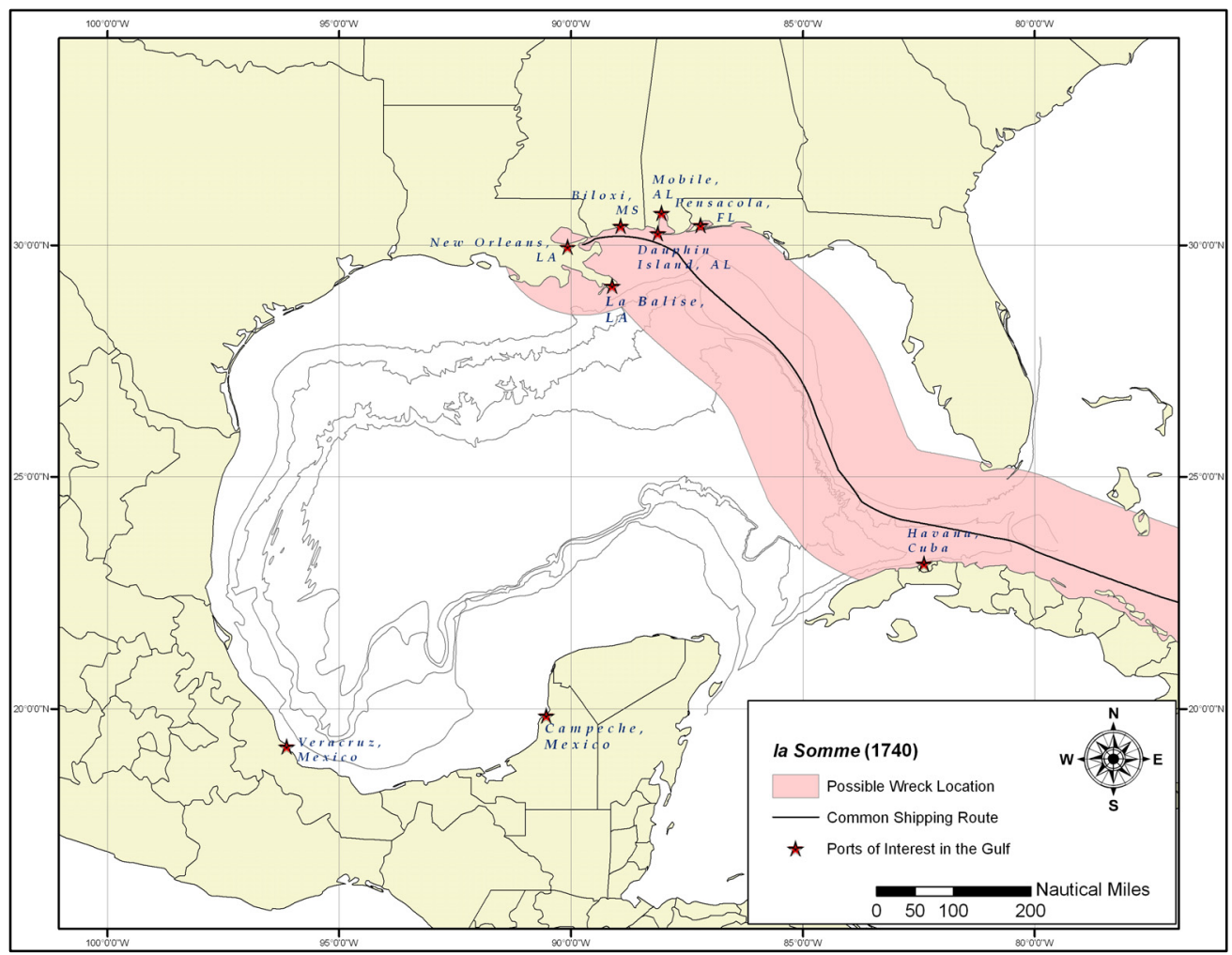

Figure 5-51. Map showing possible wreck zone of the French vessel la Somme (1740). 


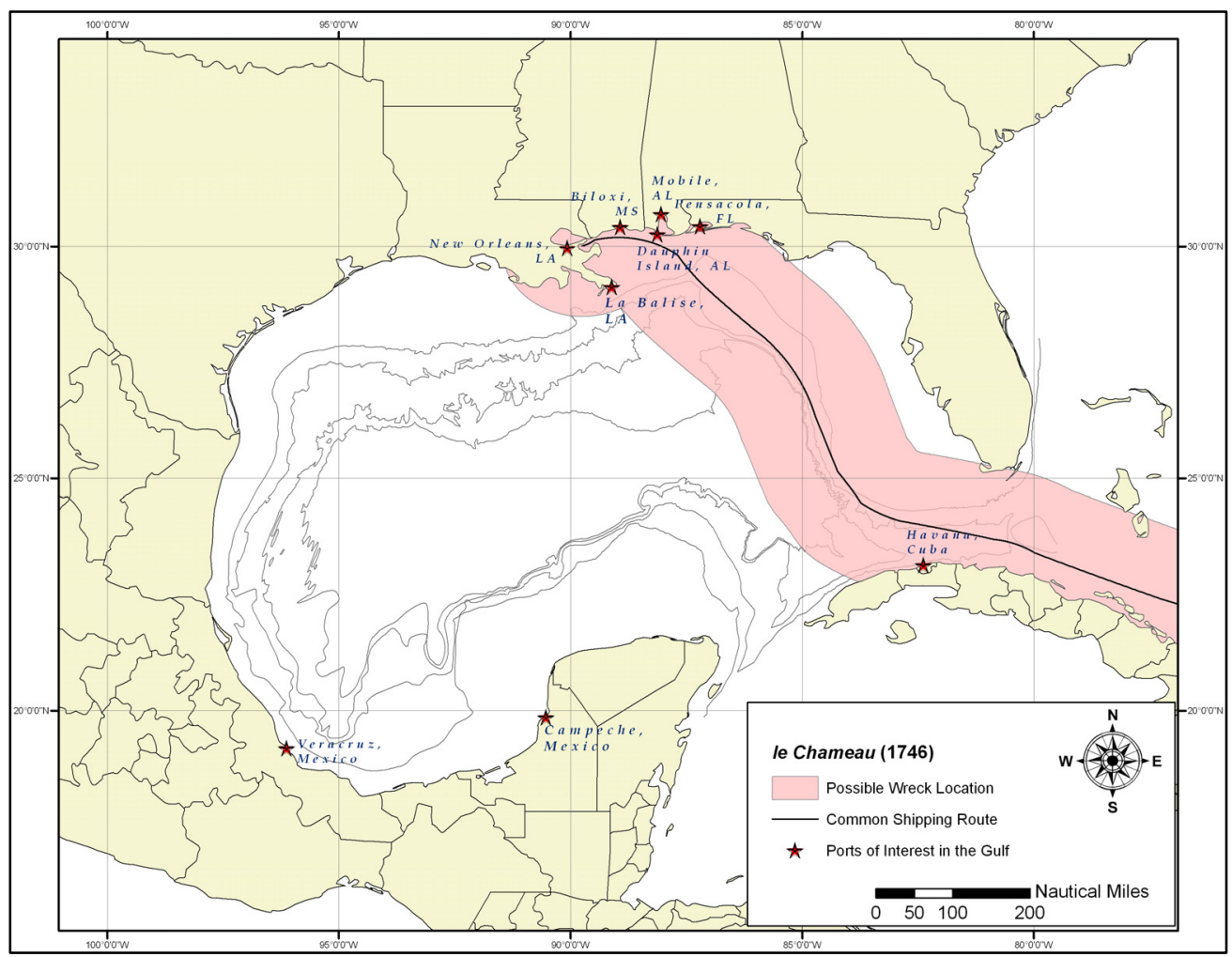

Figure 5-52. Map showing possible wreck zone of the French vessel le Chameau (1746). 
Table 5-13

Vessels with Potential for Location within the Study Area

\begin{tabular}{|c|c|c|c|c|c|c|c|}
\hline $\begin{array}{c}\text { Lost } \\
\text { Ship } \\
\text { Number }\end{array}$ & $\begin{array}{l}\text { Nationality } \\
\text { of Vessel }\end{array}$ & $\begin{array}{l}\text { Year } \\
\text { Lost }\end{array}$ & $\begin{array}{l}\text { Name of } \\
\text { Ship }\end{array}$ & $\begin{array}{c}\text { Name } \\
\text { of } \\
\text { Owner }\end{array}$ & $\begin{array}{c}\text { Port of } \\
\text { Departure }\end{array}$ & $\begin{array}{c}\text { Port of } \\
\text { Destination }\end{array}$ & $\begin{array}{l}\text { Presumed } \\
\text { Area of } \\
\text { Sinking }\end{array}$ \\
\hline 1 & Spanish & 1783 & Galgo & & Havana & $\begin{array}{l}\text { New } \\
\text { Orleans }\end{array}$ & $\begin{array}{l}\text { Gulf of } \\
\text { Mexico }\end{array}$ \\
\hline 2 & Spanish & 1787 & Sandoval & & Havana & Veracruz & $\begin{array}{l}\text { Gulf of } \\
\text { Mexico }\end{array}$ \\
\hline 3 & Spanish & 1817 & Descubridor & & Havana & Veracruz & $\begin{array}{l}\text { Gulf of } \\
\text { Mexico }\end{array}$ \\
\hline 10 & French & 1772 & $\begin{array}{l}\text { Marie } \\
\text { Thérèse }\end{array}$ & & $\begin{array}{l}\text { New } \\
\text { Orleans }\end{array}$ & $\begin{array}{l}\text { Port-au- } \\
\text { Prince }\end{array}$ & $\begin{array}{l}\text { Gulf of } \\
\text { Mexico }\end{array}$ \\
\hline 11 & French & 1725 & la Bellone & & Mobile & France & $\begin{array}{l}\text { Dauphin } \\
\text { Island, } \\
\text { Alabama }\end{array}$ \\
\hline 12 & French & 1732 & $\begin{array}{l}\text { Royal Ship } \\
\text { (name } \\
\text { unknown) }\end{array}$ & $\begin{array}{l}\text { French } \\
\text { Royal } \\
\text { Navy }\end{array}$ & $\begin{array}{l}\text { France \& } \\
\text { Cap } \\
\text { François } \\
\text { (Cape } \\
\text { Haitian) }\end{array}$ & $\begin{array}{l}\text { New } \\
\text { Orleans }\end{array}$ & $\begin{array}{l}\text { Gulf of } \\
\text { Mexico }\end{array}$ \\
\hline 13 & English & 1732 & $\begin{array}{l}\text { (name } \\
\text { unknown) }\end{array}$ & & & & $\begin{array}{l}\text { Gulf of } \\
\text { Mexico }\end{array}$ \\
\hline 14 & French & 1740 & $\begin{array}{l}\text { Royal Ship } \\
\text { (name } \\
\text { unknown) }\end{array}$ & $\begin{array}{l}\text { French } \\
\text { Royal } \\
\text { Navy }\end{array}$ & France & Mobile & $\begin{array}{l}\text { Gulf of } \\
\text { Mexico }\end{array}$ \\
\hline 15 & French & 1740 & la Somme & $\begin{array}{l}\text { French } \\
\text { Royal } \\
\text { Navy }\end{array}$ & $\begin{array}{l}\text { Cap } \\
\text { François } \\
\text { (Cape } \\
\text { Haitian) } \\
\end{array}$ & $\begin{array}{l}\text { New } \\
\text { Orleans }\end{array}$ & $\begin{array}{l}\text { Gulf of } \\
\text { Mexico }\end{array}$ \\
\hline 16 & French & 1746 & le Chameau & $\begin{array}{l}\text { French } \\
\text { Royal } \\
\text { Navy }\end{array}$ & France & $\begin{array}{l}\text { New } \\
\text { Orleans }\end{array}$ & $\begin{array}{l}\text { Gulf of } \\
\text { Mexico (?) }\end{array}$ \\
\hline
\end{tabular}




\subsection{CONCLUSIONS}

\subsection{Project Background}

The primary objective of the current investigation intended to locate primary documentation relative to historic vessel losses within the GOM from 1500 to about 1830. More specifically, the study was to focus on vessels lost in Ultra-Deepwater (UDW) in the U.S. Exclusive Economic Zone (EEZ) of the Northern Gulf of Mexico (GOM). Previous studies within the GOM have suggested that such wrecks in UDW are present in negligible numbers, based primarily on research of secondary sources. While early-period vessels (such as the 1554 fleet off Padre Island, Texas, and El Nuevo Constante [1766] off Louisiana) have been identified in the GOM, most have been located near shore, in relatively shallow-water environments. While these vessels were wrecked as a result of adverse weather conditions (i.e., hurricanes), no studies have been conducted addressing vessels lost far from land as a result of other causes, such as fire, hull failure, foundering, or armed attack (Lugo-Fernandez et al. 2007:38).

Over the past few years a number of colonial-era wreck sites have been identified within UDW, including the Mica Wreck (1775-1830) and the Mardi Gras Wreck (1810-1820). These vessels have typically been located during remote-sensing surveys associated with oil and gas activities within the GOM. Discovery of these vessels prompted BOEMRE to reconsider the potential for such wrecks in UDW and is the basis for the current investigation.

BOEMRE subsequently contracted with SEARCH of Pensacola, Florida, to conduct primary research at a variety of repositories in an effort to identify additional vessel losses within UDW. The repositories to be visited were proposed by SEARCH and approved by BOEMRE prior to research activities. Relevant documents identified and acquired at these repositories were ultimately to be transcribed and translated to English by a professional paleographer. Historical data and imagery acquired under the contract was to be analyzed to identify each vessel casualty and establish its type, date of construction, nationality, ownership (past and present), use history, mission, and cargo (if any) at time of loss, as well as factors contributing to its loss. One of the goals of the analysis was to determine each vessel's likely location and potential present condition. More specifically, archival information relative to colonial-era shipwrecks will augment BOEMRE's ability to utilize adaptive management strategies in their regulation of OCS oil and gas activities within the GOM in an effort to minimize impacts to potentially significant submerged cultural resources.

SEARCH identified archival repositories considered most relevant to the current investigation. These repositories included international repositories in Spain and Mexico as well as national repositories in St. Augustine, Florida, and the P.K. Yonge Library of Florida History at the University of Florida in Gainesville, Florida.

Since the majority of colonial-period shipwrecks within BOEMRE's jurisdiction would almost exclusively be associated with Spanish fleets leaving annually from Veracruz, Mexico, bound for Havana, Cuba, and eventually sailing for Spain, SEARCH proposed to focus exclusively on Spanish and Mexican archives as well as pertinent archives within the United States. The primary repositories identified included the Archivo General de Indias (AGI), Seville, Spain; the 
Archivo General de Simancas (AGS), Valladolid, Spain; the Museo Naval (MNM), Madrid, Spain; and the Archivo General de la Nación (AGN-M), Mexico City, Mexico.

These repositories were approved by BOEMRE, and archival research commenced during October 2008 at the AGI in Seville, Spain. During research efforts at the AGI, conversations with those familiar with the holdings at the AGI as well as other proposed archives in Spain (AGS and MNM) deduced that, considering the minimal time allotted for such an endeavor, time would be better spent solely at the AGI (versus the other two repositories in Spain). BOEMRE approved the change, and research efforts continued at the AGI. Work at the AGI was completed in late November 2008.

Additional research efforts proposed by SEARCH involved research at the Archivo General de la Nación (AGN-M) in Mexico City, Mexico. It was believed that this repository had high potential for identifying ships lost at sea in the GOM. There are two major sections of interest at this repository including the Marina and Consulados (Merchant Guilds) record group. Both groups contain correspondence dealing with maritime traffic, including ship loss reports, cargoes, owners, captains, and crew members. Archival data relevant to El Nuevo Constante, lost off the coast of Louisiana in 1766, are located at this repository. It was determined that this repository should be visited only if documents located at the AGI suggested that missing documentation may be located in the AGN-M.

Review of the records at the AGI, and subsequent conversations with other researchers familiar with the AGN-M, however, suggested that the repository may produce little to no results with regard to identifying primary archival documents relative to potential historic shipwrecks within UDW. Based on this information, it was determined that time may be better spent at another repository.

To provide BOEMRE with the most pertinent data possible, SEARCH requested a change to the archival research plan to conduct research within two archival repositories in France. These repositories include the Archives Nationales (National Archives) in Paris and the Centre des Archives d'Outre-Mer (CAOM) in Aix-en-Provence, France. This revision to the archival research plan was approved by BOEMRE and SEARCH began archival research in March 2009. This work was concluded by the middle of June 2009.

Lastly, in September 2009, SEARCH conducted archival research at the St. Augustine Foundation's Center for Historic Research in St. Augustine, Florida, as well as the P.K. Yonge Library of Florida History at the University of Florida in Gainesville, Florida. A total of one week of research was completed at each archive.

To assist in interpreting archival data acquired during the current investigation, SEARCH then used the data obtained from the archival research to reexamine sailing routes within the GOM. Primary and secondary sources, including cargo manifests and shipping documentation, were reviewed to determine the probable location for unaccounted vessels that may have been lost in UDW. A predictive model of colonial-era shipwrecks, potentially located in UDW of the GOM, was then developed. 


\subsection{Archivo General de Indias (AGI), Seville, Spain}

A total of 64 individual legajos were examined during the six-week period in the AGI, in Seville, Spain. Within these legajos, thousands of folios (individual documents) were scrutinized in various sections of the repository. Overall, 31 sets of documents were collected, transcribed, and translated. Within these 31 documents, nine Spanish vessels were identified as potential vessel losses within UDW of the GOM (Table 6-1).

Table 6-1

Vessel Losses Potentially within UDW of the GOM Identified at the AGI

\begin{tabular}{|c|c|c|c|c|c|c|}
\hline $\begin{array}{c}\text { Lost Ship } \\
\text { Number }\end{array}$ & Nationality & $\begin{array}{l}\text { Year } \\
\text { Lost }\end{array}$ & $\begin{array}{l}\text { Name of } \\
\text { Ship }\end{array}$ & $\begin{array}{c}\text { Port of } \\
\text { Departure }\end{array}$ & $\begin{array}{c}\text { Port of } \\
\text { Destination }\end{array}$ & Observations \\
\hline 1 & Spanish & 1783 & Galgo & Havana & $\begin{array}{l}\text { New } \\
\text { Orleans }\end{array}$ & $\begin{array}{l}\text { Duro writes that the } \\
\text { ship capsized and } \\
\text { then nothing else } \\
\text { was heard of it; Duro } \\
\text { does not cite his } \\
\text { source. }\end{array}$ \\
\hline 2 & Spanish & 1787 & Sandoval & Havana & Veracruz & $\mathrm{n} / \mathrm{a}$ \\
\hline 3 & Spanish & 1817 & Descubridor & Havana & Veracruz & $\begin{array}{l}\text { The 14-gun } \\
\text { brigantine } \\
\text { disappeared in late } \\
\text { September } 1817 \text { and } \\
\text { was never heard of } \\
\text { again; aboard the } \\
\text { ship were } 8 \text { officials } \\
\text { and } 112 \text { sailors and } \\
\text { soldiers. }\end{array}$ \\
\hline 4 & Spanish & 1600 & $\begin{array}{l}\text { San Antonio } \\
\text { de Padua }\end{array}$ & $\begin{array}{l}\text { Havana } \\
\text { (assumed) }\end{array}$ & Veracruz & $\mathrm{n} / \mathrm{a}$ \\
\hline 5 & Spanish & 1600 & $\begin{array}{l}\text { Santa } \\
\text { Catalina de } \\
\text { Sena }\end{array}$ & $\begin{array}{l}\text { Havana } \\
\text { (assumed) }\end{array}$ & Veracruz & $\mathrm{n} / \mathrm{a}$ \\
\hline 6 & Spanish & 1600 & $\begin{array}{l}\text { (name } \\
\text { unknown) }\end{array}$ & $\begin{array}{l}\text { Havana } \\
\text { (assumed) }\end{array}$ & Veracruz & $\begin{array}{l}\text { Ship of the } 1600 \\
\text { fleet; presumed to } \\
\text { have sunk during } \\
\text { hurricane; had a } \\
\text { cargo of mercury. }\end{array}$ \\
\hline 7 & Spanish & 1600 & $\begin{array}{l}\text { (name } \\
\text { unknown) }\end{array}$ & $\begin{array}{l}\text { Havana } \\
\text { (assumed) }\end{array}$ & Veracruz & $\begin{array}{l}\text { Ship of the } 1600 \\
\text { fleet; presumed to } \\
\text { have sunk during } \\
\text { hurricane; patache to } \\
\text { the fleet. }\end{array}$ \\
\hline 8 & Spanish & 1719 & $\begin{array}{l}\text { San Juan } \\
\text { Bautista }\end{array}$ & Cádiz & Veracruz & $\begin{array}{l}\text { The } 60 \text {-gun warship } \\
\text { was reported lost in } \\
\text { the Gulf of Mexico } \\
\text { with all souls. }\end{array}$ \\
\hline 9 & Spanish & 1612 & San Nicolás & Havana (?) & Veracruz & $\begin{array}{l}\text { The } 50 \text {-ton zabra } \\
\text { was reported lost } \\
\text { before arriving in } \\
\text { Veracruz. }\end{array}$ \\
\hline
\end{tabular}


Review of these potential vessel losses indicates that eight of the vessels were reported as sailing from Havana to Veracruz at the time of loss and were, therefore, likely sailing on a southern route within the Gulf of Mexico. While it may be anticipated that these vessels may have been lost within the southern GOM (outside of BOEMRE's jurisdiction), review of historically documented vessel losses indicates that vessels sometimes remained afloat for some time before sinking. In addition, the actual cause of loss (i.e., weather related, fire, explosion, attack) is not known for any of these vessels, which would certainly influence the actual location of loss. Therefore, without additional documentation to support a more precise location of loss, these vessels should be considered potential candidates for this study. It should also be noted that the outbound port for a number of these vessels is assumed to be Havana as that port was a common stopping point for vessels sailing from Spain to Veracruz. No documentation was identified within the primary documents to support this assumption other than it was a common occurrence for vessels to stop at this port. Documentation, does however, support the opinion that these vessels were indeed lost within the GOM.

One vessel, Galgo (reported lost in 1783), was sailing from Havana to New Orleans and therefore would likely have been sailing on a route closer to the current study area. However, similarly to the previously mentioned vessels, the cause of loss is not known and, therefore, identifying its location is speculative.

\subsection{Archives Nationales, Paris, France}

The Archives Nationales in Paris, France, includes a naval section that was reviewed by SEARCH. Considered one of the largest and most important archival collections in the world, the Archives Nationales was created in 1790. The archive houses over 226 linear miles of historic documents dating from A.D. 625 to the present. Several promising leads were developed at the Archives Nationales, but time ran out and no potential vessel losses within the GOM were identified at this repository. This is a very rich and vast repository with an important maritime section focused on French Navy ship traffic, missions, and losses. It is very likely that future research efforts at this repository may identify pertinent vessel losses within the GOM.

\subsection{Centre des Archives d'Outre-Mer (CAOM), Aix-en-Provence, France}

The time spent at the CAOM was very productive and contributed to a better understanding of the sea routes used by French and Spanish ships within the GOM during the sixteenth to eighteenth centuries. A total of seven potential vessel losses was identified at the CAOM, including six French vessels and one English vessel (Table 6-2).

From review of the various ports of departure and intended ports of arrival, it is clear that there may be a higher potential for French shipwrecks within the current study area. Sailing to and from various ports along the Gulf Coast (such as Mobile and New Orleans), these vessels would have likely been transiting along routes within the northern reaches of the GOM at the time of loss. However, as the cause of loss, or how far a particular vessel may have traveled before sinking, is not known from the primary documents examined, it is unlikely that the actual location of loss can be accurately determined for any of these vessels. 
Table 6-2

Vessel Losses Potentially within UDW of the GOM Identified at the CAOM

\begin{tabular}{|c|c|c|c|c|c|c|}
\hline $\begin{array}{l}\text { Lost Ship } \\
\text { Number }\end{array}$ & Nationality & $\begin{array}{l}\text { Year } \\
\text { Lost }\end{array}$ & $\begin{array}{l}\text { Name of } \\
\text { Ship }\end{array}$ & $\begin{array}{l}\text { Port of } \\
\text { Departure }\end{array}$ & $\begin{array}{l}\text { Port of } \\
\text { Destination }\end{array}$ & Observations \\
\hline 10 & French & 1772 & $\begin{array}{l}\text { Marie } \\
\text { Thérèse }\end{array}$ & $\begin{array}{l}\text { New } \\
\text { Orleans }\end{array}$ & $\begin{array}{l}\text { Port-au- } \\
\text { Prince }\end{array}$ & $\begin{array}{l}\text { Ship reported lost } \\
\text { between New Orleans } \\
\text { and Port-au-Prince with } \\
\text { all souls, and a cargo } \\
\text { of } 140,000 \text { pounds of } \\
\text { cannon. }\end{array}$ \\
\hline 11 & French & 1725 & la Bellone & Mobile & France & $\begin{array}{l}\text { Ship sank while at } \\
\text { anchor off Dauphin } \\
\text { Island; all cargo and } \\
\text { personnel effects lost. }\end{array}$ \\
\hline 12 & French & 1732 & $\begin{array}{l}\text { Royal Ship } \\
\text { (name } \\
\text { unknown) }\end{array}$ & $\begin{array}{l}\text { France \& } \\
\text { Cap } \\
\text { François } \\
\text { (Cape } \\
\text { Haitian) }\end{array}$ & $\begin{array}{l}\text { New } \\
\text { Orleans }\end{array}$ & $\begin{array}{l}\text { Ship sailed from } \\
\text { France in early June } \\
1732 \text {, then sailed from } \\
\text { Cape François on } \\
\text { August } 5,1732 \text {, bound } \\
\text { for New Orleans and } \\
\text { was never heard of } \\
\text { again. }\end{array}$ \\
\hline 13 & English & 1732 & $\begin{array}{l}\text { (name } \\
\text { unknown) }\end{array}$ & $\mathrm{n} / \mathrm{a}$ & $\mathrm{n} / \mathrm{a}$ & $\begin{array}{l}\text { Wreckage of ship was } \\
\text { found between Mobile } \\
\text { and Pensacola along } \\
\text { with the bodies of two } \\
\text { Englishmen. }\end{array}$ \\
\hline 14 & French & 1740 & $\begin{array}{l}\text { Royal Ship } \\
\text { (name } \\
\text { unknown) }\end{array}$ & France & Mobile & $\begin{array}{l}\text { Ship was moored at La } \\
\text { Balise (Lookout Island } \\
\text { at the mouth of the } \\
\text { Mississippi) when a } \\
\text { strong gust of wind } \\
\text { took the ship far out to } \\
\text { sea, presumably in } \\
\text { deepwater; nothing } \\
\text { was heard of her again. }\end{array}$ \\
\hline 15 & French & 1740 & la Somme & $\begin{array}{l}\text { Cape } \\
\text { François } \\
\text { (Cape } \\
\text { Haitian) }\end{array}$ & $\begin{array}{l}\text { New } \\
\text { Orleans }\end{array}$ & $\begin{array}{l}\text { Ship's hull was repaired } \\
\text { in Cape François after } \\
\text { she had grounded on a } \\
\text { reef; sailed for New } \\
\text { Orleans and was never } \\
\text { heard of again. }\end{array}$ \\
\hline 16 & French & 1746 & $\begin{array}{l}\text { le } \\
\text { Chameau }\end{array}$ & France & $\begin{array}{l}\text { New } \\
\text { Orleans }\end{array}$ & $\begin{array}{l}\text { Ship sailed from } \\
\text { France in June } 1746 \\
\text { with important official } \\
\text { documents and was } \\
\text { never heard of again. }\end{array}$ \\
\hline
\end{tabular}

An assessment of two of the vessels presented in Table 6-2 may indicate these vessels were lost within shallow water and not necessarily in UDW of the GOM. This includes the loss of la Bellone (Lost Ship Number 11), which sank while at anchor off Dauphin Island in 1725, as 
well as the unknown English vessel (Lost Ship Number 13), of which wreckage was reported between Mobile and Pensacola in 1732. While it may be speculated that the French royal ship (Lost Ship Number 14) also wrecked in shallow water off the mouth of the Mississippi River (La Balise), it is possible that this vessel was pushed far into the Gulf of Mexico and eventually sank in UDW.

Examination of the various accounts provides some interesting information relative to specific wreck losses that may assist BOEMRE in identifying certain sites in the future. For example, the loss of the French vessel Marie Thérèse indicates the vessel was lost with 140,000 pounds of cannon. Identifying a specific wreck site with a large number of associated cannon may be a clear indicator that it is in fact Marie Thérèse. Another vessel, le Chameau, if found in the future, may appear to not have much associated cargo as this vessel was reported as sailing with "important official documents." This type of cargo would likely have deteriorated quickly after the wreck event, leaving little more than hull remains and perhaps a sizable amount of ballast. Lastly, the account of the French vessel la Somme (Lost Vessel Number 15) indicates the vessel underwent hull repairs in Cape François (present-day Cape Haitian). Recovery of wood samples from a given wreck site indicating repairs using New World timber may help identify the vessel as that of la Somme. While these are very specific pieces of information relative to specific wrecks, they may assist BOEMRE in identifying future wreck sites.

\subsection{St. Augustine Foundation's Center for Historic Research, St. Augustine, Florida}

In the restricted amount of time allocated for research in this repository, no documents dealing with Florida's west coast maritime traffic and affairs were located. This is not to say that documents of interest cannot be located there, but a considerable amount of time would be needed to sift through the microfilm collection. It should be noted that conducting research by scrutinizing manuscript documents on microfilm is considerably slower than going through legajos of original documents.

\subsection{P.K. Yonge Library of Florida History, University of Florida, Gainesville, Florida}

Research at the P.K. Yonge Library of Florida History proved useful in identifying several vessel losses within the GOM (Table 6-3). However, scrutiny of the documents relative to these loss accounts indicates that all of the vessels were wrecked in shallow water and therefore may not be pertinent to the current investigation. Regardless, the information gathered is presented in Table 6-3.

While these vessels may not have foundered within UDW of the GOM, they do provide interesting information relative to vessel types, nationalities, routes, and cargos transiting the region during the late eighteenth century. It is clear from Table 6-3 that the majority of vessels lost were brigantines (four total) versus schooners (two total) and one bilander. Whether brigantines were the preferred type of sailing vessel during this period and therefore would have had a higher incidence of wrecking remains unknown. It is also interesting to note that by the late 
Table 6-3

Vessel Losses within the GOM Identified at the P.K. Yonge Library of Florida History

\begin{tabular}{|c|c|c|c|c|c|c|c|c|}
\hline Vessel & Year & Vessel Type & Nationality & Owner & Route & Cargo & $\begin{array}{l}\text { Reason } \\
\text { for Loss }\end{array}$ & Location \\
\hline $\begin{array}{l}\text { Nuestra } \\
\text { Señora del } \\
\text { Carmen }\end{array}$ & 1785 & Brigantine & $\begin{array}{l}\text { Spanish } \\
\text { (Mexican) }\end{array}$ & Unknown & Unknown & $\begin{array}{l}\text { Mexican } \\
\text { Infantry- } \\
\text { men and } \\
\text { civilians }\end{array}$ & $\begin{array}{l}\text { Adverse } \\
\text { weather }\end{array}$ & $\begin{array}{l}\text { Off St. } \\
\text { George } \\
\text { Island }\end{array}$ \\
\hline $\begin{array}{l}\text { la } \\
\text { Esperanza }\end{array}$ & 1785 & Brigantine & Unknown & Unknown & Unknown & Unknown & $\begin{array}{l}\text { Adverse } \\
\text { weather }\end{array}$ & $\begin{array}{l}\text { Off Santa } \\
\text { Rosa Island }\end{array}$ \\
\hline San Andrés & 1785 & Brigantine & Unknown & Unknown & Unknown & Unknown & Unknown & $\begin{array}{l}\text { Off Santa } \\
\text { Rosa Island }\end{array}$ \\
\hline $\begin{array}{l}\text { San } \\
\text { Salvador }\end{array}$ & 1786 & Brigantine & Unknown & $\begin{array}{l}\text { Juan } \\
\text { Salineau }\end{array}$ & Unknown & $\begin{array}{l}\text { "Negros" } \\
\text { (slaves); } \\
\text { other } \\
\text { items }\end{array}$ & $\begin{array}{l}\text { Adverse } \\
\text { weather }\end{array}$ & $\begin{array}{l}\text { Near Cape } \\
\text { San Blas }\end{array}$ \\
\hline $\begin{array}{l}\text { la } \\
\text { Resolución }\end{array}$ & 1795 & Bilander & Unknown & Henry Young & $\begin{array}{l}\text { Bound for } \\
\text { Savannah } \\
\text { from } \\
\text { Jamaica }\end{array}$ & $\begin{array}{l}\text { Coffee, } \\
\text { sugar } \\
\text { (salvaged) }\end{array}$ & Unknown & $\begin{array}{l}\text { On Santa } \\
\text { Rosa Island }\end{array}$ \\
\hline Quántico & 1795 & Schooner & American & Unknown & $\begin{array}{l}\text { Bound for } \\
\text { Pensacola } \\
\text { from New } \\
\text { Providence }\end{array}$ & Flour & Unknown & Unknown \\
\hline $\begin{array}{l}\text { Dos } \\
\text { Hermanas }\end{array}$ & 1808 & Schooner & American & $\begin{array}{l}\text { Bartolome } \\
\text { Bosque }\end{array}$ & Unknown & Flour & Unknown & Isla Guinal \\
\hline
\end{tabular}

eighteenth century, the term "American" is used with regard to the nationality of vessels. Whereas early vessel losses within the GOM would be almost solely Spanish, followed by French, and later English, the use of the term "American" as a nationality likely was fairly new.

In addition, the types of cargo (i.e., coffee, sugar, and flour) on a variety of the vessels lost indicate a growth in commerce and trade routes within the GOM during the late eighteenth century.

\subsection{Route Variability}

As the French colony of la Louisiane was developing and taking shape in the early part of the eighteenth century, with France and Spain becoming allies following Philip V's ascension to the throne of Spain, maritime traffic in the GOM increased and became more diversified. Ships now sailed regularly between the ports of New Orleans, Pensacola, and Veracruz, and as Spanish vessels often stopped in the French ports on their way to Cuba, traditional routes were modified. While Escalante de Mendoza (1575) and various derroteros (routes) offer guidance and proposed sailing routes to masters and their vessels, actual routes greatly varied depending on a number of factors, including personal choice. The vast majority of maritime traffic in the GOM is represented by ships sailing alone (navios sueltos y sin flota), leaving the choice of sailing routes to the discretion of the master or pilot. We can surmise that a not-so-negligible number of captains preferred sacrificing time for safety and sailed close enough to the coast to keep it within sight. As a case in point, the mail brigantine Floridablanca sailed from Veracruz on August 23, 1797, in the company of a war brigantine and a merchant schooner, only to lose sight of them three days later. After 30 days of sailing in adverse weather conditions, the ship reached the Dry Tortugas, which suggests Floridablanca was sailing rather close along the coast of the 
Florida peninsula (AGI Correos, 263B 2). Although her destination was the port of Havana, six days later Floridablanca found herself north of the Cay Sal Bank, where she was eventually captured by a privateer and taken to New Providence in the Bahamas. This incident clearly illustrates the type of navigational error commonly made in those days.

Another example of a ship sailing on a different route to reach Havana is the case of the Inés de Soto Shipwreck, discovered in 1992 on the Inés de Soto Reef within the Archipiélago de los Colorados off the northwest coast of Cuba (Escobar et al. 1998:51). This small, unidentified shipwreck occurred in the middle of the sixteenth century, possibly in 1555 or 1556; the lack of archival data and the material culture excavated by Cuban archaeologists combine to suggest that the ship was involved in illicit salvage of the 1554 Padre Island shipwrecks (Pino et al. 1998:241-242). If this is true, then it appears that the ship sailed southeastward across the GOM to Cabo San Antonio on the western tip of Cuba and along the northwestern coast of the island before hitting a reef and sinking in less than 3 meters of water, approximately 4 nautical miles from the modern-day city of La Esperanza. Although the sailing route taken by this particular ship was most likely to avoid detection, it nevertheless demonstrates that ship captains and navigators did not always use the established sailing paths suggested by various routes (derroteros). Other ships sailing from Veracruz and other parts of Mexico are known to have sunk off Cabo San Antonio off Cuba (AGI Santo Domingo, 99 [1590]; Contratación, 2298 [1591]). In another case, an English brigantine sailing from New Orleans to French Hispaniola sank off Cabo San Antonio in 1775 (AGI Cuba, 1180 and 1181).

The GOM was considered one of the most dangerous places in terms of navigation. Most of the danger was due to navigational hazards along the coast such as reefs (often hidden under sand), shifting sands, and weather. Because of those conditions, sailing time from Veracruz to Havana (some 1,300 kilometers) varied between 18 and 56 days depending on winds and currents, with an average sailing time of 33 days (Chaunu 1959:697). The GOM had the advantage of a rather high degree of protection against enemy attacks due to its relative isolation, navigational hazards, and navigational difficulties resulting from shifting winds and currents. In addition, the high incidence of hurricanes (something the Crown and Spanish colonial officials were well aware of), added to the difficulty of navigating within the Gulf. Yet it remained a very hazardous place for ships, and losses along the coast were significantly higher, in relation to the volume of maritime traffic, than at Havana, Nombre de Dios-Puerto Belo, and Cartagena (Chaunu and Chaunu 1955-1957:120-121).

It is for the above reasons that many captains and navigators preferred sailing within sight of the coast, avoiding sailing too close to steer clear of shoals and reefs, yet refraining from venturing too far out to sea for extended periods of time. An added inconvenience was the lack of Spanish ports around the Gulf. Veracruz was the only organized and well-defended port in the region, and Timiahua, Tampico, and Pánuco can hardly be counted as true ports that could accommodate larger ships. Chaunu writes that for a period of five and a half years, of 763 ships recorded sailing in and out of the Gulf, only six small barks sailed in and out of harbors other than Veracruz (Chaunu 1959:700). Campeche cannot be considered part of New Spain and was of little use for ships sailing between Veracruz and Havana. At best, sailing through the Gulf was unpredictable. 
An analysis of historic shipping routes combined with the results of primary archival research has revealed 10 shipwrecks that may be located within the UDW of the upper GOM. These vessels are of Spanish, French, and English origin and span a century of colonial history in the region. While 16 previously unknown vessels were identified in the archival research as being lost in the GOM during the sixteenth to eighteenth centuries, we are able to discount six based on the known routes taken between ports. All of these vessels were inbound Spanish ships traveling to Veracruz, Mexico. All but one of them was lost in the seventeenth century on the route between Havana and Veracruz, which our study has indicated to be in the extreme southern portion of the GOM and therefore outside the study area. The other was lost between Cadiz, Spain, and Veracruz, Mexico. This vessel, lost in 1719, would have taken a route that brought it into the Gulf via the Caribbean Sea and would have also followed the track into the lower Gulf. Figure 6-1 illustrates these routes in the sixteenth and seventeenth centuries.

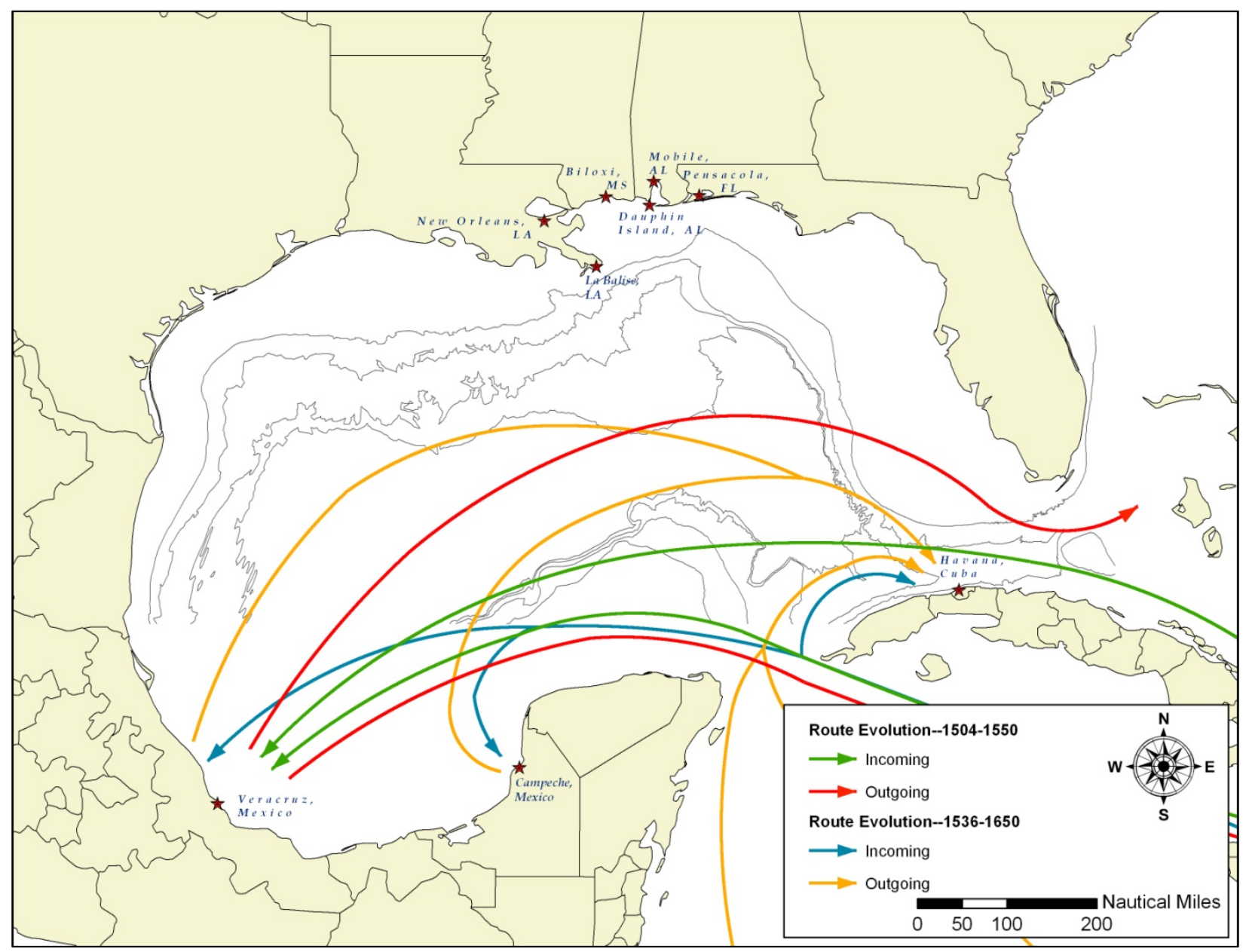

Figure 6-1. Sixteenth- and seventeenth-century shipping routes in the GOM (Chaunu and Chaunu 19551957:20-21). 


\subsection{RECOMMENDATIONS}

Results of the current investigation indicate that previously unidentified early-colonial-period vessel losses certainly exist within UDW of the GOM. However, determining where these vessel losses may have occurred within the GOM is complex, considering that many occurred away from land and with a total loss of life. Therefore, accurate accounts of where and when a vessel may have been lost are rarely available. One of the difficulties in determining where a vessel may have been lost within the GOM relates to vessel loss accounts and the navigational methods of the time. While a primary account may provide information relative to the location of a wreck event, it must be understood that sailing across open water mostly relied on dead reckoning until chronometers were developed in the eighteenth century:

Dead reckoning, in coastal waters or on the open sea, was one of the more common navigational methods. The pilot kept as accurate a record as he could of the ship's direction and speed. Direction, the course, was determined by a compass and speed by a chip of wood thrown overboard and timed (as the ship moved past). With a pair of dividers, the pilot kept a plot on his chart. But in a good wind, the ships did not sail in the exact direction the bow, or the compass, pointed. And estimates of speed were not exact.... Position fixing was somewhat crude away from land, yet methods were developed which remained the same in theory from 1500 to 1900 (Davis 1977:59).

Therefore, attempting to decipher where a wreck may have occurred along a particular sailing route can be difficult. One must consider estimated sailing times between ports, vessel type and speed, weather patterns, currents, and a number of other variables that ultimately affect where and when a specific vessel may have been lost. Coupled with limitations of primary documents (including vague locational information relative to a given vessel loss), estimating the location of a given shipwreck within UDW is nearly impossible. The problem of predicting vessel losses within the GOM has been addressed in the past:

It is apparent from these analyses that the "power of prediction" of the 1989 model [Garrison et al. 1989] in regards to shipwreck locations is extremely weak. The weakness lies, principally, in the lack of precision found in the geographic coordinates assigned to reported losses. This is certainly not surprising given the nature of much of the available information on locations of loss, and is a problem that was fully recognized by the 1989 Garrison et al. study.... If one wished to strengthen the location of loss information on the entire population of reported shipwrecks in the GOM, it would require an extensive amount of historical research, principally in primary documents, and how successful such an endeavor would be is unknown. Essentially, the locations of some wrecks are predictable and the MMS [now BOEMRE] archaeological survey program can be designed in such a way to account for this. On the other hand, the locations of a very large number of wrecks are not reliably predictable (Pearson et al. 2003:3-37).

With regard to the current investigation, it has been found that primary documents do not necessarily strengthen the location of loss of shipwrecks. In fact, the majority of documents 
found during the current investigation contained no reference to where a vessel may have wrecked other than it simply did not arrive at its intended destination. Therefore, plotting the location of a vessel loss within UDW by utilizing primary documents is still very subjective. While it may be easier to predict where vessels may have wrecked in a near-shore environment (by evaluating known obstructions, navigational hazards, established shipping routes, landmarks, proximity to established ports, and survivor accounts), the use of primary documents to establish vessel loss locations in UDW is unpredictable. The lack of precision involved with the geographic coordinates of a given vessel loss, the lack of eyewitness accounts associated with such vessel losses, variability in sailing routes, vessel speeds, and weather conditions all contribute to the randomness of vessel losses in UDW.

In addition, even if a location of vessel loss is presented within a primary document, it has been found that places regularly changed names, sometimes the result of an area's changing hands and other times the result of simple misunderstanding:

Coastal Environments, Inc. (1977:13) commented on the Spanish use of the term La Florida to refer to a huge area, encompassing parts of the Gulf of Mexico, Caribbean, and Atlantic Ocean. Some authors have placed sinkings in the Gulf of Mexico, when the only reference to the loss was "in La Florida." Numerous examples exist in changes in place names or of confusion as to where an early place name actually meant. For example, the French and Spanish originally used the name "Espîritu Santo" to refer to the Mississippi River; later the French and the Spanish used the name to refer to present-day Matagorda Bay on the central Texas coast, plus both also used the name "San Bernardo" to refer to Matagorda Bay, while the French at times used the name "Saint Louis" (Weddle 1985:369; 1991:77). Additionally, over time Spanish and French accounts named a variety of locations on the Gulf coast "Espîritu Santo" in part because of the serious misunderstandings of what was referred to in earlier accounts or errors in its true location (Weddle 1991:105) (Pearson et al. 2003:4-4).

Current research has also established that early sailing routes varied depending on weather, currents, and limitations of the vessels that were sailing these routes. It has also been found that while vessels sailing in fleets tended to stick to established routes, vessels sailing alone (or without a fleet) likely sailed the most convenient and quickest route available.

The current investigation has recognized that archival research relative to vessel losses within the GOM from the sixteenth to eighteenth centuries is a monumental task that simply cannot be thoroughly researched in a short period of time. The primary issue encountered during research activities involves the sheer amount of documents that must be reviewed in order to identify potential vessel losses within the GOM. The process of reviewing thousands of primary documents from the sixteenth to eighteenth centuries is a laborious process at best. As prominent researchers from the AGI communicated to SEARCH, not enough time was allocated for such an endeavor. The assertion that not enough time or resources were available to conduct a thorough review of primary documents applies to all repositories visited, not just the AGI. 
For example, approximately halfway through the research at the AGI in Seville, Spain, thousands of manuscript documents had been reviewed; however, only two or three promising wreck events were identified within the GOM. Discussions with the director of the archives, Doña María Isabel Simo, Victoria Stappels-Johnson (a well-known and respected Canadian researcher who came to Seville some 25 years ago to work on her doctoral thesis on paleography and ended up staying at the AGI), and Michel Paret (a French archival researcher who had been conducting research at the AGI since the 1960s) all indicated that simply not enough time was allocated for such an endeavor.

Doña María Isabel Simo expressed her opinion that the time allocated for such research was entirely too short and pointed out that when Pierre and Huguette Chaunu conducted research for their landmark publication Séville et l'Atlantique, 1504-1650 (Chaunu 1959; Chaunu and Chaunu 1955-1957), they spent five full years in Seville and employed six other paleographers/researchers full time. Even with a team of seven archival researchers, not a single loss in the open GOM was recorded with any degree of certainty.

Researching specific items in the AGI is a complicated endeavor; there are 16 different sections for a total of 49,666 legajos (bundles of documents), each legajo containing anywhere from a few hundreds to thousands of folios. While the individual legajos are indexed, there are no detailed listings of contents except for vague information such as "general correspondence between the governor of Veracruz and the Crown" or "correspondence from secular persons," among other categories, and such correspondences can span several years. A letter from the governor of Veracruz, for instance, can be quite long, and if there are any mentions of ships not arriving at their intended destination, missing ships, shipwrecks, etc., it may be in the middle part of the letter or even toward the end, depending on the seriousness of the impact such a loss or potential loss may have had on the local economy or strategic aspects of the colonial outpost or port. This is why a researcher has to "scan" through every single folio to make sure not to overlook any leads on potential shipwrecks. To further complicate the task at hand, such bits and pieces of relevant data are potentially located practically anywhere, and it is difficult to predetermine where to look. The problem is compounded by the fact that most ship loss reports are very sketchy, at best, and that bits and pieces of data are scattered among various sections; it is even common to find a ship loss report only mentioning the name of the master or owner, with no ship's name given.

When it comes to detailed information about construction, ownership of the vessels, names of captains, and nature of cargoes, this information can usually be found in depositions given at trials and civil litigations following losses of ships. Unfortunately, this type of data is usually found in the Archivo General de Protocolos de Sevilla (AGPS), an obscure repository that is poorly indexed. Script used by notaries and court clerks from the fifteenth through eighteenth centuries is extremely difficult to decipher, and thus is time consuming. Chaunu and Chaunu (1955-1957, 1959), for example, used the services of a paleographer specializing in this particular script to transcribe and translate such documents.

The current investigation also found that numerous documents found within various repositories simply cannot be deciphered due to poor preservation. It is common to find folios in such a poor state of preservation that they are impossible to read. In other cases, an entire legajo was 
literally falling apart and had to be returned with no possibility of going through any of the documents. This was the case with a couple of legajos deemed worth scrutinizing. AGI Consuldos, 853 was in such deplorable condition that when researchers unpacked and attempted to leaf through the documents, the few folios completely fell apart and work had to stop. AGI Consulados, Libro 402 was in extremely bad condition, eaten throughout by worms, and it was impossible to glean any useful data. Such problematic conditions were sporadically encountered in a number of the legajos consulted. There is no remedy for primary documents in a state of deterioration other than to report those that are illegible.

Other difficulties encountered were bad penmanship, undecipherable words (often due to misspelling), ink blotches, and holes caused by the ink acidity, making certain words or names unreadable. When ink bleeds through a page, it makes it quite difficult to read the text on that particular folio. The problem is magnified when working on photocopies, making the transcription work very slow. Overall, the latter were minor problems and most documents of interest could be accurately transcribed.

While this investigation has been successful in identifying additional vessel losses within the GOM, it may not be economically feasible to conduct similar research efforts in the future. Simply stated, this is an idealistic task considering the sheer amount of primary documentation available to researchers in numerous repositories in various countries. While this investigation confirmed that primary documents relative to such vessel losses can be found in appropriate international and national repositories, time may be better spent relying on remote-sensing surveys to identify undocumented wreck sites within the GOM, followed by archival research specific to that site. Analysis of hull remains and cargo can certainly narrow the scope of research relative to a specific site, allowing researchers to focus more on a specific time period and nationality.

Review of known shipwrecks sites located in UDW within the GOM has also determined that in all likelihood a vessel dating from the sixteenth to eighteenth century will be exposed to some degree on the seafloor. Examples presented within this report, including the Mica Wreck and the Mardi Gras Wreck, clearly indicate that vessels located in deepwater have a good chance of being exposed, even after hundreds of years on the seafloor. Even vessels located in shallower water within the GOM were found to be exposed to some degree (including El Nuevo Constante and El Cazador).

As research has indicated, examination of a shipwreck's cargo can be valuable in potentially identifying a specific wreck site. While variability in cargos certainly existed between various ports, it is also clear that many items were only being shipped to certain ports and in certain directions. For example, it is well known that vessels bound from Spain to Veracruz were often carrying mercury, whereas a vessel sailing from Veracruz to Spain would not. In addition, a Spanish vessel sailing from Veracruz to Spain may be transporting precious metals while a vessel sailing in the opposite direction would not. As transportation, commerce, and ports increased, so did the variety in cargos. Whereas items in the early sixteenth century were being sent almost specifically into and out of Veracruz, by the eighteenth century the variety of cargoes, ports, and commerce had increased dramatically. Thus, a careful examination of trade routes and cargoes can often lend insight into identifying wreck sites in the future. 


\subsection{Future Archival Research}

Future archival research should be directed to specific repositories based on data collected from remote-sensing surveys and or archaeological investigations within UDW of the GOM. Data presented within this report may help to identify the nationality and temporal period of shipwrecks within the GOM. A review of chronological trends indicates that vessels operating within the GOM from 1500 through 1650 are most likely Spanish. By the 1650s, the French had established a presence in the GOM, followed by the British and later the Americans. Therefore, researchers studying the early period (1500-1650) of the GOM may want to focus their efforts on archival repositories in Spain and Mexico. The primary repositories are the Archivo General de Indias (AGI), Seville, Spain; the Archivo General de Simancas (AGS), Valladolid, Spain; the Museo Naval (MNM), Madrid, Spain; and the Archivo General de la Nación (AGN-M), Mexico City, Mexico.

Archival research based on French vessels (post-1650) should be conducted in appropriate archives such as the Archives Nationales and the CAOM. The current investigation has found that a wealth of material pertinent to French vessels lost in the GOM may be found at these repositories. While time allocated for research in France did not allow for more than three days in the Archives Nationales, this large repository contains the Marine Section (Fond de la Marine), where it is believed additional data pertaining to ships lost in the GOM could be located. The Marine Section pertains mostly, although not exclusively, to French naval affairs, French warships, reports of ship losses, voyages of exploration (Series B1 through B7; Series C1 through C8; Series D1 through D5; Series E1 through E210; F1; Series F2; Series G1 through G256), the French East India Company (Compagnie des Indes Orientales), and the French West India Company (Compagnie des Indes Occidentales) (both Sous-série 1P). In addition, this section contains documents relative to the Hydrographic Service (Sous-série 5 JJ) and Log Books (Sous-série $4 \mathrm{JJ}$ ) covering the period from 1670 to 1789 (French Revolution) for the Séries Anciennes, and from 1789 to 1870, Séries Modernes. This latter section is very comprehensive and contains various types of data including ship losses in the Americas. It is surmised that numerous shallow-water wrecks could be identified in the Archives Nationales, many with enough data to locate geographical locations of the sinking with a certain degree of precision. In addition, researchers are allowed to photograph documents. A second important Paris archival repository with great potential is the Service Historique de la Marine (French Navy Historical Archives), in Vincennes.

Relative to English vessel losses within the GOM, future research should include the National Archives in Kew, London (formerly the Public Records Office). This is a large and very wellorganized repository with vast sections such as Admiralty, High Court Admiralty, War Office, and Colonies. There is an excellent potential for locating records of ships lost in and around the GOM during the British period.

The current investigation has succeeded in identifying previously unknown vessel losses within the GOM. However, a review of primary documents associated with these vessel losses indicates that very little information can be gathered relative to where these vessels may have actually been lost. Thus, while it may not be possible to predict where a vessel may have been lost, a review of known shipwreck sites within UDW suggests that it is likely a vessel will remain 
exposed on the seafloor (due to low sedimentation rates) for hundreds of years. Therefore, the existing strategy to locate such wrecks (i.e., the use of remote-sensing tools such as side-scan sonar) will succeed in continuing to identify such resources in the future.

The task of locating primary documents relative to early-colonial-period vessel losses within the GOM can be useful. However, it has been found that this is an immense task that may not be a cost-feasible endeavor. To conduct a thorough review of repositories' holdings can take years of research with little to no promise of identifying any pertinent documents. Therefore, research should focus on examining new wreck sites found during remote-sensing surveys to determine temporal period, nationality, and cargo, which can then be applied to pertinent archival research endeavors. This will reduce the amount of time spent in repositories and allow for a more comprehensive examination of a specific vessel loss. Analysis of hull remains and cargo can certainly narrow the scope of research relative to a specific site, allowing researchers to focus more on a specific time period and nationality. Future archival research should be directed to specific repositories based on data collected from remote-sensing surveys and or archaeological investigations within UDW of the GOM. Data presented within this report may help to identify the nationality and temporal period of shipwrecks within the GOM. 


\subsection{REFERENCES CITED}

Acton, J.E., E.D. Acton, A.W. Ward, G.W. Prothero, S.M. Leathes, and E.A. Benians. 1902. The Cambridge modern history. New York: Macmillan.

Arnold, J.B. III and R. Weddle. 1978. The nautical archeology of Padre Island: The Spanish shipwrecks of 1554.New York: Academic Press.

Arnold, J.B. III and M.A. Wickman. 2010. Padre Island Spanish shipwrecks of 1554. The handbook of Texas online. Internet website: http://www.tshaonline.org/handbook/online/articles/PP/etpfe.html. March 29.

Atauz, A.D., W. Bryant, T. Jones, and B. Phaneuf. 2006. Mica shipwreck project: Deepwater archaeological investigation of a $19^{\text {th }}$ century shipwreck in the Gulf of Mexico. Report to the U.S. Dept. of the Interior, Minerals Management Service, Gulf of Mexico OCS Region, New Orleans, LA. OCS Study MMS 2006-072.

Bascom, W. 1971. Deep-water archaeology. Science 174(4006):261-269.

Beeker, C. and S.R. James Jr. 1996. San Felipe report: Underwater archaeological investigations at the site of the 1733 Spanish fleet shipwreck tentatively identified as the San Felipe: An Indiana field school. Bloomington and Memphis: Underwater Science and Educational Resources, Dept. of Recreation and Park Administration, Indiana University, and Panamerican Consultants, Inc.

Boudriot, J. 1990. Corvette la Créole. Collection Archéologie Navale Française. Paris: Editions Boudriot.

Boudriot, J. 2000. La Belle. Collection Archéologie Navale Française. Paris: Editions Boudriot.

Bourne, E.G. 1904. Spain in America, 1450-1580. New York: Harper and Brothers.

Bulmer-Thomas, V., J.H. Coatsworth, and R.C. Conde, eds. 2006. The Cambridge economic history of Latin America, Vol. 1: The colonial era and the short nineteenth century. Cambridge: Cambridge University Press.

Calderón Quijano, A. 1953. Historia de las fortificaciones en Nueva España. Seville: Escuela de Estudios Hispano-Americanos.

Chaunu, P. 1959. Séville et l'Atlantique, 1504-1650. Partie Interprétative, Vol. VIII: Structures. Paris: S.E.V.P.E.N.

Chaunu, P. and H. Chaunu. 1955-1957. Séville et l’Atlantique, 1504-1650. 11 vols. Partie Statistique, Tome Premier Introduction Méthodologique. Paris: Librairie Armand Colin. 
Chipman, D.E. and P.R. Lemée. 2010. Louis Juchereau de St. Denis. The handbook of Texas online. Internet website: http://tshaonline.org/handbook/online/articles/SS/fst1.html. March 29.

Clark, J.G. 1969. New Orleans: Its first century of economic development. Louisiana History: The Journal of the Louisiana Historical Association 10(1):35-47.

Coastal Environments, Inc. (CEI). 1977. Cultural resources evaluation of the northern Gulf of Mexico shelf. 3 vols. Report to the New Orleans Outer Shelf Office, Bureau of Land Management, U.S. Dept. of the Interior, New Orleans, LA.

Cook, G.D., J. Bratten, J.E. Worth, K. Kennedy, D. Nones, and S. Sorset. 2009. Emanuel Point II underwater archaeology grant no. SC716. Report of investigations no. 164. Pensacola: University of West Florida Archaeology Institute.

Davis, J.L. 1977. Treasure, people, ships and dreams: A Spanish shipwreck on the Texas coast. San Antonio: Texas Antiquities Committee and the Institute of Texas Cultures of the University of Texas.

Davis, R. 1975. English merchant shipping and Anglo-Dutch rivalry in the seventeenth century. London: Maritime National Museum.

Delgado, J., ed. 1997. Encyclopedia of underwater and maritime archaeology. New Haven: Yale University Press.

De Quesada, A.M. 2006. A history of Florida forts: Florida's lonely outposts. Charleston, SC: History Press.

Duro, C.F. 1898. Armada Española desde la unión de los reinos de Castilla y de Aragón. 9 vols. AGI ID CH 725. Madrid.

Ekberg, C.J. 1996. The flour trade in French colonial Louisiana. Louisiana History: The Journal of the Louisiana Historical Association 37(3):261-282.

Escobar, F.G., J.C. Alarcón, and J.A. Forteza. 1998. Naufragio en Inés de Soto, un hallazgo de cuatro siglos. Havana: Carisub, S.A., and Corporación Cimex, S.A.

Fabel, R.F.A. 1988. Economy of British West Florida. Tuscaloosa: University of Alabama Press.

Federal Register. 1983. Secretary of the Interior's standards and guidelines for archaeology and historic preservation. 48:190:44716-44742. Internet website: http://www.nps.gov/history/local-law/arch_stnds_0.htm. July 2.

Fisher, J.R. 1998. Commerce and imperial decline: Spanish trade with Spanish America, 17971820. Journal of Latin American Studies 30(3):459-479. 
Flow, J. 1999. Tortugas deep-water shipwreck. Draft (second report). Tampa: Odyssey Marine Exploration.

Ford, B., A. Borgens, W. Bryant, D. Marshall, P. Hitchcock, C. Arias, and D. Hamilton. 2008. Archaeological excavation of the Mardi Gras shipwreck (16GM01), Gulf of Mexico continental slope. Report to the U.S. Dept. of the Interior, Minerals Management Service, Gulf of Mexico OCS Region, New Orleans, LA. OCS Study MMS 2008-037.

García-Barquero González, A. 1976. Cádiz y el Atlántico (1717-1778). 2 vols. Seville: Escuela de Estudios Hispano-Americanos de Sevilla.

Garrison, E.G., C.P. Giammona, F. Kelly, A.R. Tripp, and G.A. Wolf. 1989. Historic shipwrecks and magnetic anomalies of the northern Gulf of Mexico: Reevaluation of Archaeological Resources Management Zone 1. Report to the U.S. Dept. of the Interior, Minerals Management Service, Gulf of Mexico OCS Region, New Orleans, LA. OCS Study MMS 89-0024.

Haarman, A.W. 1960. The Spanish conquest of British West Florida, 1779-1781. Florida Historical Quarterly 39(2):107-134.

Hardy, J.D. 1966. The transportation of convicts to colonial Louisiana. Louisiana History: The Journal of the Louisiana Historical Association 7(3):207-220.

Henry, W.K., J.P. McCormack, and D.M. Driscoll. 1975. Hurricanes on the Texas coast, Vol. 2: The destruction. Austin: Texas A\&M University.

Hill, R.R. 1916. Descriptive catalogue of the documents relating to the history of the United States in the Papeles Procedentes de Cuba deposited in the Archivo General de Indias at Seville. Washington, D.C.: Carnegie Institution.

Hoffman, P.E. 1980. The Spanish crown and the defense of the Caribbean, 1535-1585: Precedent, patrimonialism, and royal parsimony. Baton Rouge: Louisiana State University Press.

Hunter, J.W. II. 2000. Leaden logs and broken ships: Pensacola's first timber industry, 16951712. Gulf South Historical Review 15(2)(Spring).

Jal, A. 1848. Glossaire nautique: Répertoire polyglotte de termes de marine anciens et modernes. p. 528. Paris: Firmin Didot Frères.

Konstam, A. 2004. Spanish galleon 1530-1690. New York: Osprey Publishing.

Lacoursière, J. 1982. La Louisiane à exploiter. In: Naissance de la Louisiane, 1682-1731. Paris: Catalogue of the Exhibition. 
Lane, K.E. 1998. Pillaging the empire: Piracy in the Americas, 1500-1750. Armonk, NY: Sharpe.

Lavery, B. 1987. The arming and fitting of English ships of war, 1600-1815. London: Naval Institute Press.

Lee, R.E. 1951. American cochineal in European commerce, 1526-1625. Journal of Modern History 23(3):205-224.

Leglaunec, J. 2005. A directory of ships with slave cargoes, Louisiana, 1772-1808. Louisiana History: The Journal of the Louisiana Historical Association 46(2):211-230.

Lesure, M. 1990. Quand voguaient les galères: Catalogue of the exhibition. Paris: Musée de la Marine.

Lugo-Fernández A., D.A. Ball, M. Gravois, C. Horrell, and J.B. Irion. 2007. Analysis of the Gulf of Mexico's Veracruz-Havana route of La Flota de la Nueva España. Journal of Maritime Archaeology 2(1)(June):24-47.

Lyon, E. and R.D. Mathewson. 1975. The historical and archaeological meaning of the 1622 shipwrecks off the Marquesas Keys, Florida. Paper presented at the Annual Meeting of the Florida Historical Society, Gainesville.

Márquez, G. 2006. The Cambridge economic history of Latin America, Vol. I: The colonial era and the short nineteenth century. Bulmer-Thomas, V., J.H. Coatsworth, and R.C. Conde, eds. New York: Cambridge University Press.

Marx, R.F. 1971. Shipwrecks of the western hemisphere: 1492-1825. New York: David McKay Company.

Mathes, W.M. 2005. Spanish maritime charting of the Gulf of Mexico and the California coast. In: Reinhartz, D. and G.D. Saxon, eds. Mapping and empire: Soldier-engineers on the southwestern frontier. Austin: University of Texas Press.

Mathewson, R.D. 1986. Treasure of the Atocha. New York: E.P. Dutton.

McAlister, L.N. 1959. Pensacola during the Second Spanish period. The Florida Historical Quarterly 37(3/4):281-327.

McAlister, L.N. 1984. Spain and Portugal in the New World 1492-1700, Vol. 3: Europe and the World in the age of expansion. Minneapolis: University of Minnesota Press.

McDonald, D. and J.B. Arnold III. 1979. Documentary sources for the wreck of the New Spain fleet of 1554. Publication no. 8. Austin: Texas Antiquities Committee.

McWilliams, R.G. 1991. Iberville’s gulf journals. Tuscaloosa: University of Alabama Press. 
Mendoza, J.E. de. 1575. Ytinarios de navegación de los mares y tierras occidentals. Unpublished manuscript. In: Duro, C.F. 1880. Disquisiciones náuticas. 5 vols. Madrid: Instituto de Historia y Cultura Naval.

Millás, J.C. 1968. Hurricanes of the Caribbean and adjacent regions, 1492-1800. Miami: Academy of the Arts and Sciences of the Americas.

Moore, J.H. 1983. The cypress lumber industry of the lower Mississippi Valley during the colonial period. Louisiana History: The Journal of the Louisiana Historical Association 24(1):25-47.

Moya, C. 1981. El buque en la armada Española. Madrid: Editorial Silex.

Muckelroy, K. 1978. Maritime archaeology. Cambridge: Cambridge University Press.

Nelson, A. 2001. The Tudor navy: The ships, men, and organization 1485-1603. Annapolis: Naval Institute Press.

Nipper, M., J.A. Sànchez Chàvez, and J.W. Tunnell, eds. 2010. GulfBase: Resource database for Gulf of Mexico research. Internet website: http://www.gulfbase.org. April 8.

Olds, D.L. 1976. Texas legacy from the gulf: A report on sixteenth century shipwreck materials recovered from the Texas tidelands. Miscellaneous papers no. 5, Texas Memorial Museum publication no. 2. Austin: Texas Antiquities Committee.

Paasch, H. 1908. De la quille à la pomme du mât. Dictionnaire de la marine. Antwerp.

Paasch, H. 1977. Illustrated marine encyclopedia 1890. Watford: Argus Books, Ltd.

Pearce, A.J. 2001. British trade with the Spanish colonies, 1788-1795. Bulletin of Latin American Research 20(2):233-260.

Pearson, C.E. and P.E. Hoffman. 1995. The last voyage of El Nuevo Constante: The wreck and recovery of an eighteenth-century Spanish ship off the Louisiana coast. Baton Rouge: Louisiana State University Press.

Pearson, C.E., S.R. James Jr., M.C. Krivor, S.D. El Darragi, and L. Cunningham. 2003. Refining and revising the Gulf of Mexico Outer Continental Shelf region high-probability model for historic shipwrecks. Report to the U.S. Dept. of the Interior, Minerals Management Service, Gulf of Mexico OCS Region, New Orleans, LA. OCS Study MMS 2003:061.

Pérez Mallaína, P.E. 1998. Spain's men of the sea: Daily life on the Indies fleets in the sixteenth century. Phillips, C.R., trans. Baltimore: Johns Hopkins University Press.

Phillips, C.R. 1986. Six galleons for the king of Spain: Imperial defense in the early seventeenth century. Baltimore: John Hopkins University Press. 
Pino, C.G. del. 2001. El corso en Cuba, siglo XVII. Havana: Editorial de Ciencias Sociales.

Pino, C.G. del et al. 1998. Naufragio en Inés de Soto, un hallazgo de cuarto siglos. Havana: Carisub, S.A., and Corporación Cimex, S.A.

Proulx, G. 1984. Between France and New France: Life aboard the tall sailing ships. Toronto and Charlottetown: Dundern Press in cooperation with Parks Canada.

Rush, N.O. 1966. Battle of Pensacola: Spain's final triumph over Great Britain in the Gulf of Mexico. Tallahassee: Florida State University.

Service Historique de la Marine. 1978. Inventaire des archives de la compagnies des Indes. SousSérie 1P, pg. 91. Paris: Etat-Major de la Marine, Service Historique.

Shipp, B. 1881. The history of Hernando de Soto and Florida, or, Record of the events of fiftysix years, from 1512 to 1568 . Philadelphia: Collins.

Smith, R.S. 1943. Shipping in the port of Veracruz, 1790-1821. The Hispanic American Historical Review 23(1):5-20.

Smith, R.C., J.R. Bratten, J. Cozzi, and K. Plaskett. 1998. The Emanuel Point ship archaeological investigations, 1997-1998. Tallahassee: Bureau of Archaeological Research, Division of Historical Resources, Florida Dept. of State.

Smith, R.C., J. Spirek, J. Bratten, and D. Scott-Ireton. 1995. The Emanuel Point ship: Archaeological investigations, 1992-1995. Preliminary report. Tallahassee: Bureau of Archaeological Research, Division of Historical Resources, Florida Dept. of State.

Stein, S.J. and B.H. Stein. 2003. Apogee of empire: Spain and New Spain in the age of Charles III, 1759-1789. Baltimore: Johns Hopkins University Press.

Taylor, P.S. 1922. Spanish seamen in the New World during the colonial period. The Hispanic American Historical Review 5(4):631-661.

U.S. Dept. of the Interior. Minerals Management Service. 1996. Handbook for Archaeological Resource Protection (620.1-H). Internet website: http://www.mms.gov/adm/PFD/rn239.pdf. July 2.

Velasco, J.L. de. 1894. Geografía y descripción universal de las Indias, recopilada por el cosmógrafo e revista desde al año de 1571 al de 1574. Madrid: Duro Zaragoza on behalf of Real Academia de la Historia.

Walling, R.A.J. 1907. A sea-dog of Devon: A life of Sir John Hawkins. London: Cassell and Co.

Weddle, R.S. 1985. Spanish sea: The Gulf of Mexico in North American discovery, 1500-1685. Austin: Texas A\&M University Press. 
Weddle, R.S. 1991. The French thorn: Rival explorers in the Spanish sea, 1682-1762. Austin: Texas A\&M University Press.

Weddle, R.S. 1995. Changing tides: Twilight and dawn in the Spanish sea, 1783-1803. Austin: Texas A\&M University Press.

Weddle, R.S. 2001. The wreck of the Belle, the ruin of La Salle. Centennial Series of the Association of Former Students, Texas A \& M University, no. 88. College Station: Texas A\&M University Press.

Wilkie, E.C., Jr., ed. 1983. New light on Galvez's first attempt to attack Pensacola. The Florida Historical Quarterly 62(2):194-199.

Woodward, R.L, Jr. 2003. Spanish commercial policy in Louisiana, 1763-1803. Louisiana History: The Journal of the Louisiana Historical Association 44(2):133-164. 


\section{APPENDIX A: DOCUMENTS PROVIDING INFORMA TION ON SPANISH, FRENCH, AND ENGLISH SHIPS PRESUMED LOST IN THE DEEP WATERS OF THE GULF OF MEXICO IN THE COLONIAL PERIOD}

(Tiras 4, 5, 8, 19, and 21, CAOM C9 A142 1773 [No folio number], CAOM C13 B1 1773 [Folio 423 recto], CAOM C13 A8 1725 [Folio 399 recto (old numbering 136)], CAOM C13 A16 1733 [Folio 178 recto], CAOM C13 A26 1741 [Folio 127 recto], CAOM C13 A32 1748 [Folio 215 recto], CAOM C13 A 301746 [Folio 131 recto], CAOM C13 A30 1746 [Folio 159 recto]) 
Introductory note: Tira 4 mentions loss of the San Antonio De Padua (Lost Ship Number 4) and also the Santa Catalina De Sena (Lost Ship Number 5). Although the ships owned by Rafael Ferrofino (Lost Ship Number 6) and Francisco Pabòn (Lost Ship Number 7) are not specifically mentioned in this document, they were lost in the same weather event that befell the San Antonio de Padua and the Santa Catalina de Sena.

\section{Tira 4}

\section{México 351}

\section{Translated by John de Bry}

The fleet whose cargo was under the orders of General Pedro de Escobar Melgarejo anchored in this port on the twenty-seventh of September with 28 ships of the original 43, with its accompanying load, but he was forced to toss overboard [jettison] half of the goods due to a storm on Sunday $17^{\text {th }}$ of September, very near the coastline, on which day two ships were lost, fully loaded, and which contents were valuable. One of them was under the orders of master Juan de Morales and the other, la Catalina, under the orders of master Andres Ximenez, of which everything was lost and no member of its crew survived, only the master and two or three sailors, and [in the case of] the one under the orders of Juan de Morales everything was lost, but the entire crew survived and were taken [aboard] the urca of Pedro de Meras ${ }^{1}$. Of the thirteen ships that could not reach the port that day the general took charge, ten were lost and two of them arrived in Campeche, one was Francisco Estupinan's, which is safely anchored in the port, and another one which belongs to Domingui Anez Home, and a patache ${ }^{2}$ which belongs to Pedro Remeral arrived at the Guaçacoalco river $^{3}$, the other ten ships crashed against the coast due to bad weather and were completely destroyed, which means that large sums of royal rights (taxes) were lost and even though some barrels of wine and goods were salvaged from the shorelines, it is too little in comparison with everything that was lost and the number of passengers and sailors who drowned which has caused great lament and compassion to the world, and in the low lying parts of the coastline Juan Martinez de Burgoa's ship ran aground and in order for the ship to be able to float it was necessary to cut the main mast, and [also] necessary to throw to the sea much goods with 195 quintales $^{4}$ of mercury belonging to Your Majesty. The summary relation of the ships which are moored in the port and the ones that were lost will be this one. However, we understand that the general will give Your Majesty a more detailed account of the events of his voyage.

Of the merchandise that was scattered on the coast which belonged to the twelve lost ships, the general interfered by putting it in his custody, since the payment of all royal rights remains in our jurisdiction, which concerns all merchandises which arrived with lost registrations

\footnotetext{
${ }^{1}$ An urca was a type of 16th-century ship, smaller than a galleon and with a broader beam and rounded hull, lightly armed and used to carry merchandises, heavy cargos, and military stores from place to place. The name was Spanish, and it was the Spaniards who chiefly used them, first in the Mediterranean, then in the Americas. The French used a similar vessel called a flute.

2 A patache was a swift sailing vessel most commonly used to carry dispatches and orders.

${ }^{3}$ The Coatzacoalcos River on which the cities of Coatzacoalcos and Manatitlán are situated.

${ }^{4}$ One quintal $=46$ kilograms x $195=8,970$ kilograms (19,500 U.S. pounds).
} 
$/ \mathrm{v} /$

and contraband for whose effect, and in order to alleviate, have been taken to customs and to the port's House of Trade in accordance with the royal decrees Your Majesty provided us with. It was asked of the general not to intervene in this matter and that he should send it to us since the merchants were afraid of the soldiers who were posted as guards [amongst] who were the robbers who came to steal night and day. The general submitted to us the reason (justification), and for our part and that of the merchants' guild it (the merchandise) has been valued with the best possible cost. In order to [best] serve Your Majesty the generals should be ordered not to meddle in these matters and obey the royal decrees that could have been issue for these instances.

[In the margin: give this chapter [...] with the accompanying instruments along with this letter in order that an account of the events is presented to the Royal Council - signature] Also, the general has interfered and continues to do so by visiting the ships and boats sailing near the coasts of this kingdom and ships arriving from Havana and Cartagena, and other windward islands, which anchored here [and] that are not under his orders or belong to his fleet, and he and his officials have charged the poor masters with eight pesos for the license, and visits their vessels and takes away their sails and rudders and sailors, prohibiting them from leaving if they do not buy a license, an affair that has never taken place with other generals. Especially when every of Your Majesty's decrees prohibits and orders that these ships' cargo is under the orders of the royal officers' judges which prevents the trade and exchange of this kingdom and many royal rights are lost and even though we requested him not to do it and presented him Your Majesty's royal decrees he has not ceased from doing it which is also in itself a detriment that prevents the speedy and good office of the fleets since these trading ships and sailing boats transport large quantities of goods of the fleet to all the coastal seaports of this kingdom and bring hides and tinta wood ${ }^{5}$, and rope and other goods that the fleet transport. It will be convenient that Your Majesty dictates an order that would remedy this situation which only damages Your Majesty's Royal Hacienda and royal rights, and orders the generals to ignore the trading ships of these coastlines and take charge only of the fleets in their charge.

Also, the general has meddled by knowing the kind of jettison and [cases] of force majeure and avería gruesa $\operatorname{tax}^{6}$ imposed upon Your [ship] masters against the merchants and holders of commissions, citizens of this kingdom, of which he has no jurisdiction, because in the royal ordinances that Your Majesty issued in [1]539 so that the official judges could resolve issues pertinent to the House of Trade of the Indies, ${ }^{7}$ which, by royal decree of Your Majesty, was later issued on the fourth of November of the year [15]50

/2/

it was ordered to hold everything that concerned trade and commerce of the Indies, among many other ordinances that were issued, there is one, which is [\#] 199, that entrusts official judges to

\footnotetext{
${ }^{5}$ Palo de Tinta is a red heartwood also known as Brazil wood (Haematoxylon campechianum); it was an important export for the colony of New Spain (Mexico). It was introduced into Europe as a dyeing agent for textiles soon after the discovery of the New World.

${ }^{6}$ Avería gruesa, (The law of) General Average is a legal principle of maritime law according to which all parties in a sea venture proportionally share any losses resulting from a voluntary sacrifice of part of the ship or fleet to save the whole in an emergency.
} 
oversee the cases of coups $^{8}$ and avería gruesa which occurred when the ships' masters suffered a sea storm and of the fortuitous cases where it is ordered to them that they have to supervise those cases and in conformity with Your Majesty's royal decree issued on the $11^{\text {th }}$ of June of the past year of [15]97 in the general instruction that Your Majesty ordered to give to the generals of the fleets, and according to chapter 72 of the same decree it orders them not to meddle with any coups $^{9}$ unloading, or avería and fortuitous cases and that these cases should be known by the ports' regular judicial authorities or the official judges of Your Majesty's royal treasury and orders them to uphold the said royal decree of the $24^{\text {th }}$, which Pedro de Escobar Melgarejo, general of this New Spain's fleet did not do. After having known the details of this case and after having made many inquiries, doctor Quesada de Figueroa who is one of Your Majesty's prosecutors of Mexico's royal audience for what concerns the benefits of Your Majesty's royal Treasury and payment of the royal rights asked provisions ordered the said general to prevent himself from overseeing the said cases and order him to refer them to the principal mayor and royal officials of this port in accordance with Your Majesty's orders, so that the contending jurisdiction over these cases would cease, and having notified the said royal provision he offered several excuses for not having done so, even though he had been notified by a second notice which informed him that he could be charged with a fine of four thousand ducats and that he should refer these cases to the principal mayor and royal officials who have rightful jurisdiction over them. If he had complied with the terms indicated by the second notice, he should have remitted the cases both to the principal mayor of this city and to the royal official judges of Your Majesty's, as it was indicated to him to do so by Your Majesty's second notice, not only to the mayor as he did, which has only harmed Your Majesty's royal Treasury and the payment of your royal rights inasmuch as the judges have the rightful jurisdiction to oversee these cases, in accordance to the said royal decrees and ordinances of the said House of Contratación and the said general excluded the judges since we have all the records and the fleets' documents which prove it, and from which we are able to estimate the goods' value that the fleets bring $/ 2 \mathrm{v} /$

and from which we estimate the royal rights, and by the same original records we are able to provide a detailed report to Your Majesty's accountants and when it deals with unloading and hechacones suits by the same records we know how much was unloaded while still in the open sea, how much was left in the ships and according to the liquidation and inquiry performed by us we determined the amount of royal rights that must be paid and also divide the funds by giving to the treasury what is owe to it. If the said records would be taken out of the Contaduría and the royal official judges did not oversee these kinds of cases, there would be abundant cases of fraud and trickery against Your Majesty's treasury performed by the masters and other persons. Therefore, so that from now on there would be no more clashing of interests between the authorities, we ask Your Majesty to order the fleets' generals not to interfere with these kinds of cases since they cannot act as judges against the neighbors of this kingdom, and that you promulgate a royal decree that determines that only royal official judges can oversee these kinds of cases as it is stated by Seville's House of Contratación's ordinances and other additional decrees and provisions that Your Majesty has provided us with, so that no other authority could interfere by trying to oversee these cases and that no one can ask for or discard the records from the Royal House of Trade because thanks to them we are able to estimate the royal rights of the

\footnotetext{
${ }^{8}$ In the original manuscript text hachaçones understood as being a corruption and derivative of hachazo, meaning a blow or stroke with an axe. This word within the context of the sentence is not well understood.

${ }^{9}$ See footnote 8 above.
} 
almojarifazgo ${ }^{10}$, especially when the fleets bring a lot of mercury, bulls, missals, and books of new prayers since these goods fall within the scope of Your Majesty's treasury and as such we have the right to oversee these cases because we are in charge of overseeing the loading and unloading of goods and the warrant of the fleets and the estimate of the royal rights and cases of avería gruesa and unloading over open seas, when they occurred. We plead Your Majesty to provide us with what is more convenient to your royal benefit and service to your royal treasury.

The Council has written Your Majesty three or four letters explaining in them how harmful and inconvenient it is to Your majesty's Royal Hacienda when the fleets ships' records do not come with them as it used to be the custom, or that at least the ships would leave Seville ten or twelve days after the fleet had sailed away so that the records would arrive simultaneously, or eight or ten days after the fleet had arrived so that we could tax the goods that come registered according with the original records. However, the [ship] masters know that the records usually arrive two or three months later after the fleets have arrived to this port and that their goods cannot be accurately taxed because they have been taken to Mexico already. They bring a lot of unregistered clothing which allows the loss of royal rights that would not be lost if the records would come earlier in order to tax the goods with them and it would register more goods

$/ 3 \mathrm{r} /$

and it would stop merchants from doing so and even though we have written you many times about this issue we have not obtained an answer from Your Majesty, and also we have written to the president and official judges of the House of Contratación because it is an issue of great importance that Your Majesty should order that the records should be sent with the fleets and the carrier ships should bypass Santo Domingo, Puerto Rico and Havana and other parts where they stop to sell goods but instead to come directly without taking any detours along the way because last year the records belonging to General Garivay (Garibay) arrived on the $23^{\text {rd }}$ of December of [15]99 and the accompanying original records arrived on the $30^{\text {th }}$ of November of this year (1600), and there is great confusion about the valuations at the time when we have to charge the royal rights, because without the records we cannot tax the goods nor we can process the fleets in order for them to sail away again. We plead Your Majesty to provide us with a convenient remedy so that the troubles we present you cease.

Along with this we are also sending you a summary of the slaves belonging to Pero Gómez Reynel that have entered in this port since the $5^{\text {th }}$ of December of last year of ninety-eight until the $6^{\text {th }}$ of May of [1]600 when General Juan Gutierrez de Garivay's fleet sailed away as Your Majesty asked us to do on your decree of $31^{\text {st }}$ of October of [15]97, which would detail the number of slaves that have entered this port and how the Council's letters demonstrate the fraud and trickery Your Majesty has been a victim in this establishment, and how much Pero Gómez has gained in detriment of Your Majesty's Royal Hacienda, not only with the registered slaves but also with the ones he is about to register because Your Majesty has rights over the slaves

\footnotetext{
${ }^{10}$ With the discovery and conquest of America, the Spanish Crown was faced with the need to make a statement regarding the taxes that could affect those who chose to reside in the new Continent. Thus, in 1497, a Royal Document exempted trade in the Indies from any type of taxes and duties. This measure was aimed at increasing and facilitating trade in American soil. Nevertheless, such measure had a short duration, since in 1543 another Royal provision, signed by Charles V, taxed this trade with what was called "Almojarifazgo", which applied a 5\% rate over the value of the goods (Source: National Customs Service of Chile).
} 
who arrive alive to this city, but Pero Gómez takes the living and the dead ones as well, which he reloads [aboard ships], and from a single record he takes advantage two or three times over, sailing to different parts and when there would be no other damage but this one it is very much inconvenient, but there is another that it is very evident in which Your Majesty gives Pero Gómez the faculty to bring to the Indies 4,250 slaves each year to pay your majesty 100,000 ducats of asiendamiento and from which Pero Gómez takes only two thousand five hundred slaves, paying 40 ducats for each license and an additional three ducats for customs, which leaves him with 1,750 free slaves each year that he reloads again with others, /3v/

including many of the death ones of which that too carry your rights without risk, and also loads the ones he is about to register, and this takes place without the applicable fines and errors which apply to this case that are very valuable, and also by having the great freedom to trade slaves in any season of the year onboard of unprotected ships without a fleet, it is of great profit to him, but it is also harmful to Your Majesty's Royal Hacienda, and also to the general trade and commerce of the Indies. Your Majesty should order what is more convenient for the better performance of your royal service and the benefit of your Royal Hacienda, our lord keeps Your Majesty for as many years as Christianity needs it and with the increasing number of other kingdoms and dominions. At the new city of Veracruz and (sic) of December $10^{\text {th }}$ of 1600 .

Pedro Coco Calderon

Antonio Cotrina

/4r/ blank

$14 \mathrm{v} /$

To the king our lord

By the hands of Juan de Herrera, secretary of your audience

It has been duplicated and has been checked

See the accompanying chapter, which highlights the enforcement of what it is ordered, which is the third.

[END] 
Introductory note: Tira 5 provides further information on the catastrophe of the 1600 fleet to Vera Cruz. It provides supplementary documentation on the lost ship San Antonio de Padua (Lost Ship Number 4), the lost ship (unnamed) owned by Rafael Ferrofino (Lost Ship Number 6), and the lost (and unnamed) ship owned by Francisco Pabòn (Lost Ship Number 7). This document also provides information on an additional lost ship, that of the Santa Catalina de Sena (Lost Ship Number 5). Aside from information on the lost ships, the document contains many interesting details about the cargoes aboard each vessel in the fleet and what was done with them in the midst of the threatening weather.

\section{Tira 5}

\section{México 351}

\section{Translated by John de Bry}

Account of the ships that came in under the command of General Pedro de Escobar Melgarejo's fleet and also of the tonnage and the ships that are presently moored in this port and of the ones that have been grounded onshore, have been lost at sea and also of the ones that have ran aground, and of what has been salvaged and those that were unloaded at sea during storms. ${ }^{11}$

Ships and pataches mooring in the port and what has been unloaded in the open sea

Tons [in the margin]

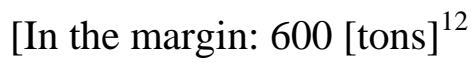

The flagship owned by Francisco de Azpur anchored ${ }^{13}$ on the $26^{\text {th }}$ of September in 43 brazas $^{14}$ inside the port, where it lost two anchors and the next day, on the $27^{\text {th }}$ of the said month it collided with Mateo de Litela's ship, causing its foresail to be broken, while Litela's ship broke Azpur's ship's bowsprit and the frame ${ }^{15}$ and ended up braking a lot of rigging in order to free both vessels.

[To the margin: 500]

The admiral ship anchored in the said 43 brazas, where it lost two anchors and two cables, which were unfurled by hand because they could not be picked up by the north wind.

[450]

The ship Sanct Pedro ${ }^{16}$ belonging to Juan Martínez de Murguía, was forced to unload a lot of goods in the sea. The general commanded to inventory what was unloaded, which he has kept until now. [The ship] anchored due to the north winds and after entering the port, it filed a report

\footnotetext{
${ }^{11}$ Alijo, naut. To unload [at sea], to jettison.

${ }^{12}$ A $16^{\text {th }}$-century Spanish tonelada was equal to 1.376 cubic meters x $600=825.6$ cubic meters.

${ }^{13}$ Surgió in the original manuscript text; an archaic nautical term in use during the $6^{\text {th }}$-century and early $17^{\text {th }}$-century meaning "anchored."

${ }^{14}$ A $16^{\text {th }}$-century Spanish braza equaled 1.694 meters x $43=72.842$ meters.

${ }^{15}$ In the original manuscript text the word ceuadera does not correspond to any nautical term and it is surmised that it is a misspelling of the word cuaderna which means frame.

${ }^{16}$ Sanct is an archaic spelling of San or "Saint."
} 
of force majeure for having to unload at sea 500 short necked jars ${ }^{17}$ of wine, 160 of oil, 5 barrels of merchandises, 37 wooden casks of unimportant clothing, two cables and other things.

[450]

La Concepcion, Master Juan Martínez de Burgoa for not having seen the light ran aground on Isla de Mujeres ${ }^{18}$, which is on the Bank ${ }^{19}$. In order to be able to sail, it was forced to cut its main mast and after the storm had passed, it was forced to unload at sea 130 large boxes of mercury belonging to the king. The general ordered to keep an eye on the mercury, and after that he filed a case of force majeure and averia gruesa ${ }^{20}$ for the unloaded mercury, along with twelve wooden casks of unimportant clothing, 16 short necked jars of almonds, the longboat, 40 quintales ${ }^{21}$ of gunpowder, 40 sailcloth, and three wooden casks of cast iron.

[600]

The galleon of Duarte de Quiros, Master Anfian Boquin unloaded goods at sea and filed a case of force majeure and declared that he unloaded all the unimportant clothing and wax he carried, and a large number of wine amphorae, artillery, cables and anchors, and other ship appurtenances.

$/ \mathrm{v} /$

And that the unimportant clothing and wax do not have a limited quantity, number or trademarks and the general ordered two guards to keep an eye on the goods and assist in the unloading.

[200]

La Contadora of Tomás Gallardo, Master Francisco Ximénez, filed a case of force majeure and did not unload anything on the open sea, except ship appurtenances.

[550]

The other ship of Duarte de Quiros, named la Concepción, Master Hernando de Quiros, filed a case of force majeure, and unloaded at sea 150 short necked jars of wine, the mizzenmast mast, two artillery pieces, three cables, three anchors, and the longboat.

[22]

The ship of Agustín de Paez, Master Hernando Cisneros, requested [to file] a case of force majeure, and that unloaded at on piece of artillery and the longboat.

[330]

The ship of Santi Santoni, Master Jerónimo Martínez, requested [to file] a case of force majeure, for having jettisoned an anchor, the main mast, 150 empty jars of wine, 21 seaman chests, and three gun carriages.

\footnotetext{
${ }^{17}$ Most likely ceramic olive jars commonly used to store and transport foodstuff and liquids.

${ }^{18}$ Isla Mujeres (Island of Women) off Cancún, Mexico.

${ }^{19}$ In the original manuscript text en la sonda: the archaic name for the Bank of Campeche.

${ }^{20}$ Avería gruesa, (The law of) General Average is a legal principle of maritime law according to which all parties in a sea venture proportionally share any losses resulting from a voluntary sacrifice of part of the ship or fleet to save the whole in an emergency.

${ }^{21}$ One quintal = 46 kilograms x $40=1,840$ kilograms (19,500 U.S. pounds).
} 
[600]

The Espíritu Santo, Master Gaspar Alvarez and owner Hernando de Aguilar, requested [to file] a case of force majeure, for having thrown an anchor and a cable.

[370]

The ship of Rodrigo Madera, Master Juan Cano, requested [to file] a case of force majeure, for having unloaded at sea 215 narrow-neck jars of wine, 350 jars of olives, the longboat, two gun carriages, 200 empty jars, one anchor, a cable, 20 seaman chests, and other things.

[800]

The urca $^{22}$ of Pedro de Meras, Master Diego de Torrijos, requested [to file] a case of force majeure for having unloaded 15 empty wooden casks of wine and ship appurtenances.

[500]

The ship Nuestra Señora del Rosario, Master Juan Martínez de Amilirua , requested [to file] a case of force majeure, for having unloaded 5 wooden casks of wine, [large] quantities of [empty] narrow-neck jars, 3 pieces of artillery, and the seaman chests and other things of little value.

[550]

The ship Espiritu Santo, ${ }^{23}$ owner Hernando de Fuentes, Master Baltasar Falero, requested [to file] a case of force majeure for having unloaded 300 short necked jars of wine, 700 empty ones, one anchor and one cable, and ship appurtenances.

[400]

La Concepción, Master Luis Ortiz, struck bottom at the entrance of the port, cut its main mast, requested [to file] a case of force majeure for having jettisoned two anchors and two cables in 43 brazas in the same place the ship struck bottom the previous night.

[370]

The ship of Martín Monte, Master Alonso Monte, requested [to file] a case of force majeure, but he did not unload any goods, only some worthless scrap from the ship.

[350]

San Francisco de Padua, Master Pedro Sánchez Figueroa, which was damaged because it was not able to anchor in the port. It was finally able to do, but it scraped its bottom on Gavias Island $^{24}$ where it ran aground. The general ordered the ship to lighten the weight and later requested [to file] a case of force majeure for unloading 676 narrow-neck jars of wine, 436 of oil, artillery and other ship appurtenances, which were sold by Melchor del Castillo to Martín Monte for 2,700 pesos with Hernán Sánchez de la Barrera’s consent.

${ }^{22}$ An urca was a cargo sailing vessel with abroad beam and rounded hull.

${ }^{23}$ The Holy Spirit.

${ }^{24}$ Isla de Gavias (Island of the Gulls); no reference could be found for this island; possibly Isla de Pajaros, 4.9 kilometers south-southeast of the fort of San Juan de Ulua and directly 3.5 kilometers east of modern-day Veracruz. 
[200]

El Cisne Blanco, ${ }^{25}$ of Tomás Gallardo, Master Juan Rodríguez Infante requested [to file] a case of force majeure for having jettisoned 270 narrow-neck jars of wine, 100 jars with olives, 90 of oil, 2 wooden casks of wine, 300 empty jars, one piece of artillery, a cable, and one anchor.

[700]

The ship of Lorenzo Grifo, Master Pedro de Cañas, ran aground and was damaged. As such, it was necessary to cut the main mast. It was able to sail because many jars were jettisoned during the storm, and now has not filed any request.

[700]

The ship of Mateo de Litela, Master Tomás de Nis, with much storm [activity] took on a lot of water through the bent rudder, the peoples, the Master and the pilot abandoned it and went over to the admiral ship onboard a shallop ${ }^{26}$ that had made five attempts to come and get them, but because they were not able to get near enough to get on board, three persons drowned, among them the artillery constable. The ship was left alone in the sea that day and that night, and the next day, the general along with soldiers and seamen and other supplies, bailed and reduced the [level of] water, fixed the sails and left the vessel under the care of trustworthy individuals until it was brought to port. It requested the unloading of the goods and later filed a case of force majeure for having jettisoned 7 wooden casks containing unimportant clothing, 6 [pieces of] artillery, and anchors and other ship appurtenances.

[350]

The frigate of Luis de Vega, did not jettison anything, or ask to file a case of force majeure.

[200]

The ship Santiago, Master Constantín Pérez, requested [to file] a case of force majeure for having unloaded 200 short necked jars, artillery, and other ship appurtenances.

$/ 2 \mathrm{v} /$

[200]

The ship Espiritu Santo, Master Antonio Hernández, requested [to file] a case of force majeure for having jettisoned 100 short necked jars, artillery, and other ship appurtenances.

[260]

The saetia ${ }^{27}$ of Sebastian de Oñate, requested [to file] a case of force majeure for having jettisoned a large quantity of merchandises. As a result, the general decided to put the goods under the care of some guards and ordered to arrest him and take him to court in order to face charges because most of the unloading was feigned.

\footnotetext{
${ }^{25}$ The White Swan.

${ }^{26}$ Shallop, longboat, launch; a small open boat fitted with oars or sails, or both, and used primarily in shallow waters. The shallop was usually stowed on the upper deck where it could be easily and quickly launched.

${ }^{27}$ A saetia was a small lateen rigged $16^{\text {th }}$-century sailing vessel, which design originated in the Mediterranean; the saetia disappeared during the first quarter of the $17^{\text {th }}$-century.
} 
[80]

The pataez ${ }^{28}$ (sic) of martín Monte, Master Francisco Monte, requested [to file] a case of force majeure, for having thrown by hand a cable and an anchor at the entrance [of the port].

[100]

The pataez (sic) la Caridad of Leonardo de Oria, which came as an aviso ${ }^{29} 15$ days prior to the fleet, and as the said Leonardo de Oria noticed the [fleet] was late arriving, he sailed aboard his vessel in his search on the sea, with 150 baggage $^{30}$ [containing] biscuits, 40 short necked jars of wine, 200 short necked jars of water, chickens, and other types of presents that he distributed among the ships, who were pleading to heaven for help because they were in need of everything and the trip had been long and so stormy.

[100]

The patache of Fernando de Fuentes, requested [to file] a case of force majeure for having jettisoned the longboat, 15 barrels of merchandises, 23 wooden casks of wine, 117 short necked jars of oil , 110 of wine, cable and anchor, and other ship appurtenances.

[100]

The patache of Cristóbal de Figueroa, requested [to file] a case of force majeure for having jettisoned the longboat, 20 short necked jars and four wooden casks of wine, rigging and artillery, and other ship appurtenances.

[320]

The ship of Don Francisco Estupiñan from Cádiz arrived in Campeche and on Tuesday $7^{\text {th }}$ of November at eight in the morning entered in this port with a fair north wind. He requested [to file] a case of force majeure, and that they jettisoned 20 wooden casks of wine, four bundles of merchandises, 6 bales, artillery, and other ship appurtenances.

\section{Ships which were lost at sea}

[300]

The ship San Antonio de Padua, Master Juan de Morales sank the day after the storm, twenty leagues $^{31}$ from the coast of Villarica. ${ }^{32}$ The people were saved and taken onboard the frigate of Agustín Paez, [but] the scribe drowned, lo (lost)

\footnotetext{
${ }^{28}$ Misspelling of patache.

${ }^{29}$ Any small and fast warship carrying dispatches.

${ }^{30}$ In the original manuscript text petates, which can mean luggage or bedding and clothes for sailors; it is not clear if this means that the biscuits were included or wrapped into sets of luggage or bedding.

${ }^{31}$ A $16^{\text {th }}$-century Spanish nautical legua was equivalent to 5.4 kilometers $\times 20=108$ kilometers.

${ }^{32}$ Villa Rica de la Veracruz, original name and site of the settlement founded by Cortez circa 1519.
} 
St (lost) were 70 crates of mercury that was being transported, [and] 250 casks of unimportant clothing, none could be salvaged.

[Tons]

[350]

The ship of Andrés Ximénez foundered on the same day in the same area, more than 60 persons drowned. 110 boxes of mercury along with 200 wooden casks of unimportant clothing were lost. These two vessels were lost since the general was not able to see them or help them.

Ships that crashed against the coast

[80]

The frigate belonging to Agustín Paez was lost in the marshes off Isla Verde's coastline, outside the port. 30 people drowned, along with 12 barrels of clothing and the rest pf the barrels. Nothing was salvaged.

[700]

The ship Santa María de Juncal was lost near Gavias Island for lack of cables and anchors that had been lost the night before due to a storm, and even though it had unloaded other stuff and while the ship was visible from the port, the storm was so intense which blew from the north, it made impossible the task of rescuing it. The passengers survived because even though they wanted to leave the ship when the storm subsided a little, the general did not allow it. To the contrary, he ordered the one-hundred passengers to be evacuated and distributed between the admiral and flagships and sent the captain Domingo de Argarete with divers and carpenters and other persons to fix what was necessary and order not to abandon the ship until it was safely anchored in the port. He escorted the vessel onboard his flagship so that he could help it with whatever was necessary and he did until it was anchored in the Gavias Island. The ship carried 26 wooden casks of unimportant clothing, none was salvaged. It did not carry mercury.

[100]

The ship of Domingo de Bodes crashed against the coast, beyond the mouth of the Medellín ${ }^{33}$ River. The passengers escaped alive. It did not bring any mercury, only 4 wooden casks of clothing that were salvaged and also the majority of the casks.

\footnotetext{
33 Río Jamapa that passes near the Veracruz municipality of Medellín de Bravo and reaches the sea at Boca del Río, just south of the city of Veracruz (Veracruz-Llave); it was named Río Medellín at the time (Ref. A New Map of North America with the West India Islands, divided according to the Preliminary Articles of Peace, Singed at Versailles, 20, january 1783, by Pownell, 1794 and Puerto de Verazruz (map) Descripción del Puerto de la nueva Veracruz en el reyno de Nueva España; contiene desde pinta Gorda hasta la punta de Antón Lizardo; reconocido y sondado últimamente el fondadero de la ysla de Sacrificios, voca del Río Medellín y su ynteriorida... Veracruz, 29 de noviembre de 1764. Archivo General de Simancas (AGS), Mapas, Planos, y Dibujos VII-153. Marina, legajo 391.
} 
[100]

La Catalina of Duarte de Quirós, was tumbled upon the coast ${ }^{34}$, five leagues beyond the mouth of the Guacacoalco River ${ }^{35}$. The passengers were saved. It did not carry mercury, but it did carry 50 marquetas (?) of wax; of these 40 were salvaged and most of the barrels.

[200]

The felibote ${ }^{36}$, master Hernán García, crashed against the coast, near to the Agualucos ${ }^{37}$, adjacent to Tabasco. 16 people drowned. I did not carry mercury or common clothing, only barrels, of which some of them were salvaged.

[200]

The ship of Lázaro de Arpide, crashed against the coast near Alvarado ${ }^{38}$. Everybody survived. It did not carry mercury or common clothing, only barrels, of which the majority was salvaged.

[250]

The ship commanded by Juan Francisco Grimaldo was lost near the mountain range of San Martín $^{39}$, over the waters of the Tlusila River ${ }^{40} .60$ passengers drowned. It did not carry mercury, only 150 barrels of unimportant clothing, which have been salvaged and the barrels that carry most of them have salvaged.

[400]

The large ship belonging to Tomas Gallardo crashed against the Mincapa coast ${ }^{41} .13$ passengers drowned. It carried 110 crates of mercury and 100 wooden casks of common clothing, which some have been salvaged, but most of the crates of mercury were lost.

[330]

The exact whereabouts of the ship belonging to Ferrofino is unknown after the first storm. We are almost certain that the vessel sank to the bottom of the sea because ever since the ship disappeared there have been no traces of it. It did not carry any clothing, only 100 boxes of mercury, which were unloaded when the ship was taking on water and were divided between the capitana and the almiranta.

\footnotetext{
${ }^{34}$ In the original manuscript text "dio a la costa en tonel” e.g. "rolled like a barrel”

35 The Coatzacoalcos River on which the cities of Coatzacoalcos and Manatitlán are situated.

${ }^{36}$ Filibote: Medium size coastal freighter, roomy and cheap to build and work, the fluyt, a vessel of Dutch origin (English 'flyboat', French 'flûte', Spanish 'felibote') was much used as a general service cargo vessel from the later sixteenth century onwards. From R. Davis, English Merchant Shipping and Anglo-Dutch Rivalry in the Seventeenth Century (London 1975).

${ }^{37}$ This place name has not been identified, but it could possibly be Agua Dulce, southeast of Coatzacoalcos

${ }^{38}$ Approximately 58 kilometers southeast of Veracruz.

39 Located about 117 kilometers southeast of Veracruz, the Sierra San Martín is known today as Sierra de Los Tuxtlas, a volcanic belt along the southeastern Veracruz Gulf coast. San Martín Tuxtla is the only recently-active volcano in the belt, erupting in 1664 and again in May 1793. It is a broad alkaline shield volcano with a one kilometer wide summit.

${ }^{40}$ Possibly a small river 1.3 kilometers south-southeast of Punta Roca Partida.

41 This place name has not been identified.
} 
[50]

We suspect that the same thing happened to the capitana pilot's patache, belonging to Francisco Pabón, because no evidence of the vessel has appeared. It did not carry mercury or clothing.

[80]

The patache belonging to Pedro de Meraz entered through the Guasaqualco River ${ }^{42}$ from where we have news. The general is anchored and it's waiting for the pas... (?) since it has not received it, he has not been able to come. ${ }^{43}$

$/ 4 \mathrm{r} /$

[250]

The ship belonging to Domingo Yanzome arrived in Campeche, where it is anchored and has been repaired in order to come, according to the information provided by the abovementioned general.

Therefore, there were 43 vessels that were coming to this port, along with the pataches, of which 29 are anchored, 10 ran aground and lost, one anchored in Campeche and another one in Guasaqualco and two that we do not know anything about, as it is reflected by this report.

$14 \mathrm{v} /$

Report of the ships that were lost at sea and on land and the cargo that they carry, what was jettisoned, and what has been salvaged.

[END]

${ }^{42}$ See Footnote 25

${ }^{43}$ This is very ambiguous and thus not well understood. 
Introductory Note: Tira 8, drafted in 1601, mentions the loss of the unnamed ship owned by Rafael Ferrofino (Lost Ship Number 6) as well as the lost ship commanded by Juan Morales. Though not named in this particular document, the ship is mention in related documents as the San Antonio de Padua (Lost Ship Number 4)]. We must also note that this document aids in understanding the overall tragedy of the 1600 fleet, which also produced the losses of the Santa Catalina de Sena (Lost Ship Number 5) and the unnamed ship owned by Francisco Pabòn (Lost Ship Number 7) although these latter two vessels are not specifically mentioned in this particular document. Along with details on certain lost ships, this document is informative as to the cargo of some of the ships of the fleet.

\section{Tira 8}

\section{México 351}

\section{Translated by John de Bry}

The archivist (or someone) has marked in pencil as copy of the one dated on $20^{\text {th }}$ of November 1600

Sires,

By decree of Your Majesty of $12^{\text {th }}$ of July 1599, it orders us to send a report of the heads of the town councils of our district and what this revenue is worth each year, along with the rest of writings that might exist about this issue so that the Council of the Indies of Your Majesty's accounting office would have a copy. Furthermore, we inform Your Majesty that in our district there is no lease or any tax roll of this revenue, nor do we have indication in this entire province that it ever existed or that it had been leased out, [but] instead it is collected faithfully on Your Majesty's account, except that now we have come to know that the viceroy of this province has given the heads of the town councils of the city of Los Angeles, of which he informs Your Majesty, and the fact that in México there is a general accountant who administers this rent, we have no knowledge of how much the councilmen might cost because they are not under our jurisdiction and also because all the concerning documents about this issue are stored in México's royal accounting office. We have written to the viceroy so that he may send the accountant to take the report that he has about this issue and send us a duplicate in order to send to Your Majesty a copy or what the viceroy ordered sent for the satisfaction of your majesty as stated and ordered by the said royal decree.

[In the margin: México's royal officials should be informed that they need to send all the collections punctually, signed]

The president, judges, and officials from House of Trade (Casa de Contratación) ${ }^{44}$ of Seville sent us in this fleet 3,393 quintales ${ }^{45}$ of mercury in 2,262 large boxes ${ }^{46}$ registered in nineteen ships of the fleet commanded by general Pedro de Escobar Melgarejo, of which twelve were lost

\footnotetext{
${ }^{44}$ House of Trade, officially known as La Casa y Audiencia de Indias.

${ }^{45}$ A quintal was equal to 4 arrobas $=46$ kilograms $=101.5$ avoirdupois $=100$ pounds (U.S.).

${ }^{46}$ Cajones in the original manuscript text.
} 
as we informed Your Majesty, and in another letter we sent Your Majesty four of them were lost with all the mercury, and in another [ship] that carry one hundred and thirty large boxes containing 195 quintales, [all] were thrown into the sea, which means that 520 large boxes of Your Majesty's mercury were lost, which contain 780 quintales.

[In the margin: the general should be informed of the content of this chapter, signed]

/v/

In this way: onboard the ship commanded by Master Bartolomé Rodríguez, belonging to Tomas Gallardo, 110 large boxes containing 165 quintales, and on the ship commanded by Master Miguel Díaz, belonging to Rafael Ferrufino, 100 large boxes containing 150 quintales, on the ship commanded by Master Juan de Morales, 70 large boxes containing 105 quintales of mercury, and on the ship commanded by Master Juan Martínez de Burgoa, 130 large boxes containing 195 quintales of mercury were thrown into the sea as the result of the storm. The five lots sum up to the said 520 large boxes of mercury which contained the said 780 quintales valued at 110 escudos of good quality gold ${ }^{47}$, the quintal is valued at 450 maravedis each peso sum 85,000 escudos worth 102,960 gold ducats of 375 maravedis each. Of the 195 quintales that were thrown into the sea belonging to Your Majesty from the ship commanded by Master Juan Martínez de Burgoa, we have confiscated his assets along with his ship, freight, rigging and tackles and the goods that were salvaged from his ship, and we also ordered that the value of the mercury should be divided and the amount of 21,450 gold escudos ${ }^{48}$ be paid to Your Majesty, whose value is 110 escudos for each quintal, which should be executed since no claimant parties have appealed to the Audience. We understand that our sentence is justified and since the rest of the ships were lost, we have not done our part as we did with this one. ${ }^{49}$

Our Lord keeps Your Majesty for many years with increasing numbers of kingdoms and dominions as Christendom requires

At the city of Veracruz, $9^{\text {th }}$ of March of 1601

We understand that this fleet would sail later than any other one that has sailed from this port due to the great losses it has experienced and due to various unloading-related suits and other problems that have been moved to the grade of appeal to Mexico's royal audience and since they have run out of time no ship has been loaded and all remain empty and delayed because of this. On our behalf, we will come to Your Office when it would be necessary with great punctuality and speed. However, if we would have the records as we have asked Your Majesty, we would not have to be working night and day so that there would be no missing ones and if Your Majesty does not resolve this problem, it will be a great inconvenient for Your Majesty's Royal Hacienda and for the fleets’ speedy dispatch.

Pedro Coco Calderon

Antonio Cotrina

\footnotetext{
${ }^{47}$ Good quality gold usually meant 22 carats or above; gold coinage was always 22 carats.

${ }^{48}$ In the original manuscript text "escudos de oro de minas"; as gold coins were not minted in the New World until 1622 in Santa Fé de Bogotá, Colombia, in 1679 in Mexico, in 1696 in Lima, Perú, and in 1698 in Cuzco, Perú, only bullion gold was available; based on weight and purity a monetary value was assigned. As gold coins minted in Spain were sporadically available, the distinction is made here and the fact that the gold in question is New World gold bullion is indicated.

49 This is a very confusing paragraph as the author of the document is trying to equate values assigned to mercury to various monetary values.
} 
[On the back of the document:]

Veracruz

\section{A SM}

1601

The royal officials $9^{\text {th }}$ of March

Seen and replied to in Valladolid the $20^{\text {th }}$ of July of 1601

\section{[END]}


Introductory Note: Tira 9 is another document that relates to the tragedy of the 1600 fleet. It provides the names, vessel types, and masters of certain ships of the fleet and also alludes to a slave cargo. Please note that the San Juan Bautista mentioned in this document is not identical to Lost Ship Number 8, another ship of the same name, which was lost well over a century after Tira 9 document was created.

\section{Tira 9}

\section{Contratación 2899}

\section{f. $56 r$}

\section{Translated by John de Bry}

The registers that have been dispatched to the province of New Spain ${ }^{50}$ and other parts carried by the fleet that traveled to the said province in this year of 1600 commanded by General Pedro de Escobar Melgarejo are as follow:

\section{To New Spain}

Juan de Ugarte, master of the flagship named San Juan Bautista

Gaspar de Carasa, master of the admiral ship named Nuestra Señora de Aranzazu

[in the right margin:] Gaspar Alvarez, master of the ship named

Francisco de la Just, master of the ship named San Pedro

Constantin Perez, master of the ship named Santiago

Diego de Torrijos, master of the urca $^{51}$ named El Salvador

Luis Ortiz, master of the ship named la Concepcion

Juan Martínez(?) de Amiluia, master of the ship named Nuestra Señora del Rosario

Esteban Fatero, master of the ship named el Espíritu Santo

Juan Mrz de Herboa, master of the ship named la Concepción

Juan de Morales, master of the ship named San Antonio

[In the left margin: Gaspar Alvarez instead of] Alvaro Bartolomé, master of the ship named el Espíritu Santo

Melchor Palomo, master of the ship named Santa Bárbara, which everyone says was lost at the exit of the uarra (sic) ${ }^{52}$

Juan Carco de Maya, master of the ship named Ma[dre] de San Vicente

Juan Bautista Jimenez, master of the ship named San Jacinto

Alonso Monte Bernardo, master of the ship named Nuestra Señora de Aranzazu

Tomás Gallardo, master of the ship named la Asunción

Pedro Sánchez de Figueroa, master of the ship named Francisco de Paula

Andrés Ximenez, master of the ship named Santa Catalina de Siena

Tomás Denis Manrique, master of the ship named la Trinidad

\footnotetext{
50 México

${ }^{51}$ An urca was a cargo sailing vessel with a broad beam and rounded hull.

${ }^{52}$ In the original manuscript text a la salida de la uarra or varra possibly barra which could mean the sand bar at Sanlúcar de Barrameda in Spain.
} 
Luis de Bega, master of the ship named Nuestra Señora del Rosario

Lázaro de Arpide, master of the ship named San Benito

Manuel Diaz, master of the ship named San Bicente

Bartolomé Dorado, master of the ships named Nuestra Señora de la Esperanza

Hernán García, master of the ship named Nuestra Señora del Rosario

Francisco Ximenez, master of the felipote $e^{53}$ named el Cisne Blanco ${ }^{54}$

Juan Francisco Grimaldo, master of the ship named San Buenaventura

[In the left margin: Tierra Firme] Francisco de Ceniceros, master of the ship named San Cristóbal

The records of the slaves and other things that were registered in the galleons that went to Tierra Firme this year under the command of Marcos de Aramburu in a [another body of] documents (?).

[END]

\footnotetext{
${ }^{53}$ Filibote or filipote: Medium size coastal freighter, roomy and cheap to build and work, the fluyt, a vessel of Dutch origin (English 'flyboat', French 'flûte', Spanish 'felibote') was much used as a general service cargo vessel from the later sixteenth century onwards. From R. Davis, English Merchant Shipping and Anglo-Dutch Rivalry in the Seventeenth Century (London 1975).

${ }^{54}$ The White Swan.
} 
Introductory Note: Tira 19, written between 1719 and 1720, reports on the status of certain vessels plying between Spain (Cádiz) and the Americas, including the Gulf of Mexico region. Particularly, the document provides evidence of the loss of the San Juan Bautista (Lost Ship Number 8)(abbreviated at one point in this document as the San Juan). Also within this document are brief notes on the cargo of vessels and also insights into sailing times.

\section{Tira 19}

\section{Ultramar 704}

\section{Libro 1, folio 8 recto - folio 9 recto}

\section{Translated by John de Bry}

$/ 8 \mathrm{r} /$

Aviso for Cartagena

[in the margin: The paquebot ${ }^{55}$ named San Carlos aka the Malta, that was substituted instead of this sloop of 60 tons burden and 100 cannon with 40 men, is the king's property, and came back to Cádiz on the $30^{\text {th }}$ of March of [1]720, and the pilot, Cueto, came under the King's orders bringing tobacco in rolls and bunches; for private individuals 26,037 e[scudos], and some letters and quantities of merchandises]

On 6 March of 1719 His Majesty's sloop named the San Andrés left from Cádiz to Cartagena under the command of captain and pilot Don Francisco Ventura Cueto.

Frigate for Buenos Aires

[In the margin: It was lost in Buenos Aires]

On April 21 of 1719, His Majesty’s frigate named the San Andrés left from Cádiz to Buenos Aires with different sealed documents.

Ships in Veracruz

[in the margin: these three ships successfully arrived in Veracruz on 5 July of [1]719. In December of [1]719, lost in the Gulf of Mexico during a squall were the ships San Luis and San Juan, the latter sunk in parts unknown with all its crew, and the San Luis, having run aground, the people were saved and the ship was lost. ${ }^{56}$

The frigate San Joseph came back to Cádiz with Guevara on 17 December of [1]721]

On 21 April of 1719 the three warships of the armada named San Luis bearing 60 cannon, San Juan Bautista of 60 cannon and the frigate San Joseph of 36, left Cádiz for Veracruz.

Don Francisco Cornejo went as captain of the ship San Luis and commander of all three; Don Juan de Córdova Lasso de la Vega as captain of the San Juan Bautista, and Don Diego de León [as captain] of the frigate.

As mercantile marine officer, Don Joseph del Capillo.

These ships should be in

\footnotetext{
${ }^{55}$ A mail boat also known as a packet boat.

56 The San Juan is a good candidate for having sunk in ultra deep water off the coast of Florida.
} 
/8v/

America until further orders, and employed, as was done in the past, by the Armada of Barlovento, ${ }^{57}$ joining those that are left, all under the command of the [above] referred Cornejo, and as second in command Don Diego Alarcón, Admiral of the Armada of Barlovento.

They took on the account of the Royal Estate different portions of iron and steel as ballast

10,277 hundredweights of mercury

474 parcels of decrees (bulls)

139 parcels of papers [official documents] for the years of [17]21 and [17]22

1200 muskets for the garrisons of New Spain, at the disposition of the viceroy Marquis de Valero

and a large portion of marine supplies for the frigates of the Armada of Barlovento that are in Veracruz.

No fruits or commercial merchandises of private individuals were loaded on those ships.

These ships must stay in

$/ 9 \mathrm{r} /$

those seas until further orders so that they may serve in the Armada of Barlovento, sailing in consort [with] 4 ships for Havana with merchandises and fruits of the account of His Majesty, and those are the same ships that are mentioned in another sheet (page).

Ships for Havana

[On the margin: On June [blank] of [1]719 these 4 ships arrived in Havana; the first 3, because of the uprising that was taking place in Havana, went to Veracruz where they arrived on the 19 of August, of the 19 (sic) having left Havana on the $10^{\text {th }}$ of the same month, El Caballo Marino left Havana for Spain on 28 January of [1]720 and arrived in Cádiz on the following $4^{\text {th }}$ of April, the trip having lasted 68 days; it brought various portions of tobacco for His Majesty, and for private individuals 36,124 pesos and some small quantities of merchandises.

The ship or frigate named the Santo Cristo de Maracaibo was lost in the expedition of the island of the Providence ${ }^{58}$ where it was taken to by Don Francisco Cornejo]

On the $21^{\text {st }}$ of April of 1719 four ships left Cádiz for Havana named Nuestra Señora de Begoña bearing 50 cannon, el Infante of 44 cannon, the Santo Cristo de Maracaibo of 12 [cannon] and the one named San Joseph aka El Caballo Marino that was chartered.

The first two ships are of the armada and the $3^{\text {rd }}$ [was] bought by Don Manuel de León for cargo. As commander of these ships Don Francisco Guerrero, ship's captain, and as captain of the referred frigate named el Infante, Don Joseph Caniz de Alzadora.

All merchandises and fruits purchased were transported on the account of the Royal Estate....

[END]

\footnotetext{
57 The Windward Fleet was based in Cartagena, Veracruz, and in the major islands of the Lesser Antilles, including Margarita Island, and the port of La Guaira in Venezuela. Created in 1575, the fleet's main purpose was to sail the Caribbean Sea and the Gulf of Mexico to protect Spanish shipping from pirates, privateer, and enemy vessels.

${ }^{58}$ New Providence Island in the Bahamas.
} 
Introductory Note: Tira 21 is a document that was drafted in 1612 in preparation for the depature of the San Nicolàs (Lost Ship Number 9), an aviso or armed dispatch vessel. The details of who and what was aboard are especially detailed and valuable. The document also gives a description of the route that the ship was to take to across the Atlantic to the Caribbean and, ultimately, to Vera Cruz.

\section{Tira 21}

\section{Contratación, 1473}

\section{No. 10, Ramo 4}

\section{Translated by John de Bry}

1612

Master Andrés Franco, commanding the aviso ${ }^{59}$ ship San Nicolás to New Spain ${ }^{60}$

Master Andrés Franco=owner Martín Monte+1612-Aviso to New Spain

This aviso sailed on Thursday, fifteenth of January of 1612 from the port of Sanlúcar ${ }^{61}$

Commission and visit of the zabra ${ }^{62}$ San Nicolás, which was the aviso to New Spain, Master Andrés Franco and owner Martín Monte Bernardo

[In the margin: zabra San Nicolás

Sailed on the $5^{\text {th }}$ of January

Reported to have been lost before arriving in New Spain]

We, the president, judges and officials of Your Majesty’s House of Trade ${ }^{63}$ of the Indies from this city of Seville, ordered captain Gabriel Maldonado, who is our Majesty's appointed inspector of the ships sailing to the Indies, that after this missive is delivered to him, he should travel to the city of Sanlúcar de Barrameda and visit the zabra called San Nicolás, owner is Martín Monte Bernardo, and Master Andrés Franco, which is being dispatched as aviso to New Spain with documents and dispatches of Your Majesty and private individuals. After having visited his ship, in accordance with this said house's ordinances, he will deliver an authorized transfer of the visit and the instructions he should follow to the said Master, and after having received it, he must acknowledge that he cannot take more people, provisions, or any other things, which contradict the agreement that was made with the said Martin Monte Bernardo. The visit would take effect in front of Your Majesty's scribe, Joseph de Ochandio, who was chosen for this commission, performing before his presence all the necessary due diligence and

\footnotetext{
${ }^{59}$ Any small and fast warship carrying dispatches.

${ }^{60}$ Mexico

${ }^{61}$ Sanlúcar de Barrameda, on the southwestern coast of Spain, is located at the estuary of the Guadalquivir River; ships sailing to and from the Americas navigated the River from and to Seville. An estimated 300 ships sunk on the bar at the entrance of the Guadalquivir.

${ }^{62}$ A ship of up to 600 toneladas ( 1.376 cubic meters x $600=825.6$ cubic meters) with two masts and square sails that could be outfitted with oars. Zabras were part of Philip II's Invincible Armada, but oars were not used (Source: El Buque en la Armada Española, Editorial Silex, Madrid 1981).

${ }^{63}$ House of Trade (Casa de Contratación), officially known as La Casa y Audiencia de Indias.
} 
procedures, so that the first time that there is good weather no further delay would take place and the said zabra would sail from this port in order to begin its journey. He would bring the original visitation and he will deliver it to the said house's accountancy. We determined to pay the said inspector one thousand maravedíes ${ }^{64}$ each day and to the notary five hundred maravedíes for each day they would take to travel from this city of Sanlúcar and return to it. We will pay them at the expense of the avería, ${ }^{65}$ as it is the practice in these cases, which we have repaid them fairly well. Written in Seville's house of contratacion at December $24^{\text {th }}$ of 1611.

Don Francisco de [Vartezeran?]

Don Melchor Maldonado

Don Antonio López de Calatayud

Ordered by the abovementioned gentlemen president and officials

Pedro de Salas, scribe.

$/ \mathrm{v} /$

[In the margin: visit]

In the port of Nuestra Señora de Bonanza, ${ }^{66}$ jurisdiction of the city of Sanlúcar de Barrameda, on the twenty-ninth of December of 1611, the captain Gabriel Maldonado, Your Majesty's appointed inspector of the ships sailing to the Indies, by virtue of the commission with which he was entrusted, visited the zabra named San Nicolás, whose owner is Pedro Monte Bernardo and the Master is Andrés Franco, is being sent as aviso to the provinces of New Spain with documents and dispatches of Your Majesty and private individual. The abovementioned visit took place in the following manner:

He visited the zabra and inspected the masts, sails, rigging, the boat, the oars and accessories, ${ }^{67}$ shape of the rudder, weapons and ammunitions, anchors, cables, provisions and seamen and it concluded as follows:

\section{Rigging}

A quintal ${ }^{68}$ of rigging of little quality ${ }^{69}$

Two sets of sails and one hundred bars of pacax (?) of little quality ${ }^{70}$

Three anchors and one rason (?)

\footnotetext{
${ }^{64}$ A copper coin, the lowest denomination in the Spanish monetary system; it served as the royal standard for determining relative values. 34 maravedíes were equivalent to 1 silver real; 272 maravedíes were equivalent to a silver 8-reales (Menzel, Sewall, Cobs, Pieces of Eight and Treasure Coins, ANS 2004).

${ }^{65}$ Avería was a tax imposed by the House of Trade from 1552 onward on merchandise going to and from the Americas (Phillips, Carla Rahn, Six Galleons for the King of Spain; Imperial Defense in the Early Seventeenth Century, John Hopkins University Press, Baltimore 1986 \& Chaunu, Huguette et Pierre, Séville et l'Atlantique (1504-1650, Partie Statistique, Tome Premier Introduction Méthodologique, Librairie Armand Colin, Paris 1955).

${ }^{66}$ The port of Nuestra Señora de Bonanza (Our Lady of Prosperity) is situated on the north side of the Guadalquivir River estuary, across from Sanlúcar de Barrameda, 44 kilometers north of Cádiz, and 126 kilometers from Seville. Due to its strategic location, the port prospered from the early $16^{\text {th }}$-century onward, but the transfer of the Casa de Contratación from Seville to Cádiz in 1711, and the Lisbon earthquake of 1755, negatively impacted navigation to Sanlúcar de Barrameda, and the port of Nuestra Señora de Bonanza fell into disuse.

${ }^{67}$ Esquipaçon in the original manuscript text; this word could not be found in various dictionaries old and modern so the word "accessories" is used as a logical possibility.

${ }^{68}$ A quintal was equal to 4 arrobas $=46$ kilograms $=101.5$ avoirdupois $=100$ pounds (U.S.).

${ }^{69}$ Menuda de respeto in the original manuscript text; this is not fully understood and the translation interpretative.

${ }^{70}$ Ibidem
} 
Four cables and one new etrenque (?)

Two pumps with their respective tackles

$/ 2 \mathrm{r} /$

One boat with eight oars

Six large oars for the zabra

Sixteen pounds of sail thread

Eighty needles

Weapons and ammunitions

Ten muskets with their powder flasks and small flasks

Three hundred lead bars

Ten pounds of arquebus wick ${ }^{71}$

Six chucos (?) and four picks

Three arrobas of gunpowder

\section{Seamen}

[In the margin: an, cappy, piloto] ${ }^{72}$

An

The captain Monte Bernardo, owner of this zabra will transfer the office of pilot to a resident of Triana, $^{73}$ who showed his certificate of proficiency of sea instruments. ${ }^{74}$

The master Andrés Franco, resident of the city of Sanlúcar de Barrameda, skilled mariner who $/ 2 \mathrm{v} /$

because he does it well was given the said office [of pilot] son of Juan, small, black-bearded of thirty-three years of age.

The foreman Antonio Pérez, born in Triana, son of Sebastián, medium height, whitish-blond hair, large forehead, fifty years of age.

Juan martín, mariner, born in Triana, son of the same [name Juan], good body, dark skin, white hair, fifty years of age.

Marcos Franco, sailor, native of the island of Palma, son of Miguel, good body, smallpox pockmarks, speckled eyes, twenty-two years of age.

\footnotetext{
${ }^{71}$ Cuerda de arcabuz in the original manuscript text; this most likely refers to the wick, or match, carried and used by arquebusiers.

${ }^{72}$ This marginal notation is not understood.

${ }^{73}$ Triana is a section of Seville on the west bank of the Guadalquivir River; named after the Roman Emperor Trajan, it was once Seville's gypsy quarter and remains to this day a traditional working-class district.

${ }^{74}$ Such as being able to read a compass in all its variations, take the altitude of the sun with an astrolabe and that of the North Star with the forestaff (ballestilla), etc. (Ref: Phillips, Carla Rahn, Six Galleons for the King of Spain; Imperial Defense in the Early Seventeent Century, The John Hopkins University Press, Baltimore1986, pp. 129130).
} 
Pedro de Paz, sailor, native of the island of Palma, son of Sebastián Hernández, good body, beardless, one lost tooth, tall, twenty-two years of age.

Antonio Mezeta, sailor, native of Motrico, ${ }^{75}$ son of Domingo, medium height, scarce blond beard, twenty-seven years of age.

$/ 3 \mathrm{r} /$

Agustín de Bastan, sailor, native of the Pasaje, ${ }^{76}$ son of the same [name Agustín], medium height, crooked and big nose, twenty years of age.

Francisco Corzo, sailor, born in Arauco in the kingdom of Chile of the Indies, ${ }^{77}$ face with Indian color, scar to the left side of his mouth, twenty years of age.

\section{Cabin Boys}

Juan de Beayn, cabin boy, born in Berg. ${ }^{\text {a }}{ }^{78}$ son of the same [name Juan], big ears, one lost tooth, tall, twenty years of age.

Andrés de Arizaga, cabin boy, native of Villa de Plasencia, ${ }^{79}$ son of Juan Pérez de Laranzchata, smallpox pockmarks, joint eyebrows, eighteen years of age.

\section{Pages}

Marcos Pérez, page, native of Triana, son of Domingo Pérez, scar in the [...] forteen years of age.

Luis Monte Bernardo, native of Triana, son of Alonso Monte Bernardo, lean, white, twelve years of age.

As a form of a right, the oath was taken by captain Martín Monte Bernardo and also by the master Andrés Franco and declared (swore) that the zabra was carrying these provisions for the present journey:

Sixteen quintales of ordinary biscuit and three barrels of white [wine]

Two hundred wine pitchers in 10 barrels [red wine]

Twenty-six pitchers of vinegar

\footnotetext{
${ }^{75}$ Motrico (Basque Mutriku) is a small fishing village situated on the Bay of Biscay in the province of Guipuscoa, in the Autonomous Community of Basque Country, in the north of Spain.

${ }^{76}$ A Pasaje or A Paxase a tiny fishing village on the north bank of the Río Minho, that serves a border between Spain and Portugal, in the Province of Galicia.

${ }^{77}$ Arauco is a very small village on the Gulf of Arauco in southern Chile, some 287 kilometers (as the crow flies) south.

${ }^{78}$ Possibly Berga, a town in Catalonia (Catuloñia

79 Plasencia is a town in the Province of Extremadura in central Spain, situated on the Río Jerte; it served as a military bastion in the $16^{\text {th }}, 17^{\text {th }}$, an $18^{\text {th }}$-century.
} 
$/ 4 \mathrm{r} /$

Twenty arrobas $^{80}$ of oil

Four quintales of codfish

Three fanegas ${ }^{81}$ of beans and chickpeas

A bit of meat

One hundred jugs of water

Salt and firewood that has been blackened [?]

Afterwards, we, the said inspector and the scribe went below the deck of the said zabra in order to inspect it from bow to stern; to which, it appeared there were no other goods than those for which he had permit and license.

It was ordered to the abovementioned master and pilot not to take onboard the zabra any other goods for which he has permission from the gentlemen president and judges, for if he does he would certainly loose them and he would incur a fine with the according penalties for those who carry goods without a permit in ships sailing to the Indies. Also, he was ordered not to take any priest or friar as passenger, nor can he transport gold, silver, slaves, weapons, or any other goods that are forbidden or he could be punished with the penalties stipulated in the ordinances

$14 \mathrm{v} /$

of the House of Trade of the Indies in the city of Seville, which must be kept or else face the penalties. They must be ready to sail at the first sight of good weather and that under no circumstances, once they are in open seas, to allow any ship to get near or accept any goods, for if they do they will be punished with all the severity stipulated for men who accept goods and people outside the scope of this permit and acts against Your Majesty's dispositions. All these issues were explained to them in the presence of the scribe and also in the presence of the good faith witnesses Hernán González and Francisco Raya, residents of this port and it was signed by the inspector.

Gabriel Maldonado

Joseph de Ochandio, scribe

I received a duplicate of this authorized visit from the current scribe along with an instruction signed by the gentlemen president and official judges of Your Majesty in the House of Trade of Seville, dated in this port of Bonanca (sic) ${ }^{82}$ on the first of January of 1612.

\section{Signed}

Monte Bernardo and Franco

Before Ochandio

\footnotetext{
${ }^{80}$ One arroba was equal to 25 libras or 11.5 kilograms.

${ }^{81}$ A unit of dry measure equal in Spain to 48 quartillos, or 55.7 liters or 1.58 U.S. bushels.

${ }^{82}$ The port of Nuestra Señora de Bonanza (see footnote 8).
} 
$/ 5 \mathrm{r} /$

Transcript of the permit ${ }^{83}$

Guards of the river of this city...allow passage to small vessels and take to the patache San Nicolás, owner Martín Monte, which is taking news to the Province of New Spain with folios and dispatches from Your Majesty, the declared permit for the service of the ship and sustenance of its crew, which are the following things:

Two hundred wine jugs

Twenty-six jugs of vinegar

Twelve quintales of biscuit

Forty jugs of capers

Ten of large capers

Thirty jugs of olives

Eight quintales of codfish

Three barrels of sardines

Three quintales of raisins

Three barrels of figs

Four fanegas of beans and chickpeas

One and a half arrobas of cheese

One hundred and thirty garlic strings

One hundred jugs of water supply ${ }^{84}$

Forty bassas ${ }^{85}$ of flagstone

Thirty pounds of sail thread

One hundred and thirty varas ${ }^{86}$ of waterproof canvas ${ }^{87}$

One quintal and a half of rigging of good quality

$15 \mathrm{v} /$

One quintal and a half of nails

Two quintales and a half of tar

Three arrobas of gunpowder

Half an arroba of rope

Twelve quintales of almonds

One barrel of rice

Dated at Seville on the twenty-first of November of sixteen hundred and eleven

Don Francisco de Vartezeran, Don Melchor Maldonado, Don Antonio López de Catalayud.

Passed by the almojarifazgo ${ }^{88}$ of the Indies the permit from the gentlemen president and official judges containing this other section. Done on the twenty-sixth of November of the year sixteen

${ }^{83}$ Copy.

${ }^{84}$ Aguada in the original manuscript text, a nautical terminology for water supply.

${ }^{85}$ Bassa or bassas, apparently a measure, could not be found neither old nor new dictionaries.

${ }^{86}$ A vara was equal to 0.83 meter or 32.9 inches.

${ }^{87}$ Lienzo parax in the original manuscript text, understood to mean that the canvas had been treated with paraffin was or some other agent to waterproof it.

88 The almojarifazgo was a payment imposed by the crown on certain goods imported or exported.

Common gold that has been assayed and the royal tax extracted (usually from the bars of gold and silver respectively) and marked with some sort of emblem or coat of arms etc, indicating royal inspection and acceptance as such (Sewall Menzel, 2009: personal communication). 
hundred and eleven. Paying on the table of the Indies the excess of two hundred reales in cash to the recipient...Juan Martínez...the wine goes in barrels and must be ten instead of the jugs, I paid six thousand and eight (remainder of the text is not readable) ${ }^{89}$

Verify by...that he took with him the said captain Martín Monte, and this duplicate was taken out in order to check commissioned visit by inspector Gabriel Maldonado, prepared in Bonanza on the twenty-ninth of December

$/ 6 \mathrm{r} /$

of sixteen hundred and eleven. Witnesses: Hernán González and Francisco de Raya, who are residents of this port.

Joseph de Ochandio, scribe.

/6v/ [blank]

$/ 7 \mathrm{r} /$

Instructions and delivery of Your Majesty's folios

Instructions of what you, Martín Monte Bernardo and Master Andrés Franco, master and pilot of the ship named San Nicolás that is sailing as aviso to New Spain, taking folios and dispatches of His Majesty, must avoid on this journey is as follows:

You will sail from this port of Sanlúcar with the first sight of good weather and you will sail to the southwest until reaching thirty leagues outside the capes and from there you will sail southwest a quarter west until you are situated north-south of island of La Palma. From there you will navigate to the west southwest until reaching eighteen degrees, thus which you will not encounter any of the Canary Islands. From the said eighteen degrees, you will sail to the west quarter southwest until reaching sixteen degrees. From there you will sail due west until reaching Antigua and pass by its north coast. Then, you will sail due west quarter northwest, which will allow you to see Puerto Rico. Without anchoring or approaching land, sail to the west until passing la Saona, ${ }^{90}$ and then continue sailing to the west northwest until seeing the island of Santo Domingo without going near the coast, and from there sail due west quarter northwest until you are able to recognize La Navaja. ${ }^{91}$ From there, sail to the northwest in order to reach Cuba and from there you will reach out for Cape Cruz ${ }^{92}$ without entering any port, sail west northwest looking for the Isle of Pines, and from there to Cape Corrientes. ${ }^{93}$ From the west look for Alacrán ${ }^{94}$ and you will get closer to the coast,

$/ 7 \mathrm{v} /$

and taking sounding for eighteen brazas, ${ }^{95}$ you will reach San Francisco. ${ }^{96}$ There you will wait until a north [wind] blows and then you will sail to the port of San Juan de Ulua, ${ }^{97}$ without entering in any other port until you entered it, under penalty of death due to the great importance

\footnotetext{
${ }^{89}$ This sentence is convoluted and difficult to fully understand.

${ }^{90}$ On the southeastern tip of Hispaniola.

${ }^{91}$ Navassa Island.

${ }^{92}$ Cabo Cruz, on the southeastern tip of Cuba.

${ }^{93}$ Cabo Corrientes, next to Cabo San Antón, on the southwestern tip of Cuba.

${ }^{94}$ Alacrán is believed to have meant Yucatán.

${ }^{95}$ A $16^{\text {th }}$-century Spanish braza equaled 1.694 meters x $18=30.492$ meters.

${ }^{96}$ San Francisco de Campeche, modern-day Campeche, on the western coast of Yucatan.

${ }^{97}$ The fort of San Juan de Ulua was located on an islet east northeast of Veracruz; it is no longer an island and is now part of the harbor of Veracruz.
} 
there is for you not to enter any other port and that you make good use of the days and hours in this journey.

Be aware at all times in your journey to constantly scrutinize the sea and the ships sailing on it by always having a sailor on the top mast. When morning breaks, make sure to furl down the sails and if there are no suspicious ships, you will continue your journey. And if you spot one, you will sail away from them. You will have to follow the same indications before nightfall, when sun is setting, so that no ship would be able to discover you. If you happen to be spotted, do not allow yourselves to fall into the hands of a privateer [in which case] you will throw all the folios and dispatches into the sea and this instruction by adding enough weight, so that it sinks all the way to the bottom. You will say that you are transporting goods to the Indies and no dispatches from His Majesty.

You will meticulously follow and comply with the mission that has been entrusted to you, for [he] relies in you due to the importance to His Majesty's service.

Dated at Seville on the twenty-forth of January of sixteen hundred and eleven.

$/ 8 \mathrm{r} /$

Receipt of the documents

We, the captain Martín Monte Bernardo and Andrés Franco, pilot and master of the ship named San Nicolás, which is sailing to the province of New Spain, taking notifications of Your Majesty that we have received from the gentlemen president and official judges of the house of Trade in the city of Seville the instruction signed with their names in the previous sheet and the documents and dispatches of Your Majesty are as follow:

One chest for the Archbishop of Mexico, who is in charge of the government of New Spain.

Sixteen of Your Majesty's documents for the Archbishop of Mexico, who by command of Your Majesty governs New Spain.

Another chest for the said archbishop with following documents:

Five documents of Your Majesty for the president and judges of Mexico’s Royal Audience .

Three documents of Your Majesty for the royal officials of Royal Hacienda of Mexico.

Another from the house [of Trade] for the royal officials of the said city of Mexico.

Two documents of Your Majesty for the attorney Gutiérrez Bernardo de Quiroz, Inquisitor of Mexico.

Another one of Your Majesty for the accounting tribunal of Mexico.

Another from Your Majesty for Doctor Antonio de Morga, criminal mayor of Mexico City. ${ }^{98}$

/8v/

Another from Your Majesty for Don Juan de Silva, Governor of Manila.

Another from the House [of Trade] for the attorney Don Pedro de Otalora (sic), Judge of the Royal Audience of Mexico.

A round box with a letter for the attorney Don Fernando de la Hoz, District Attorney of Mexico. Another folio for Diego de Ochandiano, accountant and official judge of the city of Mexico City.

${ }^{98}$ Most likely a criminal judge. 
In a chest for the royal official of Veracruz are the following documents:

Four documents of His Majesty for the royal officials of Veracruz.

Another for General Don Antonio de Oquendo

Another for the president and judges of the Audience of Guatemala, which are all from His Majesty.

Another from the House [of Trade] for the royal officials of Veracruz.

Another from the House [of Trade] for the royal officials of Guatemala.

Another from the House [of Trade] for the royal officials of Campeche.

Another from His Majesty for the Count de la Gomera, President of Guatemala.

These documents were happily ${ }^{99}$ delivered by perseverance [of Martín Monte and Franco Andrés Franco and crew] to carry and hand them over, with God's aid, to the official judges of Your Majesty of the city of Veracruz and bring proof that the said gentlemen president and official judges received them within the span of a year.

/9r/

So that this clause would be fulfilled they were compelled by a contract to cede their current and future positions if they did not and, it was signed with their names and served as witnesses Alvaro de Rebolledo, Antonio de Elorsa and Diego López de Orozco, dated in Seville on the twenty-forth of December of sixteen hundred and eleven.

In advance we informed that some of Your Majesty's documents contained within the said chests arrived from the court wet and mistreated and even though they did dry out in the sun and they were rebound with new covers, there is a chance that some letters might be spoiled, which would not be the fault of the said Captain Martín Monte Bernardo and Andrés Franco.

We also received two smaller chests containing private correspondence that should be delivered to the said officials of Veracruz

[Between lines] two/small

Signatures of Monte Bernardo and Franco

Before me Joseph de Ochandio, scribe

[In the margin: Receipt of more documents]

In the port of Bonanza, jurisdiction of the city of Sanlúcar of Barrameda, on the twenty-ninth of December of sixteen hundred and eleven, before me the scribe and witnesses granted to captain Martín Monte Bernardo, owner of the zabra San Nicolás that is sailing as aviso to the provinces of New Spain taking dispatches and to Andrés Franco, master its master, that they had received from inspector Gabriel Maldonado the following documents:

One document from Your Majesty entitled "I the king, to the royal officials of Your Royal Hacienda of the city and port of New Veracruz"

/9v/

Another from Your Majesty entitled by the king as "A Iñigo López de Salcedo, official accountant and judge of Your Majesty from the city and port of New Veracruz"

A wooden chest covered with anxeo ${ }^{100}$ entitled "To father Gabriel de Alarcón, rector of the Company of Jesus of Veracruz"

\footnotetext{
${ }^{99}$ Successfully.

${ }^{100}$ Possibly wire mesh or wire gauze, but this word, along with spelling variations, was not found in old and new Spanish dictionaries.
} 
Another document for Don Antonio de Oquendo, Captain General of the armada and of squadron of Cantabria ${ }^{101}$ and fleet of New Spain, by the King our Lord”

Another for Juan de Goycochea and in his absence to captain Lucas de Urquiaga with eighteen paintings, which he says are in a bundle lined with burlap

Another small document entitled "To Captain Bernardo de Paz, and in his absence to Captains Lucas de Urquiaga and Martín Pérez de Barrazueta, New Veracruz”

Another small one a joseph de Trujillo, his brother in Puebla de Los Angeles

Another large document along with two smaller ones tied to it, entitled "to Juan Gerónimo de Cabanas, and in his absence to Gerónimo Calar de Irolo, Mexico”

Another small one to Pedro de Izaguirre, Admiral of Your Majesty's fleet which is in New Spains’s san Juan de Ulua's fortress

/10r/

Another small one entitled "to Matías del Casto (?), San Juan de Ulua.

Another to the Duke de Medina, ${ }^{102}$ entitled "to the most illustrious Sir...master fray García Guerra, Archbishop of Mexico, who holds the office of viceroy by Your Majesty's orders in the provinces of New Spain, Mexico.

Another from the said Duke of Medina Sidonia for don Antonio de Oquendo, General of the fleet in New Spain and of the squadron of Cantabria in San Juan de Ulua.

Another from the said Duke of Medina to don Gaspar Ruiz de Pereda, Governor and Captain General of Cuba and lord of the fort in the city of san Cristóbal de la Havana.

The envoys [Martín Monte Bernardo and Andrés Franco] transporting the said documents to the royal officials of the city of New Veracruz from the provinces of New Spain were obliged to deliver them and bring back a certified receipt which demonstrates their delivery. For that they were compelled by their personal reputation and private property as guarantee. They complied with this measure and signed it. Witnesses were Hernán González and Francisco de Raya, who are residents in this port.

By orders of the Duke of Medina Sidonia a warning was issued to Captain Martín Monte Bernardo and Andrés Franco, which indicates that there are many privateers on the sea and an armada from Holland with fourteen ships, and that ten days ago it was spotted near Cape San

\footnotetext{
101 The province of Cantabria in the northern part of Spain. The city of Santander is the capital and center of Cantabria.

102 Don Alonso Pérez de Guzmán el Bueno, 7th Duke of Medina Sidonia, Grand of Spain, (full Spanish title: Don Alonso Pérez de Guzmán el Bueno, séptimo duque de Medina Sidonia, décimo conde de Niebla, quinto marqués de Cazaza, señor de Sanlúcar de Barrameda, señor de Gibraleón, caballero del Toisón de Oro, capitán general del Mar Océano y de la Armada Invencible), (1 September 1549 - 26 July 1615) was the commander-in-chief of the Spanish Armada. Regarded as the most important man after the king, the duke was often contacted first on most matters pertaining to the Spanish Armada as well as many of the New World affairs. Captain-General of the Ocean Sea, Captain-General of the Coast of Andalusia, he was in command of the 1588 Invincible Armada that suffered defeat during its attempt to invade England. When an English fleet attacked Cádiz in 1596, his slow response gave the English time enough to sack the city. In 1606 the obstinacy and folly of the duke caused the loss of a squadron which was destroyed near Gibraltar by the Dutch, yet, although his reputation had suffered tremendously, he managed to keep his position and control of the Spanish Armada until his death in 1615.
} 
Vicente ${ }^{103}$ and from there went to the Barbary Coast, ${ }^{104}$ and that they should flee from everything that they might encounter

$/ 10 \mathrm{v} /$

and to go (?) outside of the island of Palma to collect water (?) and flee if any ship approaches since there are multitudes of privateers of every nation. This was read to the said witnesses and they were informed by me, the scribe, to which I give testimony. They signed and promised to fulfill their mission.

Martín Monte Bernardo

Andrés Franco

Before me

Joseph de Ochandio

Scribe

Sailed away on the fifth of January of 1612.

[END]

103 Cape St. Vincent (Portuguese: Cabo de São Vicente), next to the Sagres Point, on the so-called Costa Vicentina, is a headland in the municipality of Sagres, in the Algarve, southern Portugal; it is the southwestern most point in Portugal.

104 The Barbary Coast, or Barbary, was the term used by Europeans from the 16 th until the $19^{\text {th }}$ century to refer to the Maghreb, the middle and western coastal regions of North Africa, what is now Morocco, Algeria, Tunisia, and Libya. The name is derived from the Berber people of North Africa. In the West, the name commonly evokes the Barbary pirates and slave traders based on that coast, who attacked ships and coastal settlements in the Mediterranean and North Atlantic and captured and traded slaves from Europe and sub-Saharan Africa (source: Wikipedia). 
Introductory Note: Like the preceding document, the document presented here provides further evidence of the loss of the French vessel Marie Thérèse (Lost Ship Number 10) in 1772.

CAOM C13 B1 1773

Série $\mathbf{C}^{13}$ - Received correspondences from Louisiana

Colonies $C^{13}$ B 1 (1773)

[Folio 423 recto]

Translated by John de Bry

In New Orleans, 9 January 1773

Triplicate

My Lord,

We have just learned through some English ships that the vessel named la Marie Thérèse of Port-au-Prince, ${ }^{105}$ captain Mr. François Lauwereyus ${ }^{106}$ (?), which sailed from here in August for the said place of Port-au-Prince, has perished with all of its crew and passengers. Mr. Bobé ${ }^{107}$, his spouse and his mother-in-law were among the passengers. He had taken aboard almost all the accounting documents of this colony, along with approximately 70 tonneaux ${ }^{108}$ of cannon of different calibers of those General O’Reilley ${ }^{109}$ did not

${ }^{105}$ Port-au-Prince; port city and capital of present-day Haiti.
${ }^{106}$ This name could not be referenced and the spelling is uncertain.
${ }^{107}$ Bobé-Descleaux, Jean-Arnoult-Valentin, chief accountant and comptroller of the Navy in Louisiana, 1760-1773 (Source : Archives Nationales, Marine $C^{7} 33$ ).

108 One French tonneau $=24$ cubic feet $=1.44$ cubic meters $=2,000$ pounds $=$ approximately 1 short ton. Accordingly, 70 tonneau represent140,000 pounds, a very substantial cargo; if there is no error in this letter, the ship must have been quite large (sources: sources: Contraste Universel, Paris, 1823; Panckoucke, Encyclopédie Méthodique du Commerce, Paris, 1783; Zupko, R. A Dictionary of Weights \& Measures, Philadelphia, 1985).

${ }^{109}$ Alexander O’Reilley (1722, Dublin, Ireland - March 23, 1794, Bonete, Spain) was a highly respected military reformer and Inspector-General of Infantry for the Spanish Empire in the second half of the 18th century. O'Reilly served as the second Spanish governor of colonial Louisiana, 1769-1770, being the first Spanish official to actually exercise power in the Louisiana territory after France ceded it to Spain. O'Reilly was appointed governor and captain-general of colonial Louisiana while in Spain in April 1769, with orders to immediately proceed to Havana, embark 3,000 troops there, put down the revolt in Louisiana, and re-establish order. Arriving in New Orleans in August 1769, O'Reilly took formal possession of Louisiana. O'Reilly then held trials and severely punished those French Creoles responsible for the expulsion of Spain's first Governor Antonio de Ulloa from the colony. He is still remembered in New Orleans as "'Bloody' O'Reilly" because he had six prominent rebel Frenchmen executed in October 1769. Other French rebels were exiled, and some sent for life imprisonment in the Morro Castle in Havana, also a World Heritage Site. Having crushed the ringleaders who had led the Rebellion of 1768, the French uprising against Governor Antonio de Ulloa, (January 12, 1716 - July 3, 1795) and Spanish rule, O'Reilly sent most of his troops back to Cuba, and focused his attention on administratively getting Louisiana back on its feet, and stabilizing the food supply. O'Reilly went on to reform many French bureaucratic practices in place before Spanish rule. Again, as in his 1765 mission to Puerto Rico, O'Reilly's proclamations and rulings affected many aspects of life in Spanish 
/v/

want to accept. As this news requires further confirmation, and that the opportunity I have to inform you of it is too rushed, I commit myself to give you longer and fuller details at the first opportunity if it is confirmed.

I am, with deepest respect,

My Lord,

Your very humble and obedient servant,

[Signature] Fazende ${ }^{110}$

[END]

Louisiana, including the ability of slaves to buy their freedom, and the ability for masters to more easily manumit slaves. He regularized the weights and measurements used in marketplaces, regulated doctors and surgeons, and improved public safety by funding bridge and levee maintenance. The insult to the dignity of the Spanish Crown having been swiftly dealt with, and good public order restored, O'Reilly assigned the post of governor of Louisiana to the colonel of the Havana Regiment in December 1769, retaining the post of captain-general for himself. Louisiana was firmly placed as a dependency of the military and political establishment in Cuba. For his much appreciated services to the Crown of Spain, he was ennobled as a conde (count), and granted a coat of arms.

110 Fazende, René-Jean-Gabriel), Scribe of the French Navy, then Commissioner of the Colonies in Louisiana, 1757-1783; son of Fazende, advisor to the Superior Council of Louisiana, died in 1749 (source: CAOM, Series E, E 180, Personnel Colonial Ancien, i.e. colonial personnel prior to the French Revolution of 1789). 
Introductory Note: This French document from the year 1773 is very brief, but it informs us of the suspected loss of the vessel Marie Thérèse (Lost Ship Number 10).

\section{CAOM C9 A142 1773}

\section{[No folio number]}

\section{Translated by John de Bry}

Serie C9 - Saint-Domingue. ${ }^{111}$ General Correspondences ; M. [Louis-Florent] de Vallière, ${ }^{112}$ gouverneur ; M. Montarcher, ${ }^{113}$ Commmissioner, 1773. (Non communicable document; exceptional authorization granted by Mr. Jacques Dion).

\section{St. Domingue}

Common Letter

Artillery

$\mathrm{N}^{\mathrm{o}} 133$

First (or firstly)

Port-au-Prince, ${ }^{114} 10$ February 1773

My Lord,

As you ordered us, by the dispatch that you honored us with the $30^{\text {th }}$ of April 1772, to send the state of the artillery that we will receive from Louisiana,

[in the margin at the bottom of the page] Mgr. de Boynes ${ }^{115}$

$/ \mathrm{v} /$

in order for you to know the quantity through this means, the shipment that are to be made from France can be reduced. As a result we have the honor to send you a lot of three crates containing

111 Saint-Domingue was the name of the French colony, now known as Haiti.

112 Vallière, Marquis Louis Laurent de, governor of Saint-Domingue, 1772-1775

113 Montarcher, Jean-François Vincent, seigneur de. Named Commissioner of Saint-Domingue in 1771 called back in 1774, he died in Paris on 13 March 1783 (source: CAOM Col. E 315 and C ${ }^{9 A} 139$ to 143).

${ }_{114}$ Port-au-Prince; port city and capital of present-day Haiti.

115 Boynes, Pierre-Étienne Bourgeois de (Paris, November 29, 1818 - Boynes, September 19, 1783), eldest son of Étienne Bourgeois de Boynes (1683-1754), Treasurer General of the Royal Bank, and his first wife, Helen Francine (1692-1722). Minister and Secretary of State to the Navy and Colonies, 8 April 1771 to 19 July 1774. In terms of policy, he took his distance from politics of René de Maupeou from late 1771 or early 1772. On April 20, 1774, he was appointed Minister of State. But with the advent of Louis XVI, was condemned for his association with the Maurepas. It claimed he had disrupted his department and he was even accused of embezzlement. Louis XVI, for his part, had told him he thought the changes he had made in the navy had come to nothing. He was fired July 20,1774 and replaced by Turgot. 
74 old muskets, complete with their bayonets originating from the said colony, sent by Mr. De l'Oppinot $^{116}$ (sic), which have been stored in the arsenal of Port-au-Prince ${ }^{117}$ as early as this past November. We were still waiting, My Lord, for the arrival of a vessel ${ }^{118}$ from this port that sailed for New Orleans at the beginning of last year under the command of Captain Lawrins ${ }^{119}$ (?), but the rumor has spread that this vessel having aboard a [large] quantity of artillery [pieces], and approximately 130 passengers and lots of merchandises, ${ }^{120}$ is lost with all souls since several months ago in the Bahama Channel ${ }^{121}$ (sic), which is very likely as it was never heard of again.

We are with our deepest respects,

My Lord,

Your very humble and very obedient servants

[Signature] Valière [signature] Montarcher

[Signature] Vallière [signature] Montarcher

[END]

${ }^{116}$ Loppinot de Beauport, Charles,-Joseph (b. 1738), ensign in Canada in 1758, posted in Louisiana in 1763, promoted to captain in 1769, to major in 1770 (source: CAOM Col. E 290).

${ }_{117}^{117}$ Port-au-Prince; port city and capital of present-day Haiti, founded in 1749 during French rules.

118 The Marie Thérèse (See CAOM Colonies $\mathrm{C}^{13} \mathrm{~B} 1$ ).

${ }^{119}$ Spelled Lauwereyus in a previous letter (CAOM Colonies $C^{13}$ B1), no biographical data could be found for this individual.

${ }^{120}$ Beaucoup d'effets in the original manuscript text, which means both merchandises and private properties.

${ }^{121}$ This assumption is flawed; by the mid to the late 1600s most ships avoided the Old Bahama Channel that runs between the north coast of Cuba and the Great Bahama Bank as it was imply too hazardous. Ships traveling to and from Port-au-Prince and New Orleans sailed to the south of Cuba within sight of the coast. This ship probably sunk somewhere between New Orleans and the western tip of Cuba, probably in deep water within the Gulf of Mexico. We can also surmise that the Marie Thérèse was overloaded, and that the excessive quantity of cannon might have contributed to the sinking. 
Introductory Note: This French document, drafted by a priest in New Orleans, reports on the sudden sinking of the vessel la Bellone (Lost Ship Number 11) at Dauphin Island. Also present is the author's account of certain transgressions that the captain of the vessel committed and the colonial court's administration of justice.

CAOM C13 A8 1725

\section{Series $C^{13}$ - Received correspondences from Louisiana Colonies $C^{13}$ A 8 (1724-1725)}

\section{Folio 399 recto (old numbering 136)}

\section{Translated by John de Bry}

15 May 1725, New Orleans. Sinking of la Bellone $e^{122}$

Letter from father Raphaël, Father Superior of the Capuchin ${ }^{123}$ missions of this Order in Louisiana.

Sir,

I received with true joy the letter you honored me with that you wrote on the 20 of July 1724, in which you had the kindness to inform me that His Majesty has named you Director of the [East and West] India Company relative to religious affairs, which allows to conceive solid hopes for a better arrangement in regards to ecclesiastic discipline in this colony and a more efficient protection to manage our ministry fruitfully. Father Matthias ${ }^{124}$ who gave me your letter of the month of this past January, arrived here in good health which he still enjoys [now]. Firstly, I responded with quite ample information on the state of religion and on secular affairs of which you wish to be informed, but it was just lost through the sad accident that happened to the ship la Bellone by which you were to receive it. This ship arrived on our coasts at the beginning of the month of September 1724, and it was to set sail for France on the first or second of April 1725. At the time the passengers were about to embark, it sunk to the bottom in front of them in front of Dauphin Island. ${ }^{125}$ The best experts in maritime affairs do not understand anything of such an

\footnotetext{
122 The ship la Bellone was named after Bellona an Ancient Roman war goddess. She is believed to be one of the numinous gods of the Romans (without a particular mythology and possibly of Etruscan origin), and is supposed by many to have been the Romans' original war deity, predating the identification of Mars with Ares. She accompanied Mars into battle and is taken variously as his sister, wife or daughter. She is also (as at her temple in Ostia) syncreted with Magna Mater. Bellona's attribute is not a sword and she is depicted wearing a helmet and armed with a spear and a torch (sources: Bulfinch’s Mythology, Crown Publishers, Inc, 1979, p. 10 \& Wikipedia).

${ }^{123}$ Capucin in the original manuscript text or Capuchin in English; the Order of Friars Minor Capuchin, an order of friars in the Catholic Church, among the chief offshoots of the Franciscans. The Capuchins are the youngest branch, going back to 1525, when some Friars Minor in the Marches wanted to live a stricter life of prayer and poverty to be closer to the original intentions of St. Francis of Assisi. Thanks to the support of the Papal Court the new branch received early recognition and grew fast, first in Italy, and since 1574 all over Europe. The name Capuchins refers to the peculiar shape of the long hood (source: Istituto Storico Cappuccini, Rome, Italy).

${ }^{124}$ Father Matthias was a priest from Mobile.

${ }^{125}$ Ile Dauphine in the original manuscript text; Dauphin Island off Bayou La Batre at the entrance of Mobile Bay, Alabama.
} 
extraordinary event, [but] it is true that the ship had suffered a little through some bad weather and for having hit bottom on the bar that is at the mouth of our river, but the weather was calm when it perished; the day before, at six in the evening it was pumped without noticing anything extraordinary, and at three and a half of the morning it had already sunk, in so little time that no one realized it. Most of the people would have drowned if it had not been for the proximity of a brigantine which favored their retreat. However, typical precipitation in these sorts of disasters caused two men to perish and two or three children. The cargo and all the properties of the private individuals

$/ \mathrm{v} /$

are lost. This loss here is causing a general consternation because it was hoped that the arrival of this ship in France could help the colony out of the general disgrace it is in the

Kingdom. It was, it can be said, richly laden for an up-and-coming [young] colony. What we regret the most is the indigo because it is said that it was better manufactured than in the past, and thus it would have given more solid hopes of returns the colony could expect in the future. This accident is being perceived in various ways and some believe they are seeing some premeditated conspiracy, but as it is up to God to penetrate the hearts and that there will be people skilled enough to weigh all the circumstances of the incident, I am content with the guidance of the Divine Providence, and to think in which manner this thing happened, and that our sins are the principal reason. It is not the first time since I am in the colony that I have noticed that our hopes have been dashed; when we think that our projects are about to succeed, and that thanks to circumstances that seemed extraordinary even to the oldest habitants of the country, which can be attributed, without pretending to elucidate the secret High Above, to great disorder amongst us and to which, until now, little justice has been handed.

To come back to the sinking of la Bellone, an enormous crime was committed aboard this ship by the captain named Beauchamp ${ }^{126}$ which could have attracted the vengeance of Our Lord. The abominable commerce of this miserable with a deck-boy was so well verified that the deck-boy was taken from him and transferred to another ship. That is the only punishment received for the crime which deserved a more exemplary one. Proofs were not lacking; the written statement from the deck-boy done in front of witnesses was in the hands of the religious chaplain from St. Domingue $^{127}$ who had shown it to several persons from here, and who having refused for this reason to sail back to France on la Bellone, were transferred on the flute named la Loire ${ }^{128} \mathrm{~A}$ secular priest ${ }^{129}$ for the same reason showed an extreme repugnance to take the place of the Dominican $^{130}$ [friar] on la Bellone. The ship surgeon who had treated the deck-boy relative to this infamy, [and] part of the crew who had particular knowledge of this, could have been heard. Finally, the thing had become public and the entire city was abuzz; ${ }^{131}$ after all this, all that was done was to send a pirogue down river after la Bellone to seize the deck-boy the captain was taking with him although he had been forbidden to. Another scandal has just taken place

\footnotetext{
${ }^{126}$ No biographical data could be found for Captain Beauchamp. The only person with the same name for that same period was Jean Jadard de Beauchamp, major in Mobile and Lieutenant of the King.

${ }^{127}$ Saint-Domingue was the name of the French colony on Hispaniola, present-day Haiti.

${ }^{128}$ The captain of la Loire was Béranger, former captain of the flute le Dromadaire. In late December 1724 he had replaced Captain Pierre de Fillart accused of embezzlement and put under arrest.

${ }^{129}$ In this context "secular" means that the chaplain was a plain priest who did not belong to any particular order.

${ }^{130}$ Jacobin in the original manuscript text.

${ }^{131}$ This is an interpretive translation as rin büe in the original manuscript text could not be understood
} 
pertaining to a Dominican priest, chaplain of the ship la Gironde, ${ }^{132}$ where the gentlemen of your council showed

/folio 400 recto/

more zeal but a little bit too passionate. ${ }^{133}$ This chaplain and Mr. de Verteuil, ${ }^{134}$ director of the concession of Mr. Paris du Vernai (sic) ${ }^{135}$ had some altercations together during the crossing; they had barely arrived that they spread their complaints against each other; Mr. de Verteuil made some strong ones against the chaplain, and he showed to numerous people the letter he was writing to Monsignor, the Bishop of Orleans in which he was calling the chaplain a defrocked monk and a corrupted man in morals and religion. At the same time a very hurtful satire surfaced against the Mr. de Verteuil, which the chaplain was being accused of writing. Mr. de Verteuil filed a petition with the Council to litigate; the prosecutor of the King joined in. I was named on behalf of the Council to attend the proceedings and to name a promoteur, ${ }^{136}$ which I did. The chaplain was only charged (accused) by one witness, all the other ones produced by Mr. de Verteuil said nothing that could be harmful to him, and this single witness was challenged in a confrontation by the chaplain for having always plotted with his party and for having made presents to the sister-in-law of Mr. de Verteuil. There was only the satire, which the chaplain admitted being the author without having been accused of it by the witnesses, but he denied that he had been the distributor, and none of the witnesses had accused him of it. The affair being in this state we believed, Monsignor Brulé, Secretary General of the Council and me, that it was time to quiet things down, and we even worked on convincing Mr. de Verteuil to reach a settlement, but he refused, and pursuing this affair in a not very Christian manner, he put part of the judges on his side. I was subpoenaed to assist in the judgment. Once the procedure had been read, and particularly the satirical libel which they wanted to be deemed defamatory, which was the only thing of concern, I instructed the judges, before passing a judgment, to [carefully] examine if this libel was truly defamatory, and because it did not seem to me to deserve this qualification, I requested to be granted custody of the accused and asked that he be sent to me, at which time, after I had retired, they gave their opinion and concluded that the libel was scandalous and insulting, stating that those two qualifications constituted an exceptional case that was of their competence. ${ }^{137}$ At the same time they rendered their judgment, in which they declared the accused guilty of having been the author and the distributor of an injurious and scandalous libel, and condemned and ordered him to compensate monetarily Mr. de Verteuil, which sentence would remain with the court with interdiction to repeat the offense under pain of corporal punishment. This sentence was followed by an order of the Council to the captain of the ship to take the chaplain ashore, which was done. It was believe that Mr. de Verteuil would leave it at that, but he had it confirmed...

\footnotetext{
${ }^{132}$ Named after the Gironde River in southwestern France, this ship appears to be a merchant ship, most likely a flute.

${ }^{133}$ More zeal than in the previous scandal concerning the captain of la Bellone and the young deck-boy.

${ }^{134}$ No biographical data could be found for Monsieur de Verteuil.

${ }^{135}$ Paris-Duverney was a concession, not a person, although the name suggests a dual ownership of the property.

${ }^{136}$ Promoteur in the original manuscript text; an ecclesiastic exercising the function of public prosecutor in an ecclesiastic tribunal, and charged of prosecuting delinquent priests, and maintain and defend the rights and immunity of the Church " En ladicte gracieuse nef n'avoit ne mal sergent ne advocaz, ne procureurs, official promoteur ou apparoicteur, qui en riens empeschassent leur marchandise et benoist arquemie, par laquelle on devient riche et mainne on belle vie. (Sources : MÉZIÈRES, Songe vieil pèl. C., t.1, c.1386-1389, 545 and Dictionnaire historique de l'ancien langage françois, ou Glossaire de la langue françoise depuis son origine jusqu'au siècle de Louis XIV. L. Favre Publisher, Paris, 1875).

137 Jurisdiction.
} 
$/ \mathrm{v} /$

[...] Mr. Le Blanc, captain, acting major, has already transported twice the treasury, twice I had it returned as it was forbidden. I will see if he will persist, and if he does I will take the action that the Lord will inspire me while waiting that the Council of the Company in France put some order in the confusions of all the things among which we live. I am persuaded, Sir, that your zeal for justice and good order will prevail, and that the protection you will be willing to give to my colleagues and me will support us in the exercise of our ministry by providing us the assistance that we need, as much as for being able to subsist as to exercise our functions with the authority necessary to serve Jesus Christ. It is the grace that I am awaiting from you, Sir, with those of [...?] trust very respectfully

Sir,

Your very humble and very obedient servant [Signature] F. Raphaël, Capuchin friar "seen” “...” (Different handwriting)

[END] 
Introductory Note: This French document is primarily focused on political relations between the French in the Lousiana colony and the local Native American groups, but it mentions the loss of two vessels: an unnamed Royal French Navy ship (Lost Ship Number 12) and an unnamed English vessel (Lost Ship Number 13). In reading this document, one gets a sense of the potentially devastating impact that a lost ship could have on a fledgling colony such as Louisiana. Also evident in this document is the action that was taken when ships were presumed to be lost or stranded in the Gulf.

CAOM C13 A16 1733

\section{Series $C^{13}$ - Received correspondences from Louisiana Colonies $\mathrm{C}^{13}$ A 16 (1733)}

\section{[Folio 178 recto]}

\section{Translated by John de Bry}

25 January 1733

M. Périer ${ }^{138}$

Read

Sir,

I did not have the opportunity to write to Your Highness since the departure of the ship from Bordeaux that carried the duplicates of the letters we wrote through Mr. de Colombe ${ }^{139}$ who commanded la Somme, ${ }^{140}$ which I learned arrived in France on the $3^{\text {rd }}$ of August of last year. Since its departure nothing of considerable importance happened except for having succeeded in unifying all the savages who had been allied to us, which the conspiring of the four nations who had revolted had divided.

\footnotetext{
${ }^{138}$ Périer, Étienne de (1687-1 April 1766) Lieutenant of the King, named Governor of Louisiana from 1726 to 1732, then Lieutenant General of Naval Forces. He was the fifth governor of the Louisiana colony. He became governor in 1727. His governorship was marked by the arrival of the first Ursuline nuns in New Orleans in 1727 to establish the first convent within the limits of what was to become the United States as well as a war against the Natchez Indians due to bad relations with Chepart, the commander at Fort Rosalie. After agitating the Indians by demanding that they give up either their village or their land, the Indians launched an attack on November 26, 1729 and killed nearly three hundred persons at Fort Rosalie. The French retaliated and by 1731 had killed or captured most of the Indians. The captured Indians were sent as slaves to St. Domingue (present-day Haiti), and the few remaining free moved further westward and joined the Chickasaw Indians. This marked the end of the Natchez Indian Nation. In the same year, the Company of the Indies (West \& East India Company) petitioned the King Louis XV of France to take back their charter, thus ending their control of the colony. Périer remained governor for two years after Louisiana was returned to the king but became frustrated with deteriorating relations with the Chickasaws and lost interest in the colony. He resigned, and Jean-Baptiste le Moyne de Bienville was chosen to yet again be governor of the colony (sources: Archives Nationales [Paris], Series Marine $C^{7}$ 242; Wikipedia).

${ }^{139}$ No biographical data could be found on this colony official.

${ }^{140}$ The merchant ship la Somme was named after a river in southwestern France in the Bordeaux region.
} 
My Lord the Count of Maurepas ${ }^{141}$ [at the bottom of the page - the recipient of the letter] /v/

I have seen with pleasure to which point the Choctaw ${ }^{142}$ have pushed their attachment to the French at a time when we were lacking everything to animate their zeal which only has fervor as long as we have enough to satisfy their souls [...?]; it is a good thing that a few chiefs I managed to win to my side the past several years made them pay dearly for learning those true [...?] of their nation which does not allow them to break our alliance without running the risk of being attacked by all the nations allied to the English as they found out more than twenty years ago, under which attacks they would have succumbed without the support of arms and munitions of war the King gave them,

/Folio 179 recto/

these times not being far removed they help them appreciate the reasons why they must remain grateful for such services. The officers who I had posted with them, who are Messrs. Régis ${ }^{143}$ and Chambellan convinced them so well that in the past month of June the Chickasha ${ }^{144}$ sent ten men with the calumet $^{145}$ to ask for peace, and they sent them back telling them that they would never make a peace that the French would not want, and that all they needed to do was to turn over the rest of the Natchez ${ }^{146}$ that were [living] with them, and with the guaranty of this good

\footnotetext{
${ }^{141}$ Maurepas, Jean-Frédéric Phélypeaux, Count of (1701-1781; Secretary of State under King Louis XV and Chief Royal Adviser during the first seven years of the reign of King Louis XVI. By dissuading Louis XVI from instituting economic and administrative reforms, Maurepas was partially responsible for the governmental crises that eventually led to the outbreak of the French Revolution.

${ }^{142}$ The Choctaw are a Native American people originally from the Southeastern United States (Mississippi, Florida, Alabama, and Louisiana). They are of the Muskogean linguistic group. The word Choctaw (alternatively spelt as Chactas in French, Chahta, Chato, Tchakta, and Chocktaw) may derive from the Castilian word chato, meaning "flat" (source: Wikipedia).

${ }^{143}$ Régis du Roullet was a French officer who often lived among the Indians, particularly the Choctaw, and kept journals about their way of life, customs, and language. His journals were published in 1922 by Baron Marc de Villiers (source: Documents concernant l'histoire das Indiens de la région orientale de la Louisiane. In: Journal de la Société des Américanistes - Notes sur les Chactas d'après les Journaux de Voyage de Régis du Roullet (1729-1732), by Baron Marc de Villiers, Paris 1922.

${ }^{144}$ The Chickasaw Indians were a tribe of great hunters and warriors whose towns were located near the headwaters of the Tombigbee River in northeastern Mississippi, but who ranged far and wide over the whole Mississippi valley region. The Chickasaw, along with the Cherokee, Choctaw, Creek and Seminole, were one of the Five Civilized Tribes which were removed to Indian Territory (now Oklahoma) in the 1830's (source: A Concise Dictionary of Indian Tribes of North America, Barbara A. Leitch; edited by Kendall T. LePoer, Reference Publications, Algonac, Michigan, 1979 - ISBN: 0917256093).

${ }_{145}$ Calumet; a highly decorated American Indian pipe symbolically used during peace talks. In this context it represents an ambassador of peace or a peace delegation.

${ }^{146}$ Natchez. A well-known tribe that formerly lived on and about St Catherine's Creek, east and south of the present city of Natchez, Mississippi. The name, belonging to a single town, was extended to the tribe and entire group of towns, which also included peoples of alien blood who had been conquered by the Natchez or had taken refuge with them. The Natchez engaged in three wars with the French, in 1716, 1722, and 1729. The last, which proved fatal to their nation, was caused by the attempt of the French governor, Chopart, to occupy the site of their principal village to turn it into a plantation; this war started with a general massacre of the French at Fort Rosalie, established in 1716. The French, in retaliation, attacked the Natchez villages with a strong force of Choctaw allies, and in 1730 the Natchez abandoned their villages, into three bodies. A small section remained not far from their former home, and a second body fled to Sicily Island, near Washita River, where they were attacked early in 1731 by the French, many of them killed, and about 450 captured and sold into slavery in Saint-Domingue (present-day Haiti). The third and most numerous division was received by the Chickasaw and built a village near them in north Mississippi, called by Nanne Hamgeh; in 1735 these refugees numbered 180 warriors, or a total of about 700 . A body of Natchez refugees settled in South Carolina by permission of the colonial government, but some years later moved up to Cherokee
} 
faith they would go with them to ask me for peace, which it seemed they wanted so much and indeed they had

$/ \mathrm{v} /$

so many needs as all the nations that surrounded them held them as trapped in their forts from which they could not go out without running the risk of losing their lives, which situation would be rendered even worst when the ship of the King arrives, bringing bombs and cannon to finish their destruction which was all but certain; it would have been so had it [the ship] arrived on time, unless the King's orders would have been contrary to my project, but I had at least the satisfaction to turn over to Mr. de Bienville ${ }^{147}$ the savages of the government under the world's best possible conditions for the service of the King. They are still presently there but it is to be feared that their zeal and their

/Folio 180 recto/

good will might be tried, something I have reason to fear if a ship does not arrive here in March. The Choctaw have, however, a month ago, taken from the English a convoy of twenty horses loaded with merchandises that were going to the Chickasha. They killed three Englishmen in this affair; I told them not to bring the scalps to Mobile or here, to take away from our neighbors (the English) this little opportunity to complain, although they did not have the same considerations for us after the massacre of the Natchez. This happened very appropriately; it was after a delegation was sent to them by the Abacas (sic) on behalf of the English to ask for peace for the

country, where they still kept their distinct towns and language up to about the year 1800. The principal body of refugees, however, had settled on Tallahassee creek, an affluent of Coosa River (source: Accessgenealogy.com).

${ }_{147}$ Bienville, Jean-Baptiste Lemoyne, Sieur de (Montreal 1680 - Paris 1767): Officer, explorer, governor of Louisiana, he belonged to a family many of whose members left their mark on the history of Canada and Louisiana. In 1712 Antoine Crozat, Marquis de Chatel (1655-1738) , a powerful and influential financier and director of the Companies of St.Domingue, appointed Antoine La Mothe Cadillac, governor, and Jean-Baptiste de Bienville lieutenant-governor. But Cadillac dying in 1715, Bienville once more assumed the reins of government. In 1716, he conducted an expedition against the Natchez Indians, and having brought them to terms, finished the fort "Rosalie" which had been commenced by his brother, Iberville, sixteen years before. In 1717, Epinay, a new governor, arrived in the colony, bringing with him the decoration of the Cross of St. Louis for Bienville. In the meantime, Crozat, failing to realize the great profits he had expected, abandoned the whole enterprise and surrendered his charter to the king in 1717. Another company was at once formed and Bienville received a new commission as governor of the province. He now resolved to remove the headquarters from Biloxi, Mobile, and St. Louis Bay to the more fertile region of the Mississippi River, and in 1718 he selected the site for a new settlement, which he called New Orleans. He left fifty persons there to clear the land and build some houses, but it was not till 1722 that it became the seat of government. Experience had shown Bienville that the fertile soil of the lower Mississippi, as well as the climate, was well adapted to the cultivation of sugar, cotton, tobacco, and rice, and that Europeans were not fitted for field-work in the burning suns of Louisiana, for they sickened and died. The first plantation of any extent was therefore commenced with Negroes imported from Guinea. In 1719, the province became involved in hostilities with the Spaniards in consequence of the war with France and Spain. The governor twice reduced the town of Pensacola and sent detachments to prevent the Spaniards from making inroads into upper Louisiana, and the country bordering on the Rio Grande. When peace was restored immigrants began to arrive in great numbers from France and Germany. In the autumn of 1726, the Government of Louisiana passed out of the hands of Bienville and he retired to France to recruit his health. In 1734, the king reappointed him Governor and Commandant-General of Louisiana, and early in the autumn he arrived at New Orleans and entered upon the duties of his office. An expedition against the Chickasaw Indians in the spring of 1736 resulted in disaster, but another expedition in 1739 met with better success. This campaign closed his military and official career in the colony. He returned to France under a cloud of censure from the Government, after having faithfully served his country for more than forty years. He was buried with military honors in Paris (sources: Library and Archives Canada, Dictionary of Canadian Biography Online; and New Advent Organization). 
Chickasha, but in case they refused, they and the English would be obliged to declare war on them, but conversely, if they accepted what had just been proposed to them

$/ \mathrm{v} /$

they would not be lacking merchandises at very low prices, something the French would not be able to do being without anything, to which the Choctaw replied that they and the English were mistaken if they thought that their attachment to the French was based on the hope of obtaining from them merchandises, that they were very pleased to disappoint them, and that they were even more wrong to threaten them to declare war, and that all they had to do is start and that time would show them that the Choctaw, who do not like to be threatened, will finish last, and that neither threats nor promises would detach them from their true friends.

Your Highness sees by the response of these

/Folio 181 recto/

Savages that they did not behave badly as the cabal ${ }^{148}$ of this place wanted to persuade them to. If my letters did not receive all the credit, I dare say, they deserved, the events will show Your Highness that I only wrote what was true and positive; no other reason except for [my] service to the King has guided me since I command in this Province, so everything I wrote on what could be advantageous to Him, or disadvantageous, is true. I have no other means to be recognized but that of the truth. If I were as close to Your Highness as I am distant, it would not take you a long time to give me the justice I deserve by my attachment and my care for the good of things I have been

$/ \mathrm{v} /$

entrusted with, and although I am regarded here as disgraced, I know your justice too well and your perception for not eagerly wishing to be relieved from here. The good of the service and my reputation that has been attacked viciously demand that I explain myself to Your Highness the motives that prompted my enemies to act in total opposition to the progress of this colony that will only prosper when the authority of the King will have extinguished the spirit of the cabal that prevails since it was established. I know that this is common

/Folio 182 recto/

I am not speaking of anyone, but it is not because of not knowing them, they are so convinced of it that it is with this reason that they wish for my departure as much as I do; beyond this libels and lengthy dissertations are so unbecoming of an officer that I would dishonor myself to indulge in such things, wasting time that I can better employ for better things. This, my Lord, I beg Your Highness to judge me through my work and by the events until such time I can give myself account of one and the other.

The digression I have just made has caused me to distance myself from the savages of which I was speaking of, so I resume telling Your Highness

$/ \mathrm{v} /$

that since eight months I have heard so much talks about the Natchez, especially in the area of the River. ${ }^{149}$ This last July the Chickasha along with 72 Natchez that were staying with them put together a party of three hundred men to strike the Chaccoumas whom I had rendered suspicious to them because they were the only ones who kept neutral vis a vis the Chickasha. They (the

\footnotetext{
${ }^{148}$ Cabal, from the Hebrew qabbâlâh, intrigue.

${ }^{149}$ Fleuve in the original manuscript text, meaning a very large river, in this case the Mississippi.
} 
Chickasha) attacked them on the $19^{\text {th }}$ or $20^{\text {th }}$ during the night and took a dozen prisoners, killed some fifteen men, and burned several of their huts. As soon as this action had taken place, the Chaccoumas came down, bringing the scalps they had taken, to tell me what had just happened to them. I responded by telling them that they had smothered themselves in their own politic, that they were neither very

/Folio 183 recto/

strong nor powerful enough to stay neutral with the Choctaw and the Chickasha, that I had myself prevented the Choctaw, as it is the truth, from destroying them, that I was sorry for this tragedy, and that I would write to the Choctaw and would receive them peacefully, and that I would avenge them; thus, I sent them away happy; having only powder and shot to give them. I made them understand that this was the most beautiful present that could be made to people who have to seek revenge; they promised me that they would waste no time and that I would soon hear about it. Indeed, three months later, having captured only a few Natchez because they were still with the Chickasha in forts, they found a way through parents they had

/v/

with the Chickasha, to make up a party strong enough in this nation to kill all the Natchez who were on their land, of which only twenty-six or twenty-seven escaped and are now without any clothing or weapons; of this number the Illinois burned [alive] two, and the Arkansas that many. I was told that the rest had fled to the Abekas and Cherokees, thus this entire nation is now destroyed and no longer in a position to be harmful to this colony, to which the destruction of the Chickasha is no less necessary for the tranquility of the subjects of the King and the union of the savages that are attached to it.

All our little nations, as much those of the Mobile River than those at the bottom of the river, ${ }^{150}$ are shrinking

/Folio 184 recto/

considerably; only the Tonika manage to sustain themselves; it is the best nation, small however, that the King has at his service; the Arkansas are also very attached to him. Mr. de Coulange ${ }^{151}$ who I posted with them two years ago, has gained their love, so much so that for the past two years they have been at war constantly, although I have had noting to give them but promises; it will be important to reward then when we are in a position to do so. ${ }^{152}$

The Ouyatanon ${ }^{153}$ with who Mr. de Vincennes is, have allied themselves with the Arkansas to fight together the Chickasaw; two months ago they sent a calumet to

/v/

the Choctaws to tell them they did not want peace with the Chickasaw. This delegation did well because it arrived at the time the English and the Abeka were about to make peace with the Choctaw, but they fear that by doing so the King would have the people of the north and those from the upper [Mississippi] River destroy the Chickasaw.

The Illinois are fairly well behaved but it is a lazy nation and not very warrior-like on which we won't be able to rely upon until such time the King will have established a large headquarters in

\footnotetext{
${ }^{150}$ Fleuve in the original manuscripts text, i.e. the Mississippi.

${ }^{151}$ Petit de Levilliers de Coulange was an army major in charge of overseeing the affairs of the Arkansas.

152 This implies that the Arkansas are fighting tribes enemies of the French.

153 The Wea Indian tribe of Indiana, part of the Miami Nation.
} 
this department ${ }^{154}$ which is as necessary to control the French who inhabit it than it is to control the savages [and] respect [the law]; it is all the coureurs de bois ${ }^{155}$ of Canada or of Louisiana who created establishments ${ }^{156}$ in order to become independent from governors and commanders of posts; it would be dangerous to allow them to remain too long in this state of mind of independence, which spoils the few soldiers we have on this post, one of which Mr. de St. Ange just had beheaded for having killed his comrade; I am enclosing the procedures that were undertaken on this subject. Your Highness will see here the necessity for a large headquarters in the Illinois. ${ }^{157}$

We have been hit on August $29^{\text {th }}$ by a hurricane that caused great damage;

/v/

it destroyed three quarters of the tobacco seeds and other plantations [and] it caused the grounding on our coasts, 8 leagues ${ }^{158}$ east of La Balise, ${ }^{159}$ of a frigate of the King of Spain of 24 guns named la Vigilante $^{160}$ that had just brought the sitio ${ }^{161}$ to Pensacola. We save the entire crew of 120 men, to whom we gave all the care possible; we sent them to Veracruz aboard two ships; one Spanish and the other of the King; ${ }^{162}$ we write, Mr. de Salmon ${ }^{163}$ and me, to Your Highness on this affair. I kept the Spaniards longer than I expected because I was expecting the ship of the King that Your

/Folio 186 recto/

Highness had notified me that he would send at the beginning of July of last year; I see through the arrival of the ship from St. Malo, ${ }^{164}$ the St. René, Capt. Frotin, who died here, that the vessel of the King left at the beginning of June. The same Capt. Frotin who had called port at la Caye

\footnotetext{
154 Region.

155 Coureur de bois; "runner of the woods", was an individual who engaged in the fur trade without permission from the French authorities. The coureurs de bois, mostly of French descent, operated during the late 17th century and early 18th century in eastern North America, particularly in New France (Canada). Later, a limited number of permits were issued to coureurs de bois who became known as voyageurs (travelers) as they rarely settled permanently anywhere. In the first quarter of the $18^{\text {th }}$-century they were a problem for the French authorities who had difficulties collecting much needed taxes on their fur trade activities. The coureurs de bois also made alliances with various Indian tribes often not in the best interest of the French colonial administration.

${ }^{156}$ Posts.

${ }^{157}$ In this case "Illinois" refers to the region occupied by the Illinois Indians.

158 A French nautical league, also called a geographical league, was equivalent to 5.556 kilometers in the $18^{\text {th }}$ century; 20 leagues were equivalent to 1 degree of latitude (source: Encyclopédie Méthodique, Marine, Paris 1786, Volume II, p. 582).

${ }^{159}$ La Balise was located on what is today Lookout Island, at the entrance of the Mississippi’s South Pass, at 29 4'57.32"N - 089 $7^{\circ} 55.14$ "W; it was a fortified lighthouse and a lookout and had a regular and permanent garrison.

160 The name la Vigilante might be a corruption of Aguila Volante resulting from the French misunderstanding of the Spanish name. La Vigilante could not be found in any Spanish records, but there was a 24-gun frigate built in the New World in 1722 by the name of Aguila Volante (source: Relación de los Buques de la Armada Española en los siglos XVIII, XIX y XX; Relación de fragatas, p. 419 in El Buque en la Armada Española, Editorial Silex, Madrid 1981).

161 Sitio corruption of the Spanish situado, i.e. "payroll”.

162 The king of France, Louis XV.

${ }^{163}$ Edme-Gatien Salmon, first judge of the superior council of Louisiana and procurator general of the King; the author of this letter errs when he writes “de Salmon” as Salmon was not a noble.

${ }^{164}$ Saint-Malo (Breton: Sant-Maloù; Gallo: Saent-Malô) is a walled port city in Brittany in north-western France on the English Channel. It is a sub-prefecture of the Ille-et-Vilaine department. During the $17^{\text {th }}$ and $18^{\text {th }}$-century it was an important commercial port and home to many privateers.
} 
St. Louis, ${ }^{165}$ told us that he learned that the vessel of the King had sailed from Cape François ${ }^{166}$ on August $5^{\text {th }}$ to come here, although we had received no news from it. We sent [search parties] to the east and to the west of the (Mississippi) River without finding anything; it was found between Pensacola and

$/ \mathrm{v} /$

Mobile wreckage that I sent to examine, which turned out to be from an English ship, [from which] two men from this nation saved themselves reaching land, but were found dead when we went to bring them help; ${ }^{167}$ nothing was observed in that area to indicate the loss of the vessel of the King on this coast, and even speaking as a man of the [maritime] trade, it could not have been, the wind storm having started from the northeast and switched to the south through the east where it [eventually] stopped. The wind was violent here on land for only 22 hours, but it lasted three to four days at sea according to the report from two [ships] that went through it; it is certain [Folio 187 recto]

that the vessel of the King could not have been far from our coasts if what the St. Malo captain told us is true, it even should have arrived having 24 days from its departure from the Cape to the hurricanes, [thinking] that calm weather might have delayed them because [even] the worst ships are the only ones that came, and even lesser [ships], from St. Domingue to here; if this ship is not lost, it has to be at the bottom of the Gulf from where it could have given us some news not being able to sail out to sea, which make me believe that this ship is lost.

We will know within six weeks via Veracruz if its is along some coast

$/ \mathrm{v} /$

of Mexico. This loss is causing considerable harm to this colony that is lacking everything. If I had lead I would be less concerned; I just sent four thousandths to the Choctaw to conceal our misery, I don't even have five hundred pounds at the time I am writing to Your Highness, to whom it must be as surprising as it is to me that since the Retrocession, that two vessels of the King were sent to me that brought me powder but forgot in the port to load shot, or at least so little that it not worth mentioning.

This oversight has put me in the necessity to seek the help of the viceroy of Mexico who I hope [Folio 188 recto]

will send me some. It is a cruel extreme, if the Illinois were well established we would not be in need of lead, but the French, and the savages only make some exclusively for their own consumption; I wrote [asking] that all that was manufactured be sent to me. You can see, My Lord, that my situation is not pleasant in this country, it would be even less if I were a man who would dwell on so many unpleasant things done to me for over a year now, thankfully I know enough to manage my way out, as it should be, of those unpleasantness people want to inflict upon me. Service to the King being my sole endeavor it is enough to guide me well until such time Your Highness grants me the favor of relieving me.

\footnotetext{
${ }^{165}$ Caye St. Louis, on the south coast of Saint-Domingue, present-day Haiti.

${ }^{166}$ Present-day Cape Haitian.

${ }^{167}$ We can surmise that two bodies were found on shore and at the time it was thought that the two men had swam and died upon reaching shore, but it is very possible that they simply washed ashore along with the wreckage; the possibility that this ship sunk in deep water is quite high.
} 
I have the honor to be with the deepest respect,

My Lord,

In New Orleans, the $25^{\text {th }}$ of January

Your very humble

and very obedient servant

[signature] Périer

[END] 
Introductory Note: This document mentions the loss of and unnamed ship of the French Navy (Lost Ship Number 14) as well as another French Navy vessel called la Somme (Lost Ship Number 15).

CAOM C13 A26 1741

[Folio 127 recto]

Translated by John de Bry

Louisiana

8 March 1741

Colonies

M. Salmon ${ }^{168}$

My Lord,

The corvette la Fée ${ }^{169}$ that Mr. the Marquis d'Antin ${ }^{170}$ had dispatched from his squadron to bring news to St. Domingue has been taken by an English ship and taken to Jamaica from where, after a short stay, she came here

/v/

in this past month of December without any food supplies or beverages. We had little help to offer until a small vessel from the islands arrived a month later from which I obtained 7 or 8 barrels ${ }^{171}$ of wine that I had delivered and which were sold at 400 livres $^{172}$ per barrel. Mr. de Roussel (sic), ${ }^{173}$ commanding by the [order?] of Mr. de Chavagnac, ${ }^{174}$ was ready to have his ship put on dry dock to inspect it, when an unforeseen event and contrary to ordinary conditions caused the river level to drop three to four feet ${ }^{175}$, causing this ship to ground, which stayed in

\footnotetext{
${ }^{168}$ Edme-Gatien Salmon, first judge of the superior council of Louisiana and procurator general of the King (source: CAOM, Series E, E 180, Personnel Colonial Ancien, i.e. colonial personnel prior to the French Revolution of 1789).

${ }^{169}$ La Fée (the fairy) was a 140-ton corvette, armed with 10 cannon built in 1734 in Rochefort under the supervision of master shipwright Julien Geslain; she was condemned in 1744 (source: Pierre, Joël Les Constructions navales à Rochefort, Brouage, Soubise et Tonnay Charente, p. 38, Éditions Le Croît vif, Paris 2003).

${ }^{170}$ Antin, Antoine François de Pardaillan de Gondrin, marquis d'; Vice-Admiral of the French Navy under Louis XV, died in 1741 (source: Archives de la Marine, Série $B^{1}, 119,120,121$ ).

${ }^{171}$ A barrique was a large barrel containing approximately 200 liters of liquid, in this case wine.

172 The French monetary system of the $17^{\text {th }}$ and $18^{\text {th }}$ century was based on a duodecimal system. Although quite complex for the largely illiterate rural population, this system lasted more than a thousand years, having been introduced during Merovingian time by King Pépin le Bref in 755 AD. The basic currencies were the livre (pound), the sol and the denier. 1 livre $=20$ sols $=240$ deniers. In certain cases the denier meant the percentage of interest per pound weight (sources: M. Barrême Les Comptes-Faits ou le Tarif Général de Touttes les Monnoyes, Jean Geoffroy Nyon (editor), Paris 1723; Nouveau Dictionnaire de Poche de la Langue Française, Imprimerie P. Catineau, Paris 1802).

${ }^{173}$ Rossel, Christophe de, French Navy ship captain, died in 1747 (source: Archives de la Marine, Série $\mathrm{B}^{1}$, 89; $\mathrm{B}^{2}$ 172, 234, 250; B ${ }^{3}$ 133, 134).

${ }^{174}$ Chavagnac, Louis Henri, comte de, Lieutenant General, died in 1743 (source: Archives de la Marine, Série B ${ }^{2}$, $65,74,117,566)$.

${ }^{175}$ A French foot, known as pied or pied de roi, during the $18^{\text {th }}$ century was equivalent to 0.32484 meter $=32.484$ cm = 12.789 inches (source: L’Ame et la Lumière; Armes et Canons dans la Marine royale fin XVII ${ }^{\mathrm{e}}-$ XVIII ${ }^{\mathrm{e}}$ siècle, p. 93, catalogue of the exhibition, Centre des Archives Nationales, Paris 27 June - 28 October 1996).
} 
this condition for nearly a month. During this time, the beverages I had bought were consumed, and had it not been for a vessel that came from St. Domingue ${ }^{176}$ eight days ago that luckily had some wine, he would have been unable to leave;

/Folio 128 recto/

he will sail today not knowing if we are at peace or at war with the English. An accident has happened to the vessel of the King la Somme $e^{177}$ just before the entrance of the Cape, ${ }^{178} \mathrm{Mr}$. de Rossel in his letter of 12 January written at the Cape, told us that she had grounded on one of the islets of La Grange ${ }^{179}$ where she took on a considerable amount of water, and that he sent divers [to conduct an inspection] and that the keel was found damaged having been [stuck] on the rocks bumping about for five hours, that he is ready to have her careened, and that he does not believe that it will take more than three weeks, however, we are 58 days from the date of his letter and have we have not yet learned any news of his arrival at La Balise. ${ }^{180}$ As if to add to our bad luck this ship does not reach its intended port, the Colony

$/ \mathrm{v} /$

will be pitied; we are short of flour as the crew of la Fée consumed a lot of it during its stay, and also for having to supply its biscuit for its voyage, so in order to make what we have left last, I had to mix our troops' bread with rice and, additionally, le flour from Illinois which arrives usually at the end of March is not expected until early May, the winter having been unusually rough and long.

We went through several hurricanes at the end of September that caused many losses for the Colony and for the King as he lost his large ship along with Captain Royer and four of the best Negroes. This ship was loaded with food supplies and

/Folio 129 recto/

Merchandises earmarked for those in Mobile. She stopped on her way at La Balise, and as she was taking on a lot of water, she was promptly unloaded and everything was put ashore at La Balise. This ship was moored with three anchors because it had been very windy for several days. The captain was alone on board with the 4 Negroes of the King when a gust of wind of extreme force took her out into the Gulf, and we never heard of her again. There were only a few bombs in the hold that Mr. de Bienville ${ }^{181}$ had given orders to be transported to Mobile. I was

\footnotetext{
${ }^{176}$ Present-day Haiti.

177 This ship was a flute, i.e. a cargo ship, built in Rochefort in 1735 by the shipwright Geslain, no data could be found as to her armament (source: Pierre, Joël Les Constructions navales à Rochefort, Brouage, Soubise et Tonnay Charente, p. 38, Éditions Le Croît vif, Paris 2003). The Somme is a river in northwestern France that empties into the English Channel after passing through the cities of Saint-Quentin, Péronne, Amiens, and Abbeville. A major military offensive against the German army took place along its banks from July to November 1916, which helped relieve pressure from the battlefield of Verdun.

${ }^{178}$ Cap François, present-day Cape Haitian on the north coast of Haiti.

${ }^{179} \mathrm{La}$ Grange is the $17^{\text {th }}$-century French name for Cayos Siete Harmanos (Seven Brothers Cays) west of Monte Cristi, Dominican Republic, and north, northeast of Fort Liberté, Haiti (source: Bibliothèque Nationale [Paris], Cartes et Plans, Portefeuille 146, Division 1, Pièce 12D - Ge. C. 4672 - Partie de la coste de l’isle de SaintDomingue, 1713).

${ }^{180}$ La Balise was located on what is today Lookout Island, at the entrance of the Mississippi’s South Pass, at 29 4'57.32"N - 089 7'55.14"W; it was a fortifies lighthouse and a lookout and had a regular and permanent garrison.

${ }^{181}$ Bienville, Jean-Baptiste Lemoyne, Sieur de (Montreal 1680 - Paris 1767): Officer, explorer, governor of Louisiana, he belonged to a family many of whose members left their mark on the history of Canada and Louisiana. In 1712 Antoine Crozat, Marquis de Chatel (1655-1738) , a powerful and influential financier and director of the Companies of St.Domingue, appointed Antoine La Mothe Cadillac, governor, and Jean-Baptiste de Bienville lieutenant-governor. But Cadillac dying in 1715, Bienville once more assumed the reins of government. In 1716, he conducted an expedition
} 
forced to dispatch warships to transport the merchandises left ashore at La Balise, no longer having the large ship that was sold

/v/

three months ago; according to what Mr. de Bienville told the captain of the port and me Mr. de Villers $^{182}$ had taken her to the Cape [François] and was asking for an extensive hull repair that would have cost as much as buying a new one, according to the inspection he had asked the carpenters of la Somme to conduct. As such, we are presently without a transport ship, luckily, we have three warships fitted with decks that I use to transport various things to different posts. Those hurricanes caused lots of damage to the fortifications of La Balise, they also toppled the jetty of Mobile that Mr. Bizoton ${ }^{183}$ had repaired and restored to new before his departure, and which cost was up to near 20,000 livres. Almost all the maize has been submerged

/Folio 130 recto]

by the Mobile River and Alabama River. ${ }^{184}$ The sea has eaten part of Dauphin Island ${ }^{185}$ and most of the farm animals that were on it have perished, which caused an increase of the cost of foodstuff, so much so that a quart of rice that was sold 6 livres has now been raised to as much as 12 livres, and that of maize that was sold at approximately the same price is currently sold at 15 or 16 livres.

Ever since Spain is at war with England, we have received the visit here of three or four Spanish vessels that were forced to leave empty for lack of finding merchandises. It arrived here a small

against the Natchez Indians, and having brought them to terms, finished the fort "Rosalie" which had been commenced by his brother, Iberville, sixteen years before. In 1717, Epinay, a new governor, arrived in the colony, bringing with him the decoration of the Cross of St. Louis for Bienville. In the meantime, Crozat, failing to realize the great profits he had expected, abandoned the whole enterprise and surrendered his charter to the king in 1717. Another company was at once formed and Bienville received a new commission as governor of the province. He now resolved to remove the headquarters from Biloxi, Mobile, and St. Louis Bay to the more fertile region of the Mississippi River, and in 1718 he selected the site for a new settlement, which he called New Orleans. He left fifty persons there to clear the land and build some houses, but it was not till 1722 that it became the seat of government. Experience had shown Bienville that the fertile soil of the lower Mississippi, as well as the climate, was well adapted to the cultivation of sugar, cotton, tobacco, and rice, and that Europeans were not fitted for field-work in the burning suns of Louisiana, for they sickened and died. The first plantation of any extent was therefore commenced with Negroes imported from Guinea. In 1719, the province became involved in hostilities with the Spaniards in consequence of the war with France and Spain. The governor twice reduced the town of Pensacola and sent detachments to prevent the Spaniards from making inroads into upper Louisiana, and the country bordering on the Rio Grande. When peace was restored immigrants began to arrive in great numbers from France and Germany. In the autumn of 1726, the Government of Louisiana passed out of the hands of Bienville and he retired to France to recruit his health. In 1734, the king reappointed him Governor and Commandant-General of Louisiana, and early in the autumn he arrived at New Orleans and entered upon the duties of his office. An expedition against the Chickasaw Indians in the spring of 1736 resulted in disaster, but another expedition in 1739 met with better success. This campaign closed his military and official career in the colony. He returned to France under a cloud of censure from the Government, after having faithfully served his country for more than forty years. He was buried with military honors in Paris (sources: Library and Archives Canada, Dictionary of Canadian Biography Online; New Advent Organization).

${ }^{182}$ Villers-Franssure, Louis Roger de; French Navy ship captain in 1741, promoted to squadron commander in 1754 , died in 1775 (source: Archives de la Marine, Série B ${ }^{3}, 212,219,224,346$ ).

${ }^{183}$ Bizoton de Saint-Martin; comptroller of the Navy, advisor to the Superior Council, commissioner in Mobile (source: CAOM, Series E, E 180, Personnel Colonial Ancien, i.e. colonial personnel prior to the French Revolution of 1789).

${ }^{184}$ In the original manuscript text the Alabama River is referred to as la rivière des Alibamons; the Alabama Indian tribe was referred to as Alibamon.

${ }^{185}$ Dauphin Island off Bayou La Batre at the entrance of Mobile Bay, Alabama. 
bark with 4 merchants who have among themselves more than 50 thousand piasters ${ }^{186}$ which they won't be able to spend unless ships from France arrive soon, the Colony being without anything.

In New Orleans

[signature] Salmon

8 March

1741

[END]

${ }^{186}$ Spanish silver pieces-of-eight. 
Introductory Note: This document is the first of three found in France that pertain to the 1746 loss of le Chameau (Lost Ship Number 16).

\section{CAOM C13 A30 1746}

\section{[Folio 159 recto]}

Translated by John de Bry

17 November 1746

Louisiana

My Lord,

Mr. Le Norman ${ }^{187}$ [this was written by the person filing this letter]

I have received the letter of this past 16 May you honored me with by the frigate la Mutine, ${ }^{188}$ which moored at La Balise ${ }^{189}$ on 9 September after having stopped over Santiago de Cuba ${ }^{190}$ to take on water. We have learned nothing since her arrival about plans our enemies might have to come attack this colony, and as we are at the end of the year, there is reason to believe they have changed their project

/v/

or have postponed its execution until next year.

You must have been made aware, My Lord, that very few troops and inhabitants are left in the lower part of the river, ${ }^{191}$ and for this reason there is an indispensable necessity to send reinforcement from France in the event of an attack; Mr. de Vaudreuille ${ }^{192}$ will have undoubtedly kept you properly informed.

\footnotetext{
${ }^{187}$ Lenormant de Mézy, Sébastien-François-Ange ; Commissioner-Organizer in Dunkerque (1701), then on Isle Royale (1718); official scribe on Isle Royale (1722), commissioner in the absence of his father (1729); Commissioner-Organizer (1735); then in Saint-Domingue (1739); in Louisiana (1744); Administrator of the Navy in Rochefort (1749). Administrator general of Naval Forces (1755); Assistant Secretary of State; Secretary of State of the Navy from February 1757 to June 1758 (source: CAOM, Series E, E 180, Personnel Colonial Ancien, i.e. colonial personnel prior to the French Revolution of 1789).

188 The light frigate la Mutine was built in Brest, France, in 1744 by the shipwright Geffroy Cadet; she was 110 feet long, had a beam of 29 feet, and carried 24 6-pdr guns; condemned in 1758 (source: Boudriot, Jean, La Frégate, Marine de France, 1650-1850, p. 61, Collection Archéologie Navale Française, Editions Ancre, Paris 1992).

${ }^{189}$ La Balise was located on what is today Lookout Island, at the entrance of the Mississippi’s South Pass, at $29^{\circ}$ 4'57.32"N - 089 7'55.14"W; it was a fortified lighthouse and a lookout and had a regular and permanent garrison.

${ }^{190}$ Santiago is a port city on the southeastern side of Cuba.

${ }^{191}$ Mississippi River.

192 Pierre François de Rigaud, marquis de Vaudreuil-Cavagnal (Quebec, 22 November 1698 - Paris, 4 August 1778): Governor of French Louisiana (1743-1753) and in 1755 became the last governor of New France (or Canada), during the period when the British conquered it in the Seven Years' War, also known in the United States as the French and Indian War (source: Dictionary of Canadian Biographies on Line).
} 
I have supplied this frigate with two months' worth of victuals beyond the provisions for her campaign that were found spoiled, along with some beverages the crew needed; I supplied it with whatever was necessary and the total expense according to the attached general financial statement amounts to 25, 395 livres 16 sols 11 deniers, ${ }^{193}$ for which reimbursement I had the treasurer issue letters of credit on the account of Mr. de Georville, ${ }^{194}$

/Folio 160 recto/

Treasurer General in office, according to the attached statement.

This frigate delivered to us 7,000 pounds of gun powder, 50 grenadier muskets with their bayonets, ${ }^{195} 19$ quintals of shot, ${ }^{196}$ and 1,100 gun flints she had on board; I had the armory keeper give Mr. Queslin (sic) a receipt, which I stamped.

We are not without worries about the flute ${ }^{197}$ of the King le Chameau that was to sail from France this past month of June, according to the communication you honored me with, loaded with supplies necessary for this colony, as well as about the private ship that was to sail with her or follow closely; we would be pitied if an accident happened to those two vessels, as we do not have in this colony, as we had the honor to let you know, any resources to substitute for it, ${ }^{198}$ so it would be

/Folio 160 verso/

most important to remedy our situation without delay.

I have an extreme need of the vacation you had the goodness to promise me for the end of the year, my poor health for which I cannot find any relief in this country, and my lack of usefulness at present due to the fact that I have completed my missions for a year now, which gives me reason to hope that you will not further extend my strenuous stay in this colony.

\footnotetext{
${ }^{193}$ The French monetary system of the $17^{\text {th }}$ and $18^{\text {th }}$ century was based on a duodecimal system. Although quite complex for the largely illiterate rural population, this system lasted more than a thousand years, having been introduced during Merovingian time by King Pépin le Bref in 755 AD. The basic currencies were the livre (pound), the sol and the denier. 1 livre $=20$ sols $=240$ deniers. In certain cases the denier meant the percentage of interest per pound weight (sources: M. Barrême Les Comptes-Faits ou le Tarif Général de Touttes les Monnoyes, Jean Geoffroy Nyon (editor), Paris 1723; Nouveau Dictionnaire de Poche de la Langue Française, Imprimerie P. Catineau, Paris 1802).

${ }^{194}$ La Tuillerie, Barthélemy Mouffle de Georville de; Treasurer General of the Navy (source: CAOM, Series E, E 180, Personnel Colonial Ancien, i.e. colonial personnel prior to the French Revolution of 1789).

${ }^{195}$ As the frigate la Mutine was a French Royal Navy ship that had sailed from France to the Louisiana colony, the muskets were most likely the 1746 standard infantry issue; the musket measured overall 1.593 meters; its barrel 1.188 meters, weighted 4.250 kilograms, and fire a $17.5 \mathrm{~mm}$ shot, while the bayonet was an unmodified 1728 model with a $379 \mathrm{~mm}$ long blade. The production of this particular model ended in 1750; an estimated 248,000 such muskets were produced (source: Boudriot, Jean, Armes à Feu Françaises, Modèles Réglementaires, pp.45-46, Éditions du Portail, La Tour du Pin 1997).

${ }^{196}$ An $18^{\text {th }}$-century French quintal was equivalent to 100 livres equivalent to 48.95 kilograms (sources : JeanFrançois-Gaspard Palaiseau, Métrologie universelle, ancienne et moderne: ou rapport des poids et mesures des empires, royaumes, duchés et principautés des quatre parties du monde, Lavigne jeune, Bordeaux, octobre 1816 ; Marion, Dictionnaire des institutions de la France aux XVII et XVIII ${ }^{\mathrm{e}}$ siè̀cles, Paris, 1993).

${ }^{197}$ A flute was a cargo sailing vessel of heavy build with a flat bottom; it usually had a large port-hole in the stem to enable the loading of large pieces of timber (source: Gilles Proulx, Between France and New France, Toronto and Charlottetown, 1984).

${ }^{198}$ To make up for the loss of the supplies aboard the two ships, this would have been considerable.
} 
I have the honor to be with a deep respect,

My Lord,

At New Orleans, the $27^{\text {th }}$ of November $\underline{1746}$

Your very humble and very obedient servant [signed] Lenormant

[END] 
Introductory Note: This document is the second of three found in France that provide useful information on the 1746 loss of le Chameau (Lost Ship Number 16).

CAOM C13 A 301746

Série $C^{13}$ - Received correspondences from Louisiana

Colonies $C^{13}$ A 30 (1746)

[Folio 131 recto]

Translated by John de Bry

26 November 1746

Louisiana

My Lord,

Mr. de Vaudreuil
Order for Mr. de Quélen

The uncertainty surrounding the [expected] arrival of the flute of the King le Chameau ${ }^{202}$ which you had mentioned to me, My Lord, expected to leave from France this past month of June, and finding ourselves today at the end of November without receiving any news from anywhere, and not knowing anything about European affairs nor on the

/v/

side of the English, who seemed to have had some urge to attempt something against this country, according to the advice you honored me with, determines me to have the frigate of the King la Mutine, ${ }^{203}$ sail for Havana to petition the governor of this place to let me know through

199 Pierre François de Rigaud, marquis de Vaudreuil-Cavagnial (Quebec, 22 November 1698 - Paris, 4 August 1778); governor of French Louisiana (1743-1753) and in 1755 became the last governor of New France (Canada), during the period when the British conquered it in the Seven Years' War, also known in the United States as the French and Indian War (source: Dictionary of Canadian Biographies on Line).

${ }^{200}$ Quélen, Chevalier de (died 1748); captain of la Mutine and later la Mégère (source: Archives de la Marine, Série $\left.\mathrm{B}^{3}, 206,210,218,230,234,235\right)$.

${ }^{201}$ Seignette; captain of the ship le Maurepas

202 This particular ship could not be identified in the Marine section of the Archives Nationales, Paris, or in the register of ships belonging to or leased by the Compagnie des Indes, in Lorient, France. Typically, a French flute of that period was a large and broad ship of 700-ton burden, 128.9 feet in length, a 34.3-foot beam, and rather heavily armed wit an average of 30 cannon of calibers 12, 8, and 4-pdr (source: Boudriot, Jean, Compagnie des Indes, 17201770 , p. 44, Collection Archéologie Navale Française, J. Boudriot Editor, Paris 1983).

${ }^{203}$ The light frigate la Mutine was built in Brest, France, in 1744 by the shipwright Geffroy Cadet; she was 110 feet long, had a beam of 29 feet, and carried 24 6-pdr guns; condemned in 1758 (source: Boudriot, Jean, La Frégate, Marine de France, 1650-1850, p. 61, Collection Archéologie Navale Française, Editions Ancre, Paris 1992). 
Pensacola some news that may have reached him; to this effect, I have asked Mr. Quélen to go and anchor ${ }^{204}$ in this port and give to this commander my letters; I offered him at the same time that he can use the frigate of the King to load [and transport] money ${ }^{205}$ or convoy, ${ }^{206}$ as some vessels to Europe la Mégère ${ }^{207}$ did last year, without however delaying her prompt return to France as the officer who command her has planned. What determined me to take this action is the confiscation of our French establishments that Mr. Seignette and others told me to have observed since the arrival of the new

/Folio 132 recto/

Governor as ordered by the King of Spain, and that they were there awaiting an opportunity to go to France, [and] as I know your intentions, My Lord, to promote commerce, I did not hesitate to find one for them ${ }^{208}$ confident that you will approve. Mr. de Quélen is even more eager to do so as he is convinced that it will please you, and that this little stop over will not delay his sailing more than twice 24 hours.

I have the honor to be with the deepest respect,

My Lord,

In New Orleans

Your very humble and very obedient servant [signed] Vaudreuil

The 26 November 1746

[END]

${ }^{204}$ Jetter un pied d'ancre in the original manuscript text, implying a short stop in Havana for la Mutine on her way to France.

${ }^{205}$ The word argent in the original manuscript text means both money and silver.

${ }^{206}$ Vaudreuil proposes the Spanish governor of Cuba to either use the service of la Mutine to send money/silver back to Spain, or use the frigate to escort Spanish ships back to Europe.

${ }^{207}$ La Mégère was a frigate built in Bayonne, southwestern France, by the shipwright Tenard; she was 116 feet long, with a 30.10-foot beam. She was armed with 26 8-pdr and 4 4-pdr cannon; condemned in 1749 (source: Boudriot, Jean, La Frégate, Marine de France, 1650-1850, p. 84, Collection Archéologie Navale Française, Editions Ancre, Paris 1992).

${ }^{208}$ An opportunity to leave for France. 
Introductory Note: Written in 1748, this document is the third of three French documents that give information on the 1746 loss of le Chameau (Lost Ship Number 16).

\title{
CAOM C13 A32 1748
}

\section{[Folio 215 recto]}

\section{Translated by John de Bry}

Louisiana

In Mobile, the 24 of October 1748

\author{
M. de Beauchamp 209
}

My Lord,

I was flattered to receive a response from Your Highness regarding the letter I had the honor to write to you, sent on the ship le Chameau ${ }^{210}$ with which I had enclosed the journal of the voyage I had undertaken to the Choctaw two year ago, as ordered by Mr. de Vaudreuil, ${ }^{211}$ to convince this nation to give us satisfaction regarding three Frenchmen the mutineer Imataha Tchitou ${ }^{212}$ had assassinated. Mr. Fleuriau ${ }^{213}$ was put in charge of the journal and the letter, but I fear that he left them on le Chameau which apparently suffered the same fate as this ship as we are without any news.

\footnotetext{
${ }^{209}$ Beauchamp, Jean Jadard de; Major, Lieutenant of King in Mobile. The Lieutenant of King was second in command after a governor, and this position was always filled by a military officer; the governor of a region, such as Louisiana, would generally have several such lieutenants of king in various parts of the colony (Étienne Taillemite, personal communication, March 2010).

${ }^{210}$ This particular ship could not be identified in the Marine section of the Archives Nationales, Paris, or in the register of ships belonging to or leased by the Compagnie des Indes, in Lorient, France. Typically, a French flute of that period was a large and broad ship of 700-ton burden, 128.9 feet in length, a 34.3-foot beam, and rather heavily armed wit an average of 30 cannon of calibers 12, 8, and 4-pdr (source: Boudriot, Jean, Compagnie des Indes, 17201770, p. 44, Collection Archéologie Navale Française, J. Boudriot Editor, Paris 1983).

${ }^{211}$ Pierre François de Rigaud, marquis de Vaudreuil-Cavagnal (Quebec, 22 November 1698 - Paris, 4 August 1778): Governor of French Louisiana (1743-1753) and in 1755 became the last governor of New France (or Canada), during the period when the British conquered it in the Seven Years' War, also known in the United States as the French and Indian War (source: Dictionary of Canadian Biographies on Line).

${ }^{212}$ Imataha Tchitou, or Matahachitoux,was known by the French as Soulier Rouge, or Red Shoe; A Choctaw chief, he was the principal leader of the Choctaw rebellion against the French with the support of the English. His influence among the Choctaws had somehow to be countered to prevent the entire nation's being subverted. Vaudreuil put a price on his head sufficiently tempting that five months later the chief was killed by some of his own people. Vaudreuil also succeeded in persuading the Choctaws to attack a Carolina trading party and pillage its 60horse pack train. The loss of their goods and horses was a serious blow to the Carolinians. They were slow to send another pack train over the mountains. This incident was not the end of the struggle but British dominance over the Louisiana tribes had been averted.

${ }^{213}$ Fleuriau; prosecutor of the Superior Council of Louisiana (source: Dictionary of Canadian Biographies on Line).
} 
Since then the English have strived to infiltrate the Choctaw ${ }^{214}$ Nation, they already had many partisans based on the inconsistency of the savages who become promptly attached

$/ \mathrm{v} /$

to newcomers, but from our side we motivated those who support our rights, which caused among this perfidious nation a civil war that killed several, especially confederates, ${ }^{215}$ the English not having been able to supply their partisans with the same celerity as we did, so ours had the advantage and forced the rebels to abandon ten or eleven villages and seek refuge amongst their neighbors, a few even joined our allies. The entire race of the mutineers is almost destroyed, [including] those who committed the first murder, and the one committed on this river in the month of September 1747. What is left of this bad family is not in a position to undertake anything, there is only his young brother who is not, however, regarded as a warrior of the nation and who has gone to the Abihkas of the Alabama, ${ }^{216}$ and has even convinced his nation to seek reconciliation with our allies, [and] that they should be satisfied with the blood that had been spilled. The partisans of the English had such a shortage of gun powder and shot that they loaded their muskets with small timber hitch of walnut and oak [trees] dried over fire.

/Folio 216 recto/

Ours, conversely, had everything that was necessary for them to fight advantageously; as a result they overtook the confederates who lost in the affair of August $16^{\text {th }}$ two of their better partisans, Captain of Boukfouka and Minkimalaha of the Abihkas, right hand of the dead mutineer, and several warriors. We learn with joy, the past few days, that the great rebel chief of the Chickasaw named Mougoulacha Mingo had been killed by five warriors from his village who punished him for the treachery he had committed by abandoning the interests of the French and for having cut and thrown away the medals they had been decorated with for their support of the mission of Reverend Father Beaudoin in this village. I hope that the death of this chief will somewhat help to restore calm in the Choctaw Nation. He was a man with a dangerous mind who fomented division through tunnels no one could discover until much later. ${ }^{217}$

If the Arkansas would do an incursion into the confederate area, as they promised our dear governor, and that

/v/

they would kill only fifteen, it would force them to quickly return to their duty and petition for peace, which I believe will happen soon because of the great famine among all the villages of the confederates, through which calm and reconciliation would take place in this nation and would restore tranquility in this colony. A few rebel partisans of the English will remain in the Alabama

\footnotetext{
214 The Choctaw are a Native American people originally from the Southeastern United States (Mississippi, Florida, Alabama, and Louisiana). They are of the Muskogean linguistic group. The word Choctaw (alternatively spelt as Chactas in French, Chahta, Chato, Tchakta, and Chocktaw) may derive from the Castilian word chato, meaning "flat" (source: Wikipedia).

${ }^{215}$ Indians from the Creek Confederacy.

${ }^{216}$ Abékas Alibamons in the original manuscript text. The Abihka constituted one of the most ancient divisions of the true Muskogee, appearing in the oldest migration legends, and are reckoned one of the four "foundation towns" of the Creek confederacy. In ceremonial speeches they were called Abihka-nagi, though what nagi signifies no one at the present time knows. They were also called "the door shutters" because they guarded the northern border of the confederacy against attack (source: Access Genealogy).

${ }^{217}$ It is surmised that this chief used tunnels to infiltrate villages and agitate against the French.
} 
[Nation] who Mr. Le Sueur ${ }^{218}$ will make sure to bring back in line as was done with the Choctaws.

It would be desirable for the ships that bring the merchandises for the savages, for trade as well as for presents for the different nations, arrive during the month of October at the latest in order to be able to take advantage of the calm waters to supply the posts of the Colony, especially Tombeké (sic) ${ }^{219}$ and Alabama where it is not possible to send large carriages (sic) ${ }^{220}$ when waters are low, which deeply hurts the interests of the King and those of the Colony, being forced to use small pirogues that can carry almost nothing, the cost of the people that takes them often exceeds the value they carry. For the support of those two posts

/Folio 217 recto/

we would have a dire need for the recruitment of 150 good men to complete our companies that are extremely weak, and at the same time to dismiss the veterans who for the longest time have sought to achieve peace so they can return home or become settlers. The reform that will take place in Europe will help to provide many, but it would be appropriate to hire only workers from different trades; those who have served in the work camps of the royal artillery regiment would be better suited than those from other regiments.

The barracks that were built last year in this fort to house soldiers and officers already threaten to fall into ruins, the roofs are worthless, [and] we will have to repair them next year. This economy will cause daily a considerable expense [just] to be poorly housed, which could have been avoided if the officers' quarters and the sodiers' barracks had been built solidly, which could have been done with stone and other materials available neaby.

$/ \mathrm{v} /$

I have learned, My Lord, through Mr. de Louboey, ${ }^{221}$ that he has requested leave to go back to France in order to put an interval between life and death, and finish his days among his family, [but] taking into consideration his poor health combined with his extreme age, he might not be able to do this; if Your Highness grants him his request I do not believe that he will feel like coming back to this colony, in which case, I dare flattering myself that you will be willing to honor me with the post of Lieutenant of the King in this department, which I have fulfilled several times in the past; no one knows better than me the interests of the colony, [and] I hope to

\footnotetext{
${ }^{218}$ Lieutenant Le Sueur commanding officer of the Tombeché outpost, then at the Alabama outpost. He was promoted to captain while at the Alabama post, and then posted in Mobile as a major.

${ }^{219}$ Fort Tombeché, whose spelling varies widely in historical records, was constructed in 1735 above the confluence of the Tombigbee and Black Warrior Rivers, in Choctaw and Chickasaw Indian country, it served as an advance base during the Chickasaw War, as a base for trade with the Choctaws, and as a check against British influence in the area. After the French and Indian War the British occupied it, renamed it Fort York, and abandoned it 5 years later. It then fell into ruins. In 1794 the Spanish rebuilt the fort and renamed it Fort Confederation. They remained until 1797, the year before Congress designated the Mississippi Territory, at which time the fort became a possession of the United States. In 1802-3 Government officials negotiated there one of a series of treaties by which the United States absorbed the Choctaw lands and by which the area along the Tombigbee-Mobile Rivers was opened to settlement. Soon afterwards the fort fell into ruins and was abandoned. The National Society of Colonial Dames of America has placed a marker on the site (source: U.S. National Park Service).

${ }^{220}$ What the author of this letter meant if that large cargo ships such as flutes, not carriages, do not have enough water to sail upstream the Mobile and Tombigbee Rivers.

${ }^{221}$ Louboey, Chevalier de; Lieutenant of King in Mobile, then lieutenant of king in New Orleans, advisor to the Superior Council.
} 
have deserved this promotion for my services, as well as in my quality of captain as that of major that I have fulfilled for 28 years in this post.

I know the savages from different areas well enough to make the difference between those who are particularly attached to us with those who are only because they are interested. I am persuaded that Mr. de Vaudreuil will have given you a truthful account of my services and of the zeal with which he has known me to accomplish my duties. Therefore I implore, My Lord, your protection and your equity to grant me my promotion, no one knows better than yourself my qualities and my zeal for the service of the King.

I have the honor to be with a deep respect,

My Lord,

[END]

Your very humble and very obedient Servant [signed] Jadard de Beauchamp 


\section{APPENDIX B: DOCUMENTS PROVIDING INFORMA TION ON SPANISH AND FRENCH CARGOES OF SHI PS SAILING IN THE GULF OF MEXICO IN THE COLONIAL PERIOD}

(Tira 6, Tira 3, Tira 22, Tira 23, Tira 25, and CAOM C13 A26 1741) 
Introductory Note: Created in 1602, Tira 6 presents an exceptionally detailed list of the contents aboard the vessels of the fleet that left New Spain for Spain in the year 1602. Also provided are the names of captains and the names of ships.

\section{Tira 6}

\section{México 351}

\section{Translated by John de Bry}

With every dispatch ship ${ }^{1}$ that have sailed from this port, we have sent Your Majesty detailed accounts of everything that has occurred and now we are doing the same through other letters and we only have to add that on the fleet, commanded by general Juan Gutierrez de Garibay, which sails today, we are sending you three thousand eight hundred ducats and twenty-two gold pesos, as you can verify through the ships' reports, where it is registered and that corresponds with the abovementioned quantity. It also includes the sixty-two thousand seven hundred and sixty-eight pesos that were paid by the Royal Bank of México to the fortress of Havana and other improved fortifications in the city and artillery casting and other things that came out of that same bank by orders of Your Majesty.

Likewise, we have also included in the abovementioned quantity one hundred and seventeen six hundred and sixty-one that we sent from Royal Bank of the new city of Veracruz that were generated by the collection of the almojarifazgo ${ }^{2}$ that belongs to Your Majesty for the goods that have entered in this port that up to now is the biggest provision we have been able to collect. This figure also includes one hundred thousand pesos collected by the Royal Hacienda of Guatemala, and sixteen thousand and seventy-seven pesos collected by the Royal Hacienda of Yucatán. May God deliver this shipment safely and grant Your Majesty many happy years, by greatly increasing the number of kingdoms and dominions like Christianity.

At the city of Veracruz, $16^{\text {th }}$ of May 1602

Pedro Coco Calderon

Antonio Cotrina

/v/ blank

$/ 2 \mathrm{r} /$

Summary of the silver, reales, ${ }^{3}$ and gold that goes on Your Majesty's account to the kingdom of Castile from provinces of New Spain ${ }^{4}$ onboard the fleet commanded by Juan Gutierrez de

\footnotetext{
${ }^{1}$ Aviso; any small and fast warship carrying dispatches.

${ }^{2}$ With the discovery and conquest of America, the Spanish Crown was faced with the need to make a statement regarding the taxes that could affect those who chose to reside in the new Continent. Thus, in 1497, a Royal Document exempted trade in the Indies from any type of taxes and duties. This measure was aimed at increasing and facilitating trade in American soil. Nevertheless, such measure had a short duration, since in 1543 another Royal provision, signed by Charles V, taxed this trade with what was called "Almojarifazgo", which applied a 5\% rate over the value of the goods (Source: National Customs Service of Chile)

${ }^{3}$ Silver coins: 8 reales $=1$ piece-of-Eight.

${ }^{4}$ Nueva España, i.e. México.
} 
Garibay, which have to be delivered to the president and official judges of House of Contratación $^{5}$ of the city of Seville and in the city of San Cristóbal de la Havana, this year of sixteen hundred and two, which is as follows.

\section{In the flagship ${ }^{6}$ commanded by Master Pedro Murguía}

[Marginal annotations to the left indicate the place of origination and the number of chests and their content, such as "Royal Hacienda of Yucatán, 4 chests." It was decided not to transcribe them because it will be redundant to do so since the information is contained in the central item. The annotations to the right is the column that subtract the common gold pesos that this operation/sum has reduced every item's cost and their partial sums, we annotated them in numbers in a line followed by each one]

Eight thousand and seventy-seven pesos and two tomines ${ }^{7}$ of common gold ${ }^{8}$ in reales [coins] stored in four chests, three of them contain two thousand pesos each and in the other one two thousand and seventy-seven pesos and 2 tomines, on the account of the Royal Hacienda of Yucatán.

$$
8,077 \text { ps } 2 \text { ts }
$$

Fifty thousand pesos of the said gold stored in twenty-five chests that contain two thousand pesos in reales each, on the account of the Royal Hacienda of Guatemala.

Thirty-seven thousand one hundred and seventy-three pesos, one tomín, and ten grains of the said common gold, stored in thirty-two chests of silver and reales, which belong to Juan de Castellanos that were collected by Captain Diego López de Oria in the city of México.

Four thousand eight hundred and seventy-five pesos of the said gold in three chests of quintada silver along with six hundred marcos. ${ }^{10}$ Each chest contains two hundred each and the silver chests which contain gold on account separately from the Royal Hacienda of México.

4,875 ps

Eleven thousand three hundred and seventy-five pesos of the said gold stored in seven chests of quintada silver of two hundred marcos each, which come from the one hundred and fifty reinforced plazas in Havana.

11,375 ps

\footnotetext{
${ }^{5}$ House of Trade, officially known as La Casa y Audiencia de Indias.

${ }^{6}$ Capitana in the original manuscript text.

${ }^{7}$ One tomín was equivalent to 1 real or 34 maravedís.

${ }^{8}$ Common gold that has been assayed and the royal tax extracted (usually from the bars of gold and silver respectively) and marked with some sort of emblem or coat of arms etc, indicating royal inspection and acceptance as such (Sewall Menzel, 2009: personal communication).

${ }^{9}$ Quintada; assayed silver. The literal translation is silver with the king's fifth extracted for royal taxes - plata [silver] quintada [fifth part taken out]. A quinto $=1 / 5^{\text {th }}$.

${ }^{10}$ A marco was equivalent to 230.04 grams or 2,400 maravedis or 50 reales.
} 
Twenty-two thousand and one pesos and one tomín of common gold stored in thirteen chests, the first eight of quintada silver of 200 marcos each and in the five in the four (sic) two thousand pesos each in reales, and in the other one thousand and one pesos and one tomín on the account of the fortress of Havana.

In the said capitana (flagship)

One chest containing two hundred marcos of quintada silver, worth one thousand six hundred and twenty-five pesos of common gold, on the account of the books of the new donations (?).

Another chest containing five hundred pesos in reales, on the account of Your Majesty's aid granted to Doña María de Sosa

Twenty-one thousand six hundred and forty-one pesos and four tomines in a chest, $\mathrm{n}^{\mathrm{o}}$ one with ten thousand six hundred and twelve castellanos $^{11}$ five tomines and eleven gold grains of different qualities and carat, on the account of the Royal Hacienda of México.

21,641 pa 4 ts

Sixteen thousand two hundred and fifty pesos stored in ten chests of two hundred marcos each, on the account of the Royal Hacienda of the city of Veracruz.

16,250 ps

Three thousand eight hundred and forty-one pesos and six granos $^{12}$ (grains) of the said common gold stored in two chests, in one of them there are two hundred marcos of quintada silver, and in the other one two hundred and seventy-two marcos and six onza ${ }^{13}$ (ounces), on the account of the deceased of this New Spain deceased, which came from the bank of Veracruz as per the order of his lordship the viceroy.

3,841 ps 6 ts

\footnotetext{
${ }^{11}$ In the beginning of the colonization period of the New World, the castellano was the unit adopted by excellence for weight and assayed gold, becoming a standard practice to stamp it on bars, fragments, nuggets and bullions, all of which could be used as currency. This action was taken because of the absence of gold coinage in the new territories and the high demand of currency in the growing New World economic transactions (Abraham Lopez, 1995; Alfredo Díaz Gámez, Naufragio en Inés de Soto, Un Hallazgo de Cuatro Siglos, Carisub, S.A., Corporación Cimex, S.A. La Habana, Cuba 1998).

${ }^{12}$ One grano $=0.049$ grams $=0.0016$ troy ounces.

${ }^{13}$ One Mexican onza $=8$ ochavos $=28.765$ grams $=0.92$ troy ounces.
} 
In the almiranta (admiral ship) of Juan de Lambarri

Eight thousand pesos of regular gold in reales stored in four chests of two thousand pesos each, on the account of the Royal Hacienda of Yucatan.

8,000 ps

Fifty thousand three hundred and thirty-four pesos 3 tomines and six grains (granos) of common gold stored in twenty-five chests in silver reales and gold of different qualities, on the account of the Royal Hacienda of Guatemala.

/3r/

$$
\frac{50,334 \text { ps } 3 \text { ts } 6 \text { grs }}{=235,693 \text { ps } 4 \text { ts } 10 \text { prs }}
$$

In the said ship almiranta

$$
=235,693 \text { ps } 4 \text { ts } 10 \text { grs }
$$

Thirty seven thousand pesos of the said gold stored in thirty-seven chests of one thousand pesos each in reales, on the account of Juan Castellanos' assets collected in the city of México.

One thousand and thirteen pesos four tomines and seven granos in a lot of reales, on the account of the assets of the said Juan Castellanos.

1,013 ps 4 ts 7 grs

Thirteen thousand pesos in eight chests of two hundred marcos of silver quintada each on the account of the gun foundry of Havana.

13,000 ps

Seven hundred and seventy-five pesos in a chest of ninety-five marcos three onzas and six granos of silver quintada, on the account of the books of the new donations (?).

775 ps

Another chest with five hundred and twenty-six pesos in reales that are being sent by the accountant Francisco González, on the account of the books of new gifts donations (?).

526 ps

Four thousand five hundred and ninety pesos and five tomines of the said gold stored in three chests, two of two hundred marcos and the other one of one hundred and sixty-five marcos of silver quintada, on the account of the Royal Hacienda of México and there are silver chests containing gold that belong to a separate account.

4,590 pa 5 ts

Eleven thousand five hundred eighty-seven pesos and four tomines of the said gold in seven chests, six of them contain two hundred marcos each and in the other one two hundred and 
twenty-six marcos one onza and two tomines, on the account of the one hundred and fifty reinforced plazas in Havana.

Twenty-five thousand eight hundred and forty-nine pesos one tomín and one grano of common gold stored in sixteen chests, the first fifteen of 200 marcos each and the other ones of one hundred and eighty-one marcos three onzas and 3 tomines, on the account of the fortress of Havana.

/3v/

$$
\begin{aligned}
& 25,849 \text { ps } 3 \text { ts } 6 \text { grs } \\
& =330,035 \text { ps 3ts } 6 \text { grs }
\end{aligned}
$$

In the said the ship almiranta

$=330,035$ ps 3 ts 6grs

Five hundred pesos of the said common gold in reales in a chest on the account of Your Majesty’s aid granted to Doña María de Sosa

One chest $\mathrm{n}^{\circ}$ two with ten thousand six hundred and twenty-six castellanos three tomines and four granos of gold of different qualities and carats, worth twenty one thousand three hundred and sixty-five pesos five tomines of the said common gold, on the account of the Royal Hacienda of México.

$$
21,365 \text { ps } 5 \text { ts }
$$

Twenty-six thousand pesos of the said gold in sixteen chests, each containing two hundred marcos of silver quintada, on the account of the Royal Hacienda of Veracruz.

26,000 ps

Three thousand eight hundred forty-one pesos and six granos in two chests, one with two hundred marcos of silver quinatada, and the other with two hundred and seventy-two marcos and six onzas, from the account of the estates of various deceased persons of this New Spain, which came from the bank of Veracruz as per the order of his lordship the viceroy.

3,841 ps 6 grs

In the ship commanded by Juan R(odrigue)s

Seventeen thousand eight hundred and four pesos and three tomines of the said common gold stored in eleven chests, ten of which contained two hundred marcos each and the other one has one hundred and ninety-one marcos, two onzas three tomines and nine granos for the leaching (extraction) of copper and casting of the artillery of Havana.

17,804 ps 3 ts 
Thirty-two thousand five hundred pesos of common gold stored in twenty chests of two hundred marcos of silver quintada each, on the account of the Royal Chamber.

32,500 ps

$/ 4 \mathrm{r} /$

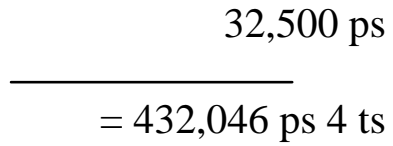

In the ship commanded by Master Baltasar R(odrigue)s $\quad=432,046$ ps 4 ts

Six chests, of which five contain two hundred marcos each of the known silver, and in the other ninety marcos and four onzas, whose total value is eight thousand eight hundred and sixty pesos, 2 tomines and four granos of common gold, on the account of the Royal Chamber.

8,860 ps 2 ts 4 grs

Twenty-two thousand seven hundred and eighty-eight pesos two tomines and two granos of the said gold stored in fourteen chests, of which the three first ones contain two hundred marcos each, and the other ones two hundred and four marcos five onzas five tomines and 6 granos, on the account of the bulls of the Holy Crusade in the charge of the treasurer Luis Núñez Pérez.

22,788 ps 2 ts 2 grs

Nineteen thousand five hundred pesos of the said gold stored in twelve chests each containing two hundred marcos, on the account of the bulls of the Holy Crusade in the charge of the treasurer don Gerónimo de Soto

$19,500 \mathrm{ps}$

Sixteen thousand two hundred and fifty pesos stored in ten chests, each one containing two hundred marcos, on the account of the Royal Hacienda of Veracruz.

$16,250 \mathrm{ps}$

In the ship commanded by Pedro Baruossa (Barboza)

Four thousand pesos in common gold stored in three chests, two of which contain two hundred marcos of silver quintada, and the other one ninety-two marcos, two onzas, three tomines and 9 granos, on the account taken over by the treasurer don Francisco Tello de Guzmán.

4,000 ps

Forty-six thousand seven hundred and seventeen pesos and six tomines of the said gold stored in twenty-nine chests, twenty-eight of them contain 200 marcos each and the other one, one hundred and forty-nine marcos and seven onzas, on the account of the Royal Hacienda of México.

46,717 ps 6 ts

$/ 4 \mathrm{v} /$

$=550,162$ ps 6 ts 6

$=550,162$ ps 6 ts 6 
In the ship commanded by Master Martín Pérez de Barracolta

Thirteen thousand two hundred and sixteen pesos, two tomines and two granos of common gold stored in eight chests, seven of which contain two hundred marcos each and the other one two hundred and twenty-six marcos, four onzas, seven tomines and six granos, on the account of the bulls of the Holy Crusade in the charge of the treasurer don Gerónimo de Soto

13,216 ps 2 ts 2

Forty-two thousand two hundred and fifty pesos stored in twenty-six chests of two hundred marcos each, on the account of the Royal Hacienda of México.

$42,250 \mathrm{ps}$

Forty-eight thousand seven hundred and fifty pesos of the said gold stored in thirty chests of two hundred marcos each, on the account of the Royal Hacienda of Veracruz.

$48,750 \mathrm{ps}$

In the ship commanded by Master Pedro Yrala

Forty-eight thousand six hundred and fifty pesos of common gold stored in thirty chests of two hundred marcos each, on the account of the bulls of the Holy Crusade in the charge of the treasurer don Gerónimo de Soto.

$48,750 \mathrm{ps}$

In the ship commanded by Master Domingo de Uribe

Forty-eight thousand seven hundred and fifty pesos stored in thirty chests of two hundred marcos each, on the account of the bulls of the Holy Crusade in the charge of the treasurer don Gerónimo de Soto.

48,750 ps 
On the ship commanded by Master Juan de Zárate

Fifty eight thousand seven hundred and thirteen pesos, seven tomines and four granos of common gold stored in thirty-four chests of silver quintada and bars from Perú, on the account of the Royal Hacienda of México.

$15 \mathrm{r} /$

58,713 ps 7 ts 4

$=810,493 \mathrm{ps}$

The said ship commanded by Master Juan de Zárate

$=810,493 \mathrm{ps}$

Two thousand seven hundred and twenty-nine pesos and one tomín of the said common gold in five bars, three of which are assayed at two thousand three hundred and eighty ${ }^{14}$ (fineness) and weigh two hundred and sixty-two marcos and six onzas, and of the remaining two, one is assayed at two thousand one hundred and fifty and weighs twenty-three marcos and five onzas, while the other one is assayed at two thousand two hundred and forty, which weighs twenty-nine marcos, four onzas and four tomines, and all were valued for the account of the Royal Hacienda of Veracruz.

2,729 ps $1 \mathrm{t}$

The total of what we are sending in the said fleet on Your Majesty's account, is eight hundred and thirteen thousand and one tomín of common gold. Dated in [the city of] New Veracruz on the sixteenth of May sixteen hundred and two.

813,222 ps $1 \mathrm{t}$

\section{Pedro Coco Calderón}

Antonio Cotrina

$15 \mathrm{v} /$

Year of 1602

Summary of the cargo carry by the fleet under the command of General Juan Gutiérrez Garivay on the account of His Majesty.

/6r/ blank

/6v/

Veracruz

To Your Majesty

1602

The royal officials on the $16^{\text {th }}$ of May

Give notice to Your Majesty

[END]

${ }^{14}$ A Ley number of 2400 indicated the highest purity; the bars mentioned above are quite pure. 
Introductory Note: Tira 3, created in 1575, supplies a representative manifest of the 1575 fleet which included silver, pearls, and spices. Of particular interest is a mention of "Chinese things".

\title{
Tira 3
}

\section{México 351}

\section{Translated by John de Bry}

Year of MDLXXV (1575)

Record of the silver and gold and other goods that were sent to Your Majesty from New Spain in the ships of the fleet under the command of General Don Antonio Manrique, appointed as one of Your Majesty's officials from the Indies' House of Trade (Casa de Contratación) ${ }^{15}$ from the city of Seville in this year of 1575.

\section{Onboard the ship la Vieja of master Ortuño de Bilbao}

\author{
Chests \\ Silver and Reales ${ }^{16}$
}

\section{LXIIII}

Firstly, 64 chests with 12,854 marcos 6 ounces 4 reales of silver coins from the Royal Hacienda, in the charge of the treasurer and commander Bernardino (Bernardo) de Albornoz.

\section{DCCC LIIII Marcos VI ounces IIII reales}

\section{IIII}

Four chests with 8,000 pesos of tipusque ${ }^{17}$ in reales of two thousand pesos each from the Royal Hacienda, in the charge of the said treasurer.

VIII thousand pesos

\footnotetext{
${ }^{15}$ House of Trade, officially known as La Casa y Audiencia de Indias.

${ }^{16}$ Silver coins: 8 reales $=1$ piece-of-Eight.

17 "Tipusque" (aka "Tepuzque" in Mexico): This is an indigenous/Spanish colonial term in the Americas for the melted down Inca, Aztec, Chibcha (Colombia), and other cultures gold objects, ornaments and regalia of one sort or another that were crudely converted into gold "tumbaga" bars, slugs and disks. Because the gold used was not uniformly of 22 carats due to the mixing of various quantities of copper, the bars had to be further refined and only then turned into gold coins (during the 16th century only Spain proper and its Iberian mints were authorized to coin gold). After the conquest of Mexico, in 1519, a serious shortage of currency developed (despite the Seville mint's efforts to provide a special provisional coinage for the Americas). So Cortez and his cohorts began to debase their captured gold and gold dust through the addition of copper. These slugs and disks of one size or another were known as "tepuzque" and denoted by their weight only. They were fairly popular as coin substitutes. While the practice was know to have been started in 1522, but there was wide spread fraud through the addition of large amounts of copper (for this reason many gold pieces and bars often have a reddish tinge to them). By 1526 the City Council (Cabildo) of Mexico passed an ordinance that owners of tepuzque would have to present their pieces to the royal foundry for formal assay. The value of the tepuzque gold was computed by weight of 96 grains so that it would be worth 272 maravedis; unrefined gold was valued at 300 maravedis; and assayed gold (presumably 22 karats) at 450 maravedies respectively. A special "quinto" (20 percent) royal excise tax stamp was sent to Mexico and depicted a castle in the center field surrounded by the legend: CAROLVS QVINTVS IMPERADOR (Sewall Menzel, 2009: personal communication - also see Menzel's Cobs, Pieces of Eight and Treasure Coins, ANS 2004, pages 37 - 39 ).
} 
I small sack

A small sack containing a marco ${ }^{18}$ and four ounces of pearls with 16 large pearls

Pearls I marco IIII ounces

Cinnamon XXVII thirds

27/3 of cinnamon from the Windward Islands that with their own burlap bags weigh CLXIII arrobas $^{19}$ XXI pounds.

XVI

CLXIII arrobas XXI pounds

Sixteen chests containing 3,200 marcos of silver in the charge of treasurer Rodrigo Franquez, proceedings of an almo[neda] (auction).

\section{III thousand and CC marcos}

Onboard the admiral ship of master Pedro de Santiago

LX

Sixty chests containing 12,000 marcos of silver coming from the Royal Hacienda in the charge of treasurer Bernardo de Albornoz.

XII thousand marcos

(N.B. Only the title and central items are transcribed not the marginal text in the original document because the information is redundant)

A crate with Chinese things and inside of it there is another smaller box with gold from the Fifth $^{20}$ Taxes from different laws, whose value is in pesos of tipusque 1 thousand CCXIIII pesos III tomines ${ }^{21}$.

Twenty-seven thirds of cinnamon from the Windward Islands that weighted with their burlap sacks CLXII arrobas XIIII pounds.

Eight chests of reales for Your Majesty from the officials of the Province of Yucatán generated by the import/export tax (almojarifazgo ${ }^{22}$ and other incomes of your charge with XV thousand pesos of tipusque and DC ducats of Castile.

One crate from the above-mentioned officials with papers and other receipts.

Another lot of silver and reales coins and silver with 577 pesos and 3 tomines of common ${ }^{23}$ gold, that with 3 pesos that were taken for transportation by the master, giving a total of 580 pesos and

\footnotetext{
${ }^{18}$ A marco was equivalent to 230.04 grams or 2,400 maravedis or 50 reales.

${ }^{19}$ One arroba was equal to 25 libras or 11.5 kilograms.

${ }^{20}$ Quinto: a Royal tax of 5\% of assessed value, which was the crown's biggest income.

${ }^{21}$ One tomín was equivalent to 12 granos or 0.599 grams or 0.019 troy ounces.

22 The almojarifazgo was a payment imposed by the crown on certain goods imported or exported.

${ }^{23}$ Common gold that has been assayed and the royal tax extracted (usually from the bars of gold and silver respectively) and marked with some sort of emblem or coat of arms etc, indicating royal inspection and acceptance as such (Sewall Menzel, 2009: personal communication).
} 
3 tomines, which represents the value of Campeche's public clerkship that was sold to Francisco Hernandez de Cueva.

A box with cinnamon water, a large jug and two long-neck bottles

Eight chests containing 1,606 marcos, one ounce 2 reales of silver and 950 pesos of tipusque.

On the ship of master Juan Luis de Chaves

Twenty-one chests containing IIII thousand $\mathrm{X}$ marcos of silver representing proceeds from the bull of the Holy Crusade, in the charge of the treasurer Bernardo de Albornoz.

Eight third of cinnamon that weighted with their burlap sacks LIII arrobas XV pounds

On the ship of master Bartolomé del Alosilla

Thirty-seven chests containing VII thousand CCCCLXVI marcos of silver and IIII silver reales, which originate from the situation given to the armada that sailed under the orders of Pedro Menendez.

Ten chests containing 2,000 marcos of silver originating from the Royal Hacienda in the charge of the treasurer Albornoz.

Twelve chests containing 24,000 pesos of tipusque in reales of 2 thousand pesos each, which originate from the said charge.

Three chests containing 597 marcos and 2 ounces of silver, which come from the three provincial clerkships that were annexed to Mexico, in the charge of the said treasurer Bernardo de Albornoz.

Ten chests containing two thousand marcos of silver, which originate from the almojarifazgo tax, in the charge of the treasurer Rodrigo Franquez.

One crate containing 1,659 pesos in reales coins, which come from the sale of arquebuses ${ }^{24}$ that were sold in Mexico, in the charge of treasurer Bernardino (Bernardo) de Albornoz.

\section{Onboard the ship of master Alonso Rodríguez de Noriega}

Forty-two chests containing 8,484 marcos, 1 ounce and 2 reales of silver, which originate from the Marquis del Valle's conviction, in the charge of the treasurer Bernardino de Albornoz.

\footnotetext{
${ }^{24}$ When hand cannon and serpentine firearms were gradually supplanted by various kind of matchlock weapons during the transition period ca. 1475-1525, the Teutonic descriptive hakenbüchse (hook gun) or its variants were often interpreted as firearms with or without a lock mechanism. In Spain hakenbüchse was borrowed almost intact, appearing as hacabuche or arcabuce. French equivalent of hook, arque, became a prefix for the corrupted German Büchse, emerging as arquebus or harquebus (Firearms in Colonial America, the Impact on History and Technology, 1492-1792, by M. L. Brown, Smithsonian Institution Press, Washington, D.C., 1980).
} 
One crate containing 169 marcos, 5 ounces and 4 reales of silver, worth one thousand ducats that Your Majesty donated to the monastery of San Gerónimo de la Mejorada, in the charge of the said treasurer Albornoz.

Sixteen chests containing 3,232 marcos, 1 ounce and 4 reales of silver, which come from the Royal Hacienda, in the charge of the said treasurer Bernardino de Albornoz .

Ten chests containing 2,000 marcos of silver, which come from the almojarifazgo, in the charge of the said treasurer Rodrigo de Franquez.

Another ten chests containing 2,040 marcos, 1 ounce and two reales of silver, which come from the bull of the Holy Crusade, in the charge of the said treasurer Albornoz.

Onboard the ship of master Anton de Fuentes

Eight chests containing 1,600 marcos of silver, intended for Your Majesty's Chamber, in the charge of the treasurer Bernardino de Albornoz

Eighteen chests containing 3,600 marcos of silver, which come from the [Holy] Crusade, in the charge of the said treasurer.

Twelve chests containing 2,400 marcos of silver from the said treasurer, proceeds from the Royal Hacienda.

Six thirds of cinnamon that weighted with their burlap sacks 39 arrobas and 14 pounds from the Windward Islands.

$/ 2 \mathrm{r} /$

Onboard the ship of master Diego Ochoa

Twelve chests containing 2,400 marcos of silver for Your Majesty's Chamber, in the charge of the said treasurer Bernardino de Albornoz.

Six chests containing 1,206 marcos 5 ounces of silver, proceeds from the Holy Crusade in the charge of the said treasurer.

Two chests containing 400 marcos of silver, from Royal Hacienda, in the charge of the said treasurer.

Onboard the ship of Juan de Ribera

Five chests containing 1,090 marcos 4 ounces of silver for Your Majesty's Chamber, in the charge of the treasurer Bernardino de Albornoz.

Thirty-five chests containing 7,000 marcos of silver, from the Holy Crusade, in the charge of the said treasurer Albornoz. 
Ten chests containing two thousand marcos of silver, from the proceeds of the rights of the almojarifazgo, in the charge of the treasurer [not Albornoz], but of Rodrigo Franquez de Villalobos.

Twenty-four chests containing 4,800 marcos of silver, proceeds from the Royal Hacienda, in the charge of the treasurer Bernardino de Albornoz.

Eleven thirds of cinnamon that weighted with their burlap sacks LXXVI arrobas and X pounds, which came from the Windward Islands.

Two leather pouches and two boxes with things from China.

One bundle containing cinnamon peeling.

Onboard the ship of master Gabriel de Herrera

Seven chests containing 1,400 marcos of silver from a Holy Crusade, in the charge of the treasurer Bernardino de Albornoz.

One chest containing CXXIII marcos and 5 silver reales, worth one thousand pesos of tipusque, in the charge of the said treasurer Albornoz.

Nineteen chests containing III thousand DCC LXXX III marcos, 7 ounces and 7 silver reales coins, from the clerkships that were sold in Mexico, in the charge of the treasurer Albornoz.

\section{Onboard the ship of master Alonso de Chaves}

Twenty-one chests containing XLII thousand pesos of common gold in reales senallos, ${ }^{25}$ from the Holy Crusade, in the charge of the treasurer Albornoz [Note: in a duplicate version of this entry it stated: 42,000 pesos of tipusque in reales].

Four thirds of cinnamon that weighted with their burlap sacks 28 arrobas and III pounds.

[END]

\footnotetext{
${ }^{25}$ The word "stamped" or "sellado" (sello is the noun form for stamp or royal/municipal/excise seal to show payment of the royal tax - on gold it eventually amounted to 10 percent, and on silver 20 percent or the "royal fifth" or quinto tax). The spelling rendered in this document is a misspelling which is a frequent mistake made Spanish scribes, especially common during the $16^{\text {th }}$-century. (Sewall Menzel, 2009: personal communication).
} 
Introductory Note: Tira 22 provides further information on cargoes from New Spain to Spain and tells who they were consigned to in Spain. Cochineal is one of several important exports that features in this document.

\section{Tira 22}

\section{Contratación 2490}

\section{f.24v}

\section{Translated by John de Bry}

Register of the said Master San Juan de Torra who received and has loaded beneath the deck of the said ship ten sacks of wool marked with the mark ${ }^{26}$ outside (well visible) [weighing] fortyfive arrobas, from Nicolás de Cacana on behalf of Garcí Núñez, who resides in Mexico. He should deliver the wool in Seville to Alonso Núñez de Badajoz or to who might have the power to represent him. The wool is sent by Garcí Núñez, on account and warrant of the partnership the two of them have, and serves to make him pay for the freightage fee and averias, which come to one crown per sack, and the said master signed it with his name on the fifth of April of the current year. Witnesses were Francisco Pérez and Diego de Vega, San Juan de Torra.

Register of the said San Juan de Torra who received and has loaded beneath the deck of his ship, from Nicolás de Cacanaon on behalf of Garcí Núñez, who resides in Mexico, three chests containing twelve sacks of mgeo (?), which weighted fifty arrobas, twenty-two pounds of cochineal grains, clean, lean and well conditioned and marked with the mark outside (visible) to be delivered in Seville to Alonso Núñez de Badajoz or to whom might have the power to represent him legally. The shipment is sent by Garcí Núñez, which includes the forty-nine arrobas and twenty-two pounds on account and warrant of the partnership the two of them have. The remaining one arroba should be taken by Alonso Núñez to Diego Sánchez Ortiz or to whom might have the power to representing him, so that it would be delivered to María de la Fuente, spouse of Juan Díaz de Toledo, and informed her that it is sent by Bernardo Hurtado [reflecting] the profits obtained from [the sale] of some clothing that she brought. She should pay for freightage fee and averías $^{27}$ seven good Castilian ducats per each case. The said master ${ }^{28}$ signed it with his name on the fifth of April of this current year. Witnesses were Francisco Pérez and Diego de Vega, San Juan de Torra.

Register of the said Master ${ }^{29}$ San Juan de Torra who received and has loaded beneath the deck of his ship, from Nicolás de Cacana on behalf of Juan Gallardo, who resides in Mexico, three cases with twelve sacks of egeo, ${ }^{30}$ which contained fifty arrobas and twenty-

\footnotetext{
${ }^{26}$ In the original manuscript document the owners' marks are inscribed in the left margin

${ }^{27}$ Avería was a tax imposed by the House of Trade from 1552 onward on merchandise going to and from the Americas (Phillips, Carla Rahn, Six Galleons for the King of Spain; Imperial Defense in the Early Seventeenth Century, John Hopkins University Press, Baltimore 1986 \& Chaunu, Huguette et Pierre, Séville et l'Atlantique (1504-1650, Partie Statistique, Tome Premier Introduction Méthodologique, Librairie Armand Colin, Paris 1955).

${ }^{28}$ In the original manuscript text the abbreviation for the word maese was used, which means maestro; this is obviously an error on the part of the scribe.

${ }^{29}$ Ibidem.
} 
/25r/

four pounds of cochineal grains clean, lean, in good condition and marked with the mark on the outside (visible) to be delivered in Seville to Hernán Pérez Estrada, or to Hernán Pérez de la Fuente or to Alonso Núñez de Badajoz or to anyone of them who might be responsible to pay in full. The said cochineal is sent on account and warrant of the partnership they all share. They should pay for freightage fee and averías seven good Castilian ducats per each case. The said master signed it with his name on the fifth of April of this current year. Witnesses were Francisco Pérez and Diego de Vega, San Juan de Torra.

Register of the said Master Juan de Etorra who received and has loaded beneath the deck of his ship, from Nicolás de Cacana on behalf of Pedro de Marquina, who resides in Mexico, a chest containing two sacks of anglo ${ }^{31}$ which contained ten arrobas of cochineal grains, clean, lean, in good condition and marked with the mark outside, to be delivered in Seville to Pedro Alvarez Arriscado and in his absence to Rodrigo de Llerena, which is sent on account and warrant of Pedro Marquina. He must pay four good Castilian ducats for the freightage fee and averías. The said master signed it with his name on the fifth of April 5 of this current year. Witnesses were Francisco Pérez and Diego de Vega, San Juan de Torra.

Register of the said Master San Juan de Torra who received and has loaded beneath the deck of his ship, from Nicolás de Cacana on behalf of Pero Núñez and Juan Pérez de Córdoba, who reside in Mexico, four chests with twenty-one sacks of anglo, containing eighty-three arrobas and one half of cochineal grain, clean, lean, in good condition and marked with the mark outside. The first forty arrobas should be delivered in Seville to Gaspar Melchor and in his absence to Andrés Pérez senior, and they are sent on account of the said Juan Pérez de Córdoba. The other forty-three and a half arrobas and should be delivered

/25v/

in Seville to Alonso de Illescas...

[END]

${ }^{30}$ This word is not understood; in Spanish, Egeo means Aegean.

${ }^{31}$ This word was not found in any new or old Spanish dictionary, but it is believed to be some sort of cotton-based fabric or textile; ... un fardo pequeño en que van 19 varas de paño de frailes y 60 pares de camisas de anglo y otros 60 pares de calzones de anglo, cinco costales de harina... 
Introductory Note: Tira 23 adds to the variety of cargoes that were sent from the Gulf of Mexico region to Spain. Included are cacao in blocks, vanilla, and sugar.

\section{Tira 23}

\section{Contratación, 2492}

\section{Translated by John de Bry}

I, Juan Carlos de la Peña, appointed by the King our Lord as chamber scribe of the Royal Audience of the House of Trade ${ }^{32}$ of the Indies in the city of Seville, which is located in Cádiz, ${ }^{33}$ provided assistance to the needs that have kept don Francisco Lorenzo de San Millán from Your Majesty's Audience in the Royal Hacienda and fiscal jurisdiction of the said Royal Audience that concerns the Royal and Supreme Audience of the Indies. To the said tribunal, I give my word that by a number of cases done by orders of the said don Francisco Lorenzo de San Millán, today on the current month, while being near the place called Entrepuntales ${ }^{34}$ in the bay of this city, onboard the ship named Nuestra Señora de la Concepción y San Joseph, which came as aviso ${ }^{35}$ from the province of New Spain, commanded by Master Luis Fernández Rendón, after visiting the said ship it seems like and holds, of what was inventoried after this visit is reflected in a shipping manifest, that the said master brought different goods and fruits and from some cases and measures done today onboard the said ship by orders of the said don Francisco Lorenzo San Millán is as follows:

[In the margin] and then unrestrainedly, ${ }^{36}$ the said master Luis Fernández Rendón said that in compliance with his duties he made a manifest declaring the kind of goods that he brought in his ship, what they are, to whom they belong and to whom they will be delivered, which is as follows:

One hundred and eleven hides with fur which the said master received from don Luis de Monterde, resident of Veracruz, to be delivered in the said city of Cádiz to don Juan Bautista Sandi and in his absence to don Gerónimo de Estrada, and the said skins have no identifying markings.

From Antonio López Correa, a chest lined with matting, with the mark in the margin, ${ }^{37}$ containing fans to be delivered in Cádiz to captain Pedro de Monares, with long staff. ${ }^{38}$

From the second lieutenant Juan de Alza, a chest that says

/v/

\footnotetext{
${ }^{32}$ Contratación; House of Trade, officially known as La Casa y Audiencia de Indias.

33 The House of Trade was moved from Seville to Cádiz in 1711 but had been operating out of Cádiz for quite some time.

${ }^{34}$ No reference to this place name was found.

${ }^{35}$ Any small and fast warship carrying dispatches.

${ }^{36}$ Of his own will.

${ }^{37}$ On the original manuscript document the identifying mark of the owner is inscribe in the left margin.

38 This is not understood.
} 
Vanilla, with the mark in the margin, which measures three quarters in length and more than one third in height and width, to be delivered to don Francisco de Berrotaran.

From Captain Domingo de Irizar, two small chests labeled in linens to Don Joseph de Irambaragua, to be delivered in Cádiz to Ramón de Arrerar. It measures three quarters in length on each side, no markings.

From Don Martín de Jáuregui, one small chest wrapped in matting, measuring half a square vara, ${ }^{39}$ with a lamp for Santa Lucía, ${ }^{40}$ with the mark in the margin, to be delivered to Don Martín de Ollo.

From Juan de Langarica, a chest that says it contains chocolate paste, measuring less than a vara in length, with the mark in the margin, to be delivered to Don Lorenzo de Ezeiza.

From Jacinto de Coto, a brick ${ }^{41}$ of cacao, with the mark in the margin, to be delivered in Cádiz to captain Pedro de los Reyes, who will receive one fanega. ${ }^{42}$

From Captain Matías de Córdoba, on third of cacao, with the mark in the margin, to be delivered in Cádiz to Sebastián Barriga.

From Gaspar de Herrera, one third of Cacao, with the mark in the margin, which he sends as a gift to Don Cristóbal de Soto, official judge of the said Royal House of Trade.

On the account [of the above] three third of purgative to be delivered in Cádiz to Doña Tomasa de Zamora.

From Don Juan Francisco de Borda, a small chest measuring a little more than half a vara, with the mark in the margin, to be delivered to Doña María Francisca de Soto.

From the said Juan Francisco de Borda, thirteen third of cacao, with the mark in the margin, to be delivered to Pablo Vizarron and in his absence to don Leon de Vizarron.

From Don Lorenzo de la Torre, ten third of cacao, with the mark in the margin, to be delivered to Rodrigo Lani, in his absence to who might have the authority.

From Captain Lucas de Llano, ten third of cacao, to be delivered to don Diego Perez de Garayo, with the mark in the margin.

From Juan Antonio de Irrarte, one third of cacao, with the mark in the margin, to be delivered to Rodrigo Lani, in his absence to Joseph Masdeu.

/2r/

\footnotetext{
${ }^{39}$ A vara was equal to 0.83 meter or 32.9 inches.

${ }^{40}$ Possibly Santa Lucía on Grand Canary Island.

${ }^{41}$ Tejero in the original manuscript text, meaning a brick or a block.

${ }^{42}$ A unit of dry measure equal in Spain to 48 quartillos, or 55.7 liters or 1.58 U.S. bushels.
} 
From Bernardo Velázquez, two boxes containing chocolate, measuring a little more than a vara in length, with the mark in the margin, to be delivered in Cádiz to Juan de Bandeplas.

From the said Bernardo Velázquez, a large box containing chocolate, measuring a little more than a vara in length, with the mark in the margin, to be delivered to Don Gabriel de Morales.

From the said Bernardo Velázquez, a large box containing chocolate, measuring a vara in length, with the mark in the margin, to be delivered to Diego Maestre.

From Captain Antonio de Aranguis, two third of cacao, with the mark in the margin, to be delivered to don Juan Fernández de Rueda.

From Jacinto López, one pouch ${ }^{43}$ of cacao to be delivered to Domingo Méndez de Granda.

From Juan Rodríguez, two third of cacao with an ink blot as a mark to be delivered to himself.

From Captain Pedro de Arbide, six third of cacao, with the mark in the margin, to be delivered to Don Ramón de Torrezar.

From Pedro de Zagarraga, one third of cacao, with the mark in the margin, to be delivered to Don Ramón de Torrezar.

From Captain Antonio Moreno, two third of cacao, with the mark in the margin, to be delivered to Miguel Pérez.

From Francisco Narbáez, two third of cacao, to be delivered to Miguel de las Infantas.

From Don Gerónimo Monterde, ten third of cacao, to be delivered to don Ramón de Torrezar, with the mark in the margin.

From Simon de Villanueva, two third of cacao, with the mark in the margin, to be delivered to himself

From don Joseph Sánchez, five third of cacao, with the mark in the margin, to be delivered to Felipe Juan

/2v/

From the said Joseph Sánchez, a brick of cacao, with the mark in the margin, to be delivered to Don Francisco Monzarrate

From Don Guillermo Bequel, one third of cacao to captain don Diego Bequel.

From Roque de Abendaño, thirty-seven third of cacao, with the mark in the margin, to be delivered to himself.

${ }^{43}$ Leather bag. 
From the priest Father Alonso del Rosario of the Order of San Francisco, ${ }^{44}$ with the mark in the margin, and in a small sugar container of normal size and labeled to father Andrés de la Barrera, to be delivered to the him.

From Pedro Garcia, nine third of cacao, with the mark in the margin, to be delivered to himself.

From Pedro García, islander, ten third of cacao; correction, sixteen third of cacao, without markings, to be delivered to himself.

From Don Esteban de Costo, a box of sugar of regular size, with the mark in the margin, to be delivered to Don Lorenzo de Costo.

From Diego Florencia, three boxes of sugar of normal size, with the mark in the margin, to be delivered to Sergeant Don Juan Pérez Caro.

From Ambrosio de Rojas, a cedar gift chest with trinkets, to be delivered to Doña Gerónima Manuela de Medina

From Second Lieutenant Juan Caraballo, a small Campechan chest with trinkets for gifts, to be delivered to Juan Bautista Cacha, labeled to Mother Santa Isabel.

From Don Francisco García Arroyo, a box of vanilla, measuring one vara in length, to be delivered to don Diego de Barrios.

From the said Francisco García Arroyo, a box labeled to Don Francisco de Vargas, to be delivered to don Pablo Vizarron, measuring

$/ 3 \mathrm{r} /$

a vara and a half in length. It seems like it hold a dais folding screen.

From Don Gerónimo de Estrada, three boxes labeled to the Duke of Medinaceli, ${ }^{45}$ measuring one vara and three quarter in length, each one seems to be folding screens, to be delivered to Sergeant Major Don Francisco Sánchez Azanero.

These said acts are contained in the inventory made by the said master Luis Fernández Rendón, which he showed to judge Don Francisco Lorenzo de San Millán, with which they were compared and correlated with the said inventory.

Likewise, he also manifested that he carried onboard a number of different boxes, which were not included in the inventory because he received them the day on which he was about to sail in the said city of Veracruz and are as follow:

Five boxes of chocolate paste, measuring less than a vara in length each, from Domingo de Irizar to be delivered to Don Ramon de Torrezar, with the mark in the margin.

\footnotetext{
${ }^{44}$ Franciscan.

${ }^{45}$ Luis Francisco Tomás de la Cerda y de Aragón, 9th Duke of Medinaceli - Folch de Cardona, (1654 - died in prison, in Pamplona fortress, 1711).
} 
From Juan Francisco de Borda, two boxes of chocolate paste, with the mark in the margin, to be delivered to Don Andrés Martínez de Murgía.

Seven small boxes, measuring half a vara in length, some more or less labeled to different persons, which indicate that they are intended as trinkets for gifts, but he does not know who brought them because they were taken onboard when he was about to sail by Don Joseph de Galves, owner of the said ship.

All the acts and goods, which are mentioned in the inventory, were declared by the said master before the said judge. His Lordship ordered to put it in writing so that there is proof of this visit. He signed it and then the said master also signed it. It is signed, Luis Fernández Rendón, before me Juan Carlos de la Peña.

[END] 
Introductory Note: Tira 25 is another document that provides information on what was being carried in the Spanish ships that traversed the Gulf of Mexico, specifically in the very early $17^{\text {th }}$ century. It should be noted that the San Juan Bautista mentioned in this document is not identical to the San Juan Bautista (Lost Ship Number 8) lost in 1719.

\section{Tira 25}

\section{Contratación 2899 A1}

\section{Book II f. 256r}

\section{Translated by John de Bry}

Registers of the ships that came from the Indies to these kingdoms and were received in this accounting office of this House ${ }^{46}$ since the beginning of January of this year of 1605 up to now are as follow:

The records that have been received in the accounting office of this said House in the galleons of the armada [commanded by] General Don Luis Fernández de Córdoba that for the month of December of 1604 came to Spain and were received in this House for the month of January of 1605 as well as gold and silver brought by the said galleons as well as the ships of the fleet which in the said year of 1604 came from New Spain, [commanded by] General Juan Pérez de Oportu, which had been left in the city of San Cristóbal de la Havana with their cargo of silver, gold, reales, ${ }^{47}$ cochineal, and indigo, which they carried and were in the said armada, and of other ships that came accompanied by the armada from Tierra Firme and other parts of the Indies, ships sailing alone unprotected and without a fleet, are as follow:

\section{Tierra Firme’s Galleons}

Ruy Lopez de Lisboa, master of the flagship galleon named San Gregorio Hernán García, master of the galleon almiranta ${ }^{48}$ named Santo Domingo in two bodies Martín de Suica, master of the galleon named San Agustín Francisco de Bustillo, master of the galleon named San Ambrosio Juan Rodriguez de Reinoso, master of the galleon named San Cristóbal Ochoa de Uribe, master of the galleon named San Francisco Melchor Baez, master of the galleon named San Gregorio

From New Spain of the ships that brought silver from the fleet of General Juan Pérez de Portu

Francisco Pérez, flagship of New Spain of the ship San Juan Bautista

\footnotetext{
${ }^{46}$ Contratación; House of Trade, officially known as La Casa y Audiencia de Indias.

${ }^{47}$ Silver coins: 8 reales $=1$ piece-of-Eight.

${ }^{48}$ Each fleet had two heavily armed large galleons escorting it; the capitana was always the point ship and the captain-general, who had overall command of the fleet, sailed on it; the second in command, the admiral, sailed aboard the almiranta that protected the rear of the fleet.
} 


\section{f. $256 \mathrm{v}$}

Juan de Morales, master of the admiral ship Nuestra Señora de los Remedios

Melchor Palomo, master of the ship named Nuestra Señora de Begoña

Gaspar de la Fuente, master of the ship named Nuestra Señora de Va

Pedro Márquez, master of the ship named Nuestra Señora del Rosario

Alonso Gómez, master of the ship named Nuestra Señora de la Concepción

Juan Garco, master of the ship named Nuestra Señora de Candelaria

From Honduras

Diego de Villavicencio, master of the ship named Nuestra Señora de Begoña

Pedro Sánchez Farfán, master of the ship named Jesus María Josephe

Francisco López Garay, master of the ship named Nuestra Señora del Valle

From different parts escorted by the galleons

Juan Ramírez, master of the ship named Nuestra Señora de la Esperanza from Cartagena

escorted by the galleons, received on the seventh of January of this year

Manuel Pérez, master of the ship San Luis of New Spain

Alonso de Utrera, master of the ship San Miguel, aviso ${ }^{49}$ from New Spain

Sebastián Hernández, master of the ship named San Francisco de Paula of Havana

Jorge Díaz, master of the ship named Nuestra Señora de Guía of Havana

Manuel Ventura, master of the ship named el Buen Jesus of Havana

[In the margin: Juan Ruiz Gallardo is master] Melchor de Hoyos, master of the ship named Santa

Ana of Havana

Independent and without a fleet

Alonso Pérez Montañez, master of the ship Nuestra Señora de la Concepción of Puerto Rico

Pedro de Urbina, master of the ship Nuestra Señora de la Concepción of Puerto rico

Alonso López, master of the ship named San Simón de Buenaventura of Puerto Rico, it entered

Cádiz

Diego Benítez de Luyando, master of the ship named //

[END]

${ }^{49}$ Aviso; Any small and fast warship carrying dispatches. 
Introductory Note: This document was selected because it is indicative of a manufactory of ship parts in French Louisiana. The colony was to provide numerous finished pieces to France for the building of a 74-gun ship. It underlines the fact that wood, fashioned or not, was an important part of products shipped from French ports in the Gulf.

\section{CAOM C13 A26 1741}

[Folio 232 recto]

Translated by John de Bry

State of oak timber that will be shaped in Louisiana for the construction of a 74-gun ship

seen

$\begin{array}{lll}\text { Length Width } & \begin{array}{l}\text { Thickness } \\ \text { Longitudinally }\end{array} \text { [feet] }\end{array}$

Stem pieces

2 stem pieces of

$22 \mathrm{ft} . \quad 20$ inch. $\quad 16$ inch. $\quad 98 \mathrm{ft}$

3 pieces of counter stem

$\begin{array}{llll}20 & 16 & 16 & 106\end{array}$

5 stem pieces with total cubic feet of

Frames

13 floor frames

16 other floor frames

14 stern frames

20 pieces for rear cant-floor

20 pieces for forward cant-floor

42 bottom half-floor

16 other bottom half-floor

70 outer half-floor

126 first futtocks

126 second futtocks

126 third futtocks

46 reverse futtocks (?)

66 other reverse futtocks (?)

20 coltis (?) futtocks

20 mooring frames (?)

2 fashion timber

2 angle bars

$\begin{array}{cccr}23 & 15 & 11 & 343 \\ 19 \text { à } 21 & 15 & 11 & 367 \\ 14 \text { à } 18 & 15 & 11 & 257 \\ 12 & 15 \text { à } 17 & 11 & 293 \\ 8 & 14 \text { à } 16 & 11 & 184 \\ 15 & 13 & 11 & 626 \\ 15 & 15 & 11 & 275 \\ 16 & 15 \text { à } 17 & 11 & 1369 \\ 16 & 12 \text { à } 18 & 11 & 2310 \\ 15 & 12 \text { à } 18 & 11 & 2166 \\ 15 & 12 \text { à } 18 & 11 & 2166 \\ 14 & 12 & 11 & 591 \\ 16 \text { à } 22 & 12 & 11 & 1150 \\ 18 & 15 \text { à } 17 & 11 & 440 \\ 20 & 15 \text { à } 17 & 15 & 666 \\ 18 & 24 & 12 & 72 \\ 23 & 14 & 11 & 49 \\ & & & \\ & & & 13324 \text { pi. }\end{array}$

745 pieces with total cubic feet of 
/v/

Length Width Thickness Cubic

Longitudinally [feet]

Riders

6 rider floor frames

$\begin{array}{cccc}19 \text { à } 23 & 16 & 12 & 168 \mathrm{ft} . \\ 14 \text { à } 16 & 16 \text { à } 18 & 12 & 149 \\ 15 & 14 & 12 & 210 \\ 15 & 15 \text { à } 17 & 12 & 280 \\ 16 & 13 \text { à } 17 & 12 & 545 \\ 15 & 13 \text { à } 17 & 12 & 457 \\ 15 & 13 \text { à } 17 & 12 & 457\end{array}$

117 pieces with total cubic feet of

2266 pi.

\section{Recapitulation}

5 stem and counter stem pieces with total cubic feet of $204 \mathrm{ft}$.. 745 frame pieces......................................13324

117 rider pieces.......................................2266.

867 pieces with a total cubic feet of $15794 \mathrm{ft}$.

Don in Brest 8 October 1741

[signature] Ollivier ${ }^{50}$

[END]

${ }^{50}$ Ollivier, Blaise; Blaise Ollivier is without doubt the most outstanding and certainly the most innovative of the French engineers and shipbuilders of the XVIIIth century. Born in 1701, he died at the age of 46 after serving as engineer-builder and general director of works in the port of Brest. He is generally known as the creator of the first "true" frigate, la Médée, in 1744, an innovation that was soon to be copied by all major naval powers. Moreover, as early as the 1720's, Ollivier broke with the more conservative trends in shipbuilding during the XVIIth century and opened the way for later developments by Bouger, Duhamel du Monceau, Borda and Sané (Source: $18^{\text {th }}$-century Shipbuilding: Remarks on the Navies of the English and the Dutch, by Blaise Ollivier (1737), edited and translated by David H. Roberts, publisher: Jean Boudriot, Rotherfield, 1992). 


\section{APPENDIX C: DOCUMENTS PROVIDING INFORMA TION ON LOSSES OR SHIP ACCIDENTS OUTSIDE OF THE DEEP WATERS OF THE GULF OF MEXICO}

(Tira 12, Tira 13, Tira 28, Tira 29, Tira 33, and CAOM C13 A13 1731 [Folio 55 recto]) 
Introductory Note: Tira 12 supplies information on the loss of the Floridablanca. The Floridablanca was reported as lost in the Gulf of Mexico by Italian archival researcher Claudio Bonifacio who lives and works in Seville, Spain, and information was posted on his website. This researcher located the legajo (AGI, Correos, 263B), read the first folio and ordered photocopies of the relevant documents. It is now clear from the transcribed and translated document below that this ship did not sink but was captured by a privateer or pirate ship and taken to New Providence. The information contained in this document, however, is useful as it gives us a better idea of routes used by ships coming from Veracruz on their way to Havana, Cuba.

\section{Tira 12}

\section{Correos 263B 2}

\section{Translated by John de Bry}

$\mathrm{N}^{\circ} .245$

The report that the mail brigantine Floridablanca was lost has been confirmed, as I had already mentioned to Your Excellencies in my previous letter dated the $3^{\text {rd }}$ of October $\mathrm{N}^{\mathrm{o}}$. 241, as this enclosed copy $\mathrm{N}^{\circ} .94$ of the letter sent from Providence ${ }^{1}$ by his commander Lieutenant Don Juan Bautista de Aranaga confirms it; and even though it mentions his eminent departure with a parliamentary, he has not arrived yet; and after I verify it, the judicial procedures should be implemented in this sub delegation, as it is stipulated in these cases.

God keeps Your Excellencies many years

Havana $23^{\text {rd }}$ of November of 1797

José Fuertes

Gentlemen General Directors of the Mail Office

Madrid

$/ \mathrm{v} /$

Havana $23^{\text {rd }}$ of November of 1797

The administrator

The news announcing that the mail [ship] Floridablanca was lost on the $3^{\text {rd }}$ of October, $\mathrm{N}^{\mathrm{o}} .241$ has been confirmed by the missive as reflected in the accompanying copy $\mathrm{N}^{\circ} .94$ of the original letter from your commander Don Juan Bautista de Aranaga, and that after he arrives to that port all the judicial procedures would be implemented as it is stipulated.

\section{$\mathrm{N}^{\circ} .94$}

New Providence, $14^{\text {th }}$ of October of 1797

My dearest Sir:

I am informing Your Excellency that on $23^{\text {rd }}$ of August of last I sailed from the port of Veracruz in order to arrive here ${ }^{2}$ onboard the mail brigantine Floridablanca, which was under my command, along with the war brigantine Resolución and a merchant schooner.

\footnotetext{
${ }^{1}$ New Providence, the Bahamas.

${ }^{2}$ Havana, Cuba.
} 
On the $26^{\text {th }}$, I lost sight of the two of them; and while continuing my course with frequent clamas $^{3}$ (sic) waves and showers, I managed to reach the shoals of the Tortugas ${ }^{4}$ on the $21^{\text {st }}$ of September.

On the $23^{\text {rd }}$, I proceeded to the coast with winds blowing from the northeast, making a loop and catching a fair wind from the south, a quarter to the southeast, and the next day the $24^{\text {th }}$, a windy storm and hard rain befell us by the second quadrant that lasted until the $26^{\text {th }}{ }^{5}$

On the $27^{\text {th }}$, by morning I considered that I was 31 leagues to the leeward from this port, I found myself to the north of los Roques. ${ }^{6}$

On the $28^{\text {th }}$, when morning broke and seeing the said cays and the Salt Cay, ${ }^{7}$ I spotted a sail to the south and even though it did not appear to be suspicious, I changed my course to the north; almost right after that I spotted two other sails on this [same] side, as a result I decided to alter my course once again and noticed that the first one was coming upon me with full sails. ${ }^{8}$ Thus, I decided to change my course once more. Even though I implemented all the sailing procedures, it was not possible to escape due to the disproportionate advantage they had over me. Therefore, I was forced to thrown into the sea nine chests

/v/

containing correspondence, and I surrendered at the discretion of a privateer ${ }^{9}$-owned brigantine named Lara of 16 cannon and a crew of 110 men, which came from this island at 9 in the morning of the $28^{\text {th }}$ of September, after 36 days of navigation. ${ }^{10}$

The next day they sent me off to this port onboard of the captured ship, along with the pilot, the page boy, and a lady passenger of combés ${ }^{11}$ from the Royal Hacienda, while the rest of my crew stayed onboard the captor [ship] until the conclusion of the cruise, as the captain told me. I and the rest of the prisoners were treated with such unusual benignity by the captain and his officials that it would be very difficult to find another nation in the world that would treat us the same.

On the $5^{\text {th }}$ of the same month, we arrived on this island, among which population we have stayed on our word of honor until this government decides to send us to that city. ${ }^{12}$ In the interim, I prayed to Our Lord that he may keep Your Excellency for many years. I kiss the hand of Your Excellency, Your most attentive and reverent subject,

Juan Bautista de Aranaga.

Señor D. José Fuertes

This is a copy of an original which I certified: Havana, twenty-third of November of seventeen hundred and ninety-seven.

Félix López Aillón.

[END]

\footnotetext{
${ }^{3}$ Possibly meant thunder.

${ }^{4}$ The Dry Tortugas, Florida.

${ }^{5}$ This sentence dealing with navigation and weather is very confusing.

${ }^{6}$ Cay Sal Bank. It is not clear why the Floridablanca was so far to the east if Havana was its intended destination, but perhaps the weather was a factor or, possibly, a navigational error.

${ }^{7}$ Probably the island on Cay Sal Bank.

${ }^{8}$ This is an indication that the ship giving chase was larger and had either more or larger sails.

${ }^{9}$ Corsario in the original manuscript text, so it could either be a privateer or a pirate.

${ }^{10}$ This seems to indicate the time it took the Floridablanca to sail from Veracruz to this location, i.e. on or around Cay Sal Bank.

${ }^{11}$ Combés is a Spanish archaic nautical term that means waist, formerly applied to that part of an upper deck between the fore castle and the poop, or a raised quarter deck. In the context of this document it probably indicated the class and the part of the ship in which this woman was lodged while traveling aboard the Floridablanca.

${ }^{12}$ Havana.
} 
Introductory Note: Tira 13, like Tira 12, supplies information on the loss of the Floridablanca. As described above, the Floridablanca was reported as lost in the Gulf of Mexico by Italian archival researcher Claudio Bonifacio who lives and works in Seville, Spain, and information was posted on his website. This researcher located the legajo (AGI, Correos, 263B), read the first folio and ordered photocopies of the relevant documents. It is now clear from the transcribed and translated document below that this ship did not sink but was captured by a privateer or pirate ship and taken to New Providence. The information contained in this document, however, is useful as it gives us a better idea of routes used by ships coming from Veracruz on their way to Havana, Cuba.

\section{Tira 13}

\section{Correos 263B 1}

\section{\#241}

\section{Translated by John de Bry}

[In the left margin: Dec. 18/ 97

That it is fine and that it must be remitted to La Coruña ${ }^{13}$ for the reasons included]

If the weather allows it, tomorrow a warship should set sail with official letters for those dominions, which has been dispatched by the General of the Navy. It occurred to me, with some reserve, that on this occasion I could send the correspondence of the Royal Service that was kept in the Administration of New Spain's and Santa Fe. ${ }^{14}$

My hopes to send this expedition on the mail brigantine Floridablanca, which sailed from Veracruz on the $23^{\text {rd }}$ of August with the correspondence of the mentioned month, were frustrated as it was captured on the $28^{\text {th }}$ day of September last by an 18-gun privateer ${ }^{15}$ near los Roques, ${ }^{16}$ where the waves and sea currents had taken the ship. According to the news that a Maonés ${ }^{17}$ just gave me, who came aboard an American ship that was also detained by the same privateer in order to inspect it, assured me that he lost sight of them on the $29^{\text {th }}$ sailing toward Providence. It seemed to me very convenient to agree with the proposition of the General Commander of the Navy.

\footnotetext{
${ }^{13}$ La Coruña or A Coruña is a port city in western Spain that played an important role in Spanish maritime history. It is from there that Philip II's 130-ship strong "Invincible" armada sailed in 1588 in an attempt to invade Protestant England. Twenty-four ships were wrecked upon the coast of Ireland, and of the original 130 ships, 50 failed to make it back to Spain and the invasion attempt was a complete failure. Located on a peninsula 2.4 kilometers from the center of the city, the 55-meter high Torre de Hércules is Europe's oldest working lighthouse, built by the Roman during the $1^{\text {st }}$ to second $2^{\text {nd }}$-century A.D.

${ }^{14}$ Santa Fe de Bogotá, Colombia.

${ }^{15}$ Corsario in the original manuscript text, so it could either be a privateer or a pirate.

${ }^{16}$ Cay Sal Bank.

${ }^{17}$ A Maonés is a native or resident of the town of Maó, or Mahón, the capital of the Balearic island of Minorca (the Balearic Islands form an autonomous Spanish community). Located in the eastern part of the island, Mahón has the deepest harbor in the world 5 kilometers long and up to 900 meters wide.
} 
In effect, I forward the correspondence

$/ \mathrm{v} /$

That it was resolved to labeled for the Gentlemen Ministers Excellencies, under individual packages for each one, so that your majesty could impose a number and weight. I enclose an index that could also be useful for the Administration of La Coruña, where Your Excellencies will take care to direct it, so that you should have it in hand when you receive the original invoices, to which you will put the corresponding annotations when the rest of the public correspondence that remains here waiting for the first opportunity goes out.

The Balahú ${ }^{18}$ Reina Luisa from Puerto Rico, which came with the last correspondence from those dominions, made its way to Trinidad; and due to the absence of the Floridablanca, I found myself in the need to point out to Your Excellencies the urgent need that I have to buy [a ship], and I will make sure when the occasion takes place to seek a ship that does not exceed (if possible) the designated dimensions, and also the fastest and cheapest possible.

When I opened the box from Guatemala, I found it to be very much ill-treated and some letters from the [mail] chiefs indicated that. I am advising Your Excellencies so that you are informed with great accuracy by the first expedition.

God keeps Your Excellencies

/2/

Many years. Havana, October $3^{\text {rd }}$ of 1797.

José Fuentes

Gentlemen General Directors of the Mail Office

Madrid.

$/ \mathrm{v} /$

Havana October $3^{\text {rd }}$ of 1797

$\mathrm{N}^{\circ} .241$

The Administrator

Replied on the $23^{\text {rd }}$ of December of 1797.

There has been a notice saying that the mail brigantine Floridablanca was captured by a privateer.

That a war-vessel was dispatched by the General of the Navy with official letters, sending the correspondence that he found there for the gentlemen ministers in separate packages, which also includes an index to be remitted to La Coruña, as it is expressed; and that it should send the rest of the public correspondence the first chance he has.

That the Balahú Reina Luisa will use the [alternative] Trinidad route, and due to the lack of the Floridablanca we are pressed to buy any ship with the designated dimensions.

/3/

(The answer's rough draft) ${ }^{18}$ balahú, was a type of schooner common in the Antilles. Besides being a term for a specific kind of ship, it was
also used contemptuously to describe inferior ships. 
The correspondence which cites the index that accompanies Your Excellency's letter, dated the $3^{\text {rd }}$ of October last $N^{\circ}$. 241, that was taken to Cádiz by a prow ship, ${ }^{19}$ which was dispatched by the General of the Navy, has been received. Taking the advantage to send it, as it was privately suggested to you, due to the capture of the mail brigantine Floridablanca on her way to Veracruz by a privateer of 18 cannon, we decided to send the abovementioned index to the Administrator of La Coruña as it was suggested by Your Excellency, so that he can have it when he receives the original invoices that he should send at the first opportunity he has along with the rest

/v/

of the public correspondence that remains in this administration.

We understand that the balahú Reina Luisa of Puerto Rico is already alternating on the Trinidad route and that due to the lack of the abovementioned brigantine Floridablanca Your Excellency urgently needs to buy any ship with the designated dimensions. The Administrator of Puerto Rico has been notified by us repeatedly to dispatch to that department all the new Balahús that they might have, and if he has fulfilled our request, Your Excellency should see if there is a need or not to buy [a ship], in (?) of which the one named el Rey, which is in Cádiz, we have determined, should travel to La Coruña so that it can sail with (?) to that port where it should remain just like the arriving valadón ${ }^{20}$ sailing from La Guayra. ${ }^{21}$

Madrid $23^{\text {rd }}$ of December of 1797

Don Joseph Fuentes

[END]

\footnotetext{
${ }^{19}$ Buque de proa in the original manuscript text; this term is not fully understood.

20 This ship was most likely named after Bartolomé Valadón, a famous corsair from Cuba who, in 1743, along with other corsairs, captured fourteen English ships that had entered the port of Santiago de Cuba.

${ }^{21}$ Founded in 1577, La Guaira is the capital of the Venezuelan State of Vargas and the country's main commercial and navy port.
} 
Introductory Note: Tira 28 mentions the loss of a ship bound from Honduras to Spain. The ship was lost on the treacherous Sanlúcar bar on the Guadalquivir River in Spain.

\section{Tira 28}

\section{Consulados 837B}

\section{Translated by John de Bry}

I, Luis de Alvarado, accountant, certifies that by orders of the [ripped off: lordships] prior and consuls of this university of stevedores of the Indies has inventoried what was saved from the ship commanded by Master Monte Mancera, which was lost on the coast of Sanlúcar at the end of last year on the sixteenth, coming from the province of Honduras, whose owner appears to be Bernardo de Torres, and that the aforementioned individual has the authorization from the said Francisco Monte to collect the freightage of the indigo chests that he picked up in the sea as contraband in the galleons and the rest that might belong to the said ship from which the said captain Bernardo de Torres, who has received different amounts of $\operatorname{marcos}^{22}$ and that in Don Andrés de Munibe's account, of which I have the records and thus I know what should be there after seizures were thrown in it by the lordships president and judges of the House of Trade by virtue of a [previous] contract from the lordships governor and judges of the Royal Audience of this city as petitioned/requested by Doña Mariana Suárez de Toledo. The said account has credit for seventy-eight thousand and ninetyeight marcos (above between lines; 80,070 marcos) and this debtor of seventy thousand seven hundred and fifty-six marcos (above between lines; 79,324 marcos), which a portion of it has been paid by the provisions [established] by the lordships governor and judges of this House of Trade to Antón de Arcos, gunner of the said ship, and also, by the ruling of the lordships president and judges of the said House, it exonerated Juan Alonso de Camino, collector of the avería, ${ }^{23}$ for another consignment dated in Lisbon which was deposited under vigilance in this ship by the governor Don Fernando Dalvia, for having been supplied through the funds ${ }^{24}$ of the averia that was distributed for the transport of the silver by land this said year, and likewise, he will be charged with the marcos spent in the sea salvage and transport to Seville of five pieces of artillery and two anchors, which are on the verge of being loaded with the said artillery and anchors to be sold by Fernando de Mesa. As such, this state has not forgotten the said bill and the said artillery, anchors and a cable which are to be sold by the said Fernando de Mesa, and the rest of what was salvaged that pertains to those interested in the merchandises sold and the insurers of the ship.

$/ \mathrm{v} /$

And by order of the said lordships prior and consuls I give this certification to be presented before the lordships president and judges of this House. Dated in Seville, $23^{\text {rd }}$ of January of the year 1618.

\section{[END]}

\footnotetext{
${ }^{22}$ A marco was equivalent to 230.04 grams or 2,400 maravedis or 50 reales.

${ }^{23}$ The Avería was a tax imposed by the House of Trade from 1552 onward on merchandise going to and from the Americas (Phillips, Carla Rahn, Six Galleons for the King of Spain; Imperial Defense in the Early Seventeenth Century, John Hopkins University Press, Baltimore 1986 \& Chaunu, Huguette et Pierre, Séville et l'Atlantique (1504-1650, Partie Statistique, Tome Premier Introduction Méthodologique, Librairie Armand Colin, Paris 1955).

${ }^{24}$ Marcos in the original manuscript text.
} 
Introductory Note: Like the preceding tira, Tira 29 relates to the loss of an Indies ship on the Guadalquivir River in Spain. This early $17^{\text {th }}$ century document also provides a glimpse into the financial side of sending vessels to the Americas.

\section{Tira 29}

\section{Consulados 837B}

\section{Translated by John de Bry}

Andrés de Munibe Rector of this [merchant] guild, from the marcos ${ }^{25}$ that Your Majesty has received of the proceeds of what was salvaged from the ship [commanded] by Master Francisco Monte Mancera, which was the flagship of the ones coming from the province of Honduras at the end of past year seventeen hundred and sixteen (sic), ${ }^{26}$ that was lost on the bar of Sanlúcar, ${ }^{27}$ whose owner appears to be Bernardo de Torres and for Your Majesty's payment to Doña Mariana Suarez de Toledo, or to whom has your authorization, the amount of 2,456 marcos, pertaining to the said Bernardo de Torres, which were exonerated [of taxes] by virtue of a provision from the Royal Audience of this city dated on the thirtieth of July of this present year before Diego de Arana, scribe of the said audience, sent as provisions and Your Majesty takes his promissory note, which along with this bank draft will be forward to Your Majesty's account. Dated in Seville on the last of July of sixteen hundred and twenty.

To Doña Mariana Suárez de Toledo, 8 reales by the reason explained above.

[END]

${ }^{25}$ A marco was equivalent to 230.04 grams or 2,400 maravedis or 50 reales.

${ }^{26}$ This is an error on the part of the clerk or scribe; the date mentioned should have been 1616.

27 The sand bar at Sanlúcar de Barrameda at the entrance of the estuary of the Guadalquivir River in Spain. 
Introductory Note: Tira 33 provides list of registers from the House of Trade in Spain for the year 1552. The names of ships, captains and their New World ports of departure can be gleaned from this document. Mention is made of a ship lost between Cartagena and Havana, but no further details are available.

\section{Tira 33}

\section{Contratación 2898}

\section{f. $178 v$ a $181 v$}

\section{Translated by John de Bry}

Records of arrivals of this year of IUDLII [1552]

I A register of the ship named Santiago, Master Melchor Diez, which came from the Puerto Plata $^{28}$

II Another register of the ship named Santa María de Guadalupe, Master Salvador Garrido and Señor ${ }^{29}$ Sebastián Ramírez of Santo Domingo

III Another register of the ship named San Mateo, Master Martín de Çavala, which came from Santo Domingo

IIII Another register of the ship named Santa María la Bella, Master Bartolomé Sánchez, which came from Santo Domingo

V Another register of the ship named Sant Antón del Brasil, Master Blas de Carrión, of Santo Domingo, the said ship was lost in the sea with everything she carried ${ }^{30}$

VI Another register of the ship named la Concepción, Master Francisco Diez who says he is from Argal ${ }^{31}$

VII Another register of the ship named Santa María de la Victoria, Master Marcos de Torres, which came from New Spain, which arrived in Lisbon

VIII Another register of the ship named Santa María de la Concepción, Master Juan Rodríguez Mondragón, which came from Tierra Firme ${ }^{32}$

IX Another register of the ship named Juan Antonio, Master Juan de Brindez, from New Spain and from Havana

$\mathrm{X}$ Another register of the ship named la Concepción, Master Tome de la Isla, which came from Tierra Firme

/179r/

XI Another register of the ship named Santa María de Begonia, Master Juan García, which came from Tierra Firme

XII Another register of the ship named la Magdalena, Master Miguel de la Borda, from Tierra Firme, who says he sailed through the Azores

\footnotetext{
${ }^{28}$ Puerto Plata, north coast of the Dominican Republic, island of Hispaniola.

${ }^{29}$ Señor in this context implies the person is most likely the owner.

${ }^{30}$ It is believed this ship sunk near the island of Bimini, the Bahamas.

31 ...que diz que a por Argal; this is ambiguous and not properly understood.

32 South America; the ship most likely sailed from Cartagena, Colombia.
} 
XIII Another register of the ship named San Juan, Master Diego de Quesada, which came from Tierra Firme

XIIII Another register of the ship named San Juan, Master Baltazar Núñez, which came from Santo Domingo

XV Another register of the ship named San Antonio, Master Juan Del Barrio, which came from from Santo Domingo

XVI Another register of the ship named El Salvador, Master Cristóbal Endrinas and Señor and pilot Miguel Bobedo, which came from Puerto Plata and from Puerto Rico

XVII Transcript of a register of the ship named Sant Andrés, Master Vicente Fernández and Señor and pilot Sebastián González, from Honduras, and said to have stopped in Havana, and other judicial decrees are inserted with it

XVIII Another register of the ship named San Antonio, Master Manuel Hernández, from Santo Domingo

XIX Another register of the ship named Santiago, Master Miguel de Oquendo and pilot Santiago de Uçin, from New Spain, and said to have sailed through the Azores, and part of the gold and silver was brought to this House ${ }^{33}$

XX Another register of the ship named San Antonio, Master Juan Corço, from Tierra Firme $/ 179 \mathrm{v} /$

XXI Another register of the ship named Santa María de Begonia, Master Juanes de Undona and pilot Francisco de Santana, from New Spain

XXII Another register of the ship named la Concepción y Espíritu Santo, Master Alonso Pérez Maldonado, from New Spain and from Havana

XXIII Another register of the ship named Santa Cruz, Master Francisco García and pilot and Señor Cosme Buytron, from New Spain

XXIV Another register of the ship named San Pedro, Master Bartolomé Farina, from New Spain XXV Another register of the ship named San Esteban, Master Juan Uzelo, from New Spain, which arrived in Cádiz and the gold and silver were brought to this House

XXVI Another register of the ship named Santa María de Loreto y San Vicente Ferrer, Master Juan Franco, from Santo Domingo

XXVII Another register of the ship named San Andrés, Master Martín de Marcana, from New Spain

XXVIII Another register of the ship named Jesús Nazareno, Master Sancho Farfán, from Santo Domingo

XXIX Another register of the ship named San Andrés, Master Alonso González and pilot and Señor Pedro González, from Santo Domingo

XXX Another register of the ship named San Nicolás, Master Tome Nuñez, which arrived from Tierra Firme and Santo Domingo

XXXI Another register of the ship named Nuestra Señora de la Esperanza, Master Diego Nieto, which came from Santo Domingo

/180r/

XXXII Another register of the ship named Regina Celi, Master Pedro Ochoa de Trabudo, from Santo Domingo

\footnotetext{
${ }^{33}$ The House of Trade, i.e. la Casa de Contratación; House of Trade, officially known as La Casa y Audiencia de Indias.
} 
XXXIII Transcript of a register that was sent from the city of Santo Domingo to this House, of the ship named San Miguel, Master Salvador Garrido, which was lost near the said city of Santo Domingo and part of the gold and silver was salvaged and brought in other ships which came from New Spain

XXXIIII Another register of the ship named Santiago, Master Benito Camacho and Señor Diego Marín, from Santo Domingo

XXXV Another record, of the ship named Catalina, Master Blas Alonso, from Santo Domingo XXXVI Transcript of a register that appears to have been done in Santo Domingo, of the ship named Santiago, Master Cristóbal Diez, which was flooded in the said city of Santo Domingo XXXVII Another register, of the ship named San Antonio, Master Pedro Polee, from Havana XXXVIII Another register, of the ship named la Concepción, Master Alonso Rodríguez de Morales, from Tierra Firme and Santo Domingo

XXXIX Another register, of the ship named Santa María, Master Pedro Machorro, from Santo Domingo

XL Another, of the ship named Nuestra Señora de Ayuda, Master and pilot Sebastián Gallego, from Puerto Rico

XLI Another of the ship named Nuestra Señora de los Remedios, Master Baltasar González and Señor Amador González, from Puerto Rico

/180v/

XLII Another of the ship named la Trinidad, Master Andrés Lorenzo de Montecristo

XLIII Another of the ship named El Espíritu Santo, Master Gaspar Barrios, from Puerto Rico

XLIIII Another of the ship named Sant Espíritu, Master Diego García, from Cuba and from Havana

XLV An account of some certificates which came registered in the ship named Santa María de Begonia, Master Hernán Vásquez, which left Cartagena

XLVI Another register, of the ship named Santa María, Master Domingo Menhieta, on which came Don Francisco de Mendoza, Captain General of Tierra Firme

XLVII Another register, of the ship named Santa María, Master Martín de Ribera, which came from Terra Firme

XLVIII Another register, of the ship named San Esteban, Master Marcos de Nápoles, from Tierra Firme

XLIX Another register, of the ship named Santa María de la Piedad, Master Sebastián Pinzón, from Terra Firme

L Another register, of the ship named Santa Clara, Master Juan de Andino, from Tierra Firme

LI Another register, of the ship named El Espíritu Santo, Master Lope Garcia Isasi, from Honduras

LII Another register, of the ship named Santa Catalina, Master Juan González de Cuerras, from Honduras

LIII Another register, of the ship named Buen Jesús, Master Juan Vélez, from Honduras /181r/

LIIII Another of the ship named Santa Catalina, Master Alonso Galdamez, from Tierra Firme, which was lost between Cartagena and Havana ${ }^{34}$

LV Another, of the ship named Santa María de Finisterra, Master Juan Rodríguez Zarco, from Tierra Firme, and the ship is said to have sailed through Havana

${ }^{34}$ There is a slight possibility that the ship could have been lost in the Gulf of Mexico, depending on weather conditions and route taken. 
LVI Another of the ship named Santa María la Bella, ${ }^{35}$ Master Sebastián de Florez, from Tierra Firme and from Havana

LVII Another of the ship named Santa María del Camino, Master Alonso Martín Morejón, from Tierra Firme

LVIII Another of the ship named la Madalena (sic), Master Juan Esteban, from Tierra Firme, and that stayed in the Azores

LIX Another of the ship named Sant Espíritu, Master Juan de Arita, from Cartagena, which was dispatched from Málaga ${ }^{36}$

LX Another register of the ship named San Antonio, Master Pedro Gutiérrez, from Tierra Firme, which stayed to follow the galleon of Don Alvaro de Bazán

LXI Another register of the ship named San Bartolomé, Master Toribio García, rumors indicate that coming from New Spain it anchored in La Yaguana, ${ }^{37}$ and since she was not able to sail everything she carried was given to the local justice

LXII Another register of the ship named Concepción, Master Juan de Arenas, from Puerto Rico

LXIII Another register, of the ship named la Piedad, Master Juan de Palacios, coming from Puerto Rico

These are all the said registers of arrivals of this year of MDLII [1552], which are 63 registers

[END]

${ }^{35}$ Santa María la Vella in the original manuscript text; in archaic Spanish, the "b" is often substituted by "v" and vice versa.

${ }^{36}$ The Mediterranean port city of Málaga in southern Spain.

${ }^{37}$ Yaguana was renamed by the French, Léogâne; it is located on the southwestern portion of Haiti, island of Hispaniola. 
Introductory Note: The French ship discussed in this excerpt sank after being taken by the current and hitting a sand or mud bank somewhere in the Louisiana colony in 1731. The rest of this letter did not contain any useful data pertaining to maritime matters, ships, or ship losses, and thus was neither transcribed nor translated in its entirety.

\section{CAOM C13 A13 1731}

\section{[Folio 55 recto]}

\section{Translated by John de Bry}

Louisiana

M. Périer ${ }^{38} 16$ April 1731

My Lord,

I sailed down [stream] aboard the flute of the King la Somme $e^{39}$ to draft a report on the pass of the bar of the

$/ \mathrm{v} /$

St. Louis River. ${ }^{40}$ I wanted at the same time to leave two ships on it (the bar) to see how much dredging they could have done in eight days, but they could not stay there because of too much current and lack of warp ${ }^{41}$. One of our ships name le Prince de Conty as she was sailing out of the said river with contrary wind, grounded on a mud bank. The ship was so old that grounding and coming apart almost took place at the same time; beaver furs and part of the cargo of cotton were saved from this ship, and only the deer skins were lost...

\section{[END]}

\footnotetext{
${ }^{38}$ Périer, Étienne de (1687-1 April 1766) Lieutenant of the King, named Governor of Louisiana from 1726 to 1732, then Lieutenant General of Naval Forces. He was the fifth governor of the Louisiana colony. He became governor in 1727. His governorship was marked by the arrival of the first Ursuline nuns in New Orleans in 1727 to establish the first convent within the limits of what was to become the United States as well as a war against the Natchez Indians due to bad relations with Chepart, the commander at Fort Rosalie. After agitating the Indians by demanding that they give up either their village or their land, the Indians launched an attack on November 26, 1729 and killed nearly three hundred persons at Fort Rosalie. The French retaliated and by 1731 had killed or captured most of the Indians. The captured Indians were sent as slaves to St. Domingue (present-day Haiti), and the few remaining free moved further westward and joined the Chickasaw Indians. This marked the end of the Natchez Indian Nation. In the same year, the Company of the Indies (West India Company) petitioned the King Louis XV of France to take back their charter, thus ending their control of the colony. Périer remained governor for two years after Louisiana was returned to the king but became frustrated with deteriorating relations with the Chickasaws and lost interest in the colony. He resigned, and Jean-Baptiste le Moyne de Bienville was chosen to yet again be governor of the colony (sources: Archives Nationales [Paris], Series Marine $C^{7}$ 242; Wikipedia).

${ }^{39}$ The Somme is a river in northwestern France that empties into the English Channel after passing through the cities of Saint-Quentin, Péronne, Amiens, and Abbeville. A major military offensive against the German army took place along its banks from July to November 1916, which helped relieve pressure from the battlefield of Verdun.

${ }^{40}$ The Mississippi.

${ }^{41}$ Warp: Rope employed for mooring a vessel in a port, and for other purposes (source: De la Quille à la Pomme du Mât, Dictionnaire de la Marine by Capt. Paasch, p. 10, Antwerp, 1908).
} 


\title{
APPENDIX D: DOCUMENTS PROVIDING INFORMA TION ON THE PROCESS OF THE SAL VAGING OF VESSELS
}

\author{
(Tira 1 and Tira 2)
}


Introductory Note: Tira 1 , written in the early $17^{\text {th }}$ century, discusses steps that were taken to redistribute the cargo of a ship that had come under distress just outside of Vera Cruz. The Santiago ran aground in harsh weather near shore and, fearing even stronger weather, the crew began to prepare the ship for potential disaster. The document tells of the unloading of the ship and how cargoes were accounted for on behalf of the King of Spain.

\section{Tira 1}

\section{México 351}

\section{Translated by John de Bry}

In the new city of Veracruz on Saturday July $22^{\text {nd }} 1628$, the official judges of the Royal Hacienda, accountant Don Juan Blasquez Mayoralgo and the treasurer Diego de Valle Alvarado told me that on Friday, which was the $21^{\text {st }}$ of this present month of July and year of the date on which the records belonging to the flagship Santiago were signed and delivered, which was under the orders of general Don Juan de Benavides' fleet, silver master Captain Juan Miguel and the admiral ship named Santa Gertrudis, silver master Captain Baltasar de Amesquita, and of all the other ships under his charge in order to sail to Castile this present year, and the frigates and ships that sail for different ports and lands seem like the same day, Friday, around 10 o'clock in the morning, the said flagship set sail as requested of her voyage, and was followed by the admiral ship and other frigates and vessels. However, having lacked the necessary wind for sailing, they anchored in this port of San Juan de Ulua and other vessels did not weigh anchor, nor could they sail on that same day for the same reason. The wind blew from the north and it rained, and while the north wind blew on Saturday it was one

$/ \mathrm{v} /$

o'clock in the afternoon when the same admiral ship [and] other vessels and frigates returned to this port. Wanting to do the same, the flagship (Santiago) ran aground and could not sail [because of being stranded]. As such they [the crew] started to throw pieces of the ship into the water as to signal other vessels for help, and immediately after the crew were forced to cut the main mast and rigging and throw them into the sea along with the main and smaller sails. When this event and calamity was known, the authorities were alerted and the Royal Treasury's judicial notary of this city was also contacted pertaining to what concerns Your Majesty's (properties) and we, as your administrators, took charge in order to save the silver and coins which were registered in the manifests of the flagship as belonging to You and also to private individuals, as well as cochineal, silk, indigo and other valuable goods of which the ship was loaded with and whose royal rights belong to Your Majesty. Having convened what was more appropriate in this case, we resolved to send the treasurer with the current notary on board the flagship to take and save the silver and coins belonging to Your Majesty and also to private individuals, and the cochineal, silk and indigo to be remitted to the Royal Contaduría ${ }^{1}$, so that it could be kept there and the rest could

$/ 2 /$

be brought here in shipments by trustworthy individuals, so that the treasurer could witness what was brought and there were no possibilities of fraud nor anything would go missing. If the involved parties need to make any complaints or other requisites and diligences, these could be

\footnotetext{
${ }^{1}$ Crown Accounting Office.
} 
written at the bottom of this relation, so that it can be demonstrated that everyone assisted and fulfilled his official obligations. They signed before me Don Juan Blasquez Mayoralgo and Diego de Valle Alvarado

Notary public, Juan Villarroel

[In the margin: diligence]

This event took place in the new city of Veracruz, on the said day and month before the treasurer and me the notary. Each of us sailed in our respective longboats in order to get to the place where the flagship Santiago ran aground, so that the events could be substantiated and I decided to put the particulars in writing, which was signed by the head guardian and executor of the Royal Hacienda Luis de Milla, who came on board with me and also the second lieutenants Miguel de Herrera y Francisco Perez, who also served as witnesses.

/v/

And many other persons who were on the wharf of this city and I signed Juan de Villarroel, notary public.

[In the margin: diligence]

Having arrived at the place where the flagship Santiago had ran aground, the treasurer Diego de Valle Alvarado and myself the official notary public, on the said month and year, and according to your majesty's orders, [made sure] that general Juan de Benavides should transport Your Majesty's silver and coinage from the said flagship's hold and take it by boat to San Juan de Ulua's fortress in order to be protected. The shipment should be received by Captain Juan Miguel, silver master in charge, who had granted many official notes of coinage and silver and that the said silver master had not abandoned the flagship and that he in fact brought the silver, coinage, and other goods on board the flagship were safely brought to land to the Royal Contaduría

/3/

Even though the north wind was blowing and was accompanied by rain and it signaled that the bad weather was going to last for awhile, which meant that the ships could sink, it was determined to salvage the goods so that a trustworthy official would safeguard them, as it was started by orders of the general, the treasurer, and captain Alonso Bernal, who after receiving the goods signed at the bottom of this relation, which is the right and just thing to do in these kinds of events, and ordered me the official notary to put it in writing and was signed before me by Diego de Valle Alvarado

Juan de Villarroel, notary public.

[In the margin: diligence]

Being on board of the said flagship Santiago in the place where the ship ran aground on the month and year already mentioned, and after having made a statement captain Juan Miguel indicated that there was no silver nor any other chest containing coinage left in the ship's storeroom and that everything else had been salvaged

$/ \mathrm{v} /$

In order to be taken by boat to the said fortress to be safeguarded there, the said treasurer told him to make sure that there was no silver or any other coinage left in the ship and that everything that had been salvaged should be remitted immediately to the fortress, to which captain Juan Miguel answered that there was nothing left in the ship's storeroom, after which he called me 
(the official notary) to make sure that there was no silver left nor any coinage in the ship's storeroom, and after having inspected the storeroom with light I saw that there was nothing left, no silver ingots nor any silver barretones [small silver bars], nor any other large or small trunk containing coinage was left, and in order to be consistent I put it in writing and captains Hernando Guerra and Jerónimo de Belena served as my witnesses and other persons who were also there and I signed it along with the treasurer and we returned to land around 11 o'clock at night after the flagship started to sink, while the said captain remained on board. Before me Diego de Valle Alvarado.

Juan Villarroel, notary public.

It agrees with the original copy, which will remain under my care as I have mentioned it, and I have also made triplicates of it. As a sign of the truthfulness of my testimony, I sign it, Juan de Villarroel.

The cosigning notaries certify

/4/

That Juan de Villarroel, who has sealed and signed this testimony is your majesty's official notary public and of records of both the old and the new city of Veracruz and of the port of San Juan de Ulúa, and that according to his testimonies, registers, and other records that have passed and keep passing through his hands, and that in order to be considered in good faith and credit I indicate this took place in the new city of Veracruz on May 29th of 1629.

[signatures]

Diego López, notary public

Sebastián Rodríguez, notary public

Francisco González (?), notary public

[END] 
Introductory Note: Tira 2, drafted in 1583, also relates to the salvaging of a ship off Vera Cruz. The cause of the ship's misfortune is not evident in the document. However, the document provides valuable insight into the troubles that port officials had in enforcing royal decrees relating to trade in this period. Also, the document mentions that mercury from this ship (and presumably others) was being transported into the interior of New Spain by land rather than by water in order to prevent the loss of this priceless commodity.

\section{Tira 2}

\section{México 351}

\section{Translated by John de Bry}

In this fleet that came under the orders of general Don Antonio Manrique, we received Your Majesty's decrees to be executed and we understood that Your Majesty ordered that we should assume that the flagship's and the admiral ship's cargoes that had been brought with them were lost and to charge the masters the according shipping fees. Also, it would be very convenient for this matter to be finally resolved that Your Majesty sends us your RC [Royal Cédula], ${ }^{2}$ so that the vessels that would unload [salvage] the flagship and the admiral ship could be appointed by us. That way no other vessels could board [the flagship and the admiral ship] without risking a fine, which would be determined by us.

The whole salvaging fleet came and everything has been unloaded without any incident. Most of the accompanying rigging that was sent by Your Majesty was transferred to the port of Acapulco and the one that remains would be eventually sent.

The mercury transported by sea is [now] being transported by land to avoid the kind of risks involved if it were to be brought by boats.

We do not know the amount of money we could provide to Your Majesty because no valuations were made as it is indicated by the Royal Audience.

The merchants brought a cédula that Your Majesty had promulgated on Tierra Firme, ${ }^{3}$ by which it orders us to do the valuations by the hundreds according to how much the goods were sold on land and even though this is alright in what concerns the goods as well as the merchants, who do not complain because the land is in need that Your Majesty favors it in what concerns the wines and oil, the Royal Hacienda happens to be harmed with a great sum of lost revenues because these articles do not generally sell in quantities of one-hundred, but they are sold in lots of one hundred barrels ${ }^{4}$ or fifty or the quantity

\footnotetext{
${ }^{2}$ A cédula was a written royal order, having the force of law. Cédulas were gathered, collated, and codified in works called registros or cedularios (source: Lyon, Eugene, The Enterprise of Florida; Pedro Menéndez de Avilés and the Spanish Conquest of 1565-1568, University Press of Florida 1974).

${ }^{3}$ South America

${ }^{4}$ Pipas in the original manuscript text; A pipa or pipe was a large wooden cask of wine with a capacity of 476 liters (126 gallons).
} 
$/ \mathrm{v} /$

that each one wants at a fixed price, and having Your Majesty order that the valuations should be executed according to the value that the goods might have on land, it causes a great harm to the Royal Hacienda because by valuating the goods by the hundred, it comes out to twelve and fifteen pesos ${ }^{5}$ each barrel and the merchants sell them at fifty and sixty pesos. Last year the merchants raised complaints over how one should understand the royal license and even though we did our best by implementing official inspections (autos de vista) and reviews, the Royal Audience orders us to resolve this issue according to the process, which we sent to the prosecutor. Since this business is of great importance, we plead with Your Majesty to send it to be reviewed, and after the harm that has been inflicted upon the Royal Hacienda has been understood, a decree could be sent to us so that the barrels and oil could be valuated according to the price they were sold and not by the hundred since valuating them by the price they are sold without taking into account the reductions and spoilage they bring, and as such they do not receive penalties. Being the other way around, it would greatly benefit the Royal Hacienda.

Your Majesty had indicated in your royal decree that the deputies of Mexico, and also of this city, should collect the royal revenues and should also make the calls and other necessary efforts, but since they have no interest in doing so they have not collect the [the revenues] as it was agreed. Therefore, after having discussed the importance of this matter we determined that the officials of Mexico should have an executor, and the viceroy Don Martín Enríquez ordered one to be appointed in this city. Your Majesty's most recent dispatch brought by the last fleet instructed us not to have one, and instead to send the ordinary deputies to collect the royal revenues and to employ wagon masters and muleteers to transport the rigging and the sailors and any other things. Still, there is the need for an appointed executor whose only job would be to collect the royal revenues, and will receive the salary of a guard. We plead that Your Majesty send a commission so that he can be named because the lack of one is very costly to the Royal Hacienda because there is no one to collect, nor anyone who understands the ordinary functions and since the deputies do not carry out this task, but instead concentrate on their own duties and other things related to their jobs, we cannot take care of our own responsibilities.

One of Your Majesty's decrees indicates that neither generals nor any officials should come onboard of any ships coming to the port, but because of their particular interest they do not follow these regulations, especially when a ship carries black slaves, because with the excuse that they want to visit the ship they end up charging a bribe

/2/

and aiding in hiding the slaves that were brought without registration. Thus, in order that the Royal Hacienda would not be defrauded, it would be very convenient that Your Majesty orders to promulgate a royal decree, so that all generals and officials of the fleet, and also the captain from the island, ${ }^{6}$ know what their responsibilities are, which do not include coming onboard the vessels, taking down records, nor intervening by doing what is our job.

When the fleets arrive at the port, the citizens and commissioned officials of this city taking heed of their own particular interests and deals they have with the masters go to the port before we do,

\footnotetext{
${ }^{5}$ A peso was equivalent to 8 reales of silver (piece-of-eight), and it took 16 reales of silver, or 2 pesos, to equal I gold escudo (Menzel, Sewall, Cobs, Pieces of Eight and Treasure Coins, ANS 2004, page 12).

${ }^{6}$ It is believe that the island referred to is San Juan de Ulúa.
} 
which ends up defrauding the Royal Hacienda. As such, we implore Your Majesty to send us a royal decree that allows us to visit the fleets before any other person dares to or they could face a fine, which would benefit Your Majesty's service. This way, there will be someone who could estimate the price of whatever goods might have been smuggled in.

This ship has been detained waiting for the Royal Audience's orders and because they did not arrive on time, it has been delayed. May Our Lord Protect Your Royal Catholic Person by enlarging your kingdoms and dominions, signed at Veracruz 3 November of 1583.

S.C.R.M. (Sacra Católica Real Magestad)

Servants of Your Majesty

Alonso de Villanueva

Don Luis de Céspedes

/v/

New Spain

A SM

1583

From the official records of Veracruz, last of November

No need to respond

[END] 


\section{APPENDIX E: DOCUMENTS PROVIDING INFORMA TION ON THE VARIOUS SAILING ROUTES AND CONNECTIONS IN THE GULF OF MEXICO}

(Tira 34, CAOM C13 A20 1735 [Folio 29 recto], CAOM C13 B1 1715 [Folio 60 recto], and CAOM C13 A16 1733 [Folio 223 recto]) 
Introductory Note: Tira 34, written in 1596, sheds light on the trade connections of the Pacific side of New Spain. Listed are connections to Japan, the Philippines, China, Indonesia, and India. Goods from these places are known to have entered into the cargoes of the vessels that traversed the Gulf of Mexico.

\section{Tira 34}

\section{México 1 A}

\section{/f.37r/}

\section{Translated by John de Bry}

In one of the latest letters received from the Count of Monterrey in the aviso ${ }^{1}$ ship that just now arrive from New Spain, it says that on the $18^{\text {th }}$ of November arrived in the port of Acapulco a galleon that had sailed from the Philippines, accompanied by three others [ships], and that on the $16^{\text {th }}$ of December the others had not arrived yet and that the one that comes as captain (sic) ${ }^{2}$ in the one that had entered Acapulco says that at the exit from there they saw arrived to Manila's bay one of the three. God allows it that the second courier ship that has been waiting in short might have good news about the others. One of which had orders from the viceroy Don Luis de Velasco that while sailing they should identify and fathom the ports, by means of which does not seem that they would be long then and it could be that all of them could come safeguarded by a convoy.

This captain also says that five ships had arrived from Japan with provisions and that the king from there had no army [raised against Spain] but against China, and that another Manila ship had arrived coming from Malacca ${ }^{3}$ with clothing from India and slaves from Molucca ${ }^{4}$ and another from the town of Arébalo ${ }^{5}$ from the same coast with slaves and some species and that all the things from there would accommodate fine. From Madrid, the $14^{\text {th }}$ of March of 1596.

\section{/v/}

Audience of the Indies

$14^{\text {th }}$ of March 1596

The viceroy of New Spain informs that this past November one of the four ships that sailed from the Philippines had arrived in Acapulco, and this is what the captain says.

Be warned about this [END]

\footnotetext{
${ }^{1}$ Aviso; Any small and fast warship carrying dispatches.

${ }^{2}$ Probably meant capitana; Each fleet had two heavily armed large galleons escorting it; the capitana was always the point ship and the captain-general, who had overall command of the fleet, sailed on it; the second in command, the admiral, sailed aboard the almiranta that protected the rear of the fleet.

${ }^{3}$ Indonesia.

4 Moluca or Malacca; a group of islands (formerly known as the Spice Islands) of eastern Indonesia between Sulawesi and New Guinea. Discovered in the early 16th century, the islands were settled by the Portuguese but taken in the 17th century by the Dutch, who used them as the basis for their monopoly of the spice trade.

${ }^{5}$ This place name could not be identified.
} 
Introductory Note: This document reveals that some of the ships sailing between New Orleans and Cap François (present-day Cape Haitian on the north coast of Haiti) sailed along the north coast of Cuba and used the Old Bahama Channel to reach Cap François or, vice versa, New Orleans, Mobile or Pensacola. It also demonstrates the close cooperation between the Spanish and the French after the ascension to the thrown by Philip V in 1700. Those ships most likely sailed close to and within sight of the west coast of Florida.

\section{CAOM C13 A20 1735}

\section{[Folio 29 recto]}

\section{Translated by John de Bry}

Louisiana

M. Salmon, 13 April 1735

Excerpt of the letter of 14 December

My Lord,

Your Highness will see through the attached duplicate of my letter of the past $14^{\text {th }}$ December that the ship La Barette ${ }^{6}$ from Bordeaux had left for St. Domingue; ${ }^{7}$ this vessel was lost near Matanza, the captain and the crew were

$/ \mathrm{v} /$

happily saved and came here with the help of a Spanish ship; I include here the deposition of the captain and his officers.

M. de Bienville will give you an account of the desertion of six Swiss from the Mobile detachment, and the extreme haste with which the governor of Pensacola where they deserted had them leave for Campeche or Veracruz, notwithstanding the existing convention. He used the pretext that they are foreigners and auxiliary troops, if it were the case we would be left without any troops and in the end would lead to the desertion of our French troops.

In New Orleans

13 April 1735

[END]

\footnotetext{
${ }^{6}$ Most likely a merchant ship from Bordeaux; no data could be located for this ship.

${ }^{7}$ La Barette left New Orleans for St. Domingue on December $14^{\text {th }}$, 1734 (source: CAOM Colonies C13 A19, folios 106-108, Salmon to the Secretary of State).
} 
Introductory Note: A Frenchman briefly discusses his travels from Martinique to the Mississippi region in the early $18^{\text {th }}$ century. At some point in his voyage, he stopped at Vera Cruz. This document also provides evidence on forces that could change a projected route, in this case, a disease on the ship.

CAOM C13 B1 1715

Série $C^{13}$ - Received correspondences from Louisiana

Colonies $C^{13}$ B 1 (1715)

[Folio 60 recto]

7 October 1715

Translated by John de Bry

M. Baron

My Lord,

I am taking the liberty to inform Your Highness of the voyage I have just undertaken to the French islands of America, from which I have been back for some time already, and I hope you will be willing to excuse me if I abbreviate my report for fear of boring you, and humbly beg you to be favorable towards me.

In the month of June of the year 1713 I left Martinique aboard a small bark ${ }^{8}$ named l'Atalante, $^{9}$ with commission from M. Phélypeaux, ${ }^{10}$ General of the Islands as of the $2^{\text {nd }}$ of January of the said year, to go to Mississippi to bring meats based on the information that we had then

/v/

regarding the extreme necessity the colony was reduced to; we only arrived there the following month of November, having stopped in Veracruz, and I was only able to sail from there in May of last year 1714. But being underway returning to Martinique after having sailed out of the

\footnotetext{
${ }^{8}$ Barque in the original manuscript text, a three masted vessel; fore-mast, main mast and mizen mast; the two fore mast are square-rigged as in a ship; the after, or mizen-mast has no yards, being fitted with a topmast only, and carries gaff-sail (called the spanker), and a gaff-topsail (source: De la Quille à la Pomme du Mât, Dictionnaire de la Marine by Capt. Paasch, p. 10, Antwerp, 1908).

${ }^{9}$ L'Atalante was a small bark from Martinique; in 1712 it was used by privateers to attack the island of Saint Lucia located directly south of Martinique (source: CAOM, Colonies, Series $C^{8 \mathrm{~A}}$, Martinique, $\mathrm{C}^{8 \mathrm{~A}}$ 19, Folios 260-307, January 1713); Atalante is French for the Greek mythological figure Atalanta, a beautiful maiden who participated in the Calydonian boar hunt. When Meleager bestowed on her as trophies the head and the hide of the boar which he had killed, she became the innocent cause of a conflict in which Meleager and two of his uncles lost their lives. According to another legend, Atalanta had been warned not to marry. In order to make things difficult for her suitors she promised to be the prize in a race. She lost the race to Hippomenes who then forgot to thank Venus and was changed into a lion as was also his bride (source: Bulfinch’s Mythology, Gramercy Books, New York 1979).

${ }^{10}$ Phélypeaux du Verger, Raymond Balthazar, cousin of Pontchartrain, Lieutenant General of the Armies, Governor General of the French Islands of America, i.e. French Caribbean possessions (source: CAOM, Series $\mathrm{C}^{8 \mathrm{~A}}$, Martinique).
} 
Bahama Channel, temperatures were so high that disease started to spread among my crew, forcing us to sail for Saint-Domingue ${ }^{11}$ where we arrived at the beginning of July, and after having sold a few savages brought from Mississippi, I used a small portion of the funds derived from that sale to buy some raw sugar and syrup of molasses to add to the small amount of furs not appropriate to be sold in warm countries, which made me take the resolution to come the Havre de Grâce with a new commission from M. the Count of Darguyan (sic) ${ }^{12}$, commander at the said Cape St. Domingue. ${ }^{13}$ We left from the said place on the $12^{\text {th }}$ of September, and around the $25^{\text {th }}$ of October, being in the middle of the English Channel on the verge of arriving, we were surprised by a west wind so strong that our sails were torn, but we were happy to distance ourselves from the coasts of England with the only square-fore-sail, and to save ourselves in these seas, luckily, we found a local bark from the Texel ${ }^{14}$ who gave us a pilot who guided us to this port. I was forced to sell the small cargo I was charged with in order to pay my crew and dismiss it, as the funds I had left over were not sufficient to careen the said bark and put it back at sea, and have enough to pay duty in France, M. the Count of Pontchartrain granted me permission to sell it here, which I did this past August, and telling me at the same time via M. de St. Gelais that I needed to go to Paris to give account and report on Louisiana. I had the honor to respond that I had the opportunity upon my arrival here to send him my report with the relation of my voyage, my observations on the said colony, and a copy of the declaration of my stop over (Veracruz), and that I could not come back to France unless he would have the goodness

/Folio 61 recto/

to grant me my personal safety because I am involved in Tours in an old unlucky affair involving investments with an Italian named Ferario who betrayed our trust in 1707, and that M. Dargenson afterwards had sent to Bicêtre ${ }^{15}$ where he died. As a result my family has done all that was possible, since I am here, to settle the said affairs so I can be free, something they could never achieve, which forced me, against my will, to remain in this city.

It is also, My Lord, what made me very humbly supplicate Your Highness to allow me to have the benefit of my said rights on the 4 to 6 deniers ${ }^{16}$ per livre withheld from the salaries of my

\footnotetext{
${ }^{11}$ Present-day Haiti.

${ }^{12}$ Arquian, Paul-François de La Grange comte d': Naval officer, ship captain in 1706, governor of St. Croix while in Cape François (present-day Cape Haitian, Haiti) in 1711, interim governor of Saint-Domingue in 1712-13, returned to Rochefort in 1723, retired as Squadron Commander, died in Rochefort in May 1745 (source: CAOM Colonies, Series E 9; 17, 179, 332, 592).

${ }^{13}$ The author of this letter, M. Baron, meant Cape François, present-day Cape Haitian, on the north coast of Haiti.

${ }^{14}$ Texel is a North Sea Dutch island as well as a municipality in the Netherlands, in the province of North Holland. It is the biggest and most populated of the Frisian Islands in the Wadden Sea, and also the westernmost of this archipelago, which extends to Denmark.

${ }^{15}$ Bicêtre was a mental hospital and a prison built in Paris in 1633 at the order of Louis XIII on the ruins of a fortress. The name Bicêtre originated from the fact that the hospital and prison were built on a terrain belonging to the Bishop of Winchester; the name of Winchester was corrupted into the French "Vincestre" then "Bicestre" (source: Sigaut, Marion, La Marche rouge, Éditions Jacqueline Chambon, Paris 2008).

${ }^{16}$ The French monetary system of the $17^{\text {th }}$ and $18^{\text {th }}$ century was based on a duodecimal system. Although quite complex for the largely illiterate rural population, this system lasted more than a thousand years, having been introduced during Merovingian time by King Pépin le Bref in 755 AD. The basic currencies were the livre (pound), the sol and the denier. 1 livre $=20$ sols $=240$ deniers. In certain cases the denier meant the percentage of interest per pound weight (sources: M. Barrême Les Comptes-Faits ou le Tarif Général de Touttes les Monnoyes, Jean Geoffroy Nyon (editor), Paris 1723; Nouveau Dictionnaire de Poche de la Langue Française, Imprimerie P. Catineau, Paris 1802).
} 
crew as well as on my cargo. I have sent reports to M. the Count of Pontchartrain; M. Radeau is close to having them in order, and once they have been [officially] recorded, I will await Your Highness's orders to have them tallied up in Paris, of if you would like better, to have M. de St. Gelais receive them here, which would be a very nice thing for me, taking into consideration the need for a prompt expedition as I cannot further delay reporting to the interested parties. ${ }^{17}$ It will be necessary for $\mathrm{M}$. de St. Gelais to give me a receipt and send a release to Martinique so my security deposit can be lifted, which will allow me to end such an unhappy voyage that has cost so much because of the problems with the vessel.

It is the favor, My Lord, that I am taking the liberty to ask Your Highness, assuring you of my perfect obedience and the profound respect I have the honor to have,

My Lord Your very humble et very obedient servant

At Amsterdam, the 7th of October

[signed] Baron

1715

[END]

${ }^{17}$ Investors 
Introductory Note: This document was selected because it gives useful data regarding sailing time between France and Cap François (Cape Haitian) on Hispaniola (52 days), and between Cap François and New Orleans (20 days).

\title{
CAOM C13 A16 1733
}

\section{[Folio 223 recto]}

\section{Translated by John de Bry}

\author{
Colonies $\quad$ M. de Bienville ${ }^{18}$
}

Louisiana

28 January 1733

My Lord,

We moored [arrived] the twenty-second of this current month after a crossing of fifty-two days ${ }^{19}$ which was happily fairly good, our new recruits supported it quite well even with all the inconvenience they suffered, having been forced to sleep on

\footnotetext{
${ }^{18}$ Bienville, Jean-Baptiste Lemoyne, Sieur de (Montreal 1680 - Paris 1767): Officer, explorer, governor of Louisiana, he belonged to a family many of whose members left their mark on the history of Canada and Louisiana. In 1712 Antoine Crozat, Marquis de Chatel (1655-1738) , a powerful and influential financier and director of the Companies of St.Domingue, appointed Antoine La Mothe Cadillac, governor, and Jean-Baptiste de Bienville lieutenant-governor. But Cadillac dying in 1715, Bienville once more assumed the reins of government. In 1716, he conducted an expedition against the Natchez Indians, and having brought them to terms, finished the fort "Rosalie" which had been commenced by his brother, Iberville, sixteen years before. In 1717, Epinay, a new governor, arrived in the colony, bringing with him the decoration of the Cross of St. Louis for Bienville. In the meantime, Crozat, failing to realize the great profits he had expected, abandoned the whole enterprise and surrendered his charter to the king in 1717. Another company was at once formed and Bienville received a new commission as governor of the province. He now resolved to remove the headquarters from Biloxi, Mobile, and St. Louis Bay to the more fertile region of the Mississippi River, and in 1718 he selected the site for a new settlement, which he called New Orleans. He left fifty persons there to clear the land and build some houses, but it was not till 1722 that it became the seat of government. Experience had shown Bienville that the fertile soil of the lower Mississippi, as well as the climate, was well adapted to the cultivation of sugar, cotton, tobacco, and rice, and that Europeans were not fitted for field-work in the burning suns of Louisiana, for they sickened and died. The first plantation of any extent was therefore commenced with Negroes imported from Guinea. In 1719, the province became involved in hostilities with the Spaniards in consequence of the war with France and Spain. The governor twice reduced the town of Pensacola and sent detachments to prevent the Spaniards from making inroads into upper Louisiana, and the country bordering on the Rio Grande. When peace was restored immigrants began to arrive in great numbers from France and Germany. In the autumn of 1726, the Government of Louisiana passed out of the hands of Bienville and he retired to France to recruit his health. In 1734, the king reappointed him Governor and Commandant-General of Louisiana, and early in the autumn he arrived at New Orleans and entered upon the duties of his office. An expedition against the Chickasaw Indians in the spring of 1736 resulted in disaster, but another expedition in 1739 met with better success. This campaign closed his military and official career in the colony. He returned to France under a cloud of censure from the Government, after having faithfully served his country for more than forty years. He was buried with military honors in Paris (sources: Library and Archives Canada, Dictionary of Canadian Biography Online; New Advent Organization).

${ }^{19}$ This is a clear indication of the amount of time it took a ship to sail from a French port to Cape François (presentday Cape Haitian) on the north coast of Haiti.
} 
$/ \mathrm{v} /$

the deck, as it was not possible to place them anywhere else, but their great youth supported them and we did not lose any.

M. Méchin ${ }^{20}$ is giving us hope that he will be in this port this week, and as we are not in the calm season, I estimate arriving within 20 days. $^{21}$

I saw here, My Lord, the Natchez chiefs who are slaves, among others the one named St. Cosme, $^{22}$ who had been given the hope that they could come back with me; they assured me that it was only their Nation who had revolted, and the firm way we had acted had determined them to act without the advice of the other nations, and if I can believe them, my arrival in the colony $^{23}$ will restore the tranquility that I had left it with. There are here several inhabitants of Louisiana who asked to return there.

/Folio 224 recto]

I had convinced M. Méchin to take a few, but the little room that there is in this ship ${ }^{24}$ did not allow me to do so.

Allow me, My Lord, to reserve for you my very humble prayers for the promotion of my nephew the Chevalier de Noyan ${ }^{25}$ who is on Isle Royale. ${ }^{26}$

I am with the deepest respect,

My Lord,

Your very humble and very obedient servant

[signed] Bienville

At Cap François the $28^{\text {th }}$

of January 1733

[END]

\footnotetext{
${ }^{20}$ Although this person's name occurs in another document, no biographical data could be located.

${ }^{21}$ The amount of time it took to sail from Cap François to New Orleans taking into consideration wind and rough seas.

${ }^{22}$ No biographical data could be found for this Natchez chief, although there was a lieutenant de Saint-Cosme who was assassinated by the Natchez in 1707 (source: CAOM Colonies C13 A2, pp. 5-32).

${ }^{23}$ Louisiana.

${ }^{24}$ The ship is not identified in this document.

${ }^{25}$ No biographical data could be found for this individual.

${ }^{26}$ Isle Royale is the former French name for Cape Breton Island, Nova Scotia, Canada (source: Harvey, David \& Gordon, Warren The Cabot Trail, Steel Town Publishing, Sydney [Canada] 1997; Wikipedia 2010).
} 